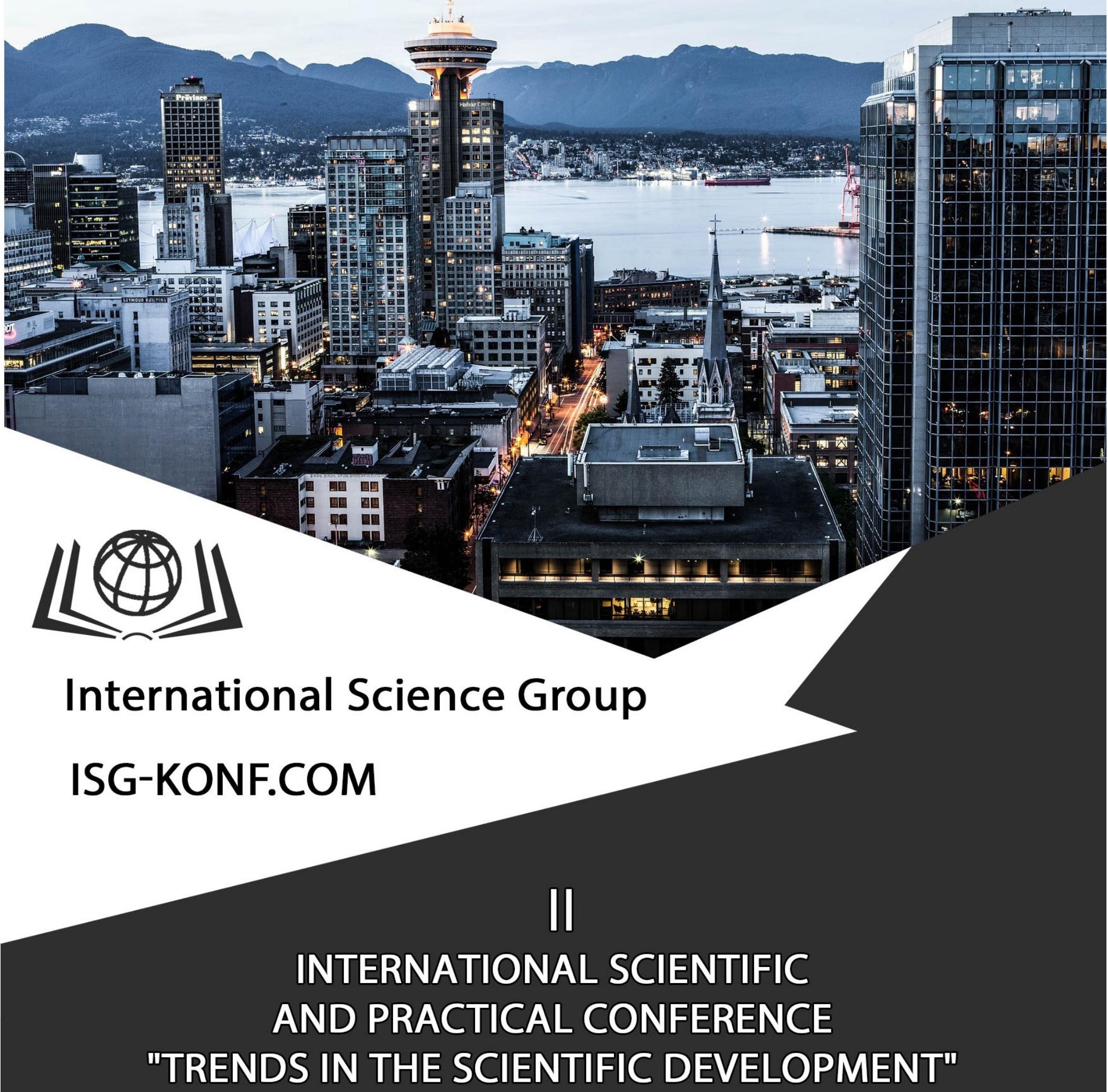

\title{
Vancouver, Canada
}

September 28 - October 01, 2021

ISBN 978-1-63972-062-0

DOI 10.46299/ISG.2021.II.II 


\title{
TRENDS IN THE SCIENTIFIC DEVELOPMENT
}

Abstracts of II International Scientific and Practical Conference

\author{
Vancouver, Canada
}

September 28 - October 01, 2021 


\section{Library of Congress Cataloging-in-Publication Data}

UDC 01.1

The II International Science Conference «Trends in the scientific development», September 28 - October 01, 2021, Vancouver, Canada. 417 p.

ISBN - 978-1-63972-062-0
DOI - 10.46299/ISG.2021.II.II

EDITORIAL BOARD

\begin{tabular}{ll} 
Pluzhnik Elena & $\begin{array}{l}\text { Professor of the Department of Criminal Law and Criminology } \\
\text { Odessa State University of Internal Affairs Candidate of Law, } \\
\text { Associate Professor }\end{array}$ \\
\hline Liubchych Anna & $\begin{array}{l}\text { Scientific and Research Institute of Providing Legal Framework for } \\
\text { the Innovative Development National Academy of Law Sciences of } \\
\text { Ukraine, Kharkiv, Ukraine, Scientific secretary of Institute }\end{array}$ \\
\hline Liudmyla Polyvana & $\begin{array}{l}\text { Department of Accounting and Auditing Kharkiv } \\
\text { National Technical University of Agriculture named after Petr } \\
\text { Vasilenko, Ukraine }\end{array}$ \\
\hline Mushenyk Iryna & $\begin{array}{l}\text { Candidate of Economic Sciences, Associate Professor of } \\
\text { Mathematical Disciplines, Informatics and Modeling. Podolsk State } \\
\text { Agrarian Technical University }\end{array}$ \\
\hline Oleksandra Kovalevska & $\begin{array}{l}\text { Dnipropetrovsk State University of Internal Affairs } \\
\text { Dnipro, Ukraine }\end{array}$ \\
\hline Prudka Liudmyla & $\begin{array}{l}\text { Odessa State University of Internal Affairs, } \\
\text { Associate Professor of Criminology and Psychology Department }\end{array}$ \\
\hline$\underline{\text { Slabkyi Hennadii }}$ & $\begin{array}{l}\text { Doctor of Medical Sciences, Head of the Department of Health } \\
\text { Sciences, Uzhhorod National University. }\end{array}$ \\
\hline Marchenko Dmytro & $\begin{array}{l}\text { Ph.D. in Machine Friction and Wear (Tribology), Associate } \\
\text { Professor of Department of Tractors and Agricultural Machines, } \\
\text { Maintenance and Servicing, Lecturer, Deputy dean on academic } \\
\text { affairs of Engineering and Energy Faculty of Mykolayiv National } \\
\text { Agrarian University (MNAU), Mykolayiv, Ukraine }\end{array}$ \\
\hline$\underline{\text { Harchenko Roman }}$ & $\begin{array}{l}\text { Candidate of Technical Sciences, specialty 05.22.20 - operation and } \\
\text { repair of vehicles. }\end{array}$ \\
\hline Belei Svitlana & $\begin{array}{l}\text { Ph.D. (Economics), specialty: 08.00.04 "Economics and } \\
\text { management of enterprises (by type of economic activity)" }\end{array}$
\end{tabular}


TABLE OF CONTENTS

\begin{tabular}{|c|c|c|}
\hline \multicolumn{3}{|c|}{ ADVERTISING } \\
\hline 1. & $\begin{array}{l}\text { Болотова В.О., Шапарньова Л.Д. } \\
\text { СОЦІАЛЬНА РЕКЛАМА ЯК ЗАСІБ ЗМІНИ ПОВЕДІНКОВИХ } \\
\text { ПАТЕРНІВ }\end{array}$ & 14 \\
\hline \multicolumn{3}{|c|}{ AGRICULTURAL SCIENCES } \\
\hline 2. & $\begin{array}{l}\text { Воропай Г.В., Молеща Н.Б. } \\
\text { ОСОБЛИВОСТІ ВОДОЗАБЕЗПЕЧЕНОСТІ МЕЛІОРОВАНИХ } \\
\text { ЗЕМЕЛЬ НА ПРИКЛАДІ ОСУШУВАЛЬНО- } \\
\text { ЗВОЛОЖУВАЛЬНОЇ СИСТЕМИ «РОМЕН» }\end{array}$ & 17 \\
\hline 3. & $\begin{array}{l}\text { ТрУскавецьКИй Р.С. } \\
\text { ПРОБЛЕМИ РАЦІОНАЛЬНОГО ВИКОРИСТАННЯ } \\
\text { ОСУШЕНИХ ЗЕМЕЛЬ В УКРАЇНІ }\end{array}$ & 22 \\
\hline \multicolumn{3}{|c|}{ ARCHITECTURE, CONSTRUCTION } \\
\hline 4. & $\begin{array}{l}\text { Skorokhodova A. } \\
\text { АДАПТАЦІЙНІ ЗАХОДИ ЯК ЗАПОРУКА ВПРОВАДЖЕННЯ } \\
\text { ІНКЛЮЗИВНОЇ ОСВІТИ }\end{array}$ & 26 \\
\hline 5. & $\begin{array}{l}\text { Петриковська А.А., Малимон С.С. } \\
\text { СУЧАСНЕ ОЗДОБЛЕННЯ ФАСАДІВ }\end{array}$ & 30 \\
\hline \multicolumn{3}{|c|}{ ART HISTORY } \\
\hline 6. & $\begin{array}{l}\text { Makieieva N., Odinets Y., Poddubnaya I., Kulikova D. } \\
\text { PAIN SYNDROME IN ART }\end{array}$ & 35 \\
\hline \multicolumn{3}{|c|}{ ECONOMIC SCIENCES } \\
\hline 7. & $\begin{array}{l}\text { Dermanska L., Kulchytska N. } \\
\text { INTERNATIONAL EXPERIENCE OF TAX STIMULATION OF } \\
\text { INNOVATIVE ACTIVITY FOR UKRAINE }\end{array}$ & 44 \\
\hline 8. & $\begin{array}{l}\text { Fostyak V. } \\
\text { ФІНАНСОВА ГРАМОТНІСТЬ ПО-СКАНДИНАВСЬКИ }\end{array}$ & 47 \\
\hline 9. & $\begin{array}{l}\text { Kozenkova V. } \\
\text { AGRICULTURAL ENTERPRISE PRODUCT COST MONITORING } \\
\text { INFORMATION SYSTEM }\end{array}$ & 50 \\
\hline
\end{tabular}




\begin{tabular}{|c|c|c|}
\hline 10 . & $\begin{array}{l}\text { Алексеєвська Г., Попова Н. } \\
\text { АНАЛІЗ ЗМІН ПЛАТІЖНОГО БАЛАНСУ УКРАЇНИ В УМОВАХ } \\
\text { ЄВРОЇНТЕГРАЦІЇ }\end{array}$ & 60 \\
\hline 11. & $\begin{array}{l}\text { Безкровний О.В., Довгаль О.Ю., Максименко С.В., } \\
\text { Щелкунова М.С., Вовченко В.Д. } \\
\text { ПОДАТОК НА ДОХОДИ ФІЗИЧНИХ ОСІБ ЯК РЕГУЛЯТОР } \\
\text { ВЗАСМОВІДНОСИН МІЖ ДЕРЖАВОЮ ТА ГРОМАДЯНАМИ }\end{array}$ & 63 \\
\hline 12. & $\begin{array}{l}\text { Джусибалиева А.К., Искакова Д.М., Искакова Д.Б., } \\
\text { Бодаухан К., Амерханова И.К. } \\
\text { ОСНОВНЫЕ ФАКТОРЫ, ПРИЧИНЫ И МОТИВЫ } \\
\text { ОБРАЗОВАТЕЛЬНОЙ И ТРУДОВОЙ МИГРАЦИИ МОЛОДЕЖИ } \\
\text { КАЗАХСТАНА ЗА РУБЕЖ }\end{array}$ & 67 \\
\hline \multicolumn{3}{|c|}{ GEOGRAPHICAL SCIENCE } \\
\hline 13. & $\begin{array}{l}\text { Лабінська Г.М. } \\
\text { РОЛЬ ІНЖЕНЕРНОГО БЛАГОУСТРОЮ У ПРОСТОРОВОМУ } \\
\text { ПЛАНУВАННІ }\end{array}$ & 76 \\
\hline 14. & $\begin{array}{l}\text { Рибалова О.В., Кусков О.Д., Кусков О.Д. } \\
\text { ОЦНКА ЕКОЛОГІЧНОГО СТАНУ РІЧКИ ЛОПАНЬ НА } \\
\text { ОСНОВ ВИЗНАЧЕННЯ ЕКОЛОГІЧНОГО ІНДЕКСУ }\end{array}$ & 83 \\
\hline \multicolumn{3}{|c|}{ JOURNALISM } \\
\hline 15. & $\begin{array}{l}\text { Горбуненко А.Ф. } \\
\text { «ТНЕ NЕW-YORКЕR» КАК ЛИТЕРАТУРНО- } \\
\text { ПУБЛИЦИСТИЧЕСКИЙ ЖУРНАЛ НОВОГО ТИПА }\end{array}$ & 89 \\
\hline 16. & $\begin{array}{l}\text { Кидакоева З.Ш. } \\
\text { ТИПОЛОГИЧЕСКИЕ ОСОБЕННОСТИ ПЕРВЫХ } \\
\text { ОПОЗИЦИОННЫХ ИЗДАНИЙ КУБАНСКОЙ ОБЛАСТИ } \\
\text { ПОСЛЕ } 1905 \text { ГОДА }\end{array}$ & 95 \\
\hline \multicolumn{3}{|c|}{ LEGAL SCIENCES } \\
\hline 17. & $\begin{array}{l}\text { Guyvan P. } \\
\text { ON THE QUESTION OF THE LEGAL CERTAINTY OF LEGAL } \\
\text { RELATIONS. TIME ASPECT }\end{array}$ & 100 \\
\hline 18. & $\begin{array}{l}\text { Khylko M. } \\
\text { STRATEGIC COMMUNICATIONS IN FOREIGN POLICY OF THE } \\
\text { UNITED STATES, EUROPEAN UNION, AND UKRAINE }\end{array}$ & 106 \\
\hline
\end{tabular}




\begin{tabular}{|c|c|c|}
\hline 19. & $\begin{array}{l}\text { Kuzmenko I. } \\
\text { ORGANIZATION OF THE EDUCATIONAL PROCESS IN } \\
\text { HIGHER EDUCATION INSTITUTIONS OF UKRAINE DURING } \\
\text { THE QUARANTINE PERIOD }\end{array}$ & 110 \\
\hline 20. & $\begin{array}{l}\text { Shevchenko N., Rudnychenko S. } \\
\text { MECHANISM OF BRINGING JUVENILES TO } \\
\text { ADMINISTRATIVE RESPONSIBILITY }\end{array}$ & 113 \\
\hline 21. & $\begin{array}{l}\text { Оболенцев В. } \\
\text { ЧИ ДОЦІЛЬНО ВВАЖАТИ ЗЛОЧИННІСТЬ СИСТЕМОЮ? }\end{array}$ & 115 \\
\hline 22. & $\begin{array}{l}\text { Камінська О., Ф Федорченко О. } \\
\text { РОЗВИТОК ЗАГАЛЬНОКУЛЬТУРНИХ КОМПЕТЕНЦІЙ } \\
\text { МАЙБУТНІХ ПРАВООХОРОНЦІВ ПІД ЧАС ВИВЧЕННЯ } \\
\text { ДИСЦИПЛІНИ «КОНСТИТУЦІЙНЕ ПРАВО» }\end{array}$ & 117 \\
\hline 23. & $\begin{array}{l}\text { Кирьянова Е.А. } \\
\text { ПАНДЕМИЯ: РЕАЛЬНАЯ ИЛИ ГЛОБАЛЬНАЯ ОПАСНОСТЬ }\end{array}$ & 120 \\
\hline 24. & $\begin{array}{l}\text { Новікова М. } \\
\text { ЗАПРОВАДЖЕННЯ ГЕНДЕРНООРІЄНТОВНОГО ПІДХОДУ ДО } \\
\text { ВІДОМЧОЇ ЮРИДИЧНОЇ ОСВІТИ В СИСТЕМІ МВС }\end{array}$ & 122 \\
\hline 25. & $\begin{array}{l}\text { Пхикидзе Н.Г., Матиашвили Г.Б. } \\
\text { ПРАВА ДЕТЕЙ В ГРУЗИИ }\end{array}$ & 125 \\
\hline 26. & $\begin{array}{l}\text { Федоров О. } \\
\text { ПОГЛЯДИ ЩОДО БІОЛОГІЧНИХ ЧИННИКІВ ЗЛОЧИННОї } \\
\text { ПОВЕДІНКИ }\end{array}$ & 130 \\
\hline 27. & $\begin{array}{l}\text { Шай Р.Я. } \\
\text { ЗАКОН ПРО КРИМІНАЛЬНУ ВІДПОВІДАЛЬНІСТЬ: КЛЮЧОВІ } \\
\text { АСПЕКТИ }\end{array}$ & 132 \\
\hline \multicolumn{3}{|c|}{ MANAGEMENT, MARKETING } \\
\hline 28. & $\begin{array}{l}\text { Voronina A., Pavlenko V., Maliuk Y. } \\
\text { RESOURCE APPROACH TO EVALUATION OF ENTERPRISE } \\
\text { MANAGEMENT EFFICIENCY }\end{array}$ & 134 \\
\hline
\end{tabular}




\begin{tabular}{|c|c|c|}
\hline 29. & $\begin{array}{l}\text { Бигельдинов Ш.К. } \\
\text { МЕТОДЫ СТРАТЕГИЧЕСКОГО ПЛАНИРОВАНИЯ }\end{array}$ & 138 \\
\hline 30. & $\begin{array}{l}\text { ФазЫЛЗянОва И.И. } \\
\text { ПОТРЕБИТЕЛЬСКОЕ ПОВЕДЕНИЕ: ПОНЯТИЕ И ЕГО } \\
\text { СУЩНОСТЬ }\end{array}$ & 146 \\
\hline 31. & $\begin{array}{l}\text { Циганкова Т.М., Трейтяк М.В. } \\
\text { МАРТЕХ ЯК ІНСТРУМЕНТ МАРКЕТИНГОВОЇ ДІЯЛЬНОСТІ } \\
\text { КОМПАНІЙ НА ГЛОБАЛЬНОМУ РИНКУ ПОСЛУГ }\end{array}$ & 149 \\
\hline \multicolumn{3}{|c|}{ MEDICAL SCIENCES } \\
\hline 32. & $\begin{array}{l}\text { Bychkova S. } \\
\text { THE IMMUNE STATUS OF COPD PATIENTS }\end{array}$ & 155 \\
\hline 33. & $\begin{array}{l}\text { Khotimska Y., Aleksieienko N., Kucherenko O., Khotimskiy B., } \\
\text { Tarasenko Y. } \\
\text { STATE OF ORAL HYGIENE IN CHILDREN WITH ACUTE } \\
\text { LYMPHOBLASTIC LEUKEMIA }\end{array}$ & 163 \\
\hline 34. & $\begin{array}{l}\text { Kilmukhametova Y. } \\
\text { TREATMENT OF PERIODONTAL TISSUE DISEASES IN } \\
\text { PATIENTS WITH URINARY SYSTEM PATHOLOGY WITH AN } \\
\text { IMPROVED SCHEME }\end{array}$ & 169 \\
\hline 35. & $\begin{array}{l}\text { Smolen Y., Tokar O., Vakharyk N., Loryna I., Drucul-Melnyk N. } \\
\text { ASSESSMENT OF THE PSYCHO-EMOTIONAL STATE OF } \\
\text { NURSES IN A COVID-19 PANDEMIC }\end{array}$ & 172 \\
\hline 36. & $\begin{array}{l}\text { Urazova S.N., Akpanova S.K. } \\
\text { THE IMMUNE-REGULATORY ROLE OF THE INTESTINAL } \\
\text { MICROBIOME AND MYCOBIOME IN AGING }\end{array}$ & 175 \\
\hline 37. & $\begin{array}{l}\text { Головащенко Г., Калашніков А., К Курділь Н. } \\
\text { РЕГЛАМЕНТАЦІЯ ФОСФАТНИХ ПОМ'ЯКШУВАЧІВ У } \\
\text { СКЛАДІ СИНТЕТИЧНИХ МИЙНИХ ЗАСОБІВ: ЕКОЛОГІЧНИЙ } \\
\text { АСПЕКТ ПРОБЛЕМИ }\end{array}$ & 178 \\
\hline
\end{tabular}




\begin{tabular}{|c|c|c|}
\hline 38. & $\begin{array}{l}\text { Мошковська Ю.О., Соболь В.О., Романченко С.С., } \\
\text { Луценко А.О. } \\
\text { ОЦНКА МАРКЕРІВ ЗАПАЛЕННЯ, ОСОБЛИВОСТЕЙ ОБМІНУ } \\
\text { МG++ ТА СТАНУ МІКРОБІОМУ КИШКІВНИКА У ХВОРИХ } \\
\text { НА АРТЕРІАЛЬНУ ГІПЕРТЕНЗІЮ З СУПУТНІМ ОЖИРІННЯМ }\end{array}$ & 183 \\
\hline 39. & $\begin{array}{l}\text { Оборонова Т.С., Потебенько М.В., КурдіЛь Н.В. } \\
\text { ДОСЛІДЖЕННЯ ВПЛИВУ ПОЛІМЕРНИХ МАТЕРІАЛІВ ЯК } \\
\text { ДЖЕРЕЛА ХІМІЧНОГО ЧИННИКА МАЛОЇ ІНТЕНСИВНОСТИ } \\
\text { В ПОВІТРІ ЖИТЛОВИХ ПРИМЩЩЕНЬ }\end{array}$ & 190 \\
\hline 40. & $\begin{array}{l}\text { Портнова О.О., Прусс С.В., Х Хрущ М.О. } \\
\text { ВІКОВІ АСПЕКТИ ХАРЧОВОЇ АЛЕРГІЇ У ДІТЕЙ }\end{array}$ & 195 \\
\hline 41. & $\begin{array}{l}\text { Хламанова Л.І., Ч Чайковський Ю.Б. } \\
\text { ДИСТАНЦЙНЕ НАВЧАННЯ В УМОВАХ ПАНДЕМІЇ: ЯК } \\
\text { ЙОГО АКТИВІЗУВАТИ? }\end{array}$ & 197 \\
\hline 42. & $\begin{array}{l}\text { Щепанський С.О. } \\
\text { НАСИЛЬСТВО У СІМ'Ї: СУДОВО-МЕДИЧНІ АСПЕКТИ }\end{array}$ & 200 \\
\hline \multicolumn{3}{|c|}{ PEDAGOGICAL SCIENCES } \\
\hline 43. & $\begin{array}{l}\text { Babakina O. } \\
\text { PROFESSIONAL MOBILITY AS A PROFESSIONAL QUALITY } \\
\text { OF THE FUTURE TEACHER }\end{array}$ & 203 \\
\hline 44. & $\begin{array}{l}\text { Bakhtadze T., Kobiashvili A. } \\
\text { THE CONCEPT OF META-TEACHING }\end{array}$ & 207 \\
\hline 45. & $\begin{array}{l}\text { Bondarenko M., Zaytseva O., Rukin O. } \\
\text { ELECTRONIC LEARNING COURSES: CREATION AND } \\
\text { IMPLEMENTATION }\end{array}$ & 212 \\
\hline 46. & $\begin{array}{l}\text { Lytvyn V. } \\
\text { CHARACTERISTICS OF THE LEADING METHODS } \\
\text { OF IMPROVING THE QUALIFICATION OF SCIENTIFIC AND } \\
\text { PEDAGOGICAL EMPLOYEES OF USA HIGHER EDUCATION } \\
\text { INSTITUTIONS }\end{array}$ & 215 \\
\hline
\end{tabular}




\begin{tabular}{|c|c|c|}
\hline 47. & $\begin{array}{l}\text { Аркушина Ю.В. } \\
\text { МЕТОД «МОВНОГО ПОРТФЕЛЮ» ЯК ОДНА ІЗ ТЕХНОЛОГІЙ } \\
\text { ФОРМУВАННЯ ІНОЗЕМНОЇ КОМУНІКАТИВНОЇ } \\
\text { КОМПЕТЕНТНОСТІ У ПРОФЕСІЙНІЙ ДІЯЛЬНІСТЬ } \\
\text { МАЙБУТНІХ ФАХІВЦІВ ПРАВА }\end{array}$ & 219 \\
\hline 48. & $\begin{array}{l}\text { Величко Н.В., Свграфова Н.І., Селезньова І.І. } \\
\text { ВИКОРИСТАННЯ ДИСТАНЦІЙНОГО НАВЧАННЯ В } \\
\text { МЕДИЧНОМУ ВУЗІ ПРИ ВИКЛАДАННІ ДИСЦИПЛІНИ } \\
\text { «ОРГАНІЧНА ХІМІЯ» }\end{array}$ & 225 \\
\hline 49. & 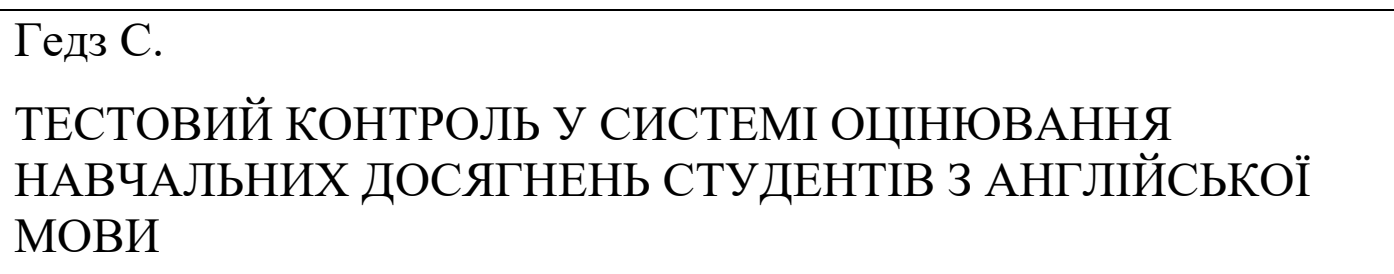 & 229 \\
\hline 50. & $\begin{array}{l}\text { Казачінер О.С., Бойчук Ю.Д. } \\
\text { ВИКОРИСТАННЯ КАЗОК КИТАЮ У ПРАКТИЦІ } \\
\text { КАЗКОТЕРАПІЇ }\end{array}$ & 231 \\
\hline 51. & $\begin{array}{l}\text { Лубышев Е.А., Сергеева Ю.С., Баранов М.Г. } \\
\text { ТИПИЧНЫЕ ПСИХОЛОГИЧЕСКИЕ БАРЬЕРЫ И ПУТИ ИХ } \\
\text { ПРЕОДОЛЕНИЯ В ПРОФЕССИОНАЛЬНОЙ КАРЬЕРЕ } \\
\text { СПОРТСМЕНОВ ВЫСОКОГО КЛАССА }\end{array}$ & 234 \\
\hline 52. & $\begin{array}{l}\text { Мінко Є.С. } \\
\text { МОДЕЛІ ОРГАНІЗАЦЇ̈ ТЕХНОЛОГІЇ ВLЕNDED LEARNING } \\
\text { НА УРОКАХ ІНОЗЕМНОЇ МОВИ В } 2 \text { КЛАСІ }\end{array}$ & 242 \\
\hline 53. & $\begin{array}{l}\text { Романенко Л.В., Чорнобай В.П. } \\
\text { ПЕРЕВАГИ ЗАСТОСУВАННЯ ПЛАНШЕТУ GEOВОАRD НА } \\
\text { УРОКАХ МАТЕМАТИКИ У } 1 \text { КЛАСІ }\end{array}$ & 246 \\
\hline 54. & $\begin{array}{l}\text { Свиридова Т.І. } \\
\text { ПОРІВНЯЛЬНИЙ АНАЛІЗ НАУКОВИХ ДОСЛІДЖЕНЬ У } \\
\text { ГАЛУЗІ ПІДГОТОВКИ ФАХІВЦІВ ДЛЯ ЗАБЕЗПЕЧЕННЯ } \\
\text { СІМЕЙНОЇ ОСВІТИ В КАНАДІ ТА УКРАЇНІ }\end{array}$ & 251 \\
\hline 55. & $\begin{array}{l}\text { Топузова А.В. } \\
\text { РОЗВИТОК ОБДАРОВАНОСТІ ВИХОВАНЦІВ ЦЕНТРІВ } \\
\text { НАУКОВО-ТЕХНІЧНОЇ ТВОРЧОСТІ }\end{array}$ & 254 \\
\hline
\end{tabular}




\begin{tabular}{|c|c|c|}
\hline 56. & $\begin{array}{l}\text { Тухтарова Т.К., Дуднік В.С. } \\
\text { ПОСТУП ЦИФРОВІЗАЦІЇ ОСВІТИ В УКРАЇНІ: ШЛЯХИ } \\
\text { РОЗВИТКУ }\end{array}$ & 264 \\
\hline 57. & $\begin{array}{l}\text { Юрченко Л.В. } \\
\text { ЗАСТОСУВАННЯ АВТЕНТИЧНИХ МАТЕРІАЛІВ ДЛЯ } \\
\text { ФОРМУВАННЯ МОВНИХ КОМПЕТЕНЦЙ НА ЗАНЯТТЯХ } 3 \\
\text { ІНОЗЕМНОЇ МОВИ }\end{array}$ & 268 \\
\hline \multicolumn{3}{|c|}{ PHILOLOGICAL SCIENCES } \\
\hline 58. & $\begin{array}{l}\text { Khabarova N. } \\
\text { LA COMMUNICATION DANS LE ROMAN DE NATHALIE } \\
\text { SARRAUTE «LES FRUITS D’OR» }\end{array}$ & 270 \\
\hline 59. & $\begin{array}{l}\text { Васта В., Пренько Я. } \\
\text { ВИКОРИСТАННЯ ІГОР У ВИВЧЕННІ ГРАМАТИКИ } \\
\text { АНГЛІЙСЬКОЇ МОВИ }\end{array}$ & 274 \\
\hline 60. & $\begin{array}{l}\text { Загнітко А.П., Овсянніков В.С. } \\
\text { ТИПОЛОГІЯ КОМУНІКАТИВНИХ ІНТЕНЦЙ ПОДЯКИ ТА } \\
\text { ПРОХАННЯ В ЕПІСТОЛЯРІЇ ВАСИЛЯ СТУСА }\end{array}$ & 277 \\
\hline 61. & $\begin{array}{l}\text { Киселевич І.В. } \\
\text { КЛАСИФІКАЦІЇ АНГЛІЙСЬКИХ ЮРИДИЧНИХ ТЕРМІНІВ }\end{array}$ & 282 \\
\hline 62. & $\begin{array}{l}\text { Колесникова Л.Л. } \\
\text { ДИСКУСІЯ ЯК ФОРМА КОЛЕКТИВНОГО ОБГОВОРЕННЯ: } \\
\text { ТЕОРЕТИЧНИЙ АСПЕКТ }\end{array}$ & 284 \\
\hline 63. & $\begin{array}{l}\text { Олійник А.М. } \\
\text { НАВЧАННЯ МОРФОЛОГІЇ УКРАЇНСЬКОЇ МОВИ В ГІМНАЗІЇ: } \\
\text { ПРИНЦИПИ ІНДИВІДУАЛІЗАЦІЇ ТА ДИФЕРЕНЦАЦІЇ }\end{array}$ & 288 \\
\hline \multicolumn{3}{|c|}{ PHILOSOPHICAL SCIENCES } \\
\hline 64. & $\begin{array}{l}\text { Козобродова Д.М. } \\
\text { РОЛЬ СТРУКТУР, ЩО САМООРГАНІЗУЮТЬСЯ В ПОВЕДІНЦІ } \\
\text { НЕРІВНОВАЖНИХ СОЦІО-ГУМАНІТАРНИХ ПРОЦЕСІВ В } \\
\text { КОНТЕКСТІ КОНЦЕПТУ «ВRAIN-PSYCHЕ- } \\
\text { MIND/CONSCIOUSNESS» }\end{array}$ & 292 \\
\hline
\end{tabular}




\begin{tabular}{|c|c|c|}
\hline 65. & $\begin{array}{l}\text { Селіверстова Г.С. } \\
\text { МІСЦЕ ХАОСУ В ПОВЕДІНЦІ ЯВИЩА, ВИРАЖЕНОГО } \\
\text { КОНЦЕПТОМ «ВRAIN-PSYCHЕ-(MIND/CONSCIOUSNESS...)» }\end{array}$ & 294 \\
\hline \multicolumn{3}{|c|}{ PSYCHOLOGICAL SCIENCES } \\
\hline 66. & $\begin{array}{l}\text { Дроздов О.Ю. } \\
\text { ПСИХОЛОГІЧНІ АСПЕКТИ ПРИЙНЯТТЯ РІШЕННЯ ПРО } \\
\text { ВСТУП ДО ЗАКЛАДІВ ВИЩОЇ ОСВІТИ ВИПУСКНИКАМИ } \\
\text { ШКІЛ (НА ПРИКЛАДІ ЧЕРНІГІВСЬКОГО РЕГОНУ) }\end{array}$ & 296 \\
\hline 67. & $\begin{array}{l}\text { Зелінська В.О., Должикова В.В., Х Хотімська А.Б., } \\
\text { Зелінська Д.А. } \\
\text { ПИТАННЯ ОПТИМІЗАЦІЇ ФУНКЦІОНАЛЬНИХ СТАНІВ } \\
\text { МУЗИКАНТІВ-ВИКОНАВЦІВ (СОЦАЛЬНО- } \\
\text { ПСИХОЛОГІЧНИЙ АСПЕКТ) }\end{array}$ & 300 \\
\hline 68. & $\begin{array}{l}\text { КрИшТаЛЬ А.О. } \\
\text { ПСИХОЛОГО-ПЕДАГОГІЧНІ АСПЕКТИ МОТИВАЦІЇ } \\
\text { МАЙБУТНІХ ФАХІВЦІВ ЦИВІЛЬНОГО ЗАХИСТУ ДО } \\
\text { НАВЧАННЯ ЯК ВИЗНАЧАЛЬНА УМОВА АКАДЕМІЧНОЇ } \\
\text { ДОБРОЧЕСНОСТІ }\end{array}$ & 304 \\
\hline 69. & $\begin{array}{l}\text { Пономарьова В.Л., Захарченко В.В. } \\
\text { ПСИХОЛОГІЧНІ ОСОБЛИВОСТІ СІМЕЙ, ЯКІ ВИХОВУЮТЬ } \\
\text { ДИТИНУ З ОСОБЛИВИМИ ОСВІТНІМИ ПОТРЕБАМИ }\end{array}$ & 306 \\
\hline 70. & $\begin{array}{l}\text { СаЛЬНікова Т.В. } \\
\text { ПОДОЛАННЯ ОСОБИСТІСНИХ ДЕЗАДАПТАЦІЙНИХ } \\
\text { ПОРУШЕНЬ ВІЙСЬКОВОСЛУЖБОВЦІВ ТА ВОЇНІВ АТО/ООС } \\
\text { ЧЕРЕЗ РЕАЛІЗАЦІЮ «Я-КОНЦЕПЦЇઁ» }\end{array}$ & 310 \\
\hline 71. & $\begin{array}{l}\text { Стрижак А.С. } \\
\text { ВРАХУВАННЯ ПОТРЕБ ОСОБИСТОСТІ У МОЛОДШОМУ } \\
\text { ШКІЛЬНОМУ ВІЦІ ЯК ОСНОВА СОЦІАЛЬНОЇ УСПІШНОСТІ }\end{array}$ & 313 \\
\hline 72. & $\begin{array}{l}\text { СУЛіцЬКИЙ В.В. } \\
\text { ПРОБЛЕМИ СУЇЦИДАЛЬНОЇ АКТИВНОСТІ СЕРЕД } \\
\text { ЗАСУДЖЕНИХ В УСТАНОВАХ ВИКОНАННЯ ПОКАРАНЬ }\end{array}$ & 317 \\
\hline \multicolumn{3}{|c|}{ SOCIOLOGICAL SCIENCES } \\
\hline 73. & $\begin{array}{l}\text { Фоміна Л.В., Марчук І.А., Ревіна Т.Г., Паюк І.М. } \\
\text { ГЕНДЕРНИЙ АСПЕКТ У ВИЩІЙ МЕДИЧНІЙ ОСВІТІ }\end{array}$ & 322 \\
\hline
\end{tabular}




\section{TECHNICAL SCIENCES}

74. Бобылькова O.М., Егорова О.А., Алексеев Г.В.

ИССЛЕДОВАНИЕ ВЛИЯНИЯ ТЕРМОХИМИЧЕСКОЙ

ОБРАБОТКИ НА ВЫХОД ПЕКТИНА

75. Gorokhovatskyi V., Baryshnikova P.

FEATURES OF DISTANCE EDUCATION IN THE FIELD OF COMPUTER SCIENCE IN UKRAINE

76. Kalinichenko Y., Kalinichenko G., Aloshyn O., Mutychko O.,

Mankevych M.

THE HISTORY OF THE EMERGENCE AND DEVELOPMENT OF THE SYSTEM AMVER AND ITS ROLE IN SEARCH AND RESCUE AT SEA

77. Miroshnikov V., Savin O., Sobol V., Younis B.

METHOD FOR REDUCING WEIGHT DESIGN OF THE

STATICALLY DETERMINATE TRUSSES OF AEROSPACE

STRUCTURES

78. Syrotenko O.

ANALYSIS OF CLUSTERING METHODS IN THE PROBLEMS OF CONSTRUCTING SOCIAL GRAPH MODELS

79. Tvoroshenko I., Kharchenko A.

SOME ASPECTS OF MODERN DEVELOPMENT FOR SIGN LANGUAGE RECOGNITION SYSTEMS

80. Tvoroshenko I., Mahomet A.

ABOUT CLASSIFICATION OF THE METHODS IN DESIGN OF MEDICAL INFORMATION SYSTEMS

81. Zatula A., Gulak N.

PROTECTION OF ELECTRONIC DOCUMENTS BY MEANS OF AN ELECTRONIC DIGITAL SIGNATURE

82. Баева Т.Ю., Гречушкина В.П.

ПРЕПОДАВАНИЕ ДИСЦИПЛИНЫ «ПРИКЛАДНАЯ МЕХАНИКА» В СОВРЕМЕННЫХ УСЛОВИЯХ ВЫСШЕГО ОБРАЗОВАНИЯ 


\begin{tabular}{|c|c|c|}
\hline 83. & $\begin{array}{l}\text { Бандура В. } \\
\text { АНАЛІЗ ТЕХНОЛОГІЙ ФУНКЦІОНАЛЬНИХ ЖИРОВМІСНИХ } \\
\text { ПРОДУКТІВ }\end{array}$ & 366 \\
\hline 84. & $\begin{array}{l}\text { Білюк І.С., Савченко О.В., Шарейко Д.Ю., Гаврилов С.О., } \\
\text { Фоменко А.М. } \\
\text { БЛОК ЖИВЛЕННЯ СИСТЕМ АВТОМАТИКИ }\end{array}$ & 368 \\
\hline 85. & $\begin{array}{l}\text { Галкін А., Пиріг Я., Роман П. } \\
\text { УДОСКОНАЛЕННЯ МЕТОДУ ВИЗНАЧЕННЯ АДГЕЗЇ̈ } \\
\text { БІТУМНОГО В’ЯЖУЧОГО ДО ПОВЕРХНІ СКЛА }\end{array}$ & 371 \\
\hline 86. & $\begin{array}{l}\text { Герасимчук О.П. } \\
\text { ТЕХНОЛОГІЯ ХЛІБА ІЗ ПРОРОСЛОГО ЗЕРНА ПШЕНИЦІ }\end{array}$ & 379 \\
\hline 87. & $\begin{array}{l}\text { Корчак М.М. } \\
\text { ОБГРУНТУВАННЯ ПРОЦЕСУ УЩІЛЬНЕННЯ СТЕБЛОВИХ } \\
\text { ЗАЛИШКІВ КУКУРУДЗИ }\end{array}$ & 382 \\
\hline 88. & $\begin{array}{l}\text { Лисяк В.Г., Сабат М.Б., Шелех Ю.Л., Чечель В.О. } \\
\text { ВПЛИВ НЕСИНУСОЇДАЛЬНОСТІ НАПРУГИ НА РОБОТУ } \\
\text { ВУЗЛА НАВАНТАЖЕННЯ З КОНДЕНСАТОРНИМИ } \\
\text { УСТАНОВКИМИ }\end{array}$ & 387 \\
\hline 89. & $\begin{array}{l}\text { Майстренко А.А., ГУЛак Н.К. } \\
\text { ИНФОРМАЦИОННАЯ БЕЗОПАСНОСТЬ В СИСТЕМАХ } \\
\text { НЕПРЕРЫВНОЙ ИНТЕГРАЦИИ И ПОСТАВКИ }\end{array}$ & 392 \\
\hline 90. & $\begin{array}{l}\text { Потапенко М.В., Шаршонь В.Л. } \\
\text { ПРОГНОЗУВАННЯ ТЕХНІЧНОГО СТАНУ } \\
\text { ЕЛЕКТРОДВИГУНІВ В УМОВАХ ЕКСПЛУАТАЦІї }\end{array}$ & 397 \\
\hline 91. & $\begin{array}{l}\text { Савенко В.І., Гончаренко Т.А., КЛюєва В.В., Полосенко О.В., } \\
\text { Победа С.С. } \\
\text { ЗАГАЛЬНА ОРГАНІЗАЦІЙНА НАУКА О.О. БОГДАНОВА - } \\
\text { ТЕКТОЛОГІЯ-ОСНОВА ТЕОРЇ СИСТЕМ ТА МЕТОДОЛОГІІ }\end{array}$ & 400 \\
\hline 92. & $\begin{array}{l}\text { Філіпович Ю.Ю., МИшкаЛо Т.І. } \\
\text { “ЕКСПЕРИМЕНТАЛЬНІ ДОСЛІДЖЕННЯ } \\
\text { ГІДРОДИНАМІЧНИХ, ЕНЕРГЕТИЧНИХ І МАСООБМІННИХ } \\
\text { ХАРАКТЕРИСТИК ЕЖЕКТОРІВ ДЛЯ ОЧИЩЕННЯ } \\
\text { ПРИРОДНИХ І СТІЧНИХ ВОД” }\end{array}$ & 404 \\
\hline
\end{tabular}


93. Шубіна Л.Ю., Чорна Т.О., Куранда А.О.

АНАЛІЗ РИНКУ ТА ПОПИТУ ШОКОЛАДУ В УКРАЇНІ 


\section{СОЦІАЛЬНА РЕКЛАМА ЯК ЗАСІБ ЗМІНИ ПОВЕДІНКОВИХ ПАТЕРНІВ}

Болотова Вікторія Олександрівна,

канд. соц. наук, доцент

Харківській національний університет ім. В.Н.Каразіна

Шапарньова Лілія Дмитрівна

студентка соціологічного факультету Харківській національний університет ім. В.Н.Каразіна

У сьогоднішньому світі стрімких соціальних змін та появи нових, часто деструктивних практик людської поведінки важливого значення набуває розвиток методів вирішення соціальних проблем, адаптації цих методів до нових соціокультурних реалій. Швидкість змін, поширення практик толерантності та контроль за дотриманням прав людини роблять необхідним інформування широких верств населення про наявні проблеми та способи їх вирішення. Одним зі способів позитивного впливу на соціальні практики $є$ технологія соціальної реклами, яка дозволяе швидко охопити цільову аудиторії, використовуючи як традиційні так і нові медіа. Експерти вважають, що соціальна реклама сьогодні $\epsilon$ одним 3 інструментів підвищення ефективності управління соціальними процесами в суспільстві [1].

Соціальну рекламу як феномен соціального життя в своїх роботах розглядають Р. Барт, А. Дейян, Д. Бурстін, Ж. Бодрійяр, Ю. Габермас, У. Еко, Дж. Россітер, У. Уеллс, Л. Шиллер. Серед сучасних дослідників, які користуються соціологічним підходом, варті уваги праці В. Коломійця, I. Крилова, В. Музи, А. Романова, О. Савельєвої, Л. Федотової.

Загалом роль реклами полягає у поєднанні людських бажань 3 виробництвом та у подальшому створенням масового ринку, а також трансформації цих бажань в економічну функцію [2, с. 68].

Спеціалісти у сфері соціології реклами зазначають, що «загальною метою створення й упровадження соціальної реклами $є$ зміна ставлення громадськості до існуючих суспільних проблем, а в довгостроковій перспективі - формування позитивно спрямованої поведінки особистості, що грунтується на системі суспільно значущих цінностей» [3, С.69].

За оцінками експертів недоцільно «виокремлювати якийсь один пріоритетний вид соціальної реклами за способом іiї поширення (відео, аудіо, друковані види соціальної реклами, реклама на транспорті, інтернет тощо). Теоретики рекламної галузі відмічають важливість усіх перерахованих носіїв рекламної інформації. Проте важливо враховувати, що для кожного виду соціальної реклами притаманні характерні особливості. Аналізуючи 
ефективність соціальної реклами залежно від способу передачі, необхідно зважати також на соціально-психологічні особливості цільової аудиторії, на яку спрямована певна рекламна інформація» [3, С.73].

Необхідно зазначити, що існуючі на сьогодні теорії і моделі зміни поведінки говорять про те, що зміна поведінки окремої людини, суспільства або організації пов'язана 3 проходженням декількох етапів:

- відсутність поінформованості;

- стурбованість і бажання довідатися більше;

- набуття знань і вироблення певних навичок;

- підсилення мотивації до зміни поведінки і формування позитивного ставлення до можливої зміни поведінки;

- готовність до змін, що стимулює бажання випробувати нову поведінку.

Після спроби нових патернів поведінки людина оцінює їх. Якщо ця оцінка позитивна, то згодом ці патерни закріплюються і стають постійною практикою. Нарешті, людина, переконана в правильності своєї нової поведінки, починає активно пропагувати ії в колі своїх друзів, знайомих і колег [4].

А. Л. Тимошенко із посиланням на думку Ю. Саєнка, вважає, що «найпереконливішим критерієм ефективності будь-яких соціальних програм $\epsilon$ позитивна динаміка змін об'єкта або процесу, на який вони спрямовані. Для оцінки динаміки потрібен науково обгрунтований прогноз поширення цього явища. Зіставлення фактичного стану справ із даними прогнозу може стати загальним критерієм ефективності заходів, що реалізуються. Будь-які методи оцінки, засновані на вимірі цього критерію, будуть об'єктивними показниками успіху соціальної реклами» [3, С.76].

Для створення ефективної сучасної соціальної реклами, яка здатна впливати на свідомість людей, використовують багато різноманітних методик, зокрема: технологію емоційної пам'яті (особливо негативні емоції), дизайн подачі інформації, створення емоційних переживань, навіювання, використання стереотипів, ефект ототожнення тощо. За допомогою них можна покращити ефективність соціальної реклами, збільшити ії вплив на поведінку людей, змінити іiї на краще.

Як мінімум третина всієї соціальної реклами розрахована на молодь, тому що ця соціально-демографічна група $є$ майбутнім країни і майбутнім нації. У зв'язку 3 цим особливе значення має аналіз ефективності соціальної реклами у молодіжному середовищі, вивчення сприйняття соціальної реклами молоддю.

За даними пілотажного соціологічного дослідження, проведеного у 20192020 рр. серед харківської студентської молоді більше половини респондентів згодні з ствердженням що соціальна реклама - це спосіб формування певного ставлення суспільства до соціальних проблем та боротьби з ними. Найчастіше респонденти звертають увагу на рекламу, спрямовану проти шкідливих звичок та на підтримку здорового способу життя. Нажаль, наразі соціальна реклама має тільки поверхневий вплив - звертає увагу на проблеми, що підіймаються в рекламних повідомленнях менше половини опитаних, замислюються над цими проблемами вже кожен п’ятий, а про наявність змін у поведінці під впливом 
реклами згадує тільки кожен десятий. Вплив на поведінку чинить, переважно, реклама, яка спрямована на зміцнення сімейних і загально-людських цінностей та реклама проти шкідливих звичок і за підтримку здорового способу життя. Змушує замислитись над проблемами реклама милосердя та благодійності.

Таким чином, соціальна реклама $\epsilon$ перспективним інструментом впровадження соціальних змін, покращення ситуації з певними соціальними проблемами, проте для підвищення iï ефективності варто звернути увагу на можливості сучасних рекламних технологій та «нових медіа», нові методики психології та соціальної психології робити акцент на створення креативних продуктів,

\section{Список літератури}

1. Горбенко Г. В. Соціальна реклама та соціальні процеси в сучасному суспільстві: взаємозв'язок і взаємовпливи / Г. В. Горбенко // Бібліотекознавство. Документознавство. Інформологія. - 2013. - № 4. - С. 56-59. - Режим доступу: http://nbuv.gov.ua/UJRN/bdi_2013_4_12

2. Jones M.G. The Cultural and Social Impact of Advertising on American Society [Електронний ресурс] / M.G. Jones // Osgoode Hall Law Journal. - 1970. - Vol. 8. P. 65-89. - Режим доступу : http://digitalcommons.osgoode.yorku.ca/ohlj/vol8/iss 1/3

3. А. Л. Тимошенко Соціальна реклама в Україні: аналіз впливу на формування позитивно спрямованої поведінки молоді / Тимошенко А. Л. // Український соціум, 2006. - №2 (13). - С. 69-77. - Режим доступу: https://ukrsocium.org.ua/uk/archive/no-2-13-2006/socialna-reklama-v-ukraini-analiz-vplivu-naformuvannja-pozitivno-sprjamovanoi-povedinki-molodi/

4. Информационные кампании по ВИЧ/СПИДу: Пособ. для организатора / Алексеева Д. В., Алексеева Е. Г., Д. О. Камалдинов, О., Е. Ю. Яшина - Режим доступу:

https://www.unicef.org/kazakhstan/media/2456/file/\%D0\%9F\%D1\%83\%D0\%B1\%D 0\%BB\%D0\%B8\%D0\%BA\%D0\%B0\%D1\%86\%D0\%B8\%D1\%8F\%20.pdf 


\section{ОСОБЛИВОСТІ ВОДОЗАБЕЗПЕЧЕНОСТІ МЕЛІОРОВАНИХ ЗЕМЕЛЬ НА ПРИКЛАДІ ОСУШУВАЛЬНО-ЗВОЛОЖУВАЛЬНОЇ СИСТЕМИ «РОМЕН»}

Воропай Галина Василівна

к.т.н., завідуюча відділу дренажу Інститут водних проблем і меліорації НААН України

Молеща Неля Богданівна

к.т.н., провідний науковий співробітник Інститут водних проблем і меліорації НААН України

Ведення аграрного виробництва на осушуваних землях гумідної зони України характеризується недосконалістю системи управління водними ресурсами та меліорацією земель. Неврегульованість механізмів використання внутрішньогосподарських меліоративних систем унеможливлює залучення коштів на здійснення заходів 3 модернізації, реконструкції наявної інфраструктури площ водорегулювання [1].

Україна має один із найнижчих серед європейських країн показників забезпеченості власними водними ресурсами - лише 1 тис. м $^{3}$ місцевого стоку на одного жителя. До того ж сучасні зміни клімату негативно впливають на стан забезпечення водними ресурсами, що спричиняє зменшення природного атмосферного живлення поверхневих і підземних вод. Встановлено, що дефіцит кліматичного водного балансу в усіх природно-кліматичних зонах істотно збільшився. На сьогодні фіксується також зменшення стоку малих і середніх річок України в середньому на 15-20\%. А через зменшення інфільтраційного живлення грунтових вод в зоні Полісся та Лісостепу України відмічається значне зниження їх рівня [2].

Тому, успішне сільськогосподарське виробництво на меліорованих землях зони північного Лісостепу України можливе, за умови підвищення водозабезпеченості території за рахунок ефективного використання наявної інженерної інфраструктури гідромеліоративних систем, та при необхідності проведення відновлення та реконструкції окремих ділянок, впровадження ефективних новітніх технологій у режимі активного водорегулювання. Забезпечити оптимальний рівень водозабезпеченості меліорованих земель головне завдання водного господарства і продовжує залишатись однією 3 найактуальніших проблем сьогодення. Вирішення цього питання, можливе лише за умови впровадження сучасних технологій для забезпечення належного 
технічного рівня, якості, надійності та ефективності роботи інженерної інфраструктури гідромеліоративних систем [3-4].

Натурні дослідження в умовах змін клімату, зростаючого дефіциту водних ресурсів щодо водозабезпеченості територій осушуваних систем, визначення особливостей формування місцевого дренажного стоку та розрахунків потенційного регульованого об'єму акумулювання води проведені на ділянках осушувально-зволожувальної системи «Ромен» (Сумська область).

Дослідження включали визначення динаміки метеорологічних факторів (температури повітря, кількості опадів), вологості грунту в зоні аерації, рівня грунтових вод (РГВ), дренажного стоку, рівня і об'єму води в акумулюючій ємності. Водоресурсний потенціал осушувально-зволожувальної системи «Ромен» визначають гідрологічні умови, а саме місце розташування і основні геоморфологічні особливості території. Територія системи «Ромен» у гідрогеологічному відношенні знаходиться в межах Дніпровсько-Донецького артезіанського басейну. Водні ресурси осушувально-зволожувальної системи це частина природних запасів води, включають в себе: води річок, каналів, водосховищ, ставків інші водойми, болота, підземні води, грунтова волога, вологість повітря. Важливим критерієм який впливає на водоресурсний потенціал території $є$ також способи використання осушуваних земель та прилеглих територій (рілля, сінокоси, пасовища, лісонасадження тощо). Водні ресурси вимагають бережного до них ставлення 3 метою їх раціонального використання та охорони від забруднення. Особливо це актуально в період інтенсивного ведення сільськогосподарських робіт в умовах змін клімату, коли більшість сільськогосподарських культур вимагають для одержання проектних врожаїв додаткового зволоження, тобто щороку зростає водоспоживання. Осушувально-зволожувальна система «Ромен» побудована для меліорації боліт та заболочених земель у заплавах річок Ромен і Торговиця загальною площею 11900 га земель, у тому числі 2000 га орних. На меліоративній системі споруджені водосховища «Карабутове», «Чумалі», «Хрещатик» для проведення зрошення та зволоження. Карабутівське водосховище було побудоване на системі «Ромен» для багаторічного зрошення та зволоження даної системи в посушливі роки. Проте в 2019-2020 рр., гостро засушливих роках, воно не змогло виконати запроектовані функції, через недостачу об'ємів води. Карабутівське водосховище, найбільше водосховище північного Лісостепу, має площу водяного дзеркала при нормальному підпірному рівні (далі-НПР) 5,02 км² (відмітка НПР 145,5 м)та повну ємність 12,97 млн.м², корисну 11,97 млн.м³. Сезонне водосховище «Чумалі» побудоване на річці Малий Ромен має площу водяного дзеркала при НПР - 110 га (відмітка НПР 139,5 м) та повну ємність 1,3 млн.м ${ }^{3}$, корисну 1,07 млн.м³ з'єднано з МК системи «Ромен».

Багаторічне водосховище «Хрещатик» має площу водяного дзеркала при НПР - 86 га (відмітка НПР 132,5 м)та повну ємність 3,2 млн.м³, корисну 2,9 млн.м³ з'єднано з МК системи «Ромен».

Меліоративна система включає руслові шлюзи, акумулюючу ємність, відкриту та закриту мережу. Наповнення акумулюючої ємності здійснюється шляхом збору дренажно-скидних вод та самопливом з магістрального каналу (р. 
Ромен). Подача води на зволоження з ємності на ділянки проводиться також самопливом [4].

Особливості погодних умов у період 2016-2020 рр. проявляються у тому, що у зазначений 5-річний період значно менше норми випало опадів у серпні та вересні, а також суттєве зменшення за останні два роки осінніх та зимових опадів. Протягом 2016-2020 pр. середньомісячна температура повітря за вегетаційний період в усі роки була близькою до середніх багаторічних значень, проте середньорічна температура за цих п’ять років на $1,9{ }^{\circ} \mathrm{C}$ збільшилася у порівнянні з кліматичною нормою.

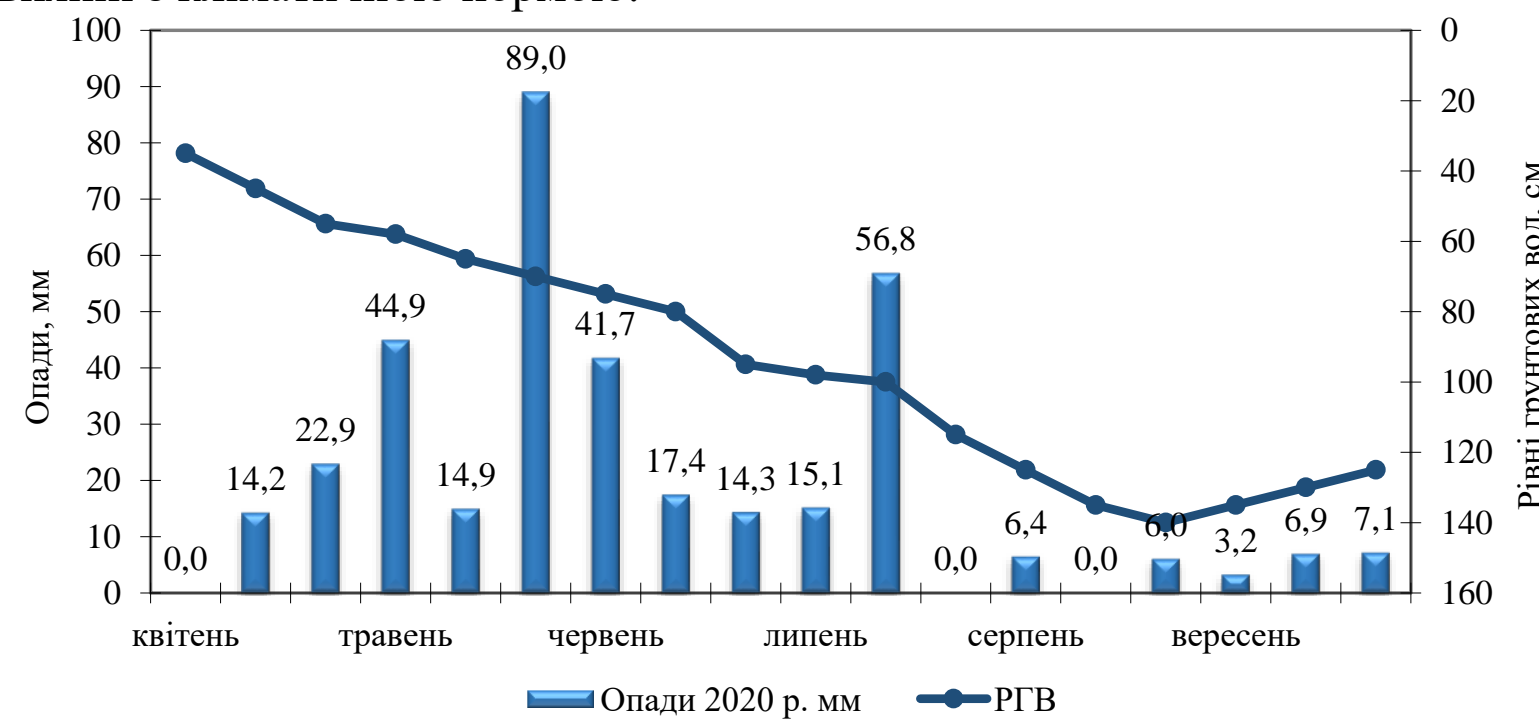

Рис. 1. Динаміка атмосферних опадів та РГВ на дослідній ділянці (ОЗС «Ромен») 2020 p.

Динаміку РГВ впродовж вегетаційного періоду на осушуваних торфових грунтах представлено на рис. 1. Як видно з рисунку, опади в кількості 148,5 мм у травні, чи 73,4 мм у червні та 72 мм у липні суттєво не впливали на положення грунтових вод. Отже, РГВ на дослідній ділянці впродовж вегетаційного періоду знаходилися в межах: у весняний період - 35-70 см, у літній період - 70-140 см, восени - 140-125 см від поверхні грунту. При цьому, вологість кореневого шару грунту залежала від кількості атмосферних опадів та живлення ГВ.

Таким чином, за останні п'ять років відзначається зміна кліматичних умов водозабезпеченості північного Лісостепу, що приводить до зниження зволоженості території. Наведені показники вказують, що досліджуваний об'єкт в середньому не дуже посушливий, хоча $є$ кожного року посушливі (бездощові) періоди, в яких протягом десяти і більше днів не спостерігаються опади, або їх добова кількість не перевищує 1 мм, що вимагає додаткового зволоження в посушливі вегетаційні періоди. Середній гідротермічний коефіцієнт протягом вегетаційного періоду 2016-2020 pp. досліджуваної території північного Лісостепу становить 1,0 - зона не дуже посушлива, хоча 40 \% випадків, 35 років спостерігаються посушливі і дуже посушливі періоди [5]. 
Таблиця 1.

Рівні та об'єм води в акумулюючій ємності у вегетаційний період 2020 року, ОЗС «Ромен»

\begin{tabular}{|c|c|c|}
\hline Місяць & Рівень води, м & Об'єм води, тис. $\mathbf{~}^{3}$ \\
\hline Квітень & 3,4 & 37,4 \\
\hline Травень & 3,5 & 38,5 \\
\hline Червень & 3,2 & 33,0 \\
\hline Липень & 2,1 & 23,1 \\
\hline Серпень & 1,1 & 12,1 \\
\hline Вересень & 1,3 & 14,3 \\
\hline
\end{tabular}

В літній засушливий період 2020 року коли випало за липень - серпень лише 82 мм опадів, що на 40 мм менше багаторічних даних, на дослідних ділянках проводити підгрунтове зволоження грунтів, подачею води 3 акумулюючої ємності, виявилося неможливим через малі об'єми води у ємності, а також неможливість використовувати шлюзування із верхнього б'єфу магістрального каналу за допомогою руслового шлюзу, через недостатні рівні води в магістральному каналі (табл.1). Рівні у магістральному каналі Конотопське МУВГ старалося регулювати підняттям шахт на Карабутівському водосховищі, проте це не дало бажаного результату через малі об'єми води у самому водосховищі. Катастрофічне зменшення об'ємів води в гостро засушливому 2017, 2019 роках призвело до незворотних процесів наповненості водосховища. Тому починаючи з 2017 року по 2020 рік включно, воно не змогло виконувати запроектовані функції, через недостачу об'ємів води у водосховищі. Об'єми води у 2020 р. зменшилися проти 2019 р. в деякі періоди на 2,5 млн. м². Причиною стали аномальна осінь - зима 2019-2020, тобто гідрометеорологічні умови спричинили обмеження у використанні води, а маловоддя водосховищ та річки Ромен призвело до пересихання малих ставків,водотоків та невеликих річок. Абсолютно ніякого глобального впливу на водність на НПР водосховища та гідрологічний режим р. Ромен не мали інтенсивні опади у травні 2020 року. Причина низької водності даної системи відсутність метеорологічної зими, відповідно не було сніготанення, що стало основною причиною неможливості сформувати весняне водопілля. Через відсутність води після танення снігу, бо снігонакопичення не було, річка Ромен, водосховища та акумулююча ємність не змогли наповнитися водою. Також прямий вплив на водність системи мають збільшення температури, а отже збільшення коефіцієнта випаровування 3 поверхні водойм.

Зростання сумарного випаровування спричинить подальше зневоднення території України та зменшення доступних для використання запасів поверхневих та підземних вод [3].

В цілому водоресурсний потенціал осушувально-зволожувальної системи «Ромен» можна охарактеризувати як недостатній. У маловодні роки відчувається істотний дефіцит води навіть у великих водосховищах та річках. Враховуючи зміни клімату потрібно більш раціонально та ефективно використовувати водні ресурси. 
Встановлені суттєві зміни водозабезпеченості меліорованих систем в зоні північного Лісостепу України, що призвело до зміни водного режиму на цих територіях та пересушення земель на значних площах, особливо в маловодні роки 3 дефіцитом атмосферних опадів. Водночас зменшились водні запаси в басейнах малих річок, які являються водоприймачами меліоративних систем, що унеможливило здійснення гарантованого двобічного регулювання водного режиму на осушуваних землях впродовж вегетаційного періоду

Зміни клімату спричиняють не тільки зростання середньорічної температури повітря в зоні північного Лісостепу, одночасно відбувається катастрофічне погіршення умов природного вологозабезпечення, яке зумовлене значним підвищенням сумарного випаровування.

Підвищити водозабезпеченость меліоративних систем в умовах змін клімату, зростаючого дефіциту водних ресурсів можливо шляхом забезпечення ефективного управління водним режимом осушуваних грунтів, що досягається завдяки створенню резервних об’ємів води в акумулюючій ємності за рахунок накопичення поверхневого та дренажного стоку. Це дасть змогу створити оптимальні умови водного режиму в кореневмісному шарі грунту, але не скиданням надлишкової вологи, а нагромадженням іiі у акумулюючих ємностях та подальшому використовувати рослинами у посушливі періоди вегетації на основі систем управління вологозабезпеченням сільськогосподарських культур на меліорованих землях.

\section{Список літератури}

1. Стратегії зрошення та дренажу в Україні на період до 2030 року: Розпорядження Кабінету Міністрів України від 14 серпня 2019 р. № 688-р.

2. Ромащенко М. І. та ін. Вплив сучасних кліматичних змін на водні ресурси та сільськогосподарське виробництво. // Меліорація і водне господарство. 2020. № 1. C. 5-22.].

3. Кузьмич Л.В., Козицький О.М., Усатий С.В., Мозоль Н.В. Аналіз водозабезпеченості меліорованих земель у межах осушувальної системи «Мар’янівка» Рівненської області.// Вісник аграрної науки. 2021, №3 С.7077.

4. Яцик М.В., Воропай Г.В., Молеща Н.Б. Підвищення водозабезпеченості меліоративних систем гумідної зони.// Меліорація і водне господарство. 2016. Вип.103. С.63-68.

5. Воропай Г. В., Молеща Н. Б. Оптимальні параметри водорегулювання при вирощуванні кормових культур на осушуваних землях північного Лісостепу України.//Theory, practice and science. Abstracts of XXIII International Scientific and Practical Conference. Tokyo, Japan. 2021. Pp. 21-25. 


\title{
ПРОБЛЕМИ РАЦІОНАЛЬНОГО ВИКОРИСТАННЯ ОСУШЕНИХ ЗЕМЕЛЬ В УКРАЇНІ
}

\author{
Трускавецький Роман Степанович, \\ доктор сільськогосподарських наук, професор, \\ Національний науковий центр «Інститут грунтознавства i \\ агрохімії імені О.Н. Соколовського», м. Харків
}

За різними оцінками в Україні налічується біля 4.5 млн. га надмірно зволожених (гідроморфних) грунтів (болотних, заболочених, підтоплених i затоплених), в тому числі органогенних (торфових) - 1.07 млн. га. Орієнтовно $75 \%$ площ перезволожених грунтів зосереджено в поліських та західних регіонах України. В названих регіонах осушувальні меліорації відносять до одного із основних заходів сприяння сталому аграрному та сільському розвитку. Переважна більшість земельних масивів заплавних територій Лівобережного Лісостепу України також піддано осушувальним меліораціям (осушувальні системи «Смолянка», «Трубіж», «Оржиця», «Недра» та інші).

Найбільш масштабних розмірів осушувальні меліорації досягли в період 1964-1990 pр., коли щорічно вводилось в експлуатацію для залучення в інтенсивне сільськогосподарське використання в середньому до 100 тис. га земель з осушувальною мережею (переважно з відкритою системою каналів).. Загальна площа осушуваних земель в 1990 році сягнула 3.1 млн. га (брутто) та 2.6 млн. га (нетто). Після цього та 3 проголошенням незалежності, роботи 3 будівництва та реконструкції дренажних мереж в Україні припинились, Використання осушених земель в даний час вкрай незадовільне - значну частину їх закинуто, а цілі масиви цих земель 3 деградованим грунтовим покривом та 3 дренажною мережею, що вийшли з ладу, постійно зростає. Такий стан негативно впливає на обсяги виробництва традиційної для поліських регіонів соціально значимої та ринково затребуваної рослинницької продукції (льон-волокно, житнє зерно, картопля, хміль, трав'яний корм, люпин, тощо). Дана обставина в свою чергу обмежує можливості відродження та розвиток тваринницької галузі. Водночас естетичний та екологічний стан навколишнього природного середовища на осушених землях істотно погіршився.

Свій початок осушувальні меліорації на території України беруть ще 3 дорадянських часів. Відомі об'ємні осушувальні роботи на Поліссі, здійснені експедицією генерала царської армії Російської імперії І. Жилінським (1893-1897 pp). Згодом (1914-1936рр.) відбулась організація Сарненської, РудняРадовельської і Панфільської дослідних станцій 3 проблем культури землеробства на осушених торфових грунтах. Висока ефективність осушувальних меліорацій проявилась ще на перших, побудованих австрійськими і польськими землевласниками в Західній Україні, дренажних системах, частина 3 яких функціонує до цього часу. Дренажні роботи в той час проводились виключно на земельних ділянках з потенційно високо родючим грунтовим покривом. Натомість в радянський період домінував плановий 
принцип „валового” підходу, що призвів до залучення в меліоративний фонд значної кількості земель низької якості. Окрім цього, масштаби осушувальних меліорацій в більшості випадків перевищували можливості господарюючих суб' єктів вчасно освоювати та ефективно вести землеробство на осушуваних землях 3 різноманітним грунтовим покривом. Запроектовані рівні урожаю сільськогосподарських культур, як правило, не досягались.

3 урахуванням сучасної соціально-депресивної ситуації та відсутності цивілізованих земельних відносин в багатьох селах і селищах північних та західних регіонів України, ефективне вирішення проблеми осушувальних меліорацій та раціонального використання наявного фонду осушених земель $\epsilon$ вельми актуальним та перспективним за умов реалізації принципово нових підходів. В даний час більшість розвинутих країн світу надають пріоритет екологічним функціям гідроморфних грунтів. Залучення їх в інтенсивне сільськогосподарське використання здійснюється тільки за умов екологічної, економічної та соціальної доцільності. Екологічна значимість гідроморфних ландшафтів в Україні, як правило, недооцінюється, не дивлячись на те, що Україна володіє незрівнянно 3 іншими державами багатим чорноземним ресурсом. В унісон існуючого досвіду багатьох країн світу, Україні вкрай необхідні спеціальні програми, спрямовані на відтворення біосферних функцій та біорозмаїття гідроморфних, передусім, торфово-болотних ландшафтів. Україна нуждається у проведенні масштабних робіт 3 ренатуралізації (реанімації) осушених торфовищ, що зазнали деградації та промислового видобутку. Поряд з цим важливо впроваджувати екологічно адаптовані методи і способи реконструкції дренажних систем, що побудовані на принципах локально-мобільного водорегулювання, завдяки чому землекористувачі позбавляються ризиків негативного впливу несприятливих, в тому числі i екстремальних, погодних умов на ведення землеробства та забезпечується стабільна урожайність.

В найближчій перспективі в Україні доцільно зосередитись виключно на відновлювальних дренажних роботах - реконструкції та модернізації існуючих осушувальних мереж. Ці роботи доцільно здійснювати на окремих земельних ділянках 3 високим потенціалом родючості. Водночас важливе значення набувають роботи 3 облагороджування окремих об'єктів навколишнього природного середовища, їх упорядкування (русла малих і середніх річок, старорічищ, блюдець, водоймищ, куртин, переїздів та інших інфраструктур) із влаштуванням спеціальних екологічних ніш на водостоках, окремих земельних ділянках, що гармонійно вписуються у місцевий ландшафт. Біогеоценотичне урізноманітнення структури гідроморфних ландшафтів, розширення природоохоронних територій як еколого-стабілізуючих земельних угідь створює сприятливі умови для відродження цінної болотної фауни і флори, зокрема рідкісних видів лікарських та ягідних рослин.

Особливого підходу вимагають осушені торфово-болотні землі як специфічні та екологічно надто вразливі природні об'єкти різновекторного використання, а саме: біогеоценотичного (заказники, заповідники, біосферники), торфовидобувного (торфове паливо, органічні і органо-мінеральні добрива, 
торфові субстрати та інша торфова продукція), сільськогосподарського - для вирощування культурних рослин переважно кормової цінності, рідше овочевих та енергетичних. За екологічними і економічними оцінками названі вектори використання можуть виявитись надто контрастними. Звідси випливає, що проблеми комплексної оцінки та диференціації вибору напряму використання різноманітних за своєю природою торфових ресурсів України в даний час $\epsilon$ архіактуальними. Не можна нехтувати i недооцінювати соціальну значимість для окремих регіонів Полісся торфу як місцевого енергетичного ресурсу. На жаль, нерегульований, безсистемний і стихійний видобуток торфу, безтурботне відношення до рекультивації і ренатуралізації вироблених торфовищ, згубні наслідки торфових пожеж, спрацювання і гідрофобізація торфу на осушених землях - всі ці явища наносять непоправні екологічні, економічні та соціальні збитки регіонам їх поширення, а в загальному й державі. Тому розумінням неприпустимості подальшого зволікання з провадженням екологічно вивірених заходів з раціонального використання осушуваних торфових земель повинен пройнятись кожний, від кого залежить доля осушених торфовищ.

Із 2.6 млн. га осушуваних земель під ренатуралізацію доцільно відвести близько 650 тис. га 3 подальшим уточненням після проведення відповідної земельної інвентаризації. Проекти ренатуралізації (реанімації) і створення еколого-стабілізуючих угідь $є$ актуальними та соціально важливими. Їхня реалізація сприятиме урівноваженню вуглецевого бюджету, зменшенню викидів в атмосферу парникових газів та відновленню біорізноманітності.

Реконструкцію і модернізацію існуючих меліоративних систем доцільно провести орієнтовно на загальній площі 1,2 млн. га 3 подальшим уточненням після інвентаризації осушених земель. Враховуючи традиційний скотарський напрям в розвитку поліського агровиробництва, на осушених землях раціонально створювати спеціалізовані фермерські господарства 3 виробництва вітамінних трав'яних кормів та організації культурних пасовиськ. Не слід забувати, що культурні пасовиська, як показала практика, дають самий дешевий трав'яний корм, що поїдається на корню. Слід рекомендувати, заохочувати i надавати відповідну фінансову підтримку землекористувачам для створення прибуткових спеціалізованих фермерських господарств на осушуваних землях. .

Землі поверхневого гідроморфізму (перезволожені) використовують аналогічно староорним автоморфним землям, проте значна частина 3 них вимагає раціонального поєднання дренажних (водовідводних) конструкцій 3 агротехнічними прийомами меліорації грунтів (вапнування, глибоке розпушення, гребенево-грядова технологія, тощо).

В завершенні слід зазначити натупне: в контексті ринкових земельних відносин, сталого соціального розвитку та в умовах глобальних змін клімату вирішення проблем раціонального використання осушених гідроморфних грунтів базується на необхідності впровадження інноваційних методів і способів мобільного водорегулювання, гармонізації продуктивних і екологічних функцій грунтового покриву, врахування соціальної та бізнесової привабливості залежно від напрямку землекористання, державної фінансової підтримки та створення комфортних умов для залучення вітчизняних і іноземних інвесторів в процес 
сільськогосподарського освоєння та ефективного використання закинутих осушених земель 3 потенційно родючим грунтовим покривом. Важливо також не ігнорувати сучасною парадигмою меліорації земель, яка передбачає необхідність враховувати такі основоположні постулати як ресурсозбереження, продовольча, екологічна, енергетична та оборонна безпеки держави, соціальне відродження сільських населених пунктів, зміна депресивного розвитку окремих регіонів на сталий прогресивний. 


\title{
АДАПТАЦЙНІ ЗАХОДИ ЯК ЗАПОРУКА ВПРОВАДЖЕННЯ ІНКЛЮЗИВНОЇ ОСВІТИ
}

\author{
Skorokhodova Alina \\ Кандидат архітектури, доцент \\ Харківський національний університет міського господарства \\ імені О.М. Бекетова
} Створення доступного середовища життєдіяльності для осіб з обмеженими
фізичними можливостями залишається одним із значущих напрямків
внутрішньої соціальної політики багатьох країн світу, включно з Україною
$[1,2,3,4,5,6]$ У межах ініціативи першої леді Олени Зеленської «Без бар'єрів»,
спрямованої на створення рівних можливостей для всіх українців, зокрема -
розбудову універсального публічного простору, дружнього до маломобільних
груп населення та сімей 3 дітьми, підписано Меморандум про розвиток безбар'єрної архітектури. Мета документа - залучення населених пунктів і територіальних громад України до процесу розвитку доступного для маломобільних груп населення середовища та напрацювання найкращих практик у створенні універсального публічного простору [7].

Архітектурна проблематика, спрямована на забезпечення соціальної рівності людей 3 обмеженими можливостями відбивається у професійній термінології. При проведенні цілеспрямованих робіт по даній темі використовуються терміни: проектування «безпечної», «безбар'єрного», «безконфліктної», «комфортної» середовища. У останні роки частіше вживається термін проектування «універсальної середовища», що найбільше відповідає ідеї соціальної рівності людей. У останні десятиліття проводиться багато наукових досліджень, i виконуються експериментальні проекти по темі проектування універсальної середовища [8,9]. На сучасному етапі розвитку в багатьох містах України можна спостерігати подальший процес укрупнення структур вищих навчальних закладів: об'єднуються ВН3 різних профілів і створюються національні дослідницькі університети. Цей процес відповідає єдиної стратегії в галузі освіти. Концентрація інтелектуальних і технічних ресурсів дозволяє отримати більший економічний ефект, також і ми маємо можливості легше вирішити соціальних проблем, в тому числі в плані створення умов та навчання студентів 3 обмеженими можливостями.

В ряду завдань, пов'язаних зі створенням універсальної середовища освітні установи займають особливе місце, оскільки просторова доступність дитячих садів, шкіл, університетів відповідає правам рівності всіх громадян на отримання освіти. У багатьох містах і сільських районах України, в рамках цільових державних i регіональних програм, реалізуються проектні розробки. Уряду інвестую значні кошти в реконструкцію столичних міст, створюючи рівні умови 
просторової доступності для їх жителів, зокрема, з 2004 року в Києві реалізується програма «Безбар'єрне середовище». Але, на жаль, надання особливих умов для вступу до вузів студентів-інвалідів в дійсності не $\epsilon$ виправданим у разі, якщо вузи не мають просторові, технічні та методичні можливостями для їх навчання. Існують різні види фізичних і сенсорних обмежень i, природно, абсолютно різні потреби в плані пристосування навколишнього середовища. Значна зміна інфраструктури потрібна для повноцінного життя людей 3 серйозним порушенням опорно-рухового апарату, зору і слуху.

На сьогоднішній день маємо розроблені вимоги до доступності при проектуванні, до них відносяться: організації безбар'єрного маршруту; вимоги до спеціального обладнання спеціальних учнівських місць (компенсує); до систем індивідуального вспоможения при пересуванні та фіксуванні тіла при сидінні; до додаткового інженерного обладнання і можливості управління ним. При визначенні складу необхідних адаптаційних прийомів і засобів особливу увагу необхідно приділялася забезпеченню зручності просторової орієнтації і безпеки пересування осіб з вираженими порушеннями в сенсорної сфері, а також тих, хто змушений пересуватися за допомогою допоміжних опор або на інвалідному кріслі-колясці. Так, слід враховувати: ділянки шляху, що відрізняються складністю просторової орієнтації, вони обладнуються 3 обох сторін напрямними турнікетами, а також додатково виділяються пристроєм спеціального дорожнього покриття 3 акустичною плиткою, яка завдяки порожнини всередині здатна істотно посилювати звук кроків, якщо по йде людина; особливо складні та небезпечні ділянки, які характеризуються, наприклад, близьким примиканням до проїжджої частини вулиці, наявністю перепадів висот, схильністю дії різних шумових, механічних та інших відволікаючих або травмуючих чинників, виділяються додатково прийомом штучного зміни поздовжнього ухилу шляху, пристроєм за кілька кроків попереджає рельєфною смуги, а також нанесенням спеціальної сигнальної розмітки, яскраво контрастує із загальним фоном дорожнього покриття; необхідно передбачати висадку остропахнущіх квітів і квітучих чагарників, які виступають в даному випадку в якості природних ароматичних орієнтирів, розрахованих на загострений нюх сліпих. Істотну допомогу незрячим в здійсненні ними дистанційних переміщень повинна надавати єдина система направляючих тактильних смуг, безперервно йдуть від найближчих зупинок громадського транспорту до вхідних дверей основних навчальних корпусів вишу; деякі види тактильно-кінестетичних і звукових орієнтирів необхідно передбачати в рішеннях внутрішніх комунікаційних просторів, наприклад, у напрямку до актової зали або їдальні та т.п.

Практична реалізація даних пропозицій буде мати першорядне значення для осіб, що пересуваються на інвалідних кріслах-колясках, а також для всіх тих, хто має будь-які порушення в сфері сенсорного та опорно-рухового апарату або страждають загальною ослабленою організму. Це в рівній мірі відноситься як до студентства, так i до професорсько-викладацькому та обслуговуючому персоналу вузу, в числі яких можуть бути люди з інвалідністю або, наприклад, фізично ослаблені люди похилого або похилого віку. Серед інших значущих 
адаптаційних заходів, слід називати певні зміни, що вносяться до функціонального та об'ємно-планувальних рішень деяких структурних підрозділів вищого навчального закладу з метою створення повноцінних i безпечних умов навчання студентів, які мають інвалідність.

Ці зміни продиктовані необхідністю врахування специфічних потреб даного контингенту студентів, необхідністю проведення 3 ними спеціальної педагогічної та корекційно-відновлювальної роботи, надання всілякої супровідної підтримки i допомоги. Впровадження в реальну практику проектування описаних вище пропозицій сприятиме більшій відкритості вузів по відношенню до осіб, які мають будь-які фізичні обмеження. Але головний соціальний та одночасно економічний ефект від реалізації запропонованих наукових розробок буде полягати в тому, що значна частина молоді 3 інвалідністю отримає можливість безперешкодно навчатися у вищих навчальних закладах, здобувати професії, відповідні їх прагненням і станом здоров'я, - що, в кінцевому підсумку, створить вагомі передумови для їх більш прискореної і більш поглибленої інтеграції в основну частину суспільства.

\section{Список літератури:}

1. Про введення в дію Закону Української РСР «Про основи соціальної захищеності інвалідів в Українській РСР» [Текст] : Постанова Верховної Ради Української РСР від 21 березня 1991 року № 876 XII // Відомості Верховної Ради України. 1991. № 21. С. 555.

2. Про внесення змін до Закону РСР «Про основи соціальної захищеності інвалідів в Українській РСР» [Текст] : Закон України від 14 жовтня 1994 року № 204/94-ВР // Відомості Верховної Ради України. 1994. № 45. С. 234-239.

3. Burkhauser, R. V. Disability and work: the experien cas of american and german men [Текст] / R. V. Burk hauser, M. C. Daly // Economic Review. 1998. № 2. P. $17-$ 29. 22. Gleeson, B. Disability and the open city [Текст] / B. Gleeson // Urban Studies. 2004. Vol. 38, № 2. P. 251-265.

4. Gray, D. B. Environmental barriers and disability [Текст] / D. B. Gray, J. E. Bickenbach // Journal of Architectural and Planning Research. 2003. № 20(1). P. 2937.

5. Gudden, A. Overcoming Barriers to Employment: Strategies of Rehabilitation Providers [Текст] / A. Gudden // Journal of visual impairment and blindness. 2005. № 6. P. 1-20.

6. Malakpa, S. Problems and prospects in employment and job retention of the blind and visually impaired in the United States: a future concern of special education [Текст] / S. Malakpa // International Journal of Special Education. 2007. № 1. P. 5358.

7. https://www.president.gov.ua/ru/news/u-mezhah-iniciativi-oleni-zelenskoyibez-baryeriv-pidpisano-65229 (дата звернення 23.09.2021)

8. Schuelka, M. J. A faith in humanness: disability, religion and development [Текст] / M. J. Shuelka // Disability \& Society. Vol. 28, № 4. P. 500-513. 
9. Терягова А. Н. Архитектурная концепция формирования безбарьерной городской средыдля пожилых людей: диссертация кандидата архитектуры: 18.00.01. - Самара, 2006. - 157 с.: ил. + Прил. (87с.: ил.). 


\title{
СУЧАСНЕ ОЗДОБЛЕННЯ ФАСАДІВ
}

\author{
Петриковська Алла Анатоліївна, \\ спеціаліст вищої категорії, викладач-методист \\ викладач будівельних дисциплін
}

Відокремлений структурний підрозділ «Рівненський фаховий коледж Національного університету біоресурсів і природокористування України»

\section{Малимон Стефанія Стефанівна}

викладач-методист, спеціаліст вищої категорії викладач землевпорядних дисциплін, екології

Відокремлений структурний підрозділ «Рівненський фаховий коледж Національного університету біоресурсів і природокористування України»

Екстер'єр будинку є його візитною карткою. Але, крім архітектурнохудожньої вимоги, оздоблення фасаду будинку повинне бути практичним. Фасад $\epsilon$ тією оболонкою, яка захищає всі архітектурні елементи будівлі від впливу зовнішніх факторів і допомагає підтримувати потрібний мікроклімат всередині. Все це говорить про важливість вибору правильного матеріалу для оформлення фасадів.

На оформлення фасаду впливає безліч факторів, у тому числі: природні умови місця розташування будинку, зовнішній вигляд навколишнього середовища, потреба в додатковій теплоізоляції, а також бажання чи небажання архітектора проявити свою індивідуальність.

При оформленні фасаду будь-якого будинку, необхідно визначитися 3 матеріалом і кольором обробки.

Одним із типів обробки фасадів є лиџьова цеегла і клінкерна плитка для фасаду будинку

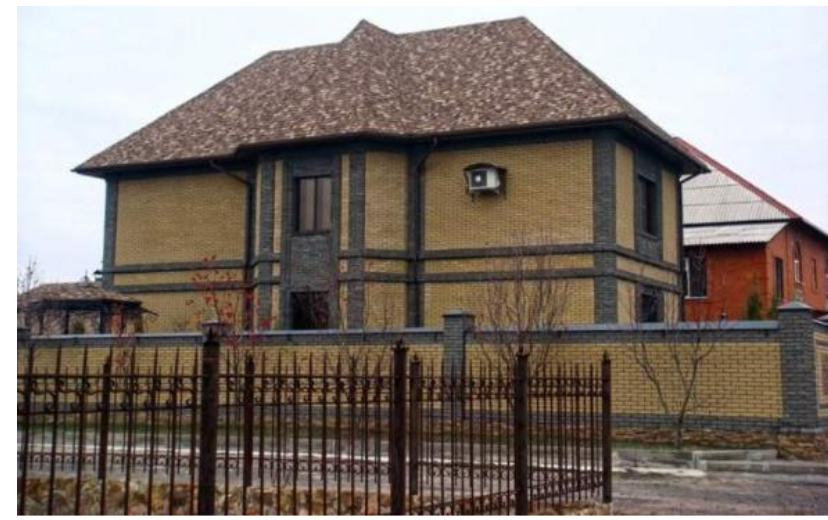

Рис.1 Оздоблення фасаду будівлі клінкерною плиткою

Навіть якщо будинок побудований не з цегли, йому можна надати такий же виразний вигляд, як у цегляного, оздобивши його лицювальною цеглою або клінкерною плиткою. Така обробка фасаду будинку пропонує велику кількість колірних рішень і варіантів оформлення лицьової сторони: глянцева, матова, 
рифлена і глазурована. Стіни будівлі, вкриті цеглою або клінкерною плиткою, не бояться вологи, та, при необхідності, їх можна мити.

Оформлення фасаду приватного будинку каменем

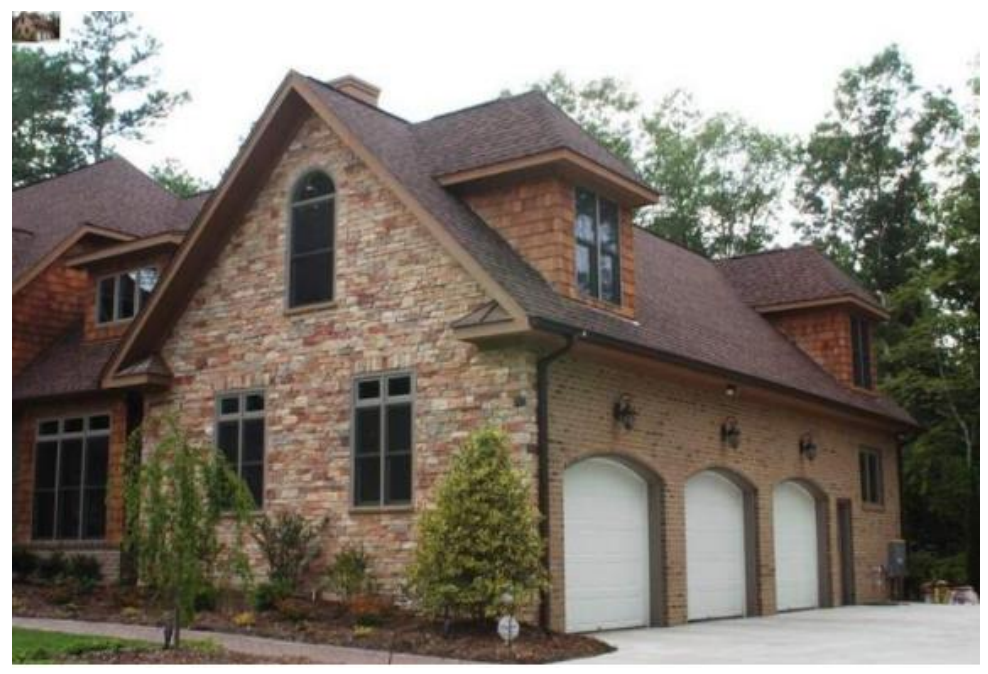

Рис.2 Оздоблення фасаду будівлі натуральним каменем

Оздоблення фасаду натуральним каменем є, мабуть, самим довговічним покриттям, яке стійке до всіх атмосферних впливів і здатне не псуватися протягом десятиліть.

Штучний камінь випускається в широкій колірній гамі різних відтінків та текстур, що імітують різні породи каменю, а за властивостями він практично ідентичний натуральному, але коштує дешевше. Істотний мінус такого покриття - це велика вартість самих матеріалів та вартість облицювальних робіт.

Варто окремо виділити варіант дизайну фасадів будинків з керамогранітною обробкою. Керамограніт $є$ сучасною заміною натуральному граніту. Таке облицювання не тільки чудово виглядає, але і не боїться атмосферного впливу та $є$ довговічним.

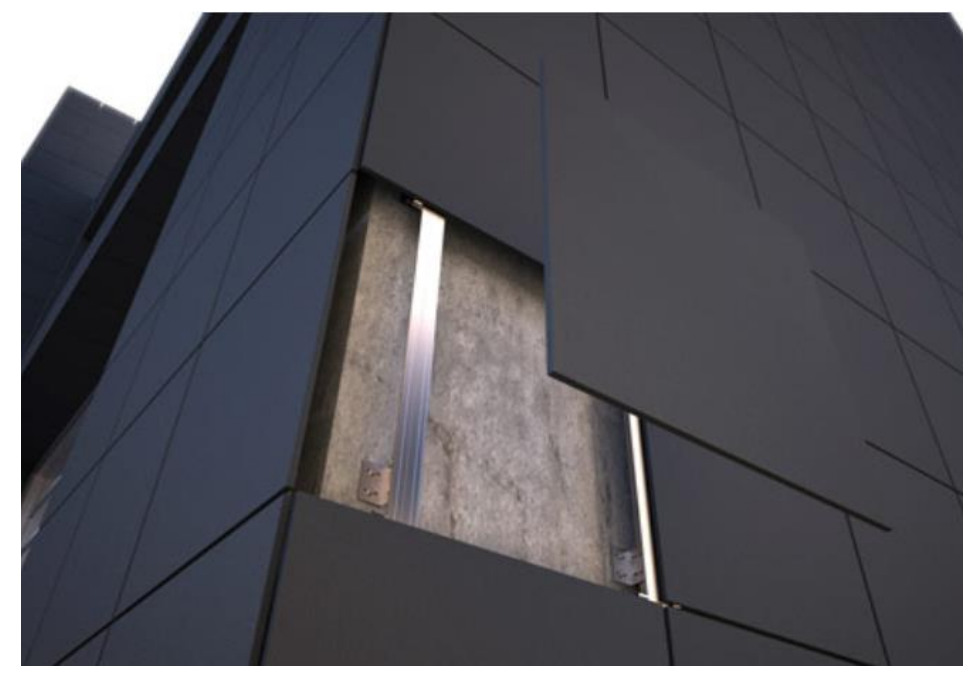

Рис.3 Оздоблення фасаду будівлі керамогранітом

Клінкерна цегла - це будівельний матеріал особливої міцності. Він виготовляється зі спеціальної глини, яка $€$ екологічно-чистою та володіє тугоплавкими властивостями. Також твердіючи, перетворюється в будматеріал, який здатен прослужити до 100 років. 


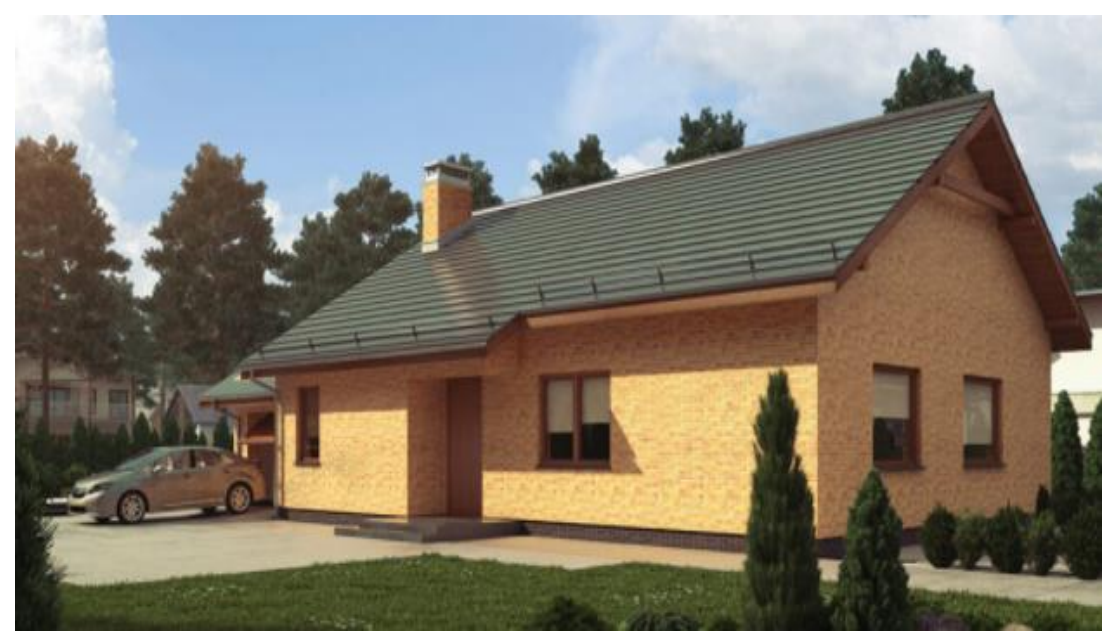

Рис.4 Оздоблення фасаду будівлі клінкерною цеглою

\section{Переваги клінкерної цегли:}

- першою, і найважливішою особливістю є ï експлуатація до 100 років без обов'язкових щорічних профілактичних та облицювальних робіт для підтримання відмінного зовнішнього вигляду споруди чи будівлі. Адже, поріг міцності на стиск цегли клінкерної становить до 350 кг/см². Будматеріал досить міцний для застосування не лише як лицювальний виріб, а й в якості несучих та самонесучих стін, також витримує динамічні навантаження. Клінкер здатний поглинати до 5\% води, не збільшуючись в об'ємі, як це буває 3 іншими будматеріалами. Значно легше аналогічних виробів, маючи пустотність до $30 \%$. Має стандартні розміри: $250 * 120 * 65 \mathrm{Mм}$, які підходять для різних проектних рішень. Цегла клінкерна здатна витримати до 210 циклів заморожування за умови повної 100\% атмосферної вологості;

- цеглу клінкерну можна виготовити також будь-якої форми чи то прямокутник 3 рівними кутами, чи то обрізна форма, ромбоподібна або кругляста. Існує величезна палітра кольорів для забарвлення продукції, вибір текстури цегли для будь-якого проекту;

- цегла клінкерна застосовується в багатьох будівельних проектах - ця особливість обумовлена величезною різноманітністю видів продукції;

- універсальний будматеріал, може використовуватися на будь-якому будівельному майданчику. Цегла, через естетичність вигляду, високу міцність, застосовується для облицювальних робіт внутрішніх, зовнішніх стін, будівництва великомасштабного об'єкту. Маючи різноманітну форму, цегла клінкерна часто застосовується для влаштування вуличних тротуарів, майданчиків, парковок.

Отже, володіючи певною універсальністю, виріб широко застосовують в різних сферах будівництвах:

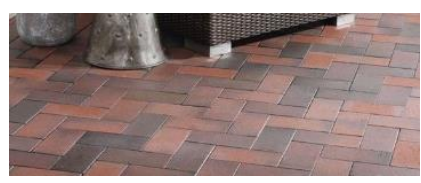

1. тротуарна - виходячи 3 назви, вид цегли широко застосовується для викладання тротуарів, доріжок, містків, дитячих і автомобільних майданчиків; 


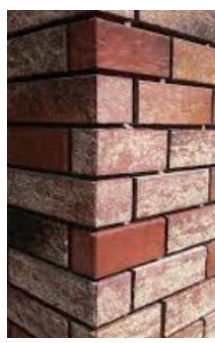

2. клінкерна плитка - вид будматеріалу має своє застосування виключно для облицювальних робіт, використовується для зовнішньої і внутрішньої обробки будівель, приміщень;

3. цегла клінкерна, що володіє кислотостійкими властивостями. Така цегла застосовується в місцях будівництва, де споруда активно контактує 3 шкідливими природними факторами (наприклад, в місцях дотику будівлі 3 грунтом);

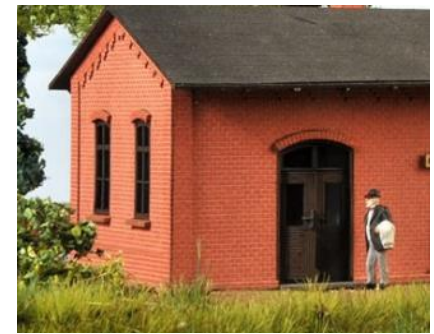

4. клінкер спеціалізованого призначення, цей вид цегли застосовується в місцях будівництва, де є будматеріал нестандартних форм - 3 обрізними кутами, круглястої, ромбоподібної форми.

За допомогою цього штучного каменю досить легко створювати горизонтальні ряди, а при створенні вертикальних шарів необхідно застосовувати метод перев'язки швів.

Винайдено цей матеріал був відносно давно, виготовляли його спочатку ручним способом. Промислові масштаби виробництво розпочало ближче до середини 19-го століття. Сьогодні цегла клінкерна облицювальна виробляється у величезних обсягах, так як користується великою популярністю в будівельній галузі.

Вартість цегли залежить від декількох факторів. В першу чергу на ціну впливає популярність виробника. Технологія виробництва цих виробів удосконалилася, що дає можливість виготовляти різні види цього матеріалу за прийнятною ціною. За сферою застосування клінкерна цегла поділяється на такі види:

- лицьова;

- вогнетривка;

- дорожня (бруківка);

- кислототривка.

Тому, виходячи з наведених характеристик, клінкерна цегла - будматеріал, що володіє високоміцною структурою. Маючи універсальність, водостійкість і морозостійкість, відмінний зовнішній вигляд, активно застосовується на більшості будівельних майданчиках. Якщо використовувати цеглу для обробки будівлі, вона буде відрізнятися естетичним зовнішнім виглядом, якщо для кладки внутрішніх стін - така кімната буде мати відмінну звукоізоляцію, буде зберігати тепло у I кліматичному районі, та створювати затишок у літню спеку.

Список літератури:

1. Пащенко Т.М., Світла 3.І. Будівельне матеріалознавство : навч. посібник . - Київ : Аграрна освіта, 2013. - 330 с. 
2. ДБН В.2.6-33:2018 Конструкції зовнішніх стін із фасадною теплоізоляцією. Вимоги до проектування. - К. : Мінрегіон України, 2018. - 25 с.

3. URL: https://www.moebo.de/

4. URL: https://zeusceramica.com/lookbook/view/ventilated_facades 


\title{
ART HISTORY
}

\section{PAIN SYNDROME IN ART}

\author{
Makieieva Nataliya \\ $\mathrm{MD}, \mathrm{PhD}$, professor, chief of the department of pediatrics №2 \\ Kharkiv National Medical University \\ Odinets Yuriy \\ $\mathrm{MD}, \mathrm{PhD}$, professor of the department of pediatrics №2 \\ Kharkiv National Medical University \\ Poddubnaya Iryna \\ $\mathrm{MD}, \mathrm{PhD}$, assistant professor of the department of pediatrics №2 \\ Kharkiv National Medical University
}

Kulikova Daria

$\mathrm{MD}, \mathrm{PhD}$, junior researcher of the department of ultrasound and clinicalinstrumental diagnostics and minimally invasive interventions of the State Institution "Institute of General and Emergency Surgery named after V.T. Zaitsev National Academy of Medical Sciences of Ukraine ", Kharkiv

It is difficult to find a person who has not experienced pain at least once in his life. Since time immemorial, people have looked at pain as a harsh and inevitable companion. Pain is a physiological phenomenon that informs us about harmful effects that damage or pose a potential danger to the body. Carl von Baeyer from the University of Saskatchewan (Canada), in collaboration with the Pain Research Unit, modified the facial pain scale, which is called the modified facial pain scale. Each of the images presented in the scale received a digital rating in the range from 0 to 10 points (1).

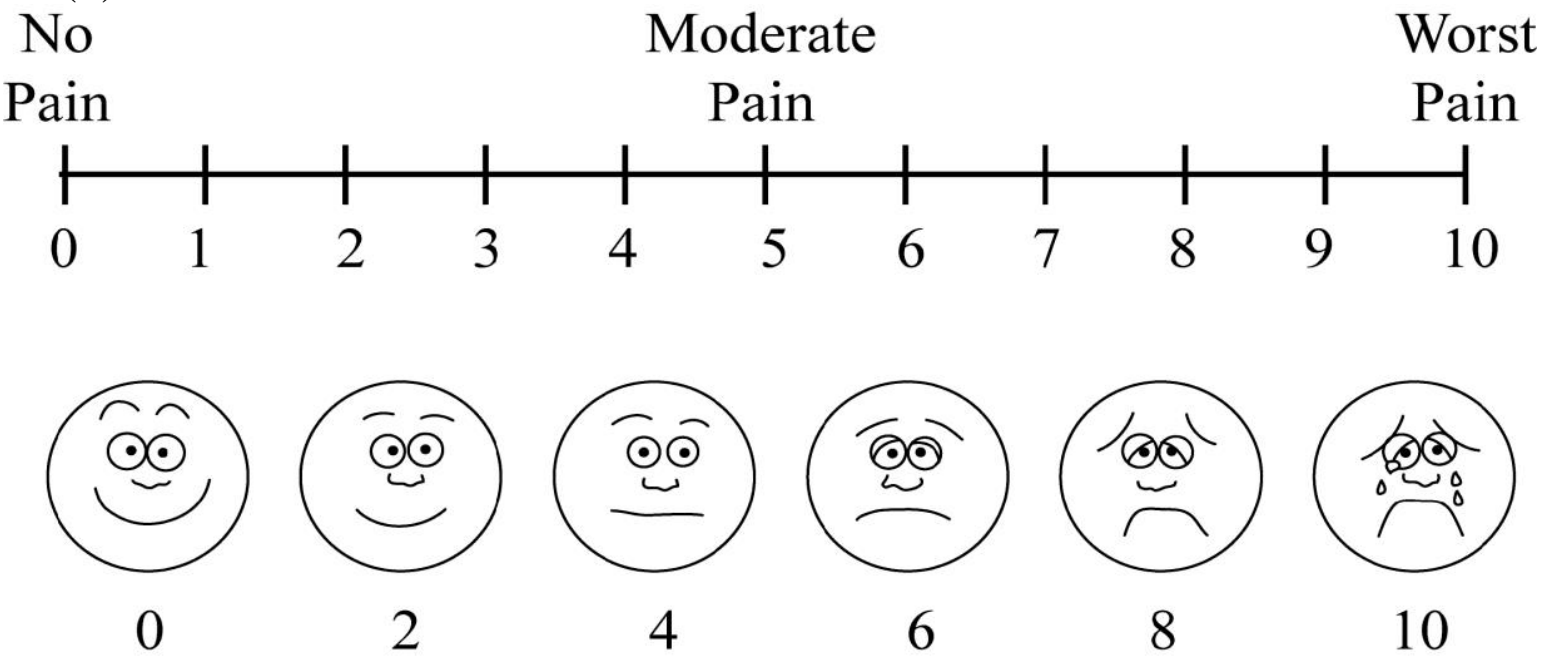

Figure 1. Visual analogue scale pain assessment tool 
Measuring pain seems to be a complex set of problems, and the definition of pain pathology remains as much an art as it is a science.

The sculptural group of Laocoon is a famous statue of the Hellenistic period, which impresses the viewer with a calculatedly strong effect of physical suffering. The bronze original of the sculpture of Laocoon was made at the turn of the 3rd-2nd centuries BC in Pergamum and has not reached our time. The well-known statue is a marble copy of the second half of the 1st century BC, excavated in 1506 on the site of the famous Golden Palace of Emperor Nero. The find was immediately examined by the architect Giuliano da Sangallo and the sculptor Michelangelo Buonarroti. They came to the conclusion that it was the work of ancient glorification mentioned by Pliny. Pope Julius II ordered the installation of a sculpture of Laocoon in the Vatican Belvedere.

Agesander, Polydorus and Athenodorus, the painters who made the magnificent sculpture depicting Laocoon and his sons, belonged to the Rhodes school. The priest Laocoon, mentioned in the myths about the Trojan War, occupies the center of the group, and his two young sons are entwined with two huge snakes, and suffer mortal torment. The sculptural group of Laocoon is rightly called a tragedy in three acts.

The middle act is depicted by the figure of the father, in which energy and pathos reach the highest degree. The muscles of the strong body tensed with pain, the chest rose from the difficulty of breathing; the abdomen retracted from the effort with which the complaint escapes from the open mouth. But in the terrible torment of the body, the spirit of Laocoon retains firmness, restrains the expression of pain; grieving for the suffering of children reduces the father's sense of his own suffering. Laocoon makes a complaint, but does not shout; on his face a slight expression of indignation, reproach for undeserved punishment; the wrinkles of his forehead show that the strength of the soul is still struggling with physical pain.

In July 1798, the sculptural group of Laocoon was taken to France: Bonaparte, who was engaged in a methodical robbery of Italian artistic treasures, took it from the defeated pope as an indemnity. After the overthrow of Napoleon, Laocoon was returned to Rome.

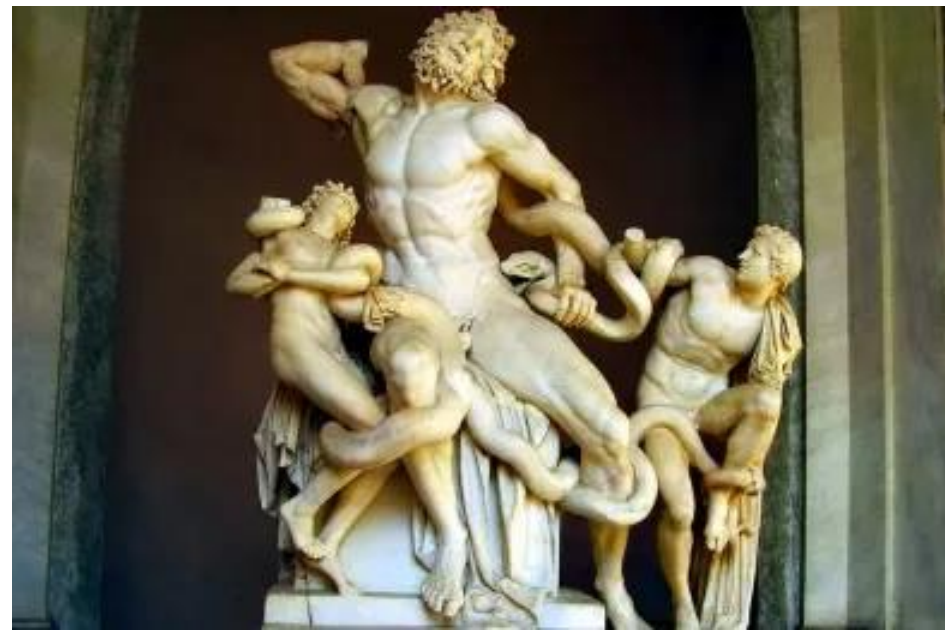

Figure 2. Agesander of Rhodes, Polydor, Athenodorus

Laocoon and his sons. 50 BC NS.

Marble, Pio Clementino Museum, Vatican

Tiziano Vecellio 
Sisyphus, the founder of Corinth, was the most cunning of all mortals. Once he revealed the whereabouts of Zeus to the river god Ason for his promise to lead the river to the Corinthian Upland. Ason kept his word and hammered the famous source of Pyrene from the rock. Zeus decided to punish the treacherous Sisyphus and sent Thanatos (Death) to him. But the cunning king put her in strong chains, so that not a single person in the country could die. Finally, the god of war Ares came and freed Death, while he cast Sisyphus into the underworld. But even here Sisyphus managed to deceive the gods. He forbade his wife to make funeral sacrifices on it. Their absence angered the entire underworld, and Persephone allowed Sisyphus to return to earth to remind the negligent wife of her responsibilities. When he returned, the cunning Sisyphus did not even think about returning to the underworld and again happily lived in his luxurious palace. Once, when he was sitting at the table, enjoying rich meals, Death suddenly entered and brought him back to the underworld. An athletic figure, illuminated by the last sunset rays of the sun, is textured and expressively sculpted, a muscular body tightly merged with a stone block, not yielding to it in hardness. It creates a simple physical sensation of stopping the flow of time and the endlessness of the heavy useless labor of the ancient hero. Sisyphus must have been tormented by the realization that no trick would help in this work, no less than its fruitlessness.

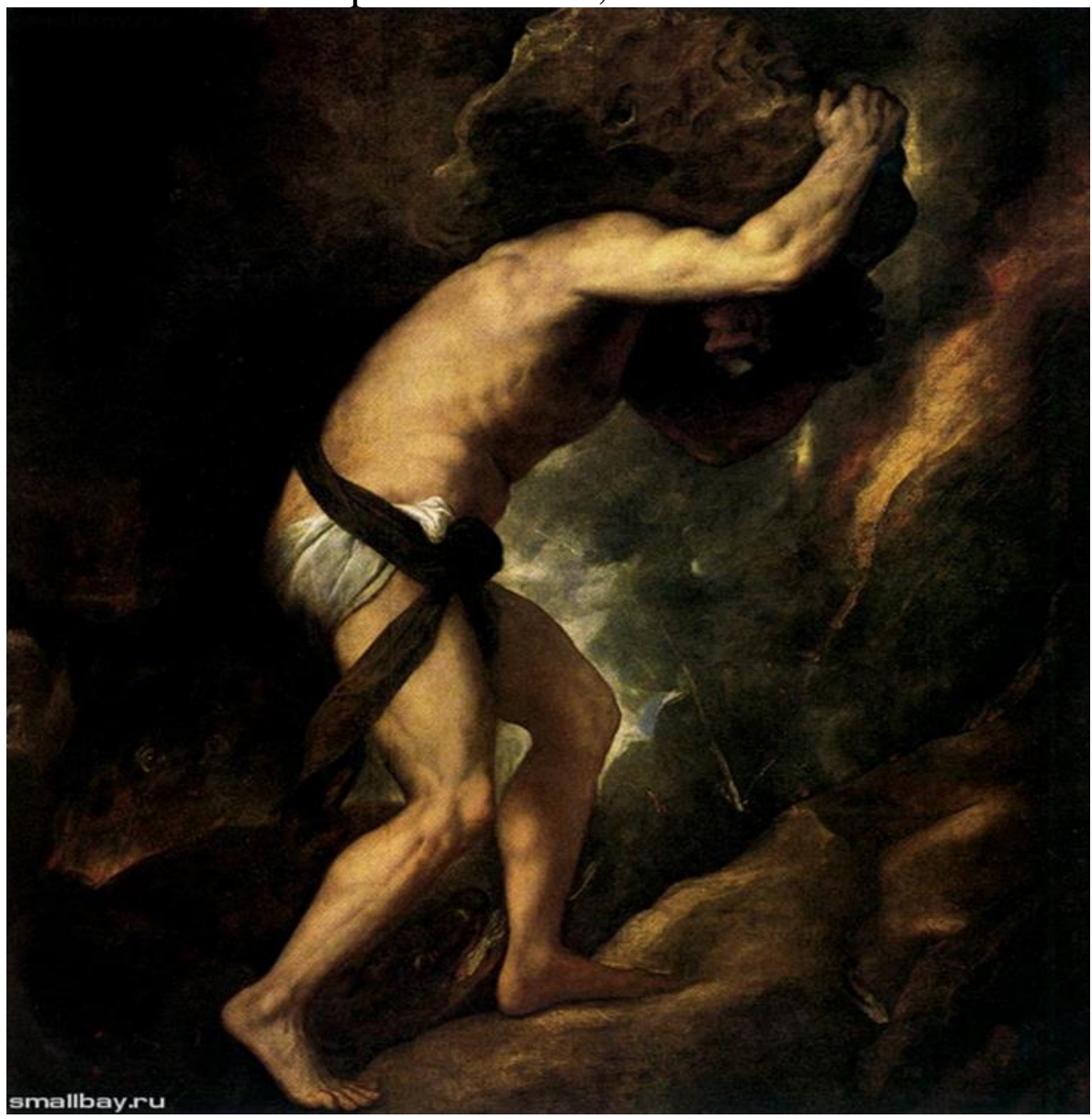

Figure 3. Tiziano Vecellio, 1545.

Sisyphus, Gallery Platina, Palazzo Pitti, Florence

Assereto Gioacchino "Tantalus" 
For the first time, when Tantalus hid the golden dog stolen by Pandareus and swore to Hermes that he did not know about it, Zeus limited himself to a serious warning. The second time he did not forgive him. First, Tantalus doubted the omniscience of the gods and decided to put them to the test. Secondly, Tantalus did it in the most disgusting way: he killed his son Pelop, cut him into pieces, fried him, garnished with an appetizing side dish and served to the gods. Zeus doomed Tantalus to eternal torment in the underworld of Hades: Tantalus stands up to his throat in clear water, but cannot quench his thirst - as soon as he bends down, the water recedes. Branches with juicy fruits hang over his head - oranges, figs, pears, apples, grapes - but as soon as Tantalus reaches out to them, the wind lifts the branches. In addition to eternal thirst and hunger ("Tantalum torments"), he is tormented by eternal fear, as a huge rock hangs over him, ready to fall on him at any second.

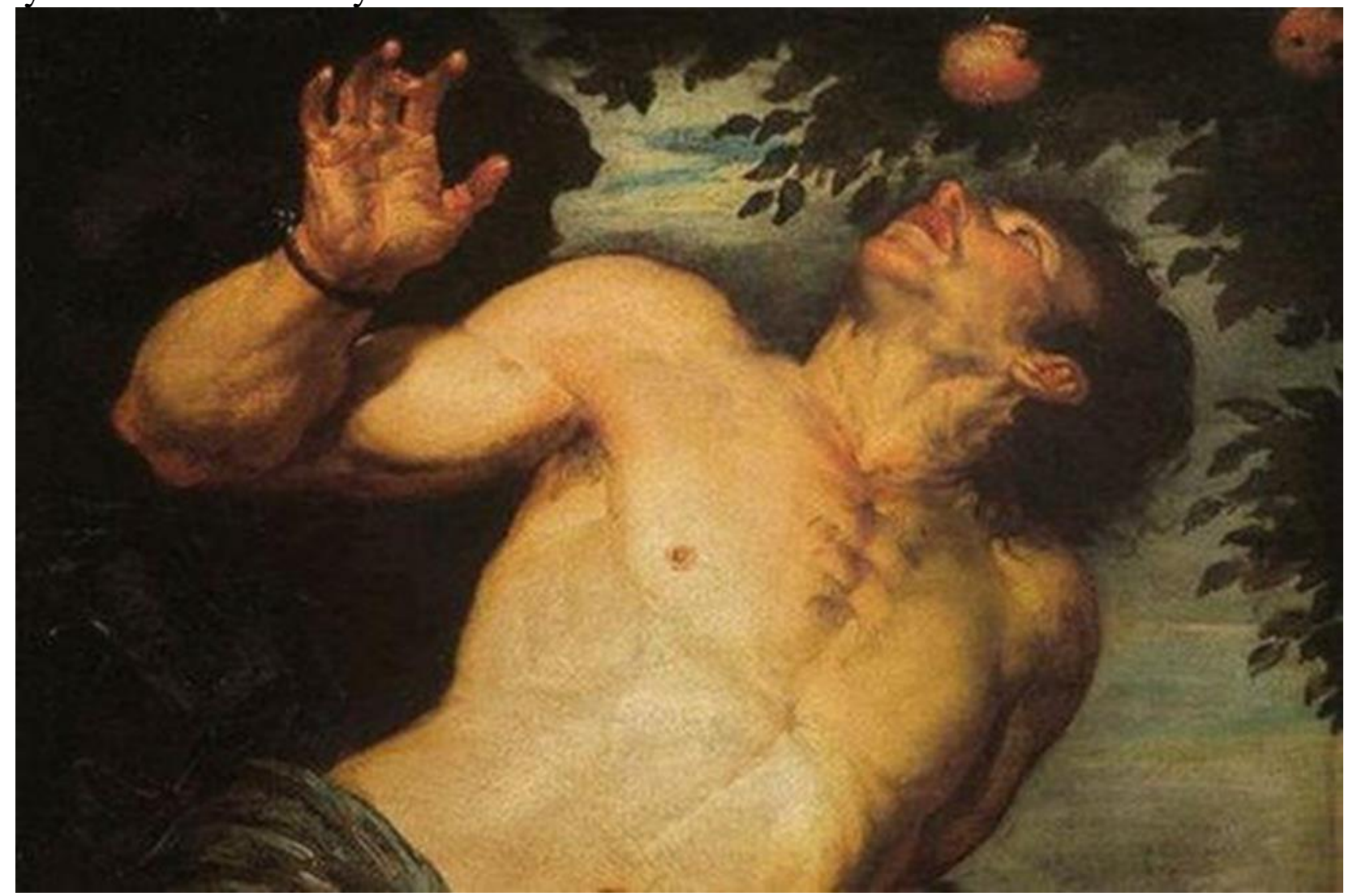

Figure 4. Assereto Gioacchino "Tantalus" 1630s. Auckland Art Gallery Toi Tamaki

\section{Peter Paul Rubens}

The suffering of Prometheus became an extremely popular subject among artists of the Baroque era - primarily because the torment, to which the powerful body of the sinned hero is subjected, gave wide scope for imagination and gave the paintings the dramatic intensity that artists loved so much in the period from 1550 to 1700 . Prometheus taught people to build dwellings, to know the time of the ascent of heavenly bodies and their ways, taught to count, write, find out the future, make sacrifices; taught them the art of medicine, navigation, and other knowledge that serves the good of life. The myth of Prometheus is a myth about the awakening of human selfawareness, about the struggle and suffering that accompanies this awakening. 


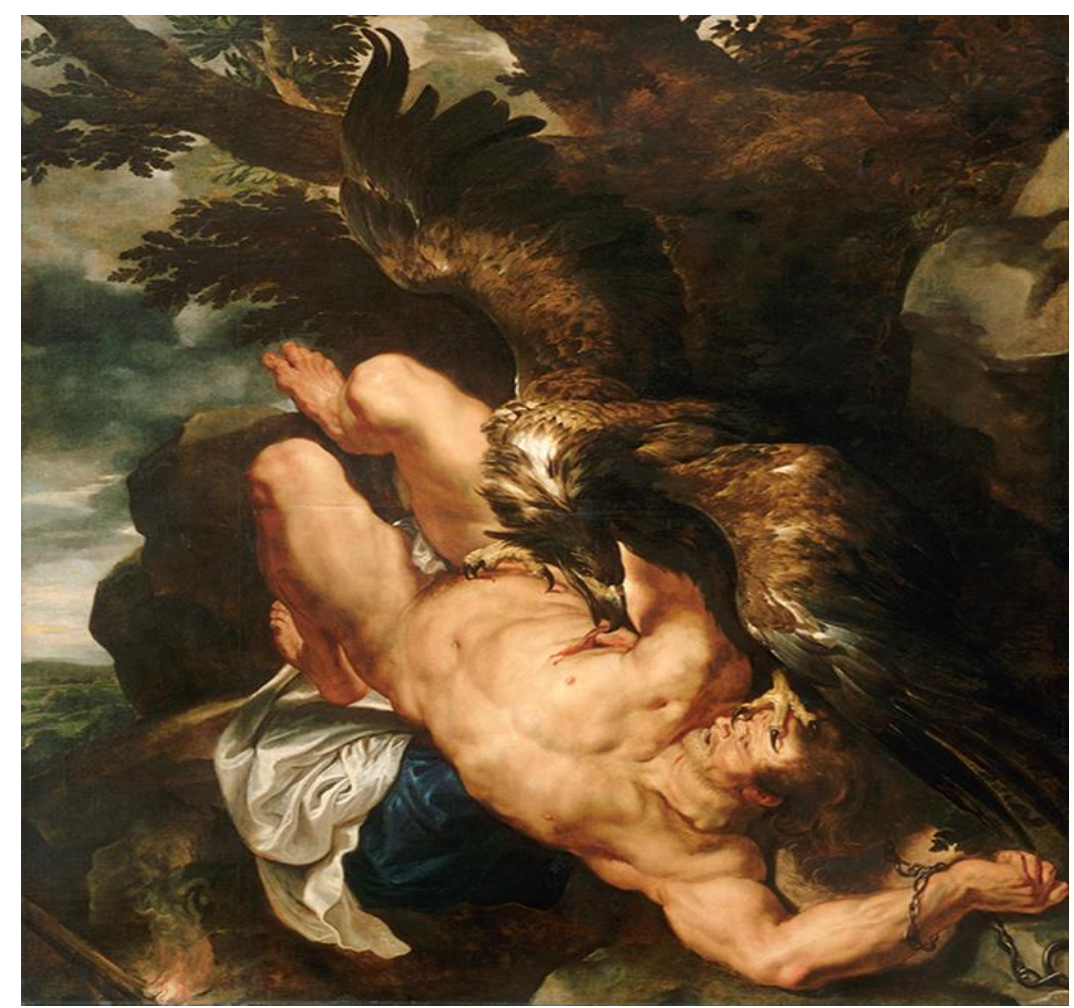

Figure 5. Peter Paul Rubens. Prometheus chained, 1610-1612

Museum of Art, Philadelphia

\section{Guido Reni}

In his painting "Saint Sebastian", Reni portrayed a hero whose body was pierced by arrows. Sebastian doubled over in pain and stared up at the sky. The play of chiaroscuro, skillfully used by the artist, gives the saint's body more pronounced volumes and texture.

Sebastian was the head of the Praetorian Guard under the emperors Diocletian and Maximilian. He secretly professed Christianity, which was revealed when two of his friends were condemned to death for their faith. Sebastian came to support the condemned, and his speech inspired the brothers and convinced them to remain faithful to Christianity. Sebastian was arrested and interrogated, after which the emperor Diocletian ordered him to be taken out of the city, tied and pierced with arrows. Thinking he was dead, the executioners left him alone, however none of his vital organs appeared to have been damaged by the arrows, and his wounds, though deep, were not fatal. A widow named Irina came at night to bury him, but found that he was alive, and nursed him. Many Christians persuaded Sebastian to flee Rome, but he refused and appeared before the emperor with new evidence of his faith. This time, by order of Diocletian, he was stoned to death, and his body was thrown into the Great Cloaca. The saint appeared in a dream to the Christian Lukina and ordered her to take his body and bury it in the catacombs, and the woman fulfilled this command. 


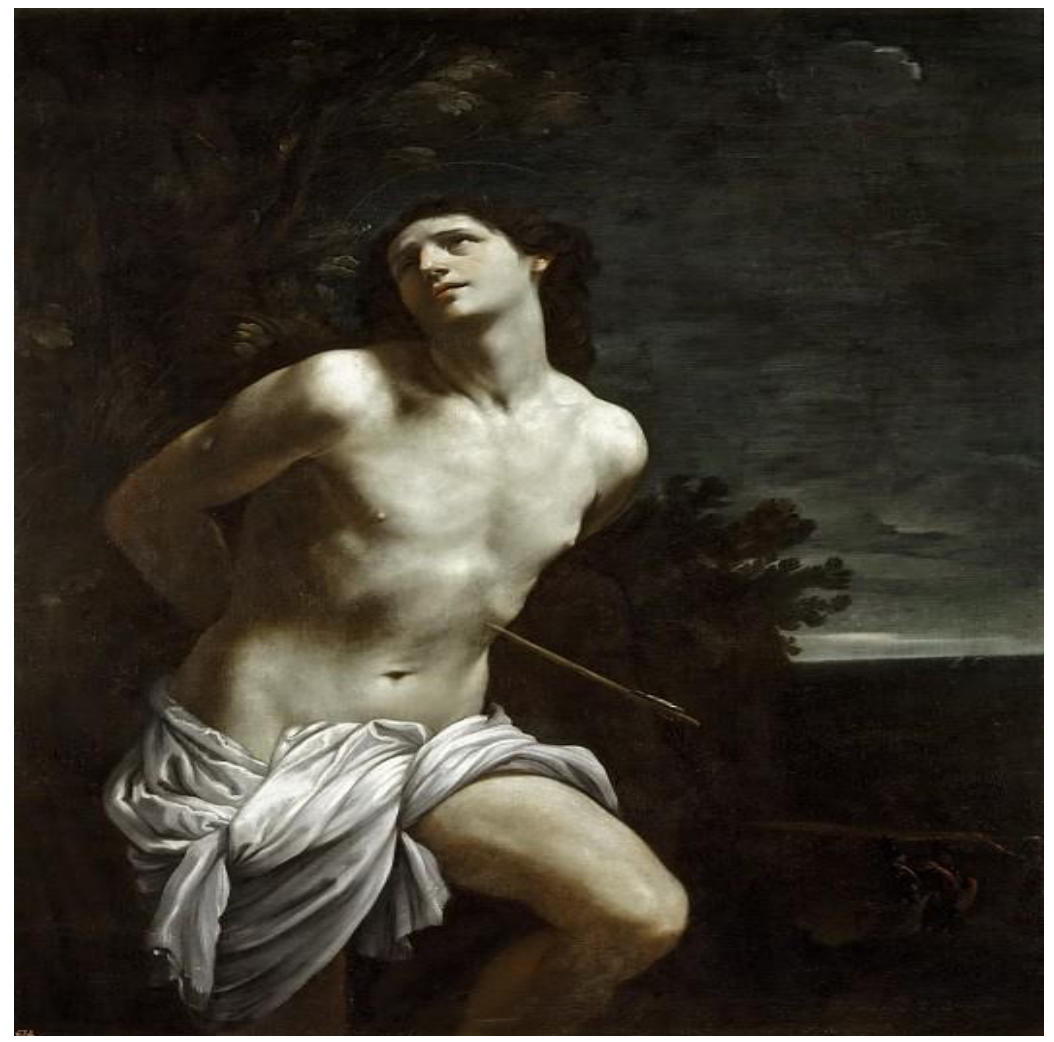

Picture 6. Guido Reni, Saint Sebastian, Prado Museum, first half of the 17th century

\section{Edgar Degas}

Degas' painting was discovered at Sotheby's in October 2010. "The Laundresses" were stolen from the museum in 1973, but the auction house was unaware of this, as the painting did not appear on the lists of stolen art objects. The owner of the painting, French collector Ronald Grelsamer, claimed to have received it as a gift from his father. According to the American authorities, Grelsamer intended to demand compensation for the painting. The painting returned to France, where it is considered a national treasure.

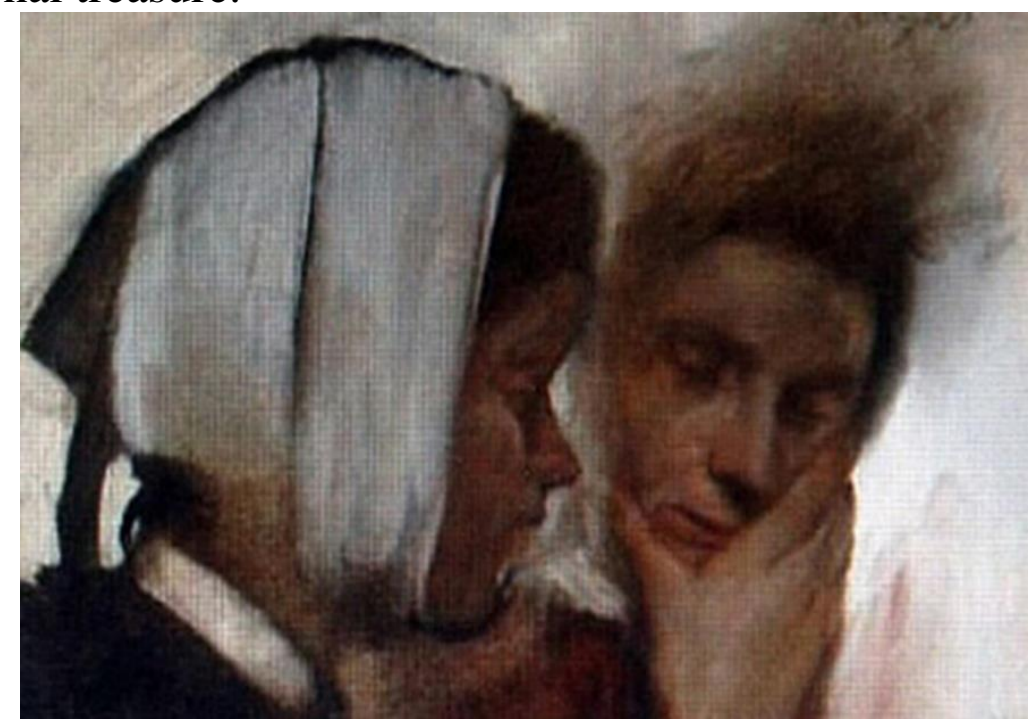

Figure 7. Edgar Degas, The Laundresses Suffering from Toothache, The André Malraux Museum in Le Havre, early 1870s.

Gustave Courbet 
Many artists creatively conveyed their physical senses, and also to demonstrate the intolerance of their pain more effectively than just words. Gustave Courbet, for example, knowing about his approaching death, repeatedly used this motif in his works in the form of a trout "caught on a hook and bleeding" to express his physical condition.

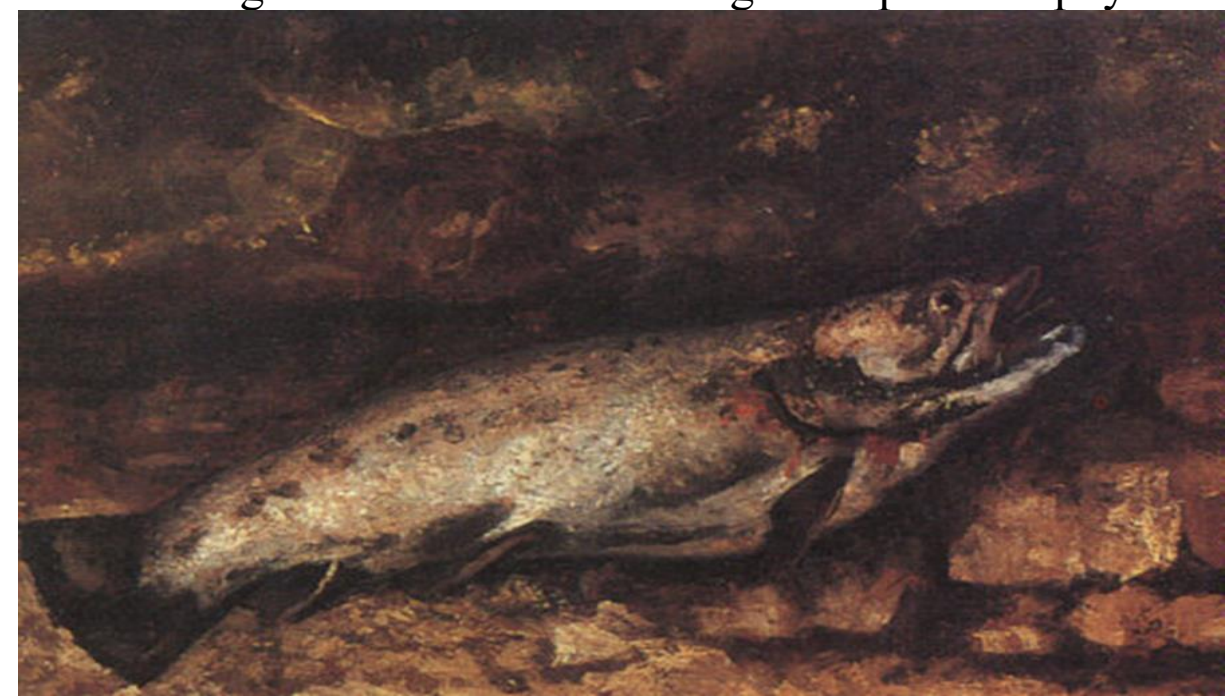

Figure 8. Gustave Courbet, 1873, Trout, Musée d'Orsay in Paris

\section{Frida Kahlo}

Even more obvious were the works of Frida Kahlo, whose pain is noticeable in most of the paintings. After being seriously injured in a car accident, physical suffering became an everyday burden for the artist, and she often refers to this topic in her work. An example of this is the painting "Broken Column", where she portrayed herself in the literal sense of being pierced by a broken column, fastened with many nails.

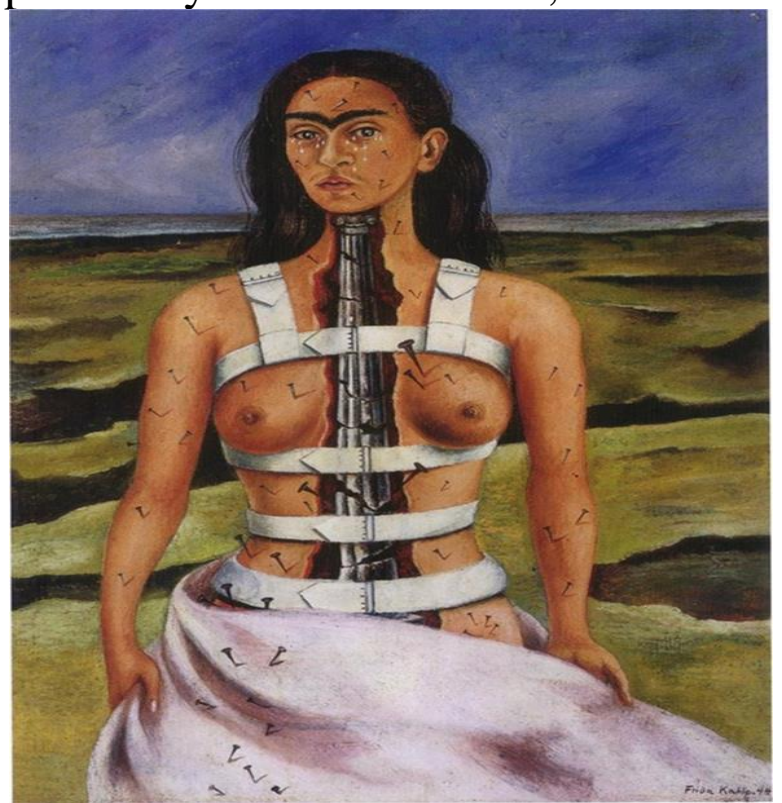

Figure 9. Frida Kahlo, 1944, "Broken Column" Dolores Olmedo Patiño Museum, Mexico City

Nikolay Ge

Russian Nikolay Ge was an atheist - perhaps because of this, his crucifixion looks more believable than that of other painters. There is nothing divine about Jesus 
Ge, and the crucifixion is presented as an ordinary painful death. Ge admitted that he portrayed physical pain too believable, and said that he himself cries if he looks at the picture for a while. The persons cry - out of despair. Because the Resurrection, if you look at this picture, does not seem possible. The picture shows the triumph of death. The artist had thoughts to destroy the work, but he did not have time: on January 17 he finished the version of the "Crucifixion", and on June 1 of the same year Nikolai Nikolayevich Ge was gone.

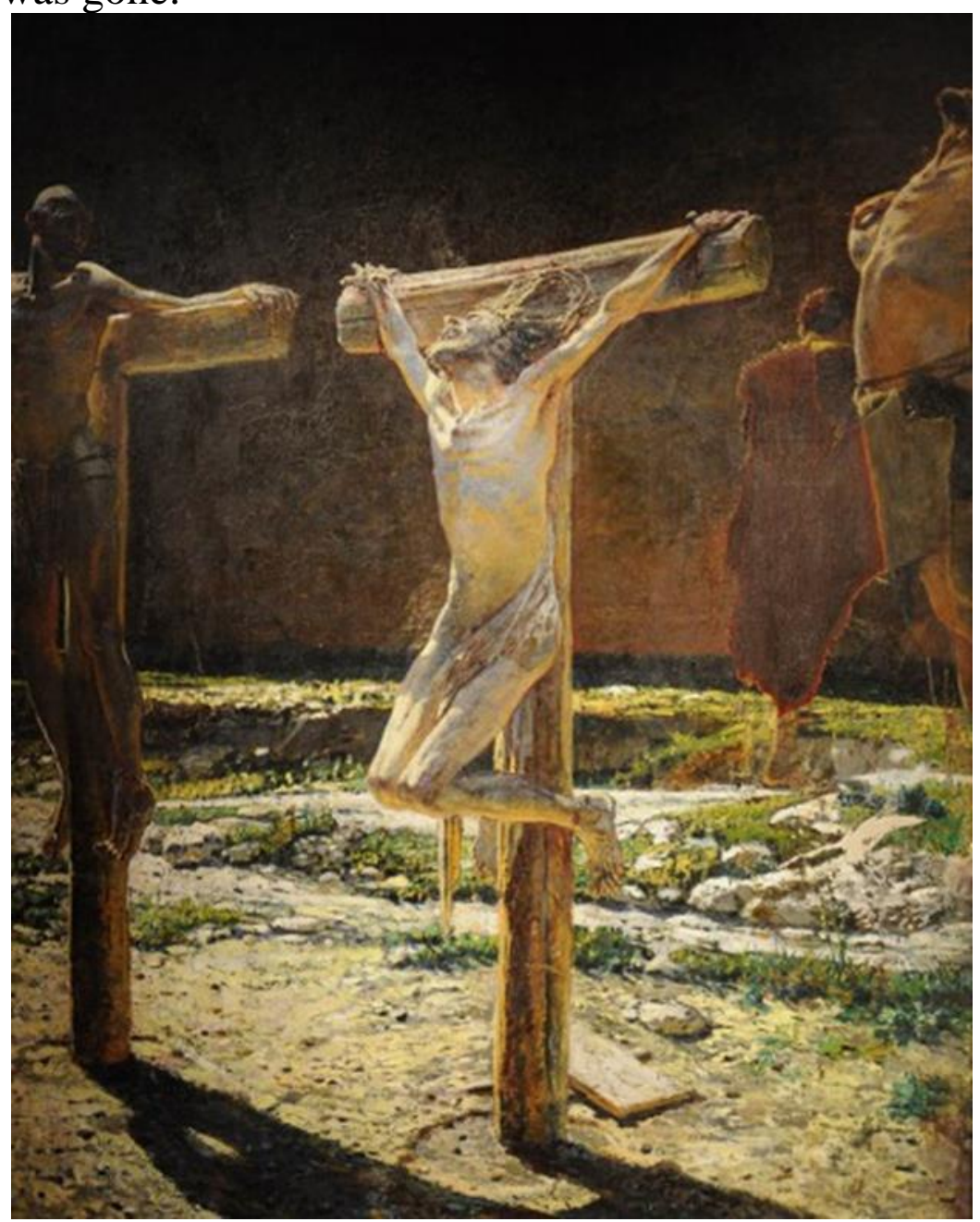

Figure 10. Crucifixion, Nikolay Ge (1892),

D'Orsay Museum in Paris

Pain goes far beyond its apparent physiology. It is that sensation that allows a person to feel his body and through this sensation to be convinced of his existence. Pain in this respect unites the external world with the internal world.

Clear assessment criteria, clear ideas about Truth, Goodness and Beauty did not allow depicting senseless human suffering. The latter were always conditioned by some circumstances and were perceived by the audience either as punishment for some crime, or as the torments of an innocent victim, which were ultimately rewarded. The interpretation of pain in art is carried out through the prism of ethical ideas. Let art remain a means of human improvement.

Let these pictures become a constant reminder to be strong in the face of suffering and to achieve worthy goals that make a person feel like a human being. 


\section{References}

1. Defining No Pain, Mild, Moderate, and Severe Pain Based on the Faces Pain Scale-Revised and Color Analog Scale in Children With Acute Pain. Pediatric Emergency Care 2016, 34(8) DOI:10.1097/PEC.0000000000000791 


\title{
INTERNATIONAL EXPERIENCE OF TAX STIMULATION OF INNOVATIVE ACTIVITY FOR UKRAINE
}

\author{
Dermanska Liudmila
}

Ph.D., Associate Professor

Chortkiv Educational and Scientific Institute of Entrepreneurship and Business West

Ukrainian National University

Kulchytska Nadiia

Ph.D., Associate Professor

Chortkiv Educational and Scientific Institute of Entrepreneurship and Business West

Ukrainian National University

The study of stimulating innovation in world practice and identifying priority areas for Ukraine requires a comprehensive approach. On the part of the state, tax benefits are an important regulatory tool, but tax incentives should take into account the specific financial and economic performance of an individual entity, which differ significantly at the stages of the innovation process.

For example, in the Czech Republic, support is provided to investment projects in the field of production activities in the field of advanced technologies, manufacturing, investment is associated with attracting foreign investors who introduce new products or expand existing production to a certain extent. In the processing industry there is a full exemption from income tax for a period of five years for start-ups and partial in case of expansion of production [7, p. 75].

As for Poland, tax credits are used, double taxation of companies with limited shares is eliminated.

There are currently a number of value added tax benefits in Austria. Thus, enterprises organized into a holding company do not pay value added tax on turnover within the holding company, which allows to neutralize the issue of transfer pricing $[4$, p.22].

In Sweden, tax incentives for innovation have been applied since 1973. The amounts subject to tax exemption are equal to $10 \%$ of the company's costs for research and development. In addition, a special $20 \%$ discount is provided from the amount of increase in research costs this year compared to the previous year [5, p. 278].

Austria uses deductions from the tax base for research and development costs ranging from $125 \%$ to $135 \%$. Belgium, the Czech Republic, and Hungary similarly grant this tax preference, with the last two deductions reaching $200 \%$ of research and development costs. Spain, Ireland, the Netherlands and Portugal use tax incentives in 
the form of a tax credit, which is $25 \%$ of the cost of research and development. [1, p.315].

Belgium and the Netherlands are also reducing tax rates on the wages of workers engaged in research and development. Zero or special corporate income tax rates apply to R\&D entities in countries such as Austria, Ireland and France. [6, p. 55].

Spanish tax law also combines voluminous and growing benefits to stimulate innovation. In 2006, innovative enterprises were allowed to write off $100 \%$ of the cost of research. In addition, additional benefits have been introduced at the regional level [2].

Depreciation policy is at the forefront of other targeted tax incentives for innovation, as it also helps reduce corporate tax liabilities. Accelerated depreciation is an important tool to stimulate the financing of innovation [3, p. 28].

In particular, in the United Kingdom, companies are entitled to tax benefits provided in the form of accelerated depreciation rates for certain types of purchased fixed assets used in research.

Tax benefits for personal income tax, VAT and excise duties complement tax incentive schemes within the special tax regimes of technology parks or small scienceintensive enterprises. This helps to strengthen the targeting of state regulatory measures. The study of specific forms and methods, positive and negative effects of tax benefits in Ukraine allows us to borrow those incentives, the implementation of which in the national tax system can give the greatest effect, and avoid the use of those associated with significant costs or other negative effects.

\section{References:}

1. Alyeksieiev, I., Zhelizniak, R. J. (2014). Vazhlyvist pravylnoho pidboru podatkovykh pilh i shliakhiv yikh nadannia pry podatkovomu stymuliuvanni innovatsiinoi diialnosti pidpryiemstv [The importance of proper selection of tax incentives and ways of providing them with tax incentives for innovation activity]. Biznes Inform [Inform Business], 2, 314-320. [in Ukrainian]

2. Avihdor, H. (2011). Innovatsiina polityka: yevropeiskyi dosvid ta rekomendatsii dlia Ukrainy [Innovation policy: European experience and recommendations for Ukraine] (Vol. 2). Kyiv: Feniks [in Ukrainian].

3. Kuzmin, O. Ye., Shotik, T. M. (2009). Finansova skladova v rozvytku i funktsionuvanni natsionalnoi innovatsiinoi systemy [The financial component in the development and functioning of the national innovation system]. Finansy Ukrainy [Finance of Ukraine], 5, 21-30 [in Ukrainian].

4. Marchenko, O. I., Melnychuk, H. S. (2013). Napriamy posylennia podatkovoho stymuliuvannia innovatsiinoi diialnosti $\mathrm{v}$ Ukraini $\mathrm{z}$ urakhuvanniam zarubizhnoho dosvidu [Directions enhance tax incentives for innovation activities in Ukraine, taking into account international experience]. Visnyk Zhytomyrskoho derzhavnoho texnolohichnoho universytetu [Bulletin Zhytomyr State Technological University], 1, 21-28 [in Ukrainian] 
5. Paliichuk T. V. (2017) Modeli fiskalnoi detsentralizatsii u reformuvanni systemy upravlinnia derzhavnymy finansamy [Models of fiscal decentralization in reforming the public financial management system]. Naukovyi visnyk Uzhorodskoho universytetu [Scientific Bulletin of Uzhhorod University]. 2, 273-279 [in Ukrainian]

6. Rusak D. M. (2015) Ekonomichna rehionalizatsiia v krainah YeS ta implementuvannia pozytyvnoho dosvidu v kontseptsiiu ukrainskoi detsentralizatsii [Economic regionalization in the EU countries and implementation of positive experience in the concept of Ukrainian decentralization]. Mizhnarodni vidnosyny. Seriia Ekonomichni nauky [International relations. Series "Economic Sciences"]. 5, 54-66. [in Ukrainian].

7. Yehorov, Ye. S. (2012). Prohramy innovatsiinoho rozvytku zarubizhnykh krain: dosvid ta dosiahnennia [Program of innovative development of foreign countries, and experience]. Aktualni pytannia innovatciinoho rozvytku [Current issues of innovative development], 2, 77-83 [in Ukrainian]. 


\title{
ФІНАНСОВА ГРАМОТНІСТЬ ПО-СКАНДИНАВСЬКИ
}

\author{
Fostyak Vira \\ Ph.D., Associate Professor \\ University of Banking
}

Одним із пріоритетів діяльності Національного банку України є фінансова інклюзія, яка нерозривно пов'язана 3 фінансовою грамотністю. Населення ефективніше та розсудливіше користується фінансовими послугами, якщо знає, як вони можуть допомогти в управлінні особистими фінансами та примноженні статків. Фінансово обізнані громадяни ухвалюють відповідальні фінансові рішення i почуваються захищенішими, адже піклуються про особистий фінансовий добробут і фінансову незалежність на кожному етапі життя, завчасно формують фінансову подушку безпеки на випадок криз та форс-мажорних ситуацій .

Сьогодні провідні країни світу, зокрема США, Великобританія, Канада, Нідерланди, Австралія, Нова Зеландія, спрямовують багато зусиль на підвищення фінансової грамотності населення. Найкращі практики об'єднуються під егідою потужних міжнародних організацій: Світового Банку, Організації економічного співробітництва та розвитку (ОЕСР), Агентства США 3 міжнародного розвитку (USAID) та ін. Цікавим є досвід країн Скандинавії.

Наприклад, ОЕСР проводить на регулярній основі дослідження рівня фінансової грамотності дорослого населення та молоді, а також створила спеціальну онлайн-платформу - Міжнародну мережу 3 фінансової освіти (англ. International Network for Financial Education, INFE) - для комунікації представників різних країн, які опікуються питаннями розробки та імплементації національних стратегій фінансової грамотності.

ОЕСР визначає фінансову грамотність як «комплекс знань, вмінь, навичок, ставлення та поведінки людини, необхідних для ухвалення важливих фінансових рішень та для досягнення особистого фінансового добробуту» [1]

У загальному розумінні фінансова грамотність - це те, як ми ставимося до грошей, управляємо фінансами, плануємо майбутнє.

На сьогодні, за даними Світового банку, 44 країни світу схвалили стратегію фінансової грамотності, а у 27 країнах цей документ знаходиться на етапі розробки [2]

За даними дослідження USAID "Фінансова грамотність, фінансова інклюзія та фінансовий добробут в Україні" рівень фінансової грамотності населення України становить 11,2 (з 21). Показник фінансової грамотності українців знаходиться на одному рівні 3 показником Польщі - найнижчим значенням індексу фінансової грамотності серед 30 країн, які брали участь в опитуванні ОЕСР у 2016 році [3]. Отримані результати підтверджують необхідність активізації роботи у сфері фінансової грамотності на національному рівні, здобуття знань і навичок дітьми та молоддю щодо управління особистими фінансами ще під час навчання у школі та закладах вищої освіти. 
Дедалі більше заходів 3 підвищення фінансової грамотності фокусуються не на інформуванні, а на розвитку практичних умінь та навичок громадян, які $\epsilon$ частиною ширшого поняття "фінансова культура", що формується у результаті виховання, розвитку, накопичення та застосування на практиці навичок і вмінь управління особистими фінансами. Підвищення фінансової грамотності в Україні можливе за рахунок вивчення зарубіжного досвіду, наприклад скандинавських країн.

Наприклад, у Данії, у Nordea можна відкрити банківський рахунок для новонародженого, в Danske Bank - оформити банківську карту для кишенькових грошей. 50\% батьків в опитуванні YouGov заявили, що дають дітям гроші на кишенькові витрати, - так вони виховують їх фінансову відповідальність. В середньому дитина в Данії отримує від мами і тата 172 DKK в місяць - це близько 700 грн. Жителі Данії - обережні інвестори: багато хто воліє просто тримати гроші на депозиті незважаючи на те, що ставки за банківськими вкладами бувають негативними. За даними Національного банку Данії, на кожного дорослого в країні припадає в середньому 208 тис. DKK, або 30,7 тис. доларів накопичень. За даними Finans Danmark, 19\% місцевих інвесторів вкладають гроші в акції, 11\% - в інвестиційні фонди, іноді комбінуючи ці інструменти. Дедалі популярнішими в країні стають пасивні інвестиційні інструменти, такі як ETF: зараз в них інвестують, за оцінкою платформи Mybanker, близько 5\% датчан, хоча в середньому по Європі цей показник вищий - близько $20 \%$. Щоб стимулювати приватні інвестиції, в 2019 році в країні запустили Aktiesparekonto - інвестиційний ощадний рахунок. Ставка податку по ньому складає $17 \%$ від отриманого доходу, тоді як на стандартні інвестиції в акціонерний капітал - від 27 до 42\%. Цей захід помітно простимулювала зростання популярності інвестицій, особливо в 2020 році: на одній $з$ найбільших в Скандинавії інвестиційних платформ Nordnet зареєструвалося понад 90 тис. нових клієнтів, $\mathrm{i}$ ще 20 тис. - в січні 2021 року. Половина 3 них - люди до 30 років. Данці інвестують в те, що знають. Це підтверджують результати дослідження: в топ-5 компаній, в які данці готові найбільше інвестувати, входять Novo Nordisk, Vestas, AP Møller-Mærsk, Novozymes i Carlsberg, все - датські бренди. Ще один помітний тренд - «зелені» інвестиції: за півтора року пенсійні фонди країни інвестували в екологічні компанії понад 8 млрд доларів накопичень простих датчан [] .

Жителі Швеції щомісяця позначаючи на сайті або в мобільному додатку свої витрати, ви зможете простежити рівень споживання послуг і різницю в їхній ціні. Шведи намагаються відкладати і вкладати гроші. Деякі батьки, які отримують допомогу на дитину до 16 років (100 євро), кладуть його або цілком на рахунок дитини, або якусь його частину. Також на дні народження дітям можуть дарувати сертифікати інвестиційних фондів. Вони коштують недорого, але 3 часом зростають в ціні. А десь 3 35-40 років шведи починають відкладати частину своїх доходів на пенсію, яку вони будуть отримувати паралельно 3 офіційною.

Банк міжнародних розрахунків у 2018 році назвав Швецію країною 3 найменшою часткою паперових грошей у світі. За оцінками Центробанку країни, 
у 2018 році лише 1\% шведського ВВП перебував у банкнотах (для США цей показник становив 8\%, для країн єврозони - 11\%)[2].

Станом на жовтень 2020 року, за оцінками фінустанови, менше ніж 10\% усіх розрахунків у Швеції здійснювалися через паперові гроші, що є найнижчим за весь час спостережень показником.

На нашу думку, формування нової фінансової культури в Україні може відбутися через призму навчання а саме:

1. Починати якомога раніше формувати фінансову культуру - знання, навички та відношення, необхідні для забезпечення відповідальної фінансової поведінки та підвищення фінансової інклюзії українців. Надання фінансової освіти ще у школі з молодого віку, крім цього залучати вчителів до професійного розвитку фінансової освіти.

2. Відійти від «універсальних програм» та адаптувати програми до потреб конкретних громад. Натомість, програми мають бути націлені на молодь, групи 3 низьким рівнем доходу, сім'ї та жінок. Програми, призначені для осіб 3 низькими доходами, можуть розпочатися 3 формування необхідних навичок для укладення кращих угод щодо фінансових контрактів, створення фондів надзвичайних ситуацій тощо шляхи кращого використання державних програм фінансової допомоги [4].

3. Фокус на навчання молоді

Молодь віком від 10 до 24 років (покоління Z та покоління Альфа) $є$ головною цільовою аудиторією. Фокус на молодь диктує нові підходи до навчання. Це передбачає надання фінансової освіти молодим людям до того, як вони почнуть брати позики для фінансування освіти, фізичним особам до укладення іпотечних договорів, працівникам до того, як вони можуть інвестувати в різні види пенсійних фондів. Такі програми, як надання фінансових послуг, консультаційні послуги працівникам, які наближаються до пенсії, виявилися успішними у збільшенні пенсійних накопичень закордоном.

Список літератури:

1. OECD (2018). OECD/INFE Toolkit for measuring financial literacy and financial inclusion. P.4.

2. World Bank (2017). Global Financial Inclusion and Consumer Protection Survey: Report. P. 14.

3. OECD (2016). OECD/INFE International Survey of Adult Financial Literacy Competencies. P. 8.

4. Beck, Ted, and Brent Neiser (2009) 'Learning and growing: Lessons learned in financial education', Community Investments 21(2): 11-14. 


\title{
AGRICULTURAL ENTERPRISE PRODUCT COST MONITORING INFORMATION SYSTEM
}

\author{
Kozenkova Vladyslava \\ Candidate of Economic Sciences, Senior Lecturer \\ Department of Information Systems and Technologies \\ Dnipro State Agricultural and Ecocnomic University, Ukraine
}

Usually, production is understood as the process of interaction of economic factors, which ends with the release of any product. Production can be thought of as an inputoutput system, in which output is what is actually produced, and input is what is consumed for the purpose of output (capital, labor, energy, raw materials). Therefore, it can be formally defined that production is a function that assigns output to each set of costs and a specific technology.

It is this simplified understanding of production as a "black box" that is embedded in the mathematical model of production. At the input of the black box costs are fed, and at the exit we receive manufactured products. The ultimate goal of an enterprise is to obtain the greatest profit from the sale of products.

The main task of an enterprise is to find such a method of production, which provides it with the greatest profit, taking into account and within the limited resources available in it. This interpretation of the purpose of an enterprise and the best mode of production is not the only possible one, but can be used as a working hypothesis for research tasks.

Mathematical models of production solve the problems of optimizing revenues and costs and reflect the relationship between resource costs and output. Models describe not production itself, but its planning. In this sense, two types of enterprise tasks are considered, firstly, maximizing profits, taking into account real restrictions on costs, and secondly, achieving the planned (fixed) level of output an enterprise with minimal costs.

The central element in this kind of model is the production function. It is defined as a mapping that puts each cost set at its maximum output. The production function can be viewed as a formalization of production technology The most popular production functions from the point of view of practical use are the Cobb-Douglas production functions, a partial expression of which is CES (production function with constant elasticity of substitution of resources), input-output production function, or function B .Leont'eva, linear production function (with resource substitution), etc. [14]. Production functions have a special property, namely the property of homogeneity, which evaluates production technology at different cost centers. That is, the production function in some points of this space can be characterized by constant income from the expansion of the scale of production, and in others - by its increase or, conversely, decrease.

The local indicator of measuring the income from the expansion of production is the elasticity of production. Elasticity is one of the most important categories of economics. It was first introduced into economic theory by A. Marshall [5] and is 
defined as a change in one variable, expressed as a percentage in response to a change in another variable, which is also expressed as a percentage. The advantage is obviously given to production with greater elasticity, because it makes sense to increase costs only in case of increased output.

It can be noted that each production function evaluates the elasticity of production. Also, it can be noted that for the practical analysis of production, there is also an interest in the elasticity of output by type of resources, as a value characterizing the percentage of increase in output with an increase in costs by $1 \%$. Therefore, in our opinion, it is necessary to use methods for assessing elasticity as methods for monitoring production costs.

Thus, the modeling of the production cost management system of an agricultural enterprise will be based on the following components:

- a complex for collecting and analyzing information on production costs, including a system for monitoring production costs, a system for converting information into a standardized form; a system for consolidating and processing information to obtain indicators suitable for analysis;

- a complex for assessing efficiency of use and making a decision on the use of this type of indicators for inclusion in the main indicators of economic enterprise`s state;

- a complex for modeling the behavior of specific types of resources (costs) based on the indicators obtained in previous complex;

- a complex for assessing the possibility of using resources based on the results of modeling and the current state of an industrial enterprise;

- a complex of resource management (cost management)

- a set of measures to reduce the level of production costs;

- a complex for assessing the results of managing production costs and developing measures to improve it.

Cost monitoring is a basic component of the function of an production cost management system, which should be based on the use of cost elasticity methods and track costs by their places of origin in accordance with the production technology.

When considering any enterprise as an open system, its production function can be defined as:

where $\bar{x}$ is the vector of resource costs;

$$
F(\bar{x}, \bar{y}, A)=0
$$

$\bar{y}$ is the vector of product release;

$A$ is the matrix of parameters (norms) of transformation of the vector of consumption of resources $\bar{x}$ into a vector of outputs $\bar{y}$.

In normalized form, the production function has the form:

$$
F\left(x_{1}, x_{2}, \ldots, x_{i}, \ldots, x_{n}\right)=0
$$

where the variables $x_{i}$ with the sign "-" mean costs, and with the sign " $+"$-product release.

In economic research, the production function usually appears in the form of an equation in which all components of output are combined into one scalar quantity $(Q)$, and the number $(n)$ of heterogeneous production resources $\left(x_{i}\right)$ is minimized, which allows the calculation of the parameters of the production function on the basis of available information: 


$$
Q=f\left(x_{1}, x_{2}, \ldots, x_{n}\right), n<10
$$

If the independent variables is the volume of resource costs $\left(x_{i}\right)$, then production function is called the function of output. If the independent variable is the size of output $(Q)$, production function is the function of costs.

The elasticity of output in relation to variable factors, or the indicator of the elasticity of production, characterizes the degree of response of output to changes in the values of variable factors, all other things being equal.

This indicator is measured as the ratio of the percentage changes in the specified values:

$$
E_{Q x}=\frac{\frac{\Delta Q}{Q} \times 100 \%}{\frac{\Delta x}{x} \times 100 \%}
$$

where $E_{Q x}$ is the coefficient of elasticity of output by a variable factor;

$\frac{\Delta Q}{Q} \times 100 \%$ is the percentage change in total product (volume of production, output);

$\frac{\Delta x}{x} \times 100 \%$ is the percentage change of a variable factor.

The coefficient of elasticity of output, in fact, shows by what percentage the output will change with a change in the variable factor by $1 \%$.

Elasticity of output costs is the degree to which costs respond to changes in output (all other things being equal); quantitatively, it is measured by the coefficient of elasticity of expenses, which shows how many percent the expenses change when the output changes by $1 \%$. It is clear that the coefficients of elasticity of all types of expenditures can be defined as the ratio of the percentage change in costs of a certain type to the percentage change in output..

The coefficient of elasticity of total production costs can be calculated by the formula:

$$
E_{Q x}=\frac{\frac{\Delta T C}{Q} \times 100 \%}{\frac{\Delta Q}{Q} \times 100 \%}=\frac{\Delta T C}{Q} \times \frac{Q}{T C}
$$

where TC (Total costs) is the total production costs of $Q$ units.

From the above formula, it can be seen that the elasticity of total output costs is the ratio of marginal costs to average total costs.

If it is necessary to determine the coefficient of elasticity for different intervals of $T C$ and $Q$ provided that the cost function within the interval is close to the linear form, can use the formula of interval (arc) elasticity:

$$
E_{T C, Q}=\frac{T C_{2}-T C_{1}}{T C_{1}+T C_{2}} \div \frac{Q_{2}-Q_{1}}{Q_{1}+Q_{2}}
$$

where $T C_{1}, T C_{2}$ is the total costs within the interval;

$Q_{1}, Q_{2}$ is the level of production within the interval.

This formula makes it possible to ensure a high, almost continuous, level of monitoring of changes.

For the practical use of the relational model of monitoring and cost management, it is fundamental to decompose the occurrence of production costs in space, that is, the formation of cost centers. The management of an enterprise also decides in what 
context to classify costs, how much to detail the places of their occurrence and how to link their activities by centers of responsibility. On the other hand, the center of responsibility monitors costs in many places of origin, provided that the costs there are formed under the influence of this center of responsibility.

Taking into account the peculiarities of the organizational structure of an agricultural enterprise, the general system of cost centers can be considered in two main groups, such as technological and discretionary cost centers. The technological ones include:

1) the cost centers of the main production (crop production, animal husbandry, processing);

2) the cost centers of the auxiliary production (repair shop, trucks, power supply, water supply, heat supply, etc.);

3 ) the cost centers for maintenance of production processes (machine and tractor fleet).

Discretionary cost centers are administrative and sales centers.

The consolidation of the centers of responsibility for the selected segments in the organizational structure of an agricultural enterprise will affect the organizational structure of management, built on the basis of cost centers (centers of responsibility); working chart of accounts; workflow, etc.

Cost management includes: forecasting and planning costs, their organization, coordination and regulation, activation and stimulation of personnel, accounting, analysis and control (monitoring). In this case, the objects of management are cost centers, which in practice are limited to the framework of the structural divisions of an enterprise.

The definition of the structural unit of the cost center allows you to localize the costs of an enterprise and approximate the indirectly distributed costs in the products produced in a given location. On the other hand, the enlargement of cost centers to the level of a structural unit of an enterprise does not allow preparing a base of standards for resource consumption for the production of cost centers products, making management decisions adequate to the production situation.

The peculiarity of planning and accounting costs is that the costs in this place are direct for him. Thus, the very concept of indirect costs disappears and the share of direct costs in the cost of agricultural products expands, which contributes to accurate calculation.

The methodology for determining cost centers is based on the idea that cost centers can be clearly defined and assigned to specific heads of departments. The purpose of the methodology is to determine the share of expenses (as well as income) of each division in the overall performance.

The work on organizing monitoring of costs by places of their occurrence includes the following stages:

1) allocation of cost centers;

2) classification of cost centers in divisions in relation to the production process;

3) development of a reference book of cost centers ciphers;

4) determination of the cost object for each cost center;

5) formation of a list of expense items. 
The result of the execution of work on listed stages is the nomenclature of articles in the context of the cost centers of each structural unit.

The purpose of cost planning at the place of their occurrence is to establish the planned amount of costs for each cost center and carrier costs on the basis of the planned production program of an enterprise and the planned norms of consumption of existing resources for a certain period.

The purpose of accounting for costs is to establish the actual amount of costs for each cost center and the cost carrier for a certain period of time.

According to this goal, the work on organizing the actual accounting of costs by places of their occurrence includes the following stages:

1) correction of forms of primary documents for accounting for various types of costs by entering the following details: cost centers code, cost bearer and responsible person;

2) grouping of primary documents by cost center;

3) correction of existing workflow schemes;

4) correction of working chart of accounts of an enterprise;

5) development of principles for the distribution of costs between cost centers and cost carriers and fixing them in the Order on the accounting policy of an enterprise.

The grouping of primary documents by cost centers codes is carried out to form the actual amount of costs for each of them. The result of the grouping of primary documents is the formation of the actual cost estimate of the cost objects of each main cost center.

Adjustment of the working plan of accounts of an enterprise is made for the purpose information base for performance of functions of administrative accounting on the basis of accounting data. As a result of made adjustments the actual sum of expenses in a cut of cost centers and carriers of expenses is formed.

The development of the principles of distribution of costs of auxiliary, service and general cost centers between the main cost centers and cost carriers is made for the purpose of definition of actual production prime cost of carriers of expenses of basic cost centers and carriers of expenses of structural division.

For distribution of expenses of general, service, auxiliary cost centers is offered. The choice of the base for the distribution of costs in each division of an agricultural enterprise is specific and is determined by the technological features of the production process. Thus, the actual production cost of the main cost carriers of main cost centers and the cost carriers of the structural unit is determined.

The operation of the cost monitoring system for cost centers involves the development of a special information base, whose features are to ensure the relationship between the standards being developed and used, as well as standards for cost carriers and their places of origin. The cost is determined on the basis of estimates of costs to be incurred in accordance with the rules, and not on the costs actually incurred. At an enterprise which has chosen this system, standards for material, labor costs, general economic expenses are established, and during work deviations on them are found out. Direct costs are normalized in advance, and estimates are made for indirect ones. This is essentially a variant of the standard-cost system. The main advantages of the system include: 
1) provision of information on expected costs;

2) identification of causes of deviations from the norm;

3) possibility of prompt correction of plans and their implementation;

4) decrease in accounting work, since management is actually carried out by deviations.

The reliability and efficiency of accounting data is growing, which unified, becoming equally suitable for all types of accounting (operational, accounting, statistical). In this regard, when introducing system, it is advisable to develop forms of analytical documents in which the collected information can be presented for various management purposes.

The implementation of a management (monitoring) system for cost centers should be preceded by serious work, which includes the following stages:

1) study of the existing regulatory framework for the formation of cost standards in the context of cost centers and cost carriers;

2) study of the limitations of the accounting and information system for working with the base of standards for direct and indirect costs;

3 ) adjustment of the accounting policy of an enterprise in terms of cost accounting;

4) development of a methodology for the formation of standards;

5) development of forms of analytical documents for various management purposes (planning, accounting, analysis, control);

6) development of a personnel motivation system to comply with cost standards for cost centers.

The purpose of the first stage is to analyze the regulatory framework of the existing enterprise and the formation of methodological approaches to creating an information base suitable for use in the system. The content of the stage is the organic relationship of norms being developed and used, and standards for cost carriers and their places of origin. It contains the following works:

1) analysis of the existing base of standards of direct costs in order to link them to the places of origin of costs and carriers of costs;

2) adjustment of existing standards of direct costs by cost centers and cost carriers;

3) development of standards for indirect costs by cost center.

The result of accomplishment is the listed works should be an information base of cost standards, which includes following details: code of the cost center; cost bearer code; resource code; rate of resource consumption; price of the resource; planned volume of production; standard of direct costs; standard of indirect costs for the planned volume of production; total cost norm.

In the course of research of the existing information base norms of expenses operating, the order of their calculation and adjustment should be analyzed.

All costs for agricultural production are divided into direct and indirect. In this case, the direct costs include only the costs of raw materials, basic materials and semifinished products. Indirect include all the costs of redistribution.

Analysis of the practice of rationing material and labor resources made it possible to reveal the following:

1) the list of rates of consumption of material resources is approved annually by order of an enterprise; 
2) the norms of material resources are developed on the basis of technological instructions and production program;

3) the norms for basic materials and semi-finished products are differentiated by cost carriers, that is, according to currently calculated types of products and positions;

4) the existing consumption rates of raw materials, basic materials and semifinished products do not take into account the influence of some factors;

5) consumption rates of the used fuel and energy resources are developed quarterly in the context of spending directions and are distributed among cost centers in proportion to the selected base;

6) when establishing rates for the consumption of auxiliary materials, replacement equipment and spare parts, different units of measurement are used:

7) the rate of labor costs is determined based on the staffing table and the production program for the year and is differentiated according to the allocated cost centers.

The purpose of the second stage is to study the limitations of the implemented automated system to identify the possibility of using the "standard cost" in the management of enterprise costs. The analysis of system limitations was carried out by interviewing specialists in the development of business processes of formation of planned and actual cost of regulatory information, study of working documents of the project and analysis of the level of project implementation.

The performed analysis showed that the following reference books of normative information can be provided in the system:

1) items of expenses for ordinary activities, expenses of future periods;

2) budget items;

3) categories of items for budgeting;

4) categories of volumetric planning;

5) categories of pricing;

6) cost centers of structural divisions of an enterprise;

7) technological maps and reference books;

8) the basis for the distribution of overhead costs.

The following limitations of the system have been identified:

1) all production costs are subdivided into basic and overhead. In this case, the main costs include only the costs of raw materials, basic materials and semi-finished products. Overhead includes all costs of redistribution;

2) the calculation of the cost of production is made according to nomenclature items;

3 ) the main expenses are grouped in quantitative terms by items;

4) overhead costs are determined in the context of cost items, elements and cost centers;

5) in cost management, the definition of the standard cost (normalized costs) is used as an application of the planned cost of the components to their actual consumption.

Based on the results of the study, conclusions were drawn about the need to create a reference book of standards for overhead costs in the context of cost centers, cost 
items and elements. Detailed differentiation of overhead cost rates requires significant labor costs and is not advisable.

The purpose of the third stage is to identify the need to adjust the accounting policy of an enterprise to disclose information on the use of accounting data when using the "standard-cost" system.

The following points should be recorded in the accounting policy:

1) object of cost accounting (cost centers);

2) selected cost accounting system ("standard cost");

3) list of direct and indirect costs in relation to the cost centers; the order of accounting for direct and indirect costs on the accounts of accounting and in terms of sub-accounts:

4) basis for the distribution of indirect costs between the cost centers.

In terms of accounting for costs of ordinary activities, along with other methods of accounting for production costs, it is necessary to provide for operational accounting of costs at the places of their occurrence;

The use of the method of accounting for production costs at the places of their origin should be regulated by the Regulations on planning, accounting and analysis of costs at the places of their origin, structural units approved by the order of an enterprise. The Regulations present the bases for the distribution of the costs of general, service and ancillary cost centers on the costs of the main cost centers.

At the same time, the main cost centers are directly involved in the production of marketable products or semi-finished products in the process of main production. Auxiliary cost centers do not directly participate in production, but are connected with the main cost center and ensure its functioning, as well as produce products (provide services) that meet the needs of the main cost center. The servicing cost centers provide services to the main and auxiliary cost centers, ensuring their uninterrupted operation (repair, power, mechanical, technological and other services). General cost centers makes up the infrastructure of an enterprise, serving the main, auxiliary and servicing cost centers.

The purpose of allocating the costs of the general, service and auxiliary cost centers to the costs of main cost centers is to determine cost of the main cost centers. The Regulations should provide a base for the distribution of energy resources by cost center.

At the fourth stage, a methodology for calculating regulatory costs is being developed. The method of calculating regulatory costs is a tool of management accounting.

When calculating standard costs, you should use reasonable rates of resource consumption, which are technically valid, data on the actual amount of costs (in kind) and the production capacity of the equipment of the cost center for the base year. It is advisable to choose the year preceding the start of the development of the regulatory framework as the base year. The development of standard costs includes the following stages:

1) compilation of cost center passports containing the cost center characteristics from the point of view of the cost bearer and cost types;

2) development of methodology for the formation of standards; 
3) approbation of methodology, analysis of the results and correction of the methodology.

Drawing up a passport should be made the responsibility of the person in charge of the cost center. The following documents are the initial information for drawing up a passport:

1) passport of a structural unit;

2) list of cost centers approved by the order for an enterprise;

3) list of those responsible for the cost centers, approved by the order of the head of the structural unit;

4) list of consumption rates for auxiliary materials, tools, spare parts in the context of a single nomenclature reference book, approved by order for an enterprise;

5) directory of items of expenses for ordinary activities, expenses of future periods;

6) distribution of the personnel of the structural unit by cost center;

7) grouping of fixed assets of the structural unit by cost center;

8) regulations on planning, accounting and analysis of costs by the places of their origin of the structural unit, approved by order for an enterprise.

The cost centers' passport becomes the basis for calculating the cost centers cost ratio.

Costs of a specific cost centers are the standard for 1 hour of cost centers work (the cost of 1 hour of work of a cost center), which is planned per year. The standard for 1 hour of work of a cost center is calculated by summing up the cost standards for all items of redistribution costs that take place at a given cost centers.

When determining the cost of 1 hour of cost centers work, all costs are calculated using the direct method. The standard for 1 hour of work of the cost center is a relatively stable value and does not change when the range of products produced at a particular hour of work changes, all other things being equal. This determines the possibility of using the standard hourly costs to determine the standard costs for redistribution of a given cost center.

Depending on the users of the information, data on planned, actual costs for cost centers and detected deviations with an indication of the reasons are grouped in various analytical forms (sixth stage). Therefore, one of the main stages of work is the identification of users of analytical information and the development of forms of analytical documents for various management purposes. The users of analytical information are: responsible for cost centers, heads of structural divisions, economists, technologists, specialists in personnel management.

For the purposes of management to each of the listed users form necessary indicators. Information on the planned and actual costs of cost centers allows you to use it to develop a system of bonuses for personnel of an enterprise depending on the results of a particular cost centers.

The practice of implementing the proposed method of forming the information base shows that the standards of resource consumption in force should be subjected to serious analysis with further adjustment. This process requires a science-based approach and involves significant labor costs. However, the effect of using the proposed method is due to the possibility of improving not only the cost management 
processes, but also the creation of real prerequisites for increasing the interest of staff in reducing costs directly at the places of their occurrence.

\section{References:}

1.Cobb Ch.W. and Douglas P.H. A theory of production (1928). - American Economic Review 18 (1, suppl.): 1309-165.

2. Heady E. and Dillon J.L. Agricultural Production Functions. Iowa State University Press, Ames, Iowa. 1961.

3. Leontev V.V. Mezhotraslevaya ekonomika. Moskva, Ekonomika, 1997. (Russian).

4. Pindyck R.S. and Rubinfeld D.L. Microeconomics. 8th edition, Pearson Higher Education, 2013.

5. Marshall A. Principy politicheskoj ekonomii: monografiya. Moskva, DirektMedia, 2012. (Russian). 


\title{
АНАЛІЗ ЗМІН ПЛАТІЖНОГО БАЛАНСУ УКРАЇНИ В УМОВАХ ЄВРОЇНТЕГРАЦІї
}

\author{
Алексеєвська Галина \\ Ph.D., старший викладач \\ Одеський національний університет ім. I. I. Мечникова \\ Попова Наталія \\ студентка 2 курсу \\ Одеський національний університет ім. I. I. Мечникова
}

Україна $\epsilon$ однією 3 шести країн (разом 3 Вірменією, Азербайджаном, Білоруссю, Грузією та Молдовою), з якими СС підтримує особливі відносини в рамках політики Східного партнерства. Разом з Грузією і Молдовою Україна підписала Угоду про асоціацію з Свропейським Союзом, яка включає в себе Поглиблену та всеохопну зону вільної торгівлі між Україною та ЄC (DCFTA), яку було введено в дію з 2016 року і доповнено автономними торгівельними преференціями в 2017 році [1]. Сьогодні вже можна бачити деякі результати дії цієї взаємодії, зокрема це відображується і у динаміці платіжного балансу України протягом 2014-2020 років, як одного 3 головних показників економічного розвитку країни.

В Україні сальдо рахунку поточних операцій протягом 2014-2020 було від’ємне протягом більшості років. Це вказує на просування на національні ринки конкурентів і на меншу конкурентоздатність економіки України по відношенню до інших держав. Проте, у 2015 та 2020 роках спостерігається додатне сальдо рахунку поточних операцій, що вказує на збільшення експорту Україною товарів та послуг.

Торговий баланс України свідчить про переважання обсягу імпортних товарів над експортом товарів за весь досліджуваний період часу. Найбільше експортувалось товарів з України у 2014 році на суму 50 млн. дол. США, а найменше 2016 року - 33 млн. дол. США. Максимальний обсяг імпорту товарів спостерігався також у 2014 році - 57 млн. дол. США, а мінімальний 2015 року - 38 млн. дол. США. За даними Свропейської Комісії, ЄС є найбільшим торговельним партнером України (на його частку припадає 40\% торгових потоків) [1,2]. Також до торгових партнерів слід віднести Росію, Турцію, Китай, Індію та Білорусь. Головними статтями експорту України $\epsilon$ продукти харчування, залізні руди та концентрати, залізо, чавун, продукція машинобудування, деревина та вироби з неї. Головні статті імпорту: продукти харчування, напої, нафта та продукти ії переробки, ліки, вугілля, брикети, транспортне обладнання. На відміну від торгівлі товарами, в Україні протягом 2014-2020 років сальдо торгівлі послугами було додатне, що, свідчить про перевагу експорту над імпортом. Основними послугами України є транспортні послуги та інші ділові, професійні та технічні, послуги із переробки матеріальних ресурсів, туристичні, комп'ютерні послуги. Пандемія COVID-19 2020 року 
суттєво вплинула на імпорт товарів та послуг, що скоротився на 17.1\% (у 2019 році збільшився на 7.8\%), натомість експорт товарів та послуг скоротився тільки на 4.6\% (у 2019 році збільшився на 7.4\%) [3]. Порівнюючи первинні та вторинні доходи, слід зазначити, що обидві статті мають однакову динаміку розвитку: сальдо $є$ додатними, тобто надходження із-за кордону перевищують виплати нерезидентам. Щодо первинних доходів, від оплати праці отримується більший об'єм прибутку, порівняно з доходами від інвестицій за весь наведений період. Стосовно вторинних доходів, сума приватних трансфертів перевищує доходи підприємств, установ і осіб невиробничої сфери. Обсяги приватних грошових переказів у 2020 році залишилися на рівні 2019 року та становили 12.0 млрд дол. США. Однак пандемія вплинула на структуру надходжень, задяки уведенню карантинних обмежень, закриття кордонів обсяги переказів, що надійшли офіційними каналами, зросли на $22.7 \%$, а неформальними каналами зменшилися на $23.9 \%$ [3].

Рахунок операцій з капіталом України має нестабільну тенденцію розвитку. За весь досліджуваний період, окрім 2017 та 2020 років, спостерігається профіцит операцій з капіталом. Тобто Україна займається більшим продажем, аніж придбанням нематеріальних нефінансових активів, що охоплюють операції 3 активами, які не $є$ результатом виробництва (земля, надра), а також невідчутні активи (патенти, авторські права, торговельні знаки і т.п.).

Щодо фінансових операцій, то слід зазначити, що В Україні фінансовий рахунок за досліджуваний період загалом зменшувався, досягнувши найбільшого дефіциту 2019 року у -8 872 млн. дол. США., а 2020 року спостерігаємо перехід від від'ємного сальдо до додатного. Це вказує на те, що резиденти знову почали стрімко вкладати в активи інших країн для отримання прибутку в довгостроковій перспективі.

Сальдо капіталовкладень у вигляді прямих інвестицій в Україні було від'ємним протягом 2014-2020 років. Дефіцит вказує на те, що кошти, контрольовані нерезидентами в країні, були більшими, ніж грошові кошти, контрольовані резидентами за кордоном. Найбільше вкладень резидентів України у цінні папери інших країн 3 правом брати участь в управлінні компанією спостерігалися у 2019 році, а найменше - у 2015 році. Протягом розглянутого періоду обсяги прямих іноземних інвестицій залишаються незначними. [4] Найбільше ПІІ надходили у наступних сферах економічної діяльності: промислова, оптова та роздрібна торгівля; ремонт автотранспортних засобів і мотоциклів, фінансова і страхова діяльність. Найбільш значущі держави-інвестори: Кіпр, Нідерланди, Великобританія, Швейцарія, Німеччина, Австрія. [5]. Баланс портфельних інвестицій характеризується від'ємним коефіцієнтом, окрім 2014 та 2020 років, коли показники мали додатне значення.

Внаслідок бойових дій в Україні відбулося значне пошкодження вантажних залізничних колій, шахт і промислових об'єктів, що перешкоджає збільшенню інвестицій в Україну [4]. Привабливими інвестиційними факторами, що сприяють розширенню інвестиційних зв'язків України $є$ велика ємність i практично необмежений внутрішній ринок, географічне розташування на перетині основних транспортних маршрутів між Європою і Азією, відносно 
недорога і водночас кваліфікована робоча сила, науковий потенціал, розвинена інфраструктура, збільшення числа туристів з року в рік та інші. [6]

Узагальнюючи слід зазначити, що торгові потоки з ЄС збільшилися в обсязі, але прямі іноземні інвестиції залишаються низькими, що підкреслює необхідність зміцнення верховенства закону і боротьби з корупцією. В цілому реформи просунулися, але деякі області як і раніше відстають, включаючи захист прав споживачів, права інтелектуальної власності та телекомунікації.

\section{Список використаних джерел}

1. Association agreement between the EU and Ukraine. 2020. EPRS | European Parliamentary Research Service, URL: https://www.europarl.europa.eu/RegData/etudes/STUD/2020/642844/EPRS_ST U(2020)642844_EN.pdf

2. International Monetary Fund. Ukraine: Balance of Payments Analitic Presentation by country. URL: https://data.imf.org/regular.aspx?key=62805740

3. Національний Банк України. Платіжний баланс у 2020 році URL: https://bank.gov.ua/files/ES/State_y.pdf

4. U.S. Departament of State. Lyn Debevoise. Investment Climate Statements: Ukraine, 2020 URL: https://www.state.gov/reports/2020-investment-climatestatements/ukraine/

5. Minystry of Economy of Ukraine. Investment activity in Ukraine, 2020 URL:https://www.me.gov.ua/Documents/Detail?lang=en-GB\&id=14fdd5c970b6-4f46-b2f2-842dfc4a7b3f\&title=InvestmentActivityInUkraine

6. DLF attorneys-at-law. Investing in Ukraine: overview, 2020 URL: https://dlf.ua/en/investing-in-ukraine-overview/ 


\section{ПОДАТОК НА ДОХОДИ ФІЗИЧНИХ ОСІБ ЯК РЕГУЛЯТОР ВЗАЕМОВІДНОСИН МІЖ ДЕРЖАВОЮ ТА ГРОМАДЯНАМИ}

Безкровний Олександр Валентинович к.е.н., доцент, професор кафедри Полтавський державний аграрний університет

Довгаль Олександр Юрійович здобувач вищої освіти ступеня доктор філософії Полтавський державний аграрний університет

Максименко Світлана Вікторівна здобувач вищої освіти ступеня магістр Полтавський державний аграрний університет

Щелкунова Марина Свгенівна здобувач вищої освіти ступеня магістр Полтавський державний аграрний університет

Вовченко Валерія Дмитрівна здобувач вищої освіти ступеня магістр Полтавський державний аграрний університет

Головним призначенням оподаткування доходів $є$ наповнення бюджету. Отримані кошти мають величезне значення для повноцінного соціальноекономічного розвитку держави.

Доцільно відзначити, що ставки податку на доходи фізичних осіб в Україні змінювалися досить часто. До 2004 р. розмір ставки залежав від оподатковуваного доходу і діяла прогресивна шкала оподаткування зі ставками від $10 \%$ до $40 \%$, залежно від доходу (чим вищий дохід, тим вищою була ставка). 32004 p. Україна перейшла на єдину ставку податку з доходів фізичних осіб $13 \%$, а 32007 р. - $15 \%$. У 2011 - 2014 pр. було встановлено дві ставки податку $15 \%$ та $17 \%$ (від суми доходів понад 10 мінімальних заробітних плат). У 2015 р. - $15 \%$ та $20 \%$ (від суми доходів понад 10 мінімальних заробітних плат). Із 2016 р. в Україні введено єдину ставку податку на доходи фізичних осіб - 18 \% [1].

Світова практика щодо справляння ПДФО, його ставок та механізмів сплати його до бюджету є досить різноманітною.

Загалом, учені виділяють чотири схеми розподілу надходжень від ПДФО між бюджетами різних рівнів:

1) з незалежним встановленням ставок податку на різних адміністративних рівнях (так звана «децентралізована») (притаманна Сполученим Штатам 
Америки, Японії, країнам Скандинавії). Центральний бюджет (бюджети регіонів) отримують свої надходження від ПДФО, а муніципалітети - свої. Величина надходжень залежить від встановлених податкових ставок. Адміністрування податку може відбуватися як лише державними податковими органами, так і паралельно з місцевими. Оскільки така система зумовлює диференціацію ставок ПДФО в межах країни та може мати вплив на міграцію населення між регіонами (муніципалітетами), органи місцевого самоврядування при встановленні своїх ставок податку відстежують величину справляння ПДФО в сусідніх муніципалітетах;

2) відрахування від єдиної ставки, встановленої центром (застосовувалась на початку 2000-х рр. у Японії). Ця схема передбачала встановлення центральним урядом загальної податкової ставки, яка потім централізовано розподіляється за єдиним нормативом; при цьому частина надходить до регіональних та місцевих бюджетів. Ця система давала змогу доволі швидко (через прийняття відповідних змін до бюджетного законодавства) посилювати чи послаблювати централізацію надходжень від ПДФО до державного бюджету;

3) централізована, за якої вся сума ПДФО надходить до центрального бюджету i не перерозподіляється до бюджетів нижчих рівнів (Франція, Великобританія). Натомість наповнення регіональних та місцевих бюджетів відбувається завдяки іншим податкам (здебільшого податку на нерухомість);

4) горизонтального («до бюджетного») вирівнювання (Німеччина). Ця схема передбачає акумуляцію надходжень від ПДФО на окремих міжбюджетних рахунках (а не в бюджеті) 3 наступним розподілом за встановленою законодавством формулою в бюджети територій [2].

Податок на доходи фізичних осіб у структурі податкових надходжень зведеного бюджету України займає найбільшу частку серед прямих податків. Це в середньому 20 - $23 \%$ (90 \% від якого - надходження до місцевих бюджетів, 10 $\%$ - надходження державного бюджету). У структурі податкових надходжень місцевих бюджетів його частка є найбільшою і становить в середньому до $60 \%$ усіх податкових надходжень.

Водночас актуальною проблемою, яка потребує вирішення, $є$ неврахування у процесі зарахування ПДФО до різних місцевих бюджетів місця реєстрації фізичної особи - платника податку. Відповідно до ч. 2 статті 64 Податкового кодексу України, зарахування ПДФО до відповідного місцевого бюджету відбувається залежно від: місцезнаходження (розташування) податкового агента - юридичної особи; місця реєстрації податкового агента - фізичної особи в органах Державної податкової служби України; податкової адреси фізичної особи, котра отримує доходи від особи, яка не є податковим агентом [3].

Діючий порядок зарахування зазначеного податку спрощує його справляння для податкових агентів та адміністрування для органів Державної податкової служби України, але в окремих випадках він слугує однією 3 причин недостатнього бюджетного забезпечення реалізації функцій органів місцевого самоврядування. Наприклад, якщо місцезнаходження податкового агента не збігається з місцем реєстрації фізичної особи - платника ПДФО, то утриманий податок надійде до місцевого бюджету за місцезнаходженням податкового 
агента, а відшкодування витрат фізичної особи, яка має право на податкову знижку з ПДФО, та фінансування наданих зазначеній фізичній особі суспільних послуг проводять за рахунок місцевого бюджету залежно від іiї місця реєстрації.

Зважаючи за збільшення сум податкових надходжень місцевих бюджетів України від ПДФО у період 2015 - 2020 рр., у відсотковому вимірі теж відбувається щорічне підвищення податкових надходжень. Ключовими чинниками, що впливають на номінальне зростання надходжень податку на доходи фізичних осіб, $є$ інфляція, а також щорічне підвищення мінімальної заробітної плати, зміни ставок оподаткування та інші новації податкових реформ останніх років.

Податок на доходи фізичних осіб - це вагомий регулятивний важіль, який розподіляє фінансові ресурси між державою та населенням. Під час справляння ПДФО формуються певні взаємозв'язки держави з населенням, адже кожен платник стає учасником бюджетного процесу в частині формування доходів. Податок на доходи фізичних осіб є одним із головних джерел доходів бюджету держави та місцевих бюджетів, завдяки якому регулюються доходи i накопичення різних соціальних груп населення. Державне регулювання ПДФО в умовах децентралізації влади - це політикоекономічний процес, що грунтується на реалізації відповідної державної податкової політики як сукупності форм i методів державного впливу на суб'єктів оподаткування та отримувачів податків. Держава регулює ПДФО з метою визначення оптимальної моделі розвитку взаємовідносин, які виникають під час адміністрування та розподілу податку. Також для регулювання в країні приймаються законодавчі нормативи, правила, вимоги та процедури адміністрування і перерозподілу ПДФО [4].

Оскільки на сучасному етапі в Україні відбулася реформа децентралізації, для успішного функціонування об'єднаних територіальних громад, їх соціального та економічного розвитку, який потребує i значних фінансових ресурсів, актуальним $\epsilon$ питання винайдення додаткових податкових інструментів-ресурсів, що формують місцеві бюджети, провідне місце серед яких займає саме ПДФО.

Це дасть змогу отримати надходження ПДФО до бюджету тієї громади, де безпосередньо здійснюється діяльність підприємств. Органи місцевого самоврядування повинні активно застосовувати наявні у них інструменти впливу на суб'єкти підприємницької діяльності для залучення до своїх громад такого необхідного фінансового ресурсу, як податок на доходи фізичних осіб, та повною мірою вживати заходів для забезпечення фінансових можливостей громад.

У сучасних умовах податку на доходи із фізичних осіб належить важливе місце в забезпеченні фінансової стабільності, соціальної справедливості та стабільного економічного розвитку. Це вимагає безумовного дотримання вимог податкового та бюджетного законодавства платниками податків, дієвого контролю за податковими надходженнями до бюджету як від податкових служб, так і органів місцевого самоврядування, реалізації чіткої державної податкової політики для визначення оптимальних норм та правил щодо процедури сплати ПДФО до відповідного бюджету з метою розвитку громад та підвищення їх платоспроможностей задля добробуту громадян. 


\section{Список літератури:}

1. Бойко О. Я. Податкові інструменти сприяння розвитку підприємництва в Україні: державно-управлінський аспект : дис. к. держ. упр. Львів : ЛРІДУ НАДУ, 2020. С. 122-123.

2. Механізми адміністративно-фінансової децентралізації: світові практики та напрямки їх імплементації в Україні / наук. ред. I. 3. Сторонянська. Львів : НАН України. ДУ «Інститут регіональних досліджень імені М. І. Долішнього НАН України», 2018. 106 с.

3. Податковий кодекс України: Закон України від 02 грудня 2010 р. № 2755VI / Верховна Рада України. URL: http://zakon.rada.gov.ua/laws.

4. Гайдай В. I. Механізм державного регулювання ПДФО в умовах децентралізації влади в Україні // Інвестиції: практика та досвід. 2019. № 17. С. 71. 


\section{ОСНОВНЫЕ ФАКТОРЫ, ПРИЧИНЫ И МОТИВЫ ОБРАЗОВАТЕЛЬНОЙ И ТРУДОВОЙ МИГРАЦИИ МОЛОДЕЖИ КАЗАХСТАНА ЗА РУБЕЖ}

Джусибалиева Аружан Казихановна,

к.э.н., ассоциированный профессор, научный сотрудник ТОО «НПП «Инноватор»

Искакова Дамира Максутовна, к.э.н., директор ТОО «НПП «Инноватор»

Искакова Дария Бериковна, $\mathrm{PhD}$ докторант 2 курса ЕНУ им. Л.Н.Гумилева, научный сотрудник ТОО «НПП «Инноватор»

Бодаухан Кайрат, к.э.н., ассоциированный профессор, научный сотрудник ТОО «НПП «Инноватор»

Амерханова Индира Кулатаевна, $\mathrm{PhD}$ докторант 3 курса КазГЮИУ, научный сотрудник ТОО «НПП «Инноватор»

В настоящее время наиболее приоритетной и значимой задачей для успешного социально-экономического развития Республики Казахстан является государственное регулирование миграции молодежи. Эффективная реализация государственной политики в области молодежной миграции влияет не только на рынки труда, но и на уровень технического и технологического развития, развития социума и культуры, а также и на общую демографическую ситуацию в стране. Миграционные процессы, особенно, миграция молодежи и трудовых ресурсов, относится к числу важных факторов, влияющих на социальноэкономическую ситуацию как в стране в целом, так и в её регионах.

Под молодежью, в соответствии с Законом Республики Казахстан от 9 февраля 2015 года №285-V ЗРК «О государственной молодежной политике», подразумевают граждан Республики Казахстан от четырнадцати до двадцати девяти лет. Целью государственной молодежной политики является создание условий для полноценного духовного, культурного, образовательного, профессионального и физического развития молодежи, участия в процессе принятия решений, успешной социализации и направления ее потенциала на дальнейшее развитие страны [1].

В Казахстане начиная с 2012 г. наблюдается отрицательное миграционное сальдо. Анализ данных по миграции населения Бюро национальной статистики Агентства по стратегическому планированию и реформам РК показывает, что за 
период с 2015 по 2021 годы, численность прибывших и выбывших людей ежегодно увеличивается, но количество выбывших людей из Казахстана с каждым годом, начиная с 2015 г. больше, чем число прибывших.

Также, по данным Бюро национальной статистики, численность молодежи в Республике Казахстан (14-28 лет) на начало 2021 года составила 3739883 чел., что составляет 19,8\% от общей численности населения в Республике Казахстан, из них 2101838 чел., или 56,2\% - это городская молодежь, а 1638045 чел., или 43,8\% - это сельская молодежь [2].

Миграция как процесс - важный фактор стабильного территориального, социально-экономического и демографического развития страны. Миграция за пределы страны предполагает отъезд более образованных, трудолюбивых, амбициозных людей, а страна в будущем теряет талантливых специалистов, ученых, образованных, активных граждан. Миграция, в частности молодежная миграция, является для принимающих стран источником дополнительных трудовых ресурсов, а также позволяет сглаживать демографические проблемы.

Основная причина миграции молодежи заключается в желании развиваться, реализовываться по курсу образования, также имеет большую значимость обладание международным образованием. Другая причина - через миграцию формируется трудовой потенциал молодежи, а трудовая миграция является более широким понятием, чем молодежная миграция, и этот вопрос можно рассматривать как на республиканском, так и на межстрановом уровне.

В общих миграционных тенденциях Казахстана в настоящее время особое внимание необходимо обратить на увеличение потоков внешней миграции и на тот факт, что в числе отъезжающих из страны на постоянное место жительства 43,8\% составляют молодые люди от 15 до 34 лет, характеризуется как стабильнонарастающий отток трудовых ресурсов страны. За последние годы наблюдается негативная тенденция роста отрицательного сальдо внешней миграции населения Казахстана, которая существенно негативно влияет на рынок трудовых ресурсов и снижает возможности экономического развития нашей страны [3].

За последние 5 лет в Казахстане растет тенденция увеличения численности молодежи, желающей получить высшее образование за рубежом, а также продолжить свое образование в магистратуре и докторантуре в зарубежных университетах. Эти показатели свидетельствуют об актуальности проблемы стабильно нарастающей утечки трудовых ресурсов, в том числе - талантливых и профессиональных молодых людей. Следовательно, по мнению авторов, возникает еще одна проблема - снижение качества человеческого капитала.

Миграционные потоки, связанные с получением образовательных услуг за пределами своей страны, рассматривается большей долей молодых граждан Казахстана, как некий трамплин для эмиграции из страны в ближайшей перспективе. По мнению аналитиков регионального офиса МОМ в Казахстане и Центральной Азии, «потенциал невозвратной миграции молодых людей, выехавших из стран Центральной Азии на работу или учебу, может быть оценен в 30-35\% с тенденцией к росту». Стоит заметить, что образовательные программы направлены, как правило, на повышение уровня имеющейся 
квалификации молодых людей внутри родной страны с тем, чтобы они на долгосрочной основе вкладывали свои знания и опыт и занимались развитием экономики своей страны. Однако, получив в зарубежных университетах высшее или послевузовское образование и опыт проживания за рубежом, образовательные мигранты, вернувшись на родину - снова ориентируются на эмиграцию за рубеж уже с целью трудоустройства, или получить гражданство той страны, либо остаться там на ПМЖ [4].

В результате проведенного исследования, исследователями (авторами статьи) были определены основные факторы, причины и мотивы выбора зарубежных университетов молодежью Казахстана для получения образования, а также эмиграции молодежи в зарубежные страны с целью трудоустройства.

По нашему мнению, основныли причинами для выбора нашей молодежью зарубежных университетов с целью обучения, являются следующие:

1. Обеспечение доступного и качественного образования;

2. Интересные и разнообразные образовательные программы;

3. Получение актуальных теоретических и практических знаний;

4. Наличие современной необходимой инфраструктуры при университетах (собственные кампусы, библиотеки, лаборатории, спортивные секции и т.д.);

5. Программы обмена, позволяющие пройти часть курса обучения в другой стране мира;

6. Адаптированные программы обучения для иностранцев, особенно для молодежи из стран СНГ;

7. Программы образования в университетах максимально приближены требованиям рынка труда;

8. Содействие университетами в трудоустройстве студентов и выпускников (ярмарки вакансий, подбор стажировок и т.д.);

9. Отсутствие перспектив (по мнению некоторых респондентов) получения качественного и доступного образования в Казахстане, и др.

Основные мотивы для молодежи страны, при принятии решения «обучение за рубежом», определены в результате нашего исследования в следующем виде:

1. Интересные и разнообразные образовательные программы и курсы, в том числе различные языковые курсы;

2. Предоставление за рубежом льгот на проживание, питание, проезд и другие услуги для обучающихся студентов, магистрантов;

3. Образовательные программы, соответствующие мировым стандартам;

4. Прикладное образование, отвечающее запросам работодателей;

5. Возможности для прохождения успешной стажировки с дальнейшим трудоустройством по специальности;

6. Большое желание учиться и проживать в другой стране, т.к. мир сегодня не имеет границ и можно попробовать разные варианты;

7. Желание проживать и учиться в той стране, где есть новые возможности для личностного роста и развития;

8. В последнее время молодежь Казахстана все больше уезжает за рубеж на учебу, на стажировку, на работу;

9. После получения образования в зарубежном вузе, большие перспективы 
найти и хорошую работу за рубежом;

10. Молодежь с хорошим зарубежным образованием более востребована на рынке труда Казахстана.

Основными факторами «притяжения» казахстанской молодежи за рубеж для получения образования, в совокупности с вышеуказанными причинами $u$ мотивами образовательной миграции, по нашему мнению, являются такие, как:

1. Доступность проживания и потребления в выбранной зарубежной стране, особенно для студентов, магистрантов;

2. Возможности быстрого трудоустройства после получения образования;

3. Близость культуры и языков для студентов, магистрантов из стран СНГ в большинстве стран ближнего зарубежья;

4. Легкий процесс адаптации для студентов, магистрантов из Казахстана;

5. Содействие развитию талантливой молодежи в зарубежных странах;

6. Доступность культурного досуга и отдыха за рубежом;

7. Благоприятные климатические условия, возможность путешествовать;

8. Проживание в зарубежной стране родителей, друзей, родственников;

9. Наличие финансовых ресурсов для обучения и проживания в этой стране.

По мнению исследователей необходимо отметить и негативные фaкторы «выталкивания», которые прямо или косвенно влияют на желание молодежи мигрировать за рубеж в образовательных целях:

1. Молодежная безработица и низкая заработная плата;

2. Коррупция и безнаказанность замешанных в этом должностных лиц;

3. Недостаточно высокий уровень образования и здравоохранения;

4. Инфляция, рост цен и ухудшение покупательских возможностей;

5. Дороговизна потребительских товаров, услуг, досуга, туризма и пр.;

6. Невостребованность специальностей, профессий на рынке труда;

7. Слабые социальные программы для поддержки молодежи, в том числе для талантливой молодежи, и другие негативные факторы.

По нашему мнению, та часть населения Казахстана, которая эмигрирует за рубеж, в том числе молодежь - стремиться, прежде всего, получить престижное образование, найти достойную и хорошо оплачиваемую работу, создать свой собственный бизнес, достичь материального благополучия, улучшить качество жизни и условия проживания, получить хорошее образование и иметь перспективы для карьеры в Казахстане.

Проведенное исследование показало, что есть определенные трудности, которых опасается молодежь Казахстана, и эти трудности отрицательно влияют на миграционные настроения молодежи:

- Не получить доступного и качественного образования;

- Не найти хорошую работу по специальности;

- Проблем с трудоустройством из-за отсутствия опыта работы, которые требуют работодатели;

- Трудностей реализации своих жизненных целей;

- Выбрать не перспективную специальность или профессию;

- Сложностей в реализации своих предпринимательских идей;

- Финансовых трудностей, в т.ч. остаться без средств к существованию; 
- Трудностей остаться без друзей, без поддержки и т.п.

Все рассмотренные выше ключевые факторы, основные мотивы и причины образовательной миграции молодежи Казахстана за рубеж, были представлены в разработанных исследователями анкетах социологического опроса, которое было проведено в виде анкетирования среди выпускников некоторых школ, лицеев, гимназий и колледжей, среди выпускников бакалавриата, магистратуры некоторых университетов 5-ти городов: Нур-Султан, Алматы, Актобе, Уральск и Петропавловск.

Необходимо отметить, что основными направлениями эмиграции молодежи из Казахстана в настоящее время с целью получения образования являются такие страны, как: Российская Федерация, Германия, Чехия, Турция, Китай, США, Южная Корея, Великобритания, Канада и другие страны.

Ежегодно миллионы людей со всего мира отправляются в другие страны для получения знаний: для получения высшего и поствузовского образования, изучения иностранных языков, для прохождения стажировок, повышения квалификации. На сегодня главными потребителями услуг на международном рынке высшего и поствузовского образования являются, прежде всего, представители из стран Азии, а также Западноевропейских стран.

Возможность предоставить высшее образование иностранным студентам представляет собой показатель успешности «мягкой силы» принимающей стороны. Кроме того, у иностранного обучающегося появляется возможность раскрыть весь накопленный собственный образовательный и культурный потенциал и возможности. В целом, привлечение иностранных студентов в образовательные учреждения зарубежной страны рассматривается в качестве значимого показателя развитости «мягкой силы» государства, в то время, как образовательная миграция выступает в качестве условия для успешной реализации взаимного культурного обогащения [5].

Авторы статьи считают, что повышенный интерес молодежи Казахстана к обучению за рубежом во многом представляется реакцией на доступное и относительно недорогое высшее образование, льготные условия, предлагаемые в ряде зарубежных стран достаточно активно (путем постоянных рекламных роликов, инструкций по поступлению, а также видео почти во всех социальных сетях), наличие всех необходимых условий и высокой инфраструктуры при университетах, собственных кампусов для обучения и проживания студентов. Также, важным фактором влияния на образовательную миграцию молодежи в последнее время можно с уверенностью назвать отмену вступительных экзаменов, приемы на обучение без сдачи ЕНT и KTA, IELTS и TOFEL, SAT и т.д. Также необходимо отметить достаточно привлекательные условия для поступления в зарубежные вузы в виде гибкого графика учебы, доступной стоимости, дистанционных программ - играют большую роль при выборе зарубежного университета, чем отечественного. Также, авторы хотят отметить достаточно «навящевую» $и$ «привлекающую» рекламу зарубежных вузов в рубриках «Образование за рубежом». К примеру, часто на сайтах зарубежных университетов можно увидеть видеоролики, где сами казахстанские студенты рекламируют зарубежный вуз, привлекают поступать молодежь Казахстана в 
университеты, в которых они обучаются.

Молодежная миграция представляет собой отдельное самостоятельное направление исследований, так как основной причиной выезда является получение образования. Фокус внимания постепенно смещается к наиболее молодым возрастам - к периоду, когда принимается первичное решение о миграции с целью получения образования. Такое решение оказывает колоссальное влияние как на последующую жизнь молодого человека, так и в целом на пространственное распределение человеческого капитала. Конкуренция за лучшую молодежь становится существенным фактором развития [6].

Динамика молодежной миграции, её объемы, а также мотивы, драйверы и факторы, влияющие на молодых граждан, во многом зависят от того, насколько эффективна молодежная политика, проводимая в стране и как она взаимосвязана с механизмами регулирования миграционных процессов и институтами, ее осуществляющих. Особенно важно отметить, что вопросы миграции молодежи за рубеж, в частности проблемы образовательной и трудовой миграции молодежи Казахстана, в настоящее время не исследованы на достаточном уровне и требуют дальнейшей проработки и изучения.

Серьезную проблему для Казахстана, по оценкам экспертов, представляет образовательная миграция. По разным данным в зарубежных вузах обучается от 70 до 85 тысяч казахстанских студентов, и это число с каждым годом увеличивается. При этом вопрос о возвращении студентов после окончания учебы остается открытым.

Что касается факторов и мотивов трудовой миграции молодежи за рубеж, в результате нашего исследования, проведенного на данный момент времени, можно отметить следующие основные причины, которые «подталкнули» искать работу и трудоустроиться молодежью Казахстана за рубежом:

1. Отсутствие возможности самореализации на равных условиях;

2. Сложности трудоустройства на хорошо оплачиваемую работу;

3. Сложности трудоустройства на работу по специальности;

4. Невостребованность высококвалифицированных специалистов;

5. Слабое функционирование и регулирование рынков труда;

6. Потеря работы, длительный поиск нового места работы;

7. Отсутствие постоянного места работы, нестабильность в работе;

8. Ухудшающаяся экономическая ситуация, экономический кризис;

9. Отсутствие демократических изменений, независимой судебной системы;

10. Неразвитость социальной и трудовой инфраструктуры в целом.

В качестве основных факторов «выталкивания», побуждающих молодежь страны мигрировать за рубеж в целях трудоустройства, нами определены такие:

1. Молодежная безработица, низкий уровень заработной платы в целом;

2. Высокие цены на потребительские товары, услуги, растущая инфляция;

3. Высокая стоимость найма и покупки жилья, «дороговизна жизни»;

4. Низкий уровень оплаты труда, низкая оценка человеческого капитала;

5. Безработица, нарушения трудовых отношений и произвол работодателей;

6. Отсутствие социальных гарантий, в том числе, от безработицы;

7. Неуверенность молодежи в своем будущем и будущем своих детей; 
8. Невостребованность полученной профессии на рынке труда;

9. Отсутствие перспектив самореализации, как в профессиональной, так и предпринимательской сфере;

10. Нестабильная социально-экономическая ситуация, неравенство доходов и разрыв общества;

11. Коррупция, волокита и бюрократия, безответственность чиновников;

12. Неэффективное государственное управление, регулирование экономики;

13. Низкий уровень правовой защищенности, несовершенство судебной системы;

14. Образовавшиеся конфликты разного рода (семейно-бытовые, трудовые);

15. Неблагоприятная экология и климатические условия.

Необходимо отметить, что в соответствии с Концепцией миграционной политики Казахстана на 2017-2021 годы выделяется перечень проблем, которые «требуют расширения концептуальных основ миграционной политики», в частности, это проблемы:

- Дефицита квалифицированных кадров в отдельных секторах экономики;

- Регулирование межрегиональной миграции, решение проблем трудодефицитных и трудоизбыточных регионов;

- Риска роста оттока квалифицированных кадров и талантливой молодежи [7].

Что касается факторов «притяжения» и мотивов, побуждающих молодежь Казахстана переехать за гранииу в целях трудоустройства, нами определены основные факторы и мотивы трудовой миграции молодежи в следующем виде:

- Трудоустройство на достойную и интересную работу;

- Официальное трудоустройство с получением достойной заработной платы;

- Упрощение разрешительных процедур для трудоустройства;

- Доступные и хорошие условия для профессионального, интеллектуального и физического развития молодежи;

- Достойная оплата труда, высокие социальные гарантии;

- Возможности для самореализации, карьерного роста, профессионального развития;

- Налаженная связь университетов с работодателями, что упрощает поиск работы выпускникам зарубежных ВУЗов;

- Содействие трудоустройству молодежи в стране, поддержка талантливой молодежи;

- Доступность аренды жилья, качество жизни и потребления в этой стране;

- Возможность получения визы, равной виду на жительство;

- Социально-экономическая стабильность, развитая экономика страны;

- Возможности приобретения новых знаний, профессий, жизненного опыта;

- Низкий уровень коррупции, отсутствие протекционизма и дискриминации;

- Высокий уровень культуры населения, комфортность социальной среды;

- Высокий уровень качества сферы образования и медицины;

- Высокий уровень развития науки и научно-технического прогресса;

- Высокий уровень безопасности, защищенность свобод и прав общества;

- Развитое гражданское общество, эффективная работа институтов власти.

Таким образом, в настоящее время актуальной проблемой для Казахстана 
является не только трудовая эмиграция молодежи, но и трудовая миграция населения за рубеж разных возрастов, причем специалистов жизненно важных профессий. Итак, за первое полугодие 2021 года из Казахстана эмигрировали 14192 чел., из них в Россию - 11614 чел., Германию - 1575 чел., Польшу - 158 чел., Беларусь - 116 чел. и в Израиль - 110 чел. Если анализировать данные за последние 5 лет по численности трудовой эмиграции граждан Казахстана в зарубежные страны (2016-2020 годы) в разрезе специальностей, то наблюдается следующая картина: среди уехавших граждан в основном это специалисты с техническим, экономическим, педагогическим и медицинским профилем - это очень значимые и жизненно необходимые сферы [8].

Однако это не полные данные. Известно, что значительное количество людей, в т.ч. молодых специалистов уехали на ВНЖ или ПМЖ в такие страны, как Турция, Канада, Южная Корея, ОАЭ и другие страны по разным причинам.

Насколько «утечка мозгов» является актуальной проблемой для нашей страны на сегодняшний день? Насколько в этом отношении можно говорить об угрозах для экономического развития нашей страны?

Насколько широки и масштабны могут быть последствия такой тревожной динамики образовательной и трудовой миграции молодежи Казахстана для жизнедеятельности государства и общества?

На основе проводимого глубинного анализа и исследования вопросов образовательной и трудовой миграции молодежи Казахстан за рубеж, изучив опыт зарубежных стран к подходам в регулировании миграционных потоков молодежи, авторы статьи разработают некоторые рекомендации, которые могут быть положены в основу разработки новой Концепции молодежной политики Казахстана до 2025 года. Эффективная реалиация молодежной и миграционной политики Казахстана должна сократить растущий отток молодежи за рубеж с целью получения образования и трудоустройства, и уменьшить число тех молодых людей, которые принимают решение об отъезде за рубеж по разным факторам, причинам и мотивам миграции.

\section{Список литературы:}

1. Закон Республики Казахстан от 9 февраля 2015 года №285-V ЗРК «О государственной молодежной политике». https://adilet.zan.kz/rus/docs/Z1500000285

2. Численность молодежи Республики Казахстан (2020-2021 годы) / Демографическая статистика - [Электронный ресурс]. - URL: https://stat.gov.kz/official/industry/61/statistic/5

3. Джусибалиева А.К., Искакова Д.М., Бодаухан К., Искакова Д.Б. Тенденции образовательной миграции молодежи Казахстана за рубеж. // Молодёжь, наука, образование: актуальные вопросы, достижения и инновации: сборник статей II Международной научно-практической конференции. - Пенза: МЦНС «Наука и Просвещение». - $\quad 2021 ., \quad$ c.62-66. https://naukaip.ru/wpcontent/uploads/2021/06/MK-1128.pdf

4. Внешняя молодежная миграция в странах Центральной Азии: анализ рисков и минимизация негативных последствий / Международная организация 
по миграции (МОМ) / Субрегиональный Координационный офис в Центральной Азии. - Республика Казахстан, 2019 г. - [Электронный ресурс]. - URL: https://publications.iom.int/system/files/pdf/external_youth_migration_ru.pdf

5. Jussibaliyeva Aruzhan Kazikhanovna et al. 2021. Interregional Migration: Economic Aspects and Foreign Experience of Public Regulation. Academy of Strategic Management Journal. Volume 20 (Special Issue 1), Strategies in Modern Economy \& Economic Policy, 47-59 (Scopus).

https://www.abacademies.org/articles/interregional-migration-economic-aspects-andforeign-experience-of-public-regulation-10234.html

6. Smith D.P., Rerat P., Sage J. (2014) Youth Migration and Spaces of Education // Children's Geographies. Vol. 12. No 1. P. 1-8.

7. Концепция миграционной политики Казахстана на 2017-2021 годы / Утверждена Постановлением Правительства Республики Казахстан от 29 сентября 2017 года №602. - [Электронный ресурс]. - URL: https://tengrinews.kz/zakon/pravitelstvo_respubliki_kazahstan_premer_ministr_rk/ho zyaystvennaya_deyatelnost/id-P1700000602/

8. Из Казахстана уезжают специалисты жизненно важных профессий: стоит ли бить тревогу? / Караван. Аналитика / 23.09.2021 г. - [Электронный ресурс]. URL: - $\quad$ https://www.caravan.kz/articles/iz-kazakhstana-uezzhayut-specialistyzhiznenno-vazhnykh-professijj-stoit-li-bit-trevogu-774289/ 


\title{
РОЛЬ ІНЖЕНЕРНОГО БЛАГОУСТРОЮ У ПРОСТОРОВОМУ ПЛАНУВАННІ
}

\author{
Лабінська Галина Миколаївна \\ кандидат географічних наук, доцент \\ Львівський національний університет імені Івана Франка
}

Благоустрій населених пунктів згідно Закону України визначають як “комплекс робіт з інженерного захисту, розчищення, осушення та озеленення території, а також соціально-економічних, організачійно-правових та екологічних заходів з покращення мікроклімату, санітарного очищення, зниження шуму та інше, що здійснюються на території населеного пункту з метою ї̈ раціонального використання, належного утримання та охорони, створення умов щодо захисту і відновлення сприятливого для життєдіяльності людини довкілля" [1]. В утриманні належного стану території надзвичайно важливу роль відіграє інженерна інфраструктура - “комплекс інженерних споруд $i$ комунікаиій" [2], маючи на увазі сукупність транспортної, водогосподарської, енергетичної та інших комунікацій і споруд, які обслуговують господарство території. У світлі реформи децентралізації характеристики інженерної інфраструктури набули форм вагомого ресурсу територіальної громади, здатної вплинути на ії конкурентоспроможність.

На щастя, вже усвідомлена потреба комплексного розгляду питань інженерної підготовки усієї проектованої території на етапі напрацювання проектно-планувальних рішень. Підготування території для будівництва пов'язана із забезпеченням захисту від затоплення і підтоплення, пониження рівня грунтових вод, осушення заболочених місцевостей, необхідністю організації поверхневого стоку, регулювання водотоків, облаштування водойм, боротьби з яроутворенням, абразією, зсувними і селевими явищами.

Інженерно-меліоративна підготовка земель охоплює також кліматичну, водну, снігову, земельну, а також фітомеліорацію. Зокрема, під кліматичною меліорацією, якій надають все більшої уваги, мають на увазі комплекс заходів, спрямованих на позитивні зміни місцевих кліматичних умов у потрібному для людини напрямі. Кожен з видів меліорації призначений для покращення того чи іншого компонента довкілля. Пов'язані між собою компоненти меліорації обумовлюють синергетичний вплив на природні умови території.

Господарська діяльність людини, що спричинює зміни у співвідношенні складових радіаційного та теплового балансу атмосфери, стану іiі прозорості, призводить до різноманітних змін клімату. Розрізняють макро-, мезо- i мікрокліматичну меліорацію, проведення яких має вплив на клімат у межах міст, промислових майданчиків, місць відпочинку, а також окремих кліматичних районів і віддалених ділянок. 
Своєрідний мікроклімат формується у великих містах, де постійно виділяється в атмосферу велика кількість пилу, газів та тепла і створюються перешкоди для повітряних потоків. У зв'язку 3 цим у великих містах підвищується температура, посилюється частота й інтенсивність туманів, мають місце контрасти у розподілі обсягів атмосферних опадів між центральними і окраїнними районами тощо. Кліматична меліорація передбачає заходи 3 поліпшення клімату великих міст шляхом корекції розміщення промислових підприємств, регулювання режиму їхньої роботи та спеціалізації, раціонального розміщення житлових масивів і зелених зон, концентрації висотних споруд у різних районах тощо. Корегувати клімат окремих регіонів можна й шляхом регулярного безпосереднього впливу на погодні процеси - розсіювання хмар i туманів, викликання опадів, а також прискорення танення льодового і снігового покриву, впливаючи на їх альбедо тощо. Через створення штучних водойм, заліснення, осушення, зрошення земель, розміщення селітебних і промислових площ 3 врахуванням локальних природних умов змінюють режим зволоження, тепловий режим грунту і надземного прошарку повітря, вітровий режим.

Показовим у цьому відношенні є китайський проект “Лісових агломераиій” [3]. Країна взяла зобов'язання сформувати шість агломерацій лісових міст, з'єднаних екологічними коридорами з твердих лісів та водно-болотних угідь. Амбітне завдання видається досяжним у зв'язку з тим, що площа лісу в китайських містах стрімко зростає: щорічно на $1 \%$ від загальної міської площі. Проект "Міські ліси” анонсували у Парижі [4]. Рясну рослинність висадять біля низки визначних об'єктів міста. Це змінить звичний архітектурний вигляд Парижа, а новостворені “острівці свіжості” нівелюватимуть вплив високих літніх температур у місті. До 2030 р. заплановано засадити рослинністю близько половини площі міста, озеленюючи паркінги, облаштовуючи зелені зони у подвір'ях шкіл, на дахах, створюючи нові сквери і парки. Створення “зеленого" міста майбутнього з акцентом на нових технологіях і зелених просторах анонсувала Малайзія [5]. Статус біофільних міст вже отримали Вашингтон, Веллінгтон, Единбург, Панама, Сінгапур та інші. Широко відомі й новітні архітектурні проекти житлових будинків з інклюзією зелених насаджень [6].

В Україні Міністерство захисту довкілля та природних ресурсів, у свою чергу, оголосило про початок проекту великого заліснення до 2030 р. Ліси займають майже 16\% територій України, однак через зміну клімату, посухи та поривчасті вітри все частіше виникають лісові пожежі. Окрім цього, у країні немає реальної оцінки масштабів незаконних рубок лісу! У планах також розширення Смарагдової мережі в Україні з 10\% площі країни до 20\%.

У Львові зокрема, у даному контексті, почали затверджувати межі зелених зон. На території Львова розкинулося 33 парки та 108 скверів різних за площею та локаціями. За відсутності офіційних меж зелені зони швидко втрачають площу. У 2020 р. процес оформлення землі парків став одним із міських пріоритетів: 21 парк та 35 скверів отримали визначені кадастрові номери та чітко встановлені й закріплені в документах межі.

У Вінниці, а згодом і у Львові, висунули екоініціативу щодо комбінування ефективного громадського транспорту і креативного ландшафтного дизайну, яку 
у 2018 р. підхопило Міністерство регіонального розвитку, будівництва та житлово-комунального господарства, запропонувавши навіть закріпити вимоги до облаштування зелених колій у нових державних будівельних нормах (ДБН). У такий спосіб трамвай стає більш дружнім до екосистеми поселення через створення рослинної “подушки” вздовж трамвайних маршрутів. А все тому, що озеленення трамвайних колій має позитивний ефект на якість повітря, його очищення від викидів та твердих частинок пилу; поглинання вібрацій та шумів від руху трамваїв; акумуляцію надлишку опадів; створення нових зелених територій; нейтралізацію перегрівання поверхонь у спекотні дні.

Екологи також переконують, що містам важливо відмовитися від скошування трави. У світі вже перейшли до більш прогресивних технологій догляду за газонами, через управління трав'яним покривом: його наявністю, склад трави і частотою покосів. Значний досвід у практиці переосмислення управління трав'яним покривом мають міста США, Австралії, Кореї. Для України ця тема $\epsilon$ новою, проте надзвичайно актуальною 3 огляду на кліматичні зміни, а саме: частота покосів істотно впливає на водний баланс території; більшість зелених зон міст косять 3 використанням газонокосарок на паливі; працююча газонокосарка здатна видавати шум 90-180 $d B$; через часте косіння більшість рослин не встигають заквітнути (дослідження у Нью-Йорку довело, що газонокосіння зумовлює кризу запилюючих комах. Так, у Варшаві у 2020 р. перші покоси відбулися після завершення цвітіння кульбаб); економія ресурсів.

Надзвичайно важлива оцінка території поселень за природними умовами $\mathrm{i}$ антропогенними чинниками. Оцінка території за природними умовами передбачає врахування рельєфу, геологічної будови і наявності корисних копалин, гідрогеологічних і інженерно-геологічних умов, клімату, грунтів, рослинності. До антропогенних чинників оцінки території відносять: санітарногігієнічні умови території; насиченість іiі транспортними i інженерними мережами і спорудами; транспортну досяжність основних промислових, адміністративно-господарських і культурних центрів; вимоги охорони довкілля; архітектурно-естетичні чесноти окремих природних і культурних ландшафтів.

Проведення інженерно-геологічного зонування території полегшує прийняття рішень щодо локалізації будівель, сільськогосподарських підприємств і угідь, виділення місць під лісозахисні зони, заповідники і т. д. Необхідність таких кроків візуалізують конкретні приклади. Так, у селі Піски у Львівській області всього за одну ніч (20.04.2021 р.) з'явилося велике карстове провалля [7]. Це вже третій випадок у даному селі, яке розміщене на карстових порожнинах. Як і в попередні рази (у 1973, у 2010 рр.), розглядається можливість засипати провалля глиною. Однак, процес зсуву та розширення воронки, як засвідчують місцеві, триває і далі. А у Львові, усупереч приписам, активно провадять житлове будівництво на карстонебезпечних ділянках [8].

Формування єдиної взаєпов'язаної системи інженерних заходів грунтується на функціональному зонуванні території поселення. Цьому передує інженерна підготовка території, яка охоплює інженерно-меліоративні, інженернобудівельні роботи і рекультивацію порушених земель. При вирішенні цих завдань послідовно розглядають заходи регіонального, обласного і локального 
рівнів. Аналізують наявні проекти, проводять оцінку впливу їх реалізації на санітарно-гігієнічні умови і природні ресурси регіону, на організацію розселення й виробництва.

Трактування основних понять у даному контексті: “містобудівна документація", "лінії регулювання забудови", "містобудівні умови та обмеження забудови земельної ділянки”, “план зонування територіі”, “червоні лінії", подає Закон України "Про регулювання містобудівної діяльності". Регулювання стану й розвитку інженерної інфраструктури в Україні здійснюють у відповідності до нових ДБН [9].

Для комплексного вирішення питань транспортної інфраструктури (цю тему, на нашу думку, слід розглядати окремо) потрібна координація усіх видів транспорту, які забезпечують внутрішні і зовнішні зв'язки між поселеннями. В Україні реалізують проект універсальної базової мобільності: доволі розвинута мережа велодоріжок у містах, з'являються альтернативні способи пересування $\mathrm{i}$ станції прокату. За підтримки німецької неприбуткової організації: Deutsche Gesellschaft für Internationale Zusammenarbeit (GIZ) в Україні реалізують проект: "Integrathed Urban Development in Ukraine" [https://www.giz.de/en/worldwide/32413.html], який підтримує інтегрований розвиток українських міст (у їх переліку активні Житомир, Вінниця, Львів, Полтава та ін.). Так, у Львові працює кілька сервісів 3 оренди електросамокатів: Kiwi, Electro Lviv, E-wings, Easy, Bolt; активно розвивається мережа заправок для електромобілів. У цьому контексті у Львові активно працюють над втіленням Плану сталої мобільності [10]. У місті також презентували “Інтегровану концепцію розвитку: Львів 2030” та План дій “Зеленого міста” до 2035 р. Метою поставлено досягнення візії міста як кліматично-нейтрального та енергонезалежного вже до 2050 p.

Для великих міст, подібно Львову, іманентна зростаюча автомобілізація. Загалом, в Україні у 2000 р. фіксували 17 автомобілів/100 домогосподарств, у 2019 - вже 25 [11]. У зв'язку з цим давно назріла потреба кардинальної реорганізації сучасного простору житлових кварталів. У великих містах спостережено дві тенденції: намагання наблизити місця постійного паркування індивідуальних транспортних засобів до житлових районів і віддалення гаражів від місць проживання. Нестача вільних територій у містах й інтенсивність використання міських земель 3 іншою метою стимулює забудовників пропонувати варіанти багатоповерхових гаражів-стоянок, планувати прибудинкові території відповідно да запитів часу. У невеликих містах й далі переважає індивідуальна форма зберігання легкових машин. Фахівці рекомендують запроваджувати диференційований ступінь автомобілізації: для великих міст він може бути прийнятий меншим, ніж для малих і середніх.

Життєвоважливою стає проблема забезпечення водними ресурсами в Україні. Кожен регіон має принципову схему водозабезпечення i водовідведення, де враховано особливості водогосподарських балансів територій. Важливе місце на сучасному етапі належить обліку водоспоживання: господарсько-побутового, виробничого, сільськогосподарського. 
Вирішення питань водопостачання i водовідведення можливе через запровадження систем вторинного водопостачання, безстічних систем каналізації і повторного використання очищених стоків на виробництві чи для зрошення, впровадження розробок 3 опріснення морських i підземних слабосолених вод, утилізація доочищених вод, використання термальних вод, поповнення запасів грунтових вод і т. д.

Вже зараз окреслилася проблема водозабезпечення регіонів з дефіцитом прісної води, особливо це стосується півдня країни. Довготривалі посухи, нерівномірні опади та активніше випаровування вологи внаслідок потепління призводять до постійного зменшення водності річок. Нераціональне використання запасів води та постійне забруднення водних ресурсів тільки погіршують ситуацію. Інститут водних проблем і меліорації прогнозує, що уже до 2050 р. Україні доведеться імпортувати питну воду [12].

В анексованому Росією Криму у грудні 2020 р. було оголошено про пошук прісної води під Азовським морем. Реалізація такого плану, на думку науковців, позначиться на якості питної води в пробурених свердловинах по всьому Криму, може статися порушення природних процесів водообміну і формування ресурсів підземних вод. До того ж проект дороговартісний, а запаси прісної води під Азовським морем, згідно оцінки українських і закордонних геологів, дуже незначні. Більшість аналітиків сходяться на думці, що такі заяви робляться для заспокоєння населення. Адже у Криму масово всихають водосховища; місцеві жителі скаржаться на жахливий стан води; у багатьох поселеннях запроваджено подання води за графіком. До анексії $85 \%$ потреб півострова у прісній воді забезпечувала Україна через Північно-Кримський канал.

Впроваджувані зміни торкаються і якості питної води. Так, більшість мешканців Львова вже отримують воду без хлору [13]. Реконструкція насосних станцій міста дала змогу перевести їх на альтернативний спосіб дезінфекції води за допомогою гіпохлориту натрію.

Трансформаційні зміни відбуваються в електро- й теплоенергетиці і паливноенергетичній базі країни загалом. Ринкові підходи застосовувані при формуванні паливно-енергетичного балансу країни, а енергоаудит став вже постійним елементом на макро- і на мікрорівні країни. Енергоощадні технології активно впроваджують у житловому будівництві. Провадять утеплення фасадів, підвалів, горищ. Сучасні багатоквартирні будинки оснащені індивідуальним опаленням, лічильниками обліку тепла; є можливість терморегуляції.

Модернізація стану інженерної інфраструктури житла чи мікрорайону стала важливою потребою сучасності. Потрібна комплексна оцінка технікоекономічних та екологічних умов функціонування інфраструктури поселень [14].

Після 2014 р. змінилася структура виробництва електроенергії в Україні: знизилася частка ТЕС, натомість зросла частка АЕС. Прогнозують подальше зростання потужностей “зеленоі” енергетики, як і збільшення іiі частки у загальній структурі виробництва електроенергії в Україні. До прикладу, в Овручі, у Житомирській області, запустили нову кліматично-нейтральну Поліську ТЕС, яка здатна забезпечити безперебійне постачання електроенергії у період пікових навантажень. ТЕС разом 3 плантаціями енергетичної верби 
утворює зелений енергетичний кластер - повний цикл від вирощування палива до виробництва електроенергії. На переконання інвесторів, для будівництва нової енергетичної інфраструктури в Україні, з максимальним використанням відновлювальних джерел, наявні всі ресурси [15]. 3 іншого боку, у Дніпровському районі Києва мешканці багатоповерхівки здали дах 14під'їздного будинку в оренду під сонячні панелі. Доходи від оренди витрачають на ремонт і благоустрій. Інвестор - українська компанія “Аврора Терм", відремонтував покрівлю будинку і встановив там електростанцію 31200 сонячних панелей, загальною потужністю - 330 кВт. Подібний проект реалізовано і у Львові.

Тішить, що обсяги капітальних інвестицій в інженерні споруди в України, як засвідчує статистика, з року в рік зростають. У 2019 р. вони складали $24 \%$ до загального обсягу інвестицій в матеріальні активи [11].

\section{Список літератури:}

1. Закон України "Про благоустрій населених пунктів". URL: Про благоустрій населених пу... | від 06.09.2005 № 2807-IV (rada.gov.ua)

2. Закон України “Про регулювання містобудівної діяльності". URL: Про регулювання містобудівно... | від 17.02.2011 № 3038-VI (rada.gov.ua)

3. Китай прагне до 2020 року сформувати шість агломерацій міст-лісів. $U R L$ : Китай стремится к 2020 году сформировать шесть агломераций городовлесов (ecology.md)

4. Біля визначних пам'яток Парижа висадять сади й гаї (проект). URL: Біля визначних пам'яток Парижа висадять сади й гаї (проект) | Хмарочос (hmarochos.kiev.ua)

5. У Малайзії збудують “зелене” місто майбутнього. URL: У Малайзії збудують «зелене» місто майбутнього - НОВИНИ - Телеканал Індиго ТВ. Путь к гармонии (indigotv.com.ua)

6. “Лісові міста" - радикальний план, щоб врятувати Китай від забруднення повітря [переклад з англ. Оксани Вергелес]. URL: «Лісові міста»-радикальний план, щоб врятувати Китай від забруднення повітря - новини ZIKUA.TV

7. У Львівській області посеред села за ніч утворилося 30-метрове карстове провалля. $U R L$ : У Львівській області посеред села за ніч утворилося 30-метрове карстове провалля: фото - vininform.com.ua

8. Михалик B. У Львові зводять будівлі над небезпечними підземними порожнинами. $U R L$ : У Львові зводять будівлі над небезпечними підземними порожнинами - Четверта студія (4studio.com.ua)

9. ДБН В.2.2-12:2019 “Планування та забудова територій”. URL: В2212IB.vp (dbn.co.ua)

10. Ейсмунт B. Місто коротких відстаней. Як розробляють План сталої мобільності для Львова. / Вікторія Ейсмунт. URL: Місто коротких відстаней. Як розробляють План сталої мобільності для Львова (tvoemisto.tv)

11. Офіційний сайт Державної служби статистики України. URL: Державна служба статистики України (ukrstat.gov.ua) 
12. Україні вже до 2050 року загрожує дефіцит питної води.URL: Україні загрожує дефіцит прісної води вже до 2025 року, - Держекоінспекція - Новини України - 112 Україна (112ua.tv)

13. Ще один район Львова отримуватиме воду без хлору. URL: Ще один район Львова отримуватиме воду без хлору (tvoemisto.tv)

14. Аналіз стану еколого-техногенної безпеки інженерної інфраструктури міст і селищ. Аналітична записка / Відділ екологічної та техногенної безпеки (С.Іванюта, О.Мартюшева). URL: "Аналіз стану еколого-техногенної безпеки інженерної інфраструктури міст і селищ". Аналітична записка : Національний інститут стратегічних досліджень (niss.gov.ua)

15. Енергетична децентралізація: нова ТЕС на біомасі запущена в Овручі. $U R L$ : Енергетична децентралізація: нова TEC на біомасі запущена в Овручі (uabio.org) 


\title{
ОЦІНКА ЕКОЛОГІЧНОГО СТАНУ РІЧКИ ЛОПАНЬ НА ОСНОВІ ВИЗНАЧЕННЯ ЕКОЛОГІЧНОГО ІНДЕКСУ
}

\author{
Рибалова Ольга Володимирівна, \\ канд. техн. наук, доц., доц. \\ Національний університет \\ цивільного захисту України
}

Кусков Олег Дмитрович,

студент

Національний університет цивільного захисту України

Кусков Олександр Дмитрович, студент

Національний університет цивільного захисту України

Аналіз екологічного стану річок Харківської області свідчить про досягнуту межу використання їх водних ресурсів. Методи нормування антропогенного навантаження на водні об'єкти, засновані на гігієнічній регламентації, не дозволяють оцінити можливість використання водних ресурсів транскордонних річок 3 дотриманням рівноважного стану водних екосистем.

Напрямком досліджень роботи обрано визначення можливості використання водних ресурсів на основі оцінки екологічного стану водних об'єктів, що є надзвичайно важливою задачею при вирішенні питання про першочерговість реалізації природоохоронних заходів.

Річка Лопань належить до басейну р. Сіверський Донець, що є найбільшою річкою в Харківській області. Басейн річки Лопань розташовується в межах південного відрога Середньо - Російської височини (рис.1).

Рельєф і клімат регіону в цілому сприятливі для активного промислового і сільськогосподарського освоєння його території. Характерними тут є лісостепові ландшафти на півночі (до лінії Старовірівка - Зміїв - Балаклея - Куп’янськ) і степові розчленовані ландшафти на більшій частині басейну, що відрізняються помірно-континентальним кліматом з порівняно холодною малосніжною зимою, жарким і посушливим літом. Період з температурою понад $+10^{\circ} \mathrm{C}$ становить 155 - 170 днів, сума активних температур $2600-3150{ }^{\circ} \mathrm{C}$. Опадів випадає $375-556$ мм на рік, найбільше - в межах Донецького кряжа. У теплий період року випадає $70-80 \%$ опадів.

Особливості рельєфу та кліматичних умов сприяли формуванню специфічного грунтового покриву району. Більшу його частину займають середньогумусні чорноземи, на півночі поширені звичайні чорноземи. Зустрічаються також опідзолені різновиди, дерново-глеєві, алювіальні, 
солонцюваті і супіщані грунти. Переважна більшість грунтів має високу родючість.

Характерними процесами в басейні річки Лопань $є$ яругоутворення (більше 1/3 територіі), плоска ерозія та заболочування.

Аналіз даних, що характеризують схили долини, заплаву й русло показує, що відбуваються ерозійні процеси, часткове певна дефляція, невеликі зсуви, що сприяє замуленню русла, підйому рівня грунтових вод і підтопленню прилягаючих територій (табл. 1).

Ці процеси вимагають проведення спеціальних заходів запобіганню негативних наслідків.

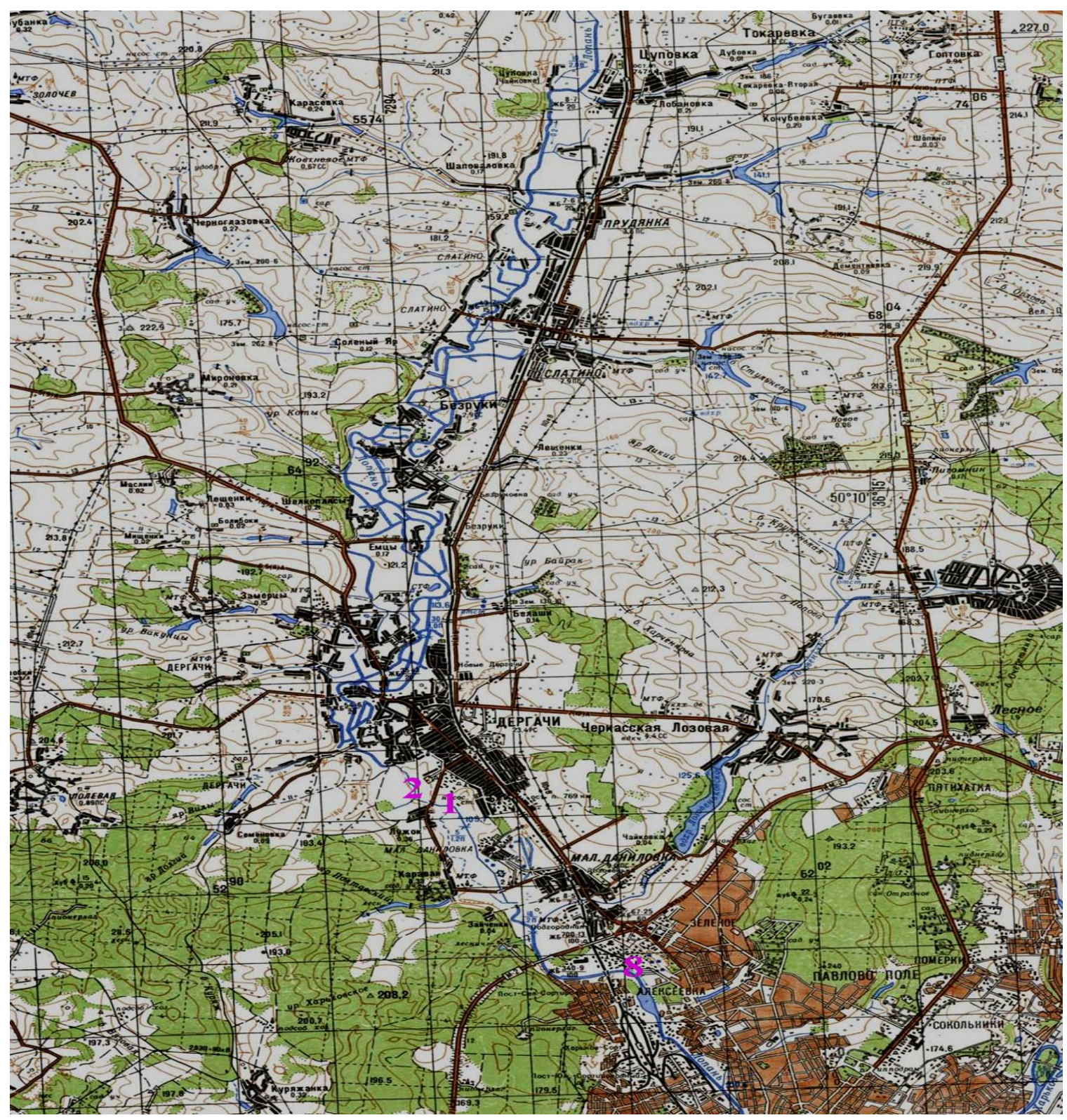

Рисунок 1. Карта - схема р. Лопань (українська частина) 
Таблиця 1.

Морфологія й стан схилів річкової долини

\begin{tabular}{|c|c|c|c|c|c|}
\hline \multicolumn{2}{|c|}{ Характеристика } & $\begin{array}{l}\text { Розмір- } \\
\text { ність }\end{array}$ & $\begin{array}{l}\text { Ділянка } \\
\text { річки }\end{array}$ & $\begin{array}{l}\text { Основна } \\
\text { річка }\end{array}$ & $\begin{array}{l}\text { Притоки } \\
\text { довжиною більше } \\
10 \text { км } \\
\end{array}$ \\
\hline \multicolumn{2}{|c|}{ Залісенність } & $\%$ & & 2 & 0,5 \\
\hline \multicolumn{2}{|c|}{ Залуженність } & $\%$ & & 35 & 14,5 \\
\hline \multicolumn{2}{|c|}{ Розораність } & $\%$ & & 35 & 14,5 \\
\hline \multicolumn{2}{|c|}{ Заболочуваність } & $\%$ & & 0,7 & 1,3 \\
\hline \multicolumn{2}{|c|}{ Меліорованість } & $\%$ & & 19,7 & \\
\hline \multicolumn{2}{|c|}{ Урбанізованість } & $\%$ & & 10,5 & 22 \\
\hline \multirow{8}{*}{$\begin{array}{l}\text { Джерела } \\
\text { забрудне } \\
\text { ння } \\
\text { поверхн } \\
\text { евих i } \\
\text { підземн } \\
\text { их вод }\end{array}$} & Вид & - & \multicolumn{3}{|c|}{ Стоки тваринницьких комплексів } \\
\hline & Кількість & шт & \multicolumn{3}{|c|}{6} \\
\hline & Вид & - & \multicolumn{3}{|c|}{ Промислові стоки } \\
\hline & Кількість & шт & \multicolumn{3}{|c|}{13} \\
\hline & Вид & & \multicolumn{3}{|c|}{ Поля фільтрації й поля зрошення } \\
\hline & Кількість & шт & \multicolumn{3}{|c|}{2} \\
\hline & Вид & & \multicolumn{3}{|c|}{ Господарсько-побутові стоки } \\
\hline & Кількість & & \multicolumn{3}{|c|}{6} \\
\hline \multirow[t]{6}{*}{ процеси } & Вид & & \multicolumn{3}{|c|}{ яругоутворення } \\
\hline & Ступінь прояви & & \multicolumn{3}{|c|}{ більше $1 / 3$ території } \\
\hline & Вид & & \multicolumn{3}{|c|}{ плоскосна ерозія } \\
\hline & Ступінь прояви & & \multicolumn{3}{|c|}{ більше $1 / 3$ території } \\
\hline & Вид & & \multicolumn{3}{|c|}{ Заболочування } \\
\hline & Ступінь прояви & & \multicolumn{3}{|c|}{ У незначному ступені } \\
\hline
\end{tabular}

Басейн ріки розташовується в межах геологічної структури південнозахідного Воронезького кристалічного масиву. У геологічній будові бере участь породи чотирьох, неогенових, палеогенових і крейдових відкладень.

Відповідно до районування території України по потенційній небезпеці ерозійних процесів басейн р.Лопань розташовується в другому ерозійному районі лісостепової агрогрунтової зони. Ступінь прояву ерозії середня до 50\% змитих грунтів і середня вітрова (вітровий індекс $1,0-1,7)$.

Річка Харків - ліва притока р. Лопань, є транскордонним водотоком, бере початок на території Бєлгородської області РФ, зливається 3 р. Лопань у іiі гирловій частині, протікає по території м. Харків (10 км) та Харківського р-ну (45 км), є об’єктом розташування рекреаційних зон обласного центру.

Пункт спостереження (ПС) у с. Стрілече є репрезентативним по відношенню до транскордонної ділянки. Якість річкової води на цій ділянці обумовлюється природними факторами, що притаманні цій частині суббасейну, забрудненням поверхневого стоку та впливом сільськогосподарської діяльності у Бєлгородській області РФ. 
ПС у м. Харків на р. Харків є репрезентативним по відношенню до гирлової ділянки річки. Якість річкової води на цій ділянці обумовлюється значним антропогенним навантаженням: скидами комунальних стоків, надходженням забруднень 3 поверхневим стоком 3 території м. Харків, процесами самоочищення, а влітку - «цвітіння» у водосховищі.

Система екологічної класифікації якості поверхневих вод, побудована за екосистемним принципом, представлена в "Методиці встановлення i використання екологічних нормативів якості поверхневих вод суші та естуаріїв України" [1]. Відповідно до системи екологічної класифікації якості поверхневих вод суші й естуаріїв України кожен водний об'єкт можна віднести до одному 3 п'яти класів і семи підлеглих їм категорій і відповідно охарактеризувати його якісний стан від відмінного (I клас,1 категорія) до дуже поганого (V клас,7 категорія).

Екологічна оцінка $\epsilon$ неодмінною умовою екологічного нормування якості поверхневих вод, його попереднім етапом. При обчисленні екологічної оцінки необхідно зіставити отримані результати зі значеннями екологічних нормативів, встановленими для даного водного об'єкта.

Екологічна класифікація якості поверхневих вод суші та естуаріїв України побудована за екосистемним принципом. Необхідна повнота і об'єктивність характеристики якості поверхневих вод досягається достатньо широким набором показників, які відображають особливості абіотичної і біотичної складових водних екосистем [1].

Значення екологічного індексу якості води визначається за формулою [1]:

$$
I_{e}=\frac{\left(I_{1}+I_{2}+I_{3}\right)}{3}
$$

де

$\mathrm{I}_{1}$ - індекс забруднення компонентами сольового складу;

$\mathrm{I}_{2}$ - індекс трофо-сапробіологічних (еколого-санітарних) показників;

$\mathrm{I}_{3}$ - індекс специфічних показників токсичної і радіаційної дії.

Екологічний індекс якості води, як і блокові індекси, обчислюється для середніх і для найгірших значень категорій окремо: $\mathrm{I}_{\text {Eсер }}$ та $\mathrm{I}_{\text {емах }}$ Вiн може бути дробовим числом.

Сольовий склад оцінювався за сумою іонів та концентрацією хлоридів $\mathrm{i}$ сульфатів. При групуванні даних у просторі і часі оцінка дається за середніми i максимальними (найгіршими) значеннями показників. Клас води визначається за переважаючими аніонами, групи - за переважаючими катіонами. Типи вод визначаються за співвідношенням між іонами.

Екологічна оцінка якості за трофо-сапробіологічними (еколого-санітарними) критеріями виконувалася на підставі середніх та найгірших значень кожного 3 гідрохімічних, гідробіологічних, бактеріологічних показників, а також індексів сапробності. В кінцевому підсумку вони відповідають певному ступеню трофності та зоні сапробності вод. Загальна кількість показників цього блоку для забезпечення обгрунтованих висновків не повинна бути меншою, ніж 10. 
Середній екологічний індекс за даними аналітичного контролю якісного стану річок Харківської області за 2020 рік представлено у табл. 2 та на рис. 2.

Згідно розрахунку середнього екологічного індексу, що виконано за «Методикою встановлення і використання екологічних нормативів якості поверхневих вод суші та естуаріїв України» [1] р. Лопань (п. Казачья Лопань) відносяться до 2 класу якості 3 добре станом, а р. Лопань (м. Харків) відноситься до 3 класу якості з задовільним станом, а р. Лопань (гирло, м. Харків) відноситься до 5 категорії якості із незадовільним станом.

Найбільш забрудненою з розглянутих є р. Лопань, гирло м.Харків (рис. 2).

Таблиця 2.

Визначення середнього екологічного індексу річки Лопань в Харківській області

\begin{tabular}{|c|c|c|c|c|c|c|}
\hline \multirow{2}{*}{$\begin{array}{c}\text { Показники } \\
\text { якості води, } \\
\text { мг/л }\end{array}$} & \multicolumn{2}{|c|}{$\begin{array}{c}\text { р. Лопань, } \\
\text { п. Казачья Лопань }\end{array}$} & \multicolumn{2}{|c|}{$\begin{array}{l}\text { p. Лопань, вище } \\
\text { м. Харків, }\end{array}$} & \multicolumn{2}{|c|}{$\begin{array}{c}\text { p. Лопань, гирло, } \\
\text { м. Харків }\end{array}$} \\
\hline & $\begin{array}{l}\text { Середній } \\
\text { екологіч } \\
\text { ний } \\
\text { індекс }\end{array}$ & $\begin{array}{l}\text { Екологі } \\
\text { чний } \\
\text { індекс }\end{array}$ & $\begin{array}{l}\text { Середній } \\
\text { екологіч } \\
\text { ний } \\
\text { індекс }\end{array}$ & $\begin{array}{l}\text { Екологічн } \\
\text { ий індекс }\end{array}$ & $\begin{array}{l}\text { Середній } \\
\text { екологічний } \\
\text { індекс }\end{array}$ & $\begin{array}{l}\text { Екологічний } \\
\text { індекс }\end{array}$ \\
\hline \multicolumn{7}{|c|}{ Блок сольового складу } \\
\hline Хлориди & \multirow[t]{2}{*}{3,5} & 3 & \multirow[t]{2}{*}{4,5} & 3 & \multirow[t]{2}{*}{5} & 4 \\
\hline Сульфати & & 4 & & 6 & & 6 \\
\hline \multicolumn{7}{|c|}{ Блок трофо-сапробіологічних (еколого-санітарних) показників } \\
\hline $\begin{array}{l}\text { Азот } \\
\text { амонійний }\end{array}$ & \multirow{5}{*}{4,2} & 5 & \multirow{5}{*}{4,8} & 5 & \multirow{5}{*}{5,8} & 6 \\
\hline Азот нітритний & & 2 & & 5 & & 7 \\
\hline Азот нітратний & & 7 & & 7 & & 7 \\
\hline $\mathrm{XCK}$ & & 3 & & 3 & & 4 \\
\hline $\mathrm{ECK}_{5}$ & & 4 & & 4 & & 5 \\
\hline \multicolumn{7}{|c|}{ Блок показників вмісту і біологічної дії специфічних речовин } \\
\hline Залізо загальне & \multirow{7}{*}{3} & 4 & \multirow{7}{*}{3,1} & 4 & \multirow{7}{*}{3,2} & 4 \\
\hline Мідь & & 4 & & 4 & & 4 \\
\hline Цинк & & 1 & & 1 & & 2 \\
\hline Нафтопродукти & & 5 & & 5 & & 5 \\
\hline СПАР & & 3 & & 4 & & 4 \\
\hline $\begin{array}{l}\text { Хром } 6 \\
\text { валентний }\end{array}$ & & 2 & & 2 & & 2 \\
\hline Марганець & & 2 & & 2 & & 2 \\
\hline $\begin{array}{l}\text { Середній } \\
\text { екологічний } \\
\text { індекс }\end{array}$ & \multicolumn{2}{|c|}{3,56} & \multicolumn{2}{|c|}{4,13} & \multicolumn{2}{|c|}{4,6} \\
\hline $\begin{array}{l}\text { Категорія якості } \\
\text { вод }\end{array}$ & \multicolumn{2}{|c|}{3 - добре } & \multicolumn{2}{|c|}{4 - задовільно } & \multicolumn{2}{|c|}{5 - незадовільне } \\
\hline Клас якості вод & \multicolumn{2}{|c|}{2 - добре } & \multicolumn{2}{|c|}{3 - задовільно } & \multicolumn{2}{|c|}{3 - задовільно } \\
\hline
\end{tabular}




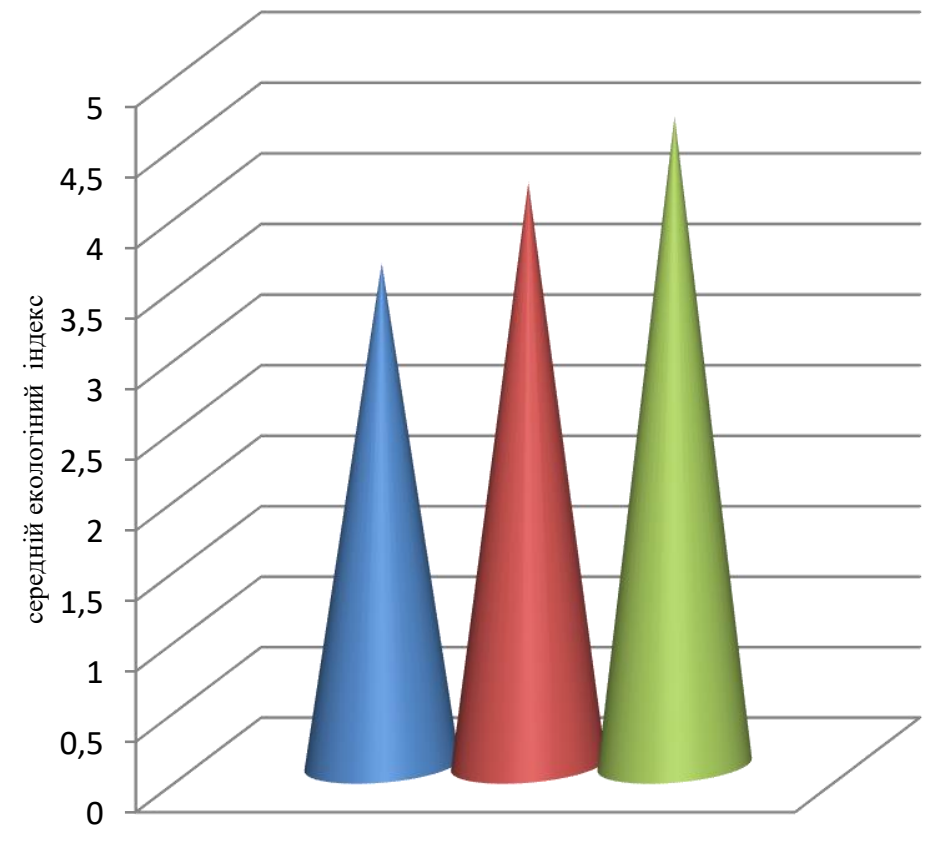

р.Лопань, п.Казачья Лопань

р.Лопань, м.Харків, вище

р.Лопань, устье, м.Харків

Рисунок 2. Середній екологічний індекс річок Харків та Лопань за даними аналітичного контролю якісного стану за 2020 рік

Оцінка стану водних екосистем і комплексне екологічне нормування впливу на них $\epsilon$ актуальною задачею, тому що визначення величин критичних навантажень на водні об'єкти дозволяє регламентувати господарську діяльність і прогнозувати зміни, що відбуваються у водних об'єктах.

Аналіз якісного стану поверхневих вод басейну р.Лопань показав, що найбільш забрудненим створом є гирло р. Лопань в м. Харків. Це пояснюється надзвичайним антропогенним навантаженням одного 3 найбільших індустріальних центрів України - м. Харків.

Розвиток виробничих сил практично неможливий без впливу на навколишнє середовище, але необхідно прагнути до мінімізації негативних наслідків антропогенного впливу і створення оптимальних умов для життєдіяльності населення та збереження природної цінності екосистем.

\section{Список літератури}

1. Романенко В.Д,, Жукинський В.М., Оксікюк О.П. та ін. Методика встановлення і використання екологічних нормативів якості поверхневих вод суші та естуаріїв України - К., 2001. - 48с 


\title{
«THE NEW-YORKER» КАК ЛИТЕРАТУРНО- ПУБЛИЦИСТИЧЕСКИЙ ЖУРНАЛ НОВОГО ТИПА
}

\author{
Горбуненко Анастасия Филипповна \\ Кандидат филологических наук, без зв., доцент \\ Кубанский государственный университет
}

Ситуация, сложившая в модернистском журнальном пространстве к двадцатым годам XX века, располагала к дальнейшему развитию сформировавшейся идеологии. «Городская элита начала выступать за широту взглядов, интеллектуальность, интерес к мировым проблемам» [1]. Все это должно было найти выход в новой, более устойчивой форме, которой стало влиятельнейшее литературно-публицистическое издание мира «The NewYorker».

Журнал был основан репортером «The New-York Times» Гарольдом Россом и его женой Джейн Грант в феврале 1925 года. Росс хотел создать изысканный юмористический литературный журнал, который мог бы удовлетворить читателя и дать пищу для размышлений.

Об отношении журнала к читателю хорошо высказался Курт Воннегут. Он писал:

«Ограничивающим фактором [в литературе] является читатель. Ни одно другое искусство не требует от зрителя быть исполнителем. Вы должны рассчитывать на то, что читатель будет хорошим исполнителем, и вы можете написать музыку, которую он абсолютно не может исполнить - и в этом случае это перебор. ... писатели, ... и я сам учим аудиторию играть такую музыку в своих головах. Это процесс обучения, и «The New-Yorker» очень хорошо справлялся с этим. У него есть плененная аудитория, он выходит каждую неделю, и люди ... могут выполнять какие-то упражнения в своих головах и наслаждаться этим» [4, pp. 163-164].

Специально для издания «The New-Yorker» Рауль Флейшман и Гарольд Росс основали издательский дом «F-R Publishing Company». Издание не приносило прибыли, тираж падал, а Флейшман был вынужден вкладывать в это предприятие все больше и больше своих личных финансов. В мае 1925 года, спустя всего три месяца после страта, Флейшман и Росс даже подумывали закрыть журнал.

Но, по стечению обстоятельств, они оба встретились на свадьбе общего друга буквально через несколько часов после принятия такого решения. И там, «в этой атмосфере надежды, нового начала и выпитого шампанского, они решили попробовать еще раз» [10, р. 20-41]. Издатели не смогли смириться с тем, что их усилия не увенчались успехом.

Гарольд Росс придерживался мнения, что редакторская политика издания не 
должна зависеть от финансовой стороны. Ему повезло работать с Раулем Флейшманом, который верил в разделение редакторских и деловых функций. Росс возложил на него все издательские функции, а сам занимался редактированием журнала вплоть до своей смерти в 1951 году.

Чтобы привлечь внимание к журналу, Росс предлагал публиковать в нем рекламу совершенно бесплатно, ради внешнего вида. Тогда же он попросил американского юмориста Кори Форда нарисовать рекламные объявления для «The New-Yorker».

Получилась серия из 20 частей под названием «Создание журнала». Это была своего рода экскурсия для читателя по «обширной организации «The NewYorker»»", от фабрики по щекотке кальмаров, где собирают чернила, до фермы пунктуации, где выращивают маленькие метки. Все эти процессы игнорируются мистером Юстасом Тилли, денди, того самого, чей профиль размещен на обложке первого номера «The New-Yorker». Тилли стал настолько вездесущей частью Нью-Йоркской культуры, что Росс, в конце концов, даже занес его имя в телефонный справочник [3].

C тех пор самой заметной особенностью «The New-Yorker» стали карикатуры. Денди эпохи английского ампира с моноклем из первого номера был нарисован художником Ри Ирвином. А имя - Юстас Тилли, - придумал для него Кори Форд. Такую фамилию носила его незамужняя тетушка, как писал Форд в своих воспоминаниях, а имя было выбрано «из соображений благозвучия». По другой версии имя Юстас было заимствовано у Юстаса Тейлора, собрата Форда по университетскому обществу «Delta Kappa Epsilon» [7, p. 512].

Также особая роль в журнале «The New-Yorker» отводилась обложке и оформлению. Каждая из обложек представляет художественную ценность как отдельный элемент, позволяя считать журнал синонимом неизменно высокого стиля.

Что касается оформления и подачи материалов, то здесь выделяются особенности типографики журнала. Для оформления текстов «The New Yorker» использует надстрочные знаки, которые выделяют повторяющиеся гласные, произносимые отдельно. Курсив в журнале используется только для написания названий других печатных изданий и чисел.

Давая характеристику журналу известный американский писатель и журналист Том Вулф писал: «Стиль «The New-Yorker» был ... забавным, когда находился в юмористическом режиме, тавтологичным и литотичным - в серьезном; он был постоянно усиливающимся, квалифицированным, подчеркнутым, тонким и обновленным, пока бледно-серые страницы журнала превращались в триумф Высокого Барокко» [11].

Но стоит отметить, что добиться такого успеха журналу удалось только к 1928 году. «The New-Yorker» пережил падение тиража от 15 тысяч экземпляров в марте 1925 года до 2700 экземпляров - в августе того же года. Отчасти такую ситуацию можно объяснить широким успехом других литературных изданий, выходивших в этот период в Нью-Йорке.

«Малые» журналы, возникшие в период расцвета модернизма и 
зарекомендовавшие себя как проводники современных культурных тенденций, все еще были популярны и имели достаточное влияние на американскую аудиторию.

Многие из известных писателей, с которыми Росс был знаком еще со времен работы в «The New-York Times», находили его журнал забавным и достаточно интересным. Но далеко не все из них стремились помочь ему, предлагая свои рукописи для публикации. Кто-то в силу занятости в других журналах, кто-то изза весьма скромного гонорара, который Росс с трудом мог себе позволить. В ранних редакционных статьях «The New-Yorker» Росс признавался в плачевной ситуации с персоналом, описывая собрания редколлегии как «массовое собрание двух участников журнала».

«The New-Yorker» столкнулся с еще одной проблемой вначале своего существования. Этой проблемой был сам Росс. А точнее, чувство юмора, которое он стремился сделать главным достоинством журнала. Возможно, в силу того, что он не получил должного образования, так как бросил школу в маленьком городке на Среднем Западе, большинство ранних шуток были далеки от утонченных и принятых в обществе.

Ни Росс, ни Ри Ирвин, казалось, не имели представления об образе жизни, который сложился в американском истеблишменте, а таем более в Нью-Йорке, в «ревущие двадцатые». Юстас Тилли был далек от кабаре, ночных клубов и бесконечных карнавалов, которые характеризовали общество в эту обрушившуюся на Нью-Йорк «Эпоху Джаза».

Росс делал все больший акцент на карикатуры, превращая журнал в одну большую шутку. В октябрьском номере «The New-Yorker» за 1925 год Росс писал: «Все говорят об искусстве «The New-Yorker», то есть о его иллюстрациях, и его называют лучшим журналом в мире для человека, который не умеет читать» $[9$, р. 6].

Ситуация начала меняться в 1926 году, когда в журнал пришла Кэтрин Уайт в качестве помощника литературного редактора. Росс быстро понял, что может довериться ее вкусу и положиться на обширную базу знаний, полученную во время учебы в колледже «Bryn Mawr». Уильям Шон, занимавший пост редактора «The New-Yorker» с 1952 по 1987 годы, считал, что «Кэтрин Уайт придала «The New-Yorker» его форму и направила в нужное русло».

В тот же год к журналу присоединился американский художниккарикатурист Джеймс Тербер. А в 1928-ом в издание приходит писательюморист Уолкотт Гибс, сразу после ухода Александра Вулкотта, который назвал «The New-Yorker» журналом, «выпускаемым бездарным репортером с помощью двух деревенщин». Гиббс остается сотрудником журнала до своей смерти в августе 1958 года.

В журнале публикуется американская писательница и поэтесса Дороти Паркер, которая вскоре начинает вести свою колонку книжных обозрений под названием «Постоянный читатель». Также Росс приглашает репортера Морриса Марки, который тоже начинает свою колонку «Репортер на свободе» с эпиграфом к каждой: «Будьте честны любой ценой».

Джейн Грант уговорила американскую писательницу и журналистку Джанет 
Фланнер, вести раздел «Письма из Парижа». Приглашенный Россом Льюис Мамфорд, вел колонку архитектурной критики под названием «Горизонт».

Еще одной инновацией, появившейся в «The New-Yorker», стала проверка фактов. В газете «The Saturday Evening Post» существовал специальный отдел проверки фактов, о которой узнал Росс, и решил в качестве эксперимента попробовать эту систему в своем журнале. Эксперимент Росса в «The NewYorker» непросто удался, а прославил этот отдел «точностью, которая иногда отклонялась назад».

Гарольд Росс настаивал на том, «что каждый раз, когда в истории говорится или подразумевается, что человек мертв, это утверждение или подтекст должны проверяться. Я бы распространил это на таких людей, как Наполеон, но особенно интересовался бы менее известными людьми, или людьми, родившимися гораздо позже».

Тербер шутил по этому поводу, говоря: «если вы упоминаете Эмпайр Стейт Билдинг в разговоре, Росс не будет уверен, что он все еще там, пока мы не проверим его». Стоить отметить, что редакция журнала по сей день придерживается данной политики в отношении проверки фактов. Это не дает аудитории «The New-Yorker» сомневаться в достоверности публикуемых в нем сведений.

На протяжении всего существования журнала в нем работали лучшие художники-карикатуристы. Среди них были Чарльз Адамс, Питер Арно, Чарльз Барсотти, Джордж Бут, Том Чейни, Лев Каллум, Ричард Дэккер, Эд Корен, Джордж Прайс и многие другие.

На страницах «The New-Yorker» всегда присутствовало чувство юмора. Но это не помешало ему зарекомендовать себя как платформу для серьезной художественной литературы и журналистики. Например, после окончания Второй мировой войны журналист и писатель Джон Херси заполнил практически весь выпуск своим эссе «Хиросима».

В последующие десятилетия журнал опубликовал рассказы многих известных и уважаемых писателей XX века. Энн Битти, Джон Чивер, Рональд Даль, Джеффри Хеллман, Джон МакНалти, Элис Манро, Харуки Мураками, Владимир Набоков, Джон О 'Хара, Филип Рот, Дж. Д. Сэлинджера, Ирвин Шоу, Джеймс Тербер, Джон Апдайк и другие публиковали здесь свои работы впервые. Рассказ Ширли Джексон «Лотерея» вызвал такой поток читательских писем в редакцию, которого журнал не помнит за всю историю своего существования.

Ориентированный на публику с развитым художественным вкусом, «Тhe New-Yorker» установил новые стандарты журнальной литературы - с мастерски написанными рассказами, блестящими эссе, тонким юмором, содержательными карикатурами, рецензиями на незаурядные книги, спектакли, фильмы [6].

«The New-Yorker» как никакой другой журнал оказывал сильнейшее воздействие на читателей не только благодаря коллективу авторов, карикатуристов и журналистов. Журнал имел свой стиль, что играло особую роль в формировании мнений и тенденций, а также позволило достичь статуса культурного феномена, привлекая внимание всего мира к культурной жизни Нью-Йорка. 
В статье «A Gaggle of Cartoonists», опубликованной в одном из номеров «The New York Times», говорилось о роли редактора в судьбе журнала:

«В 1920-х и 1930-х годах, когда Росс был редактором, а Ри Ирвин художественным редактором, «The New-Yorker» помог создать идею космополитичного Манхэттена. Со временем, когда редакторы обзавелись семьями и переехали в пригород, стиль журнала тоже стал более пригородным. Город все еще появлялся в «The New-Yorker», но к 1950-м годам он стал, как выразился мистер Корен, «памятью о городской жизни» [5].

«Представляемая «Нью-Йоркером» культура была элитарной, благопристойной и даже изящной. Культура была объектом устремлений, оставаясь при этом достаточно демократичной: ею мог обладать любой, даже если у него не было кофейного стола, чтобы выложить ее на всеобщее обозрение. Использование местоимения «мы» в редакционных статьях журнала предполагало существование некоего центра культуры, точки зрения, с которой любой мог увидеть все важное в культуре, а то, чего он видеть не мог, представлялось не слишком важным» [2].

Джозеф Розенблюм, в рецензии на книгу Бена Ягоды «О городе» (включающей историю журнала с 1925 по 1985 год), писал:

««The New-Yorker» действительно создал свою собственную вселенную. Как писал один давний почитатель Ягоды, это было место, «где жил Питер Деврис ... вечно поднимал бокал «Piesporter», где Никколо Туччи (в сливовом бархатном смокинге) флиртовал по-итальянски с Мюриэл Спарк, где Набоков потягивал рыжеватый портвейн из призматического бокала (в то время как «красный адмирал» пристроился на его мизинце), и где Джон Апдайк спотыкался о швейцарские туфли хозяина, очаровательно извиняясь» [8, р. 5].

Таким образом, «The New-Yorker» с самого начала своего существования стал одним из влиятельнейших источников формирования литературных и культурных тенденций, аккумулировав эстетические находки модернистских «малых» журналов, адаптировав их под более широкую аудиторию.

Более того свой стиль и влияние на литературные и культурные взгляды читателя «The New-Yorker» сохраняет и в наши дни, успешно переживая дигитализацию журнального пространства.

Список литературы:

1. Макеева H. The New Yorker: толстый, умный, смешной и не для всех // Cablook. URL: http://www.cablook.com/inspiration/the-new-yorker-tolstyj-umnyjsmeshnoj-i-ne-dlya-vseh/

2. Сибрук Д. Nobrow // «Критическая Масса». - М., 2004. № 3. URL: http://magazines.russ.ru/km/2004/3/si12.html

3. «The New Yorker» - Ross's Little Magazine (1925-1951) // The Hitchhiker's Guide to the Galaxy: Earth Edition. July, 2006. URL: https://h2g2.com/edited_entry/A21723121\#footnote1

4. Allen W.R. Conversations with Kurt Vonnegut. - Jackson, MI: University Press of Mississippi, 1988. - PP. 163-164. 
5. Boxer S. A Gaggle of Cartoonists // The New York Times, 2000. (Feb., 14). URL: https://www.nytimes.com/2000/02/14/arts/gaggle-cartoonists-but-it-s-not-allsmiles-new-yorker-exhibit-some-artists.html?sec=\&spon=\&pagewanted=all

6. Franklin R. «The Lottery» Letters // The New-Yorker, 2013. (Jun., 25.). URL:https://www.newyorker.com/books/page-turner/the-lottery-letters

7. Kunkel T. Genius in Disguise: Harold Ross of the New Yorker. - N.Y.: Carroll\&Graf Publishers, 1996. - P.512.

8. Rosenblum J. About Town // Wilson J.D.; Kellman S.G. Magill's Literary Annual 2001: Essay-Reviews of 200 Outstanding Books Published in the United States During 2000. - Pasadena, Calif.: Salem Press, 2001. - P. 5.

9. The New-Yorker, 1925. (Oct., 10.). - P.6.

10. Thurber J. The Years With Ross. - Boston: Little, Brown, 1959. - P. 2041.

11. Wolfe T. Foreword: Murderous Gutter Journalism. - N.Y.: Farrar Straus Giroux, 2000. 


\title{
ТИПОЛОГИЧЕСКИЕ ОСОБЕННОСТИ ПЕРВЫХ ОПОЗИЦИОННЫХ ИЗДАНИЙ КУБАНСКОЙ ОБЛАСТИ ПОСЛЕ 1905 ГОДА
}

\author{
Кидакоева Зарема Шихамовна \\ Кандидат филологических наук, без зв., доцент \\ Кубанский государственный университет
}

Период первой русской революции, когда изменились социальнополитические условия функционирования прессы, стал наиболее плодотворным для развития оппозиционных изданий Кубанской области. Закончилась монополия официальных «Кубанских областных ведомостей» и на региональном информационном пространстве появились частные газеты, имеющие определенную политическую окраску и претендующие на особое место в оппозиционном лагере исследуемого региона.

Действительно, 1906 год - один из наиболее своеобразных периодов в истории повременной печати Кубанской области. Выборы в государственную Думу, лихорадочное партийное строительство, перемежаемое открытыми столкновениями правых и левых группировок, совпали с отменой института предварительной цензуры, что привело к быстрому росту числа наспех открываемых газет [6. С.7].

Особенностью таких оппозиционных изданий является их недолговечность. Так, история проэсеровской газеты «Земля и народ» длилась всего четыре номера.

Емельян Ефимович Вилямовский, «частный землемер и таксатор», проживавший в городе Екатеринодаре, являлся революционером прогрессивных взглядов, поэтому не мог отказать себе в реализации политических и публицистических амбиций. Сам Вилямовский позиционировал себя социалистом-революционером, и некоторое время посещал местный комитет. Но эсеры относились к нему холодно, сомневались в его искреннем сочувствии партии.

Так в самом конце 1905 года Вилямовский подает прошение на имя Его Превосходительства Начальника Кубанской Области и Наказного Атамана Кубанского Казачьего Войска о разрешении ему издавать в Екатеринодаре ежедневную газету:

«Желая послужить своей родине в такое тяжелое время шатания умов и имея материальные средства, я покорно прошу разрешить мне издание, под моим личным редакторством газеты «Народный голос Екатеринодара» [1.Л.3].

В прошении Вилямовский немного лукавит, признаваясь, что в издании газеты не преследует никаких политических интересов. «Своей святой обязанностью газета ставит не преследование каких бы то ни было узко партийных целей, а разумное служение русскому народу и его интересам. Не ставлю я своей задачей, как редактор и издатель газеты, материальные выгоды, 
что видно из указанных цен, а служение правде и добру, как ревнитель величия и процветания нашей дорогой разноплеменной родины» [1.Л.3].

В искренность намерений и светлость целей Вилямовского Начальник области поверил и выдал свидетельство об издании газеты за номером 3077 в январе 1906 года.

Сложно сказать, что помешало Емельяну Ефимовичу осуществить свои планы, может, финансовые сложности или организационные вопросы, но уже 20 февраля к Начальнику области он обращается с новой просьбой:

«По своей специальности будучи всесторонне знаком с нуждами земледельческого класса населения и столь волнующим теперь земельным вопросом, я желал бы оказать посильную помощь народу изданием дешевой народной газеты.

Почему покорно прошу разрешить мне, под моим редакторством, издание еженедельной газеты «Земля и народ», которая для удобства и дешевизны будет издаваться в городе Анапе Кубанской области.

В заявлении Вилямовский, как и в прошлый раз, подчеркивал единственное желание быть полезным Родине: «Руководствуясь в данном случае, не материальными выгодами, коих при издании такой дешевой газеты и быть не может, а единственным желанием, как истинный сын России, послужить Родине в это тяжелое время. Не принадлежа лично ни к какой из существующих на Руси партий, я буду и в предполагаемой к изданию газете держаться прогрессивносозидательного направления, не гоняясь за сенсационными, часто дутыми новостями» [2.Л.5].

Разрешение на издание газеты было получено 3 марта 1906 года, и уже через 12 дней, 19 марта, в свет вышел первый номер газеты «Земля и народ».

Линию служения Родине, а не какой-либо политической мысли, продолжает Вилямовский в программной статье:

«Выпуская в свет газету «Земля и народ», редакция руководствуется не материальными и иными выгодами, а единственной целью послужить многострадальному русскому народу правдивым словом, <..> газета ставит своей обязанностью бороться против зла, по мере сил и возможностей, освещая все стороны жизни русского народа, не преследуя каких-либо узких партийных целей. Заранее газета приветствует тружеников на тернистой ниве народного образования и твердо надеется на их благородное содействие на благо и счастье народу, призывая их на помощь. Не будет места в газете для произведений реакции и не страшит ее злобное рычание «реакционеров». «Воздадим кесарево кесарю, а Богу Богово»[4].

Печаталась газета в первой частной типографии города Анапа, которая находилась по улице Рождественской в собственном доме мещанина из Екатеринодара Антония Демьяновича Басанько. Отдельный номер газеты можно было приобрести в Анапе и в Екатеринодаре всего за 5 копеек. Подписная цена за год - 2 рубля, для учащих и учащихся, а также народных библиотек - на год 1 рубль 60 копеек.

Но, несмотря на обещания, первый номер получился довольно провокационным. 
Во-первых, на трех полосах восьмиполосной газеты для ознакомления избирателей с порядком выборов была опубликована наглядная таблица выборов в Государственную Думу по Кубанской области и Черноморской губернии. Таблица сопровождалась небольшим комментарием, подписанным редактором легко узнаваемым псевдонимом - «В-ій».

В комментариях Вилямовский осторожно подводит итог таблицы и приходит к мнению, что плохое представление в Думе будут «иметь рабочие и вообще бедные люди». Тут же автор предлагает решение данного вопроса: «следует стараться проводить в выборщики, а выборщикам в члены государственной думы людей отзывчивых к нуждам обездоленных своих, меньших братьев во избежание негодования с их стороны. <..> Следует памятовать, что нужда народная создала массу «горючего материала», готового вспыхнуть с всякой искры. <..> Хотя бы в силу самосохранения нужно постараться сделать «горючий материал» не горючим и от поджога безлопастным» [3].

Во-вторых, на той же странице, чуть ниже, Вилямовский публикует перепечатку стихотворной сатиры Александра Валентиновича Амфитеатрова «Акафист неподобному Сергию Каменноостровскому» [7.С.76] из газеты «Русь», в которой затрагивалась фигура Сергея Юльевича Витте.

В-третьих, фигура премьер-министра еще раз была затронута в следующем материале «Екатеринодар», подписанный псевдонимом «- Ям...».

Автор делится с читателями историей путешествия екатеринодарских мещан в Петербург с ходатайством «об удовлетворении местных нужд» и последствиями поездки: «... Особой неподатливостью отличился один из депутатов г. Бесходарный, дерзнувший в печати описать разговор с гр. Витте[8], а по возвращении с другим депутатом г. Сухицким, позволили себе вопреки положению об усиленной охране в г. Екатеринодаре рассказывать о результатах поездки».

Оба депутата были отправлены в местную тюрьму «для покаяния в содеянных тяжких грехах. В конце статьи автор не удержался от ехидного комментария: «Не помогли Сухицкому поцелуй и 20 рублей, даренные графом Витте. Вот что значит: захочу люблю, захочу - разлюблю. Да и пословицу русскую депутатам следовало бы помнить: «Ласковое телятко - двух маток сосет!». От себя же прибавим: «что строптивое - не пососет ни одной, да еще получит колом по ребрам». Забегая вперед, оговоримся, что Вилямовский «по ребрам получит» именно за первый номер своей «Земли и народа». Сложно сказать, что именно из перечисленного заставило властей запретить газету, но на четвертом номере история «Земли и народа» закончилась.

Необходимо отметить, что в информационном пространстве Кубанской области наряду с легальными оппозиционными изданиями время от времени появлялись и нелегальные газеты.

Так, в октябре 1906 года на территории области с лозунгом «Пролетарии всех стран объединяйтесь!» появляется газета «Армавирский пролетарий». Газета социал-демократической рабочей партии распространялась в Екатеринодаре за 3 копейки. 
В свое время Владимир Ильич Ленин обратил внимание на инициативу армавирских социал-демократов и отозвался небольшой статьей «Как армавирские социал-демократы ведут избирательную кампанию?».

Порицая блок с кадетами в восьмом номере журнала «Пролетарий» от 23 ноября 1906 года, В. И. Ленин пишет:

«На выборах в первую Думу армавирские социал-демократы заключали блоки с кадетами. Об этом писала в свое время «Волна», резко порицая армавирцев. По этому поводу писал тогда в Армавир и ЦК нашей партии, ставя на вид тамошним товарищам нарушение ими директивы Объединительного съезда. $<\ldots>$ Перед нами № 1 газеты «Армавирский Пролетарий», издание Армавирского комитета РСДРП, помеченное октябрем 1906 г. и вышедшее в 5000 экземпляров.

В передовой статье читаем:

«Пусть кадеты, купцы, чиновники, помещики, либералы танцуют под дудку правительства, пролетариат не пойдет на поклон и примирение».

В следующей статье, специально посвященной призыву готовиться к выборам, говорится:

«Сплотитесь, голосуйте, берите Думу! Довольно посидели на бархатных креслах Таврического дворца бары-кадеты. Пора мозолистым рукам рабочих вышвырнуть этих болтунов и дармоедов!»

«Торопитесь обеспечить свое пролетарское место в Думе, чтобы из кадетской говорильни сделать ее революционным полем битвы с палачом народа, проклятым самодержавием».

В листке «К избирателям», помеченном ноябрем 1906 года и изданном в 3000 экземпляров, Армавирский комитет пишет:

«Понял народ, что только силой да властью возьмет он то, что не дает ему добровольно коченеющее самодержавие, что не дала ему безвластная кадетская Дума... Поведем чрез нее, через эту Думу, свою революцию, введем в лице своих депутатов в Таврический дворец народную мощь, разложим в новой Думе руками своих депутатов жаркий костер революционного пламени и раздуем его бурным дыханием всей пролетарской и революционной России. В новую Думу, в новую Думу!

... Товарищи и граждане! Наша будущая Дума не будет черносотенной, не будет и кадетской - она будет пролетарской и крестьянской - нашей полновластной Думой».

Повторяем, было бы мелочно придираться к форме или к частностям этих обращений. Важен их дух. Важна самостоятельная политика армавирских с.-д., прошедших через чистилище блоков с говорунами и дармоедами.

На борьбу же, все революционные с.-д.! На борьбу против блоков с кадетами! Товарищи меньшевики пройдут, подобно армавирцам, через чистилище блоков с оппортунистами буржуазии и вернутся к революционной социал-демократии» [5].

Так, изменения структуры информационного пространства после октября 1905 года, как в Кубанской области, так и по всей стране привели к появлению оппозиционных изданий. 
Еще одной особенностью первых оппозиционных издания, наряду с недолговечностью, является их преемственность, когда после вынужденного закрытия газеты, редактор возрождал ее формально под другим названием, оставляя типологическую и содержательную модель без изменения. Также большую часть этих изданий возглавляли не профессиональные журналисты, а лица, стремившиеся реализовать внезапно появившиеся политические амбиции. В большинстве случаев такие начинания заканчивались в лучшем случае закрытием издательского проекта, в худшем - арестом издателя.

Список литературы:

1. ГАКК. Ф.454.оп.2д.6265.Л.3

2. ГАКК. Ф454 оп. 2 д.6267.Л.5

3. Газета «Земля и народ», №1, от 19 марта 1906 г.Л.3

4. К г.г. Читателям//Земля и народ, №1, от 19 марта 1906 г.

5. Ленин В.И. Сочинения. М.: ОГИЗ, 1947. Т. 11. С. 290 - 291.

6. Лучинский Ю. В. «Дубинка» семьи Бесходарных/Журналистика: информационное пространство, 2007.С.7

7. Подробнее о данной публикации - Лучинский Ю.В. «Акафист» Амфитеатрова: судебная история одной перепечатки // Голос минувшего. Кубанский исторический журнал. 2001. № 3-4. С.76 - 80.

8. Подробнее о поездке кубанских мещан - Лучинский Ю.В. Визит к Витте//Убийство турецкого консула. Документальные хроники.Краснодар.2008. $-156 \mathrm{c}$. 


\title{
ON THE QUESTION OF THE LEGAL CERTAINTY OF LEGAL RELATIONS. TIME ASPECT
}

\author{
Guyvan Petro \\ Professor of Poltava Institute of Business, \\ k. yu. Sciences, Honored Lawyer of Ukraine
}

The exercise of subjective rights consists in the use by the right holder of the possibilities inherent in the law as its content. Their implementation is usually the result of lawful actions. Therefore, it is quite logical that the hypotheses of most legal norms contain rules of lawful conduct, and such behavior is the result of the exercised or exercised right. In other words, subjective rights are exercised mainly in regulatory legal relations, although sometimes for their implementation it is necessary to use the mechanisms inherent in security relations. If the subjective right is a measure provided by civil law of possible behavior of the entitled person (right to own actions) and the right to demand specific behavior from others, the social value of such a right is manifested in the reality of its exercise to meet the needs of the owner [1, p . 22]. The established civil tradition defines the specified term "measure", not as a quantitative indicator that characterizes the scope of powers of a person, but as a delineation of the limits within which the managed person can act [2, p. 29-31]. In view of this, the above classical definition of subjective law, in our opinion, should take into account all the statutory criteria for lawful conduct of a person and, in particular, the deadlines for taking appropriate action. Therefore, as an important conclusion, the exercise of a subjective right is possible only if it occurs within the established time limits. That is, temporal certainty is a necessary element of the essence of subjective law.

In scientific works, the issues of temporal certainty in the construction of civil relations, including during the implementation of regulatory and protective interactions, have been studied by some scientists. In their works, an analysis of the temporal component of a person's right to perform their own productive actions and demand the necessary behavior from the counterparty, both during proper execution and after the offense. However, the main problems of the organization of interaction of subjects in time at the level of the authorized - the obliged person remain unsolved. After all, the mechanism of temporal regulation of individual protective interactions is practically undefined, and in practice, temporal tools inherent in litigation are often unjustifiably applied in practice to others, which should not have such temporal regulators. Thus, the term in civil law is mainly considered not in the context of its impact on the content of subjective law, as it should be, but as a separate socio-legal phenomenon, detached from the essence of the relationship. And this, one way or another, leads to an isolated analysis and a possible narrow assessment of this legal regulator. This work is aimed at achieving certainty in this issue. 
Subjects of law and obligation realize the legal relationship mainly not at the time of its occurrence, but some time after the establishment. And, regardless of whether the long or very short period of time between the establishment of the content of the subjective right and its exercise, as a general rule, the concepts of "duration of the legal relationship" and "time of exercise of the subjective right" are not identical. The behavior of counterparties is usually determined in time, but its duration is not always equal to the duration of the relationship. First of all, this is that the moment of the relationship does not always coincide with the moment of its implementation. This is especially true for the exercise of authority (performance of duties) that occurs as a result of a single action. For example, the transfer of money takes place within a period of time that is within a specified period. Instead, the time for the exercise of a subjective right coincides with the period of its existence. Along with the legal relationship there is not the behavior itself, but only a legal means of ensuring such behavior - a subjective right and legal obligation [3, p. 567]. In this sense, it is appropriate to quote O. Pecheny, who fundamentally separated the concept of the term of the contract and the periods of performance of certain obligations under the agreement [4, p. 90-93]. But by the time of delay, such a relationship in any case develops in a regulatory, that is, proper state. Another thing is when an offense occurs. Then a protective mechanism should be applied, including through the use of judicial state coercion. However, it is not always easy to establish a temporal boundary when an intact right passes to a disturbed state. This means that there are certain problems in accessing the appropriate protective tools.

As life shows, the establishment of the appropriate duration of a particular substantive relationship depends largely on the correct definition of their legal nature. Different approaches to law enforcement involving incorrect temporal mediation due to the misapplication of a mechanism that cannot be applied to it are quite common. And the most illustrative example is the unjustified mixing of tools that regulate regulatory and security relations. After all, the first occurs under the condition of normal development of material relations between the parties, while the protective one concerns the protection of the already violated subjective right. For example, it is quite obvious that the claim of the insured to the insurer for the payment of insurance indemnity is a regulatory right of the party to the contract, which is implemented within the relevant regulatory relationship. In case the latter fails to fulfill his obligation to pay the funds, the insured will have a protective power of the same content - to demand payment of the sum insured. In other words, the right of the creditor under the regulatory obligation to obtain insurance will arise from the time of application to the counterparty within the term of the contract in the event of an insured event. It will last for the period specified in the contract. But the right of the insured to sue will appear only in case of violation of that regulatory right - failure to fulfill the relevant obligation by the insurer. However, it happens that some researchers assume the substitution of these two terms [5, p. 30]. Meanwhile, this should not be done: one of them mediates the content of the regulatory obligation, the other - is part of the security - the right to sue. Thus, the occurrence of the insured event is not a violation of the right to receive compensation by the insured, as sometimes indicated in the literature [6, p. 40-41]. At this point, the relevant regulatory right to receive the amount of compensation within a specified period only begins. And 
the claim for enforcement of this requirement will appear only after the expiration of such period.

The peculiarities of the real essence of the protective relationship are that in the case of violation of subjective substantive law, there is a different interaction than before, which is protective and legal in nature. It includes the material claim of the right holder to the infringer and the corresponding obligation of the latter. Forms of implementation of the protection requirement of the holder of the new right may be different, each of them has its own time regulators. For example, a lawsuit is filed for a limited period of time - a statute of limitations, while for operational measures or other out-of-court claims there are special deadlines, or no time limit at all. At the same time, most researchers focus only on the coercive (through the court) exercise of a person's protective authority. At the same time, the unjustifiably protective legal material requirement is reduced only to the claim of the commissioner. Meanwhile, the latter is not obliged to defend his right only in court. Others - non-judicial methods of protection also occur through the implementation of the protection requirement of the person arising from the offense and is the authority of the protection relationship. This requirement is not covered by the statute of limitations, it is usually not subject to limitation and exists for the duration of the protection right.

As for the content of the protective non-judicial claim, it may be the same as the claim. Varieties of claims are listed in Article 16 of the Civil Code of Ukraine as ways to protect the subjective right of the court. Indeed, in resolving a dispute, the judicial body uses exactly the method of protection chosen and set out by the plaintiff in the claim. At the same time, we think that a non-judicial protection claim may also consist in terminating the infringing action, restoring the situation that existed before the violation, compensating for the damage, and so on. It is clear that, since the protection of the violated substantive law takes place without the assistance of a jurisdiction, such a requirement is devoid of coercion. However, regardless of whether a non-judicial protection claim has been filed, the right holder has a material right to sue from the moment the right is violated. During the statute of limitations, this entity may implement it. In this case, state coercion will be a means of protecting the violated regulatory right and at the same time - a way to implement the protection requirement [7, p. 155]. Thus, both claim and non-claim claims are equal mechanisms for the protection of the same protected object - regulatory substantive law [8, p. 38].

As we can see, after the violation of subjective civil law, a person has a substantive protective right, which can be exercised by filing both non-judicial and judicial claims, the latter of which is repaid by statute of limitations. The order and content of these requirements do not depend on each other. Thus, due to various factors of subjective order, the holder of the violated right to receive the result of work may file a claim for damages caused by delay in performance, and at the same time - out of court performance in kind of overdue obligation. The only difference is their ability to enforce: the claim is endowed with such a property, non-claim - no. Regardless of the order of realization of the protective right to protection - claim or non-claim, in any case it is carried out within the protection-legal relationship. However, in the case where the protection relationship is enforced without recourse to a state jurisdiction, the right to protection, as opposed to harassment, can sometimes be exercised through the active 
conduct of the commissioner himself, such as self-defense, the introduction of means of operational influence. A protective non-litigation power can also be exercised by filing a claim or other claim. In practice, in the event of a violation of his right, the right holder often first exercises his protective right out of court. The claim is made in the form of a statement, claim, etc., even when the agreement or law does not provide for a claim procedure.

In case of non-fulfillment of this legal obligation by the obligated person, which corresponds to the content of the claim, this protection right remains unrealized. In this case, the right holder may, by filing a claim within the statute of limitations, to exercise their protection right in another way - in court. In view of the above, the obligation arising, for example, from the detection of defects in the goods during the warranty period, is a normal protection and legal relationship, which occurs without the use of state coercion. In this sense, it is almost no different from any protective relationship, not secured by a claim. The only characteristic feature of such an obligation is that it can always be enforced $[9$, p. 56] in the case of an appeal to the court with a material claim within the statute of limitations (which, in fact, begins from the time of detection of the defect). Therefore, its non-compliance voluntarily leaves the creditor the opportunity to exercise the right to protection in court. Whereas, for example, a non-judicial claim for elimination of a violation in case of non-compliance is filed after the expiration of the statute of limitations, it is not provided with a further possibility of judicial protection.

Again, the right to protection of a person arises solely as a result of its violation. Therefore, according to the generally accepted notion, a civil legal relationship exists for some time in a regulatory state, which determines its normal development in accordance with the rules of conduct of the subjects determined by law or contractors. This applies to both absolute and binding legal relationships. And only after the violation of this subjective right there is a protective relationship with the same subjective composition, the content of which is the protection of the violated regulatory right, in particular, through the judicial implementation of the protective civil claim. But the scope of powers of the right holder will be different: he acquires additional protective capabilities compared to those that he had in the regulatory relationship, for example, to recover from the violator a penalty and compensation for damage caused by the violation. Thus, the long-term thesis of M.A. Gurvych that civil law in its transition to the state of the right to sue (in particular, the absolute right) does not change its content [11, p. 169], which has a significant circle of supporters and now, does not receive practical confirmation.

As follows from the analysis conducted in this material, a fairly simplified approach would be to consider a judicial or non-judicial sanction implemented within a protective relationship, only as a mechanism to motivate the offender to comply with the established rule of conduct, ie to understand the sanction only in the context of its restorative value $[12$, c. 8]. The civil sanction has other functions: compensatory, penalty, operative, etc. For the right holder it is often impossible, and sometimes inexpedient, to further exercise the authority inherent in the violated right. However, it is clear that the very possibility of applying a sanction significantly affects the obligation of the obligor to fulfill its regulatory obligation. It is quite logical that the possibility of a protective legal relationship of a different content than that inherent in the regulatory 
in case of violation of the latter, does not fit into the concepts that determine the provision of subjective rights protection (including claims) as an integral part part or state of the substantive law itself, in which it passes after the violation. This theory also does not agree with the fact that the protective legal relationship may have specific substantive and legal methods of implementation, different from the methods of implementation of the relevant regulatory relations.

Indeed, the protective legal relationship among other remedies has its own specific, which is not inherent in the regulatory, and is manifested for civil relations in the form of a lawsuit. The substantive claim is reflected in the claim and characterizes it as a substantive right to sue, which arises from the moment of violation. However, the claim is only one of the elements of the content of the protective relationship. It, as well as other ways of protection of the infringed right, arises from the time of realization by the right holder of the fact of infringement and proceeds during the statute of limitations. However, the specific relationship between the claim as a special procedural requirement to the court for protection and the protective substantive legal relationship is not manifested from the time of the latter, but with the appeal to the court of one of the parties to the legal relationship [13, p. 92]. Thus, as we can see, the protection requirement may be related to the claims of the entitled person to the jurisdiction, the regulatory legal relationship in an intact state has no such connection. Therefore, the content of the substantive protective law is determined not only by regulatory law, but also by the nature of the protective requirement and the form of its implementation.

Thus, despite the formal similarity of the legal configuration of regulatory and protective legal relations, their content differs significantly in the scope of powers of the right holder. For example, the buyer, in the exercise of his powers under the contract, has the right to demand the transfer of the goods to him, and the seller, being a debtor in this obligation, must transfer the goods to him. When there is a breach of this obligation (the thing was not transferred in time or it is of poor quality, etc.), a protective relationship arises, the content of which will no longer be identical to the regulatory one. The buyer may (including with the use of state coercion) demand payment of penalties, elimination of defects, damages, termination of legal relations, etc. That is, he can apply within the protection obligation almost the entire range of sanctions provided for in Art. 16 of the $\mathrm{CCU}$ and, in addition to them, other protective options stipulated in the contract or a special provision of the law. Of course, the creditor has the right to demand from the debtor such actions that constitute the content of the regulatory obligation: in doctrine and law such a requirement is called - the performance of a duty in kind. But this claim will already be an element of the protective relationship and will be included in its content along with other requirements (penalty, compensation, etc.). The protective requirement to perform the duty in kind will differ from the same regulatory one, firstly, by the fact that it is endowed with coercive capacity, and secondly, by the fact that its content does not include a term stipulated by the parties or a normatively established term for normal exercise his condition. The protection right is exercised in court through the presentation of a claim, which has its own period of implementation: the statute of limitations, if the believer chooses a protection scheme with the participation of a state jurisdiction. If a non-judicial method of protection is chosen or the statute of limitations 
is missed, the term of realization of the protection right on a voluntary basis will be unlimited.

Summing up, we must come to the following conclusion. Subjective regulatory substantive law is terminated in case of its violation, when the term of its existence, established by law or contractors has not yet expired, but with the violation disappears the possibility of its implementation in kind (destruction of the object of the contract). This right is also terminated if it has not been exercised by the holder during its duration (violation is the delay of implementation). Termination of regulatory substantive law with ongoing enforcement may not occur before the expiration of its validity, regardless of the degree of its implementation and the existence of the right to judicial protection, which arose from violations in certain periods of its validity. But in any case, as a result of the offense there is a new relationship that did not exist before, and its winter is the creditor's protective right to eliminate the consequences of the violation, including new powers that were not in the regulatory state of interaction, namely compensatory and penalty. Therefore, a clear definition of the state of the legal relationship provides an opportunity to apply the necessary regulatory or protective measures of influence with their adequate temporal regulation.

\section{List of sources used:}

1. Gribanov V.P. Exercise and protection of civil rights. Moscow: Statut, 2000. 411 s.

2. Malein N.S. Law, responsibility and abuse of rights. Советское государство и право. 1991. № 11. pp. 28-35.

3. Ioffe O.S. Civil law. Selected works. Moscow: Statut, 2000. 781 p.

4. Pecheny O. Some problems of terms in contractual obligations. Мала енциклопедія нотаріуса. 2008. №1. Рp. 90-94.

5. Krasheninnikov E.A. The concept and subject of the statute of limitations. Yaroslavl, 1997. $80 \mathrm{p}$.

6. Voshatko A.V. Beginning of the limitation period for claiming insurance indemnity. Problems of protection of subjective civil rights. Collection of scientific works. Yaroslavl: Из-во ЯрГУ, 2001. Р. 39-45.

7. Yakovlev V.F. Civil law method of regulating public relations. 2nd ed. Moscow: Statut, 2006. 240 p.

8. Goryainov A.M. Coercion and civil liability. Вісник Верховного Суду України. 2012. № 3 (139). Pp. 36-39.

9. Jurista O. On the concept and basic features of law enforcement. Право України. 1997. №10. P.55-58.

10. Guyvan P.D. Theoretical questions of terms in private law. Monograph. Kharkiv: Pravo, 2014. 620 p.

11. Gurvich M.A. Right of claim. Ed .: Kleinman A.F. M., Leningrad: Изд-во АН CCCP, 1949. 216 p.

12. Zhitsinsky Yu.S. Sanctions of the norm of the Soviet civil law. Author's ref. diss. .... cand. jurid. science. Kiev: Kiev state. Univ. TG Shevchenko, 1966. 18 p.

13 Eliseikin P.F. The concept of a claim as a procedural means of protection of rights and interests. Problems of protection of subjective rights and Soviet civil proceedings. Yaroslavl: 1976. Issue. 1. P.82-126. 


\title{
STRATEGIC COMMUNICATIONS IN FOREIGN POLICY OF THE UNITED STATES, EUROPEAN UNION, AND UKRAINE
}

\author{
Khylko Maksym \\ Ph.D., Senior Research Fellow, \\ National Academy of Sciences of Ukraine
}

There is not consensus on the definition of strategic communications among the experts and academia, but the most popular interpretations of this phenomenon consider it as a combination of concerted actions, messages, images and other forms of representation or interaction intended to inform, influence or persuasion of target groups in order to realize national interests $[1 ; 2]$.

In the United States, a leader in the use of strategic communications in foreign policy, the Strategic Communication and Public Diplomacy unit of the US National Security Council prepared the 2007 U.S. National Strategy for Public Diplomacy and Strategic Communication. The documents set out a vision for how the United States can communicate effectively with the world in order to achieve the following main objectives: to champion human dignity; to strengthen alliances against terrorism; to defuse regional conflicts; to prevent threats from weapons of mass destruction; to encourage global economic growth; to expand the circle of development; to cooperate with other centers of global power; and to transform America's national security institutions to meet the challenges and opportunities of the twenty-first century [3]. Subsequently, the U.S. government agencies regularly prepared similar documents that set out the goals and formats of using strategic communications to promote and protect the U.S. interests and values in the world.

The European Union traditionally been less active than the United States in promoting its strategic narratives to the outside world. Until 2014, the EU focused mainly on trying to improve communications within the Union itself: a number of documents to improve EU communication were developed: Communication on implementing the information and communication strategy for the European Union (2004) [4], Action plan to improve communicating Europe by the Commission (2005) [5], The Commission's contribution to the period of reflection and beyond: Plan-D for Democracy, Dialogue and Debate (2005) [6], White Paper on a European Communication Policy (2006) [7], Communicating Europe in partnership (2007) [8], Europe for Citizens Programme (2007-2013) [9]. However, this policy was not very successful, and most importantly, it focused mainly on internal communication in the European Union, paying insufficient attention to both the EU's work with external audiences and the protection of the EU's communication space from external interference.

Realizing the vulnerability of the population of the European Union and partners to destructive information influences, in 2015 the East StratCom Task Force was established within the European External Action Service [10]. 
The need to strengthen its positions in the field of strategic communications was realized in the North Atlantic Alliance as well. In early 2014, the NATO Strategic Communications Centre of Excellence (NATO StratCom COE) was established in Riga, Latvia [11].

On 22 September 2015, Secretary of the National Security and Defense Council of Ukraine Oleksandr Turchynov and NATO Secretary General Jens Stoltenberg signed the "Strategic Communications Partnership Road Map". It is a unique document of cooperation and the only one of this kind between NATO and the partner country, designed to enhance and sustain a level of greater collaboration among the Ukrainian authorities to communicate national strategic objectives, government policies and ongoing reforms. The implementation of strategic communications also became part of the Annual National Program (ANP) of Ukraine-NATO Cooperation for 2016 [12].

In 2015, the term 'strategic communications' for the first time appeared in Ukrainian legislation, in the Military Doctrine of Ukraine, approved by Presidential Decree of September 24, 2015 [13]. The growth at the highest level in Ukraine of attention to the issue of strategic communications was indicated by the appearance of the relevant section in the Analytical Report to the Annual Address of the President of Ukraine to the Verkhovna Rada of Ukraine "On Ukraine's Internal and External Situation in 2016" [14].

In 2016, the Ministry of Information Policy of Ukraine developed and presented a plan for interdepartmental coordination in the field of strategic communications, according to which at the strategic level the Interdepartmental Working Group must include representatives of the Presidential Administration, the National Security and Defense Council, the Governmental Secretariat, the Ministry of Information Policy, the Ministry of Foreign Affairs, and the National Institute for Strategic Studies [15].

In the context of the development of strategic communications, the Public Diplomacy Department (later transformed into the Communications and Public Diplomacy Department) was established within the Ministry of Foreign Affairs of Ukraine in 2015 as a mechanism for promoting Ukraine in the world and interacting with the public. An important step was the creation in 2017 of the Ukrainian Institute under the Ministry of Foreign Affairs of Ukraine as a state institution that represents Ukrainian culture in the world and shapes a positive image of Ukraine abroad [16]. In 2020-2021, for the first time in the history of Ukraine, the Ministry of Foreign Affairs developed the Public Diplomacy Strategy and the Communication Strategy. Both documents were approved by the decision of the Board of the Ministry of Foreign Affairs on March 24, 2021 [17].

Growing importance of public diplomacy was indicated in the new Strategy of Foreign Policy of Ukraine, approved by the Decree of the President of Ukraine of August 26, 2021. The document calls public diplomacy "an important tool for shaping a positive image of Ukraine as a reliable partner and outpost for the protection of democratic values in Europe, which becomes especially relevant in the context of growing hybrid threats" [18].

Thus, strategic communications are enshrined in Ukrainian legislation, institutions responsible for the implementation of strategic communications have been established, 
and practical coordination of the activities of strategic communications entities in foreign policy has been established as well.

At the same time, important tasks remain: elaboration of the Ukrainian narrative, which will be communicated to the world through the system of strategic communications; professional training of specialists in specific areas of strategic communications; expanding the range of subjects of strategic communications in foreign policy (including through representatives of the academic and expert community, cultural figures, arts, sports, etc.) while ensuring the overall coordination of their activities in this area; more structured work with different target audiences. Successful implementation of these and other tasks will contribute to the further strengthening of strategic communications of Ukraine, their contribution to the successful implementation of domestic and foreign policy, the establishment of Ukraine as a subject of international relations.

\section{References:}

1. Paul Ch. (2011), Getting Better at Strategic Communication, RAND, available at: https://www.rand.org/content/dam/rand/pubs/testimonies/2011/RAND_CT366.pdf

2. Cornish P., Lindley-French J., Yorke C. (2011), Strategic Communications and National Strategy, Chatham House, available at: https://www.chathamhouse.org/sites/default/files/r0911es\%E2\%80\%93stratcomms.p df

3. U.S. National Strategy for Public Diplomacy and Strategic Communication (2007), U.S. Department of State, available at: https://20012009.state.gov/documents/organization/87427.pdf

4. Communication on implementing the information and communication strategy for the European Union (2004), available at: https://eurlex.europa.eu/LexUriServ/LexUriServ.do?uri=COM:2004:0196:FIN:EN:PDF

5. Action plan to improve communicating Europe by the Commission (2005), available at: https://ec.europa.eu/transparency/documentsregister/detail?ref=SEC(2005)985\&lang=uk

6. The Commission's contribution to the period of reflection and beyond: Plan-D for Democracy, Dialogue and Debate (2005), available at: https://eurlex.europa.eu/LexUriServ/LexUriServ.do?uri=COM:2005:0494:FIN:en:PDF

7. White Paper on a European Communication Policy (2006), available at: https://europa.eu/documents/comm/white_papers/pdf/com2006_35_en.pdf

8. Communicating Europe in partnership (2007), available at: https://eurlex.europa.eu/summary/ET/legissum:110117

9. Europe for Citizens Programme (2007-2013), available at: https://ec.europa.eu/citizenship/europe-for-citizens-programme/programme-20072013/index_en.htm

10. Questions and Answers about the East StratCom Task Force (2021), available at: https://eeas.europa.eu/headquarters/headquarters-homepage/2116/-questions-andanswers-about-the-east-stratcom-task-force_en

11. NATO Strategic Communications Centre of Excellence (2021), available at: https://stratcomcoe.org/about_us/about-nato-stratcom-coe/5 
12. Указ Президента України Про затвердження Річної національної програми співробітництва Україна - НАТО на 2016 рік (2016), available at: https://zakon.rada.gov.ua/laws/show/45/2016/page

13. Указ Президента України Про рішення Ради національної безпеки i оборони України від 2 вересня 2015 року "Про нову редакцію Воєнної доктрини України" (2015), available at: https://zakon.rada.gov.ua/laws/show/555/2015

14. Аналітична доповідь до Щорічного Послання Президента України до Верховної Ради України «Про внутрішнє та зовнішнє становище України в 2016 році». - К.: НІСД (2016), available at: https://niss.gov.ua/sites/default/files/201610/poslanya_new-cc2e3.pdf

15. Побудова системи державних стратегічних комунікацій України (2016), available at: https://mip.gov.ua/files/documents/Stratcom_Report_2016_UKR_updated.pdf

16. Статут державної установи «Український інститут» (2018), available at: http://old.mfa.gov.ua/mediafiles/files/misc/2018-01-17/2018-01-23_n540_statute.pdf

17. Дмитро Кулеба представив першу Стратегію публічної дипломатії МЗС України та назвав сім ії напрямів // Міністерство закордонних справ України (2021), available at: https://mfa.gov.ua/news/dmitro-kuleba-predstaviv-pershustrategiyu-publichnoyi-diplomatiyi-mzs-ukrayini-ta-nazvav-sim-yiyi-napryamiv

18. Указ Президента України №448/2021 Про рішення Ради національної безпеки і оборони України від 30 липня 2021 року "Про Стратегію зовнішньополітичної діяльності України" (2021), available at: https://www.president.gov.ua/documents/4482021-40017 


\title{
ORGANIZATION OF THE EDUCATIONAL PROCESS IN HIGHER EDUCATION INSTITUTIONS OF UKRAINE DURING THE QUARANTINE PERIOD
}

\author{
Kuzmenko Iuliia \\ PhD, assistant professor, professor Department of Administrative Law and \\ Administrative Procedure (Kherson Faculty of Odesa State University of Internal \\ Affairs, Kherson, Ukraine)
}

The problem of the COVID-19 pandemic is acute today in Ukraine and in the world. In particular, issues of public safety and order in quarantine are important. There is a need to ensure the safety of health and life of the population, and therefore the issues of legal regulation of the introduction of measures to prevent the spread of coronavirus are relevant today. The analysis of the legal field in this area gives grounds to note that the following legal documents are valid: Resolution of the Cabinet of Ministers №1236 "On the establishment of quarantine and the introduction of restrictive anti-epidemic measures to prevent the spread in Ukraine of acute respiratory disease COVID-19 caused by coronavirus SARS-CoV-2", which was established from December 19, 2020 to 28 quarantine on the territory of Ukraine, extending the quarantine established by the resolutions of the Cabinet of Ministers of Ukraine of March 11, 2020 № 211 "On prevention of the spread of acute respiratory disease COVID-19 caused by coronavirus SARS-CoV-2" on the territory of Ukraine, of May 20, 2020 № 392 "On establishing quarantine in order to prevent the spread of acute respiratory disease COVID-19 caused by coronavirus SARS-CoV-2 in Ukraine" and of July 22, 2020 № 641 "On establishing quarantine and introduction of enhanced antiepidemic measures in the area with a significant spread of acute respiratory disease COVID-19 caused by coronavirus SARS-CoV-2"[1].

According to Art. 1 of the Law of Ukraine "On protection of the population from infectious diseases" quarantine is an administrative and health measures used to prevent the spread of particularly dangerous infectious diseases [2]. The procedure for establishing quarantine restrictions is enshrined in Art. 29 of the above law and Art. 40 of the Law of Ukraine "On Ensuring Sanitary and Epidemic Welfare of the Population".

With the entry into force of the resolution on the establishment of quarantine in Ukraine, there was a problem with the organization of the educational process in educational institutions. Taking into account the need to ensure appropriate antiepidemic measures aimed at preventing the spread of the disease, on August 22, 2020 the Ministry of Health of Ukraine together with the Chief State Sanitary Doctor of Ukraine approved Resolution № 50 "On approval of anti-epidemic measures in educational institutions for quarantine. ligament in violation of coronavirus disease (COVID-19)". It outlines recommendations for the implementation of a safe educational process in universities. 
It is determined that the organization of the educational process primarily depends on the level of quarantine restrictions. Educational institutions of the regions located in:

- "green" and "yellow" levels have no restrictions on attendance,

- the "orange" level prohibits attending educational institutions in groups of more than 20 people, except for preschool and general secondary education institutions,

- "red" level - it is forbidden to attend educational institutions.

It is mandatory to provide staff and students with personal hygiene and personal protection, disinfectants, hand antiseptics, non-contact thermometers. It is established that the head and founder of the institution is responsible for the lack of these funds.

In addition, there are clear rules for the organization of the educational process, which include:

1. Entrance to the premises of the institution is allowed in the presence of a protective mask or respirator. Protective masks may not be used during classes in classrooms. The use of protective masks is mandatory when moving around the premises of the educational institution.

2. Occupancy of lecture halls during classes involving a combination of several classes (groups) should not exceed 50\% while ensuring the maximum distance between students. In regions belonging to the "orange" level of epidemic danger, the number of classes (groups) should not exceed 20 people, except for preschool, general secondary, extracurricular and specialized art education. In such cases, the founder (owner) and the head of the educational institution must adapt the training schedule in advance and form groups at the time of establishing the appropriate level of epidemic danger.

3. In case of confirmation of a case of coronavirus disease COVID-19 in one of the students (students), all other students (students) of the relevant group are recognized as in need of self-isolation and must take measures provided by industry standards in health care.

4. Liquid soap and paper towels (or electric hand dryers) should be provided in the bathrooms. The use of reusable towels is prohibited.

5. After classes at the end of the working day it is necessary to clean and disinfect surfaces (including door handles, tables, seats, railings, etc.) [3].

As mentioned above, in the regions that belong to the "red" level of quarantine restrictions, visiting educational institutions is prohibited. In this case, distance learning is introduced for participants in the learning process. Distance learning means an individualized process of acquiring knowledge, skills, abilities and ways of human cognitive activity, which occurs mainly through the indirect interaction of distant participants in the learning process in a specialized environment that operates on the basis of modern psychological, pedagogical and information and communication technologies [4]. Distance learning can be implemented through distance learning as a separate form of education or distance learning technology to provide training in various forms of education, their combination.

This form of educational process has a number of advantages and disadvantages. Determining the positive aspects of distance learning, it is necessary to emphasize the availability of educational materials when using technical means and the Internet; 
significant savings in time spent on the way to educational institutions, the use of minimal financial resources.

However, the disadvantages of distance learning are: lack of practical skills, most of the material remains for self-study, which reduces the level of awareness of the topic, the presence of academic dishonesty, lack of social interaction, low material level of technical equipment in educational institutions.

In conclusion, we note that the current state, which is characterized by mass disease of coronavirus disease, has led to the introduction of anti-epidemic measures with a high percentage of restrictions. In particular, in the context of public safety and order in the conditions of quarantine, the issues of peculiarities of the organization of the educational process in the universities of Ukraine, in accordance with the current legislation, are important. Depending on the "level of quarantine restrictions" in the region depend on the requirements for training. Considerable attention is paid to personal hygiene and personal protection, the number of participants in the educational process, the introduction of distance learning in educational institutions and more.

\section{References}

1. Про встановлення карантину та запровадження обмежувальних протиепідемічних заходів з метою запобігання поширенню на території України гострої респіраторної хвороби COVID-19, спричиненої коронавірусом SARSCoV-2: Постанова Кабінету Міністрів від 09.12.2020 р. №1236. Дата оновлення: 10.04.2021. URL: https://www.kmu.gov.ua/npas/pro-vstanovlennya-karantinu-tazaprovadzhennya-obmezhuvalnih-protiepidemichnih-zahodiv-1236-091220. (дата звернення: 21.08.2021).

2. Про захист населення від інфекційних хвороб: Закон України від 06.04.2000 p. № 1645-III. Дата оновлення: 23.05.2020. URL: https://zakon.rada.gov.ua/laws/show/1645-14\#Техt (дата звернення: 23.08.2021).

3. Про затвердження протиепідемічних заходів у закладах освіти на період карнатину у звязку з порушенням коронавірусної хвороби (COVID-19): Постанова Головного державного санітарного лікаря України від 22.08.2020 року №50 URL: https://zakon.rada.gov.ua/rada/show/v0050488-20\#n7 (дата звернення: 21.07.2021).

4. Про затвердження положення про дистанційне навчання: Наказ Міністерства освіти і науки України від 25 квітня 2013 року № 466. Дата оновлення: 16.10.2020. URL: https://zakon.rada.gov.ua/laws/show/z0703-13\#Text (дата звернення: 11.09.2021). 


\title{
MECHANISM OF BRINGING JUVENILES TO ADMINISTRATIVE RESPONSIBILITY
}

\author{
Shevchenko Nadiya
}

Associate Professor of Administrative Law and Administrative Procedure, Kherson Faculty, Odessa State University of Internal Affairs, Candidate of Law

\section{Rudnychenko Svetlana}

Associate Professor of Administrative Law and Administrative Procedure, Kherson Faculty, Odessa State University of Internal Affairs, Candidate of Law

Administrative liability is a special type of legal liability, it has all the hallmarks of the latter. In the legal literature, the problems of administrative responsibility have been and are given a lot of attention.

Many scholars in their work pay attention to the study of administrative liability of certain categories of persons, including minors.

Yu. I. Kovalchuk understands the administrative responsibility of minors as "application in the prescribed manner by administrative bodies of administrative penalties and measures of educational influence on minors guilty of committing administrative offenses, to instill in them respect for laws, rules of social coexistence, as well as prevention new offenses "[1].

Thus, the administrative liability of minors has features due to the age of the person being prosecuted, as well as related to the special protection of the interests of the minor.

Thus, persons who have reached the age of 16 at the time of committing an administrative offense are subject to administrative liability. In this case, age can be both a mitigating circumstance and a burden. If an administrative offense (misdemeanor) was committed by a person between the ages of 16 and 18, it will be a mitigating circumstance, and in the case of involving such a person in the commission of an offense by another person - an aggravating circumstance.

The administrative responsibility of minors is mainly educational in nature. The Code of Ukraine on Administrative Offenses stipulates that the following measures of influence are applied to persons aged 16 to 18 who have committed administrative offenses:

1) an obligation to publicly or otherwise apologize to the victim;

2) warning;

3) reprimand or severe reprimand;

4) transfer of a minor under the supervision of parents or persons replacing them, or under the supervision of the teaching or labor team with their consent, as well as individual citizens at their request.

However, the Code of Ukraine on Administrative Offenses (hereinafter KUPAP) does not specify who will be responsible for committing an offense to a minor who has a psychological and mental illness, and this is a significant gap in the legislation. 
The purpose of the administrative responsibility of a minor causes a smaller amount and degree of deprivation or restriction of rights and freedoms, compared to persons over 18 years of age. In particular, administrative arrest is not applied to minors.

This rule is fully in line with international legal standards, in particular the United Nations Standard Minimum Rules for the Administration of Juvenile Justice (Beijing Rules), which aim to reduce the use of juveniles in isolation. [2] .

According to the law, administrative and coercive measures can be applied not only to minors, but also to their parents (Article 184 of the Code of Administrative Offenses). In this case, a fine is imposed on the parents or guardians [2].

In the case of a juvenile offense, parents or guardians must be notified of the detention of a juvenile for an administrative offense. However, the law does not define the procedure for such notification, and the question of the lawfulness of the detention of a minor without the presence of parents remains unclear.

Procedural features of administrative liability of minors are related to its application in court, the possibility of applying administrative and coercive measures to the parents of a minor, the participation of legal representatives and representatives in representing their interests, the obligation to notify parents or guardians of the detention of a minor, as well as the impossibility of applying administrative sanctions as a substitute for criminal liability.

Paragraph 3 of the first part of Article 6 of the Law of Ukraine "On bodies and services for children and special institutions for children" [4]. it is provided that the courts consider cases against minors who have committed administrative offenses between the ages of 16 and 18 .

Such cases are considered by specially authorized judges (judges) with the participation of representatives of children's services, except as provided by law (part two of Article 6 of the Law of Ukraine "On bodies and services for children and special institutions for children") [4] .

According to Article 221 of the Code of Administrative Offenses, cases of administrative offenses committed by persons aged 16 to 18 are considered exclusively by judges of district, district in the city, city or city district courts [1].

Therefore, when bringing a juvenile to administrative responsibility, his / her age should be taken into account, and the nature of the committed administrative offense should be commensurate with the measures of influence. Moreover, it is necessary to take into account the legal guarantees of protection of the rights and legitimate interests of minors in order to prevent their violation.

\section{Literature}

1. Kovalchuk YI Features of administrative liability of minors. Law of Ukraine. 2016. № 6. S. 111-114.

2. Code of Ukraine on Administrative Offenses // https://zakon.rada.gov.ua/laws/show/80731-10

3. Muratova DB, Naychuk GO Some problematic issues of administrative liability of minors. Scientific review. 2017. № 6 (38). URL: http://oaji.net/articles/2017/7971502027116.pdf.

4. Law of Ukraine "On bodies and services for children and special institutions for children" URL: https://zakon.rada.gov.ua/laws/show/20/95-\%D0\%B2\%D1\%80\#Text 


\title{
ЧИ ДОЦІЛЬНО ВВАЖАТИ ЗЛОЧИННІСТЬ СИСТЕМОЮ?
}

\author{
Валерій Оболенцев, \\ Ph.D., Associate Professor \\ Yaroslav Mudryi National Law University
}

Системою згідно усталених поглядів фахівців-системотехніків вважається сукупність взаємозалежних елементів, що утворюють виокремлене ціле і мають єдине призначення або мету [1, с.84]. Фахівці стверджують, що відносно різних завдань та на різних рівнях аналізу один й той самий об'єкт можна досліджувати як системний або несистемний [2, с. 167]. На цей час розуміння злочинності як системного об'єкту ще не знайшло однозначної підтримки у науковому світі.

Б.М. Головкін стверджує, що системний підхід до пізнання злочинності передбачає розгляд цього об'єкта як множини одиничних і групових проявів, що інтегруються в структурні елементи, пов'язані між собою. На думку науковця 3 методологічної точки зору злочинність являє собою систему взаємозв'язків i відношень між іiі структурними елементами у межах системи суспільних відносин. Внутрішня стійкість системи злочинності забезпечується через цілеутворення злочинної поведінки (діяльності), або вибір соціальними суб'єктами незаконних шляхів і засобів задоволення спільних інтересів, вирішення схожих життєвих проблем, досягнення загальних цілей. Зовні така стійкість виражається у формі повторності і рецидиву вчинюваних кримінальних правопорушень. Внутрішня взаємодія структурних елементів злочинності відбувається через сукупність злочинних посягань, ідеальне або реальне поєднання різних форм злочинної поведінки, а також шляхом співучасті у вчиненні кримінальних правопорушень членів злочинних груп, організованих злочинних груп і злочинних організацій. Як відкрита соціальна система, злочинність зовні взаємодіє із подібними явищами і процесами, постійно змінюється під їх впливом і поширюється у просторі та часі. Крім того, будучи невід'ємною складовою суспільного буття, злочинність має властивість до самовідтворення і розвитку, пов'язаного із розвитком суспільства, зміною умов життя людей[3, с.171-172].

Ми ж вважаємо, що саме розуміння злочинності як системи відкриває можливість реалізувати нову стратегію правоохоронної діяльності.

Відповідно до концепції, коли злочинність розглядається в якості окремого системного об'єкту1 запобіганням злочинів розуміються заходи, спрямовані на нейтралізацію ресурсів цієї системи, керуючих обставин, виконавців, зв'язків із зовнішнім середовищем та її обернених зв'язків. У випадку ж, коли злочини розглядаються в якості проблеми системного об'єкта - держави України, то запобіжні заходи орієнтуються на вдосконалення i розвиток існуючих суспільних відносин.

Універсальними заходами запобігання злочинності для обох підходів $є$ такі. 
1. Стримуючий влив на свідомість криміногенних осіб через встановлення санкцій за вчинення протиправних дій.

2. Нейтралізація внутрішньосистемних зв'язків злочинності:

2.1. Перешкоджання поширенню інформації про латентність по сягань, яка спонукає до нових неправомірних зв'язків:

2.1.1. Мінімізація випадків самої латентизації;

2.1.2. Перешкоджання поширенню інформації про факти та технології латентизації посягань.

2. Нейтралізація кримінальної субкультури - інформаційної складової масової кримінальної практики.

3. Превентивний контроль - моніторинг інформації про охоронювані об'єкти.

4. Превентивне обмеження:

4.1. Нейтралізація зовнішніх зв'язків злочинності з елементами суспільних відносин: - 3 потенційними об'єктами злочинних посягань; - 3 потенційними жертвами злочинних посягань (зменшення віктимізації).

4.2. Нейтралізація обернених зв'язків злочинності - позбавлення можливості використання результатів злочинів для нових посягань (наприклад, запобігання легалізації доходів, одержаних злочинним шляхом, із подальшим їх використанням у злочинній діяльності, та ін).

4.3. Обмеження фізичних можливостей потенційних та фактичних правопорушників щодо здійснення злочинної діяльності.

Список літератури.

1.Методы исследований и организация экспериментов / под ред. К. П. Власова. Харьков : Гуманит. Центр, 2002. 256 с.

2.Блауберг И. В., Юдин Э. Г. Становление и сущность системного подхода. М.: Наука, 1972. 270 с.

3.Головкін Б.М. Теперішнє і майбутнє кримінології. Проблеми законності. 2020. № 149. C. 168-184. 


\title{
РОЗВИТОК ЗАГАЛЬНОКУЛЬТУРНИХ КОМПЕТЕНЦЙ МАЙБУТНІХ ПРАВООХОРОНЦІВ ПІД ЧАС ВИВЧЕННЯ ДИСЦИПЛІНИ «КОНСТИТУЦЙНЕ ПРАВО»
}

\author{
Камінська Олена, \\ к.і.н., доцент, професор кафедри \\ загальноправових та соціально- \\ гуманітарних дисциплін \\ Херсонського факультету ОДУВС
}

\author{
Федорченко Олег, \\ к.і.н., завідувач кафедри \\ загальноправових та соціально- \\ гуманітарних дисциплін \\ Херсонського факультету ОДУВС
}

Актуальність теми дослідження обумовлена, перш за все, тим, що розвиток компетенцій студентів на сьогоднішній день $є$ одним із пріоритетних напрямків модернізації сучасної системи освіти.

З одного боку, формуванню загальнокультурних компетенцій присвячено велику кількість праць, написано підручники. «Прописним істинам» навчають у педагогічних вишах. Однак, на практиці в студентській аудиторії викладачу доводиться постійно застосовувати творчий підхід, шукати альтернативні форми роботи з метою забезпечення доступності інформації і полегшення iï сприйняття студентами, підтримки інтересу до дисципліни і навчання в цілому. 3 іншого, вивчення «Конституційного права», як фундаментальної дисципліни, направлено на формування у студентів як основи знань у галузі конституційного права, так і в силу універсального значення його положень - основи юридичного мислення взагалі.

Метою компетентнісного підходу є забезпечення якості освіти, а це означає, що зараз актуальним є не що робити, а як правильно робити. У чому ж повинна полягати якість навчання? Визначається вона сукупністю показників, що характеризують різні аспекти навчальної діяльності освітнього закладу, які забезпечують розвиток компетенцій молоді, що навчається: матеріально-технічна база, кадровий склад, зміст освіти, форми і методи навчання і т.п.

Зупинімося на формах навчання і для початку розглянемо стан справ з лекціями. Час, відведений на лекції (16 годин для спеціальності «Правоохоронна діяльність»), дозволяє викладачеві дати лише побіжний і поверхневий огляд. Відразу варто обмовитися, що чим більше викладач заглиблюється у зміст дисципліни, тим більше інформації може дати студентам, тому поріг «достатньої кількості» годин на вивчення дисципліни встановити не можливо.

Потрібно шукати альтернативні форми в межах виділеного часу. Наприклад, крім традиційної текстової форми може бути застосована схематична, таблична тощо. Студент може відносно легко повертатися до розглянутих схем, малюнків i 
сюжетів для уточнення або зв'язку нової теми з раніше вивченим матеріалом. Істотним $є$ і спрощення ведення студентами конспектів, оскільки вся навчальна інформація представлена в компактній, лаконічній формі.

I все ж, лекція не дозволяє викладачам повною мірою викласти матеріал у межах усього курсу. Відповідно, більш глибоке вивчення окремих питань конституційного права має відбуватися на семінарах.

Саме слово «семінар» походить від латинського «Seminarium»- розсадник $\mathrm{i}$ пов'язано з функціями «посіву» знань, що передаються від учителя до учнів i «проростають» у свідомості вихованців, здатних до самостійних суджень, до відтворення і поглиблення отриманих знань [1, с.89]. Практика показує, що не дотримання деяких умов семінару перетворює його на подобу лекції. Замість двостороннього контакту «викладач - студенти», зазвичай має місце односторонній контакт, при якому або студенти механічно повторюють заздалегідь підготовлену відповідь на поставлене запитання, або в разі непідготовленості студентів говорить викладач. I навіть, у першому випадку в роботі бере участь не вся група студентів, а окремі особи.

Чому ж відсутня активність студентів? Частково це викликано нерозумінням необхідності вивчення конституційного права. Серед здобувачів вищої освіти побутує думка, що оскільки прямої реалізації його положень в майбутній роботі немає, то слід зосередитись на вивченні більш «практичних» галузей: кримінального, цивільного тощо. Справа в тому, що студенти першого курсу ще не мають значного культурного рівня розвитку для усвідомлення необхідності його вивчення. У цій ситуації доводиться директивно вказувати на «визначальне значення положень i принципів конституції для усіх галузей права», знання якої стане в нагоді при вивченні галузевих законодавств на старших курсах.

Існують найрізноманітніші форми роботи на семінарах.

1) Найбільш поширеною $\epsilon$ розгорнута бесіда, яка передбачає підготовку студентів 3 питань семінару з єдиним для групи переліком рекомендованої літератури [1, с.91]. Однак, як показує практика, студенти розподіляють між собою питання і готують спеціально лише одне-два, інший матеріал нерідко залишається неосвоєним достатньою мірою. Вихід вбачається у поєднанні виступів студентів (за викликом викладача і за їхнім бажанням або ж за бажанням надавати можливість виступати тільки у якості доповнень).

2) Підготовка студентами рефератів і доповідей. Звичайно, не справедливо вимагати від 18-19-річних студентів «наукової новизни». Але студент повинен проявити навички самостійної роботи, під час відповіді спиратися на думки вченихюристів і авторів наукової літератури. На практиці часто доповідач просто копіює текст підручника чи реферат, опублікований в Інтернеті. Інші студенти під час доповіді проявляють пасивність і непідготовленість. Або, як і під час розгорнутої бесіди, пропонують питання, які вже висвітлив доповідач. Для подолання цього необхідно перед захистом реферату ознайомити з ним групу (або хоча б вибрану ініціативну групу). Або організувати підготовку однієї теми ініціативною групою. Це надасть можливість проведення дискусії з ключових проблем теми.

3) Опанування термінологічно-понятійного апарату. Дуже важливо використовувати різні способи освоєння понять: ведення словників, 
запам'ятовування і відтворення юридичних визначень, правил і термінів, складання схем з їх використанням.

4) Читання законодавчих джерел. Для того щоб знання були достовірними, істинними, студентові необхідно знайомитись з існуючими нормативними актами 3 тієї або іншої теми. Щоправда, конституційне право має велику кількість законів та підзаконних актів. Користуватися всіма або хоча б більшою частиною з них на семінарах незручно. Навіть, використовуючи Інтернет, студенту важко швидко знайти потрібну норму. Тобто, необхідні спеціальні хрестоматії, складені 3 урахуванням задач, що пропонуються до вирішення студентам.

5) Рішення задач - найбільш складна форма роботи, але й одна з найцікавіших. У процесі пошуку рішення задачі студент змушеній переглянути значну кількість інформації, зокрема норм права у джерелах. Крім того, рішення задач оживляє аудиторію, спричинює дискусію. Складність полягає у недостатності знань студентів із певної теми, і незручності використання першоджерел. Вихід бачиться у самій формі роботи: рішення задач повинні проводитись групами 3 використанням спеціальних хрестоматій.

Нарешті, семінару властива i функція контролю за змістом, глибиною i систематичністю самостійної роботи студентів. 3 метою активізації підготовки студентів до кожного заняття доцільним $є$ використання проміжних форм контролю, у формі тестів, задач, відтворення і складання схем, використовуючи юридичні визначення, правила і терміни.

Отже, зважаючи на обмежений час, відведений на лекції, більш глибоке вивчення конституційного права має відбуватися на семінарах. Ефективність останніх визначається активністю студентів, інтенсивністю їх спілкування між собою і 3 викладачем, інтересом до обговорюваної проблеми й активізацією їх розумової діяльності. Застосування і поєднання різноманітних форми роботи у різному співвідношенні на кожному семінарському занятті призведе до спільної творчої співпраці викладача і студентів, поліпшить результативність обміну інформацією, полегшить студенту освоєння курсу конституційного права, тим самим значно підвищить продуктивність формування і розвитку загальнокультурних компетенцій.

Список літератури:

1. Педагогика и психология высшей школы: Уч.пособ. / Отв.ред. М.В.БулановаТопоркова. Ростов н/Д: Феникс, 2002. 544 с. 


\title{
ПАНДЕМИЯ: РЕАЛЬНАЯ ИЛИ ГЛОБАЛЬНАЯ ОПАСНОСТЬ
}

\author{
Кирьянова Е.А., \\ кандидат юридических наук, юрист \\ НАО «Павлодарский педагогический университет»
}

Детьми мы подсчитывали: сколько лет нам будет в 2020 году, чего могли бы ждать от этой даты в том возрасте, когда время кажется нам таким же плавным и бесконечным, как жизнь. Праздника, конечно, грандиозного праздника всех людей.

Мы выросли, стали реалистами, узнали, что жизнь состоит не из одних только праздников. Теперь мы прекрасно отдаем себе отчет в том, что календарные рубежи - всего лишь дань условности и наивно ждать от них чуда. Но ожидание нового, праздничного нет-нет, да и коснется сердца при взгляде на календарь: сколько еще магических круглых цифр осталось до 2022 года, что нам принесет эта дата. Автору стало интересно: как встречало человечество 1001год? Оказывается, он не оставил следа в памяти. Историки говорят, что жизнь тогда замерла. Пришли в упадок ремесла, стояли заброшенные поля, даже войны прекратились. Люди замерли в страхе. Они ждали конца света.

Тысячу лет спустя мы полны деловитости и надежд. Не покидает ощущение, что новый век и новое тысячелетие приходит, когда во всех сферах человеческой деятельности происходит или намечается переворот во взглядах, привычках, образе действий. На принципиально новых основах перестраиваются материальные ценности.

И трагическая ирония истории заключается в том, что создано оружие, способное покончить с человечеством и его историей. Великие эпохи порождают личности, способные осмыслить происходящее, предвидеть будущее и нащупать то ключевое звено, которое дает понимание всей цепи событий. Но что важнее, у человечества есть конкретный план избавления от опасности и бремени страха перед химической или любой иной угрозой уничтожения и в твердой уверенности в том, что род человеческий будет продолжен. Общество и государство сильны тогда, когда массы все знают обо всем, могут судить и идут на все сознательно. Без убежденности в способности человека перестраивать мир на принципах разума и морали. Без доверия нет смысла говорить о будущем.

Человек разумный, способный осмыслить законы развития и действовать в соответствии с ними, - это и есть гарантия поступательного движения истории. Все яснее становится одна историческая закономерность. Пока человек, вооруженный мечем и луком, мог убить другого человека, но не был в состоянии уничтожить человечество, он спокойно перекладывал на богов заботу о том, чтобы всходило солнце, текли реки, что бы жил человек на земле. Сегодня, когда человек обрел силу, сравнимую с природной стихией, когда он способен уничтожить человечество, он обнаружил, что никто не разделит с его разумом, его совестью, ответственность за судьбу планеты. Но очень остро мы ощущаем 
трагические последствия разделения человечества на соперничающие группировки.

Сегодня развитие мировых событий подошло к такой черте, когда требуются особо ответственные решения, когда бездействия или промедление в действиях преступны, ибо речь идет о сохранение цивилизации и самой жизни. Вопрос сегодня стоит в высшей степени остро и определенно: надо осознать коллективную ответственность всех государств перед лицом опасности, подстерегающей сообщество людей. В завтрашнем дне мы видим торжество вечных ценностей: справедливости, мира, человеколюбие. Вечные ценности, вечные истины.

Каждое новое поколение открывает их для себя заново, только после десятка проверок в уме и на деле оно готово признать их непреходящую ценность. Страх перед химической и биологической смертью поражает и более широкие слои, порождая, в частности, «философию бегства». Но угроза человечеству - это реальная или глобальная опасность, и убежать от нее невозможно, просто некуда. Бегство еще не решило ни одной проблемы, ни в индивидуальном, ни в общечеловеческом масштабе. Хуже того, принять сегодня «философию бегства» значит стать соучастником, пусть невольным, тех сил, которые своими действиями как раз приближают мировую катастрофу. Если все останется постарому, катастрофа неизбежна. Переступив черту, отделяющую праобщество от общества, обретя могущество, сравнимое с геологической силой, способность менять облик планеты, человек сохранил потребительское отношение к ней.

Существует хорошая традиция: перед дальней дорогой присесть и подумать: ничего ли не забыто в суматохе дел, не тащим ли мы с собой отживший, старый хлам, который будет только мешать в пути, может быть, данная статья станет поводом еще раз оценить предстоящий путь и взвесить собственные силы. Реалистически оценивая предстоящее, автор предвидет, что нам предстоит заниматься кропотливой, напряженной работой по накоплению необходимого для будущего скачка потенциала. 


\title{
ЗАПРОВАДЖЕННЯ ГЕНДЕРНООРІЕНТОВНОГО ПІДХОДУ ДО ВІДОМЧОЇ ЮРИДИЧНОЇ ОСВІТИ В СИСТЕМІ МВС
}

\author{
Новікова Марія \\ кандидат юридичних наук, доцент \\ доцент кафедри професійних та \\ спеціальних дисциплін Херсонського \\ факультету Одеського державного \\ університету внутрішніх справ
}

Ключовим елементом концепції побудови спроможного до активних дій суспільства виступає формування середовища, яке здатне виховувати незалежних, дієвих та здатних до змін учасників. Важливим аспектом виховання активних членів громади виступає гендерноорієнтований підхід, який сприяє формуванню гендерно-орієнтованих екосистем, що на думку Енн Лоре Гумберт здатні протидіяти проявам сексизму, гендерно-обумовленого насильства та сексуальних домагань [1, с. 3] у суспільстві. Відповідно, провідну роль у формуванні антидискрмінаційної позиції у членів сучасного українського суспільства повинна відігравати сфера освіти. При цьому, враховуючи важливу роль працівників правоохоронних органів у становленні та забезпеченні демократичних засад розвитку суспільства, у правничій освіти також слід робити акцент на запровадження гендерноорієнтовного підходу.

Обгрунтування доцільності запровадження гендерноотрієнтованого підходу до відомчої юридичної освіти в системі МВС обумовлює мету даного дослідження.

Концепція впровадження гендерноорієнтованого підходу в освітній процес обумовлюється прагненням світової спільноти до забезпечення прав і свобод людини, гендерної рівності, антидискримінації та верховенства права. Починаючи з 2000 року питання гендерної рівності виступає одним із провідних у роботі ООН та партнерських організацій у iї системі, серед яких $\mathrm{CC}$, Європейський інвестиційний банк та уряди провідних країни світу (Великобританії, Данії, Канади, Нідерландів, Німеччини, Норвегіï, Польщі, Швейцарії, Швеції та Японії). Поєднання прагнень світової спільноти з позицією країн СС призвело до появи важливих нормативних актів, які впливають на формування світової сфери освіти. Зокрема, Конвенції про боротьбу 3 дискримінацією у сфері освіти (1960р.); Конвенція ООН Про ліквідацію всіх форм дискримінації щодо жінок (1979 р.); Цілі сталого розвитку (2015 р.); Директиви Ради про реалізацію принципу рівності в питаннях працевлаштування, професійної освіти, просування по службі та умов праці 76/207/ECC (1976 p.); Рекомендація Ради Свропи CM/Rec 2007, 13 Комітету міністрів для держав-членів щодо запровадження гендерно-орієнтованого підходу в освіті (2007р.) тощо. 
На національному рівні питання впровадження гендерноорієнтованого підходу в систему освіти грунтується на Конституції України, Законі України «Про забезпечення рівних прав та можливостей жінок і чоловіків». Однак Закон України «Про освіту» [2] містить тільки одну згадку терміну «гендер» у контексті «гендерного балансу» у складі Національного агентства і забезпечення якості вищої освіти. Принцип рівності чоловіків та жінок у здобутті освіти знаходить своє відбиття у ч. 2 ст. 3 та ст. 6 Закону України «Про освіту» через рівні умови доступу до освіти незалежно від статі, а також принципу нетерпимості до дискримінації за будь-яким ознаками. Якщо звернутися до статистичних даних, наданих Державною службою статистики за 2020 рік щодо, наприклад, фахівців, які випустилися із ЗВО у 2020 році, то з загальної кількості осіб - 385700 осіб 205935 осіб складають жінки [3], що відповідно складає 53\% від загальної кількості. Однак, ми погоджуємося з тим, що сьогоднішня освіта має елементи гендерної дискримінації, що особливо проявляється у закритих відомчих системах, які споконвічно вважаються чоловічими (військові навчальні заклади та заклади системи МВС).

Слід відмітити, що сутність гендерноорієнтованого підходу у освіті не завжди розуміється належно і є заангажованим. На думку К.Б. Левченко основними проблемами у сфері освіти 3 гендерного питання виступають: недостатня обізнаність 3 гендерної проблематики; поширеність гендерних стереотипів в освітньому середовищі; відсутність гендерних підходів до програм підготовки освітян; вплив антигендерної ідеології на академічне середовище $[4$, с. 102]. Ці проблеми значно збільшуються у вищих навчальних закладах відомчої освіти. Як приклад можна навести упереджене ставлення та сексистські зауваження з боку викладачів під час проведення таких занять як спеціальна фізична підготовка, тактико-спеціальна підготовка, бойова підготовка тощо, а також під час професійно-виховної діяльності з курсантами.

Зниження проявів гендерної дискримінації у сфері відомчої освіти можливе лише у разі запровадження гендерно-орієнтованих механізмів, які мають включати в себе: 1) приведення змісту навчальних та робочих програм дисциплін, що викладаються у закладах відомчої освіти системи МВС до принципу гендерної рівності; 2) інтеграція гендерного підходу у методи викладання та форми навчання, підвищення рівня соціальної взаємодії курсантів, привернення уваги до проявів гендерної дискримінації у повсякденному житті; 3) привернення уваги науково-педагогічного складу закладів системи відомчої освіти МВС до гендерноорієнтованих питань у контексті їх спеціалізації; 4) забезпечення у закладах відомчої освіти системи МВС гарантії протидії гендернообумовленому насильству, проявам сексизму та сексуальних домагань

Обгрунтована нами позиція відповідає системі компетенцій, викладених у стандарті вищої освіти за спеціальностями «Право» та «Правоохоронна діяльність», які є провідними для вузів системи МВС. Зокрема, загальній компетенція № 12 стандарту вищої освіти для за спеціальністю «Право» [5], яка передбачає здатність майбутнього юриста усвідомлювати рівні можливості та гендерні проблеми. 
На підставі вищезазначеного, ми вважаємо, що запровадження гендерноорієнтованого підходу до відомчої юридичної освіти в системі МВС здатне сприяти: 1) запровадженню принципу недискримінації та створенню безпечного освітнього середовища у відомчій освіті системи МВС; 2) створенню належної позиції у майбутніх правоохоронців щодо гендернообумовлених дискримінаційних проявів; 3) формуванню навичок виявлення у суспільстві проявів гендерно-обумовлених правопорушень.

\section{Література}

1. Гумберт, Енн Лоре Впровадження гендерного підходу у вищій освіті: контрольний перелік питань для правничих шкіл. Київ: Cover and layout: Friends of Brands, 2020. 20 c. URL: https://rm.coe.int/a4-enchanted-gmchecklist-ukr-122020pdf/1680a135fe (дата звернення до ресурсу 24.09.2021 року)

2. Про освіту: Закон України від 05.09.2017 № 2145-VIII. URL: https://zakon.rada.gov.ua/laws/show/2145-19\#Text (дата звернення до ресурсу 24.09.2021 року)

3. Випуск фахівців із ЗВО у 2020 році за освітніми ступенями (освітньокваліфікаційними рівнями) та регіонами URL: http://www.ukrstat.gov.ua/

4. Гендерна політика в нормативно-правових документах. Частина 1. За заг.ред Левченко К.Б. / Г.Г. Жуковська, К.Б. Левченко, О.О. Остапенко, О.І. Суслова. Київ, 2020. 186 с

5. Про затвердження стандарту вищої освіти за спеціальністю 081 «Право» для першого (бакалаврського) рівня вищої освіти: Наказ Міністерства освіти і науки України № 1379 від 12.12.2018 року. URL: https://mon.gov.ua/storage/app/media/vishchaosvita/zatverdzeni\%20standarty/12/21/081-pravo-bakalavr.pdf (дата звернення до ресурсу 24.09.2021 року) 


\title{
ПРАВА ДЕТЕЙ В ГРУЗИИ
}

\author{
Пхикидзе Наили Гришаевна, \\ Ph.D OF LAW, Доктор права. \\ "Тбилиский Государственный Технический \\ Университет" Грузия, Тбилиси.
}

\section{Матиашвили Гиорги Бакурович, \\ Бакалавр /MВА/международного права \\ Франция, г. Гренобль. Высшая европейская школа менеджмента группы CEFERH. Academy of Management and Performance}

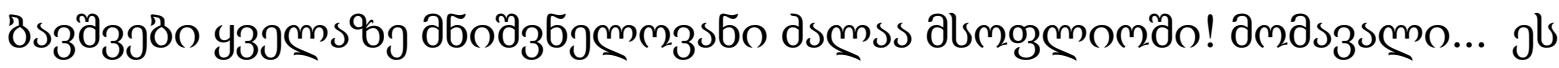

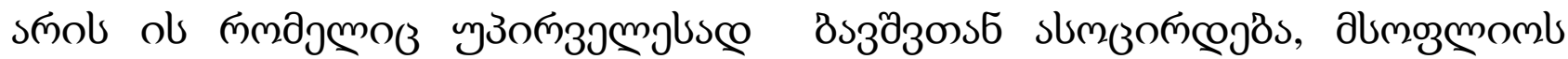

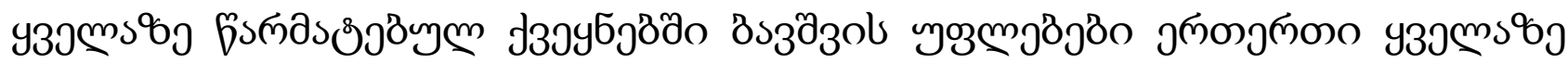

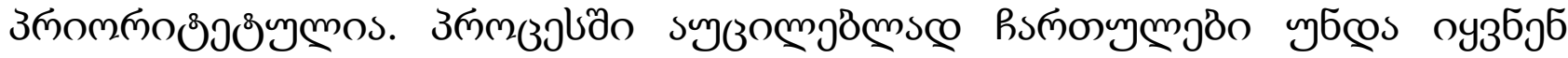

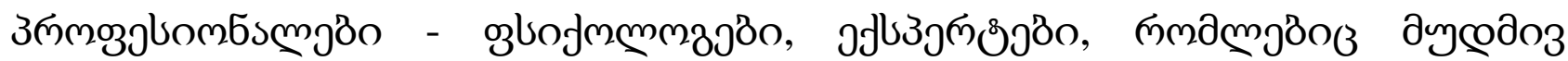

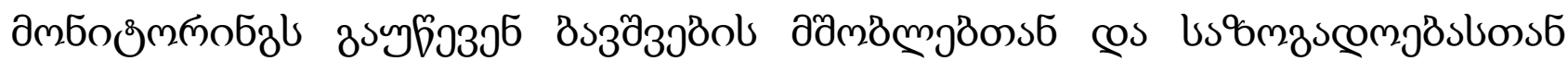

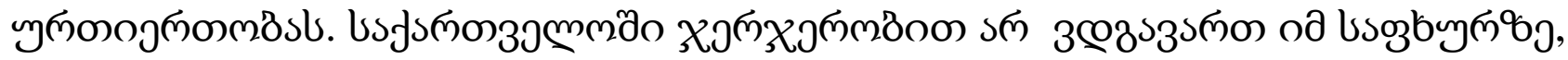

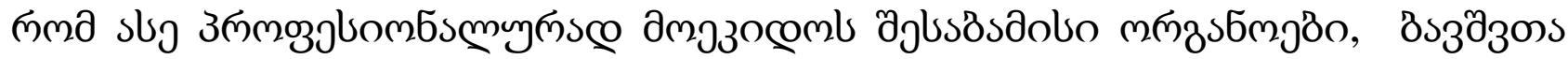

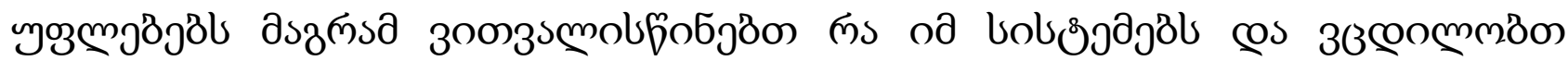

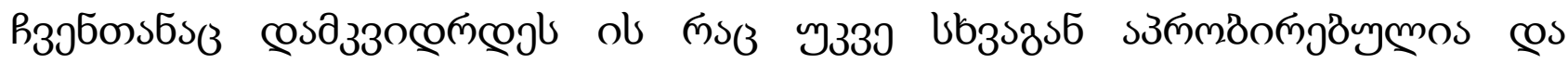

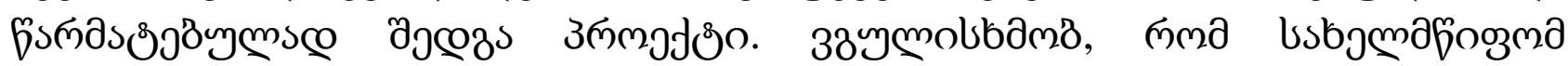

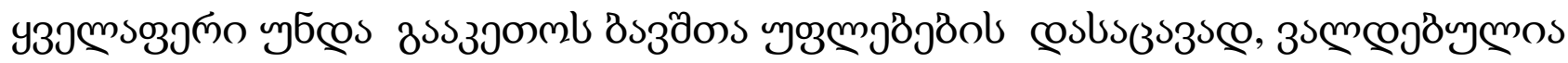

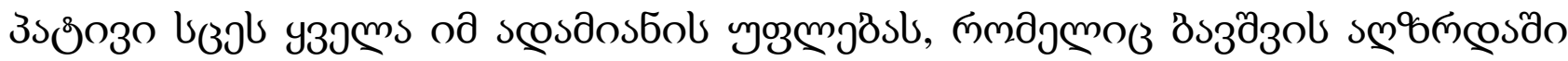

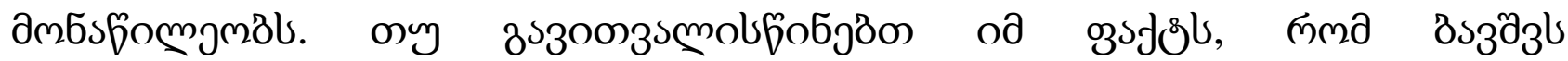

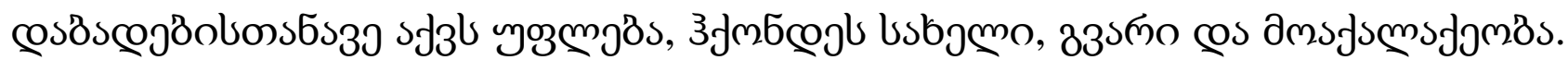

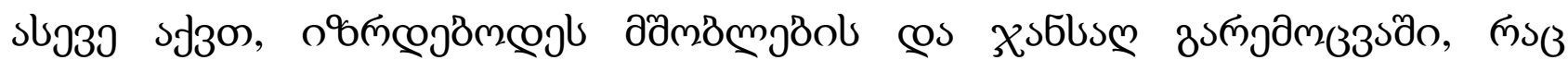

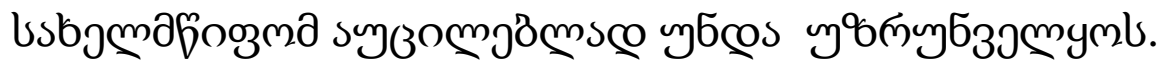

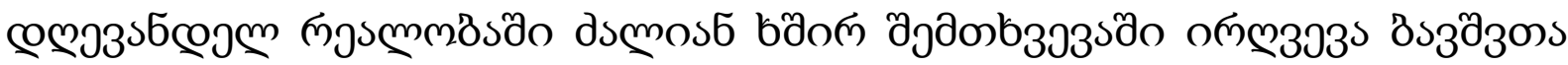

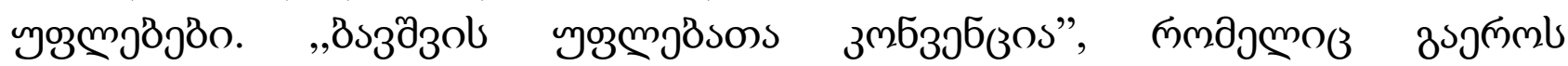

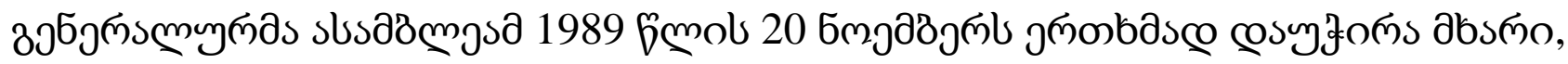
almoзмом asläss

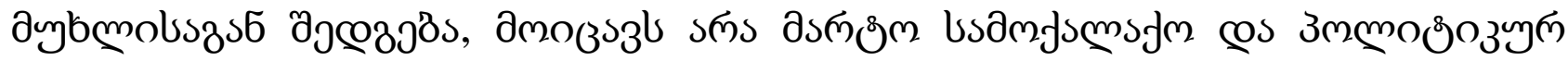

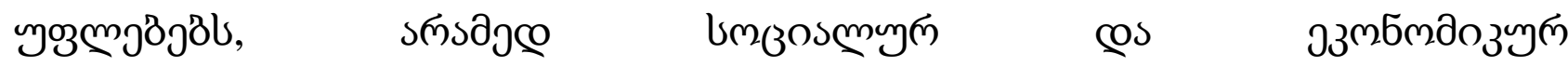

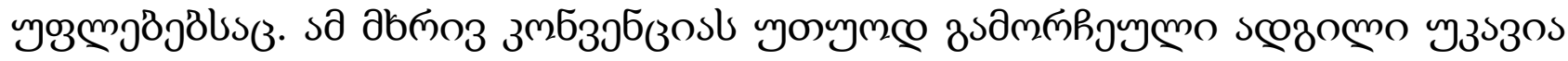

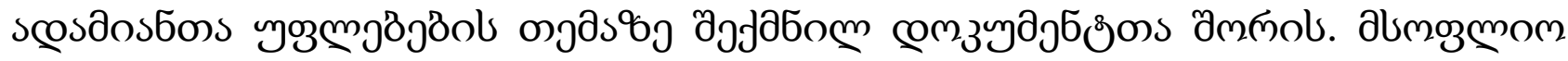

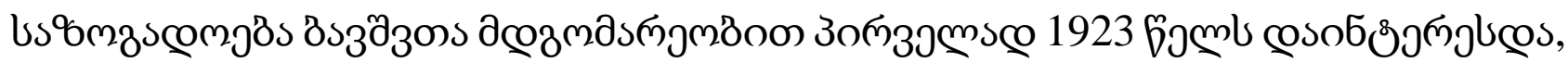

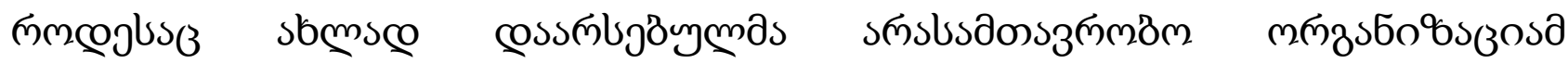

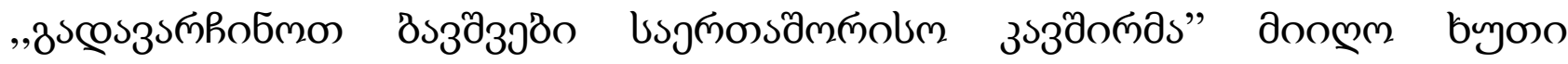




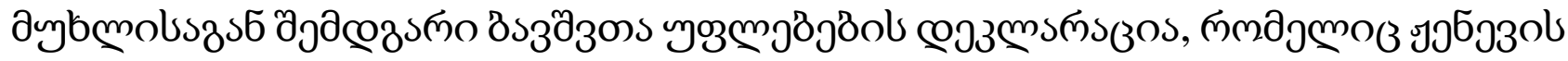

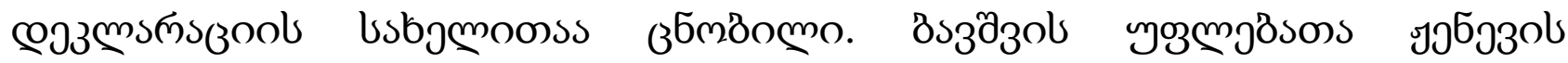

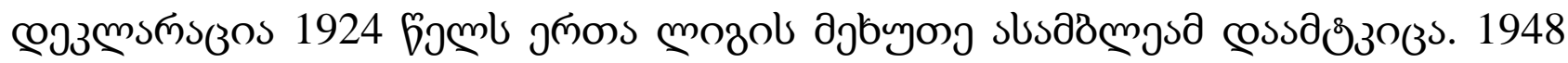

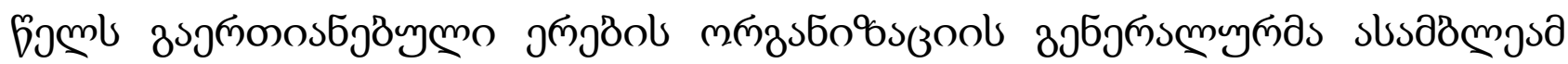

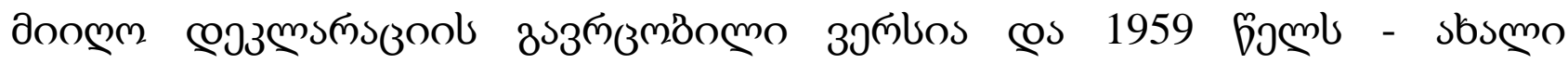

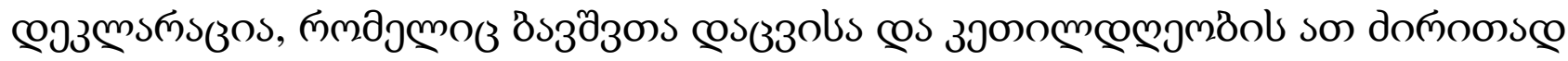

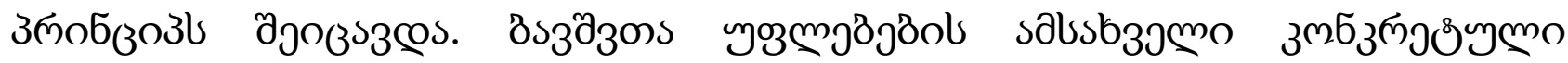

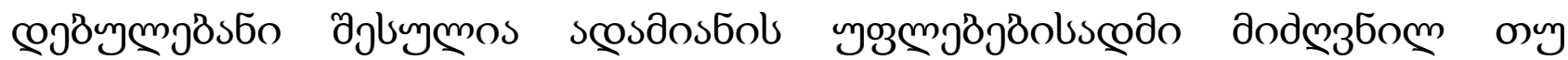

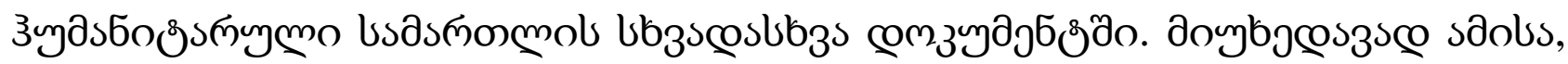

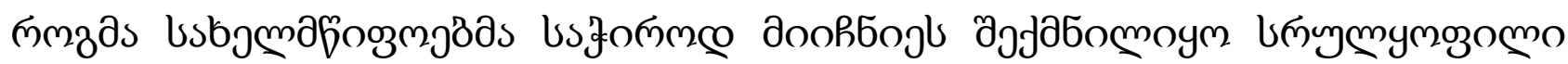

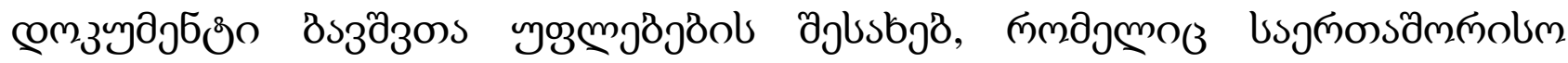

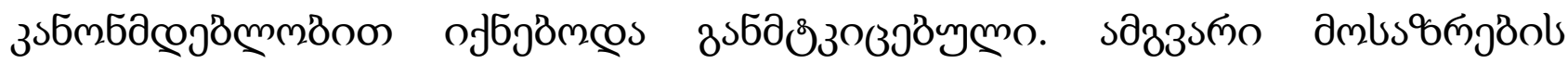

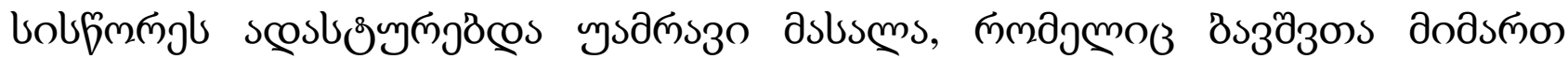

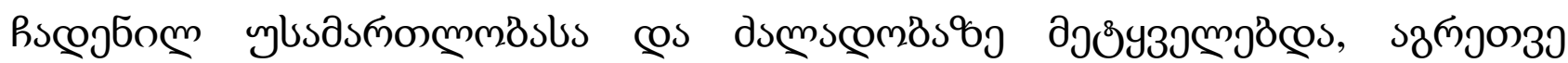

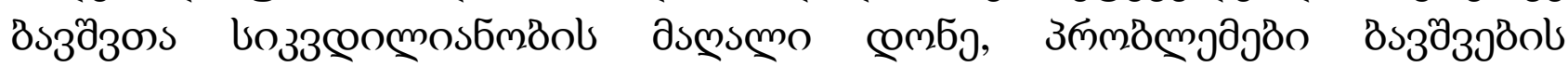

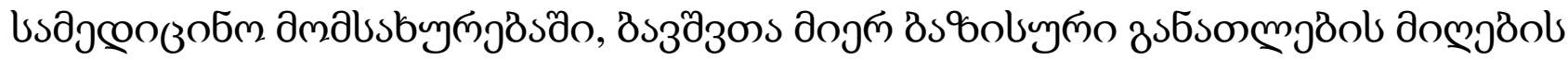

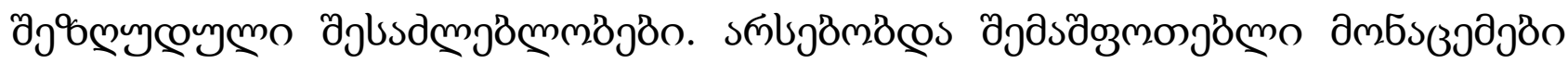

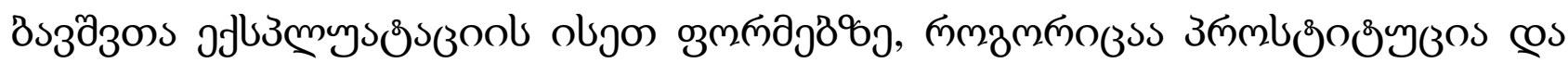

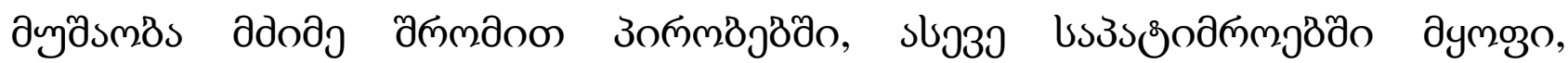

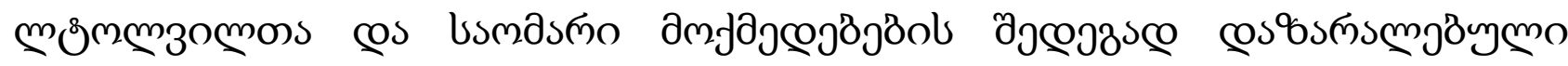
Bszä3jöol ajlusbjö.

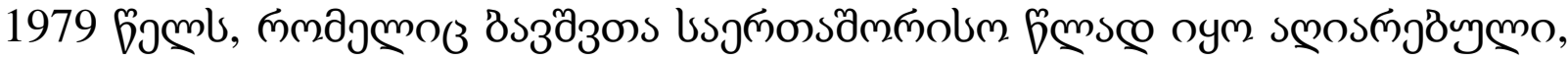

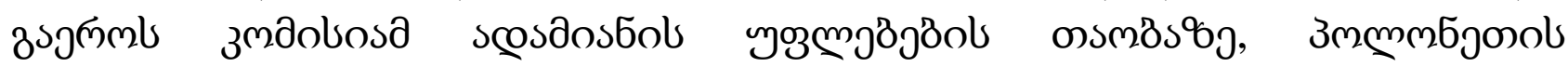

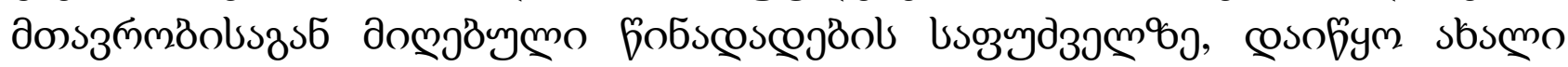

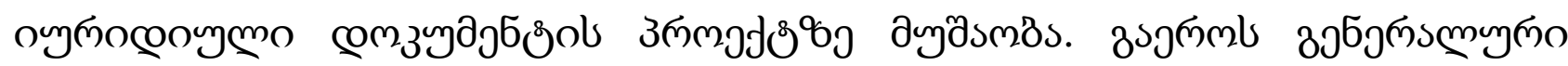

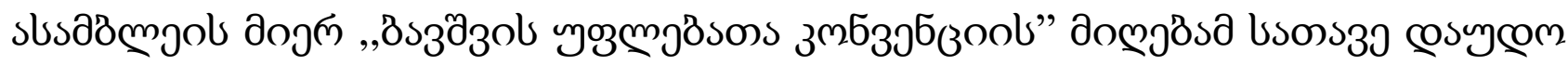

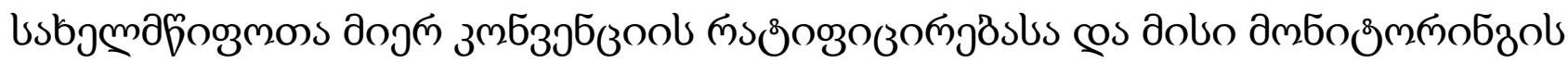

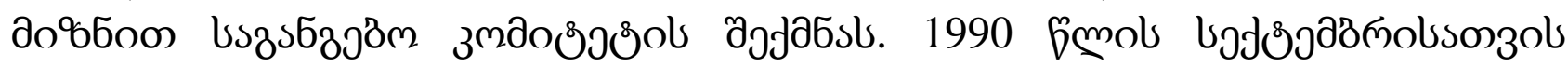

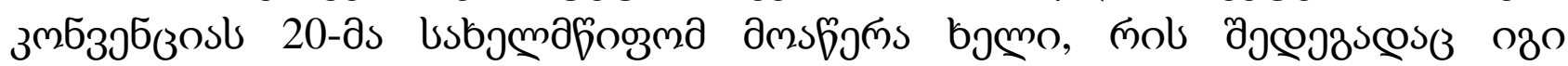

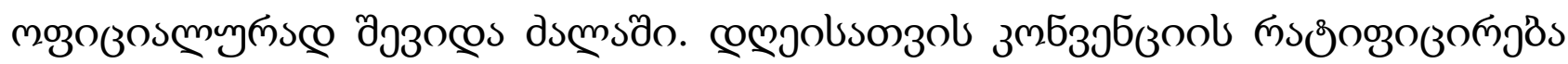

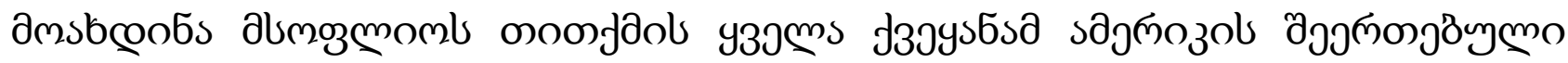

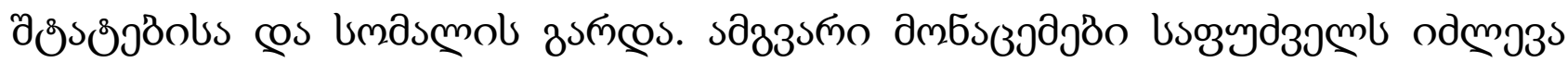

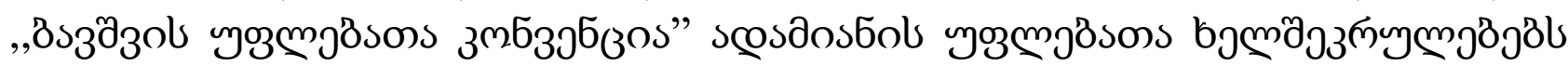

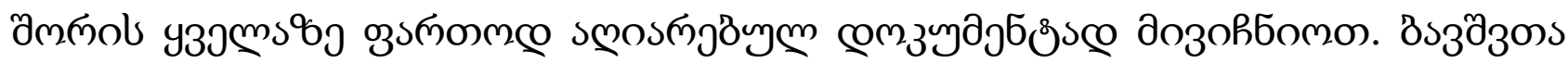

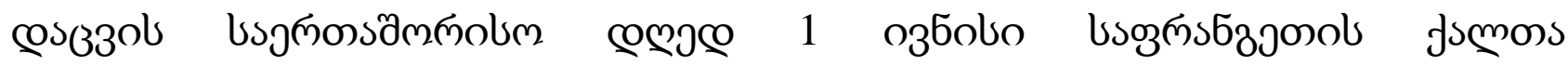

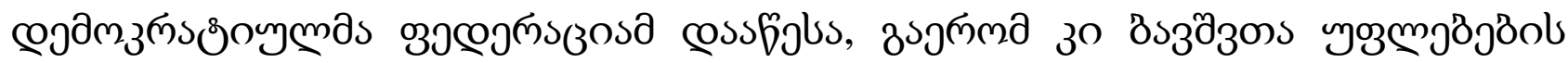

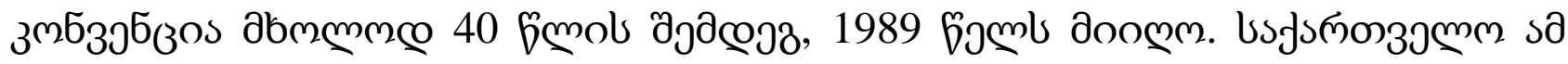

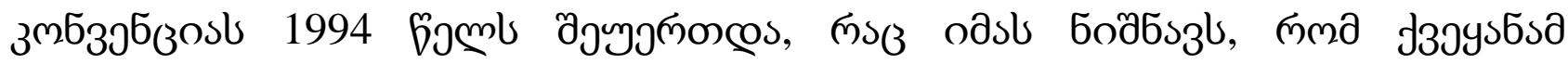

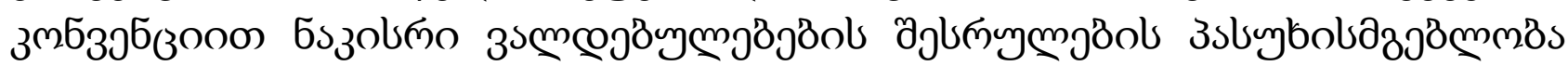




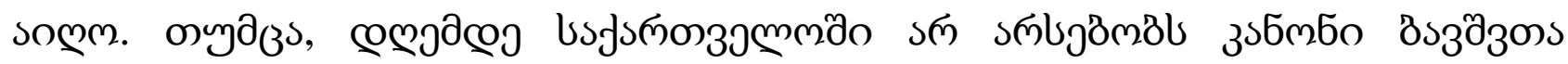

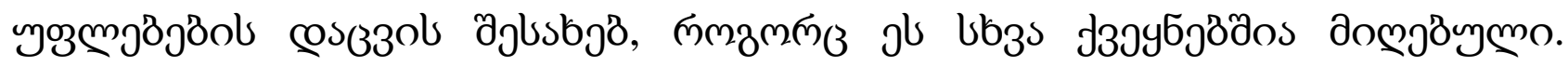

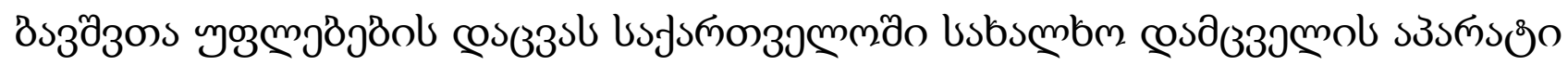

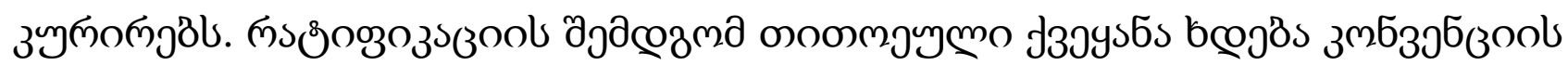

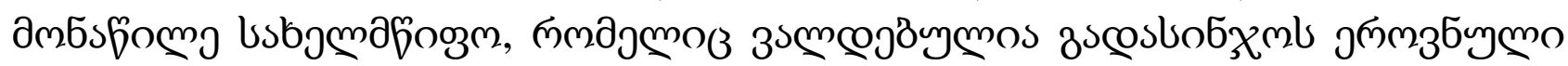

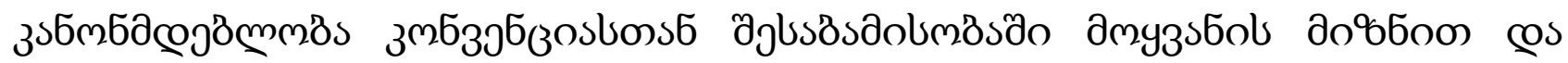

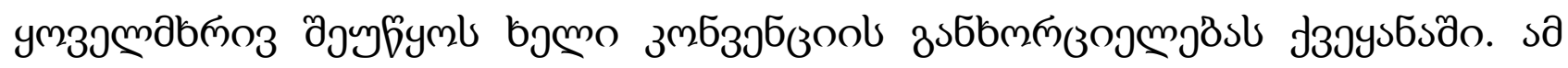

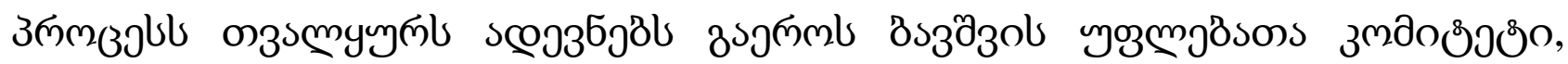

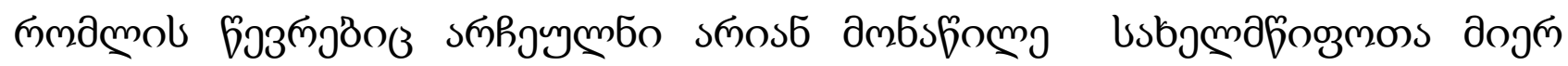

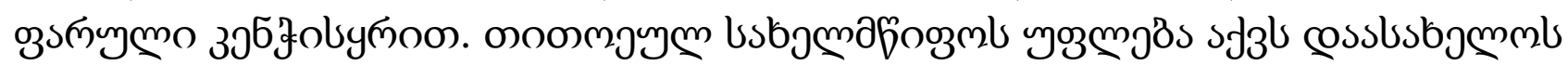

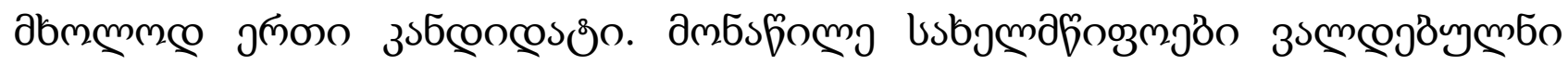

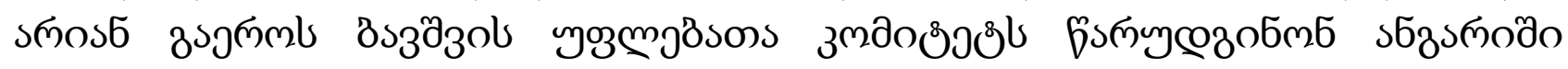

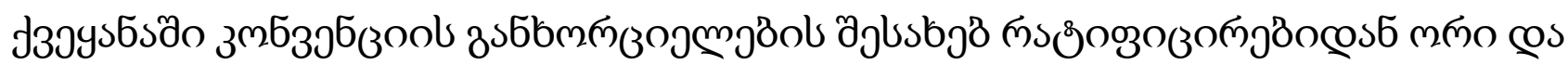

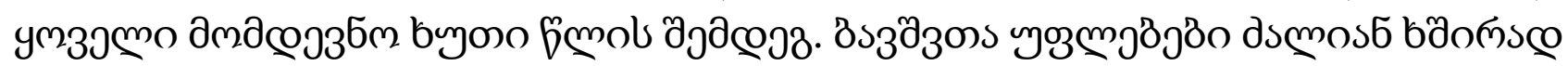

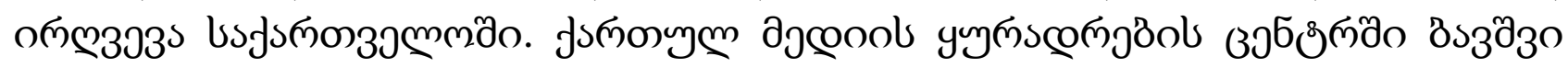

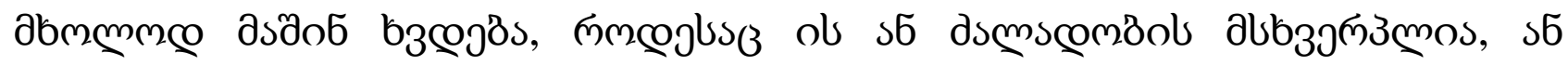

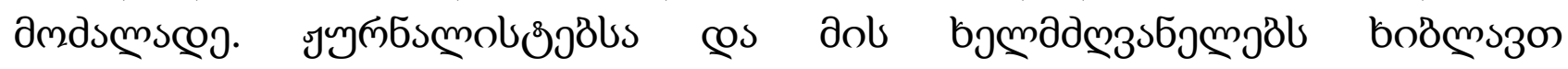

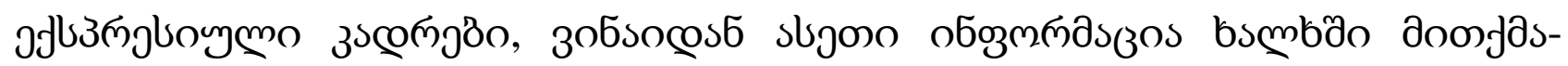

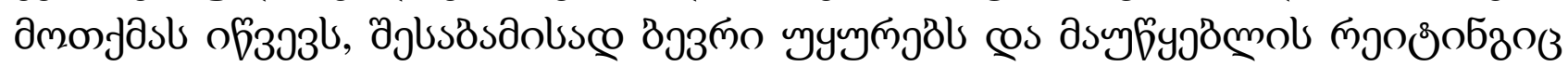

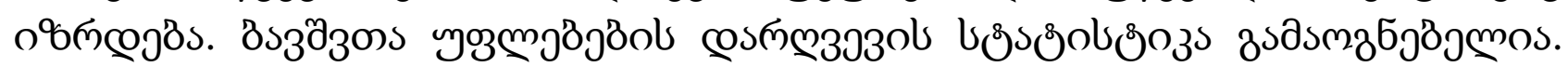

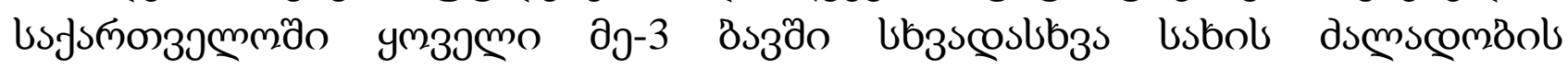

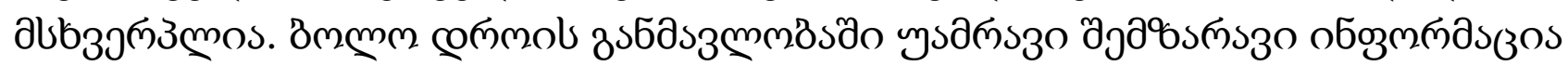

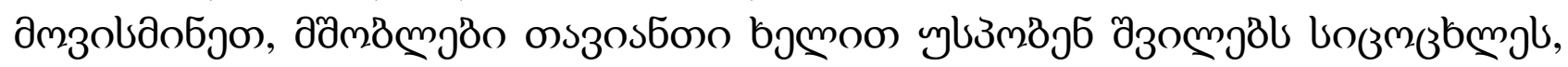

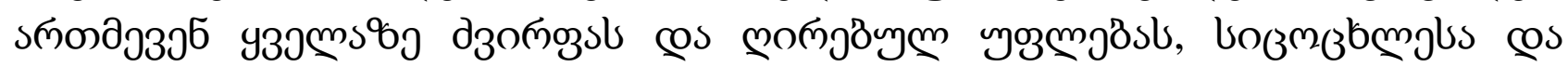

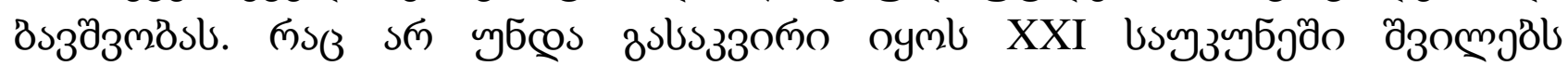

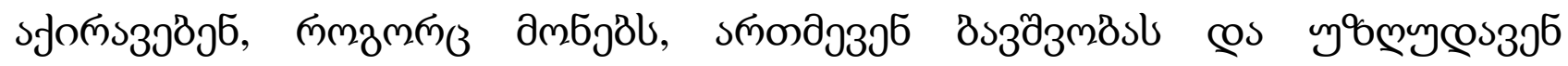

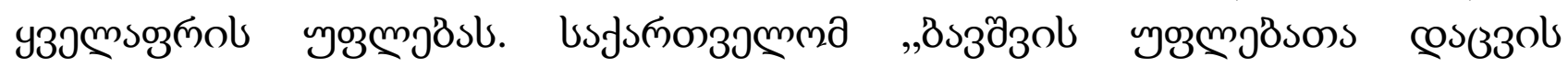

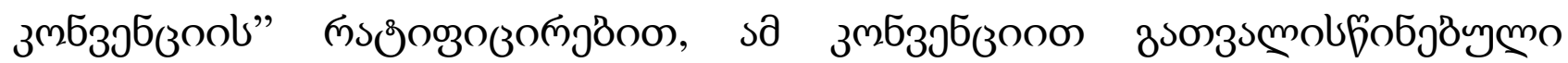

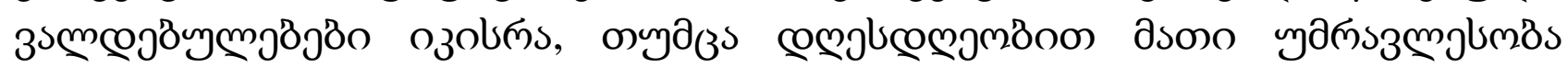

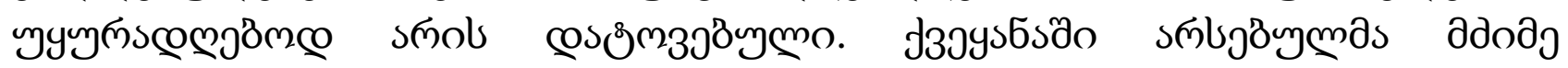

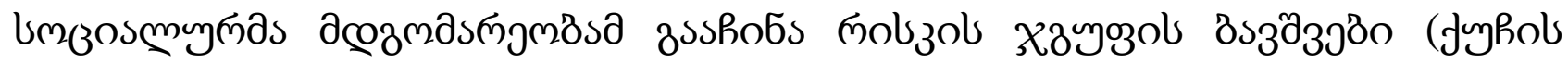

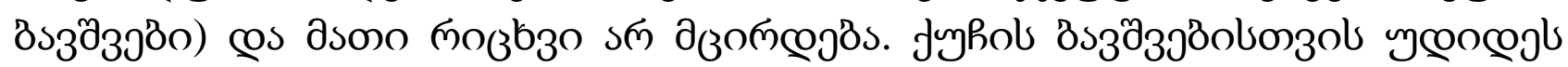

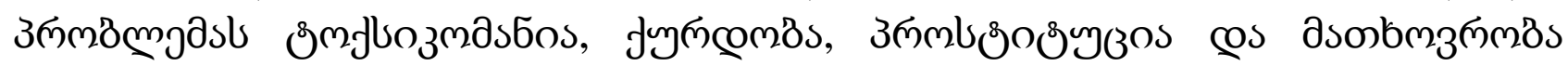

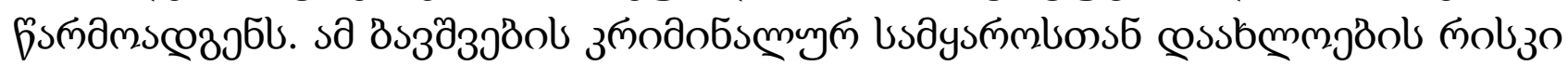

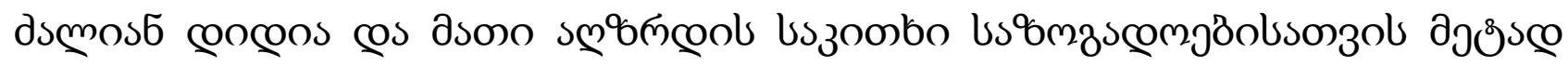

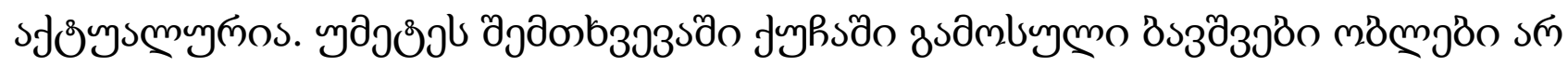

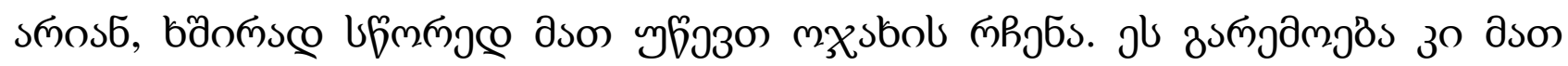

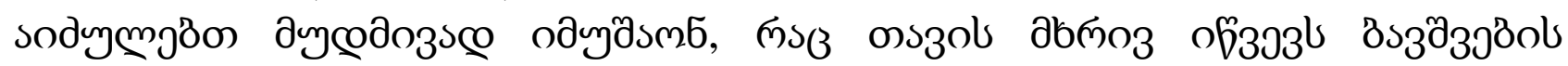




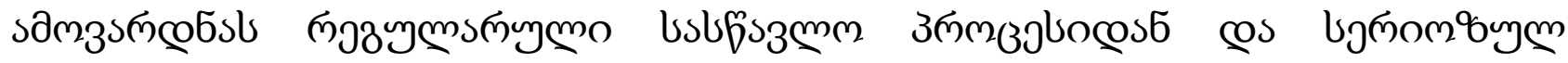

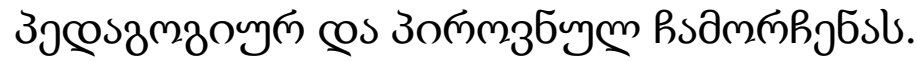

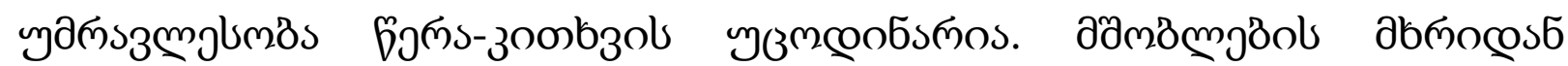

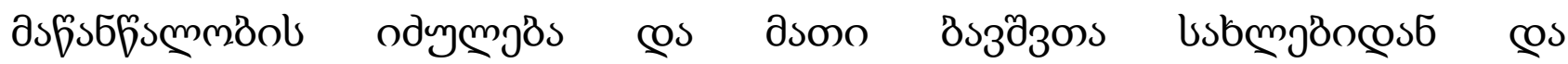

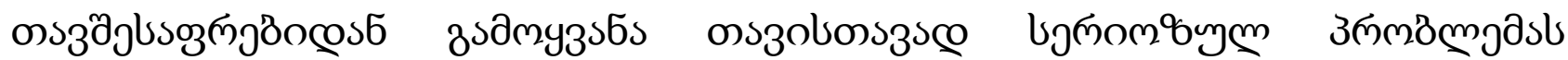

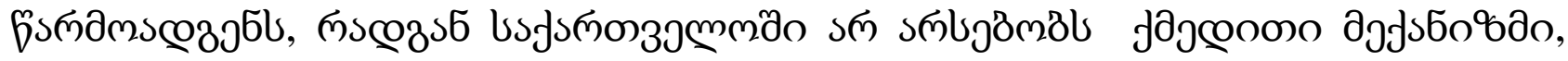

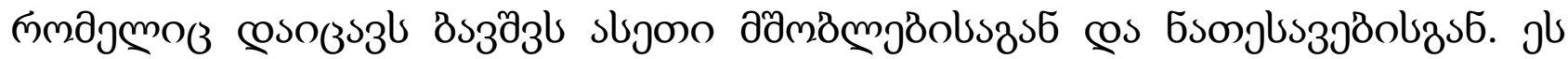

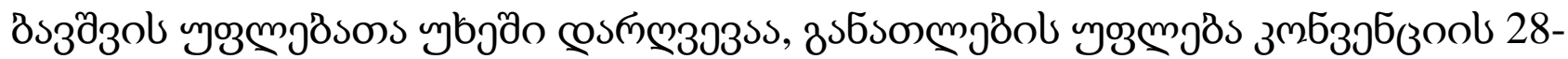

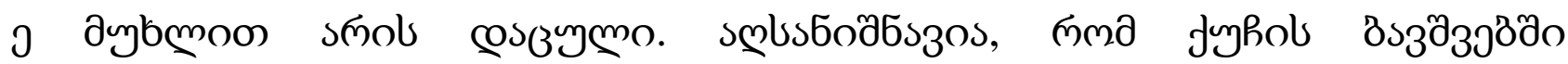

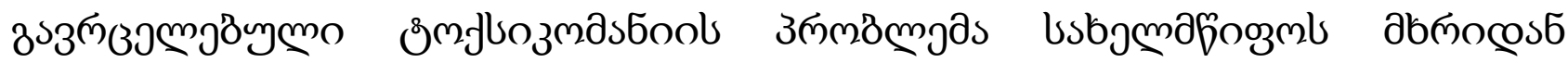

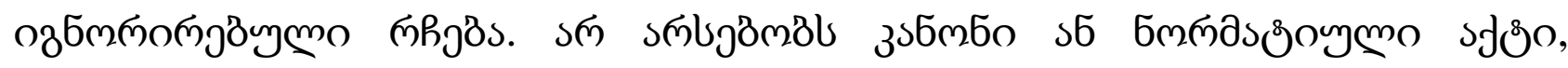

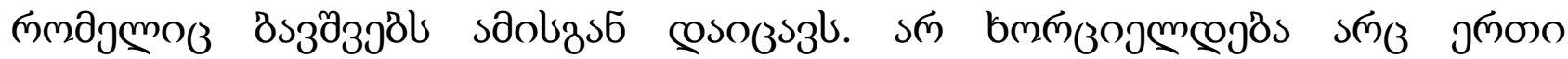

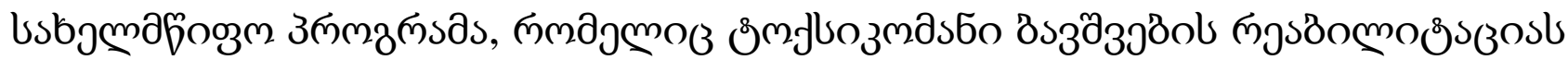

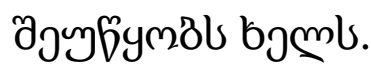

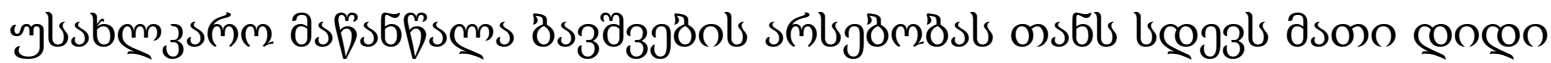

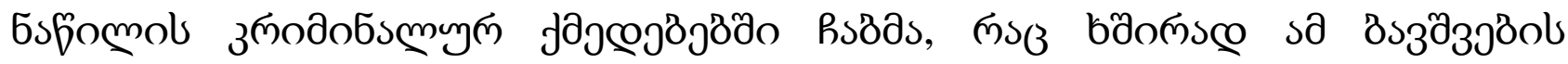

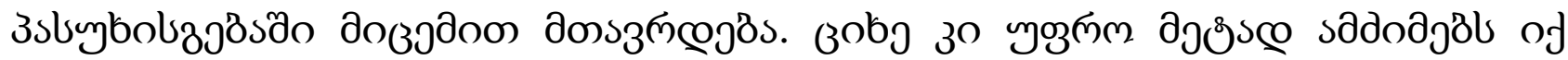

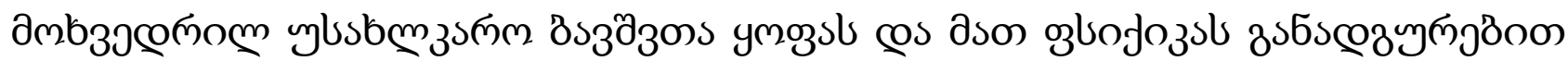

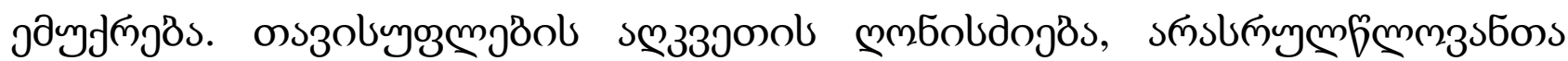

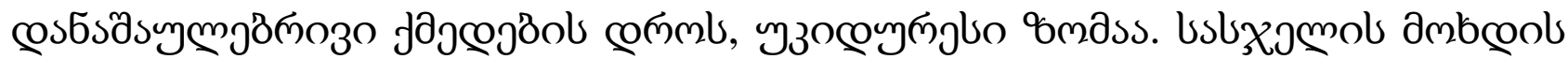

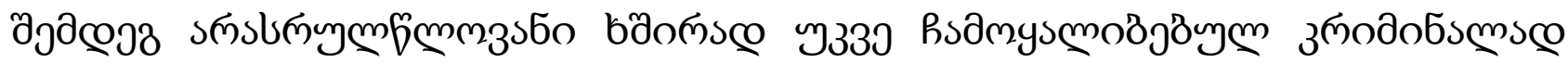

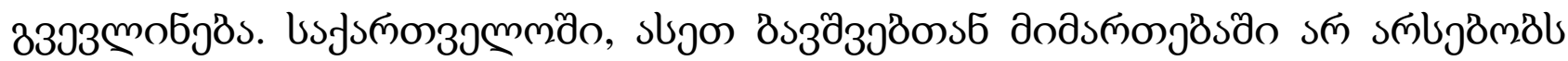

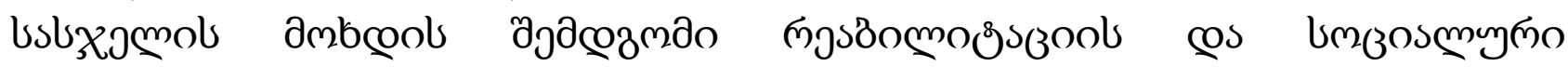

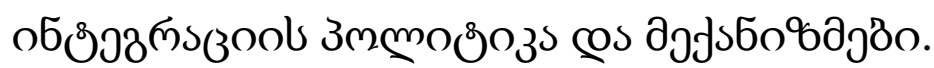

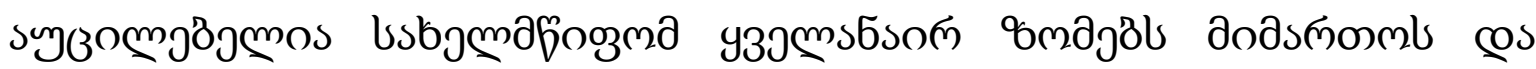

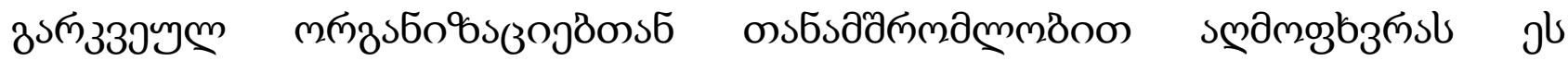

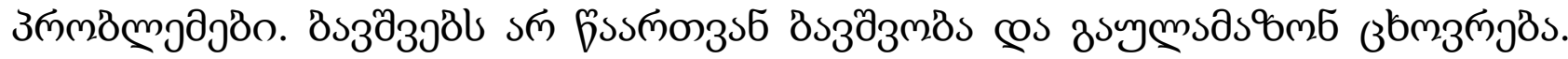

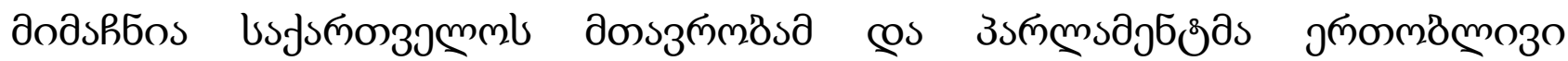

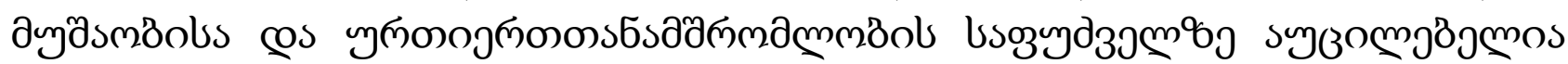

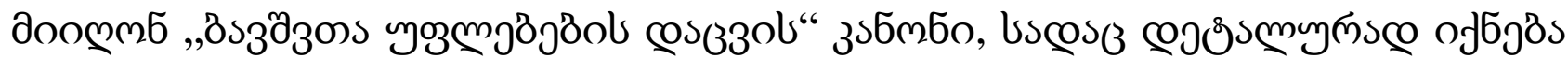

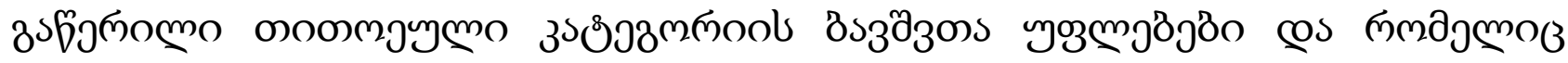

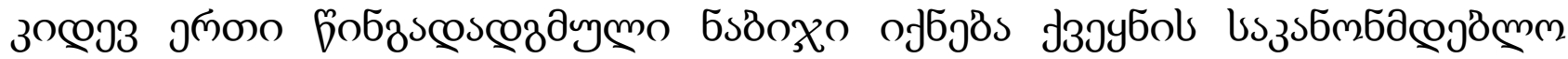

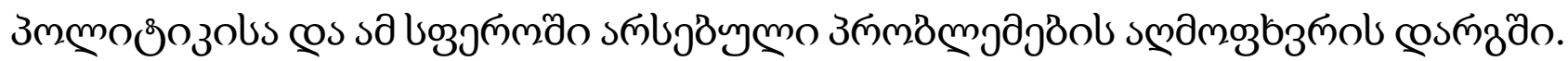

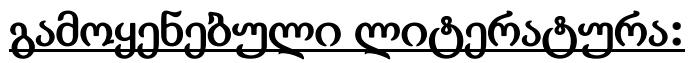

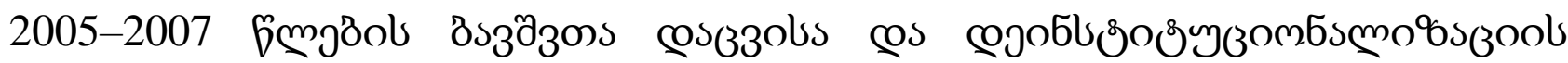

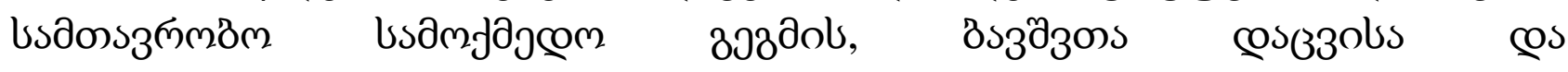

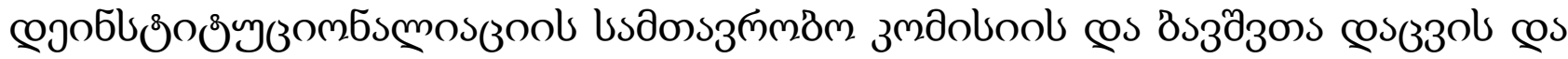

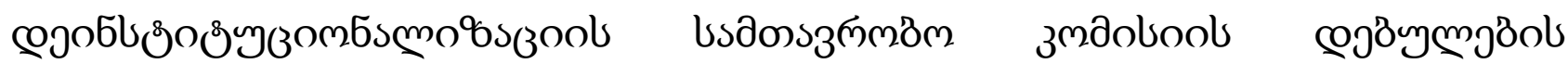

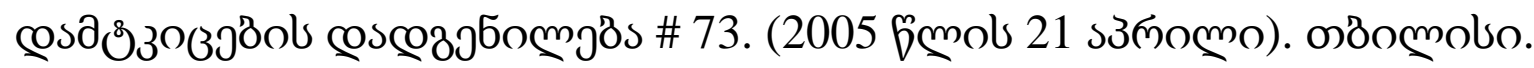




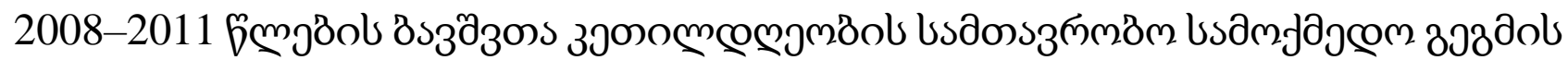

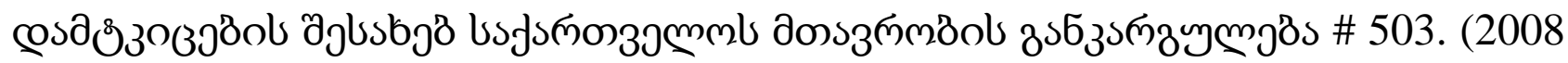
fenol 14 ozmolo). ob̉omolo.

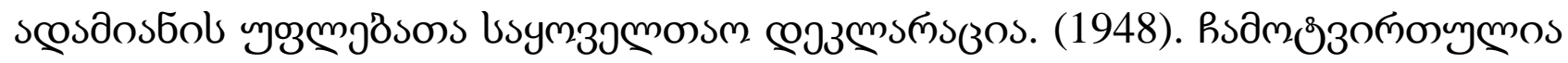
2015 fmol 7 бmgågnо

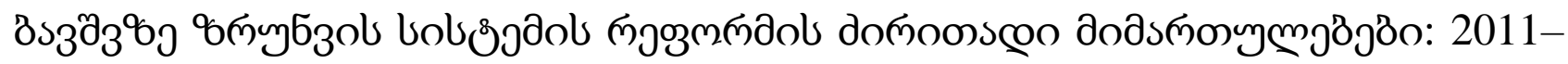

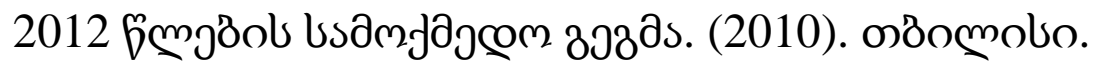

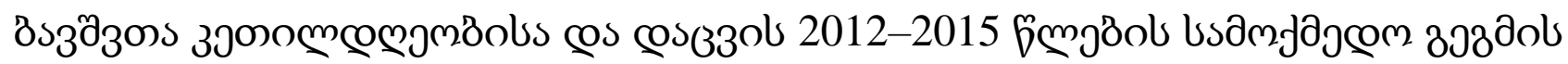

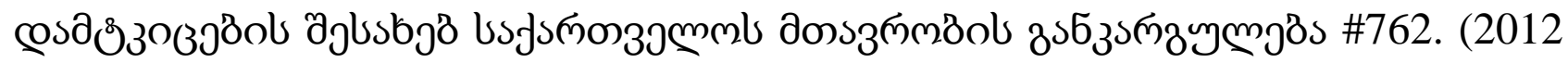

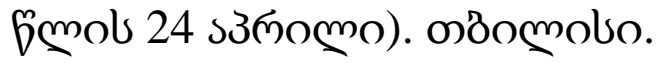

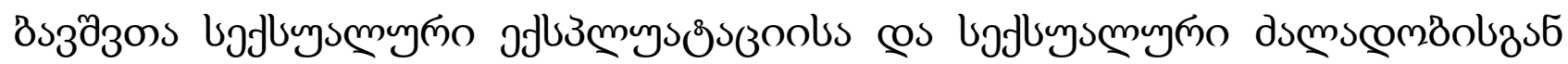

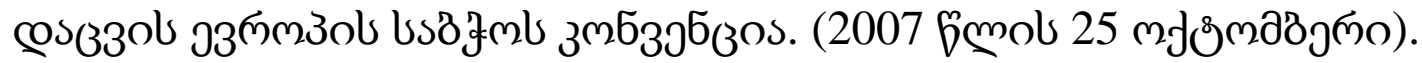




\title{
ПОГЛЯДИ ЩОДО БІОЛОГІЧНИХ ЧИННИКІВ ЗЛОЧИННОЇ ПОВЕДІНКИ
}

\author{
Федоров Олег, \\ graduate student \\ Yaroslav Mudryi National Law University
}

Відповідь на питання про причини злочинної поведінки має принципове значення задля визначення підстав кримінальної відповідальності як базової обставини у формуванні доктрини кримінального права. Відповідно до цього мають бути зорієнтовані і заходи запобігання кримінальних правопорушень.

Загальновідоме різномаїття поглядів за окресленою тематикою[1]. I окреме місце тут займають теорії біологічних (антропологічних) причин злочинів.

Ще у XIX сторіччі Чезаре Ломброзо у своїх працях стверджував про існування природжених злочинців. У своїй роботі «Новітні успіхи науки про злочинця» [2, с. 166-167] він описав характерні антропологічні риси злочинців. Для вбивць такими у роботі визначено кривизна голови, масивна нижня щелепа, волоси чорні та в'ються, коротка кисть руки. У злочинців проти тілесної недоторканості на його думку найбільш стабільна ознака - брахіцефалія, також довгі кісті рук та самі руки. Для насильників стверджується маленький зріст та відносно велика вага тіла, короткі руки та кісті, вузьке чоло та дуже маленьке передне напівколо голови; щодо розбійників курчаве волосся, рідкая борода; для шахраїв - масивна щелепа, велика вага тіла. Випадкові ж злочинці на думку дослідника проявляють властивості вроджених злочинців, аде у пом'якшеній формі. Аномалії (особливо черепу) зустрічаються більш рідко, але завжди щодо них можна знайти окреслені антропологічні властивості, притаманні намислим злодіям. До того ж серед них зустрічається більше рецидивістів. Також Чезаре Ломброзо стверджував про спадкованість антропологічних властивостей осіб, що вчиняють злочини[2, с. 104-114]. Показово і те, що у своїх роботах дослідник наводив велику кількість даних з результатів узагальнень й інших прибічників теорії вродженого злочинця: Марро, Тенчини, Лемуан, Гетцен та ін.

Окреслені теорії розроблялися відповідно до рівня наукових знать про людину на момент їх створення. У зв'язку ж з розвитком генетики наукові пошуки антропологічних причин злочинної поведінки отримали новий поштовх. Тезу про генетичну обумовленість злочинної поведінки на початку XX сторічча за допомогою методу близнюків перевіряв німецький психіатр Йохан Ланге. За його результатами у 77\% випадків у однояйцевих близнюків якщо злочини вчиняв один, то й інший був злочинцем[4, с. 124]. За результатами дослідження Ф. Штумпфіля з використанням аналогічної методики парне вчинення злочинів мало місце у $61 \%$ близнюків з однаковими генотипами, та лише у $36 \%$ близнюків зрізними природніми властивостями цього виду[4, с.125].

Пізніше Патрісія Джекобс здійснила дослідження хромосомної схильності людей до вчинення злочинів. За результатами вивчення засуджених осіб вона 
встановила, що серед злочинців осіб з хромосомним відхиленням типу «ХУУ» кратно більше, ніж серед законослухняних громадян[4, с.129].

У американській кримінології пошуки причин злочинів серед антропологічних властивостей людини тривають до останнього часу[]. Їх зміст узагальнила у своїй роботі[5] Шостко О.Ю.

Втім, згадані теорії антропологічної схильності до вчинення злочинів не знайшли свого підтвердження у грунтовних дослідженнях інших фахівців. Ми ж узагальнюючи наведені та інші матеріали щодо поясненні причин злочинної поведінки маємо заметувати так обставини.

По-перше, визнання антропологічних властивостей людини в якості першоджерела протиправних дій спричинить фундаментальні зміни у концепції кримінально-правового регулювання. Злочин зараз розуміється як усвідомлений вчинок правопорушника. Людина розуміє та керує своєю поведінкою, свідомо обираючи цінності та шляхи їх отримання. Саме такий усвідомлений вибір $\epsilon$ підставою для кримінальної відповідальності. Відповідно й засоби покарання спрямовуються на виправлення свідомості правопорушника, уникнення таким чином рецидиву злочинних дій і забезпечення превенції (загальної та спеціальної)[6].

Список літератури:

1. Оболенцев В. Ф. Нові кримінологічні теорії та перспективи розвитку кримінології в Україні. Проблеми законності. 2012. Вип. 120. С. 183-194. Режим доступу: http://nbuv.gov.ua/UJRN/Pz_2012_120_22.

2.Чезаре Беккариа. Новейшие успехи науки о преступнике. Преступный человек: зб. наук. праць. М.: Мидгард, 2005. 877 с. С. 166-167.

3.Чезаре Беккариа. Преступный человек. Преступный человек: зб. наук. праць. М.: Мидгард, 2005. 877 с. С. 104-114.

4.Иншаков С.М. Зарубежная криминология. М.: Инфра-М-Норма, 1997. 383 c. C. 124 .

5.Шостко О. Ю. Біологічні та психологічні теорії пояснення злочинної поведінки неповнолітніх у США. Теорія і практика правознавства. 2015. Вип. 1. Режим доступу: http://nbuv.gov.ua/UJRN/tipp_2015_1_26.

6.Оболенцев В.Ф. Системний аналіз та моделювання системи запобігання злочинності в Україні: монографія. Ха рків: Юрайт, 2021. 192 с. 


\title{
ЗАКОН ПРО КРИМІНАЛЬНУ ВІДПОВІДАЛЬНІСТЬ: КЛЮЧОВІ АСПЕКТИ
}

\author{
Шай Роман Ярославович \\ кандидат юридичних наук, доцент, \\ доцент кафедри кримінального права та процесу \\ НУ «Львівська політехніка»
}

Як нам відомо, будь-яка діяльність плідна та ефективна, коли вона здійснюється з повним розумінням справи.

Щодо закону про кримінальну відповідальність, то в найбільш широкому розумінні він розглядається як система національних законодавчих актів України та імплементованих у них положень міжнародних договорів, що містять норми кримінального права, а у вузькому розумінні - це законодавчий акт Верховної Ради України, який містить одну, кілька або систему взаємопов'язаних і взаємоузгоджених кримінально-правових норм.

Можемо виділити декілька аспектів, якими визначається значення закону про кримінальну відповідальність як системи законодавчих актів кримінальноправового характеру.

1. Закон про кримінальну відповідальність є одним із важливих засобів охорони життя, здоров'я, честі, гідності, недоторканності і безпеки людини як найвищої соціальної цінності, державного ладу України, іiї політичної та економічної систем, власності й усього правопорядку від злочинних посягань $і$ засобом боротьби з ними.

2.Лише закон про кримінальну відповідальність містить кримінально-правові норми, які визначають загальні положення кримінального права, злочинність та караність діянь, види цих діянь та покарань за їх вчинення, підстави, обсяг та межі кримінальної відповідальності, підстави звільнення від кримінальної відповідальності чи покарання.

3.Закон про кримінальну відповідальність $є$ певним засобом виховного та превентивного впливу на осіб, засуджених за вчинення злочину, а також на інших громадян.

Враховуючи зміст та обсяг правової регламентації і джерела походження кримінально-правової норми, у розумінні закону про кримінальну відповідальність можна виділити чотири аспекти.

По-перше, закон про кримінальну відповідальність - це Кримінальний кодекс - єдиний кодифікований законодавчий акт, який містить переважну більшість кримінально-правових норм. Кримінальний кодекс можна визначити як прийнятий, зазвичай, Верховною Радою України закон, який містить систему взаємопов'язаних і взаємозумовлених юридичних норм, що розкривають загальні поняття та принципи кримінального права України, умови й підстави притягнення до кримінальної відповідальності та звільнення від неї і визначають, які суспільно небезпечні діяння $€$ злочинами та які покарання потрібно застосовувати до осіб, які їх вчинили [1]. На сьогодні в нашій державі чинним $\epsilon$ 
Кримінальний кодекс України від 5 квітня 2001 р., який відтоді зазнав значних змін і доповнень.

По-друге, закон про кримінальну відповідальність - це і окрема стаття Кримінального кодексу або ії частина, що передбачає відповідальність за злочин певного виду [2]. Наприклад, ч. 2 ст. 185 КК передбачає відповідальність за крадіжку чужого майна, вчинену повторно або групою осіб за попередньою згодою, тощо.

По-трете, закон про кримінальну відповідальність - це окремий законодавчий акт, що містить лише одну правову норму, яка стосується загальних положень кримінального права або регулює відповідальність за злочин певного виду [3].

По-четверте, закон про кримінальну відповідальність - це і передбачені ст. 9 Конституції України відповідні положення міжнародних договорів, імплементовані у кримінальне законодавство України на загальногалузевому рівні Законом України "Про дію міжнародних договорів на території України" від 10 грудня 1991 р. Згідно із цим Законом укладені та належним чином ратифіковані Україною міжнародні договори становлять невід'ємну частину національного законодавства України i застосовуються у порядку, передбаченому для норм національного законодавства [4].

Викладені вище положення дозволяють зробити висновок про те, що проблематика кримінальної відповідальності та іï реалізація відносяться до найскладніших у теорії кримінального права України.

\section{Список літератури:}

1. Кримінальне право України : Загальна частина : підручник / Ю.В. Баулін, B.I. Борисов, В.І. Тютюгін та ін. ; за ред. В.I. Борисова, В.Я. Тація та В.I. Тютюгіна. 5-те вид., переробл. і допов. Х. : Право, 2015. 528 с.

2. Кузнецов В. Подвійні стандарти нового кримінального законодавства //Вісник прокуратури.2002.№6.c.32-34.

3. Фріс П.Л. Кримінальний закон. Лекція. Івано-Франківськ, Сімик. 2002. 35 c.

4. Лихова С. Конституція України та кримінальне законодавство України (окремі питання взаємодії). Вісник Конституційного Суду України. 2005. № 2. c. $95-100$. 


\title{
RESOURCE APPROACH TO EVALUATION OF ENTERPRISE MANAGEMENT EFFICIENCY
}

\author{
Voronina Alevtyna, \\ Ph.D., Associate Professor \\ Dniprovsk State Technical University \\ Kamianske, Ukraine \\ Pavlenko Vladyslava \\ Undergraduate \\ Dniprovsk State Technical University \\ Kamianske, Ukraine \\ Maliuk Yevhenii \\ Undergraduate \\ Dniprovsk State Technical University \\ Kamianske, Ukraine
}

Efficiency is one of the main characteristics of the effectiveness of enterprise management, which necessitates its detailed study. However, today the issues of its definition are debatable. Ensuring efficiency is directly related to its evaluation. Solving the issues of improving and maintaining the efficiency of enterprise management is impossible without a comprehensive assessment of its level. The results of such assessment allow to establish the scale and change of direction in the management of the enterprise, to predict their impact on key functional subsystems of the enterprise, to make appropriate management decisions to improve and maintain the efficiency of management, to choose methods, ways, tools to manage the enterprise.

The basis of socio-economic development of any enterprise is its resource potential, quantitative and qualitative characteristics of which reflect an orderly set of resources, including financial, production, labor and information resources. The natural result of using the resource potential of the enterprise is, first of all, the production of high quality products, which makes it possible to obtain high returns. The resource potential of the enterprise should be considered, on the one hand, as a specific economic category, which is a consequence of the interaction of all resources of the enterprise, not only available but also hidden, and on the other - as the economic basis of the enterprise. resources, but also their reserves, which can be used under certain conditions [1]. 
Assessment of resource management of the enterprise should be comprehensive; i.e. it can be obtained as a systematization of the results of comprehensive economic analysis. Such an assessment should contain generalized conclusions on the use of enterprise resources, based on the principle of systematicity. The evaluation process must also take place in a certain sequence and need a clear organization. That is, evaluation is the result of determining and analyzing the qualitative and quantitative characteristics of the enterprise. Therefore, such an assessment makes it possible to establish how the resource potential works, whether the goals are achieved, how changes and improvements in management affect the completeness of the use of enterprise resources and the effectiveness of its management.

Among the existing approaches to assessing the effectiveness of resource potential management, the most common is the method of diagnosing resource potential, which should be carried out in the form of a comprehensive, step-by-step and element-byelement study. Thus, in a comprehensive form of resource potential assessment, all the resources of the enterprise are integrated, which are integrated into a single indicator. The main methods of integrating indicators are expert and rating. Using step-by-step evaluation, attention is often focused on the main criteria that determine the ability of the enterprise to solve its main tasks. In this case, the problem comes down to detailing the main criteria that provide a comprehensive assessment.

The condition for the development of the resource potential of the enterprise is not only an absolute increase in its level, but also ensuring its effective use, taking into account the qualitative characteristics of the resource potential. Quantitative characteristics are designed to assess the volume and speed of reproduction of individual resources and resource potential in general, and qualitative characteristics, in turn, are the basis for determining the efficiency of resource use. The use of quantitative and qualitative characteristics of the resource potential of the enterprise allow: to analyze the initial level of development of resource potential; identify existing disparities between the resources of the enterprise; identify priority areas for resource development; to determine, based on the achieved level and directions of development of the enterprise, the allowable production, social and economic burdens.

A characteristic feature of effective management of resource potential is, first of all, the assessment of the efficiency of resources of the enterprise, where the useful result of the enterprise is compared with the cost of obtaining this useful result. A useful result is seen as an effect that can be economic, in the form of enterprise profits, and social, in the form of ensuring the formation of a better standard of living for man.

In addition, assessing the effectiveness of resource management is necessary to ensure a more complete and rational use of enterprise resources. It is important to describe not only the available but also the actual amount of resources used. Therefore, the system of indicators for assessing the management of resource potential should 
include indicators that characterize the availability, composition, state of resources and indicators of resource efficiency. When assessing the resource potential and efficiency of its use, it is necessary to clearly present the structure of the potential, the main characteristics of the constituent elements, their ratio and use in the production process. It is important to understand the place and role of material elements of resource potential, their connection with other components.

On the basis of the conducted analysis we have defined system of the basic indicators characterizing efficiency of management of resource potential of the enterprise and are reduced to the following (fig. 1):

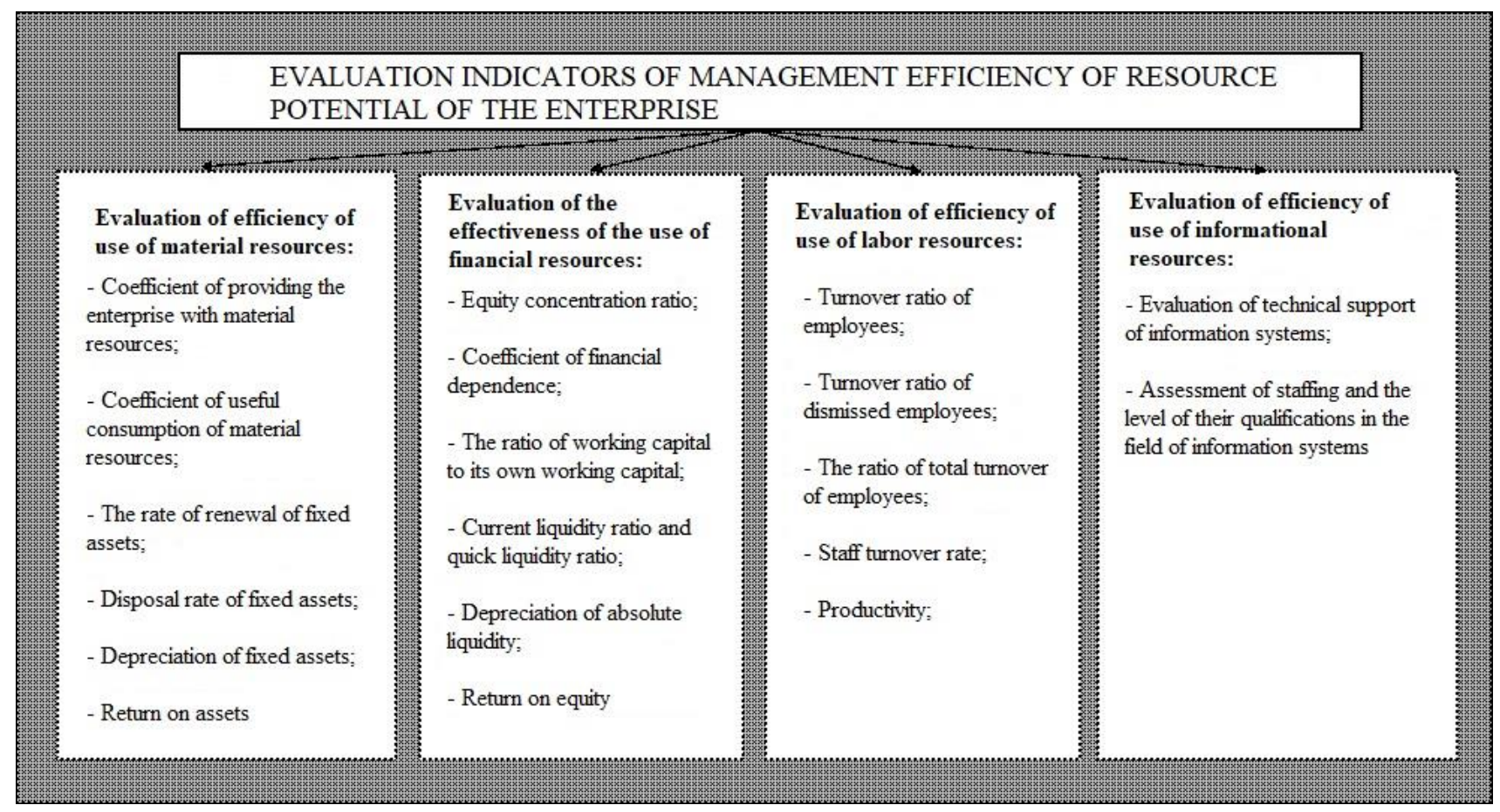

Fig. 1. The system of evaluating the effectiveness of resource management of the enterprise

- material resources, the assessment of which includes an analysis of the potential of objects and means of labor, technical and technological resources of the enterprise;

- financial resources, the evaluation of which consists in the analysis of financial indicators, indicators of profitability, liquidity and solvency;

- the level of labor productivity;

- provision of information systems and analysis of staffing and the level of their qualification in the field of information systems.

"Efficiency" is a complex, multifaceted, evaluative category, and, at the same time, a characteristic that reflects the course of the management process, determines the state of the object of management, its quantitative and qualitative characteristics [2]. Also, today there are radical changes in the restructuring, diversification of production of existing industrial enterprises and the formation of new business structures that operate 
on the basis of a market economy. In these processes, a huge role belongs to the human factor and the level of management development. Under such conditions, it is the presence of effective management that will create the conditions for the gradual development of these enterprises.

\section{References:}

1. Ravenko N. G. Organizational and technological principles of reforming the management systems of industrial enterprises. Monograph / N. G. Ravenko, A. S. Zenina-Bilichenko. - Dniprodzerzinsk: 2011. - 257 p.

2. Voronina A. V. Management: Tutorial / A. V. Voronina. - Kamyanske: DDTU, 2019. $-356 \mathrm{p}$. 


\section{МЕТОДЫ СТРАТЕГИЧЕСКОГО ПЛАНИРОВАНИЯ}

Бигельдинов Шалкар Калиевич, Докторант программы «Доктор делового администрирования (DBA) в здравоохранении» Казахского национального университета им. аль-Фараби, г.Алматы, Казахстан

"Сейчас планируют почти все. Планирование является самой основной из всех управленческих функций. Оно наводит мост между нашим нынешним положением и тем, которого мы хотим достичь» «Планирование - это система заранее принятых ремений». (Г.Куни и С.О. Доннел)

Стратегическое планирование некая система мероприятий, направленная на сбалансированное управление компанией. В условиях коронокризиса процесс стратегического планирования на наш взгляд будет действенным инструментом по эффективному реагированию на кризис глобальной пандемий. В свою очередь стратегическое планирование состоит из совокупности взаимосвязанных управленческих процессов, вытекающих один из другого, таких как определение миссии компании, формулирование целей и задач компании, оценку и анализ внутренней и внешней сред, определение стратегических возможностей компании, выбора стратегии и ее реализаций, оценку и контроль выполнения стратегии. Реализация данных процессов или стратегическое планирование базируется на результатах стратегического исследования, которое использует методы стратегического анализа и экспертного прогнозирования [1].

К методам стратегического планирования можно отнести приведенные на рис. 1 «Методы, используемые в стратегическом планировании».

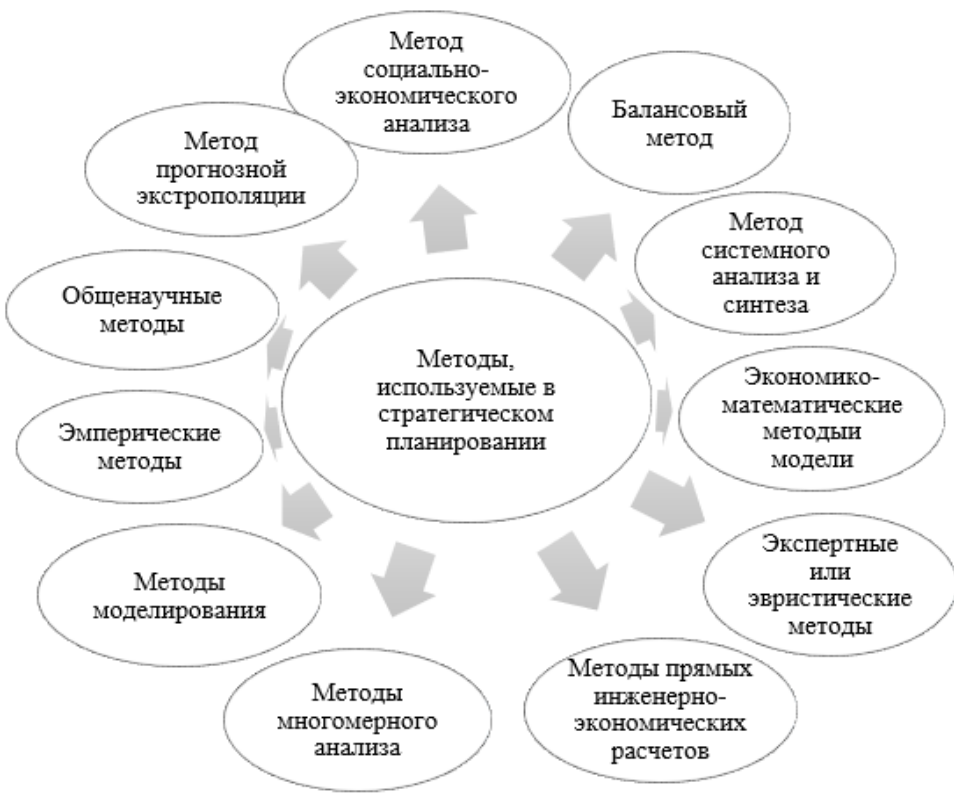

Рисунок 1. «Методы, используемые в стратегическом планировании». 
Экспертные (эвристические) методы или методы экспертных оценок - это комплекс логических и математических решений, применяемых для получения информации от респондентов для подготовки и выработки рациональных решений при планировании и прогнозировании. Данный метод подразделяют на индивидуальные и коллективные.

Под индивидуальным методом экспертной оценки подразумевается глубинное интервью и метод Дельфи, но при данном методе имеется субъективность в суждении(оценке). Ярким примером данной методики является анкетирование, т.е. сбор мнений в форме ответов на вопросы.

Под методом Дельфи предполагается интерактивная процедура анкетирования экспертов в несколько этапов с анализом результатов каждого этапа отдельно и используется для выявления закономерностей в ответах респондентов.

К коллективным методам стратегического планирования относятся такие методики как деловые игры, совещания, мозговые штурмы.

Метод деловой игры подразумевает моделирование достижения поставленных задач (целей) группой экспертов и определяет возможные сценарии развития ситуации. А вот метод мозгового штурма заключается в генерировании идеи коллективом для решения конкретной задачи или достижения определенной цели.

Совещательный метод, наиболее часто используемый, который предполагает проведения дискуссий для определения общего мнения и решения поставленных задач.

Методы социально-экономического анализа подразумевает всестороннее изучение как социальных, так и экономических связей компании, с целью определения новых возможностей и тенденции, произведение расчетов коэффициентов корреляции и регрессии, исчислении балансовых разниц.А вот метод прямых инженерно-экономических расчетов используются при проектировании роста производства, в т.ч. экономической эффективности производства, инвестиции, ресурсов и определении (построении) норм производства, например: основных производственных фондов, норм окупаемости и т.д. Под балансовыми методами понимаются методики используемые для обеспечения равновесия между показателями компании и построение систем балансов. Экономико-математические методы исследуют вопросы прогнозирования экономического роста, равновесия экономики. Методы моделирования являются важнейшими экономики- математическими моделями, примерами которых являются система национальных счетов, межотраслевые балансы, сетевые модели, бизнес-планы и т.д. Метод синтеза предполагает изучение объекта стратегического планирования целостно и неотделим от системного анализа. Эвристические методы основываются на интуиции экспертов, к ним так же можно отнести метод Дельфи, также методы комиссий, матричные методы. Общенаучные методы - используются в теоретических, а также в эмпирических исследованиях, всесторонние изучение вопроса. 
К методам стратегического планирования предъявляются следующие принципы $\neg$ это конкретность в задачах стратегического планирования, моделирование деятельности компании, непротиворечивость (логичные), устойчивость (независимость от ситуационных изменений), низкая затратность, полноценность (метод должен достигаться без введения дополнительных алгоритмов), доступность и простота в применении, применимость, системность.

Методы стратегического анализа используются как средства преобразования базы данных, полученных в результате анализа среды, в стратегический план компании [1]. Разработку и реализацию стратегического плана можно разбить на следующие этапы и стадии указанные в таб. 1. «Методы, используемые при стратегическом планировании».:

Таблица 1 «Методы, используемые при стратегическом планировании».

\begin{tabular}{|c|c|}
\hline $\begin{array}{l}\text { Стадии формирования } \\
\text { стратегии }\end{array}$ & $\begin{array}{l}\text { Возможные методы, используемые в } \\
\text { планировании }\end{array}$ \\
\hline \multirow[t]{3}{*}{$\begin{array}{c}\text { Подготовительный этап } \\
\text { (предварительный } \\
\text { стратегический анализ) }\end{array}$} & $\begin{array}{l}\text { Исследование рынка, определения } \\
\text { позиции: } \\
\text { Балансовый метод } \\
\text { Метод сценариев } \\
\text { Матрица МсKinsey } \\
\text { Матрица БКГ }\end{array}$ \\
\hline & $\begin{array}{l}\text { Моделирование стратегического } \\
\text { планирования : } \\
\text { Дерево-решений } \\
\text { Подход Байеса } \\
\text { Матрица А.Д. Литлла (ADL) } \\
\text { ТОП- анализ }\end{array}$ \\
\hline & $\begin{array}{l}\text { Сбор и обработка } \\
\text { инфеобходимых } \\
\text { стратегического } \\
\text { Социологические опросы } \\
\text { Экспертный метод } \\
\text { Системный анализ } \\
\text { Анализ динамики издержек и кривая } \\
\text { опыта }\end{array}$ \\
\hline \multirow[t]{2}{*}{$\begin{array}{l}\text { Этап планирования } \\
\text { (выбора) }\end{array}$} & $\begin{array}{l}\text { Определение миссии и цели } \\
\text { организации: } \\
\text { Метод Дельфи } \\
\text { Экспертная оценка } \\
\text { Метод сценариев } \\
\text { Мозговой штурм } \\
\text { Дерево целей } \\
\text { Анализ временных рядов }\end{array}$ \\
\hline & $\begin{array}{l}\text { Анализ внешней и внутренней среды: } \\
\text { SWOT - анализа } \\
\text { Анализ по Ансоффу «поля силы» }\end{array}$ \\
\hline
\end{tabular}




\begin{tabular}{|c|c|}
\hline & $\begin{array}{c}\text { РЕST анализ } \\
\text { Анализ ключевых факторов успеха }\end{array}$ \\
\cline { 2 - 3 } & Анализ выбора стратегий и/или выборе \\
уровней стратегии (корпоративная, деловая, \\
функцинальная) : Матрица Ансоффа \\
Анализ жизненого цикла организации \\
Модель ADLILC, анализ динамики рынка \\
Анализ рынка (модель Хофер и Шендел) \\
Стержневые компетенции компании
\end{tabular}

Первая стадия - подготовительный (организационный), включающий в себя возможные методы ресурсного анализа организации, в т.ч. готовности руководства компанией к организационным, структурным изменениям.

Следующая стадия - непосредственно само стратегическое планирование, т.е. определение миссии и целей компании, анализ внутренней и внешней среды компании, выбор стратегии, анализ альтернативных стратегии.

Третья стадия выделяем «стадия реализации принятого решения», который характеризует методы реализации, оценки и контроля выполнения стратегии предприятия. Для трансформации данных этапов в стратегию организации используется различные методы стратегического планирования, но при этом сам процесс стратегического планирования сводятся к интуиционому и теоретическому анализу ее позиций. Тем самым стратегия организации не может быть абсолютно точной и детально просчитанной, в связи с чем возникает необходимость в беспрерывном процессе анализа деятельности, вектора развития, целей и задач стратегии компании с использованием методов стратегического планирования для своевременной корректировки.

Для систематизации множества методов стратегического планирования считаем необходимым структурировать их стадиям формирования стратегии компании согласно представленной выше таблице1 «Методы, используемые при стратегическом планировании», где на подготовительном этапе планирования определяется заинтересованность сторон в необходимости стратегическом планировании [2], так же проводиться исследование рынка для определения конкурентов и своей позиции на рынке, проводиться моделирование стратегического планирования, например создается дерево решений. При этом для исследования рынка возможно использование следующих методов 
стратегического планирования таких как: балансовый метод, который используется для разработки сбалансированных между собой разделов общего плана или отдельных видов ресурсов (матричный подход) [3], метод сценариев (так же можно отнести к косвенным методам) - используется для определения вероятности возможного хода развития социально-экономических событий по отношению к планированию стратегии компании, матрица McKinsey или как еe еще называют матрица роста доли рынка - это метод портфельного анализа продукта компании (ассортимент) для определения ниши на рынке и при необходимости корректировки ассортимента продукта компании, матрица БКГ - также инструмент (метод) портфельного стратегического анализа, характеризующий анализ самой компании, подразделений или же товара компании через определение доли на рынке и его темпов рыночного роста. Данный метод стратегического анализа весьма популярный и запоминающийся, т.к. он визуально представляет диаграмму, разделенную на четыре сектора со звучными названиями, такие как: «звезды - высоко инвестируемый продукт, подразделение или компания с высокими тепами рыночного роста, при замедлении темпов роста переходят в нишу дойные коровы», «дойные коровы - большая доля рынка характеризованная низким темпом роста и с умеренным инвестированием», «трудные дети (темные лошадки - доля на рынке не большая при относительно высоких уровнях продаж и при необходимых корректировках возможен переход к заездам» и «дохлые собаки - рентабельность на низком уровне или же определяет только самоокупаемостью, рекомендуется перепрофилировать, продать/ свернуть компанию, подразделение или продукт». Использование матрицы БКГ и других методик портфельного анализа дают возможность в определении видов стратегии компании, например удержания позиции или роста доли на рынке.

А вот при моделировании стратегического планирования можно использовать метод «дерево решений» - математическая модель определения вероятностей исхода принятых решений, влияющих на исход событий. Данная модель применима при условиях неопределенности и высокого риска. Следующая модель стратегического планирования возможно применить при моделировании стратегии это так называемый подход Байеса, т.е. основанная теорема теории вероятностей, которая позволяет более точно пересчитать вероятность, взяв в расчет как ранее известную информацию, так и данные новых наблюдений. Минусом данного метода в требовании большого количества расчетов и вычислений. Байесовская вероятность имеет следующее выражение [4]:

$P\left(\frac{A}{B}\right)=\frac{P\left(\frac{B}{A}\right) P(A)}{P(B)}$, где

$\mathrm{P}(\mathrm{A})$ - вероятность гипотезы А;

$\mathrm{P}(\mathrm{A} / \mathrm{B})$ - вероятность гипотезы А при наступлении события B;

$\mathrm{P}(\mathrm{B} / \mathrm{A})$ - вероятность наступления события И при истинности гипотезы $\mathrm{A}$;

$\mathrm{P}(\mathrm{B})$ - полная вероятность события В.

Следующим интересным методом стратегического анализа отмечаем матрицу А.Д.Литлла (ADL), ее структуру отражает четыре стадий жизненного 
цикла компании (рождение, рост, зрелость и спад) и пяти конкурентных позиций, таких как ведущая, сильная, заметная, прочая и слабая позиция компании. Использование данного метода в стратегическом планировании повышает оперативное планирование и соответственно является тщательно выверенным набором стратегических решений. Данная матрица имеет следующий вид (рис.2):

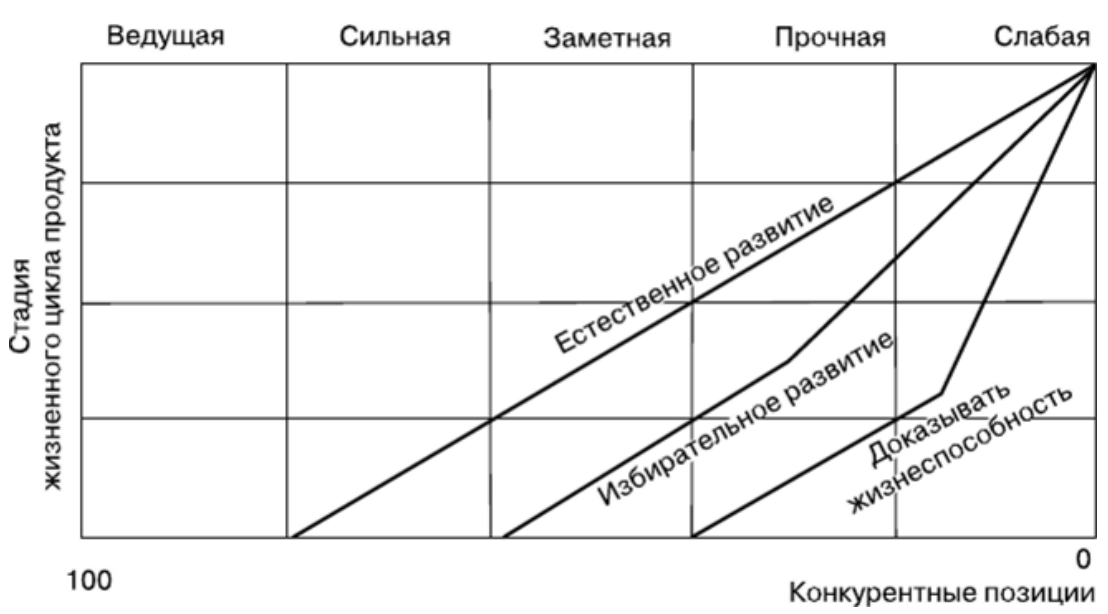

Рисунок 2. Матрица А.Д.Литлла (ADL) [5].

Как видно из рисунка матрица А.Д.Литтла учитывает взаимовлияние конкурентных позиции компании (продукта) на рынке и жизненного цикла компании. Изучив данный метод, мы пришли к выводу, что матрица ADL применима для высокотехнологических компании с коротким жизненным циклом продукции и соответственно организации необходима своевременная корректировка стратегии и дифференциация выпускаемой продукции, что актуализирует использование данного метода в стратегическом планировании.

Особенность метода стратегического планирования «ТОП - анализ» является его ориентация на 3 ключевых процесса компании: первое - тестирование управленческих процессов, второе - оценка качества управленческих процессов, третье - проектирование управленческих процессов, которые можно применять на основе программных продуктов.

Для сбора информации для стратегического планирования возможно применение методов социологического опроса (опрос респондентов), экспертного метода (интервьюирование), системного анализа и использование кривой опыта. Данные методы используются как для внешнего, так и для внутреннего анализа среды организации.

Следующим блоком этапов стратегического планирования считаем определение миссии, цели компании и выбора стратегии компании. При этом используется различное множество методов, рассмотрим некоторые из них: экспертная оценка, метод сценариев, мозговой штурм, дерево целей, GAP анализ.

Методы экспертных оценок используются в основном при сборе первичной информации (данных) опыта экспертов в заданном диапазоне необходимых данных с последующей возможностью количественного анализа данных. Мозговой штурм представляет собой метод получения определенного количества идей от экспертного круга лиц. GAP - анализ - это анализ, 
направленный на определение уровня отставания в достижение стратегических целей. Также есть методики по определению влияния стратегии на прибыльность, например метод PIMS, который основывается на использовании эмпирической модели, которая характеризует возможность организации генерировать доход через стратегические и ситуационные переменные. Данные методы используют человеческий ресурс, соответственно во избежание некорректностей (достоверности) в полученной информации необходимо анализировать максимально конкретную задачу с большим количеством респондентов.

А вот уже при выборе стратегии компании возможно провести анализ по следующим методам: матрица Ансоффа - уникальный метод дифференцированного роста продукции компании на конкурентном рынке, характерна для определения позиции и проникновения на новые конкурентные рынки в условиях неопределенности перспектив продаж продукта. Использование данного вида анализа весьма удобно при выборе маркетинговых стратегии компании. Анализ жизненного цикла организации исследуется для определения изменений в деятельности организации. Модель жизненного циклов является одним из инструментов менеджмента и подразделяется на 5 стадий деятельности компании:1) рождение (выход на рынок), 2) детство / юность - обуславливается выходом захватом рынка , присущ довольно жестким стиль управления, 3)зрелость - акценты расставляются на приобретение своего имени (имиджа), управление сводиться на возможность делегирования части полномочий. 4) старение - стремление к удержанию имеющихся позиции на рынке, 5) возрождение/ исчезновение - возможно при омоложении ресурсных баз компании и внедрении инновационных для организации механизмов как управления, так и производства.

Такие методы как PEST анализ, анализ по Ансоффу «поля силы», анализ ключевых факторов успеха используются в основном для определения внутренней и внешней среды компании. Также для анализа внутренней и внешней среды популярным или традиционным методом при разработке стратегии считается Гарвардская школа бизнеса, которая на сегодняшний день является азбучной истиной для управленцев и раскрывает подходы к формированию стратегии следующих авторов и их утверждений: К. Эндрюс, М. Портер, К. Прахалад и Г. Хэмел.

К. Эндрюс предложил, так называемую «экономическую стратегию», основанную на анализе знаний о внутренней и внешней средах компании, также разграничил понятия стратегий корпоративного и бизнес-планирования, а основным его вкладом в развитие стратегического менеджмента является разработка SWOT - анализа. Название которого является аббревиатурой следующих английских слов: Strengths - силы, Weaknesses- слабости, Opportunities - благоприятные возможности и Threats - угрозы. SWOT - анализа предполагает выявлением внутренних сильных и слабых сторон организации и определяет внешние возможности и угрозы, в т.ч. установлений связей между ними. При проведении анализа необходимо руководствоваться следующими правилами для его более точного результата: 1) необходимо максимально 
конкретизировать объект анализа; 2) для внутреннего анализа рассматривают силы и слабости (SW), а для внешнего анализа - возможности и угрозы (OT); 3 ) использовать разносторонние и объективные источники информации; А вот в модели пяти сил конкуренции М. Портера, как всем нам известно, дается определения сильных и слабых сторон организации на конкурентном рынке, которые имеют возможное влияние на развитие бизнеса через своевременное корректирование стратегических направлений в маркетинговых стратегиях компании. Данный метод в разработке и планировании стратегии компании носит названия «Стратегия бизнеса». Следующих ставший уже традиционным видом разработки и планировании стратегии является «Стратегия лидерства» по Г. Хэмел и К. Прахалад, которая раскрывает стержневые компетенции организации, влияющие на ее лидерские позиции среди конкурентов и стремящихся к уникальности как минимум продукта или же самой организации.

Вышеизложенная традиционная школа формирования стратегии организации является ни чем иным как выверенной системой методов по формированию прогнозных, стратегических программ для принятия управленческих решений, которая формирует методологию стратегического планирования в организации.

Выводом исследования послужило следующее утверждение, что методология стратегического планирования - это есть модель стратегии компании, которая включает в себя весь набор инструментария, применяемого при стратегическом планировании, и является выверенной совокупностью методов, принципов и правил принятия управленческих решений для достижения целей субъекта рынка в долгосрочном периоде времени для перспектив развития.

\section{Список литературы}

1. Сироткин С.А., Кельчевская Н.Р. С 40 Стратегическое планирование: учебник / С.А. Сироткин, Н.Р. Кельчевская. Екатеринбург: УрФУ, 2011. 298с.

2. Васецкий А.А., Козырев А.А., Тарасов Н.А., Яновский В.В. Основы менеджмента: учебное пособие по направлению "Менеджмент" / СевероЗападная академия государственной службы. Санкт-Петербург, 2011.275 с.

3. Владимирова, Л.П. Прогнозирование и планирование в условиях рынка: учебное пособие / Л.П. Владимирова. - 4 изд., перераб. и доп. - М.: Издательсско-торговая корпорация «Дашков и К», 2005.- 400с.

4. Judgment under Uncertainty: Heuristics and Biases / Daniel Kahneman, et al. 21st. - Cambridge University Press, 2005. - 555 p. - ISBN 978-0-521-28414-1.

5. Ефремов В. С. Стратегия бизнеса. Концепции и методы планирования : учеб, пособие. М. : Финнресс, 1998. 


\title{
ПОТРЕБИТЕЛЬСКОЕ ПОВЕДЕНИЕ: ПОНЯТИЕ И ЕГО СУЩНОСТЬ
}

\author{
Фазылзянова Ильзида Ильдаровна \\ Специалист Департамента территориального \\ и стратегического развития
}

\begin{abstract}
Аннотация: Экономический рывок во всех сферах заставляет рынок экономики развиваться сверх молниеносно, а также обращать внимание производителей товаров и услуг на построение особой методологии взаимоотношений между «потребителем» и «продавцом». В подавляющем большинстве компаний основную роль играют потребители рынка, а также факторы, влияющее на их поведение. Таким образом, в статье мы детально разберем, что такое потребительское поведение, всевозможные его трактовки, а также узнаем, различные подходы к определению данного термина.

Ключевые слова: маркетинг, потребительское поведение, экономический рынок, ценности потребителей, мотивационный тип.

Впервые «потребитель» как объект исследования стал применяться еще в фундаментальном труде основоположником экономической теории как науки А. Смитом. Согласно его исследованию «экономический человек» - это субъект, который тянется к личному и общественному благу. Также исследователь определяет его как автономный индивид, которым движет два мотива собственный интерес и склонность к обмену. Также А. Смит выделял некоторые свойства такого человека: во-первых, он склоне обменивать одну вещь на другую, и во-вторых, такому человеку присущ свой собственный интерес, т.е. такое качество, как стремление улучшить свое положение. [1, 225 с.]

Более полное картину, что из себя представляет «экономический человек» были даны Д. Рикардо и другими маржиналистами, которые акцентировали свое внимание именно на причины того или иного экономического действия человека. Впервые при объяснить термин «потребитель» были учтены и психологические особенности человека. Представители данного течения основной акцент сделали именно на отношения человека и товара в процессе потребления. Этим самым маржиналисты одними из первых описывали и объясняли поведения потребителя и его выбора, а также особое внимание уделяли мотивам поведения, связываемыми ими с максимизацией полезности.

Переходя непосредственно к теме исследования нам для начала необходимо понять, что такое «потребительское поведение», так как данное понятие достаточно многогранное и дать однозначное определение такого сложного термина невозможно. Для этого нам нужно обратиться к экспертам из разных областей, ведь их видение с профессиональной точки зрения даст уже полное представление «потребительского поведения» с разных его аспектов.

На сегодняшний день «Потребительское поведение» междисциплинарным объектом изучения, который охватывает не только экономические, но и маркетинговые, социологические психологические знания.
\end{abstract}


П. Миниарда, Дж. Энджела, и Р. Блэкуэлла (известные исследователи в сфере маркетинга) трактуют поведение потребителей как сочетание определённых действий, которые совершаются людьми при приобретении, потреблении, а также при освобождении товаров и услуг.

Определение, данное американскими исследователями, включает в себя несколько этапов, а именно: приобретение, под которым понимается действия потребителя, ведущие к приобретению того или иного товара, потребление - то есть в каких случаях потребители используют приобретенные товары и освобождение, означающее деятельность потребителей при избавлении от товаров и их упаковки. [2, с.35]

Если рассматривать труды Ф. Котлера, то он «поведение потребителей» описывал как «процесс выбора, приобретения, использования и ликвидации товаров, услуг, идей или впечатлений отдельными покупателями, группами и организациями для удовлетворения своих нужд и желаний». [3, с.181]

Под «потребительским поведением» Алешина Ирина Викторовна понимает деятельность, которая состоит из: приобретения, использования и избавления от продуктов, услуг, а также включает в себя решения потребителя, как что-то предшествующие этой деятельности, так и следующие за ней. Российский ученый под «процессом решения» закладывает следующий смысл: поиск потребителем товаров и услуг. Следовательно, согласно ее теории, основной и содержательной частью consumer behavior выступает этап принятия решения о покупке товара и аспекты, влияющие на этот процесс. Также она приводит следующую последовательность этапов принятия такого решения: осознание проблемы (потребности), поиск информации, выбор с оценкой альтернатив, выбор источника приобретения и само приобретение, пользование приобретения и оценка этого пользования. [4, с.49]

Если рассматривать с точки зрения социологии, то в данной науке преобладает следующее определение «потребительского поведения» - это поток взаимосвязанных социальных активно и социально пассивных актов, осуществляемые человеком, которые включают в себя осознаваемые им общественные интересы и потребности, поиск информации, оценку альтернатив и непосредственно покупку. [5, с.105]

Все вышеперечисленные определения можно отнести к «классическому подходу», где главным объектом является сама потребность человека, тогда как существует и «неклассический» подход, где преобладающим составляющим является сам потребитель.

Современные исследователи Ш. Шварц и В. Билски выдвинули, в свою очередь, объяснение мотивационных типов личности и ценностей покупателя. Представленные ниже ценности выполняются вне зависимости от ситуации, а также контролируют выбор и оценку человека, его поведением.

Стоит отметить, что названные типы человеческих потребностей в той или иной степени удовлетворяются через реализацию нескольких мотивационных типов личности, которые, в свою очередь, формируются на основе определенных личностных ценностях потребителя. 
Ш. Шварцу и В. Билски подчеркнули следующие мотивационные типы личности: [6, с.98] стимулирование - (ценности: разнообразие в жизни, захватывающая жизнь, смелость); гедонизм (ценности: комфорт, игра, наслаждение); власть - (ценности: авторитет, общественный статус, влияние, подавление, материальные средства); конформизм - (ценности: умиротворение, спокойствие, выдержка, самоконтроль); благосклонность (ценности: польза, толерантность, поддержка, надежность, искренность, верность); достижение (ценности: профессиональные навыки, призвание, самообразование, личностные способности, результат, развитие, образованность); традиция - (ценности: для уважение, духовность, признание норм, скромность.

Таким образом, на сегодняшний день существует достаточное количество определений «потребительского поведения», ни одно из которых не будет являться априори истинной. Будучи столь многогранным понятием, широко использующийся практически во всех сферах нашей деятельности, данный термин включает в себя не только экономический, но и психологический, социологический аспекты, поэтому и трактовать его одним единым определением не считается верным.

\section{Список литературы:}

1. Смит А. Исследование о природе и причинах богатства народов. - М.: Ось89, 1997. -255 c.

2. Р. Блэкуэлл, П. Миниард, Дж. Энджел: «Поведение потребителей». 10 изд. Москва. 2007, 35 с.

3. Котлер, Ф., Келлер, К. Л. (2014). Маркетинг менеджмент. 14-е изд. СанктПетербург, $181 \mathrm{c.}$

4. И.В. Алёшина: «Поведение потребителей». Москва. 2006, 49 с.

5. Ромашкова Е. М. «Поведение потребителей на рынке услуг: социологический, анализ»: Автореф. канд. диссертации. Москва, 2003. с. 105

6. Шварц, В. Билски: «Мотивационные типы и ценности». 1987, с. 98 


\title{
МАРТЕХ ЯК ІНСТРУМЕНТ МАРКЕТИНГОВОЇ ДІЯЛЬНОСТІ КОМПАНІЙ НА ГЛОБАЛЬНОМУ РИНКУ ПОСЛУГ
}

\author{
Циганкова Тетяна Михайлівна \\ д.е.н., професор, завідувач кафедри міжнародної торгівлі і маркетингу, \\ КНЕУ ім. В. Гетьмана
}

\section{Трейтяк Мирослава Вячеславівна} аспірант, кафедра міжнародної торгівлі і маркетингу,

КНЕУ ім. В. Гетьмана

Сучасні тенденції цифровізації (“діджиталізації”) економічної сфери у світі, які $є$ наслідками четвертої промислової революції формують нові економічні ринки та запити споживачів, що в свою чергу підштовхують постачальників шукати більш ефективні шляхи завоювання таких ринків.

Поняття, яке поєднує в собі маркетинг, технології та управління (у першу чергу, даними), а саме мартех, останнім часом отримало неабиякий розвиток. Основними завданнями мартеху $є$ автоматизація маркетингової діяльності, а також удосконалення роботи 3 даними, які можуть допомогти в підвищення ефективності реалізації маркетингової стратегії та бізнес діяльності компанії.

Мартех $є$ тільки складовою частиною загального поняття маркетингових технологій. За критеріями типізації, їх можна віднести до інноваційних (за новизною) та цифрових (за ступенем діджиталізації) маркетингових технологій. $[8$, c. 10$]$

Цифрові маркетингові технології часто потребують інвестицій значних розмірів. За даними звіту Martech: 2020 and Beyond, стореного компаніями BDO, WARC, та Університетом Брістоля в 2020 році, загальні витрати на цифрові технології у світі в 2020 році склали близько 121,5 мільярдів доларів США. У той самий час, середній відсоток маркетингового бюджету компаній у Великобританії та Північній Америці, що витрачається на мартех у 2019 році складав 22-30\%. [10]

У компаніях сектору послуг мартех $\epsilon$ особливо актуальним, адже глибоко інтегрується практично на всіх етапах надання продукту (послуги), починаючи від пошуку інформації про базову потребу споживачем до стадії після безпосереднього споживання послуги. Зі зростанням компанії зростає і кількість процесів в її діяльності. Коли ж мова йде про міжнародні та глобальний ринки, постачання послуг та процеси в діяльності компанії ускладнюються ще більше.

Враховуючи складність та вартість, мартех найчастіше використовується компаніями, які ведуть активну міжнародну діяльність та постачають послуги на глобальному ринку. Глобальні послуги - це економічна діяльність, що здійснюється однією стороною та направлена на зміну стану людини, товару або об'єкта власності для задоволення потреби іншої сторони в усіх, або в переважній 
більшості країн світу. Цікаво, що мартех може бути як інструментом глобальної маркетингової діяльності сервісної компанії, так і самою глобальною послугою, яка надається продуктовими технологічними компаніями на міжнародних ринках.

Цифрові маркетингові технології в компаніях глобального рівня застосовуються як інструмент маркетингової діяльності з різних причин. До таких причин можливо віднести наступні:

- стандартизація процесу надання послуги (це особливо актуально в сфері business-to-business, коли корпоративні клієнти прагнуть отримувати послуги однакової якості та за однаковим сценарієм в усіх власних представництвах світу);

- спрощення (у тому числі, автоматизація) процесу надання послуги шляхом перенесення її в онлайн канал за умови можливості та доречності (привабливість онлайн постачання постійно зростає, та має беззаперечні переваги - зручність, легкість пошуку, ширший вибір, потенціал отримання кращої ціни, 24/7);

- бажання адаптації до локального ринку зі збереженням впізнаваності бренду шляхом імплементації інноваційних рішень (наприклад, створення інноваційних локацій (beauty-labs, розважальні центри, та ін.), які поєднують в собі інноваційні технології - штучний інтелект (AI), віртуальна реальність (VR), штучна реальність (AR), технології самообслуговування (SST) та ін.);

- оптимізація управління маркетинговою стратегією на глобальному та локальних рівнях (включаючи, планування, імплементацію, визначення основних показників успішності виконання та реалізації проектів та кампаній (як наприклад ROI, ROMI, показник кількості залучених та утриманих клієнтів, формування та рівень лояльності споживачів і т.п.)). [9]

Середовище застосування MarTech на сьогодні включає шість сфер, а саме: реклама та просування, контент та досвід споживачів, соціальні мережі та взаємовідносини, комерція та продажі, дані та управління (табл. 1).

Таблиця 1.

Сфери застосування мартех в 2020 році

\begin{tabular}{|l|l|l|}
\hline № & Сфера & Підвиди \\
\hline 1 & $\begin{array}{l}\text { Реклама та } \\
\text { просування }\end{array}$ & $\begin{array}{l}\text { Друк, РR, відео реклама, пошукова реклама та реклама в } \\
\text { соціальних мережах, нативна та контентна реклама, мобільний } \\
\text { маркетинг, медійна та програмна реклама }\end{array}$ \\
\hline 2 & $\begin{array}{l}\text { Контент та } \\
\text { досвід } \\
\text { споживачів }\end{array}$ & $\begin{array}{l}\text { Iнтерактивний контент, відео маркетинг, контентний маркетинг } \\
\text { в мобільних застосунках, етаil маркетинг, пошукова } \\
\text { оптимізація (SEO), управління цифровими активами (DAM), }\end{array}$ \\
\hline
\end{tabular}




\begin{tabular}{|c|c|c|}
\hline & & $\begin{array}{l}\text { управління інформацією про продукт (РIM) та управління } \\
\text { маркетинговими ресурсами (МRM), оптимізація, персоналізація } \\
\text { та тестування, створення та управління веб-досвідом, } \\
\text { автоматизація маркетингу та кампанії, управління потенційними } \\
\text { споживачами (leads) }\end{array}$ \\
\hline 3 & $\begin{array}{l}\text { Соціальні } \\
\text { мережі }\end{array}$ & $\begin{array}{l}\text { Впливовці (інфлуенсери), спільноти та огляди, маркетинг в } \\
\text { соціальних мережах та моніторинг, адвокаційний маркетинг, } \\
\text { лояльність та рекомендації, розмовний маркетинг та чати (у } \\
\text { тому числі, чат-боти), досвід споживача, service \& success } \\
\text { маркетинг, маркетинг ключових клієнтів (ABM), управління } \\
\text { взаємовідносинами з клієнтами (CRM), аналітика та управління } \\
\text { дзвінками, події, зустрічі та вебінари }\end{array}$ \\
\hline 4 & $\begin{array}{l}\text { Комерція та } \\
\text { продажі }\end{array}$ & $\begin{array}{l}\text { Роздрібна торгівля, безконтактний маркетинг та інтернет речей, } \\
\text { афілійований маркетинг та управління, канали, партнерський та } \\
\text { локальний маркетинг, маркетинг в електронній комерції, } \\
\text { автоматизація продажів, активація, інтелект, платформи та } \\
\text { кошики електронної комерції }\end{array}$ \\
\hline 5 & Дані & $\begin{array}{l}\text { Панелі моніторингу та візуалізації даних, мобільна та веб- } \\
\text { аналітика, маркетингова аналітика, ефективність, атрибуція, } \\
\text { аудиторія / маркетингові дані та покращення даних, бізнес, } \\
\text { клієнтська розвідка та наука про дані, платформа клієнтських } \\
\text { даних (CDP), платформа управління даними (DMP), уряд, } \\
\text { комплаєнс, приватність, IPass, хмарні технологї̈ / інтеграція } \\
\text { даних, роботизована автоматизація процесів (RPA), управління } \\
\text { тегами }\end{array}$ \\
\hline 6 & Управління & $\begin{array}{l}\text { Аналіз постачальників, гнучке управління, управління } \\
\text { колабораціями, управління талантами, управління продуктом, } \\
\text { бюджетування та фінанси, управління проектами та робочими } \\
\text { процесами }\end{array}$ \\
\hline
\end{tabular}

Джерело: розроблено авторами на основі [2]

Зростання сектору цифрових маркетингових технологій $є$ незаперечним та задає нові тренди сутності маркетингової діяльності компаній, а також ролі експертів сфери маркетингу. У першому кварталі 2020 року кількість маркетингових технологій склала 8000 одиниць, у порівнянні зі всього 947 рішеннями у 2014 році, що свідчить про приріст сектору мартеху майже у 8,5 разів. [3]

Розвиток таких масштабів має свої причини. Як показали дослідження фірми Gartner, проведені експертами в 2020 році, пандемія COVID-19 привела до скорочення маркетингових бюджетів на 5-15\%, зменшення попиту та зниження ефективності економіки загалом. Тим не менше, не зважаючи на вище згадані наслідки, керівники маркетингових департаментів компаній відзначають, що інвестиції в мартех будуть так само пріоритетним напрямом в наступні 12-18 місяців, а $68 \%$ з опитаних навіть прогнозують збільшення інвестицій та частки 
маркетингового бюджету саме на користь сектору мартех. Разом 3 тим, частка маркетингових бюджетів, яка відводиться на цифровий маркетинг також планується до збільшення у 2021-2022 роках 74\% відсотками опитаних. [4]

Окрім негативних наслідків можна спостерігати і позитивні тенденції, які створила пандемія та умови карантину в секторі мартеху, адже багатьом компаніям довелося перевести свою комерційну діяльність в цифровий простір, або ж інвестувати у впровадження цифрових інструментів маркетингу для того, щоб продовжити своє існування.

Так, наприклад, фінансування у розмірі 160 мільйонів доларів США в 2020 році отримали Sendinblue, восьмирічний стартап з Франції, який створив платформу для малих та середніх організацій, яка допомагає з організацією маркетингової діяльності, у тому числі з управлінням email, sms та чатами, а також автоматизацією реклами в соціальних мережах та ретаргетингу. [5]

Іншим прикладом можна назвати фінансування французькою інвестиційною компанією IDI у розмірі 27 мільйонів доларів США, яке було направлено на розвиток технологій Sarbacane. Sarbacane - французька компанія, яка розробила платформу для еmail маркетингу та контент-маркетингу на основі програмного забезпечення мартех. [6]

InfoSum, лондонський стартап, який створив спосіб для організацій обмінюватися своїми даними між собою, не передаючи їх одна одній - за допомогою федеративної, децентралізованої архітектури, яка використовує математичні формули для організації, “зчитування” та запиту даних також отримали фінансування у розмірі 15,1 мільйонів доларів США. [7]

Українські компанії, серед усіх інших, успішно розвивають мартех та виводять на глобальний рівень. Рейтинг 2021 за редакцією видання Forbes Україна відзначило 30 українських стартапів, які стали так чи інакше глобальними або які продовжують активну експансію на міжнародних ринках. Серед усього іншого, до переліку увійшли й компанії, що розробили продукт мартех, включаючи: (i) Grammarly, вебсервіс, що допомагає багатьом компаніям побудувати правильні, з точки зору граматики, комунікації іноземною мовою; (ii) People.ai, CRM-система, що допомагає оптимізувати продажі передовим глобальним брендам; (iii) Restream, сервіс, що дає можливість брендам проводити трансляцію (“стріми”) з будь-якої точки світу; (iv) Epom, сервіс для автоматизації реклами; та (v) Scallar, сервіс для регулювання та оптимізації реклами на мобільних пристроях.

Аналіз проведеного дослідження дозволяє припускати, що компанії продовжать розвивати синергію технологій та маркетингу ще 3 більшими зусиллями, адже мартех є одним із ключових інструментів маркетингової діяльності представників глобального сектору послуг, та компаній, які прагнуть вийти на міжнародні ринки. Подібна тенденція, характерна для маркетингу в цілому, посилюється ще й впливом пандемії поточного року, яка змусила бізнес перевести свою діяльність в цифровий простір на тривалий час. Таким чином, мартех вже сьогодні посідає ключові позиції в рамках глобального маркетингу послуг, адже комунікаційні канали змінили пріоритети в бік цифрового простору, можливо, назавжди. 3 іншого боку, цифровий простір дає доступ до 
глобального ринку, глобальної експертизи та пулу фахівців, а отже, підвищує в деяких моментах ефективність результатів маркетингової діяльності.

Список використаних джерел

1. What is MarTech \& How Does the DAM Fit In? [Електронний ресурс] // MerlinOne. - 2020. - Режим доступу до pecypcy: https://merlinone.com/whatis-martech/.

2. Brinker S. Marketing Technology Landscape Supergraphic (2020): Martech 5000 — really 8,000, but who's counting? [Електронний ресурс] / Scott Brinker // Chief Marketing Tehnologist Blog by Scott Brinker. - 2020. - Режим доступу до ресурсу: https://chiefmartec.com/2020/04/marketing-technology-landscape2020-martech-5000/.

3. Brinker S. Marketing Technology Landscape Supergraphic (2020) (image) [Електронний ресурс] / Scott Brinker // Chief Marketing Tehnologist Blog by Scott Brinker. - 2020. - Режим доступу до pecypcy: https://www.martechalliance.com/hubfs/MarTech\%20Landscape\%202019/Mar Tech\%20Landscape/martech-landscape-2020-martech5000-slide.jpg.

4. Ramaswami R. 8 Top Findings in Gartner CMO Spend Survey 2020-2021 [Електронний ресурс] / Rama Ramaswami // Gartner. - 2020. - Режим доступу до ресурсу: https://www.gartner.com/en/marketing/insights/articles/eight-topfindings-gartner-cmo-spend-survey-2020-2021.

5. Lunden I. France's Sendinblue, an all-in-one digital marketing platform, raises \$160M [Електронний ресурс] / Ingrid Lunden // TechCrunch. - 2020. - Режим доступу до ресурсу: https://techcrunch.com/2020/09/30/frances-sendinblue-anall-in-one-digital-marketing-platform-raises-160m/.

6. Lunden I. Sarbacane, maker of Mailify, raises $\$ 27 \mathrm{M}$ for marketing tools [Електронний ресурс] / Ingrid Lunden // TechCrunch. - 2020. - Режим доступу до ресурсу: https://techcrunch.com/2020/09/07/sarbacane-maker-of-mailifyraises-27m-for-marketing-tools/.

7. Lunden I. InfoSum raises $\$ 15.1 \mathrm{M}$ for its privacy-first, federated approach to big data analytics [Електронний pecypc] / Ingrid Lunden // TechCrunch. - 2020. Режим доступу до ресурсу: https://techcrunch.com/2020/09/01/infosum-raises15-1m-for-its-privacy-first-federated-approach-to-big-data-analytics/.

8. Іщенко А. В. МАРКЕТИНГОВ ТЕХНОЛОГІЇ РОЗВИТКУ КОНКУРЕНТОСПРОМОЖНОСТІ ТОВАРНОГО ЕКСПОРТУ : авТореф. дис. на здобуття наук. ступеня канд. ек. наук : спец. 08.00.02 "Світове господарство і міжнародні економічні відносини" / Іщенко Анна Володимирівна - Київ, 2017. - 21 с.

9. Савчук А. ЕФЕКТИВНІСТЬ МАРКЕТИНГОВОЇ ДІЯЛЬНОСТІ ПІДПРИЄМСТВ0 [Електронний ресурс] / Анастасія Савчук // Вісник КНТЕУ. - 2015. - Режим доступу до ресурсу: http://visnik.knute.edu.ua/files/2015/05/4.pdf.

10. Brinker S. Martech is now a $\$ 121.5$ billion market worldwide [Електронний pecypc] / Scott Brinker // Chief Marketing Tehnologist Blog by Scott Brinker. 2019. - Режим доступу до ресурсу: https://chiefmartec.com/2019/10/martech- 
now-121-5-billion-market-

worldwide/\#: :text=Martech\%3A\%202020\%20and\%20Beyond\%2C\%20a,mark eting\%20technology\%20is\%20\%24121.5\%20billion.

11. Найкращі стартапи України [Електронний ресурс] // Forbes України. - 2020. - Режим доступу до ресурсу: https://forbes.ua/ratings/30-luchshikh-startapov02042021-1251. 


\title{
THE IMMUNE STATUS OF COPD PATIENTS
}

\author{
Bychkova Svitlana \\ $\mathrm{PhD}$, Candidate of medical science, Associate Professor, \\ Associate Professor of Military Therapy Department \\ Ukrainian military medical academy
}

Chronic obstructive pulmonary disease (COPD) and cardiovascular diseases are considered as the leading causes of death and mortality in developed countries, the clinical significance of which increases progressively as far as the aging of population [1, p.367]. Thus, according to the WHO in 2005 in the world among all deaths 30\% occupied by cardiovascular causes, $13 \%$ - cancer, $2 \%$ - diabetes and 7\% - COPD. It is believed that over the next 10 years, COPD will take second place as a cause of death in the population [7, p.347]. Also, COPD and Arterial hypertension (AH) have the same pathogen feature as subclinical inflammation, which include disturbances in different parts of immune system.

One of the classic features of a patient, who suffers from COPD, always has been reduced body weight as a result of muscular dystrophy, which is caused by disorder of metabolism under the influence of systemic inflammation, hypoxia, and prolonged use of $\beta 2$-agonists [2, p.13]. However, in recent decades was formed COPD in a combination with metabolic syndrome (MS), which is another global disease of civilization and progress, which was a blend of overweight or obesity with hypertension, lipid and carbohydrate metabolism and diabetes. Overweight alongside smoking are the main risk factors for general morbidity and mortality all over the world. Thus both overweight and smoking may interact synergistically and be associated with the development of insulin resistance, oxidative stress, and increased content of cytokines and other inflammatory markers, which currently leads to endothelial dysfunction, cardiovascular disease and high risk of other diseases [1, p.368; 6, p.47]. In recent years, we can see active developing of the study of systemic effects in COPD when patients with this disease showing signs of diseases of the cardiovascular system and features of MS [6, p.46]. Arterial hypertension (AH) is one of the main components of MS, which has the great influence to the development of COPD, results of the disease. To correct the main manifestations of dyslipidemia as a major component of MS has been successfully using the statins all over the world. The appearance reductase inhibitors of 3- hydroxy-3-metylhlyutaryl-coenzyme A, or statins, have made a revolution in the treatment of hypercholesterolemia. Statins are drugs that are most commonly prescribed to treat these conditions because of their effectiveness in reducing the content of low density lipoprotein (LDL) and good tolerance and safety of use.

It is known that chronic inflammatory changes in the immune system combined with changes in lipid metabolism in blood, liver, adipose and other tissues. In the 
scientific literature it is discussed two main mechanisms of integrating lipid metabolism and immune responses, one of which is associated with the synthesis of cholesterol and other - with activity of superfamily of nuclear X-receptors. It is proved that statins have a multipronged effect - anti-inflammatory, immunomodulatory and antiatherogenic.

Purpose of work - to determine the effect of atorvastatin on parameters of cellular and humoral immune system and the functional activity of immune cells in patients with COPD, combined with AH and MS.

Materials and Methods. The study involved 47 patients with A group of COPD and presence of the metabolic syndrome (group 1) and 81 patients with B group of COPD and metabolic syndrome (group 2), the average age was 51,3 \pm 4.2 years. All the patient had the II stage of AH. The diagnosis of COPD is established according to the Order of Ministry of Health of Ukraine № 555 [4, p.12]. The diagnosis of MS was established on the basis of detailed anamnesis, clinical, laboratory and instrumental methods in identifying the main criteria for the syndrome on the recommendations of the International diabetes Federation (IDF), 2005 [3, p.5]. All patients were examined during remission of COPD and were treated with basic therapy of prolonged inhaled anticholinergic drugs and short on-demand drugs without inhaled corticosteroids. To correct the existing violations of lipid metabolism in MS, patients were treated with atorvastatin at a daily dose of $10 \mathrm{mg}$. To achieve the target blood pressure levels, all patients with $\mathrm{AH}$ received enalapril at a daily dose of $20-40 \mathrm{mg}$, if not successful it was added amlodipine in dose of $10 \mathrm{mg}$. The control group consisted of 36 healthy persons randomized by age and sex, with no signs of MS, AH and COPD. All patients were evaluated by indicators of immune status, which included the tests of I and II levels as required by the Memorandum of WHO [5, p.26]: quantitative assessment of the major populations and subpopulations of lymphocytes, determination of activated subpopulations of lymphocytes CD54 +, CD95 +, HLA-DR +, CD25 +, levels of proand anti-inflammatory cytokines determine spontaneous and mitogen-induced lymphocyte proliferative activity, the level of circulating immune complexes (CIC) of different molecular weight in the serum and the phagocytic activity of peripheral blood neutrophils, the concentration of serum immunoglobulins (IgG, IgA, IgM). Immunological examination was performed twice before carrying statin therapy and in the dynamics after 3 months of continuous use.

Results and Discussion. As a result of studies, we found that in the first group of patients with COPD I stage combined with MS, the main indicators of lymphocyte populations did not have probable differences in the values of the control group $(p>0,1)$ and did not significantly change in the dynamics of treatment (Table 1). The relative number of T, B lymphocytes and NK-cells had no significant differences in the values of the healthy people. The same trend was found for the percentage of key immunoregulatory subpopulations - T-helper and T-cytotoxic lymphocytes/ suppressor whose content in the peripheral blood of patients in group 1 parameters consistent treatment of the dynamics of the control group $(p>0,1)$. 
Table 1

The content of basic and activated populations and subpopulations of Lymphocytes in the peripheral blood of patients with COPD with AH and MS in dynamic of treatment $(\mathrm{M} \pm \mathrm{m})$

\begin{tabular}{|c|c|c|c|c|c|}
\hline \multirow[t]{2}{*}{ Indicators } & \multicolumn{2}{|c|}{ Group $1 \quad(n=47)$} & \multicolumn{2}{|c|}{ Group $2(n=81)$} & \multirow{2}{*}{$\begin{array}{l}\text { Control } \\
\text { group } \\
(n=36)\end{array}$} \\
\hline & $\begin{array}{l}\text { Before } \\
\text { treatment }\end{array}$ & $\begin{array}{c}\text { After } \\
\text { treatment }\end{array}$ & $\begin{array}{l}\text { Before } \\
\text { treatment }\end{array}$ & $\begin{array}{c}\text { After } \\
\text { treatment }\end{array}$ & \\
\hline $\begin{array}{l}\text { Leukocytes, } \\
10^{9} / \text { Л }\end{array}$ & $6,24 \pm 1,13$ & $6,11 \pm 1,18$ & $6,36 \pm 1,19$ & $6,25 \pm 1,09$ & $6,76 \pm 0,82$ \\
\hline $\begin{array}{l}\text { Lymphocytes, } \\
\%\end{array}$ & $\mid \begin{array}{c}33,26 \pm \\
1,31\end{array}$ & $32,85 \pm 1,27$ & $\begin{array}{l}41,15 \pm 2,75 \\
*\end{array}$ & $\begin{array}{l}36,4 \pm 2,18^{*} \\
x\end{array}$ & $31,64 \pm 3,90$ \\
\hline $\begin{array}{l}\text { CD3+ } \\
\text { lymphocytes, \% }\end{array}$ & $\begin{array}{l}64,73 \pm \\
3,45\end{array}$ & $65,28 \pm 3,21$ & $61,30 \pm 2,86$ & $\begin{array}{l}64,55 \pm \\
3,68\end{array}$ & $65,85 \pm 6,55$ \\
\hline $\begin{array}{l}\text { CD4+ } \\
\text { lymphocytes, }\end{array}$ & $\begin{array}{l}35,40 \pm \\
1,84\end{array}$ & $34,74 \pm 1,65$ & $\begin{array}{l}41,78 \pm \\
1,86^{*}\end{array}$ & $\begin{array}{c}37,62 \pm \\
1,26^{*} \mathrm{x}\end{array}$ & $33,23 \pm 3,90$ \\
\hline $\begin{array}{l}\text { CD8+ } \\
\text { lymphocytes, }\end{array}$ & $\begin{array}{l}22,48 \pm \\
0,96\end{array}$ & $22,13 \pm 1,04$ & $\begin{array}{c}17,24 \pm \\
0,85^{*}\end{array}$ & $\begin{array}{l}18,28 \pm \\
0,95\end{array}$ & $21,50 \pm 2,01$ \\
\hline CD4+/CD8+ & $1,57 \pm 0,11$ & $1,56 \pm 0,10$ & $2,42 \pm 0,13^{*}$ & $\begin{array}{l}2,07 \pm \\
0,11 * x\end{array}$ & $1,55 \pm 0,29$ \\
\hline $\begin{array}{l}\text { CD22+ } \\
\text { lymphocytes, } \%\end{array}$ & $\begin{array}{l}25,54 \pm \\
1,17\end{array}$ & $24,93 \pm 1,15$ & $\begin{array}{c}31,45 \pm \\
1,13^{*}\end{array}$ & $\begin{array}{l}27,56 \pm \\
1,12\end{array}$ & $24,03 \pm 1,50$ \\
\hline $\begin{array}{l}\text { CD16+ } \\
\text { lymphocytes, \% }\end{array}$ & $\begin{array}{l}16,29 \pm \\
0,87\end{array}$ & $17,03 \pm 1,01$ & $16,92 \pm 0,93$ & $\begin{array}{l}17,34 \pm \\
1,02\end{array}$ & $18,85 \pm 2,30$ \\
\hline $\begin{array}{l}\text { CD25+ } \\
\text { lymphocytes, } \%\end{array}$ & $\begin{array}{l}12,31 \pm 0,24 \\
*\end{array}$ & $9,03 \pm 0,56 x$ & $15,61 \pm 0,45^{*}$ & $\begin{array}{c}11,74 \pm \\
0,36^{*} \mathrm{x}\end{array}$ & $8,96 \pm 0,39$ \\
\hline $\begin{array}{l}\text { HLA-DR+ } \\
\text { lymphocytes, } \%\end{array}$ & $\begin{array}{c}14,72 \pm \\
0,31^{*}\end{array}$ & $\begin{array}{l}12,81 \pm 0,32 \\
x\end{array}$ & $\begin{array}{c}17,61 \pm \\
0,29^{*}\end{array}$ & $\begin{array}{c}15,47 \pm \\
0,21^{*} \mathrm{x}\end{array}$ & $12,3 \pm 1,27$ \\
\hline $\begin{array}{l}\text { CD95+ } \\
\text { lymphocytes, \% }\end{array}$ & $\begin{array}{r}4,98 \pm \\
0,12 *\end{array}$ & $3,14 \pm 0,09 x$ & $7,35 \pm 0,11^{*}$ & $\begin{array}{l}5,16 \pm \\
0,08^{*} \mathrm{x}\end{array}$ & $3,04 \pm 0,09$ \\
\hline $\begin{array}{l}\text { CD54+ } \\
\text { lymphocytes,\% }\end{array}$ & $\begin{array}{l}18,36 \\
\pm 0,61 *\end{array}$ & $\begin{array}{l}14,28 \\
\pm 0,37 * \mathrm{x}\end{array}$ & $21,02 \pm 1,01 *$ & $\begin{array}{c}17,73 \pm \\
0,89 * \mathrm{x}\end{array}$ & $11,07 \pm 1,65$ \\
\hline
\end{tabular}

Notes: - probability of difference of about the control $(\mathrm{p}<0,05)$;

$\mathrm{x}$ - Probability of difference in dynamic of treatment $(\mathrm{p}<0,05)$;

$\mathrm{n}$ - Number of patients 
In the patients of the second group relative content of CD3 + and CD16 + cells in peripheral blood was not significant differences in the values in healthy ones as well as the dynamics of treatment, but it was discovered phenomenon of B-lymphocytosis, when the relative number of CD22 + cells exceeded the rate of the control group at 23, $59 \%$ ( $\mathrm{p}<0,05)$. In the dynamics of statins treatment was observed decrease in the percentage of CD22 + cells at $12,37 \%(\mathrm{p}<0,05)$, but with a significant predominance over the number of healthy patients to $12,81 \%$ ( $\mathrm{p}<0,05)$. In patients of the second group was found fundamental imbalance of immunoregulatory subopulyations relative predominance of $\mathrm{CD} 4+\mathrm{T}$ cells, leading to growth rate immunoregulatory index to $35,95 \%$ compared with healthy individuals. Such disturbances in the immune status are inherent, usually in patients with asthma when the basis for the pathogenesis of allergic inflammation is a reverse airflow obstruction, combined with the excessive formation of IgE. In our group of patients during the dilated bronchial test repeatedly confirmed irreversible airflow obstruction with no or little increase forced expiratory volume in 1 second (FEV1), which is one of the main criteria for the diagnosis of COPD. Thus, these changes in the immune system that are in imbalance contents of Thelper cells and T-lymphocyte cytotoxic / suppressor due to the presence of AH and MS, for which are typical autoimmune changes. In the dynamics of inclusion atorvastatin treatment was a significant decrease in immune regulatory index of 1,17 times, but it remained higher than the standard values at $25,12 \%(\mathrm{p}<0,05)$. The content of activated lymphocyte subpopulations of CD25 + phenotype in patients of group 1 before treatment exceeded the control group on the rate of $37,4 \%(\mathrm{p}<0,05)$, but in the dynamics of treatment with atorvastatin inclusion it decreased by $26,6 \%(\mathrm{p}<0,05)$ to normative values. In group II of patients the percentage of CD25 + lymphocytes exceeded the standard value at $74,2 \%(\mathrm{p}<0,05)$, in the dynamics of treatment significantly decreased by $24,8 \%(\mathrm{p}<0,05)$, but remained above the level of healthy individuals to $31,03 \%$ ( $p<0,05$ ). Similar changes were characteristic of activated HLADR +lymphocytes, the content of which in the first group of patients was higher than grandstanding healthy individuals at $16,44 \%$ ( $\mathrm{p}<0,05$ ), and the second - to $43,17 \%$ $(\mathrm{p}<0,05)$ in the dynamic of treatment both parameters significantly decreased by $12,98 \%$ and $12,15 \%$, but in the second group it remained significantly higher than in healthy individuals at $25,77 \%(\mathrm{p}<0,05)$. Number of activated lymphocytes that express FAS-receptor in patients of group 1 was significantly higher than the value of healthy individuals at $38,96 \%(\mathrm{p}<0,05)$ and dynamic of treatment significantly decreased to normative values, while in the second group of patients was higher than normal - at 2,41 times $(\mathrm{p}<0,05)$, in dynamic of treatment decreased, but exceeded the rate in the control group in 1,70 times $(\mathrm{p}<0,05)$. The relative number of CD54+ subpopulation of lymphocytes in both groups of patients to treatment exceeded the rate of healthy persons in 1,66 $(\mathrm{p}<0,05)$ and 1,90 times $(\mathrm{p}<0,05)$, in dynamic of treatment decreased the quantity of this subpopulation of lymphocytes however, their number exceeded the level of healthy individuals at $29,01 \%(\mathrm{p}<0,05)$ and $60,16 \%(\mathrm{p}<0,05)$.

As it can be seen from the data presented in Table 2, spontaneous proliferative activity of lymphocytes in both groups of patients was increased without significant differences between them. In the dynamics of treatment was probable decline of index of spontaneous RBTL in group $1(\mathrm{p}<0,05)$ at 1,49 times the values of healthy 
individuals $(p>0,1)$, while in the second group - only 1,16 times $(p<0,05)$, which exceeded the control group at $35,77 \%(\mathrm{p}<0,05)$. The index of stimulated PHA RBTL in group 1 had probable difference from healthy individuals in dynamic of treatment, and in patients of the second group during the primary examination, it was raised to $11,76 \%$ ( $p<0,05$ ), and in dynamic of treatment significantly decreased to values of healthy individuals. Phagocytic activity of neutrophils, which was estimated by counting the number of phagocytes (NF) and phagocytic index (FI) in both groups of patients, was reduced.

Table 2

The indicators of functional activity of immune competent cells in COPD patients with $\mathrm{AH}$ and $\mathrm{MS}$ in dynamics treatment with statins $(\mathrm{M} \pm \mathrm{m})$

\begin{tabular}{|c|c|c|c|c|c|}
\hline \multirow[t]{2}{*}{ Indicators } & \multicolumn{2}{|c|}{ Group $1 \quad(n=47)$} & \multicolumn{2}{|c|}{ Group $2(\mathrm{n}=81)$} & \multirow{2}{*}{$\begin{array}{l}\text { Control } \\
\text { group } \\
(\mathrm{n}=36)\end{array}$} \\
\hline & $\begin{array}{l}\text { Before } \\
\text { treatment }\end{array}$ & $\begin{array}{c}\text { After } \\
\text { treatment }\end{array}$ & $\begin{array}{l}\text { Before } \\
\text { treatment }\end{array}$ & $\begin{array}{c}\text { After } \\
\text { treatment }\end{array}$ & \\
\hline $\begin{array}{l}\text { RBTL } \\
\text { spontaneous, \% }\end{array}$ & $\begin{array}{c}2,87 \pm \\
0,12 *\end{array}$ & $\begin{array}{l}1,92 \pm 0,11 \\
*\end{array}$ & $\begin{array}{l}3,18 \pm 0,11 \\
*\end{array}$ & $\begin{array}{l}2,74 \pm 0,09 \\
*_{\mathrm{x}}\end{array}$ & $1,76 \pm 0,61$ \\
\hline RBTL with PGA, $\%$ & $\begin{array}{l}80,24 \pm \\
3,16\end{array}$ & $\begin{array}{l}78,17 \pm 3,2 \\
1\end{array}$ & $\begin{array}{l}89,41 \pm 3,2 \\
2 *\end{array}$ & $\begin{array}{l}79,45 \pm 3,0 \\
6\end{array}$ & $80,0 \pm 4,70$ \\
\hline $\begin{array}{l}\text { Phagocyte's } \\
\text { Number (NP) }\end{array}$ & $\begin{array}{l}5,02 \pm \\
0,16^{*}\end{array}$ & $\begin{array}{l}5,61 \pm 0,18 \\
x\end{array}$ & $\begin{array}{l}4,68 \pm 0,17 \\
*\end{array}$ & $\begin{array}{l}5,31 \pm 0,21 \\
*_{\mathrm{x}}\end{array}$ & $6,50 \pm 0,60$ \\
\hline $\begin{array}{l}\text { Phagocyte index } \\
\text { (PI), \% }\end{array}$ & $\begin{array}{l}52,68 \pm 2,7 \\
5^{*}\end{array}$ & $\begin{array}{l}63,24 \pm 2,8 \\
4 x\end{array}$ & $\begin{array}{l}51,26 \pm 2,5 \\
2 *\end{array}$ & $\begin{array}{l}60,21 \pm 2,4 \\
3 x\end{array}$ & $\begin{array}{l}69,80 \pm 7,2 \\
0\end{array}$ \\
\hline
\end{tabular}

Notes $*$ - probability of difference of index due to the control $(\mathrm{p}<0,05)$;

$\mathrm{x}$ - Probability of difference of index in dynamic of treatment $(\mathrm{p}<0,05)$;

n- Number of patients

The dynamics of treatment in group 1 figure NP increased by $11,75 \%(\mathrm{p}<0,05)$, and PI - by 20,04\% ( $p<0,05)$ to the values of the control group. In the second group also occurred partly recovery parameters: phagocytic number increased to $13,46 \%$ $(\mathrm{p}<0,05)$, and the phagocytic index - by $17,46 \%(\mathrm{p}<0,05)$, but did not reach the level of the control group.

Influence of statin therapy on serum concentrations of $\mathrm{IgG}$ and $\mathrm{CIC}$ is given in Table 3.

Table 3

Dynamics of humoral immune system indicator's in patients with COPD, combined with $\mathrm{AH}$ and $\mathrm{MS}(\mathrm{M} \pm \mathrm{m})$

\begin{tabular}{|l|c|c|c|c|l|}
\hline \multirow{2}{*}{ Indicators } & \multicolumn{2}{|c|}{ Group 1 $(\mathrm{n}=47)$} & \multicolumn{2}{c|}{ Group 2 $(\mathrm{n}=81)$} & $\begin{array}{l}\text { Control } \\
\text { group } \\
(\mathrm{n}=36)\end{array}$ \\
\cline { 2 - 5 } & $\begin{array}{c}\text { Before } \\
\text { treatment }\end{array}$ & $\begin{array}{c}\text { After } \\
\text { treatment }\end{array}$ & $\begin{array}{c}\text { Before } \\
\text { treatment }\end{array}$ & $\begin{array}{c}\text { After } \\
\text { treatment }\end{array}$ & \\
\hline Ig G, g/l & $\begin{array}{c}14,75 \pm \\
14,98\end{array}$ & $14,95 \pm 1,08$ & $\begin{array}{c}16,28 \pm 1,17 \\
*\end{array}$ & $16,36 \pm 1,05^{*}$ & $12,68 \pm 1,42$ \\
\hline Ig A, g/l & $1,31 \pm 0,12$ & $1,34 \pm 0,11$ & $1,06 \pm 0,13^{*}$ & $1,02 \pm 0,18^{*}$ & $1,52 \pm 0,19$ \\
\hline
\end{tabular}




\begin{tabular}{|c|c|c|c|c|c|}
\hline Ig M, g/l & $0,96 \pm 0,06$ & $0,97 \pm 0,09$ & $0,95 \pm 0,10$ & $0,97 \pm 0,11$ & $0,98 \pm 0,09$ \\
\hline $\begin{array}{l}\text { CIC large (> } 19 \\
\text { S), } \\
\text { conventional } \\
\text { units }\end{array}$ & $\begin{array}{l}23,02 \pm 0,41 \\
*\end{array}$ & $\begin{array}{l}35,14 \pm 0,81 \\
*_{x}\end{array}$ & $\begin{array}{c}21,17 \pm 0,49 \\
*\end{array}$ & $\begin{array}{c}33,75 \pm 1,12 * \\
\mathrm{x}\end{array}$ & $51,7 \pm 3,12$ \\
\hline $\begin{array}{l}\text { CIC medium (11- } \\
\text { 19S), } \\
\text { conventional units }\end{array}$ & $\begin{array}{r}55,28 \pm \\
2,36 * \\
\end{array}$ & $\begin{array}{l}42,73 \pm 1,22 \\
* x\end{array}$ & $\begin{array}{c}61,55 \pm 2,34 \\
*\end{array}$ & $\begin{array}{l}46,94 \pm 1,63 * \\
x\end{array}$ & $34,54 \pm 2,02$ \\
\hline $\begin{array}{l}\text { CIC small }(<11 \\
\text { S), } \\
\text { conventional units }\end{array}$ & $\begin{array}{l}43,22 \pm 1,64 \\
*\end{array}$ & $\begin{array}{l}18,96 \pm 0,73 \\
*_{x}\end{array}$ & $\begin{array}{c}52,37 \pm 1,72 \\
*\end{array}$ & $\begin{array}{l}24,39 \pm 1,05^{*} \\
x\end{array}$ & $10,94 \pm 1,13$ \\
\hline
\end{tabular}

Notes * - the probability of difference of the index in the control $(\mathrm{p}<0,05)$;

$\mathrm{x}$ - the probability of difference of the index in the dynamics of treatment $(\mathrm{p}<0,05)$;

$\mathrm{n}$-number of patients

As can be seen from the data presented in Table 3, patients of group 1 in the dynamics of treatment with the inclusion of atorvastatin was seen likely changes in serum levels of $\operatorname{IgG}, \operatorname{IgM}, \operatorname{IgA}$, their concentration is consistent with normative values ( $p>0,1$ ). In group 2 patients found an increased content of serum IgG and significantly lower than the control group level data IgA, the dynamics of treatment there was no significant change in both indicators, which may be due to the formation of antibodies in response to antigenic stimulation of microbial frequent exacerbations of COPD. In both groups, the patients with primary immunological study revealed an imbalance of serum CIC with a significant prevalence of pathogenic CIC content. Atorvastatin had a significant positive impact on content as pathogenic and physiological CIC. In group 1 content of the average molecular CIC significantly decreased by $29,37 \%(\mathrm{p}<0,05)$, and small - to $127,95 \%(\mathrm{p}<0,05)$, while increasing the content CIC large - at 52,65\% $(p<0,05)$. In group II patients the level of pathogenic CIC small and medium size was significantly higher than those of the healthy subjects and those of the group 1, the dynamics of inclusion atorvastatin treatment decreased their level respectively 1,31 $(p<0,05)$ and 2,15 times $(p<0,05)$, but both values significantly higher than levels in healthy individuals in $1,36 \quad(\mathrm{p}<0,05)$ and 2,23 times $(\mathrm{p}<0,05)$. The level of physiological CIC large size was reduced, and the dynamics of treatment increased to 1.59 times $(\mathrm{p}<0,05)$, but has not reached the performance of the control group and remained lower at 1,53 times $(\mathrm{p}<0,05)$. Serum levels of cytokines in patients with COPD, combined with AH and MS, in dynamics of treatment are presented in Table 4. 
Table 4

Serum levels of cytokines in patients with COPD, combined with AH and MS, in the dynamics of complex treatment $(\mathrm{M} \pm \mathrm{m})$

\begin{tabular}{|c|c|c|c|c|c|}
\hline \multirow[t]{2}{*}{ Indicators } & \multicolumn{2}{|c|}{ Group $1 \quad(n=47)$} & \multicolumn{2}{|c|}{ Group $2(\mathrm{n}=81)$} & \multirow{2}{*}{$\begin{array}{l}\text { Control } \\
\text { group } \\
(\mathrm{n}=36)\end{array}$} \\
\hline & $\begin{array}{l}\text { Before } \\
\text { treatment }\end{array}$ & $\begin{array}{c}\text { After } \\
\text { treatment }\end{array}$ & $\begin{array}{l}\text { Before } \\
\text { treatment }\end{array}$ & $\begin{array}{c}\text { After } \\
\text { treatment }\end{array}$ & \\
\hline TNF- $\alpha$, пг/мл & $123,6 \pm 9,5^{*}$ & $61,5 \pm 5,7 * x$ & $126,9 \pm 7,5^{*}$ & $\begin{array}{l}77,9 \pm 3,12^{*} \\
\mathrm{x}\end{array}$ & $42,3 \pm 4,9$ \\
\hline IL-1 $\beta, \mathrm{pg} / \mathrm{MЛ}$ & $110,6 \pm 7,1^{*}$ & $54,7 \pm 6,8 \mathrm{x}$ & $105,1 \pm 6,8^{*}$ & $\begin{array}{l}72,6 \pm 3,82 * \\
x\end{array}$ & $39,42 \pm 4,5$ \\
\hline IL-6, pg/мл & $36,2 \pm 1,6^{*}$ & $17,8 \pm 1,9 * x$ & $68,3 \pm 2,2 *$ & $\begin{array}{l}24,7 \pm 1,31^{*} \\
\mathrm{x}\end{array}$ & $10,31 \pm 2,3$ \\
\hline IL-4, pg/мл & $22,4 \pm 1,7$ & $24,7 \pm 1,8$ & $17,5 \pm 1,1^{*}$ & $22,7 \pm 1,2 \times$ & $25,42 \pm 3,3$ \\
\hline
\end{tabular}

Notes * - the probability of difference of the index in the control $(\mathrm{p}<0,05)$;

$\mathrm{x}$ - the probability of difference of the index in the dynamics of treatment $(\mathrm{p}<0,05)$;

$\mathrm{n}$-number of patients

As can be seen from the data presented in Table 4, patients of group 1 in serum was found increased proinflammatory cytokines TNF- $\alpha$ at 2,92 times $(p<0,05)$, IL-1 $\beta$ - at 2,81 times $(\mathrm{p}<0,05)$ and IL -6 - to 3,51 times $(\mathrm{p}<0,05)$ compared with healthy individuals. The dynamics of the combined treatment was significant reduction in serum levels of proinflammatory cytokines, which, however, still higher than standard rates. In the second group of patients was also found growing content of proinflammatory cytokines, but the degree of increase was uneven with a significant

prevalence of elevated levels of IL-6 (6,62 times relative standard values). The dynamics of treatment decreased serum concentrations of TNF- $\alpha$ at 1,64 times $(\mathrm{p}<0,05)$, IL-1 $\beta$ - at 1,46 times $(\mathrm{p}<0,05)$ and IL-6 - at 2,77 times $(\mathrm{p}<0,05)$. However, their level is significantly lower than in healthy individuals. In the second group of patients with primary immunological study found reduced levels of anti-inflammatory IL-4, which after treatment was significantly increased to 1,3 times the level of healthy subjects $(\mathrm{p}>0,1)$.

\section{Conclusions.}

1. Established immune-corrective role of statins (atorvastatin) in the treatment of patients with COPD, combined with $\mathrm{AH}$ and MS, which is the presence of antiinflammatory action, reducing the symptoms of autoimmune disorders, reducing the relative content of activated lymphocyte subpopulations and elimination of imbalance of the CIC.

2. In patients with group B COPD, combined with AH and MS, appear to be more profound changes in the immune system, which is a partial recovery after a 3-month course of therapy with atorvastatin.

3. Revealed changes in the immune system and their partial recovery under the action of atorvastatin is the basis for the use of immune modulators in these patients. 


\section{References:}

1. Agusti A.G. Systemic effects of chronic obstructive pulmonary disease// Proc. Am. Thorac. Soc.- 2005.-V. 2(4).-P.367-370.

2. Berezin AE. Chronic obstructive pulmonary disease and cardiovascular risk // Ukrainian Medical Journal «Chasopys».- 2009.-V. 2(70).-P.12-18.

3. Diagnosis and treatment of metabolic syndrome, diabetes, and cardiovascular diseases. Methodological recommendations. - K -2009.- 40s

4. Order No.555 of the Ministry of Health of Ukraine as of June 27, 2013. On Approval and Implementation of Medico-Technological Documents on Standardization of Medical Care for Chronic Obstructive Pulmonary Disease. http://www.moz.gov.ua/ua/portal/dn_20130627_0555.html

5. Perederij V.G., Zemskov A.M., Bychkova N.G., Zemskov V.M. Immune status, the principles of it detection and correction the immune disturbances.-Kyiv.: Zdorovja.-1995.-211p.

6. Prozorov G.G., Volkorezov I.A., Pashkova O.B. Features of Clinically flow of the COPD: the role of systemic inflammation // Clearing aspects of medicine.- 2009.V. 12(2).-P.46 -49.

7. Vestbo J. Global strategy for the diagnosis, management and prevention of COPD - COPD executive summary / J. Vestbo, S.S. Hurd, A. Agusti // American Journal Respiration. - 2013. - Vol.187. - P.347-365. 


\title{
STATE OF ORAL HYGIENE IN CHILDREN WITH ACUTE LYMPHOBLASTIC LEUKEMIA
}

\author{
Khotimska Yuliia, \\ Ph.D, Associate Professor of the Department of Pediatric Dentistry, \\ Dnipro State Medical University
}

\begin{abstract}
Aleksieienko Nataliia, Ph.D, Associate Professor of the Department of Pediatric Dentistry, Dnipro State Medical University

Kucherenko Oleksandr, Ph.D, Associate Professor of the Department of Pediatric Dentistry, Dnipro State Medical University

Khotimskiy Boris, Chief Physician, PE "Dental clinic of doctor Khotimskiy"

Tarasenko Yuliia, dentist-therapist, PE "Center of Dentistry" Estet ", Dnipro, Ukraine
\end{abstract}

Introductions. The importance of proper hygienic education of both healthy children and those with somatic pathology is very great. Because most children do not yet have a need for a healthy lifestyle, they are genetically programmed up to a certain age to be cared for by their parents. Therefore, the formation of motivation to carry out hygienic measures for the care of the oral cavity requires a lot of attention, patience and should be carried out by the joint efforts of the dentist and parents.

The state of oral hygiene in children plays a significant preventive role in the development of both dental and somatic diseases. Therefore, individual prevention and personal hygiene of the oral cavity is one of the effective methods of preventing diseases of both the hard tissues of the teeth and the mucous membrane of the oral cavity, determining the quality of life of the child.

Keywords: leukemia, acute lymphoblastic leukemia, children, oral mucosa, oral hygiene.

Aim. To investigate the state of oral hygiene in children with acute lymphoblastic leukemia in different periods of the disease in order to develop a set of preventive measures.

Materials and methods. For the general characteristic structural analysis of the state of oral hygiene, we examined 126 children with acute lymphoblastic leukemia aged 2 to 18 years. All examined children were treated in the oncohematology department. Among them are 44 girls and 82 boys. All examined patients were divided into 3 subgroups depending on the clinical course of acute lymphoblastic leukemia: 1 
subgroup is 61 children (48.4\%) with the first acute period of acute lymphoblastic leukemia; Subgroup 2 consisted of 30 children (23.8\%) with acute lymphoblastic leukemia in remission, and subgroup 3 included 35 patients $(27.8 \%)$ with relapse of acute lymphoblastic leukemia. In each subgroup, patients studied oral hygiene indicators using an index assessment.

Results and discussion. Analyzing the data of a survey conducted in 126 children with various dental diseases on the background of acute lymphoblastic leukemia, the frequency of brushing was found, a survey was conducted on individual hygiene products, regularity and correctness of brushing. The results of the survey indicate a lack of awareness of children and their parents about oral care skills and a low level of hygienic education.

Hygienic awareness of children of the surveyed groups and their parents with oral care skills was insufficient (Table 1).

Less than $50 \%$ of children of all ages had adequate oral hygiene skills and brushed their teeth twice a day, in the morning and in the evening. According to the results of the survey and testing of practical skills, only 28 children brushed their teeth once a day in the first acute period of acute lymphoblastic leukemia, 14 children - in remission and 8 - during the recurrence of the disease. A large percentage of children performed oral hygiene irregularly (not every day). 15 (11.9\%) children, mostly younger preschool age (2-5 years), did not have a toothbrush at all, they do not have basic knowledge and skills in oral care.

Analyzing the data in Table 1, there is a tendency to increase the number of children who regularly brush their teeth ( 2 times a day: morning and evening) with their age, so, in groups of children 15-18 years, the highest indicators of regular oral hygiene. It should also be noted that children with acute lymphoblastic leukemia brush their teeth more often and better in remission of the underlying disease and much less often in the acute period or during relapse. This is due to the fact that oral care in patients with acute lymphoblastic leukemia is often complicated by the difficult general condition of patients and due to painful sensations in the oral cavity in this disease, which interfere with full personal hygiene.

Table 1

Regularity and frequency of individual oral hygiene in children who were

\begin{tabular}{|c|c|c|c|c|}
\hline \multirow{2}{*}{$\begin{array}{c}\text { The period of } \\
\text { the clinical } \\
\text { course }\end{array}$} & $\begin{array}{c}\text { Age } \\
\text { groups of } \\
\text { children, years }\end{array}$ & 2 times a day & 1 time a day & Irregular \\
\hline \multirow{4}{*}{$\begin{array}{c}\text { First } \\
\text { acute } \\
\text { period }\end{array}$} & $2-5(\mathrm{n}=21)$ & - & 30,0 & 70,0 \\
\cline { 2 - 5 } & $6-8(\mathrm{n}=9)$ & 11,1 & 44,4 & 44,5 \\
\cline { 2 - 5 } & $9-11(\mathrm{n}=7)$ & 42,9 & 28,6 & 28,5 \\
\cline { 2 - 5 } & $12-14(\mathrm{n}=16)$ & 43,8 & 43,8 & 12,4 \\
\cline { 2 - 5 } & $15-18(\mathrm{n}=18)$ & 44,5 & 44,5 & 11,0 \\
\hline
\end{tabular}




\begin{tabular}{|c|c|c|c|c|}
\hline \multirow{4}{*}{$\begin{array}{c}\text { Stage of } \\
\text { remission }\end{array}$} & $2-5(\mathrm{n}=8)$ & 12,5 & 50,0 & 37,5 \\
\cline { 2 - 5 } & $6-8(\mathrm{n}=5)$ & 20,0 & 60,0 & 20,0 \\
\cline { 2 - 5 } & $9-11(\mathrm{n}=4)$ & 25,0 & 50,0 & 25,0 \\
\cline { 2 - 5 } & $12-14(\mathrm{n}=5)$ & 40,0 & 40,0 & 20,0 \\
\cline { 2 - 5 } & $15-18(\mathrm{n}=9)$ & 55,6 & 33,3 & 11,1 \\
\hline \multirow{5}{*}{ Relapse } & $2-5(\mathrm{n}=6)$ & - & 16,7 & 83,3 \\
\cline { 2 - 5 } & $6-8(\mathrm{n}=5)$ & 20,0 & 40,0 & 40,0 \\
\cline { 2 - 5 } & $9-11(\mathrm{n}=3)$ & 33,3 & 33,4 & 33,3 \\
\cline { 2 - 5 } & $12-14(\mathrm{n}=5)$ & 40,0 & 40,0 & 20,0 \\
\cline { 2 - 5 } & $15-18(\mathrm{n}=5)$ & 40,0 & 40,0 & 20,0 \\
\hline
\end{tabular}

When analyzing the hygienic condition of the oral cavity, attention was paid to the nature of plaque on the teeth. In addition to soft dental plaque, hard dental plaque and dense pigmented plaque were found in all groups of children with acute lymphoblastic leukemia. It was most often placed on the necks of teeth from the vestibular and oral surfaces, but there were cases when a dense film of plaque completely covered the tooth surfaces. It should be noted that the plaque on the teeth was not monochrome, there was a difference in color from yellow and brown - to gray-black. Hard dental plaque in the form of tartar is observed in children both in the acute period of acute lymphoblastic leukemia and in remission. The obtained data confirmed this trend, which is the absence of statistical difference in the hygienic condition of the oral cavity between children of the first acute period and recurrence of acute lymphoblastic leukemia, established as a result of analysis of oral hygiene indices - OHI-S and Silness-Loe indices. Significant differences in these indices were observed only in the group of children who were in remission of acute lymphoblastic leukemia.

The level of oral hygiene was assessed by a set of indices, taking into account the high score. The evaluation of the results of the study was carried out according to the gradation by WHO: "good", "satisfactory", "unsatisfactory", "bad" oral hygiene. The obtained research data are shown in tables 2-3.

Table 2

The state of oral hygiene in children with acute lymphoblastic leukemia in the first acute period, $\mathrm{M} \pm \mathrm{m}$

\begin{tabular}{|c|c|c|}
\hline Age of children & OHI-S (points) & Silness-Loe (points) \\
\hline $2-5(n=21)$ & $2,4 \pm 0,12$ & $2,46 \pm 0,13$ \\
\hline $6-8(n=9)$ & $2,3 \pm 0,12$ & $2,35 \pm 0,12$ \\
\hline $9-11(n=7)$ & $1,5 \pm 0,08$ & $1,95 \pm 0,11$ \\
\hline $12-14(n=16)$ & $1,4 \pm 0,07$ & $1,77 \pm 0,09$ \\
\hline $15-18(n=18)$ & $1,3 \pm 0,07$ & $1,55 \pm 0,08$ \\
\hline
\end{tabular}


Analyzing the results of the study (table 2) it was found that the indicators of hygiene were "bad" or "unsatisfactory" in all age groups of children in the first acute period of acute lymphoblastic leukemia. Thus, the worst state of oral hygiene was observed in children of the younger group (2-5 years): only 10\% "satisfactory", more than $50 \%$ of children in this group had a "poor" state of oral hygiene. The hygienic OHI-S index in children with acute lymphoblastic leukemia in the first acute period ranged from $1.3 \pm 0.07$ points to $2.4 \pm 0.12$ points, and the Silness-Loe index $-1.55 \pm$ 0.08 points $-2.35 \pm 0.12$ points.

This indicates a low level of hygienic education of primary school children 6-8 years and insufficient awareness of parents of children of primary school (2-5 years), which requires active forms of work on hygiene training in order to develop sustainable skills of systematic oral care. In the groups of children aged 9-11 and 12-14 with acute lymphoblastic leukemia in the first acute period in $10.4 \%$ of subjects oral hygiene was "good". 63.3\% of children have a "satisfactory" hygienic condition of the oral cavity, and "unsatisfactory" - in $26.3 \%$. The OHI-S hygiene index was $1.4 \pm 0.07$ points, and Silness-Loe $-1.77 \pm 0.09$ points.

However, with age, oral hygiene has improved. Thus, in the age group of 15-18year-old children, the hygienic indices OHI-S and Silness-Loe corresponded to $1.3 \pm$ 0.07 points and $1.55 \pm 0.08$ points. At the same time, only $15.3 \%$ of children had oral hygiene "unsatisfactory", and $82.4 \%$ and $2.3 \%$ were defined as "satisfactory" and "good", respectively.

These data from the study of the hygienic condition of the oral cavity indicate that in children aged 15-18 years unsatisfactory numerical values of the hygiene index were the lowest, and satisfactory and good - the highest, which is associated, in our opinion, with a conscious understanding of the meaning of those actions. which the child does to improve his health, and these children were more responsible compared to younger schoolchildren and preschoolers in performing hygienic measures.

A similar trend was observed in groups of children with acute lymphoblastic leukemia during disease recurrence (Table 3).

Table 3

The state of oral hygiene in children with acute lymphoblastic leukemia in the

\begin{tabular}{|c|c|c|}
\hline \multicolumn{2}{|c|}{} & relapse, $\mathrm{M} \pm \mathrm{m}$ \\
\hline Age of children & OHI-S (points) & Silness-Loe (points) \\
\hline $2-5(\mathrm{n}=6)$ & $2,5 \pm 0,13$ & $2,48 \pm 0,13$ \\
\hline $6-8(\mathrm{n}=5)$ & $2,4 \pm 0,12$ & $2,37 \pm 0,12$ \\
\hline $9-11(\mathrm{n}=3)$ & $1,6 \pm 0,08$ & $1,97 \pm 0,10$ \\
\hline $12-14(\mathrm{n}=5)$ & $1,5 \pm 0,08$ & $1,81 \pm 0,09$ \\
\hline $15-18(\mathrm{n}=5)$ & $1,4 \pm 0,07$ & $1,59 \pm 0,08$ \\
\hline
\end{tabular}

Thus, according to the OHI-S and Silness-Loe index in children 2-5 years with acute lymphoblastic leukemia during recurrence, the indicators were the worst and amounted to $2.5 \pm 0.13$ points and $2.48 \pm 0.13$ points in children primary and secondary school 
age - from $1.5 \pm 0.08$ to $2.4 \pm 0.12$ points was the Green Vermilion index and $1.81 \pm$ $0.09-2.48 \pm 0.13$ points - the index of Silness- Loe, in children 15-18 years $-1.4 \pm$ 0.06 points and $1.59 \pm 0.08$ points, respectively.

However, analyzing the numerical values of hygienic indices obtained in children with acute lymphoblastic leukemia in remission, it is possible to conclude that the number of children with poor hygiene was lower compared to groups of children of the first acute period and recurrence of acute lymphoblastic leukemia (Table 4).

Table 4

The state of oral hygiene in children with acute lymphoblastic leukemia in the

\begin{tabular}{|c|c|c|}
\hline \multicolumn{2}{|c|}{} & \multicolumn{2}{r|}{ remission, $\mathrm{M} \pm \mathrm{m}$} \\
\hline Age of children & OHI-S (points) & Silness-Loe (points) \\
\hline $2-5(\mathrm{n}=8)$ & $2,1 \pm 0,11$ & $2,27 \pm 0,12$ \\
\hline $6-8(\mathrm{n}=5)$ & $1,8 \pm 0,09$ & $2,01 \pm 0,10$ \\
\hline $9-11(\mathrm{n}=4)$ & $1,4 \pm 0,07$ & $1,52 \pm 0,08$ \\
\hline $12-14(\mathrm{n}=5)$ & $1,2 \pm 0,06$ & $1,37 \pm 0,07$ \\
\hline $15-18(\mathrm{n}=9)$ & $1,1 \pm 0,06$ & $1,22 \pm 0,06$ \\
\hline
\end{tabular}

Conclusions. 1. Thus, studies of the hygienic condition of the oral cavity show that in children with acute lymphoblastic leukemia, on average, the hygienic index corresponds to "bad" in preschool (2-5 years) and primary school age (6-8 years). Adolescents have a tendency to improve the hygienic care of the front group of teeth. However, a large number of children at this age, who have an unsatisfactory hygienic condition of the oral cavity and are at risk of lesions in both the hard tissues of the teeth and periodontal tissues, are alarming.

2. In addition, the numerical values of hygienic indicators OHI-S and Silness-Loe depend not only on the age of the child, but also on the period of the clinical course of leukemia. Thus, the lowest values of the indicators characterizing the hygienic condition in the oral cavity are found in children in remission, and high - against the background of recurrence of acute lymphoblastic leukemia, which is associated, in our opinion, with severe general condition and oral pain in this contingent. children. We link the stability of the importance of hygienic indicators even in the stage of remission of acute lymphoblastic leukemia with the negative impact of chemotherapy on the hygienic condition of the oral cavity of these children.

3. The data obtained as a result of dental examination and examination indicate the need for preventive measures aimed at improving oral hygiene, reducing the prevalence and intensity of dental caries, periodontal disease in all age groups of children with acute lymphoblastic leukemia.

\section{References:}

1. Менткевич Г.Л. Лейкозы у детей / Г.Л. Менткевич,С.А. Маякова. Москва: Практ. медицина, 2009. - 384c.

2. Чехун В.Ф. Злокачественные новообразования гемопоэтической системы 
/ В.Ф. Чехун. - Киев: Доктор Медиа,2012. - 590с.

3. Мамаев Н.Н. Гематология. Руководство для врачей / Н.Н Мамаев. - 2-е изд. доп. и испр. - СПб.: Спец. лит., 2011. -615с.

4. Дементьева И.И. Патология системы гемостаза: руководство/ И.И. Дементьева, М.А Чарная., Ю.А. Морозов. - Москва: ГЭОТАР-Медиа, 2011. $288 \mathrm{c}$.

5. Вейнер М.А. Секреты детской онкологии и гематологии / М.А. Вейнер, М.С. Кейро. - Москва: Бином, Диалент 2008. - 272c.272c.

6. Заболевания эндодонта, пародонта и слизистой оболочки полости рта / под. ред..проф. А.К. Иорданишвили. - Москва: МЕДпресс-информ, 2008. - 344с.

7. Гусева С.А. Болезни системы крови / С.А. Гусева. - Москва: МЕДпрессинформ, 2004. - 488c. 


\title{
TREATMENT OF PERIODONTAL TISSUE DISEASES IN PATIENTS WITH URINARY SYSTEM PATHOLOGY WITH AN IMPROVED SCHEME
}

\author{
Kilmukhametova Yuliia \\ Assistant Professor of Department of \\ Therapeutic Dentistry of \\ Bukovinian State Medical University
}

The aim of the study. Study of the effectiveness of our proposed scheme of treatment of periodontal tissues in patients with pathology of the urinary system comparing to a traditional scheme.

Research methods. The study involved 72 patients with pathologies of the urinary system: glomerulonephritis, pyelonephritis and urolithiasis. They were divided into 2 groups: basic and comparison. The first group received our treatment, which consisted of professional hygiene and subsequent application of a combination of ointments of Thiotriazoline and Zinc Oxide, and rinsing with $0.05 \%$ solution of Chlorhexidine bigluconate for 5 days. The traditional treatment consisted of professional oral hygiene and rinsing with $0.05 \%$ chlorhexidine bigluconate solution twice a day for 5 days. Patients before and after treatment were examined and indexed. In patients with a complex of antioxidant drugs, the results were better than in patients who underwent traditional treatment of periodontal tissues.

Scientific novelty. Periodontal tissue pathology is one of the predominant groups of diseases of the oral cavity, so the problem of their treatment or prevention is quite relevant. Periodontal diseases in patients with pathology of the urinary system to date are studied insufficiently. There are not enough studies about the causes, features of the course, treatment and prevention of periodontal pathologies in this group of patients. Therefore, the development of new or improvement of existing treatment regimens in patients with diseases of the urinary system is of considerable interest to both scientists and practitioners.

Conclusions. Our results showed that our proposed scheme of treatment of periodontal tissues in patients with pathologies of the urinary system is more effective than traditional treatment. This was proved by statistical data: the indexes of the main group were better than those of the group of comparison.

\section{References:}

1. Bandrivskyi Yu.L., Bandrivska N.N., Avdieiev O.V. (2008) Vzaiemozv'iazok zakhvoriuvan parodontu iz somatychnoiu patolohiieiu [The connection between periodontal disease and major systemic diseases].Galician Medical Journal. [in Ukrainian]. 
2. Barylo O.S., Skliaruk N.V., Tsaryk N.P. (2014). The features of condition of periodontium and oral hygiene in patients with chronic parodontitis on a background of chronic tonsillitis.Reports of Vinnytsia national medical university.

3. Godovanets O.I., Moroz A.V. (2015). Dental pathology in children with endocrine diseases.Clinical and experimental pathology.

4. Goncharuk L.V., Kosenko K.N.,Goncharuk S.F. (2011). Relationship of inflammatory periodontal diseases and somatic pathology. Sovremennaja stomatologija.

5. Kashivska R.S., Rozhko M.M. (2015). The changes in total protein level in blood serum and oral fluid of the patients during the treatment of generalized periodontitis combined with chronic liver diseases .Ukrainian dental almanac.

6. Kuzniak N.B., Godovanets O.I., Goncharenko V.A. (2013). Stomatological morbidity in children with endocrine pathology. Clinical and experimental pathology.

7. Kulyhina V.M., Levytska O.V. (2008) Rezultaty obstezhennia klinichnoho stanu ta hihiieny rotovoi porozhnyny khvorykh na dysbakterioz kyshkivnyka [Results of examination of the clinical condition and hygiene of the oral cavity of patients with intestinal dysbiosis]. Proceedings of the III(X) annual meeting of Ukrainian dental association "Innovative technologies for dental practice"; 2008 Oct 16-18; Poltava. Poltava: "Divosvit". [inUkrainian].

8. Manashchuk N.V., Chorniy N.V., Shmanko V.V. (2011). Interconnection between periodontium pathology and pathology of gastrointestinal tract. Clinical Dentistry.

9. Khomenko L.O., Marushko Yu.V., Moskovenko O.D., Duda O.V. (2015). Relationship of inflammatory periodontal tissues and somatic diseases in children. Literature rewiew. Novyny stomatolohii.

10. Tomashevskyi Ya.I., Andrushko V.T., Bumbar O.I., Tomashevska N.Ya., Bumbar Z.O., Milkosh L.Ya. (2013). Study of bioethical aspects of genetic susceptibility of people to diabetes and research optimization for methods to prevent inefficiency disorders (based on the strategy of sustainable development).Scientific bulletin of UNFU.

11. Homenko L.O., Gavrilenko T.I.,Ostapko O.I., Moskovenko O.D., Duda O.V. (2013). Peculiarities of cytokine status in children with chronic catarrhal gingivitis accompanying with somatic pathology. Bulletin of problems in biology and medicine.

12. Samoilenko A.V. (2003). Modern aspects of etiology, pathogenesis and treatment of different clinical variants of generalized periodontitis. Manuscript.Thesis for a doctor's degree by speciality 14.01.22 - stomatology. Institute of Stomatology of AMS of Ukraine, Odesa.

13. Shylivsky I.V., Nemesh O.M., Vaskiv N.B. (2006). Osoblyvosti klinichnoho perebihu heneralizovanoho parodontytu u khvorykh na sechokam'ianu khvorobu 
[Clinical features of generalized periodontitis in patients with urolithiasis]. Praktichna medicina. [inUkrainian].

14. Shylivskyi I.V., Nemesh O.M., Honta Z.M. (2016). Modern concepts of etiology and pathogenesis of inflammatory periodontal diseases, the irrelationship with pathology of urinary system (review of the references and author's own researches). Buk. Med. Herald.

15. Moshel T.M. (2008). Mikrobiolohichne obgruntuvannia zastosuvannia novoho sposobu likuvannia heneralizovanoho parodontytu u khvorykh z khronichnymy kholetsystpankreatytamy [The microbiological ground of application of new treatment method of marginal periodontitis in patients on a background of chronic cholecystopancreatitis]. World of medicine and biology. [inUkrainian]. 


\title{
ASSESSMENT OF THE PSYCHO-EMOTIONAL STATE OF NURSES IN A COVID-19 PANDEMIC
}

\author{
Smolen Yuliana, \\ Student of Bukovinian State Medical University
}

Tokar Olesia,

Student of Bukovinian State Medical University

Vakharyk Nataliia

Student of Bukovinian State Medical University

Loryna Ivanova

$\mathrm{PhD}$, Associate Professor of Department of Pediatrics and Children Infectious Diseases of Bukovinian State Medical University

\begin{abstract}
Drucul-Melnyk Natalia
postgraduateof Department of Pediatrics and Children Infectious Diseases of Bukovinian State Medical University
\end{abstract}

The COVID-19 pandemic has increased the burden on the health care system worldwide. Higher workloads contribute to mental health problems among healthcare professionals. Working in a pandemic, the need to be constantly in a protective suit, the risk of getting sick - all this negatively affects the psycho-emotional state of health workers. However, nurses working in coronavirus departments rarely seek psychological help. Their fears are largely related to the loss of career prospects and stigmatization in society. As a result, it leads to natural consequences: chronic stress seriously affects physiological health and can lead to depression and anxiety disorders.

The aim is to study the impact of the COVID-19 pandemic on the psychoemotional state of nurses working in wards for patients with coronavirus infection, based on the study of meta-analysis and systematic reviews.

Results. Recent work [1-4] indicates that more than $40 \%$ of health professionals in the UK report mental health problems caused by a coronavirus pandemic. They claimed that they were feeling worse than before the quarantine restrictions. In October $2020,6,610$ health workers working across the country were interviewed. More than $40.0 \%$ of them said that at the time of the survey they experienced the following symptoms: stress, signs of burnout, depressive disorders, anxiety, emotional disorders and other mental disorders associated with working conditions during the pandemic. $12.0 \%$ of workers said they had some mental health problems, but they also had a pandemic. 39\% of respondents said that before the quarantine and pandemic they had no mental problems. $6 \%$ of respondents said they prefer not to say so. Also, according to the survey, it turned out that $72 \%$ are not sure that social services will be able to cope with the problem. 
In the United States, according to The American Psychological Association (APA), almost half of those surveyed reach severe levels of anxiety, with $40 \%$ fearing that they or their loved ones may become seriously ill and die of COVID-19 [5-6].

In connection with the above, in the current situation, health workers, both in outpatient practice and in the hospital need more attention from doctors, including sanitary and educational work to explain the need to adhere to the regime of selfisolation and preventive measures sanitary and hygienic measures. In addition, measures should be taken to counteract the negative psychological pressure of the media, including panic and misinformation on the current situation of coronavirus infection.

Conclusion. One of the reasons for the sharp increase in the number of clinical cases of mental disorders among health workers in a pandemic was the forced restriction of access to qualified psychological care. In these conditions, the only way out is urgent establishment in psychiatric services of telemedicine (telepsychiatry) and remote video communication with the patient [7-8]. The first positive experience of its use and even cognitive-behavioral psychotherapy for the treatment of depression and anxiety disorders during the COVID-19 epidemic in China, South Korea and the United States has already been accumulated [9-11]. Such support has been especially important and effective for nurses working directly in the epidemic center with infected patients [12].

Another practical problem that needs to be addressed as soon as possible is the selection of effective psychopharmacological agents for the treatment of mental disorders, taking into account the need for their combination with antiviral drugs in somatically debilitated COVID-19 patients [5].

Key words: COVID-19, pandemic, mental health, nurses.

\section{References:}

1. Brooks SK, Webster RK, Smith LE, et al. The Psychological Impact of Quarantine and How to Reduce It: Rapid Review of the Evidence. Lancet. 2020 Mar 14;395(10227):912-20. doi: 10.1016/S0140- 6736(20)30460-8. Epub 2020 Feb 26.

2. Courtet P, Olie E, Debien C, Vaiva G. Keep socially (but not physically) connected and carry on: preventing suicide in the age of COVID-19. J Clin Psychiatry. 2020 Apr 14;81(3):20com13370. doi: 10.4088/JCP.20com13370

3. Li W, Yang Y, Liu ZH, et al. Progression of Mental Health Services during the COVID-19 Outbreak in China. Int J Biol Sci. 2020 Mar 15;16(10):1732-8. doi: 10.7150/ijbs.45120. eCollection 2020.

4. Liu N, Zhang F, Wei C, et al. Prevalence and predictors of PTSS during COVID-19 Outbreak in China Hardest-hit Areas: Gender differences matter. Psychiatry Res. 2020 May;287:112921. doi: 10.1016/j.psychres.2020.112921. Epub 2020 Mar 16.

5. Kostyukova EG, Malin DI, Mosolov SN, Tsukarzi EE. Lekarstvennaya terapiya lits s psikhicheskimi rasstroystvami, zabolevshikh koronavirusnoy infektsiyey (COVID-19). Informatsionnoye pis'mo Drug therapy for people with mental disorders who contract coronavirus infection (COVID-19). Information mail. Moscow; 2020. 14 p. Available from: https://psychiatr.ru/news/1116 (In Russ.)]. 
6. Mosolov SN. Mental health problems in the context of the COVID-19 pandemic. Zhurnal nevrologii i psikhiatrii im. S.S. Korsakova. 2020;120(5):7-15. doi: 10.17116/jnevro20201200517 (In Russ.).

7. Agamamedova IN, Bannikov GS, Keshchyan KL, et al. Psikhicheskiye reaktsii i narusheniya povedeniya u lits s COVID-19. Informatsionnoye pis'mo [Mental reactions and behavioral disorders in persons with COVID-19. Information mail. Moscow; 2020. 9 p. Available from: https://www.elibrary.ru/ item.asp?id=42724333 (In Russ.)].

8. Sorokin MYu, Kas'yanov ED, Rukavishnikov GV, et al. The structure of anxious experiences associated with the spread of COVID-19: data from an online survey. Vestnik RGMU. 2020;(3). doi: 10.24075/vrgmu.2020.030 (In Russ.)].

9. Garriga M, Agasi I, Fedida E, et al. The role of Mental Health Home Hospitalization Care during the COVID-19 pandemic. Acta Psychiatrica Scandinavica. 2020 May;141(5):479-80. doi: 10.1111/acps.13173

10. Goldberg JF. Psychiatry's niche role in the COVIDE19 pandemic. J Clin Psychiatry. 2020 Apr 7;81(3):20com13363. doi: 10.4088/JCP.20com13363

11. Lai J, Ma S, Wang Y, et al. Factors Associated With Mental Health Outcomes Among Health Care Workers Exposed to Coronavirus Disease 2019. JAMA Netw Open. 2020 Mar 2;3(3):e203976. doi: 10.1001/jamanetworkopen.2020.3976.

12. London RT. Is COVIDE19 leading to a mental illness pandemic? Presented by ID PracEtitioner in MDedge Infectious disease [published online March 25, 2020]. Available from: https://www.mdedge.com/infectiousdisease/article/219612/coronavirusEupdates/ covidE19EleadingEmentalEillnessEpandemic?f bclid (accessed April 4, 2020). 


\title{
THE IMMUNE-REGULATORY ROLE OF THE INTESTINAL MICROBIOME AND MYCOBIOME IN AGING.
}

\author{
Urazova Saltanat Nurgozhaevna, \\ Doctor of Medical Sciences, Professor \\ Department of Family Medicine №3 \\ NJSC "Astana Medical University, Nur-Sultan
}

\author{
Akpanova Saniya Kudaybirgenovna, \\ Master of Medicine \\ Department of Family Medicine №3 \\ NJSC "Astana Medical University, Nur-Sultan
}

Physiological aging of the body is accompanied by a serious functional and organic restructuring of the digestive system and all other life support systems: cardiovascular, respiratory, nervous, endocrine, immune, etc. In old age, the digestive organs undergo functional and structural changes, which allows the gastrointestinal tract to adapt to the changing conditions of life and activity of the body. The phenomena of impaired coordination and reduced efficiency of the nervous, hormonal, immune and other parts of the regulation of their main functions are developing.

In most studies devoted to the study of the features of the qualitative and quantitative composition of the resident intestinal microflora, it was noted that in elderly people there is a decrease in the quantitative content of bifidobacteria and lactobacilli. Bifidobacteria and lactobacilli are among the important and useful types of the large intestine. A decrease in the number of bifidobacteria is one of the most significant changes in the intestines in old age. Such a decrease can lead to inhibition of immune reactions in the intestine, a decrease in colonization resistance and an increased susceptibility to the development of gastrointestinal infections [1].

In the aging process, the variation of the intestinal microbiome plays a key role, which is facilitated by the nutrition, genetics and lifestyle of older people. In this regard, the study of the intestinal microbiome/mycobiome of long-lived people can lead to an understanding of how, with an increase in life expectancy, the intestinal microbiota adapts to changes and contributes to the maintenance of metabolic and immunological homeostasis of the body, as well as supports qualitative aging and increases the survival of the body.

Changes in the immune system associated with age are interconnected by inflammation and aging, which can explain and cause some aspects of aging. As it is known, $80 \%$ of immunity is contained in the intestines, so the intestinal microbiome and mycobiome play an important role in the immunological theory of aging. At the same time, the main factor in determining health is nutrition, which is directly related to the intestines [2]. 
The intestines are not only a digestive organ, but also an organ that reacts to everything coming from outside, it is autoflora, medicines, etc. When studying the immune theories of aging, the role of intestinal local immunity remains poorly understood. Due to the increase in the average life expectancy of the population, the study of factors leading to the development of longevity remains an urgent topic today.

However, despite numerous studies concerning the study of the immune status of centenarians, to date there is no data on changes in local immunity. To date, no correlation analysis of the local and general immune status has been carried out. Therefore, the study of local intestinal immunity in people over 95 years of age will become a promising area in the study of the immune-regulatory mechanism of aging, where the intestinal microbiome and mycobiome play an important role.

As is known, almost $99 \%$ of the microbiome is accounted for by the bacterial composition, along with this there is the concept of "mycobiomes", they can interact with other communities of microorganisms [3]. But to date, there is poorly studied and insufficient information about the origin of the fungal community, how they change in the vital activity of the body and how they affect age-related changes, i.e. whether they have a useful and harmful function for the body. The fungal component of the microbiome plays a significant role in maintaining the microbial community. Hoffmann et al. conducted studies in the study of the relationship between nutrition and the mycobiome, in which 66 genera of fungi were identified, among which fungi of the genus Ascomycota or Basiodiomycota predominated. In $30 \%$ of the samples, Methanobrevibacter was the most common [4]. According to HMP (Human Microbiome Project, Houston, Texas), the intestinal microbiome was dominated by a population of yeast Saccharomyces, Malassezia and Candida [5].

To study why and how people age at different rates, it is necessary to determine the main indicators / biomarkers of the healthy aging process. This is the only way to distinguish the phenomenon of aging from the processes caused by various diseases that are usually associated with the aging process.

One of these markers is the p16 protein, which is encoded by the CDKN2A gene. Its concentration increases with aging. According to a recent study conducted in London, the expression of certain genes increases with aging. The study was conducted on young patients aged 27 to 60 years and elderly patients aged 70 to 89 years. A quantitative PCR analysis was performed using the ascending and descending sections of the colon (without the mucous membrane). The genes were tested in this area. The CDKN2A gene (encoding P16) was elevated in both areas of the colon. The concentration of such genes as ATG5, GPX1, PINK1 and VEGFB was also increased. As a result, changes were identified.

Currently, there is no "gold standard" for the process of cellular aging or healthy aging of the body. The biomarkers described in the literature do not meet all the criteria of an ideal biomarker of aging and actually represent various signs of the aging process. Most biomarkers that are currently being studied as biomarkers of aging are associated with age-related diseases, and not with the process of healthy aging. In addition, a combination of several biomarkers should be used. Their detection, in particular, quantitative assessment and validation, are necessary for understanding the aging processes (diagnostic biomarkers), monitoring the aging rate (prognostic) and the 
possible use of appropriate therapeutic intervention (pharmacodynamic biomarkers). Identification and selection of reliable biomarkers, as well as the use of reproducible methods can help to better understand the complex network of aging processes. Despite new discoveries at the cellular and molecular level, the understanding of the aging process is still limited [6].

\section{References:}

1. Enriched taxa were found among the gut microbiota of centenarians in East China, Na Wang, Rui Li, Haijiang Lin, Chaowei Fu, Xuecai Wang, Yiming Zhang, Meifang Su, Peixin Huang, Junhua Qian, Feng Jiang, Hexing Wang, Lufang Jiang, Xin Yu, Jianxiang Liu, Yue Chen, Qingwu Jiang; PLoS ONE 14(10): e0222763. https://doi.org/ 10.1371/journal.pone.0222763

2. Age-Associated Changes in Gut Microbiota and Dietary Components Related with the Immune System in Adulthood and Old Age: A Cross-Sectional Study, Nuria Salazar, Silvia Arboleya, Tania Fernández-Navarro, Clara G. de los Reyes-Gavilán, Sonia Gonzalez and Miguel Gueimonde, Nutrients. 2019 Aug; 11(8): 1765, 2019 Jul 31. doi: $10.3390 /$ nu11081765

3. Metagenomics Study Reveals Changes in Gut Microbiota in Centenarians: A Cohort Study of Hainan Centenarians, Zhe Luan, Gang Sun, Yun Huang, Yunsheng Yang, Ruifu Yang, Congyong Li, Tingting Wang, Di Tan, Shirui Qi, Chen Jun, Cong Wang, Shufang Wang,Yiming Zhao, and Yujia Jing, Front Microbiol. 2020; 11: 1474. doi: 10.3389/fmicb.2020.01474

4. Hoffmann C, Dollive S, Grunberg S, Chen J, Li H, Wu GD, Lewis JD, Bushman FD. 2013. Archaea and fungi of the human gut microbiome: Correlations with diet and bacterial residents. PLoS ONE 8: e66019.

5. Nash AK, Auchtung TA, Wong MC, Smith DP, Gesell JR, Ross MC, Stewart CJ, Metcalf GA, Muzny DM, Gibbs RA, Ajami NJ, Petrosino JF. 2017. The gut mycobiome of the Human Microbiome Project healthy cohort. Microbiome 5:153. doi:10.1186/s40168-017-0373-4.

6. Senescence-like activity within myenteric neurons of the aged colon: a potential marker of declining function, Alexandra Palmer, Sarah Epton, Ellie Crawley, Luke Gammon, Meghan M. Edgar, Yichen Xu, Shezan Elahi, Joanne Chin-Aleong, Joanne E. Martin, Cleo L. Bishop, Charles H. Knowles, Gareth J. Sanger, Aging Cell 2020 Jul 4, 3-11 


\section{РЕГЛАМЕНТАЦІЯ ФОСФАТНИХ ПОМ'ЯКШУВАЧІВ У СКЛАДІ СИНТЕТИЧНИХ МИЙНИХ ЗАСОБІВ: ЕКОЛОГІЧНИЙ АСПЕКТ ПРОБЛЕМИ}

Головащенко Ганна, старший науковий співробітник Державного підприємства «Науковий центр превентивної токсикології, харчової та хімічної безпеки імені академіка Л.І. Медведя Міністерства охорони здоров’я України», м. Київ, Україна

\section{Калашніков Андрій,} доктор медичних наук, професор, провідний науковий співробітник Державного підприємства «Науковий центр превентивної токсикології, харчової та хімічної безпеки імені академіка Л.І. Медведя Міністерства охорони здоров'я України», м. Київ, Україна

Курділь Наталія, кандидат медичних наук, заступник директора Державного підприємства «Науковий центр превентивної токсикології, харчової та хімічної безпеки імені академіка Л.І. Медведя Міністерства охорони здоров’я України», м. Київ, Україна

Вступ. Не викликає сумнівів той факт, що фосфати в складі мийних засобів (М3) сприяють розвитку негативних процесів у водному середовищі: збільшують об'єм поживних речовин і прискорюють розвиток водоростей та інших форм рослин, що призводить до евтрофікації - порушення балансу водних організмів, тому складно переоцінити важливість міжнародних ініціатив 3 розробки регламентуючих заходів із забезпечення високого рівня захисту навколишнього середовища від можливих негативних наслідків використання фосфатів у складі M3.

Мета. Узагальнення існуючих підходів до регламентації безпечного застосування фосфатних з'єднань у складі МЗ на прикладі регламентуючих документів країн Європейського Союзу (ЄС); аналіз показників, які враховуються в процесі оцінки екологічного ризику та обгрунтування необхідності впровадження регламентів безпеки.

Матеріали і методи дослідження: нормативно-правові і регламентуючі документи ЄС та України з питань екологічної безпеки і обмеження використання фосфорних з'єднань в побутових МЗ; методи системного i порівняльного аналізу.

Результати дослідження. Основним документом, що регламентує безпечність використання синтетичних М3, в тому числі для навколишнього середовища в країнах ЄС $є$ Регламент (ЕС) №648/2004 Європейського Парламенту та Ради Європи [1]. Однак, у зв'язку з розвитком евтрофікації, 
Комісією розроблено пропозицію про поетапну відмову або обмеження фосфатів. Безумовно, введення на європейському рівні обмеження використання фосфорних з'єднань в побутових МЗ зменшує вклад фосфатів в ризик евтрофікації водойм країн ЄС і знижує вартість видалення фосфору на очисних спорудах. Разом з тим, існують інші (не фосфатні) пом'якшувачі води, але їх використання, як правило, має різні обмеження, особливо при необхідності особливо якісного очищення. Обмеження фосфатів є економічно доцільнішим заходом, ніж введення до складу побутових МЗ альтернативних пом'якшувачів. Обмеження в СС застосування фосфатів для посудомийних машин і засобів промислового і громадського використання в даний час не виправдано, тому що альтернативні варіанти, як правило, не можуть задовольнити технічні вимоги, що пред'являються до якості і ефективності очищення. Таким чином, при відсутності в даний час прийнятних технічних і економічних альтернатив для заміни фосфатів у всіх типах МЗ, крім засобів для прання, і з огляду на те, що саме ці засоби є основною складовою загального навантаження фосфоровмісних сполук, запропоновано не обмежувати вміст фосфатів в інших типах М3 [2].

Слід зазначити, що в складі М3 3 альтернативними фосфатам пом'якшувачами можуть бути інші сполуки, що містять фосфор, наприклад фосфонати, які розкладаються дуже повільно та можуть створювати ризик для оточуючого середовища (хронічна токсичність для дафній, накопичення у донному осаді). Науковий комітет по токсичності, екотоксичності та навколишньому середовищу, дійшов висновку, що використання цеолітів не призведе до токсикологічних або екотоксикологічних проблем, проте існує рекомендація приділяти більше уваги до екотоксикологічних чинників.

Згідно з остаточним звітом, підготовленим для Європейської Комісії компанією Risk \& Policy Analysts Limited (англ., Final Report - June 2006 prepared for the European Commission by Risk \& Policy Analysts Limited (RPA), встановлені ризики для інших компонентів мийних засобів [3]. Так, ЕДТА та його солі можуть впливати на оточуюче середовище, з урахуванням їх використання у виробничій сфері, але не для побутових мийних засобів (там їх використання обмежено). Крім прямого ризику існує можливість мобілізації металів в придонних відкладеннях та грунтах, що призводить до забруднення поверхневих та грунтових вод (для розчинних ЕДТА). Нітрилотриоцтова кислота, хоч і не несе великого навантаження для оточуючого середовища, однак, іiі присутність в мийному засобі (як і для ЕДТА) виключає можливість надання знаку екологічної безпеки в зв язку з ii потенційною канцерогенністю, так тринатрієва сіль нещодавно була класифікована як канцероген - категорія 3 (R40), що обумовлює необхідність досліджень ризику тринатрієвої солі для здоров`я людини та обговорення цього питання на рівні країн СС.

Враховуючи серйозні наслідки для оточуючого середовища і подальший вплив на здоров'я людини у багатьох країнах Європи, Канаді, США уже відмовилися або обмежили застосування в побуті фосфатних МЗ, посилаючись на Регламент (ЕС) № 648/2004 Свропейського Парламенту та Ради Свропи. Серед документів $\mathrm{CC} є$ окрема група, яка визначає основні положення 3 посилення заходів захисту здоров'я людини i охорони навколишнього 
середовища, наприклад - рішення Комісії від 28.11.2011 р. про встановлення екологічних критеріїв для присудження маркування «ЕC Ecolable». Цей знак надається продуктам з пониженим впливом на навколишнє середовище протягом всього їх життєвого циклу.

Критеріями відбору препаратів для присудження продукції знаку екологічної безпеки $є$ мінімальний вплив на водні екосистеми, обмежений вміст небезпечних речовин, попереднє тестування експлуатаційних характеристик, скорочення споживання енергії при використанні для прання низьких температур. Всі компоненти рецептури, концентрація яких перевищує $0,01 \%$ маси препарату, повинні відповідати екологічним критеріям. Для консервантів, барвників i ароматизаторів відповідність критеріям необхідно визначати незалежно від їх концентрацій. Токсичність критичного обсягу розведення розраховується за формулою, в якій враховується доза речовини, фактор деградації і фактор токсичності. Для продукції, що $є$ екологічно безпечною, встановлюється також межа вмісту речовин, які чинять спротив аеробному i анаеробному біохімічному розкладу. В засобах, які мають знак «EC Ecolable», не повинні бути присутніми фосфати, ЕДТА і інші інгредієнти, позначені в переліку небезпечних факторів відповідно до статті 57 Регламенту СС №1907/2006. Також введені спеціальні правила до упаковки, що виражаються в дотриманні співвідношень вага/корисність і спрямовані на зниження утворення відходів [4].

Основні показники, які повинні контролюватися відповідно до сертифікаційної системи «Blue Angel» такі: вміст відновлюваної сировини в поверхнево-активних речовинах; здатність органічних речовин продукту розщеплюватись; ступінь токсичної дії на водні організми; вміст біоцидів, ароматизаторів, барвників, летких органічних речовин, фосфатів, ферментів; вміст речовин, які викликають особливе занепокоєння (англ., A substance of very high concern- SVHC); вміст речовин, які відповідно до критеріїв Регламенту (СC) № 1272/200810, відносяться до H/P phrases (Health and safety): токсичні речовини (H300, H301, H304, H310, H311, H330, H331, EUH070, H370, H371, H372, H373); канцерогенні, мутагенні та репродуктивно токсичні речовини (H340, H341, H350, H350i, H351, H360F, H360D, H360FD, H360Fd, H360Df, H361f, H361d, H361fd, Н362); водонебезпечні речовини (H400, H410, H411, Н412, Н413); небезпечні речовини для озонового шару (Н420); сенсибілізуючі речовини (H334, H317) [5].

В Україні діє «Технічний регламент мийних засобів», який обмежує загальний вміст фосфатів та інших сполук фосфору в мийних засобах. Так, ліміт вмісту фосфору встановлено на рівні 0,5 грама в рекомендованій кількості та/або дозуванні прального порошку для використання в основному циклі процесу прання у жорсткій воді для стандартного завантаження пральної машини в побутових засобах для прання, ця норма введена в дію через 12 місяців з дня набрання чинності Постанови Кабінету Міністрів України від 12.06.2013 р. № 408 [6]. Документом передбачено, що з 01.01.2017 року загальний вміст фосфору в мийних засобах для побутових посудомийних машин не повинен становити чи перевищувати 0,3 грама в стандартній дозі мийного засобу для використання в 
основному циклі миття для завантаження посудомийної машини столовим набором на 12 персон.

В проекті доповнень до Технічного регламенту викладено і узгоджено графік обмеження вмісту фосфору в мийних засобах - додаток №1 ТР «Обмеження щодо вмісту фосфатів, фосфонатів та інших сполук фосфору в мийних засобах»:

- на мийні засоби для прання загальний вміст фосфору не більше 0,2 г в рекомендованій кількості для використання в основному циклі прання у жорсткій воді для стандартного завантаження пральної машини, при цьому масова частка фосфору в МЗ не повинна перевищувати 0,1 \% з 31 грудня 2023 р. 3 подальшим зменшення до 0,05 \% 331 грудня 2026 р.;

- на МЗ для побутових посудомийних машин - загальний вміст фосфору не більше 0,1 г в стандартній дозі для використання в основному циклі миття 31 грудня 2023 р.;

- на мийні засоби для промислових посудомийних машин - масова частка фосфору в МЗ не повинна перевищувати 0,25 \% - 331 грудня 2023 р. 3 подальшим зменшення до $0,1 \%$ з 31 грудня 2026 р.;

- для МЗ для ручного миття - масова частка фосфору не повинна перевищувати $0,05 \%$ - 331 грудня 2023 р.

Зазначені норми дадуть можливість водоканалам оптимізувати свої витрати та покращать очищення стічних вод, проте треба зазначити, що один 3 найбільш проблемних напрямів такої програми є створення сировинної бази функціонально-технологічних замінників триполіфосфат натрію та інших фосфатів.

Основними альтернативними компонентами фосфатам в наш час $€$ синтетичні алюмосилікати (цеоліти), цитрат натрію, полікарбонат натрію, нітрилотриоцтова кислота (Trilon A), сесквікарбонат натрію (мінерал трони), фосфорити. Найбільш розповсюджені з них - цеоліти. Але вони теж мають ряд суттєвих недоліків: сприяють евтрофікаціїза рахунок крем'янистих водоростей; характеризуються високим вмістом силікатів, сполук алюмінію, аніонних поверхнево-активних речовин; спричиняють погане виполіскування порошку 3 тканини і іï руйнування, негативно впливають на колір текстилю; прання має відбуватися за підвищених температур, що не сприяє енергозбереженню.

Окрім того є ризики, що для досягнення миючого ефекту буде використовуватись більша кількість та концентрації миючих речовин, що може в свою чергу підвищити негативний вплив М3.

Висновки. Не зважаючи на міжнародні ініціативи, що знайшли відображення у Регламенті (ЕС) № 648/2004 Свропейського Парламенту та Ради Європи та інших документах, питання обмеження використання фосфатів у складі МЗ залишається актуальною проблемою, зокрема для України. Сьогодні екологічна безпека М3 є ключовим компонентом у складі багатофакторного несприятливого впливу на здоров'я людини та середовище ії життєдіяльності. Швидкому вирішенню проблеми обмеження фосфатів заважає економічний аспект проблеми - М3, в яких використовуються замінники фосфатів, мають більш високу собівартість i, як наслідок, є менш конкурентоздатними. 


\section{Список літератури:}

1. Regulation (EC) No 648/2004 of the European Parliament and of the Council of 31 March 2004 on detergents. - OJ L 104, 8.4.2004. [Електронний ресурс] - Режим доступу: https://www.legislation.gov.uk/eur/2004/648/annexes.

2. Regulation (EU) No 259/2012 of the European Parliament and of the Council of 14 March 2012 amending Regulation (EC) No 648/2004 as regards the use of phosphates and other phosphorus compounds in consumer laundry detergents and consumer automatic dishwasher detergents Text with EEA relevance. - OJ L 94, 30.3.2012. [Електронний ресурс] - Режим доступу: https://euroalert.net/oj/19294/regulation-eu-no-259-2012-of-the-european-parliamentand-of-the-council-of-14-march-2012-amending-regulation-ec-no-648-2004-asregards-the-use-of-phosphates-and-other-phosphorus-compounds-in-consumerlaundry-detergents-and-consumer-automatic-dishwasher-detergents.

3. Final Report - June 2006 prepared for the European Commission by. Risk \& Policy Analysts Limited (RPA). [Електронний pecypc] - Режим доступу: https://www.google.com/search?q=Final+Report+-+June+2006.

4. Регламент CC №1907/2006 REACH. [Електронний ресурс] - Режим доступу: http://www.reach.ck.ua/ec-regulations/reach-regulation.html.

5. Сертифікаційна система «Blue Angel». Офіційний сайт. [Електронний pecypc] - Режим доступу: https://www.blauer-engel.de.

6. Про затвердження Технічного регламенту мийних засобів: Постанова Кабінету Міністрів України № 717 від 20.08.2008 (зізмінами та доповненнями). [Електронний ресурс] - Режим доступу: http://zakon2.rada.gov.ua/laws/show/7172008-\%D0\%BF. 


\section{ОЦІНКА МАРКЕРІВ ЗАПАЛЕННЯ, ОСОБЛИВОСТЕЙ ОБМІНУ $\mathrm{Mg}^{++}$ТА СТАНУ МІКРОБІОМУ КИШКІВНИКА У ХВОРИХ НА АРТЕРІАЛЬНУ ГІПЕРТЕНЗІЮ 3 СУПУТНІМ ОЖИРІННЯМ}

Мошковська Ю.О.

к.м.н., доцент кафедра внутрішньої медицини №4

НМУ імені О.О.Богомольця

Соболь B.O.

к.м.н., асистент кафедра внутрішньої медицини №4

НМУ імені О.О.Богомольця

Романченко G.C. студентка 6 курсу медичного факультету №2 НМУ імені О.О.Богомольця

Луценко А.O. лікар-інтерн, НМУ імені О.О.Богомольця

Україна та увесь світ сьогодні визначають артеріальну гіпертензію (АГ) як соціальну проблему, яка впливає на здоров'я суспільства та тривалість життя громадян. Дослідження, які проводили за останні десятиліття, вказують на невпинне зростання поширеності та смертності від хвороб системи кровообігу, провідною патологією в їх структурі залишається АГ, частка якої коливається в межах $40-46 \%$, а темпи приросту становлять 58,0\%. За даними експертів Європейського товариства кардіологів/Свропейського товариства гіпертензії (ESC/ESH, Мюнхен, Барселона, 2018), до стійкого підвищення артеріального тиску (АТ) схильні понад 1 млрд людей у світі. Тривалий час в патогенезі артеріальної АГ розглядались переважно фактори, які пов'язані з генетикою та епігенетикою, оточуючим середовищем та чисельними порушеннями гомеостазу (вегетативна нервова система, імунна система, ренін-ангіотензинальдостеронова система). Роль кишкової мікробіоти як самостійного фактора, що сприяє, так і протидіє розвитку АГ, отримала визнання відносно нещодавно. Під кишковою мікробіотою розуміють сумарну кількість мікробів, усіх їх представників (бактерії, гриби, археї, віруси та протозоа), які колонізують шлунково-кишковий тракт свого «господаря». Кишкова мікробіота представлена понад 5000 видів мікроорганізмів, понад 100 трильйонами мікробів, що вдесятеро більше, ніж кількість клітин, з яких складається організм людини. Сумарний вміст геномів мікробіоти (мікробіом) у 150 разів більше, ніж геном 
людини, а його розшифровка визнана одним із десяти найбільших наукових відкриттів XXI століття. Такі обставини спричинили назву кишкової мікробіоти - «забутий орган». Досить часто клічний перебіг АГ супроводжується різними метаболічними порушеннями, i, насамперед, абдомінальним ожирінням. Майже у 40\% хворих на АГ спостерігаться підвищена маса тіла та гіперінсулінемія. Відомими прискорювачами атеросклерозу $є$ інсулінорезистентність, дис- i гіперліпідемії, які розвиваються при дефіциті $\mathrm{Mg}^{++}$[1,с.967]. У ряді досліджень проведено аналіз механізмів впливу дефіциту $\mathrm{Mg}^{++}$на патогенез і прогресування АГ. Несприятливі ефекти дефіциту магнію на серцевосудинну систему відзначають у вигляді підвищення тонусу судин, а також підвищення чутливості до вазоконстрикторних агентів: серотоніну, ангіотензину, норадреналіну, ацетилхоліну. Вазоконстрикція обумовлена збільшенням надходження кальцію всередину клітини при зниженні рівня позаклітинного $\mathrm{Mg}^{++}$. Пацієнти з високим вмістом реніну плазми мали знижений вміст $\mathrm{Mg}^{++}$в плазмі і краще відповідали на додатковий прийом $\mathrm{Mg}^{++}$. Встановлена обернена залежність між рівнем альдостерону і реніну плазми. Це свідчить про те, що низький рівень $\mathrm{Mg}^{++}$ пов'язаний 3 підвищенням активності ренін-ангіотензин-альдостеронової системи, що сприяє в свою чергу розвитку та прогресуванню АГ, виникненню серцево-судинних катастроф [2, с.204;4,с.58]. При досягненні задовільного контролю АГ рівень вільного $\mathrm{Mg}^{++}$нормалізується.

Незважаючи на широку доступність фармакологічних гіпотензивних засобів, результати лікування багатьох пацієнтів на АГ не завжди є втішними, хоча захворювання вважається контрольованим [3]. АГ- це захворювання багатокомпоненетне за своїм патогенезом. Останніми роками увага науковців прикута до ролі кишкової мікробіоти в патогенезі розвитку серцево-судинних захворювань (СС3) та АГ зокрема. Накопичені дані підтверджують, що метаболіти бактерій кишківника здійснюють вагомий внесок в розвиток атеросклерозу, АГ, ожиріння, цукрового діабету, серцевої недостатності. Взаємодія мікробіоти та організму людини-хазяіна опосередкована безліччю механізмів, зокрема, обміном триметил-N-оксиду (ТМАО), коротколанцюгових жирних кислот (КЛЖК), вторинних жовчних кислот (ЖК). ТМАО (продукт окислення в печінці бактеріального метаболіту триметиламіну) збільшує гіперреактивність тромбоцитів, ризик тромбозів, $\epsilon$ предиктором розвитку кардіальних катастроф. КЛЖК та ЖК, які продукуються за участю мікробіоти, здатні впливати на обмін жирів та вуглеводів людини через такі рецептори, як Gбілок, фарнеозидний X-рецептор печінки (FXR). Через FXR здійснюється ауторегеляція синтезу ЖК: при їх зв'язуванні з FXR 19 в тонкому кишківнику людини активується фактор росту фібробластів. Останній через рецептори FGF4/b-Klotho гепатоцитів інгібує холестерол-7- альфа-гідроксилазу, яка відповідає за синтез ЖК. Розмаїття пулу ЖК забезпечується ферментативною активністю мікробіоти. Із первинних ЖК, що синтезуються в печінці (холева, хенодезоксихолева) під дією бактеріальної гідролази утворюються вторинні ЖК (літохолева, дезоксихолева). Останні менш розчинні та гірше всмоктуються зворотньо в кишківнику. При їх надлишковому утворенні та виведенні із організму за механізмом негативного зворотнього зв'язку підвищується синтез 
ЖК de novo, що призводить до зниження концентрації холестерину в плазмі [4,5]. Крім того, FXR пригнічує ліпогенез в печінці, знижуючи експресію транскрипційного фактору SREBP-1, підвищує активність ліпопротеїнліпази, знижує секрецію ліпопротеїнів дуже низької щільності [6]. Ще одним рецептором ЖК є Takeda-рецептор, асоційований з G-белком 5 (TGR5), який експресується на L-клітинах кишківника, клітинах бурої жирової тканини. B останніх аткивація цього рецептора призводить до підвищення витрат енергії через індукцію експресії рецептора тиреоїдних гормонів [7,8]. Мікробіота за рахунок активності бактеріальних ферментів змінює склад пулу жовчних кислот, сприяючи активації/пригніченню активності вищеозначених рецепторів, впливаючи на жировий обмін людини.

Згідно даних експериментальних досліджень на щурах продемонстровано феномен передачі фенотипу АГ в результаті трансплантації фекальної мікробіоти (ТФМ): ТФМ від солерезистентних щурів до солечутливих щурів призводила до підвищення АТ в останніх. Аналогічна ситуація спостерігалась при ТФМ спонтанно гіпертензивних щурів нормотензивним щурам. В дослідженні 2015 poкy Yang та співавтори продемонстрували значне зниження різноманіття мікробіоти у спонтанно гіпертензивних щурів в порівнянні з нормотензивними. При підвищенні АТ виявлено підвищення співвідношення Firmicutes/Bacteroides, зниження кількості бактерій, які продукують КЛЖК, збільшення бактерій, що продукують лактат. За даними літератури роль КЛЖК в патогенезі АГ опосередкована рецепторами Olfr78 та GPR41. GPR41 знаходиться в ендотеліi, його стимуляція призводить до зниження AT. Olfr78 локалізований в приносній артеріолі нефронІв, що відіграє роль в регуляції секреції реніну, а також в гладком'язевих клітинах периферичних судин. Стимуляція рецепторів Olfr78 призводить до підвищення АТ. Відсутність даних рецепторів характризується зниженням рівня реніну в плазмі та гіпотонією. Важливо, що чутливість вказаних рецепторів до КЛЖК різна: для активації Olfr78 потрібне значне підвищення концентрації КЛЖК [9].

B 2017 році Li та співавтори провели дослідження мікробіоти у 99 хворих на АГ [10]. Було виявлено, що пацієнти 3 АГ характеризуються збіднілою за видовим складом мікробіотою з переважанням бактерій філотипу Prevotella, що узгоджується із даними робіт з тваринами. Зниженою виявилась кількість представників філотипів Bacteroidetes, Bifidobacterium, Roseburia та інших продуцентів КЛЖК. Дослідники провели також ТФМ хворим на АГ мишам, в результаі чого спостерігалось підвищення АТ у останніх, що в черговий раз підтверджує участь мікробіоти в регуляції АТ.

На початку 1990-х pp. Hotamisligil і співавт. описали зростання рівня фактору некрозу пухлини (ФНП) у жировій тканині та, навпаки, покращення периферичного захоплення глюкози при нейтралізації ФНП у тваринних моделях ожиріння й діабету. Ця знахідка відкрила нову еру розуміння того, що субклінічний запальний процес запускає й інсулінорезистентність, і метаболічну дисфункцію. СРБ є білком гострої фази, який приймає участь у вроджених імунних реакціях та забезпечує активацію системи комплементу та фагоцитозу. Ймовірно СРБ стимулює могоцити до вивільнення прозапальних цитокінів, 
таких як інтерлейкін-6 (IL-6), интерлейкін-1 бета (IL-1ß) та фактор некрозу пухлини альфа (TNF- $\alpha$, ФНП), а також ендотеліальні клітини до експресії внутрішньоклітинних адгезивних молекул (ICAM-1) та судинних клітинних адгезивних молекул (VCAM1), ефекти яких сприяють подальшому запаленню.

Харрісон та колеги висунули гіпотезу щодо здатності гіпертонічних стимулів сприяти накопиченню активованих Т-клітин в периваскулярній жировій клітковині та нирках. В цих місцях активовані Т-лімфоцити виділяють цитокіни, які впливають на сусідні клітини судин та епітелій канальців нирок. Згідно 3 даними уявленнями цитокіни, що продукуються Т-лімфоцитами та іншими запальними клітинами сприяють розвитку АГ. [11] .

Зважаючи на вище сказане метою нашого дослідження стало вивчення особливостей обміну $\mathrm{Mg}^{++}$, цитокінового статусу та дослідження мікробіоти у хворих на АГ із супутнім ожирінням.

Для здійснення встановленої мети покладено клінічне спостереження 191 хворого на АГ І-ІІ стадій та 1-3 ступенів із супутнім ожирінням, які знаходились на стаціонарному лікуванні у кардіологічному та терапевтичному відділеннях КМКЛ №12. Серед обстежених пацієнтів 170 жінок (89\%) та 21 чоловік (11\%). Середній вік хворих становив $59,09 \pm 6,25$ років. Отримані результати порівнювали 3 даними практично здорових осіб (20 чоловік) репрезентативних за віком та статтю, які формували групу контролю. Для контролю маси тіла використовували індекс маси тіла, окружність талії. Із АГ І ступеня тяжкості було 17 хворих (8,7\%), II ступеня - 115 (60 \%) хворих, III ступеня - 59 (31,1\%) пацієнтів. Середній вік та тривалість захворювання в роках становили в залежності від ступеня тяжкості АГ $39,8 \pm 2,2$ та 2,4 $40,4,48,3 \pm 2,5$ та 10,3 $\pm 1,6$, $53,2 \pm 1,9$ та $18,3 \pm 1,6$ відповідно. Показники систолічного та діастолічного артеріального тисків (САТ і ДАТ) визначали за допомогою апарату Omron M10 (Японія). Реєстрацію САТ та ДАТ в положенні сидячи проводили на одній і тій же руці двічі 3 інтервалом 3-5 хвилин, якщо різниця між вимірами не перевищувала 5 мм.рт.ст. У разі більшої різниці виміри робили тричі та розраховували середнє значення з двох або трьох послідовних вимірів. САТ та

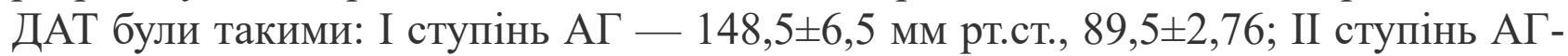
$165,2 \pm 4,38,99,2 \pm 1,70$ мм рт.ст.; III ступінь АГ - 182,1 $\pm 1,60,114,04 \pm 0,16$ мм рт.ст. За результатами багатьох досліджень, значним фактором ризику розвитку уражень органів мішеней, а особливо розвитку гіпертензивного серця $\epsilon$ порушення циркадного ритму серця. Характер циркадного ритму АТ оцінювали за величиною добового індексу (ДІ). Серед хворих на АГ із ожирінням 63 (32,9\%) мали нормальний циркадний ритм АТ, який характеризувався зниженням АТ вночі в межах 10-20\%, вони були віднесені до групи “dipper”, у 83 (43,5\%) хворих відмічалося недостатне зниження АТ вночі, ДІ був менше $10 \%$, віднесені до групи "non-dipper", у 11 (5,9\%) хворих - надмірне зниження (ДІ вищий 20\%, віднесені до групи “over-dipper”), та у 34 (17,7\%) хворих спостерігався підвищений АТ вночі, порівняно з денним, такі хворі мали від’ємні значення ДІ та були віднесені до групи "night-peaker". Maca тіла у хворих на АГ перевищувала масу тіла у групі контролю на 32\%, ІМТ - на 32,8\%, ОТ - на 14,4\%. Пацієнтам був притаманний центральний (абдомінальний) тип ожиріння різного 
ступеня тяжкості. На початку дослідження $76 \%$ хворих не отримували гіпотензивну терапію, 24\% -отримували неадекватну гіпотензивну терапію (переважно у вигляді монотерапіі).

Рівень біометалу $\mathrm{Mg}^{++}$визначали в плазмі крові хворих на АГ із супутнім ожирінням спектрофотометричним методом. Вміст ФНП- $\alpha$ та ІЛ- $1 \beta$ визначали імуноферментним методом та обчислювали в пкг/мл. Дослідження мікробіоти кишківника проводилось шляхом комплексної оцінки бактеріологічного складу біоматеріала $(\mathrm{КУО/Г)} \mathrm{із} \mathrm{визначенням} \mathrm{чутливості} \mathrm{умовно-патогенної} \mathrm{флори} \mathrm{до}$ антибіотиків. Забір матеріала здійснювався вранці і впродовж 2 годин доставлявся в бактеріологічну лабораторію. Дослідження проводилось через 1421 день після відміни прийому антибактеріальних та пробіотичних препаратів. Результати досліджень були оброблені на персональному комп'ютері за допомогою пакету програм Mikrosoft Office. Достовірність відмінностей між середніми значеннями показників різних груп виявлялась за допомогою визначення t- критерію Ст'юдента.

Результати дослідження. В порівнянні 3 групою контролю знайдено підвищення концентрації $\mathrm{Mg}^{++}$в плазмі крові хворих на $\mathrm{A} Г$ із супутнім

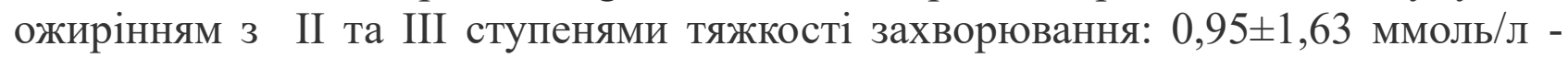

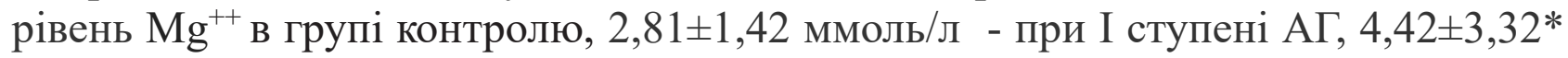
ммоль/л - при II ступені АГ, 4,93 $\pm 5,14 *$ ммоль/л - при III ступені АГ (* достовірна різниця 3 групою контролю $(\mathrm{p}<0,05)$. Аналізуючи отримані дані можна сказати, що в гамі метаболічних порушень при АГ порушення в обміні $\mathrm{Mg}^{++}$відводиться чільне місце. Зростання вмісту $\mathrm{Mg}^{++}$залежно від ступеня тяжкості АГ можна розцінювати як захисну, пристосувальну реакцію спрямовану на запобігання розвитку вазоспастичних реакцій з одного боку, з іншого - на зростання ризику розвитку аритмій за умови зниження вмісту $\mathrm{Ca}^{++}$в плазмі крові. Дослідження цитокінового обміну характеризується недостовірним зростанням ФНП- $\alpha$ у хворих на А $з$ супутнім ожирінням I ступеня тяжкості $(47,4 \pm 3,53$ пкг/мл проти 43,51 33,47 пкг/мл в групі контролю), тоді як при II ступені тяжкості ФНП- $\alpha$ зріс до $117,8 \pm 13,7$ пкг/мл * (p<0,05) в порівнянні з групою контролю та $81,83 \pm 6,43$ пкг/мл становив у хворих на АГ ІІІ ступеню тяжкості $(\mathrm{p}<0,05)$. Вміст ІЛ-1 узгоджується із вмістом ФНП- $\alpha$, і при цьому достовірно підвищений рівень спостерігається у всіх групах хворих: 62,63 $\pm 3,0$ пкг/мл - I ступінь тяжкості,

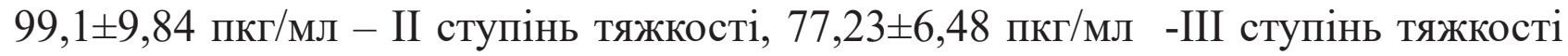
проти 45,34 2,54 пкг/мл в групі контролю. Аналізуючи вміст цитокінів в крові хворих на АГ з супутнім ожирінням враховували факт їх прооксидантного впливу. В дослідженні виявлене достовірне їх зростання в крові хворих на АГ всіх ступенів тяжкості, причому максимальний вміст спостерігався при II ступені тяжкості, а у хворих III ступеня тяжкості ці показники були вищими, ніж у хворих I ступеня тяжкості. Така різниця, можливо, пов'язана з тим, що у хворих на АГ III ступеня тяжкості підвищені показники прооксидантної активності і пов'язано це 3 активацією всіх ферментних систем в результаті порушення функції ендотелію [12].

В фекаліях хворих на АГ виявляли Streptococcus salivarius - в 75\%, Staphylococcus epidermidis - в $62 \%$, Bifidumbacterium - 38\%, Lactobacillus - в 42\%, Bacteroides 
spp. - в 28\%, Staphylococcus aureus - в 15\%, Escherichia coli слабоферментуюча у $8 \%$. В фекаліях групи контролю було виділено Bifidobacterium- у 94\%, Lactobacillus - y 57\%, Staphylococcus epidermidis - в 45\%, Streptococcus salivarius — в 23\%, Staphylococcus aureus - у 6\%, Escherichia coli - в 86\% . Провівши якісний аналіз кишкової мікрофлори хворих на АГ звертає на себе увагу надзвичайно низька частота виявлення Bifidobacterium, Lactobacillus, Escherichia coli в порівнянні з групою контролю. Низький рівень лактобацил, біфідобактерій може призводити до недостатнього вироблення ними газоподібних сполук, таких як $\mathrm{NO}, \mathrm{CO}, \mathrm{H} 2 \mathrm{~S}, \mathrm{H} 2$, які є плейотропними медіаторами, що мають свої мішені в органах серцево-судинної системи. Так, $\mathrm{H} 2 \mathrm{~S}$ має захисний вплив на кардіоміоцити шляхом зниження їх скоротливої активності та активації ангіогенезу. Дисбаланс H2S створює передумови до підвищення АТ. Н2 та СО є потужними антиоксидантами, захищають організм людини від розвитку запалення та ішемії. NO підтримує нормальний судинний тиск, має антиагрегантну дію щодо тромбоцитів. Мікробіоту на сучасному етапі потрібно розглядати як обов'язковий складник організму людини, а не як мешканців довкілля, котрі колонізували людське тіло. Сучасні дослідження показують, що сукупність мікробних геномів доповнює геном людини. Мікробіом є генетичною характеристикою всієї мікробіоти в певній тканині. Його взаємодія з імунною системою модулює та регулює імунну відповідь.

Висновки. 1. АГ в сучасних умовах найчастіше поєднується з абдомінальним ожирінням. 2. У хворих на АГ з супутнім ожирінням встановлені особливості цитокінового обміну в залежності від ступеня тяжкості АГ. 3.У хворих на АГ з супутнім ожирінням виявлені значні зміни вмісту біометалу $\mathrm{Mg}^{++} .4$. У хворих на АГ 3 супутнім ожирінням спостерігаються зміни мікробіому товстого кишківника, що супроводжується зменшенням вмісту лактобацил, біфідобактерій, кишкової палички, та збільшенням вмісту стрептококів, стафілококів. 5. Хоча мікробіота дитини «дозріває» вже у віці 3 років, мікробіом продовжує змінюватися під дією епігенетичних механізмів, на які впливають різні ендо- й екзогенні чинники. Зміни складу кишкової мікробіоти та іiі функціональної активності шляхом призначення пробіотиків, пребіотиків до комплексного лікування хворих на АГ з супутнім ожирінням може призвести до більшої контрольованості даного захворювання, уповільнення його прогресування та зниження ризику гострих серцево-судинних подій. Загалом персоналізована медицина на основі пребіотиків, пробіотиків і спеціальної дієти може стати новим, додатковим терапевтичним інструментом у лікуванні даної когорти пацієнтів.

\section{Список літератури:}

1.Pearson P. S., Evora P. R., Seccombe S. F., SchaffH. V. Hypomagnesaemia Nitric Oxide Release from Coronary Endothelium: Protective Role of Magnesium Infusion After Cardiac Operation // Ann.Thorac.Surg. 1998; 65: 967-972.

2.Ekmekci O. B, Donma O, Tunckale A. Angiotensin-converting enzyme and metals in untreated essential hypertension. Biol. Trace Elem. Res. 2003. Dec; 95 (3):203-210. 3.Мошковська Ю.О., Соболь В.О., Луценко А.О., Лісова В.О. Патогенетичні ланки артеріальної гіпертензії: особливості мембранної концепції гіпертонічної 
хвороби у хворих із супутнім ожирінням // Медичний форум -№19(19) - 2020 c.58-63.

4.Ridaura V.K., Faith J.J., Rey F.E., Cheng J.Gut microbiota from twins discordant for obesity modulate metabolism in mice. Science. 2013;341(6150):1241214. doi: 10.1126/science. 1241214 .

5.Lau K., Srivatsav V., Rizwan A. et al. Bridging the Gap between Gut Microbial Dysbiosis and Cardiovascular Diseases. Nutrients. 2017;9:859; doi:10.3390/nu9080859.

6.Chávez-Talavera O., Tailleux A., Lefebvre P. et al. Bile Acid Control of Metabolism and Inflammation in Obesity, Type 2 Diabetes, Dyslipidemia, and Nonalcoholic Fatty Liver Disease. Gastroenterology. 2017;152(7):1679-94.e3. doi: 10.1053/j.gastro.2017.01.055.

7. Khan M., Gerasimidis K., Edwards C. Role of Gut Microbiota in the Aetiology of Obesity: Proposed Mechanisms and Review of the Literature. Journal of Obesity. 2016;2016:7353642. doi: 10.1155/2016/7353642.

8.Qin J., Li Y., Cai Z. et al. A metagenome-wide association study of gut microbiota in type 2 diabetes. Nature. 2012;490:55-60. doi: 10.1038/nature11450.

9. Pluznick J. A novel SCFA receptor, the microbiota, and blood pressure regulation. Gut Microbes. 2014;5(2):202-7. doi: 10.4161/gmic.27492.

10.Li J., Zhao F., Wang Y. et. al Gut microbiota dysbiosis contributes to the development of hypertension. Microbiome. 2017;5(1):14. doi: 10.1186/s40168-0160222-x.

11.D. G. Harrison, T. J. Guzik, H. E. Lob, M. S. Madhur, P. J. Marvar, S. R. Thabet, A. Vinh, C. M. Weyand. Inflammation, Immunity, and Hypertension // Hypertension. 2011. - 57. - P. 132-140.

12.Васькина Е.А., Демин А.А. Эндотелиальная дисфункция и окислительный стресс при артериальная гипертензии. Новосибирск: Сибмедиздат.- 2003.- 92с. 


\section{ДОСЛІДЖЕННЯ ВПЛИВУ ПОЛІМЕРНИХ МАТЕРІАЛІВ ЯК ДЖЕРЕЛА ХІМІЧНОГО ЧИННИКА МАЛОЇ ІНТЕНСИВНОСТИ В ПОВІТРІ ЖИТЛОВИХ ПРИМЩЕНЬ}

Оборонова Тетяна Сергіївна, лікар з загальної гігієни Державної установи «Київський міський центр контролю та профілактики хвороб Міністерства охорони здоров'я України»

Потебенько Мар'яна Володимирівна директор Центральної випробувальної державної лабораторії Держпродспоживслужби в Київській області та м. Києві

Курділь Наталія Віталіївна заступник директора Державного підприємства «Науковий центр превентивної токсикології, харчової та хімічної безпеки імені академіка Л.І. Медведя МО3

України», м. Київ, Україна

Вступ. Хімічному складу повітряного середовища житлових будинків, як фактору формування здоров'я населення, приділяється значна увага у всьому світі. Повітряне середовище має багатокомпонентний склад, а його відхилення від оптимальних параметрів незаперечно впливає на якість життя як окремого індивіда, так і соціуму вцілому. Тому, особливої уваги заслуговує повітря житлових приміщень, в якому людина, залежно від вікової категорії і способу життя, проводить від 8 до 24 годин на добу.

Мета. Проведення досліджень повітря житлових приміщень на вміст пріоритетних хімічних забруднювачів на критичних рівнях і рівнях малої інтенсивності та оцінка їх впливу на здоров'я людини із застосуванням методу анкетування.

Матеріали і методи дослідження: метод опитування у поперечному розрізі (анкетування); епідеміологічні, санітарно-гігієнічні, санітарно-хімічні, фізіологічні, аналітичні (системного та порівняльного аналізу), статистичні (дисперсійний аналіз ANOVA, метод кореляції Спірмена (r), статистична значимість $\mathrm{p} \leq 0,05)$. В дослідженнях взяли участь 126 осіб, мешканці 48 квартир і 36 осель сільської місцевості, які були відібрані методом анкетування. В дослідну групу були включенні особи міського населення, що проживали в приміщеннях, насичених полімерними матеріалами, і мали перевищення вище ГДКсд рівнів хімічних речовин в повітрі житлових приміщень, що мігрують 3 полімерних матеріалів, а також мали симптоми, характерні для синдрому «хворого будинку» (загальна стомлюваність, зниження працездатності, подразнення слизових обличчя та верхніх дихальних шляхів, загострення хронічних алергічних захворювань та захворювань дихальних шляхів та ін.). 
Було враховано, що у осіб дослідної групи не повинно бути професійного контакту 3 хімічними речовинами, які можуть виділятися 3 полімерних матеріалів у повітря. До контрольної групи були включені практично здорові дорослі особи сільської місцевості, повітря осель яких характеризувалося відсутністю хімічних речовин, що виділяються з полімерних матеріалів, а також у яких були відсутні симптоми, характерні для синдрому «хворого будинку» $\mathrm{i}$ виключено професійний контакт 3 хімічними речовинами, термін виконання досліджень 2016-2020 pp.

Дослідження здійснені в межах науково-дослідної роботи Державного підприємства «Науковий центр превентивної токсикології, харчової та хімічної безпеки імені академіка Л.І. Медведя МОЗ України» (Науковий центр) на тему: «Наукове обгрунтування безпечності для здоров'я людини пестицидів та агрохімікатів, нових технологій, речовин, матеріалів, виробів, об'єктів довкілля, харчових продуктів та продовольчої сировини; розробка відповідних медичних критеріїв і показників (санітарних та епідеміологічних); санітарно-хімічна, токсиколого-гігієнічна оцінка, регламентація, нормування», державна реєстрація № 0112U001133, термін виконання: 2011-2021 pp. Дослідження виконані відповідно до принципів Гельсінської декларації (BMA, 1964 р.) та схвалені місцевим Комітетом з біоетики.

Результати дослідження. За даними Всесвітньої Організації Охорони Здоров'я (ВООЗ) широке застосування ПМ і ПБМв життєдіяльності людей формує в житлових будинках особливе повітряне середовище, якість якого істотно впливає на рівень здоров'я населення. При цьому ПМ і ПБМ можуть бути джерелом одночасної присутності в повітрі 150-280 хімічних забруднювачів, які відносяться до різних класів небезпеки, деякі з них викликають такі ефекти, як: ембріотоксичний, гонадотоксичний, канцерогенний, алергічні захворювання тощо $[1,2]$.

Попередніми дослідженнями, виконаними на базі Наукового центру, доведено, що хімічні забруднювачі повітря житлових приміщень, які утворюються за присутності полімерних матеріалів (ПМ) і полімерних будівельних матеріалів (ПБМ), є фактором хімічного впливу, в тому числі малої інтенсивності, і за ступенем впливу на здоров'я людини розподіляються на дві основні групи: фактори, які $\epsilon$ безпосередньою причиною захворювання, i фактори, які є умовами, що збільшують перебіг основного захворювання, викликаного іншими причинами [3-5].

Ретроспективний аналіз санітарно-гігієнічної оцінки повітря приміщень житлових будинків, виконаний ДУ «Київський міський центр контролю та профілактики хвороб Міністерства охорони здоров'я України» за 2010 - 2015 рр. та дані власних досліджень за період 2016-2019 рр. демонструють, що якість повітря житлових приміщень в багатьох випадках не відповідає існуючим нормам. Концентрації різних поллютантів уповітрі закритих приміщень перевищувала атмосферні в 2-34 рази.

Нами отримані дані, що демонструють рівні (по відношенню до ГДКсд) маркерних хімічних забруднювачів у повітрі житлових приміщень (рис. 1), зокрема формальдегіду (рис. 2). Лише протягом останнього десятиліття (2010- 
2019 рр.) у повітрі сучасних будівель виявилося близько 30 летючих сполук хімічної природи, з них більшість поширюється з полімерних матеріалів, які широко використовуються в будівництві в якості оздоблювальних, звукоізоляційних, теплоізоляційних матеріалів, лакофарбних виробів, для виготовлення меблів та інше. За токсичними властивостями ці хімічні забруднювачі віднесені до різних класів небезпеки.

При проведенні опитування дорослих мешканців житлових будинків $(\mathrm{n}=126)$ була застосована «Анкета суб'єктивної оцінки умов проживання мешканців житлових приміщень, де застосовуються полімерні матеріали», яка містила 34 оціночних критеріїв. Дослідженнями встановлено, що хімічні забруднювачі можуть виявлятися в повітрі, як в концентраціях набагато вище п'яти ГДКсд, так і на рівні фактору малої інтенсивності, що обумовлено грубими порушеннями технології виготовлення, відсутністю проведення санітарно-епідеміологічної експертизи полімерних зразків. Дія цих речовин при тривалому впливі в умовах житла може становити ризик розвитку передпатологічних станів і захворювань, як здорових осіб, так і особливо чутливого контингенту, зокрема дітей, осіб похилого віку, хворих на хронічні захворювання i вагітних жінок. За результатами опитування були складені «Протоколи біомедичного дослідження».

За результатами оцінки протоколів визначено, що, в залежності від рівня перевищення маркерних хімічних забруднювачів, найчастіше спостерігалися наступні порушення регуляторних механізмів: порушення когнітивних функцій, астенічні стани $(\mathrm{r}=0,072, \mathrm{p}<0,0001)$; дисфункція ендокринної системи (наприклад, порушення менструального циклу та ін.) (r=0,069, $\mathrm{p}<0,0001)$; зниження неспецифічної резистентності організму і зростання захворюваності $(\mathrm{r}=0,067,<0,0001)$, зокрема дисбактеріоз ( $\mathrm{r}=0,062, \mathrm{p}=0,0001)$; порушення імунного гомеостазу, розвиток сенсибілізації і поява алергії по відношенню до раніше стерпних алергенів $(\mathrm{r}=0,059, \mathrm{p}=0,001)$.

Найчастіше респонденти вказували на такі прояви, як: загальна стомлюваність $(\mathrm{r}=0,058, \mathrm{p}=0,002)$, зниження працездатності $(\mathrm{r}=0,051, \mathrm{p}=0,003)$, подразнення слизових обличчя та верхніх дихальних шляхів $((\mathrm{r}=0,049, \mathrm{p}=0,011)$, загострення хронічних алергічних захворювань $(\mathrm{r}=0,048, \mathrm{p}=0,011)$, та захворювань дихальних шляхів ( $\mathrm{r}=0,045, \mathrm{p}=0,016)$, та ін.

Виявлення за допомогою методу опитування у поперечному розрізі (анкетування) критеріально значущих показників ранніх (донозологічних) змін в стані здоров'я мешканців житлових будинків надало можливість планування та проведення цілеспрямованих профілактичних заходів 3 метою мінімізації ризиків здоров'ю людини, що перебуває в умовах тривалого впливу хімічного фактору малої інтенсивності, джерелом якого є ПМ. 


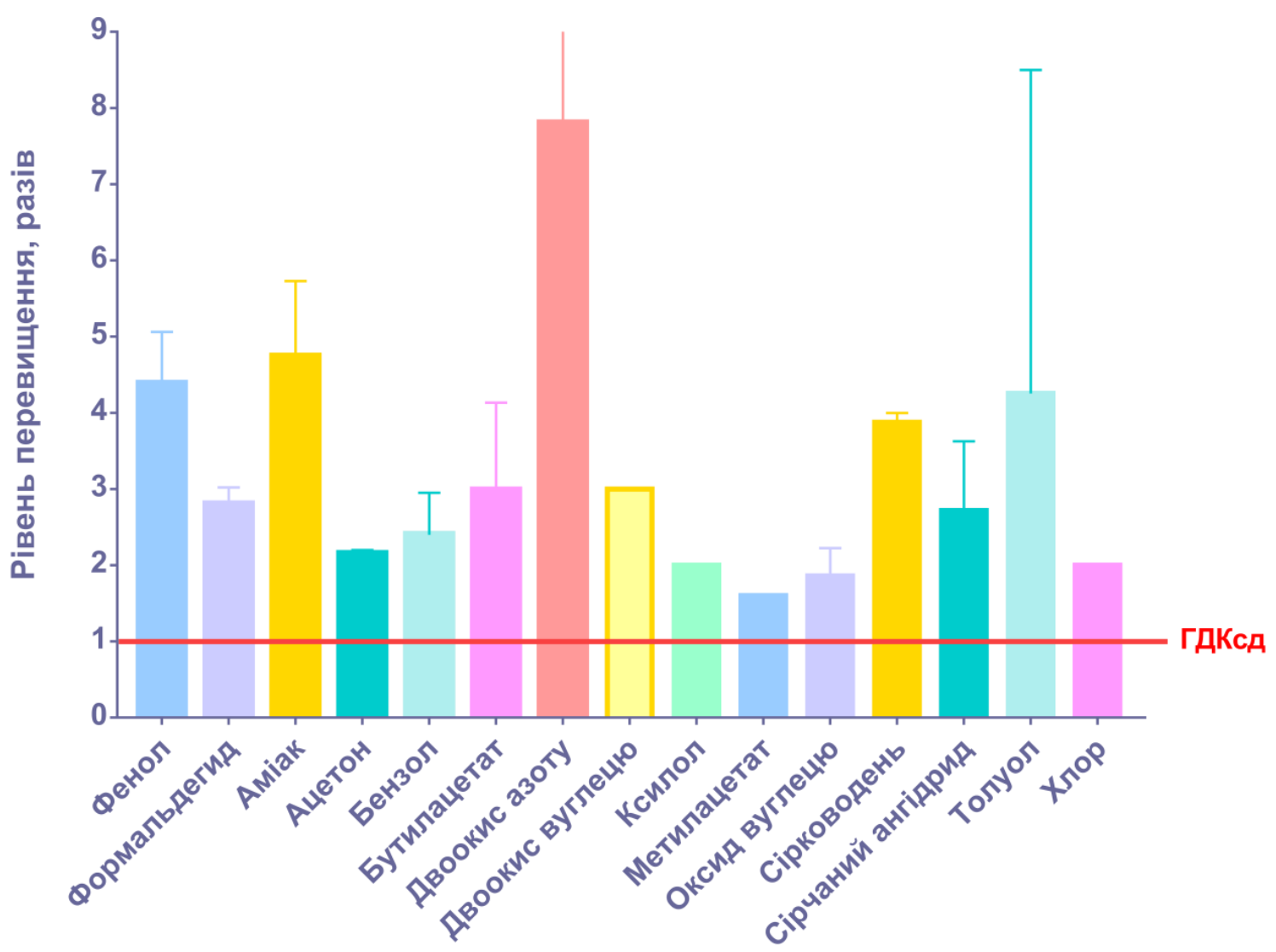

Рисунок 1. Рівень перевищення (в рази) концентрації маркерних забруднювачів у повітрі житлових приміщень по відношенню до ГДКсд $\left(\right.$ мг/ $\left.\mathrm{M}^{3}\right)$.

\section{Formaldehyde}

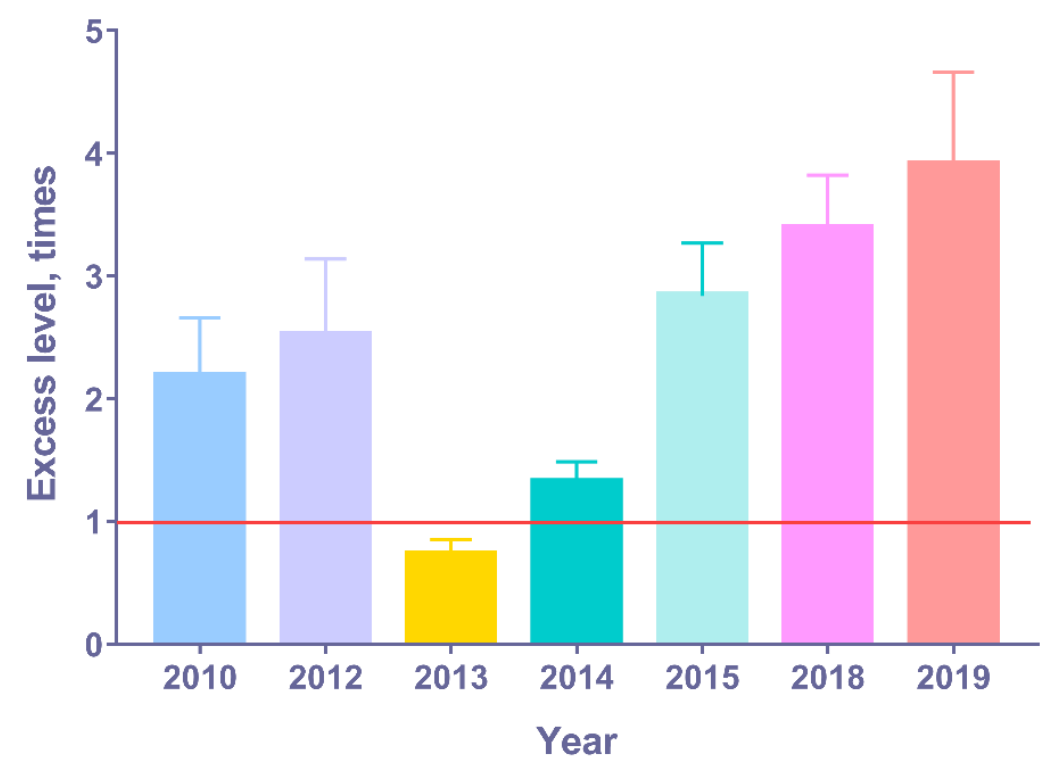

Рисунок 2. Рівень перевищення (в рази) концентрації формальдегіду у повітрі житлових приміщень по відношенню до ГДКсд $=0,03$ мг $/ \mathrm{m}^{3}$. 
Висновки. За результатами досліджень хімічних забруднювачів повітря житлових приміщень підтверджено необхідність введення додаткових критеріїв безпечності для полімерних матеріалів. Проведена оцінка ризику впливу хімічних забруднювачів 3 полімерних матеріалів на рівні фактору малої інтенсивності демонструє його істотний вплив на функціонування фізіологічних систем організму людини, що проявилося у порушеннях регуляторних механізмів різного ступеня та зниження показників стану функціонального резерву організму. У зв'язку з вищезазначеним назріла необхідність у створенні державної системи моніторингу хімічних забруднювачів середовища життедіяльності людини; затверджені нових методичних підходів до оцінки ризику впливу полімерних матеріалів на здоров'я людини і удосконаленні методів діагностики предпатологічних станів і захворювань, як здорових осіб, так і особливо чутливих контингентів.

Ключові слова: полімерні матеріали, повітря житлових приміщень.

\section{Список літератури:}

1. Руководство ВОЗ по качеству воздуха в помещениях: отдельные загрязнители. - Европейское региональное бюро ВОЗ. 2010 г. - 454 стр.

2. Development of WHO Guidelines for Indoor Air Quality. Report on Working Group Meeting, (Germany, 23-24 October 2006) /World Health Organization; Regional Office for Europe. - Copenhagen, 2006. - 27 p.

3. Токсиколого-гигиеническая значимость полимерных материалов как источника химического фактора малой интенсивности в среде жизнедеятельности человека / В.Ф. Шилина, Н.Е. Дышиневич, Е.Л. Перегуда, TC. Оборонова // Сучасні проблеми токсикології. -2011. -№ 5 (55). -С. 165.

4. Дишінєвич Н.С. Вплив полімерних матеріалів і критерії небезпеки / Н.Є. Дишінєвич // СЕС профілактична медицина. -2006. -№ 3. - С. 54-59.

5. Проданчук М.Г., Дишінєвич Н.Є., Баглій Є.А. Обгрунтування необхідності приведення у відповідність 3 міжнародними вимогами критеріїв оцінки безпечного для здоров'я людини застосування полімерних будівельних матеріалів / М.Г. Проданчук, Н.Є. Дишінєвич, Є.А. Баглій // Сучасні проблеми токсикології. - 2003. - № 3. - С. 4-9. 


\section{ВІКОВІ АСПЕКТИ ХАРЧОВОЇ АЛЕРГІЇ У ДІТЕЙ}

\section{Портнова Ольга Олександрівна}

к.мед.н., доцент кафедри педіатрії №2

Одеський Національний Медичний Університет

\section{Прусс Станіслав Валентинович}

Науковий ступінь - нет

Головний лікар санаторію «Хаджибей»

\section{Хрущ Максим Олександрович}

Студент 6 курсу

Одеський Національний Медичний Університет

Харчова алергія (XА) - важлива проблема охорони здоров'я, яка значно погіршує життя пацієнта та членів його родини, особливо якщо хворіє дитина. ХА найчастіше спостерігається серед дітей раннього віку, маніфестація здебільшого відбувається протягом першого року життя[1,2]. Характер клінічних проявів ХА обумовлено патогенетичними механізмами реалізації, які визначаються, у свою чергу, віковими особливостями пацієнта. Численними дослідженнями доведено, що саме вік початку маніфестації клінічних проявів ХА визначає подальший каскад алергічних реакцій та прогноз захворювання $[3,4]$.

За літературними джерелами, після 3 років у певної частини дітей прояви XА вщухають [5]. Дані щодо поширеності XА серед дітей не однорідні, що пов'язано з неоднозначним трактуванням терміну «харчова алергія», різними критеріями діагностики цього стану, проблемою вибору та оцінки діагностичних тестів, використанням лабораторних тест-алергенів різного ступеня очистки, особливостями контингенту обстежуваних дітей (регіональні стереотипи харчування населення) [6,7].

У зв'язку з цим метою дослідження стало вивчення вікової динаміки відповідної реакції антитіл на харчові продукти у дітей.

Під спостереженням перебувало 67 дітей у віці від 2 міс до 12 років 3 різноманітними клінічними проявами харчової алергії. Програма діагностики складала: збір анамнезу, загальноклінічні обстеження, відповідь на елімінаційні дієти, визначення рівня загального та специфічного IgE. Усі пацієнти були розподілені на наступні вікові групи: 2-5 місяців, 6-18 місяців, 1,5-4 років, а також 4-10 та старше 10 років.

На підставі отриманих досліджень, у більш ніж половини дітей раннього віку спостерігалась сенсибілізація до білків коров'ячого молока та курячого яйця. У цієї віковій групі позитивний результат полівалентної верифікації $\operatorname{IgE~склав~}$ $17,6 \%$ від усіх обстежених малюків.

У віці 1,5-4 роки спектр харчової алергії представлений практично ідентичними алергенами. Слід, відмітити, що в даній віковій групі збільшувалась 
сенсибілізація до злакових продуктів - ячменю - 31,3\%, кукурудзи - 22,4\%, рису - 14,9\%. У дітей віком 4-10 років сенсибілізація до курячого яйця реєструвалася у 44,8\%, до коров'ячого молока - у 22,3\% пацієнтів. Алергія до яловичини виявлялася у 5,9\%, до курки - у 10,4\% дітей. У школярів віком старше 10 років поступово знижувався рівень та змінювався спектр ХА. Так у дітей цієї вікової групи на перше місце, за рівнем алергогенності, виходили продукти рослинного походження, риба та морепродукти, шоколад. Слід зазначити, що у 3/4 дітей старшої групи маніфестація ХА припадала на ранній вік.

Таким чином, виявлення закономірностей змін характеру сенсибілізації до харчових продуктів залежно від віку дитини дозволяє визначити найбільш актуальні діагностичні панелі та призначити адекватну елімінаційну терапію для різних вікових діапазонів.

Список літератури:

1. Leung A.S.Y., Wong G.W.K., Tang M.L.K. Food allergy in the developing world. J. Allergy Clin. Immunol. 2018;141:76-78. doi: 10.1016/j.jaci.2017.11.008.

2. Savage J., Sicherer S., Wood R. The natural history of food allergy. J. Allergy Clin. Immunol. Pract. 2016;4:196-203. doi: 10.1016/j.jaip.2015.11.024.

3. Peters R.L., Koplin J.J., Gurrin L.C., Dharmage S.C., Wake M., Ponsonby A.L., Tang M.L., Lowe A.J., Matheson M., Dwyer T., et al. The prevalence of food allergy and other allergic diseases in early childhood in a population-based study: HealthNuts age 4-year follow-up. J. Allergy Clin. Immunol. 2017;140:145-153. doi: 10.1016/j.jaci.2017.02.019.

4. Sasaki M., Koplin J.J., Dharmage S.C., Field M.J., Sawyer S.M., McWilliam V., Peters R.L., Gurrin L.C., Vuillermin P.J., Douglass J., et al. Prevalence of clinicdefined food allergy in early adolescence: The SchoolNuts study. J. Allergy Clin. Immunol. 2018;141:391-398. doi: 10.1016/j.jaci.2017.05.041.

5. Sicherer S.H., Sampson H.A. Food allergy: A review and update on epidemiology, pathogenesis, diagnosis, prevention and management. J. Allergy Clin. Immunol. 2018;141:41-58. doi: 10.1016/j.jaci.2017.11.003.

6. Burks A.W., Sampson H.A., Plaut M., Lack G., Akdis C.A. Treatment for food allergy. J. Allergy Clin. Immunol. 2018;141:1-9. doi: 10.1016/j.jaci.2017.11.004.

7. Dunlop JH, Keet CA. Epidemiology of food allergy. Immunol Allergy Clin North Am. 2018;38(1):13-25. doi:10.1016/j.iac.2017.09.002 


\section{ДИСТАНЦЙНЕ НАВЧАННЯ В УМОВАХ ПАНДЕМІЇ: ЯК ЙОГО АКТИВІЗУВАТИ?}

Хламанова Лідія Іванівна

кандидат біологічних наук, доцент кафедри гістології та ембріології

Національний медичний університет імені О.О.Богомольця, Київ.

\section{Чайковський Юрій Богданович}

доктор медичних наук, професор, член-кореспондент НАМН України завідувач кафедри гістології та ембріології

Національний медичний університет імені О.О.Богомольця, Київ.

Вступ. Дослідження в реалізації педагогічних інновацій щодо вирішення сучасних проблем якості вищої освіти набувають особливої важливості в умовах пандеміїі з провадженням карантину у пацієнтів із COVID-19.

Мета роботи. Визначити переваги та недоліки дистанційного навчання студентів у медичному виші та окреслити можливі шляхи вдосконалення викладання базових медико-біологічних дисциплін в умовах пандемії COVID 19.

Результати дослідження. У науковій літературі представлені дані про розробки різноманітних навчально-методичних матеріалів та їх імплементацію на основі застосування новітніх інформаційних технологій. Ними визначені головні негативні риси дистанційного навчання: 1) спокуса та достатня можливість у студентів застосовувати несамостійне навчання - знання інших студентів та 2) викладач не має можливості для якісного контролю. В аналізі організації дистанційного навчання підкреслюється важливість вибору різноманітних методів навчання та визначається, що дистанційне навчання вимагає багато уваги викладачів, додаткового їх часу та підготовки, труднощі й недоліки лежать в проведенні об'єктивного оцінювання знань студентів. Наше дослідження періодичних літературних джерел та наш накопичений педагогічний досвід дозволяє підкреслити, що на першому плані у сучасних підходах до навчання у вищій медичній школі має бути практична складова набутих знань на основі інноваційних методів викладання базових медикобіологічних дисциплін, а також високий рівень зацікавленості і залученості студентів до самостійної роботи та мотивація студентів до подальшого безперервного їх розвитку. Нами визначена проблема, шо на початкових курсах студенти потребують допомоги викладача щодо осмислення надмірної кількості доступної їм інформації. Мотиваційне навчання за своєю природою $\epsilon$ розвивальним навчанням: по-перше, це розвиток навичок пошуку інформації, iї аналізу й обробки; по-друге, розвиток навичок самостійної роботи студентів; по- 
третє, розвиток професійних компетенцій. Студенти насамперед мають навчатися у процесі діяльності та індивідуального віднайдення смислів щодо усвідомлення ними важливості ролі фундаментальних знань для майбутньої професії лікаря. Оскільки лекція залишається основним і провідним методом навчання, тоді під практичним кутом зору, в аспекті пріоритетів «Закону України про вищу освіту» (2014) важливим ключовим аспектом має бути якісне засвоєння викладеного інформаційного матеріалу на основі поглибленого наукового та мотиваційного узагальнення із орієнтацією на формування професійної компетенції та розвитку творчої особистості, що необхідно в умовах ринкових відносин. Слід підкреслити, шо презентація аудіо- лекційного викладення фундаментальних медико-біологічних знань в процесі дистанційного навчання не спроможна здійснити необхідний рівень зворотного зв'язку викладача та студента. Безумовно, поєднання методу дистанційного читання аудіо-лекцій 3 широким використанням наочності та керованою самостійною діяльністю студентів, як показує наш педагогічний досвід, значною мірою може активізувати їх пізнавальну діяльність. Особливо треба зазначити, що в процесі дистанційного навчання студентів початкових курсів медичного університету великого значення набувають їх індивідуально-психологічні особливості для засвоєння ними знань $з$ фундаментальних дисциплін.

Слід зазначити, що навчання в медичному виші пов'язане чи не з найбільшим обсягом різноманітної інформації щодо засвоєння знань та застосування їх у діагностичному та лікувальному процесі. Доречно підкреслити, що цей обсяг інформації постійно оновлюється та переглядається, що потребує безперервності процесу післядипломного навчання. В період пандемії нами розроблена методологія та методика діагностичного аналізу гістологічних препаратів у вигляді мультимедійної презентації шляхом організації ZOOM-meeting (1 та 2 ). На першому здійснюється обговорення дослідженого об’єкта (клітини, тканини або органу), що проводиться від загального до часткового, 3 акцентом на цілісність та зв'язок структури і функції. В процесі бесіди викладач направляє діяльність студентів на закріплення теорії та практичних навичок. Слід підкреслити, що обов'язковим елементом обговорення передбачається ультраструктурна, гістохімічна, функціональна характеристика гістологічних структур. В цьому процесі передбачені дискусії та постановка проблемних питань (ситуацій). До цього етапу практичного заняття за методикою передбачається підготовка в такій послідовності: 1) студент виконує домашнє завдання - дає відповіді на поставлені викладачем питання, 2) початкове самостійне вивчення студентом гістологічного препарату у вигляді мікрофотографії в атласі, 3) студент формує рисунок у своєму альбомі та визначає структури. На першому етапі (ZOOM-1) кожний студент бере участь у процесі обговорення мультимедійних презентацій, а викладач надає необхідні пояснення для формування уміння застосовувати знання в діагностиці гістологічних структур в нормі та трактувати можливі прояви патологічних змін. Якщо вивчається орган, 1) спочатку треба визначити його місце в функціональній системі організму, та надати загальну характеристику (походження, визначити загальний план його будови, показати частини чи 
оболонки, визначити діагностичні ознаки; 2) надається детальний гістологічний аналіз структур та їх функціональних властивостей: 3) кожний гістологічний препарат вивчається в два етапи. На першому етапі студент навчається «читати» мікропрепарат та формувати його «візуальний образ» в нормі та набуває уміння діагностувати можливі зміни в нормальній структурі. На другому етапі (ZOOM 2) викладач здійснює контроль набуття та закріплення практичних навичок діагностичного аналізу гістологічних препаратів: 1) викладач показує студентам для розпізнавання схеми, електронограми та мультимедійні презентації тих мікрофотографій, які були представлені студентам для формування рисунків, 2) кожний студент представляє свої рисунки в альбомах та дає їх характеристики, 3) викладач та студенти аналізують активність кожного студента, 4) висновки робить викладач та визначає оцінку (кількість балів, враховуючи активність студента на всіх етапах заняття та результати контрольного тестування на платформі «Лікар».

Висновки. В процесі організації дистанційного спілкування (ZOOM conference) та імплементації інноваційних методів викладач набуває змоги реалізувати важливі функції в підвищенні оптимізації навчання студентів: 1) методологічна - вироблення наукового підходу до предмету, репрезентація змісту теми, актуальність, структурованість, медичне значення; 2) виховна спонукає студентів до самовпевненості та саморозвитку; 3) розвивальна активізує пізнавальну активність студентів в процесі інтерактивної взаємодії (дискусії); 3) діагностична - імплементація інтерактивних методів у вивчення гістологічних слайдів, що надає можливість студенту набувати креативне образне мислення, практичні навички в діагностиці (розпізнаванні) тканин і органів в нормі та в аналізі можливих проявів порушення структури та функції; 4) стимулююча - проведення диференційованого підходу до контролю знань та практичних умінь кожного студента в умовах інтерактивної взаємодії. 


\section{НАСИЛЬСТВО У СІМ'Ї: СУДОВО-МЕДИЧНІ АСПЕКТИ}

\section{Щепанський Сергій Олександрович,}

Лікар судово-медичний експерт Київського міського клінічного бюро судово-медичної експертизи

Проблема насильства в сім’ї являється одною 3 найбільш небезпечних медико-соціальних явищ в сучасній Україні. Особи які піддаються насильству або зазнавали насильства у минулому, часто страждають у подальшому житті на психічні розлади. Діти та підлітки, які стали свідками домашнього насильства, переймають відповідну гендерну модель поведінки і відтворюють іiі y наступному поколінні.

Із 11 січня 2019 року в Україні набув чинності Закон "Про запобігання та протидію домашньому насильству", яким суттєво змінена міра відповідальності за прояви насильства в сім'ї. Відповідно до нової статті 126-1 КК України, домашне насильство, тобто умисне систематичне вчинення фізичного, психологічного або економічного насильства щодо подружжя чи колишнього подружжя, або іншої особи, з якою винний перебуває (перебував) у сімейних або близьких відносинах, що призводить до фізичних або психологічних страждань, розладів здоров'я, втрати працездатності, емоційної залежності, або погіршення якості життя потерпілої особи,- - карається громадськими роботами на строк від ста п'ятдесяти до двохсот сорока годин, або арештом на строк до шести місяців, або обмеженням волі на строк до п'яти років, або позбавленням волі на строк до двох років [1-3].

Сім'я - це важливий атрибут сучасного суспільства. Відповідно до змісту ст. 3 Сімейного кодексу України, сім'ю складають особи, які спільно проживають, пов'язані спільним побутом, мають взаємні права та обов'язки [3].

Законодавство України у сфері протидії домашньому насильству закріплює чотири форми такого насильства: фізичне, сексуальне, психологічне, економічне.

За статистикою, яку оприлюднили під час голосування за Закон України "Про запобігання та протидію домашньому насильству", понад 3 мільйони дітей в Україні щороку спостерігають за актами насильства у сім'ї або є їхніми вимушеними учасниками, а майже $70 \%$ жінок піддаються різним формам знущань і принижень. Щорічно близько 1500 жінок, і ця тенденція збільшується за останні три роки, помирають від рук власних чоловіків. Діти скривджених матерів у 6 разів схильніші до суїциду, а 50 \% - до зловживань наркотиками. Майже $100 \%$ матерів, які зазнали насильства, народили хворих дітей переважно з неврозами, заїканням, енурезом, церебральним паралічем, порушенням психіки. Розрахунки, проведені Інститутом демографії і соціальних досліджень на замовлення Фонду народонаселення ООН, говорять про те, що 
щорічно 1,1 млн українок стикаються з фізичною та сексуальною агресією в сім'ї, і більшість 3 них мовчать.[7]

В групі потерпілих переважають особи середнього працездатного віку (25-48 років). Інші вікові групи осіб, що потерпіли від насильства в сім'ї, мають значно меншу питому вагу. Близько 90\% тих, хто звертається по допомогу через насильство в сім'ї,- - жінки. За даними різних авторів, основна вікова група потерпілих жінок - це 20-45 років. За ступенем тяжкості серед завданих жінкам тілесних ушкоджень переважають легкі, що мали незначні скороминущі наслідки (синці, садна, поверхневі рани тощо), а також легкі тілесні ушкодження із короткочасним розладом здоров'я (рани від тупих і гострих предметів, легкі форми черепно-мозкової травми). Як і в групі дітей, що постраждали від домашнього насильства, частіше траплялась тупа травма (більше 90\%), решту складали ушкодження гострими предметами, термічні та хімічні опіки i вогнепальні поранення $[4,5,6]$.

Висновок: Наслідками сімейного насильства можуть бути тілесні ушкодження, психічні розлади, втрата жертвою почуття самоповаги, суїцид. Систематичне жорстоке поводження здатне спровокувати у жертви відповідні насильницькі дії відносно агресора або викликати у неї т. з. "стокгольмський синдром". Ставлення до домашнього насильства в суспільстві формується, передусім, належним вихованням дітей у сім'ї, закладах освіти, інших інституціях як повноцінних членів суспільства.

Судово-медична експертиза у справах про домашнє насильство не становить особливого виду експертизи, виявлені особливості та соціальна значимість явища, свідчать про необхідність не лише удосконалення методики експертного дослідження, але й чіткої взаємодії з медичними установами, правоохоронними, соціальними органами та громадськими організаціями. Крім того, доцільним було б залучення до проведення судово-медичної експертизи таких постраждалих відповідних спеціалістів - психолога або психотерапевта з метою профілактики довготривалих наслідків від домашнього насильства.

Актуальність проблеми попередження насильства у сім'ї в сучасному суспільстві зумовлена небажанням соціуму розглядати це питання відкрито.

Таким чином, проблема домашнього насильства потребує докладного вивчення i об'єднання зусиль правоохоронних органів, судовомедичних, медичних установ і громадських організацій.

\section{Список літератури:}

1. Кримінальний кодекс України. https://zakon.rada.gov.ua/laws/show/2341-14 2. Закон України від 07.12.17 р. № 2229VIII "Про запобігання та протидію домашньому насильству". https://zakon.rada.gov.ua/laws/main/2229-19 3. Сімейний кодекс України. https://zakon.rada.gov.ua/laws/show/2947-14 4. Лобанов А.М, Теньков А.А, Тучик Е.С. Судебно-медицинская экспертиза последствий агрессивных действий человека; 2010. 416 с. 5. Мішалов В.Д, редактор. Судовомедична експертиза дітей: навч.посіб. Київ: Здоров'я; 2010.

215

c. 
6. Задарновский А. Л. Судебно-медицинская экспертная оценка вреда, причиненного здоровью, в случаях насилия в семье; 2010. 29 с. 7. Методичні рекомендації щодо запобігання та протидії насильству. https://zakon.rada.gov.ua/rada/show/v5480729-18 


\title{
PROFESSIONAL MOBILITY AS A PROFESSIONAL QUALITY OF THE FUTURE TEACHER
}

\author{
Babakina Oksana \\ Doctor of Pedagogical Sciences, Associate Professor, \\ Professor at the Department of Pedagogy, Psychology, \\ Primary Education and Education Management \\ Municipal Establishment \\ «Kharkiv Humanitarian-Pedagogical Academy» \\ of the Kharkiv Regional Council
}

Modernization of education in the conditions of intensive development of society in Ukraine is aimed at training new generation teachers, formation of future specialists' internal need to implement and implement innovative ideas, to provide conditions for active entry of our country into the international educational space through accession to the Bologna process. The European integration vector of educational policy requires the development of a qualitatively new, innovative, adapted to social change technology for the training of competitive professionals successful in the international labor market.

Modern society needs a specialist who can quickly update their knowledge, quickly adapt to complex conditions of social and professional reality, flexibly navigate the ever-changing information environment, mobile management of subject resources and professional behavior, strategically construct social reality and professional circumstances, independently and responsibly to make decisions focused on success and constant self-improvement, ie to be - professionally mobile.

The normative legal act declaring the need to train a mobile professional is the Resolution of the Cabinet of Ministers of Ukraine "On approval of the Regulation on the procedure for exercising the right to academic mobility", based on the Law of Ukraine "On Higher Education". In particular, it is noted that "academic mobility is the transfer of students or teachers-researchers to study or conduct research for a certain academic period in another educational institution (in the country or abroad) with the mandatory rethinking of acquired curricula, transfer of scientific experience to his educational institution and using it in his own research" [7].

Academic mobility allows you to: test yourself in a different system of higher education; gain additional knowledge in the professional field; to use modern technical equipment in foreign educational institutions and training centers to solve the tasks; to improve the level of knowledge of foreign languages; ability to think in a comparative aspect; intercultural communication [2].

Despite the variety of theoretical approaches to understanding the essence of the concepts of mobility and professional mobility, in the modern scientific literature there is no fixed definition of this term. However, the vast majority of studies emphasize the 
importance of updating individual experience in professional activities, developing the ability to discover and flexibly realize personal potential, enrich the value-semantic space of one's own life and the world of others.

Mobility in the general scientific sense - mobility, the ability to move and act quickly, to variability and adaptation (from the Latin mobilis - mobile) [8].

The very term "mobility" was first recorded in the work of the eminent philosopher and sociologist of the past Georg Simmel "Sociology of Space", in which, however, meaningfully this concept is used as "movement". G. Simmel substantiated a number of socio-spatial patterns of mobility, which he considered as "intensification of nervous stimulation caused by a sharp and continuous change of external and internal stimuli" [11].

In modern philosophical literature, mobility is described as an important attribute of social existence, which can be represented as a way of existence of an open nonlinear system formed by the interaction of social actors and dynamic and static elements, which includes constant and variable components.

In L. Sushentseva's research the mechanisms of realization of mobility in the life of society are interpreted. Qualification mobility, according to the researcher, indicates not only job promotion, but also characterizes the professional and industry stability of the employee. This two-way dialectical process organically combines seemingly contradictory elements - the employee's ability and prerequisites for vertical movement, on the one hand, and his ability to "stay" in the profession or industry for a certain period of his work - on the other [9].

L. Goryunova, describes "professional mobility" as a kind of triad, which includes: personality qualities (provide an internal mechanism of human development through the formation of key and general professional competencies); human activity (determined by events that change the environment and the result of which is human self-realization in life and profession) [1].

We are impressed by the position of O. Nikitina on the emphasis on the two-way professional mobility of teachers - organizational and social, which, on the one hand, determines the development of the internal position of the future teacher, and on the other - moving forward, implementing and developing innovations. Designing an educational environment is not possible without mobile, competent activities of individuals [6].

In the works of modern scientists there are different interpretations of the concept of "professional mobility":

- mobility - a measure of the ability of the factor of production to move between areas of use [9];

- mobility - mobility, readiness for quick reaction, quick involvement in activities [10];

- mobility - an integrative quality of personality that combines the formed internal need for professional mobility, ability and knowledge of the basics of professional mobility [3];

- mobility is one of the essential characteristics of a person, which is manifested in the process of work, ie professional activity. The mobile specialist must represent the person as a universe [4]. 
G. Medenkova interprets the professional mobility of a future college teacher as a degree of readiness for permanent or temporary changes in professional functions that depend on the socio-economic and socio-cultural situation and do not require a change of workplace [5].

In the context of research issues, professional mobility is understood as one of the essential characteristics of a person, which is manifested in professional activity, its goals and content, as an important component of professionalism, in particular the teacher, his professionalization. We emphasize the multifunctionality of professional mobility of the teacher, which is manifested in the actualization of the development of internal mechanisms of the individual, personal qualities, mental operations and judgments. Significant is the fact of direct impact of professional mobility on the activities of the specialist, the manifestation of changes in attitudes to the results of their work in accordance with the requirements of time, self-esteem, intensification of the transformation process, a new vision of the profession.

Professional mobility is the basis of effective response of the individual to the "challenges" of modern society, provides flexible orientation and activity response in dynamic social and professional conditions in accordance with their own life positions, readiness for change and its implementation in their lives, determines professional activity, subjectivity, creative attitude to professional activity, personal development.

Thus, modern changes in education lead to the reform of the entire pedagogical system, respectively, mobilize other professional competencies of teachers, actualize other values and a new vision of themselves in the profession. The future teacher must be able to make decisions and be responsible for them, to develop not only professionally significant qualities that have a multiprofessional, multifunctional nature, but also a subjective readiness for continuous self-education, which allows to emphasize the prognostic function of professional mobility. their professional training.

\section{Reference}

1. Horiunova L. V. Profesiina mobilnist spetsialista yak problema rozvyvalnoi osvity [Professional mobility of a specialist as a problem of developmental education] : dys. ... dokt. ped. nauk : 13.00.08. 2006. $337 \mathrm{~s}$.

2. Dubaseniuk O.A. Modernizatsiia osvity Ukrainy u konteksti yevrointehratsiinykh protsesiv: istoryko-pedahohichnyi aspekt [Modernization of education in Ukraine in the context of European integration processes: historical and pedagogical aspect]: monohrafiia. Zhytomyr: Vyd-vo ZhDU im. I. Franka, 2008. 300 s.

3. Ivanchenko Ye. A. Formuvannia profesiinoi mobilnosti maibutnikh ekonomistiv u protsesi navchannia u vyshchykh navchalnykh zakladakh [Formation of professional mobility of future economists in the process of studying in higher educational institutions] : dys. ... kand. ped. nauk : 13.00.04. Odesa, 2005. $262 \mathrm{~s}$.

4. Kuzmich T. A. Proektuvannia pedahohichnoho prostoru dlia stymuliuvannia vnutrishnoi i zovnishnoi mobilnosti uchasnykiv navchalno-vykhovnoho protsesu 
[Designing a pedagogical space to stimulate internal and external mobility of participants in the educational process] : metod. rekom. Kherson, 2012. $18 \mathrm{~s}$.

5. Medenkova H. V. Rozvytok profesiinoi mobilnosti vykladacha koledzhu v diialnosti predmetno-tsyklovoi komisii [Development of professional mobility of a college teacher in the activity of the subject-cycle commission] : avtoref. dys. ... kand. ped. nauk : 13.00.01.2007. $24 \mathrm{~s}$.

6. Nikitina O. A. Pedahohichni umovy formuvannia mobilnosti maibutnoho pedahoha [Pedagogical conditions of formation of mobility of the future teacher] : dys. ... kand. ped. nauk : 13.00.01. 2007. $224 \mathrm{~s}$.

7. Pro zatverdzhennia Polozhennia pro poriadok realizatsii prava na akademichnu mobilnist [On approval of the Regulations on the procedure for exercising the right to academic mobility]. URL : https://zakon.rada.gov.ua/laws/show/579-2015$\%$ D0\%BF\#Text (data zvernennia : 02.09.2021).

8. Proskura O. V. Poniattia mobilnosti. Vydy mobilnosti. Akademichna mobilnist [The concept of mobility. Types of mobility. Academic mobility]. 2014. № 13 (342). Vyp. 4. S. 94-98.

9. Sushentseva L. Profesiina mobilnist yak suchasna pedahohichna problema [Professional mobility as a modern pedagogical problem. Creative pedagogy]. Kreatyvna pedahohika : nauk.-metod. zhurn. 2011. Vyp. 1. S. 129-136.

10. Khomiuk I. V. Teoretyko-metodychni zasady formuvannia bazovoho rivnia profesiinoi mobilnosti maibutnikh inzheneriv [Theoretical and methodological principles of forming the basic level of professional mobility of future engineers] : monohrafiia. Vinnytsia: VNTU, 2012. $379 \mathrm{~s}$.

11. Ianenko O. A. Profesiina mobilnist yak umova profesiinoho zrostannia maibutnoho vykladacha [Professional mobility as a condition for professional growth of the future teacher]. Osobystist ta suspilstvo: aktualni problemy pedahohiky ta psykholohii : materialy mizhnar. zaochnoi nauk.-prakt. konferentsii, 27 lystopada 2012 r. Ch. I. 2012. S. 109-113. 


\title{
THE CONCEPT OF META-TEACHING
}

\author{
Bakhtadze Tengiz \\ Candidate of Technical Sciences, Professor, \\ Professor of Software Engineering, \\ Georgian Technical University, Tbilisi
}

Kobiashvili Ana

Candidate of Technical Sciences, Professor,

Professor of Software Engineering, Georgian Technical University, Tbilisi

The year 2020 has radically changed the specifics of the education system. Globalization, the rapid leap in technology, the transition to digital technologies, and, of course, the coronavirus pandemic have had a profound effect on many areas of our lives, including the education system [1].

By 2021, the main trends that will become dominant in the field of education in the future have been identified.

Modern educational trends are looking for new ways and means to interest the people involved in the learning process. If in the past it was enough to use new technologies, now it has become important to change the roles of student and teacher.

Based on the above, the work of teachers in higher education institutions in the future should be conducted in the following areas:

1. Constant work on yourself. The teacher should be constantly aware of all the news in his/her field of teaching or research.

For many centuries, the concept of LLL (Life Long Learrning) has been actual. Georgian proverb says: „Learn until death", and even at the beginning of our era, the great philosopher Seneca said: "No matter how much you live, you must learn all your life."

People in general need to learn, grow and develop throughout their lives, although the idea of lifelong learning has become especially popular in recent times. People realized the need for self-improvement. The main reason for this is competition. In addition, everyone is constantly surrounded by a flow of information, and the renovation of this flow is incredibly fast. This leads to rapid aging of information. Therefore, continuous learning is needed so that we do not lag behind in the development process.

This can be achieved by the fact that the teacher can join many professional communities, attend webinars as listener, participate in various trainings and workshops, correspond with various authors. Consider an example of self-assessment as a teacher: You have become a headmaster or just a lecturer of a student who claims to have been working in this field for 3 years, is paid a salary and he/she knows 
everything; And if you can show him/her that he/she does not know or does not understand some of the issues, then consider that you are in a good shape.

It is a well-known fact that in modern times it is rare for a person to work for the same company for all his/her life. It is now considered normal to change jobs every 5 years. This requires professional development. It is therefore necessary to teach students that continuous learning is essential for their professional development and increasing competition in order to find and establish their own place.

2. We call our approach meta-teaching. A meta-lecturer is a lecturer who uses meta-teaching (especially in master's and doctoral stages of teaching). The essence of the idea, in short, is to teach how to teach a given subject (issue). If a student has any questions, he/she can contact us at any time. If this method works poorly for some students, we move on to more classical methods.

3. Interactivity. We tell students: Stop me at any moment and ask me a question. We never answer: questions at the end of the lecture. This means that we use the interactive method of teaching, which is one of the modern teaching trends.

4. Principles of adaptability. In the field of education, the principles of adaptability have finally been established. Teachers have learned that students should not adapt to teachers, but teachers to them. It was often talked about before, but only after the development of artificial intelligence did it become real. Using the principles of adaptability and artificial intelligence, it becomes realistic to adapt the educational process to each student with a view to fully exploiting his/her strengths and correcting his/her weaknesses.

The principles of adaptability, unfortunately, are not yet sufficiently developed to be used in humanitarian programs and specialties in which they are particularly rapidly changable.

5. Communication. Full communication with all students is essential; We must use all modern means of communication: a mobile phone, an e-mail, a social network. We require at least 2 accounts: Microsoft and Google.

6. Students should be provided with all types of materials electronically, including, through their own Google Drive.

The educational space has long been the subject of digitalization. In recent years, however, this process has become extremely large-scale [2]. One of the hallmarks of the success of this process is the ease with which schools and universities can simply move to distance learning.

Another reason for the total digitalization of the higher education system is the increase in the number of students. The population of the earth is growing, which is also leading to the increase in the number of students. Due to this, universities will find it difficult to provide education for all those wishing to study, and the number of distance learning courses offered by universities will increase. This will be especially 
convenient for foreign students. They will no longer have to leave their home country to obtain a diploma from a prestigious higher education institution.

From the second half of 2020, the number of online schools and courses began to increase. Online courses mainly serve two purposes:

- Access to up-to-date educational data for the maximum number of people.

- Transform the educational process into a more open, interactive and interesting process.

7. You should not fill the student with knowledge, you should ignite the student. After listening to the course, he/she should be able to independently further deepen and develop the acquired knowledge.

8. Freedom. We give complete freedom, for example, if the student is late, he/she should take place silently. Also, if necessary, quietly leave and enter the room or laboratory. Also serve coffee and non-alcoholic beverages, provided there is no residue.

9. Individual approach. It is necessary to use tailored approaches specifically for individual students and groups of students. The student contingent differs in terms of level of preparation and language skills. Therefore, an individual approach is necessary for everyone.

10. Increase motivation. Talking about the motivation of learning the subject is never considered a lost time, on the contrary, it is the most important.

11. Cyclicity of the teaching process. In the modern world, the problem of refining the educational process is becoming more and more urgent. This process is constantly updated and, in our opinion, it is necessary to ensure the cyclicality of the teaching and learning process - the program should be constantly modified on the basis of the evaluation of the learning outcomes, which, in turn, allows students to raise the level of learning.

12. Interdisciplinarity and transdisciplinarity. In general, all fields of science study their object not only in the narrow confines of the discipline, but also to transfer the research to other disciplines to ensure the completeness of knowledge, i.e. it has an interdisciplinary character [3 ]. This feature is especially relevant in the field of informatics, because today, without informatics, it is impossible to develop natural sciences, engineering, banking and other fields. Moreover, informatics is perhaps more transdisciplinary than any other field, and in itself implies the results of research in various disciplines which often leads to the creation of something new and sometimes even to discovery. Pre-modern science is based on this kind of integration of knowledge. As a result of interdisciplinary cooperation, new knowledge is acquired, which goes back to the disciplines involved in the research and enriches them.

13. Development of communication skills. Today we see a significant problem in the development of students' ability to accurately convey their creative ideas. 
Knowledge based on modern scientific achievements should enable the student to expand his/her knowledge area and use innovative research methods in interdisciplinary and transdisciplinary contexts; Also be able to communicate their own ideas not only in their native, but also in a foreign language and, consequently, internationalize these ideas.

14. Execution of scientific projects. Higher education institutions around the world are focused on educating scientific and practical staff, as future technical progress depends on them [4]. Most of the world's scientists agree that project implementation is a system of teaching that focuses not only on acquiring basic knowledge, skills and habits, but also on developing creative skills and intellectual ability in the process of solving problematic situations.

Using the design method in the learning process allows to solve a number of tasks:

- First of all, it is a way to increase students' motivation. Students are motivated to develop research skills, to independently acquire knowledge from different sources and to use this knowledge to solve practical tasks.

- Through projects, students realize the principles of person-centered learning, as they can carry out projects according to their skills, abilities and interests.

- During the implementation of various projects, students master the algorithms of research activities, learn to produce information extraction and analysis independently, and integrate knowledge gained from different disciplines. It develops their creative and intellectual skills, shapes such qualities as independence, responsibility, initiative, sociability, decision-making. They also get real professional experience and problem solving experience.

The project implementation process is presented according to the following general scheme:

1. Develop a project framework plan;

a. Project title;

b. Project objectives;

c. Possible project results;

d. Motivation to participate in the project.

2. Software design

a. Representation of subsystems as trees;

b. Compilation of technical assignments and specifications for each node;

c. Customer interface development.

3. Comparative analysis and research of instrumental tools

a. Consideration of previous knowledge and experience;

b. Access (must be free);

c. Efficiency and documentation.

4. Software code implementation, testing, approbation and maintenance 
a. Write code with selected tooling;

b. Development and implementation of a logical database model;

c. Software testing;

d. Analysis of results.

This scheme is general in nature and is useful for many tasks. It does not reflect the feedback or recurrent and iterative processes that characterize each real project.

Below is an outline of two possible projects:

1) Use of great data and deep teaching methodology

a. in the fight against covid pandemic;

b. in the implementation of the recognition system. For example, the system can determine with a photograph whether the fungus in Georgia is poisonous or not.

2) Development of a system, which will automatically display the minimum list of academic subjects according to the name of the subject, which is a prerequisite for the teaching of a given subject.

a. compiling a database of subjects;

b. compiling a database of concepts and categories;

c. Development of algorithms that list the prerequisites for the study of the subject on the basis of these two bases and issue recommendations.

Usually, this issue is resolved subjectively, by the author of the syllabus. In the proposed version, the result is based on the analysis of specific data and, consequently, claims more objectivity and scientific justification.

The implementation of this project will be impossible without the permission and support of the top management and quality service.

According to the mission of the universities, every effort should be made by the joint efforts of the professors to enable the students to acquire the appropriate knowledge and skills in modeling, designing, implementing and operating in the relevant fields, which is essential for their future successful professional career. The ultimate goal of the training should be to raise the level of students' cognition to the highest level and the readiness of the graduates to adapt as much as possible to the requirements of both Georgian and the international labor market.

\section{References}

1. https://prostudenta.ru/post-986.html

2. teachthought.com/pedagogy/modern-trends-education-50-differentapproaches-learning/

3. https://hospitalityinsights.ehl.edu/2021-education-trends

4. https://www.edsys.in/educational-trends-for-2019 


\title{
ELECTRONIC LEARNING COURSES: CREATION AND IMPLEMENTATION
}

\author{
Bondarenko Maryna \\ Ph.D. (Physics and Mathematics), Associate Professor \\ Kharkiv National Medical University \\ Zaytseva Olga \\ Dr.Sci. (Biology), Professor \\ Kharkiv National Medical University \\ Rukin Oleksiy \\ Ph.D. (Physics and Mathematics), Senior Lecturer \\ Kharkiv National Medical University
}

Currently, higher education in Ukraine is at the stage of radical and global changes and reforms in search of new effective ideas, values and long-term priorities. The trajectory of changes in the modern higher education system of Ukraine meets the objectives of the Bologna Process, the Law of Ukraine "On the National Informatization Program", and in recent years is largely subject to global changes in human life associated with the coronavirus pandemic.

One of the important tasks of the Bologna Process is to create a global international educational environment, the main advantage of which is the presentation of educational material in a didactically unified and formalized form and the creation of conditions for its use anywhere and anytime, regardless of student's type of education [1-4].

In these conditions, the introduction of information and communication technologies (ICT) in the educational process is a prerequisite for the student to have access to the global information educational environment and, in particular, to the information environment of the university.

The task of implementing ICT in higher education is quite complex, multifaceted and multilevel. It requires sufficient computerization of the educational process, understanding by scientific and pedagogical staff the state policy in the field of elearning, understanding how to plan their learning process using ICT, the ability to use innovative pedagogical technologies of distance learning and the ability to create new e-learning resources.

One of such resources is e-learning courses (ELC). E-learning course is a set of electronic educational and methodical materials created for the organization of individual and group learning using distance technologies based on Internet technologies, in accordance with the schedule of the educational process of higher education [2]. E-learning courses are placed on the learning portal in a distance learning system organized on the basis of learning resources management. An example of such an information and educational portal 
for distance learning is the environment Moodle (Modular Object Oriented Dynamic Learning Environment) - a course management system (e-learning) also known as a learning management system or virtual learning environment, which is a free web application that allows to create e-learning courses to support learning. Moodle has a variety of features for both informative content and for testing and tracking student performance, and there is support for their registration with secure authentication.

It is assumed that students master the study material of the discipline, for which the ELC is developed, under the guidance of a teacher. In the process of approbation of the course, i.e. in the process of its use by students, the teacher can change the structure and content of the ELC in order to improve it.

The use of resources and services available in the information and educational environment of the university allows students to get education extraterritorially, synchronously and asynchronously in time, flexibly choose curricula, pace and timing of studies, expands access to educational and scientific information resources significantly.

The use of distance learning technologies requires from the teacher of constant readiness to carry out pedagogical activities in new, rapidly changing conditions, and, consequently, constant self-development to acquire certain (and not only professional) competencies, in particular, information and communication competencies. Taking into account the current trends in the development of education, the teacher is faced with the issue of continuous training in the use of innovative educational technologies.

\section{References}

1. Morse N.V., Glazunova O.G. Quality criteria for e-learning courses developed on the basis of distance learning platforms. // Information technologies in education. 2009. - №4. - P.63-75. (In Ukrainian)

2. Morse N.V., Glazunova O.G., Mokriev M.V. Methods of creating an e-learning course (based on the distance-learning platform Moodle3): Textbook. $2^{\text {nd }}$ edition, supplemented and revised. - Kyiv: Agrar Media Group, 2016. - 240 p. (In Ukrainian) 3. Gritsak N.R. The use of e-learning course "Ancient Literature" in the training of students of philology. // Journal «ScienceRise: Pedagogical Education». - 2017. - №12 (20). - P. 17-22. (In Ukrainian)

4. Bykov V.Yu. Cloud computing technologies are the leading information technologies for further development of informatization of the education system of Ukraine. // Computer at school and family. - 2011. - №6. - P. 3-11. (In Ukrainian) 
TRENDS IN THE SCIENTIFIC DEVELOPMENT 


\title{
CHARACTERISTICS OF THE LEADING METHODS OF IMPROVING THE QUALIFICATION OF SCIENTIFIC AND PEDAGOGICAL EMPLOYEES OF USA HIGHER EDUCATION INSTITUTIONS
}

\author{
Valentyna Lytvyn \\ Doctor of Philosophy, \\ Teacher at the Department of Pedagogy, \\ Psychology, Primary Education \\ and Education Management \\ Municipal Establishment \\ «Kharkiv Humanitarian-Pedagogical Academy» \\ of the Kharkiv Regional Council
}

In the developed countries of the world, higher education in general and the system of professional development of research and teaching staff of higher education institutions in particular have become determining factors in the socio-economic development of states.

O. Stoyka notes that "the indicator of modern world educational trends is the American higher school, which effectively fulfills the tasks of providing education to all categories of the population and meeting the needs of the labor market in specialists of various qualifications. USA higher education is a priority area of USA public policy, because the level of education depends on the economic situation of the country" [2].

Postgraduate pedagogical education at the present stage of development is characterized by a variety of organizational structures, content, forms and methods of adult education, due to the specific features of historical development, national traditions and priorities of educational needs of teachers. At the same time, the formed system is significantly influenced by external factors: the processes of globalization of society, internationalization of education, the activities of international organizations that accumulate progressive pedagogical ideas, violate the urgent requirements for its improvement. There is a formation of common trends in the development of the pedagogical field in the world educational space, which outlines the vectors of further reform of the national system of postgraduate pedagogical education. The issue of teacher training and development in modern conditions is reflected in the following important documents of international organizations adopted at the beginning of the XXI century: OECD / UNESCO "Teachers for the schools of the future: an analysis of world indicators in education in 2001" (Teachers for Tomorrow's Schools: Analysis of the World Education Indicators. 2001 Edition); World Bank Report "Life long Learning in the Global Knowledge Economy: Challenges for Developing Countries"; OECD Report "Attracting, Developing and Maintaining Effective Teachers" (Attracting, Developing and Retaining Effective Teachers), prepared based on the results of an international study [1]. 
An important step in the training of teachers in the USA was the establishment of the National Research Center for Teacher Education, which initiated large-scale international research in postgraduate teacher education to find ways to optimize the functioning of the training system, rational use of available material resources, and exchange and study experience gained by each country.

Therefore, it is important nowadays to cover the leading methods of professional development of research and teaching staff of higher education institutions in the USA in order to update the American positive experience in the system of professional development of research and teaching staff in Ukraine.

Personality-oriented methods of professional development of research and teaching staff of higher education institutions in the USA include:

1. Coaching ("coaching") - it is based on an informal dialogue between the coach and the research and teaching staff (individually or in a group), so they come to an independent solution to the problems. The use of this method provides personal and professional growth of a teacher of higher education;

2. "Mentoring" - a method of professional development of research and teaching staff, in which a more experienced teacher (mentor) trains a "young" employee for some time [6]. In domestic pedagogy, this method is called "mentoring". In our opinion, mentoring is a broader concept than mentoring, as it includes not only assistance in a specific situation, professional activity, but also informal knowledge transfer and psychological support in the process of professional development;

3. Peer-mentoring - a kind of "mentoring", based on partnership and cooperation, aimed at training and retraining of more experienced research and teaching staff. Such peer-mentoring is necessary because sometimes more experienced teachers also need help in modernizing their professional activities.

Experienced research and teaching staff can formally or informally "mentor" each other, share knowledge and practical experience, contacts in the professional sphere, etc [5].

4. The method of numerical mnemonics - allowed research and teaching staff to memorize a series of consecutive events. This method is based on the system of using binding, which means information that is "tied" to a known sequence, as well as "binds" events to images that rhyme with numbers from 0 to 9 . If the information is missing, you must select and continue the sequence from anywhere in the list, because the sequence of numbers cannot be forgotten. In the process of implementing this method, the faculties-developers aimed to follow the following rules: to create in memory an image in which numbers are represented instead of events that rhyme with numbers; select bright images; associate images with events that need to be remembered. Generally, the more unexpected the images, the better they are remembered. The number associated with the image is mentioned first, followed by the entire image [5].

The new methods of problem-based learning, which are widely used in the system of professional development of research and teaching staff of higher education institutions in the USA, include:

1. Method "Ladder Technique" - the purpose of its use was to encourage individuals to make group decisions. This technique, developed by American scientists $\mathrm{S}$. Rogelberg, D. Barnes-Farrell and L. Charles [7], was aimed at inspiring all participants 
before they were "imposed" with other people's ideas. The "ladder technique" was implemented in five main steps: before starting the group work it was necessary to voice the task or problem for all members of the group (4-6 people), giving enough time to comprehend it and formulate their own opinion on its solution; form a group of two members and ask them to discuss the problem; then the third participant presents ideas for the first two before hearing the ideas that have already been discussed. After that, the expressed ideas are discussed collectively; this process is repeated, involving the fourth participant, then the fifth, sixth; the final decision should be made only after discussing all the ideas [7].

2. Method "Learning Strategies" - aimed at developing the competencies of research and teaching staff on the effectiveness of the educational process in general and teaching the discipline in particular (developing a clear logic of the discipline, structuring its content) based on building a "chain of strategies"; use of the "here and now" strategy; coaching participants through practical projects, role-playing games, interactive discussions; minimization of passive learning techniques; creating a positive dynamics of learning over a long period of time through interactive learning and in small groups; adaptation of methods and various learning styles; providing prompt feedback based on two questions to the activity: confirmation (what work was done by the group member and at what level?) and effectiveness (what specific actions should be taken in addition and what pedagogical tools should be used to improve the quality of teaching?); requirement from group members of specific results, demonstration of acquired knowledge, skills and abilities until the completion of each module (topic, course, etc.); focus on a positive result" [4].

3. TSED (The Teacher's Self-Evaluation of Discomfort) method - was used at the beginning and at the end of these courses. The main features of the method: lasted no more than a minute; helped some new scientific and pedagogical workers to increase their level of comfort in courses with the help of a faculty developer (estimated on a 100-point scale: 1 - no discomfort, 100 - maximum discomfort). The method has eight positions: entrance to the audience; communication with students before classes; beginning of the lecture; answers to the first questions from students; the presence of signs of disapproval or lack of interest of students; the course of the lesson; completion of the lesson; communication with students after classes [3, p. 140].

4. TSEIC method (The Teacher's Self-Evaluation of Improvements in Comfort). The level of change and improvement of comfort in courses for research and teaching staff was assessed on a 7 - point scale, where 1 - ineffective training, and 7 - very effective. The method has seven positions: ignoring the anxiety that is observed at the beginning of classes; feeling of comfort when any discomfort disappears during the lesson; conscious slowing down of a lecture or presentation; patient listening and summarizing; feeling of obvious pleasure from the lesson; slowness at the beginning and at the end of the lesson; moments of pauses and silence during the lesson [3, p. 140-141].

Thus, summarizing all the above on the development of methods of professional development of research and teaching staff of higher education institutions in the USA, we can conclude that the main teaching methods were: personality-oriented (coaching, 
mentoring, peer mentoring, numerical mnemonics, etc.), methods questionnaires (TSED and TSEIC); problematic ("Ladder Technique", "Learning Strategies" etc).

\section{Literature}

1. Клясен Н. Післядипломна педагогічна освіта: зарубіжний досвід та сучасна практика. Нова педагогічна думка, 2014. № 2. С. 187-190.

2. Стойка О.Я. Державна політика США у сфері вищої освіти (друга половина XX-го ст.). Вісник Луганського національного університетів імені Tараса Шевченка. Педагогічні науки : зб. наук. пр. 2012. № 19 (254). Ч. III. C. 234-241.

3. Boice R. The new Faculty Member. Supporting and Fostering professional Development. San Francisco, 1992. 378 p.

4. Mental-skills. URL : http://www.mental-skills.ru/synopses/5991.html (дата звернення : 12.09.2021).

5.

Mindtools : website. URL : http://www.mindtools.com/pages/article/newCT_9 $\underline{1 . h t m}$ (дата звернення : 21.08.2021.

6. Odiorne G. S. Mentoring - An American management innovation. Personnel Administrator. 1985. № 30 (5). P. 63-70.

7. Robertson D.L. Establishing an Educational Development Program. A Guide to Faculty Development. San Francisco, 2010. P. 35-53. 


\title{
МЕТОД «МОВНОГО ПОРТФЕЛЮ» ЯК ОДНА ІЗ ТЕХНОЛОГІЙ ФОРМУВАННЯ ІНОЗЕМНОЇ КОМУНІКАТИВНОЇ КОМПЕТЕНТНОСТІ У ПРОФЕСІЙНІЙ ДІЯЛЬНІСТЬ МАЙБУТНІХ ФАХІВЦІВ ПPABA
}

\author{
Аркушина Юлія Віталіївна \\ аспірант кафедри педагогіки та менеджменту освіти \\ Центральноукраїнського державного педагогічного університету \\ імені Володимира Винниченка
}

Введення. Однією із особливостей функціонування світової спільноти в кінці XX - початку XXI століття виступає інтенсивний розвиток міжнародних відносин на економічному, політичному, культурному та багатьох інших сферах суспільної життєдіяльності [1, с. 23]. Такі процеси свідчать про те, що прагнення країн до політичної незалежності, укріплення національних пріоритетів, з однієї сторони, а 3 іншої - інтернаціоналізація правових систем, відкритості національних юридичних інститутів, поглиблення міжнародного поділу праці, що й передбачає глобальні зміни, зростання масштабів розширення рамок всіх міжнаціональних зв'язків.

Входження України до Болонського процесу вимагає різностороннього розвитку особистості, яке передбачає наявність у молодих людей - майбутніх фахівців права навичок володіння іноземною мовою. Володіння іноземною мовою - це показник не тільки конкурентоспроможності спеціаліста в області юриспруденції, але й якості особистості, відповідальної за свої результати навчання та здатної до самооцінки й самоаналізу.

Метою статті є розкриття особливостей методу «портфелю» як одного із компонентів формування професійної лінгводидактичної компетентності у майбутніх фахівців права.

Результати дослідження. Свропейський мовний портфель - це пакет документів, за допомогою яких студенти відображають свої досягнення та досвід у вивченні іноземних мов, збирають зразки виконаних робіт, отримують свідоцтва та сертифікати. За допомогою «портфелю» студенти самостійно відслідковують свій досвід та прогрес у вивченні мов, інформують про отримання мовної кваліфікації i змісту мовних курсів, планують мету подальшого навчання.

Важливим компонентом при визначенні сформованості самоосвітньої компетентності у студентів-юристів виступає оцінка якості науково-дослідного чи творчого проекту, який демонструє готовність випускника закладу вищої освіти до професійної діяльності.

Технологія «мовного портфелю» активно використовують в системах середньої і вищої зарубіжної освіти цілого ряду нормативних документів, які розроблені в рамках діяльності Європейського Союзу. На сучасному етапі в 
зарубіжних школах та закладах вищої освіти використовують різноманітні версії «мовного портфелю», однак в їх структурах представлені три основні компоненти: Паспорт, Мовна біографія, Досьє. Незалежно від конкретної цільової домінанти реалізація технологій «мовного портфелю» в навчальноосвітньому процесі заснована на шести рівнях володіння іноземної мовою і дескрипторах таких рівнів шляхом опису відповідних кожному рівню здатності студентам здійснювати взаємопов'язані види іноземної мовленевої діяльності в типових комунікативних ситуаціях (читання, аудіювання, говоріння, письмо, мовне посередництво).

Представляється можливим говорити і про значний досвід сучасної лінгводидактики, який застосовують для аналізу освітнього потенціалу технологій «мовного портфелю». Однак у вітчизняній середній і вищій освітах така технологія поки що не досягнула рівня системного та послідовного впровадження в навчально-освітній процес. На наш погляд, технологія «мовного портфелю» може сприяти здатності підвищення якості професійної освіти в міжнародно-орієнтованих вітчизняних закладах вищої освіти.

В процесі розробки компонентів технологій «мовного портфелю» необхідно спиратися на лінгводидактичні принципи навчання (системність, концентризм, розмежованість явищ на рівні мови і мовлення, функціональність, стилістична диференціація і мінімізація) і методичні принципи навчання іноземної мови i перекладу (комунікативність, мотивованість і інформативність, ситуативність, еврестичність і проблемність).

При розробці технології «мовного портфелю» і його введення в навчальноосвітній процес актуальним являється також врахування психологічних принципів навчання, серед яких особливу увагу, на наш погляд, необхідно приділяти індивідуально-психологічним особливостям студентів-юристів і поетапному формуванню компетенцій.

Особливу увагу приділяють практичному застосуванню проектній методиці, яка сприяє пошуковим і аналітичним можливостям студентів. В умовах постіндустріального інформаційного суспільства навчання за технологією «мовного портфелю» і його матеріальна уява здійснюється на базі інфо-комунікаційних технологій, в електронній формі.

В аспекті організації і структури подачі матеріалу технології «мовного портфелю» для вивчення іноземних мов студентам-юристам включають використання методики «зворотнього навчання», яка передбачає самостійну, індивідуальну і колективну діяльність студентів щодо засвоєння навчального матеріалу в електронній сфері і подальшої продуктивної діяльності студентів $\mathrm{i}$ викладачів в аудиторному форматі [1].

Зміст навчання іноземної мови студентами-юристами на основі технології «мовного портфелю» визначається на основі змісту загальноєвропейських компетенцій володіння іноземною мовою, враховуючи список іноземних комунікативних компетенцій, сфер їх реалізації, на основі змістовних характеристик компетенцій різноманітних рівнів володіння нерідною мовою і рівневих дескриптів, які відображають основні ситуації, цілі і комунікативні завдання міжкультурного спілкування. 
Однак розробка змісту навчання за технологією «мовного портфелю» для організації мовної підготовки студентів юридичної спеціальності у закладі вищої освіти, проектування змісту іноземної комунікативної компетенції, підбір та розробку навчального матеріалу необхідно здійснювати, виходячи зі сфер професійної діяльності випускника закладу вищої освіти, вимог до змісту підготовки майбутнього фахівця права, списку його загальнокультурних i професійних компетенцій, які зазначені в Державних освітніх стандартах для направлення «юриспруденція». Таким чином, зміст навчання на основі технології «мовного портфелю», засоби навчання, список завдань для студента, способи формування, критерії і форми оцінки компетенцій, формат вербального оформлення рефлексії студента в процесі навчально-професійної діяльності в закладі вищої освіти необхідно розробити на основі сфер (експертна, правозастосовча, науково-дослідна, педагогічна) і компетенцій.

При побудові системи роботи 3 «мовним портфелем» матеріальних $\mathrm{i}$ операційних засобів навчання здійснюється відповідно до цілей і завдань навчання. Сукупність операційних засобів навчання, які детермінують дії суб'єктів навчального процесу, включають в себе імітацію, трансформацію, постановку, комбінування, конструювання і так далі, в той час, як в комплексі матеріальних засобів навчання входять концептуальні карти, діаграми, схеми, моделі, ресурси і тому подібне.

При виборі операційних засобів навчання за технологією «мовного портфелю» особливу роль відіграє комбінування, конструювання і так далі; при формуванні комплексу матеріальних засобів увага приділяється іноземним друкованим текстам, аудіо- і відеоджерелам правового направлення, на основі яких можливо моделювати навчально-професійну діяльність майбутніх юристів.

Особливої уваги потребує розробка і дотримання критеріїв відбору джерел для використання в якості навчального матеріалу і представлення результату його засвоєння в структурі «мовного портфелю». В якості критеріїв ми пропонуємо наступні параметри:

- відображення в письмовому, аудіо-, відеоресурсі лінгвокомунікативних характеристик, типових для конкретного жанру професійної юридичної діяльності;

- жанрову i ресурсну різноманітність джерел в рамках навчального матеріалу;

- відображення типових способів дискурсивної реалізації юридичних понять і категорій;

- стандартність і варіативність мовного оформлення типових юридичних текстів офіційно-ділової і наукової направленості, відповідно до предметних і іномовних знань студентів в різних галузях права, освітня і виховна цінність ресурсу, який використовують в навчальних цілях, можливість використання в якості навчального матеріалу ресурс для самостійної продуктивної діяльності, системний взаємозв'язок навчальних матеріалів для навчання різноманітними видами іномовної діяльності з метою створення індивідуального результату професійної юридичної діяльності на іноземній мові [2]. 
Відбір і проектування засобів навчання за технологією «мовного портфелю» направлені на синтез методичних (аналіз, синтез, узагальнення, систематизація, зіставлення мовних явищ) i предметних (аналітичних i функціональних) прийомів навчання, на основі яких рекомендується наступні типи завдань (апробування в практиці професійно-орієнтованого мовного навчання студентівюристів): завдання на аналіз, переклад і підготовку на іноземній мові фрагментів нормативно-правових актів; завдання на моделювання юридичних дій у відповідності із законодавчою базою і їх вербальних представлень на іноземній мові в усній і письмовій формі; завдання на аналіз юридичних фактів, обставин і ситуацій, зазначених на іноземній мові, завдання на виклад на іноземній мові фактів, обставин і ситуацій, які зазначені українською мовою; завдання на переклад юридичних документів 3 іноземної мов на українську і з української на іноземну з використанням електронних баз даних і словників; завдання на відображення результатів професійної діяльності в юридичній та іншій документації на іноземній мові; завдання на участь в юридичній експертизі юридичних документів на іноземній мові в цілях визначення їх відповідності із законодавчими нормами; завдання на тлумачення різноманітних правових актів на іноземній мові; завдання на підготовку юридичного висновку і проведення консультацій на іноземній мові; завдання на усний послідовний переклад як компонент перерахованих вище видів професійної діяльності юриста в різноманітних сферах.

Перераховані види завдань корелюють зі сфери професійної діяльності юриста і професійними компетенціями, визначеними за освітніми стандартами, створюють умови для формування і розвитку вмінь здійснювати різноманітні види іноземної мовної діяльності в професійній сфері, забезпечують можливість системного представлення результатів їх виконання в структурі «мовного портфелю».

В процесі проектування технології «мовного портфелю» для студентівюристів особливу увагу приділяється розробці дескриптів комунікативної компетенції для всіх видів мовленевої діяльності. Так як професійно-мовна компетенція формується на основі комунікативних мовних компетенцій, які в процесі засвоєння мови на рівні А1 (елементарне володіння) і A2 (рівень виживання), то для компетенцій «мовного портфелю» студента-юриста на рівнях B1-B2 нами в процесі дослідження були розроблені змістовні характеристики дескриптів іномовної комунікативної компетенції юристів в сфері професійної діяльності [3].

Основні вміння, якими володіє студент-юрист рівня В2:

В процесі усного сприйняття іномовної інформації стосовно юридичної проблематики студенти цілком розуміють навчальні аудіо- і відеоматеріали за професійною тематикою, сприймають матеріали лекцій, семінарів і конференцій, які стосуються сфери юриспруденції, на матеріалі засвоєної програми, в умовах чіткої вимови і знання спеціальної проблематики, здатні виокремити із мовлення специфічну інформацію, яка стосується професійної теми та відреагувати на неї при умові нормативної вимови і дотримання помірного темпу мовлення. 
В процесі читання студенти розуміють зміст публікацій за широким колом професійних тем i володіють навиками реферативного відпрацювання текстового матеріалу за спеціальністю, здатні в різноманітних правових джерелах знайти і виокремити інформацію, яка стосується трактування того чи іншого юридичного терміну в різноманітних правових системах, вміють підбирати матеріал/інформацію стосовно правових аспектів і підходів до їх вирішення не тільки в нашій країні, а й країнах Європи та США, здатні до оцінки і аналізу юридичних текстів.

У сфері усної комунікації студенти здатні приймати участь в дискусіях щодо вивчення професійних проблем і в ході обговорення акцентувати увагу на найбільш складних питаннях, мають аргументовано оцінювати думку однокурсників і спеціалістів в області юриспруденції, готові дати коментарі щодо теми, яку обговорюють, вміють без підготовки доволі вільно приймати участь в діалогах з носіями мови, яку вивчають, по знайомій професійній проблемі аргументують та відстоюють свою точку зору.

В монологічному мовленні студенти здатні проілюструвати особливості використання юридичних термінів в різноманітних правових системах, вміють робити короткі не підготовлені повідомлення на професійні теми, здатні провести консультацію щодо основних направлень юриспруденції, готові прийняти участь в конференціях $\mathrm{i}$ засіданнях стосовно професійної проблематики, здатні пояснити свою точку зору, використовуючи всі аргументи «за» $\mathrm{i}$ «проти».

В письмовому мовленні студенти можуть викласти зміст статті щодо юридичної проблематики, застосовуючи до цього навички роботи 3 різноманітними правовими джерелами, здатними узагальнити інформацію щодо професійних питань, використовуючи різноманітні джерела та пошукові системи, залучаючи паперові та електронні ресурси, підготовляючи текст наукової статті щодо досліджуваної проблематики, здатні написати реферат випускної кваліфікаційної роботи на іноземній мові і приймати участь в процедурі іiі захисту на іноземній мові, здатні створити протокол судового засідання і судових рішень.

Для рівня В2 були також розроблені дескрипти професійно-орієнтованих комунікативних вмінь юристів, що здійснюють лінгвокультурне представництво в професійній сфері. Здатність реалізувати такий вид мовленевої діяльності характеризується через такі вміння: студент володіє спеціальною термінологією в тій галузі права, яку вивчає; вміє здійснювати аналіз мови джерела та мови перекладу з точки зору схожих та відмінних рис концептуального, лексичного i граматичного аспектів; здатні оформити переклад паспорту, свідоцтва про народження, диплома про здобуття освіти, текстів науково-публіцистичного і правового характеру, текстів типових юридичних документів (типового договору, доручення з іноземної мови на українську) із застосуванням, у випадку необхідності, перетворення мовних структур для передачі вихідного повідомлення в адекватній формі i здійснення найпростіших видів синтаксичного поєднання простих речень в складні, заміна активної форми на пасивну конструкцію, поєднання слів ключовими поняттям; у випадку часткової 
розбіжності обсягу понять вихідної і мови перекладу вибрати еквівалентний варіант перекладу; володіють навичками реферування текстів правової спрямованості іноземною / українською мовами; вміють зіставляти довідкові та спеціалізовані анотації іноземною мовою [4].

Висновок. Отже, засвоєння іноземної мови на принципах технології «мовного портфелю» дозволяє майбутнім фахівцям права, студентамвипускникам закладів вищої освіти продемонструвати роботодавцям об'єм і рівень іноземної компентентності в сфері професійної діяльності.

\section{Використана література:}

1. Куликова Э. Г. Юридически значимые номинации и «ключевое слово эпохи»: семантика и актуальная прагматика // Филос. права. 2015. № 6 (73).

2. Европейская система уровней владения иностранным языком. URL: http://linha.ru/evropeiskaya sistema urovnei vladeniya inostrannim yazikom.htm

3. Солдатов Б. Г. Модульное обучение в педагогическом процессе по иностранному языку // Акад. вестн. Ростов н/Д, 2013. No 1 (14).

4. Атабекова А.А., Крузе И.И. ЯЗЫКОВОЙ ПОРТФЕЛЬ КАК ЛИНГВОДИДАКТИЧЕСКАЯ ТЕХНОЛОГИЯ ПРОФЕССИОНАЛЬНО ОРИЕНТИРОВАННОГО ОБУЧЕНИЯ ИНОСТРАННОМУ ЯЗЫКУ СТУ ДЕНТОВ-ЮРИСТОВ // Фундаментальные исследования. - 2014. - № 3-1. C. $184-188$ 


\section{ВИКОРИСТАННЯ ДИСТАНЦЙНОГО НАВЧАННЯ В МЕДИЧНОМУ ВУЗІ ПРИ ВИКЛАДАННІ ДИСЦИПЛІНИ «ОРГАНІЧНА ХІМІЯ»}

Величко Наталія Володимирівна к.х.н., доц. кафедри загальної та біологічної хімії №1 Донецький національний медичний університет

Свграфова Наталія Іванівна, к.х.н., доц. кафедри загальної та біологічної хімії №1 Донецький національний медичний університет

Селезньова Ірина Ігорівна, асистент кафедри загальної та біологічної хімії №1 Донецький національний медичний університет

В сучасному світі все більш актуальним в навчанні стає застосування прийомів і методів, які формують вміння самостійно здобувати нові знання, збирати необхідну інформацію, висувати гіпотези, робити висновки. Загальна дидактика та окремі методики, види занять в рамках навчальної дисципліни закликають вирішувати проблеми, пов'язані з розвитком у здобувачів вищої освіти умінь і навичок самостійності та саморозвитку. А це передбачає пошук нових видів навчання, оновлення змісту освіти, посилення мотивації здобувачів вищої освіти до пізнання.

Дистанційне навчання - це такий вид навчання, який дозволяє включати в освітній процес сучасні інформаційні технології, що сприяють створенню комфортного середовища і атмосфери активної участі в навчальному процесі.

Питання використання дистанційних технологій та електронного навчання стало особливо актуальним в період епідемії, коли кожна освітня організація була змушена шукати засоби для проведення занять в нових умовах 3 урахуванням специфіки навчального закладу. Інформаційні технології в сучасності дають змогу підвищити та вдосконалити ефективність освітнього процесу в закладах вищої освіти, в т.ч. і медичних.

У Донецькому національному медичному університеті (ДНМУ) також використовується дистанційне навчання одночасно 3 класичною формою навчання.

На сайті ДНМУ для здобувачів вищої освіти розміщено Інструкцію для використання дистанційного навчання та усі рекомендації з дистанційної освіти при навчанні, в тому числі і на кафедрі загальної та біологічної хімії №1 (http://biochemistry.dsmu.edu.ua/) (рис.1). 


\section{Кафедра загальної та біологічної хімії №1 ДНМУ}

Головна Дисципліни Студентам Науковий кружок Наукова робота кафедри Дистанційна освіта Програми Освітні програми

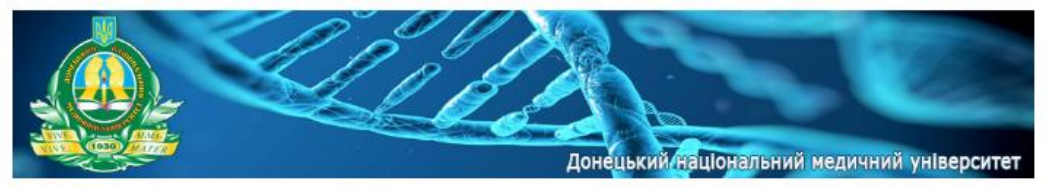

Органічна хімія

В категории нет материалов.

Календарно-тематичний план

Методичні вказівки

Підручники

Головна , Дисципліни , Органічна хімія

Рис. 1 - Інтерфейс сторінки кафедри «Загальної та біологічної хімії №1»

Навчальний процес на кафедрі був побудований виходячи із затвердженої програми за фахом, 3 аналогічними модулями та кількістю годин, однак практичні заняття та лекції проводилися дистанційно на платформі Google (рис. 2).

Для контролю знань використовувались усне опитування, індивідуальні самостійні роботи та тестування (рис. 3). Для вивчення тем викладачі використовували такі форми подачі знань: лекції та практичні заняття у формі ознайомлення 3 відео-лекціями, лекціями-презентаціями, а також бесід, пояснень, відповідей на питання, детального розбору письмових домашніх завдань, самостійної роботи 3 підручником, ознайомлення 3 методичними вказівками та відеороликами на YouTub.

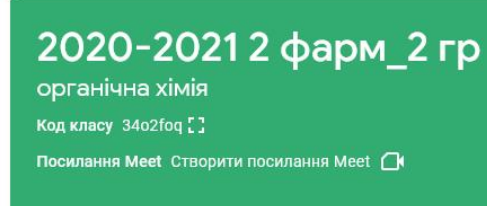

2020-2021 2 фарм_2 гр

Кон кпесу 3402 roq : :

посилання Meet створити посилання Meet $\square$
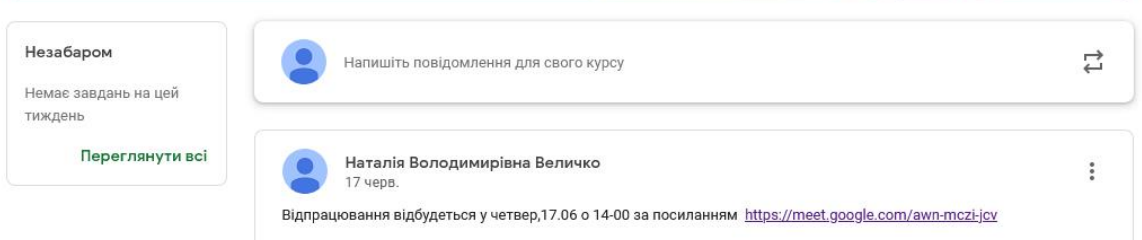

Рисунок 2 - Інтерфейс сторінки 3 дисципліни «Органічна хімія» 


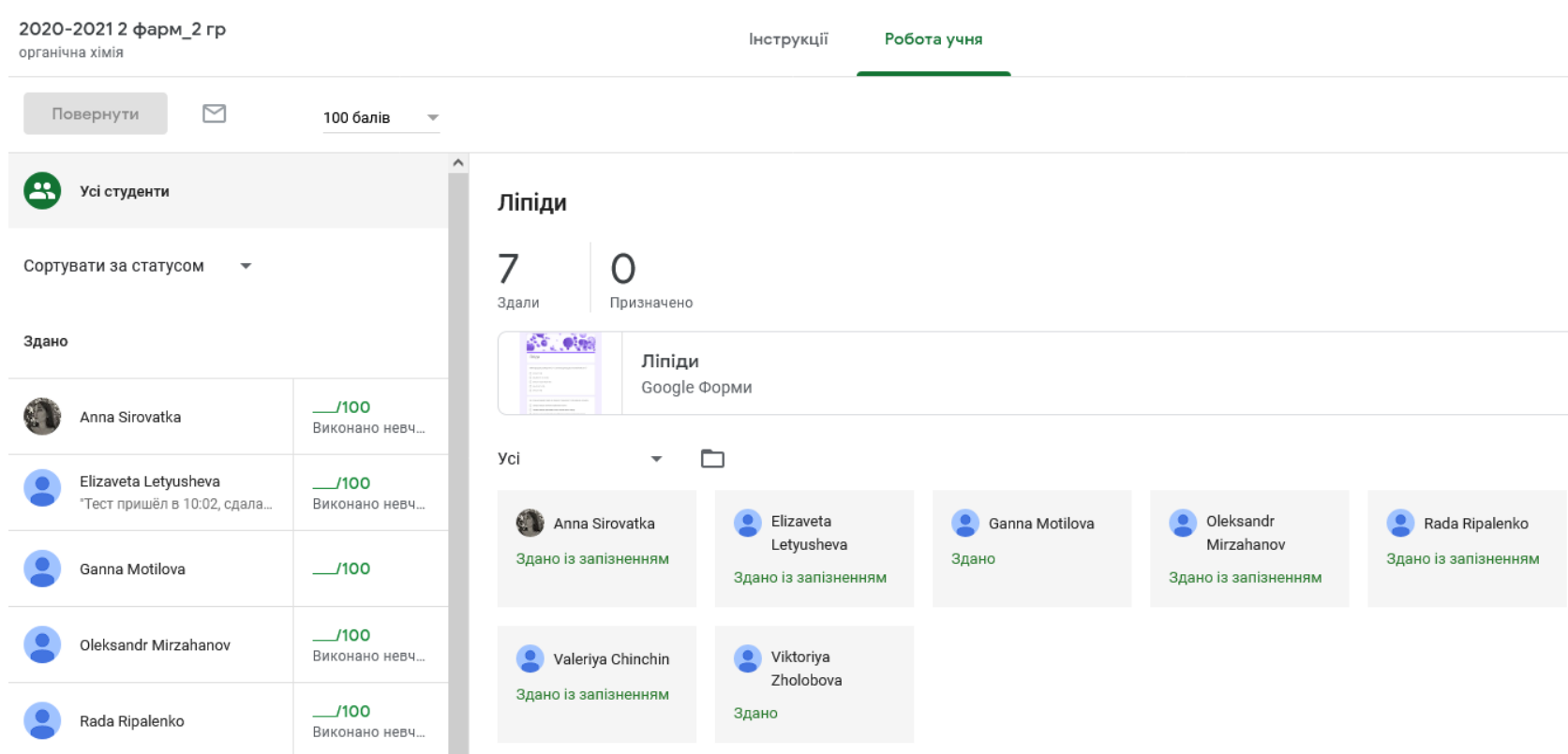

Рис. 3 - Інтерфейс сторінки $з$ виконаним завданням 3 «Органічної хімії»

У дистанційного навчання маса плюсів, воно дозволяє:

- знизити витрати на проведення навчання (не потрібно витрат на оренду приміщень, поїздок до місця навчання, як учнів, так і викладачів тощо);

- скоротити час на навчання (збір, час у дорозі);

- підвищити якість навчання за рахунок застосування сучасних засобів, об'ємних електронних бібліотек і т.п.

- проводити оцінку знань, тестування он-лайн;

- створити єдине освітнє середовище.

Насправді при дистанційному навчанні $є$ кілька труднощів: низький ступінь взаємодії викладача та учня, низька швидкість взаємодії, високі вимоги до мотивації, високі вимоги до вміння самостійно освоювати матеріал та ін.

При розробці програм дистанційного навчання важливо ретельно розпланувати заняття, організувати навчання 3 постановкою цілей та завдань навчання. Здобувачі вищої освіти повинні розуміти призначення запропонованого курсу. Потрібно враховувати психологічні закономірності сприйняття, пам'яті, мислення, уваги, вікові особливості здобувачів вищої освіти.

Отже, можемо зазначити, що педагогічний потенціал дистанційної освіти величезний. В системі такої освіти формуються найважливіші якості, які зможуть стати основою успішної освітньої діяльності людини протягом усього життя: здатність планувати свою освітню траєкторію, організовувати процес навчання і - головне - нести відповідальність за його результати. Така освітня самостійність дуже важлива особливо сьогодні - в тому «суспільстві знання», в якому будуть жити випускники, де основа успішної життєдіяльності безпосередньо пов'язана 3 готовністю людини вчитися протягом усього життя. Розвиток дистанційного навчання в українських медичних закладах вищої освіти буде продовжуватися i вдосконалюватися 3 розвитком інформаційнокомунікаційних технологій. 


\section{Література}

1. Екстрене дистанційне навчання в Україні: Монографія / За ред. В.М. Кухаренка, В.В. Бондаренка. Харків:. Вид-во КП «Міська друкарня», 2020. 409 c.

2. Закон України "Про національну програму інформатизації" про URL: https://zakon.rada.gov.ua/laws/show/74/98-\%D0\%B2\%D1\%80\#Text

3. Державна національна програма «Освіта: Україна XXI століття». Київ, 1994 // Законодавчі акти та нормативні документи (на допомогу керівникам закладів та установ освіти). URL: https://zakon.rada.gov.ua/laws/show/896-93$\% \mathrm{D} 0 \% \mathrm{BF}$ 


\title{
ТЕСТОВИЙ КОНТРОЛЬ У СИСТЕМІ ОЦНЮВАННЯ НАВЧАЛЬНИХ ДОСЯГНЕНЬ СТУДЕНТІВ 3 АНГЛІЙСЬКОї МОВИ
}

\author{
Гедз Світлана, \\ кандидат філологічних наук, доцент, \\ завідувач кафедри іноземних мов гуманітарних спеціальностей, \\ Волинський національний університет імені Лесі Українки
}

Модернізація освіти в умовах сьогодення висуває велику кількість завдань, пов'язаних із удосконаленням якості підготовки фахівців у закладах вищої освіти, що пояснюється передусім невідповідністю результатів навчання суспільним запитам та потребам учасників навчального процесу. Володіння іноземною мовою (головним чином англійською) стало важливою складовою професійної підготовки студентів різних галузей у зв'язку із необхідністю їх мобільності у межах світового освітнього та економічного середовища, що може стати можливим не лише завдяки їх грунтовній професійній підготовці, але й за умови оволодіння ними іноземною мовою, тобто, формування в них іншомовної професійної компетенції. Одним із способів досягнення якої $\epsilon$ створення стимулюючої системи контролю викладачем навчальної діяльності студентів. Регулярний аналіз викладачем об'єктивних даних щодо результатів навчальної діяльності студентів $\epsilon$ необхідним чинником покращення ефективності навчання. Доцільність та актуальність впровадження та удосконалення форм тестового контролю пояснюється, зокрема, можливістю оперативного отримання достовірної інформації щодо рівня навчальних досягнень здобувачів вищої освіти.

Як відомо, традиційними видами тестового контролю є вихідний, поточний і підсумковий контроль. Вихідний контроль націлений на встановлення початкового рівня знань студентів $з$ предмету задля ефективного планування навчального процесу, правильного підбору навчально-методичної літератури 3 дисципліни з урахуванням ступеня володіння вступниками англійською мовою. Крім цього, така форма контролю дозволяє здійснювати поділ студентів на групи та підгрупи, зважаючи на рівень підготовленості з іноземної мови, що не лише сприяє підвищенню рівня їх знань, але й значно спрощує підготовку викладача до занять. Поточний тестовий контроль дає змогу отримати інформацію щодо рівня оволодіння студентами певним обсягом навчального матеріалу, завдяки чому викладач може вчасно скорегувати та допомогти усунути можливі прогалини в знаннях 3 усієї теми чи окремого питання навчальної програми. Як показує досвід, використання цього виду тестування формує в студентів усвідомлення необхідності системної роботи над вивченням англійської мови, допомагає простежити рівень нинішніх особистих досягнень 3 предмету і порівняти їх із попереднім, а також сприяє підвищенню мотивації до 
вивчення іноземної мови. Підсумковий тестовий контроль має на меті з'ясувати результати навчання студентів упродовж семестру або навчального року.

В останні роки у Волинському національному університеті імені Лесі Українки на немовних спеціальностях широко практикується така форма підсумкового контролю як комп'ютерне тестування знань з іноземної мови, для проведення якого викладачі кафедри іноземних мов гуманітарних спеціальностей розробили і щороку удосконалюють зміст тестових завдань для перевірки рівня сформованості лексичної, граматичної, соціокультурної та лінгвокраїнознавчої компетентностей. Зокрема, студентам пропонуються такі формулювання завдань: оберіть правильну форму дієслова, оберіть правильні варіанти даного речення у пасивному стані, оберіть правильний варіант речення 3 непрямою мовою, оберіть правильну відповідь, заповніть відповідність між дефініцією та словом тощо. Приклад тестового завдання для студентів факультету філології та журналістики з формулюванням: заповніть пропуски цифрами, які відповідають правильному слову в тексті [1]:

There are events such as the ....... Lviv International Book Fair and Literature Festival. There, readers are not only...... the chance to meet and ....... to their favourite writers from Ukraine and other countries but also learn things about the world of ....... . This festival and other similar ...... show that modern Ukrainian literature is achieving the international recognition it deserves.

1) offered; 2) annual; 3) produce; 4) writing; 5) events; 6) expensive; 7) talk.

Перспективним вважаємо зосередження зусиль заради розробки методики укладання різнорівневих тестових завдань для проведення тестового контролю щодо формування базових англомовних компетентностей.

\section{Список літератури}

1. Англійська мова. Підсумковий контроль у формі комп'ютерного тестування: навчально-методична розробка для студентів III курсу гуманітарних спеціальностей СНУ імені Лесі Українки, ОКР бакалавр // Воробйова Т.В., Гордієнко Ю.А., Гусак Л.С., Кондрук А.Ю., Мельник О.М., Передон Н.О. та ін. - Луцьк: Вежа-Друк, 2019. - 260 с. 


\title{
ВИКОРИСТАННЯ КАЗОК КИТАЮ У ПРАКТИЦ КАЗКОТЕРАПІЇ
}

\author{
Казачінер Олена Семенівна, \\ доктор педагогічних наук, доцент, доцент кафедри здоров’я людини, \\ реабілітології і спеціальної психології \\ Харківського національного педагогічного університету \\ імені Г.С.Сковороди
}

\section{Бойчук Юрій Дмитрович,}

доктор педагогічних наук, професор, член-кореспондент НАПН України, професор кафедри здоров'я людини, реабілітології і спеціальної психології, ректор Харківського національного педагогічного університету імені Г.С.Сковороди

Казка супроводжує людину з самого дитинства. Вона ознайомлює малюка 3 навколишнім світом, сприяє формуванню життєвих цінностей, художнього, естетичного смаку, духовному зростанню. Саме за допомогою казки дитина пізнає та сприймає оточуючий світ, отримує уявлення про добро і зло, прекрасне та потворне. Під час роботи над казкою у дитини розвивається усне мовлення, формуються риси характеру.

Казкотерапія як один із напрямів арт-терапії $є$ дуже ефективним засобом навчання, виховання та розвитку дітей, у тому числі з особливими освітніми потребами. Загальновідомо, що гарна казка має терапевтичне значення і сприяє становленню людини як особистості.

Мета дослідження полягає у визначенні можливості використання казок Китаю у практиці казкотерапії. Свій вибір країни ми обгрунтовуємо тим фактом, що унікальність китайської культури полягає в тому, що в ній віками утверджувалися традиційні цінності: шанобливе ставлення до старших, допомога ближньому, родинні стосунки, самовдосконалення людини, пошук нею іiі особистого життєвого шляху, прагнення до поєднання внутрішнього бажання й громадянського обов'язку, поклоніння перед природою як приклад гармонії та вічності. Здавна китайська культура була заснована на визнанні сили морального прикладу. Шляхетна людина, як свідчить давня китайська мудрість, уникає ненависті, не спричиняє чвар, стримана в словах, шаноблива в спілкуванні. Кожна людина має дбати про те, щоб ставати кращою, утверджувати й збагачувати мораль свого народу.

Основною метою китайської народної творчості, як й інших країн світу, $\epsilon$ утвердження ідеалу. У Стародавньому Китаї саме мистецтво було ідеалом, тобто втіленням мрій і прагнень народу про покращання життя. Китайській культурі здавна притаманне прагнення відтворити зв'язок людини з природою - водою, повітрям, землею, рослинами, птахами й тваринами. Життя природи та їх сприйняття людиною, радощі та печалі існування, любов до вітчизни й співчуття до всього сущого - усе це надихало китайських майстрів слова [2]. 
Найромантичніші казки створив китайський народ. I не важливо, що китайці практичні в реальному житті, але в чарівних історіях прості селянські хлопці стають знатними чиновниками, а іноді навіть імператорами. Звичайно, їм допомагають чарівні сили, на боці добра виступають всі чотири стихії та їх володарі. Вогнедишні дракони готові за помахом руки казкового героя битися 3 військом загарбників і розметати по пагорбах їх тлінні тіла [3].

Серед найцікавіших китайських казок слід назвати такі: «Бай Шан та черепаха», «Брати Лю», «Вдячний дідусь», «Гора Сонця», «Дівчина-півонія», «Дідусь Кам'яна Голова», «Жовтий лелека», «Міст матері та сина», «Три брати», «Три дерева», «Чарівний пензлик Маляна», «Чому сова кричить тільки вночі» та інші. За мотивами деяких казок створено мультиплікаційні фільми.

Стародавній китайський народ має свою власну філософію укладу життя і посвоєму трактує деякі значущі віхи віку людини. Але загальнолюдські цінності шануються в Китаї навіть більшою мірою, ніж в інших країнах. Судді в казках мирять тварин, стихії, людей та роз'яснюють нерозумним душам про погані вчинки, підкреслюють важливість життя по совісті.

Варто зауважити, що основним джерелом дитячої літератури Китаю слугують саме народні казки міфологічного характеру, які були написані багато століть тому. Слід також враховувати той факт, що через політичний та соціальний устрій КНР та історичні події довгий час дитячої літератури, що мала б розважальні функції, не існувало взагалі. Тому характер китайських казок більш повчальний та серйозний, ніж у європейських. Персонажі казок - це правителі та імператори, а другорядні персонажі - сановники та чиновники [1].

Китайські казки про тварин грунтуються на поясненнях поведінки тварин, їх особливостей і середовищі існування. У хитромудрих історіях йде мова про те, чому собаки виють на місяць, чому миші бояться котів, чому їжак колючий. Не забуті оповіді про звірячі хитрості, де маленький завжди обдурить великого звіра і вийде переможцем.

Окрема категорія, яка розділена на кілька напрямків - це казки про тварин. Тварини-перевертні і люди, які вміють набувати іншого вигляду, обов'язково присутні в казках. Китайці настільки вірять у всяких перевертнів, що в середні століття у книжках видавали рецепти їх вигнання. I зараз у багатьох провінціях, перед кожним початком важливої справи, відбувається обов'язковий ритуал відлякування злих демонів і перевертнів.

Працьовитість китайського народу нам відомо не з чуток, але от китайські казки про ремісників мало кому відомі. Звичайний для них сюжет, це коли відомий майстер навчає інших людей або людина приносить себе в жертву заради допомоги майстру [3].

Пропонуємо деякі творчі запитання і завдання, які можна поставити учням для роботи над казками Китаю:

1. Як міг би допомогти хлопчик Малян людям за допомогою чарівного пензлика? Уявіть, що чарівний пензлик втратив свою добру силу і став оживляти тільки погане. Що б Малян зміг зробити, аби відновити чарівну силу пензлика? («Чарівний пензлик Маляна») 
2. Яким ви уявляєте подальше життя імператора з казки «Чарівний пензлик Маляна»? А імператора 3 казки «Жовтий лелека»? Чи могли б вони стати добрими та людяними? Чому? Якщо так, які б добрі справи вони могли б зробити для свого народу?

3. Намалюйте та зробіть розповідь про те, яким може бути життя мешканців Китаю після того, як лелека покинув палац імператора та прилетів до («Жовтий лелека»).

4. Намалюйте та зробіть розповідь про те, які добрі справи зможуть зробити людям і тваринам брати Лю після перемоги над імператором («Брати Лю»).

5. Уявіть, що брати Лю - недобрі люди, а імператор - гарний та чуйний. Чого б він зміг навчити братів? Зробіть ілюстрацію до сюжету казки («Брати Лю»).

Таким чином, наприкінці тез можна дійти висновку про те, що казки Китаю можна успішно застосовувати у практиці казкотерапії 3 метою формування позитивних рис характеру, працелюбності, шанобливого ставлення до людей та загальнолюдських цінностей у цілому. Повчальні елементи, мораль творів збігається 3 уявленням казок у слов'янській та західній літературі: добро перемагає зло, любов перемагає ненависть, оспівується любов до батьків, батьківщини, вірність друзям та інше.

Список літератури:

1. Дзюбишина-Мельник Н.Я. Художній стиль і мова творів для дітей. Культура слова. 1992. Вип. 42. С.85-90.

2. Китайська народна казка - казки народів світу. Електронний ресурс. Режим доступу: https://zarlit.com/textbook/5klas/16.html

3. Китайські казки. Електронний ресурс. Режим доступу: http://kazkar.info/ua/kitaysk_kazki/ 


\title{
ТИПИЧНЫЕ ПСИХОЛОГИЧЕСКИЕ БАРЬЕРЫ И ПУТИ ИХ ПРЕОДОЛЕНИЯ В ПРОФЕССИОНАЛЬНОЙ КАРЬЕРЕ СПОРТСМЕНОВ ВЫСОКОГО КЛАССА
}

\author{
Лубышев Евгений Александрович \\ кандидат педагогических наук, доцент \\ Российский университет дружбы народов, г. Москва \\ Российский экономический университет им. Г.В. Плеханова, г. Москва \\ Сергеева Юлия Сергеевна, \\ кандидат биологических наук, доцент \\ Российский университет дружбы народов, г. Москва \\ Баранов Михаил Георгиевич \\ старший преподаватель \\ Российский университет дружбы народов, г. Москва
}

Введение. В связи со значимостью физической культуры и спорта, как для личности, так и для государства, актуальным является выявление различного рода барьеров, препятствующих занятиям данными видами деятельности, а также достижению высоких спортивных успехов. Особая роль, согласно исследованиям, принадлежит психологическим барьерам, которые относятся к категории психических состояний и проявляются в переживаниях, неуверенности в себе, тревоге, страхе, стыде, заниженной самооценке, обусловливающих низкую активность и пассивность субъекта в направлении осуществления тех или иных действий $[3,4]$. Применительно к спортивной деятельности С.И. Самыгин, П.С. Самыгин [2] указывают на то, что психологические барьеры могут служить серьезным препятствием на пути к достижению высоких результатов. Согласно статистическим данным, лишь $0,004 \%$ физически подготовленных юных спортсменов достигают уровня мастера спорта международного класса. При этом 70 \% из тех, кто прекратил занятия спортом, не дойдя до уровня кандидата в мастера спорта (КМС), главной причиной прекращения своей спортивной карьеры считают потерю интереса к спортивным занятиям и негативные отношения с тренером.

В числе психологических барьеров спортсменов-легкоатлетов многие исследователи называют следующие: переутомление, боязнь услышать замечание тренера, страх не оправдать надежд, боязнь нарушить правила соревнований, предстартовая лихорадка, негативные мысли, прерывистый сон. Несмотря на представленные и другие исследования, по-прежнему остаются неизученными психологические барьеры, затрудняющие переход из массового спорта в спорт высших достижений, а также структура психологических барьеров для определения ведущих направлений профилактической, психокоррекционной и психоразвивающей работы. 
Цель исследования - выявление уровня сформированности и путей снятия психологических барьеров на протяжении профессиональной карьеры спортсменов высокого класса

Методы и организация исследования. В ходе эмпирического исследования использовались следующие психологические методики и тесты:

1) Анкета с предложенными вариантами ответов для выявления характера взаимоотношений респондентов со спортом и их спортивных достижений;

2) Методика диагностики ценностных ориентаций в карьере «Якоря карьеры»;

3) Авторский опросник для выявления психологических барьеров спортсменов.

В качестве испытуемых выступило 106 студентов ФГБОУ ВО «Российский университет дружбы народов» (в возрасте от 18 до 35 лет).

Результаты исследования и их обсуждение. По результатам анкетирования испытуемые студенты были разделены на три группы:

1) Студенческий спорm (СС) представляли студенты гуманитарносоциального факультета - будущие социологи, педагоги, клинические психологи (37 человек), регулярно посещающие занятия по физической культуре и участвующие во многих внутривузовских соревнованиях.

Надо заметить, что их будущая профессиональная карьера, как правило, не связана со спортом;

2) Профессионально-прикладной спорт (ППС) представляли студенты, обучающиеся по направлениям подготовки «Физическая культура», «Физическая культура для лиц с отклонениями в состоянии развития»

(42 человека), для которых спорт является элементом их профессиональной карьеры, выступая как средство подготовки к определенной профессии (военное и служебное многоборье, пожарно-прикладной спорт, тренеры детских юношеских спортивных школ и т.д.). Спортом занимаются для поддержания хорошей спортивной формы, участвуют в спортивных соревнованиях преимущественно в рамках своей профессии;

3) Cпорт высших достижений (СВД) представляли студенты заочной формы обучения направлений «Физическая культура», «Физическая культура и спорт» (27 человек), которые регулярно занимаются спортом, участвуют в спортивных соревнованиях различного уровня и стремятся достичь в них максимально высоких результатов.

Данная группа студентов имела высокие спортивные разряды, достижения и звания. Их профессиональная карьера предположительно, будеттесно связана со спортом.

В ходе математической обработки результатов исследования подсчитывались и сравнивались средние арифметические показатели выраженности психологических барьеров в каждой группе испытуемых студентов Гуманитарно-социального факультета РУДН, г. Москва. Наивысшие показатели сформированности психологических барьеров выявлены у испытуемых, активно занимающихся спортом в рамках дополнительных образовательных программ для студентов(первая группа), наиболее низкие 
показатели - у испытуемых, представлявших спорт высших достижений (третья группа), в свою очередь промежуточные результаты продемонстрировали испытуемые, представляющие профессионально-прикладной спорт (вторая группа).

Достоверные различия в уровне сформированности психологических барьеров были выявлены у второй и третьей групп испытуемых, поскольку отрыв третьей группы от первой, был выражен более явственно.

Сравнительный анализ результатов исследования явственно продемонстрировал, что ряд психологических барьеров может иметь одинаковую выраженность у всех групп спортсменов, в то же время у студентов третьей группы, представлявших спорт высших достижений, по сравнению со студентами второй группы, выявлены значимо более низкие показатели по следующим психологическим барьерам: нежелание делать свою жизнь более сложной, напряженной, тратить силы на практически недостижимый результат; понимание того, что успех не всегда оправдывает затраченные силы и средства; понимание того, что желаемое в спорте уже достигнуто, и в приоритете сейчас совсем другие ценности и цели; понимание бесполезности своих усилий в силу ряда внешних факторов (существующих правил, традиций, законов, отношений и др.); малый или недостаточный уровень профессиональной подготовленности/образования; отсутствие в университете (в котором я работаю/учусь) необходимых условий для достижения успехов, профессионального роста; нежелание ограничивать себя в интересных увлечениях, различных удовольствиях; отсутствие нужных связей и знакомств.

Полученные результаты исследования позволяют достоверно утверждать, что именно указанные барьеры являются наиболее проблемными и затрудняющими переход из массового (общедоступного) спорта в спорт высших достижений. Они могут быть обусловлены как внешними факторами, так и индивидуально-типологическими особенностями спортсменов, требующими серьезных мероприятий направленных на психокоррекцию и минимизацию негативного психологического влияния указанных явлений.

Многообразие психологических барьеров потребовало их группирования связанного с необходимостью осуществления комплексной работы по их преодолению. Предпринятый нами в ходе исследования факторный анализ методом главных компонент с последующим Varimax вращением позволил выявить основные 8 факторов, которые в совокупности объясняют 76,2\% дисперсии.

Первый фактор представлен следующими барьерами: нежелание делать свою жизнь более сложной, напряженной, тратить силы на мифически достижимый результат; понимание того, что желаемое в спорте достигнуто, в и в данный момент у меня в приоритете совсем другие ценности и цели; понимание бесполезности своих усилий в силу ряда внешних факторов (существующих правил, традиций, законов, отношений); нежелание ограничивать себя в интересных увлечениях; желание сменить профессию, вид спорта; потеря интереса к спорту/профессии, связанных со спортом и физической культурой. 
Представляется очевидным, что, этот фактор объединяет психологические барьеры, связанные со снижением мотивации в занятиях спортом, нежеланием усложнять жизнь и ограничивать себя в различных привилегиях.

Второй фактор включает в себя следующие барьеры: страх неудачи, боязнь нового; неуверенность в своих силах; ожидание негативного отношения окружающих вследствие неудачи; разочарование в себе, в своих достижениях в своей спортивной профессии; трудности управлять своим психическим состоянием, делать волевые усилия. Указанный фактор объединяет психологические барьеры эмоционального круга, связанные со страхами, разочарованиями, трудностями эмоционально-волевой сферы.

Третий фактор иллюстрирует степень сформированности следующих психологических барьеров: понимание того, что успех не оправдывает затраченных сил, средств; плохие семейные условия/проблемы; низкий престиж данного вида спорта/профессии, связанной со спортом, физической культурой; лень или нежелание покидать устойчивую зону комфорта. Тем самым указанный фактор охватывает психологические барьеры, связанные с завышенными ожиданиями от спорта для себя и своей семьи, низким уровнем престижности спортивных профессий в обществе, снижающими уровень личной активности спортсмена.

Четвертый фактор освещает уровень сформированности следующих психологических спортивных барьеров: отсутствие моральной поддержки со стороны окружающих; высокая конкуренция, наличие серьезных соперников. Указанный фактор касается прежде всего, сложностей в построением конструктивных взаимоотношений с другими людьми.

Пятый фактор имеет в своем составе следующие барьеры: недостаточный уровень собственных спортивных способностей и умений; состояние моего здоровья; опасение за свое здоровье, которое, возможно, потребуется для достижения желаемого успеха. Данный фактор касается самооценки состояния здоровья и собственных физических способностей.

Шестой фактор включает следующие барьеры: недостаток материальных ресурсов, стесненные жизненные обстоятельства; отсутствие в организации (в которой я работаю/учусь) необходимых условий для достижения успехов, профессионального роста; отсутствие нужных связей и протекций. Данный фактор отражает внешнюю позицию субъекта, на фоне высокой выраженности которой ответственность за неудачи в спорте перекладывается на внешние факторы, которые на самом деле практически никогда не бывают полностью удовлетворительными.

Cедbмой фактор включает в себя следующие барьеры: эмоциональную, профессиональную усталость; трудности управлять своим психическим состоянием, волей. Выявленные данным фактором барьеры касаются, скорее всего, эмоционального и профессионального выгорания, которое уже не поддается саморегулированию.

Восьмой фактор представлен следующими барьерами: недостаточный уровень собственных физических способностей; низкий уровень технической или тактической подготовленности/образования; лень (нежелание выходить из 
зоны комфорта). Данные барьеры частично уже входили в другие факторы. Здесь они, по-видимому, символизируют самокритичность, которая носит, скорее всего, пассивно-оправдательный, а не активизирующий характер.

Также были вычислены коэффициенты корреляции выраженности психологических барьеров и карьерных ориентаций студентов. В результате получены отрицательные корреляции выраженности психологических барьеров со следующими карьерными ориентациями спортсменов: «профессиональная компетентность» $(\mathrm{r}=-0,214, \mathrm{p}<0,05)$; «вызов» $(\mathrm{r}=-0,272, \mathrm{p}<0,01)$. Полученные результаты свидетельствуют о том, что психологических барьеров тем меньше, чем выше у спортсмена стремление к реализации своих талантов и физических способностей, стремление к мастерству, готовность к преодолению препятствий, решению трудных проблем, к открытой конкурентной борьбе, соревнованию, способности переживать спортивный настрой и азарт. Учитывая, что карьерные ориентации являют собой глубинные психологические установки личности в отличие от психологических барьеров, их выявление может выступать хорошим прогнозом на будущие успехи.

Вывод. Проведенное исследование открывает перспективы для разработки соответствующих оценочных шкал, а также позволяет определить направления профилактики возникновения некоторых психологических барьеров в процессе построения профессиональной карьеры спортсменов высокого класса, осуществлять необходиую адресную психокоррекционную и психоразвивающую работу.

Осознаваемые субъектами психологические барьеры их профессиональной деятельности на самом деле имеют в своей основе определенные индивидуально-типологические особенности, в качестве которых предположительно могут выступать внешний локус контроля, стремление к избеганию неудач, некоторые свойства темперамента, карьерные ориентации и другие базовые свойства личности спортсмена. Именно они определяют устойчивый психологический потенциал, обеспечивающий предсказуемость и поступательность в достижении желаемого уровня его карьерных предпочтений. Более широкое их изучение является наиболее перспективным и востребованным направлением в дальнейших исследованиях психологических барьеров спортсменов.

\section{Литература}

1. Закиров Ф.Х. Организация обучения студентов по спортивным дисциплинам в условиях COVID 19 // В сборнике: Вопросы профессионального развития. Материалы III международной научно-практической конференции. 2021. C. 56-64.

2. Закиров Ф.Х. Современные направления развития отечественной отрасли физической культуры и спорта // В сборнике: Вопросы профессионального развития. Материалы III международной научно-практической конференции. 2021. C. 50-55.

3. Zakirov F.Kh., Krasilnikov A.A. Age-related differences in decision-making process in the context of healthy aging // B сборнике: BIO Web of Conferences. 2020. C. 01022 . 
4. Красильников А.А., Федорова Е.Ю. Информационно-компьютерные технологии как определяющий фактор трансформации образовательного пространства организации // В книге: Приоритетные направления развития спорта, туризма, образования и науки. сборник материалов международной научно-практической конференции. Нижний Новгород, 2021. С. 665-674.

5. Губернаторова Т.О., Красильников А.А. Проведение мероприятий по спортивному ориентированию в современной городской среде // В книге: TRENDS AND DIRECTIONS OF DEVELOPMENT OF SCIENTIFIC APPROACHES AND PROSPECTS OF INTEGRATION OF INTERNET TECHNOLOGIES INTO SOCIETY. Abstracts of VI International Scientific and Practical Conference. Stockholm, Sweden, 2021. C. 374-379.

6. Лубышева Г.С., Красильников А.А., Чубанова Г.Р. Определяющие изменения образовательной среды в контексте внедрения информационнокомпьютерных технологий // Управление образованием: теория и практика. 2021. № 1 (41). С. 150-159.

7. Красильников А.А. Международные интеграционные процессы в сфере физической культуры и спорта в контексте внедрения информационнокомпьютерных технологий // В сборнике: Актуальные научные проблемы физической культуры и спорта. Материалы международной научнопрактической конференции. 2021. С. 73-77.

8. Пушкина В.Н., Битейкин М.М., Красильников А.А. Применение дистанционных образовательных технологий по дисциплине «Физическая культура» как способ мотивации школьников к самостоятельной двигательной активности // В сборнике: APPLIED AND FUNDAMENTAL SCIENTIFIC RESEARCH. Abstracts of XIX International Scientific and Practical Conference. 2021. C. 170-175.

9. Красильников А.А. Формирование цифровой образовательной среды образовательной организации в контексте внедрения информационнокомпьютерных технологий в образовательной // В сборнике: TOPICAL ISSUES OF PRACTICE AND SCIENCE. Abstracts of XXVI International Scientific and Practical Conference. 2021. C. 443-452.

10. Закиров Ф.Х. Тенденции ценностно-ориентированного подхода в сфере здорового образа жизни // В сборнике: Актуальные научные проблемы физической культуры и спорта. Материалы международной научнопрактической конференции. 2021. С. 21-27.

11. Красильников А.А. Психологические основы формирования мотивации к занятиям спортом в молодежной среде // В сборнике: Студенческий научный форум - 2020. сборник трудов научно-практической конференции со Всероссийским участием. АНО «Институт профессионального развития персонала», Научный журнал «Вопросы профессионального развития персонала». 2020. С. 80-91.

12. Красильников А.А. Ведение карты здоровья как индикатор индивидуализации физического воспитания студента // В сборнике: Бюллетень института естествознания и спортивных технологий. Сборник научных статей. 
МОСКОВСКИЙ ГОРОДСКОЙ ПЕДАГОГИЧЕСКИЙ УНИВЕРСИТЕТ. МоскВа, 2021. С. 56-61.

13. Красильников А.А., Закиров Ф.Х. Использование технологии подкастинга как инновационного метода обучения в физической культуре // В сборНИКе: ИННОВАЦИОННЫЕ ТЕХНОЛОГИИ В СПОРТЕ И ФИЗИЧЕСКОМ ВОСПИТАНИИ ПОДРАСТАЮЩЕГО ПОКОЛЕНИЯ. МатериалЫ IX Всероссийской научно-практической конференции. Институт естествознания и спортивных технологий Московского городского педагогического университета Коллектив авторов. 2019. С. 112-116.

14. Красильников А.А. Информационные технологии как ведущий фактор трансформации образовательного пространства // В сборнике: Актуальные научные проблемы физической культуры и спорта. Материалы международной научно-практической конференции. 2021. С. 102-109.

15. Красильников А.А. Использование информационных технологий в обучении // В сборнике: Наука - образование - производство. Сборник материалов конференции. 2007. С. 16-20.

16. Красильников А.А. Внедрение информационных технологий в методологию физического воспитания студентов-филологов // В сборнике: Бюллетень института естествознания и спортивных технологий. Сборник научных статей. Москва, 2021. С. 152-157.

17. Красильников А. А. Оценка личностной рефлексии в качестве построения положительной Я-концепции у студенток, занимающихся спортом // В сборнике: Вопросы профессионального развития. Материалы III международной научно-практической конференции. 2021. С. 73-80.

18. Красильников А.А. Спортивные игры как средство и метод развития двигательных способностей юных волейболистов // В сборнике: Инновационные технологии в спорте и физическом воспитании подрастающего поколения. Сборник статей по материалам XI научно-практической конференции с международным участием. Москва, 2021. С. 145-152.

19. Губернаторова Т.О., Красильников А.А. Проведение мероприятий по спортивному ориентированию в современной городской среде // В книге: TRENDS AND DIRECTIONS OF DEVELOPMENT OF SCIENTIFIC APPROACHES AND PROSPECTS OF INTEGRATION OF INTERNET TECHNOLOGIES INTO SOCIETY. Abstracts of VI International Scientific and Practical Conference. Stockholm, Sweden, 2021. C. 374-379.

20. Красильников А.А. Восприимчивость учреждения среднего профессионального образования к новшествам на примере гжельского колледжа // В сборнике: Вопросы профессионального развития. сборник материалов II международной научно-практической конференции. 2020. С. 27-36.

21. Красильников А.А., Эволюция системы профессионального образования с точки зрения математики // В сборнике: Инноватика в образовании. Сборник статей по материалам III научно-практической конференции. 2015. С. 98-101.

22. Красильников А.А. Типичные стратегии развития учреждения среднего профессионального образования // В сборнике: Образование. Наука. 
Культура. IV Международная научно-практическая конференция, сборник научных статей. 2012. С. 273-277.

23. Красильников А.А. Влияние подвижных и спортивных игр на скоростносиловую выносливость волейболистов // В сборнике: Бюллетень института естествознания и спортивных технологий. Сборник научных статей. Москва, 2021. С. 140-151.

24. Пушкина В.Н., Битейкин М.М., Красильников А.А. Геймификация как способ повышения мотивации обучающихся к занятиям физической культурой // В сборнике: RESEARCH AND DEVELOPMENT RESULTS. Abstracts of XVIII International Scientific and Practical Conference. 2021. C. 137142.

25. Красильников А.А., Закиров Ф.Х. Возможности применения информационно образовательных технологий и цифровых образовательных ресурсов в преподавании физической культуры // В сборнике: Современные проблемы физического воспитания и спорта, безопасности жизнедеятельности в системе образования. Сборник научных трудов III Всероссийской научнопрактической конференции с международным участием, посвященной юбилею доктора педагогических наук, профессора Л.Д. Назаренко. Под редакцией Л.И. Костюниной. 2019. С. 492-496.

26. Красильников А.А. Возможности применения цифровых ресурсов в образовательном процессе системы высшего образования // В сборнике: Академические исследования в области междисциплинарных инноваций. 2020. C. 278-283.

27. Красильников А.А. Новые технологии обучения в образовательном процессе по физической культуре // В сборнике: ADVANCING IN RESEARCH AND EDUCATION. Abstracts of XII International Scientific and Practical Conference. 2020. C. 348-353. 


\title{
МОДЕЛІ ОРГАНІЗАЦІї ТЕХНОЛОГІЇ ВLЕNDЕD LEARNING НА УРОКАХ ІНОЗЕМНОÏ МОВИ В 2 КЛАСІ
}

\author{
Мінко Свгенія Сергіївна \\ Студентка 2 (магістерського) рівня вищої освіти \\ Спеціальності «Початкова освіта» \\ Київський університет імені Бориса Грінченка
}

Динаміка змін, що відбуваються в світі та процеси глобалізації вимагають постійної взаємодії між людьми різних країн та культур в науці, авіації, дипломатії, туризмі та багатьох інших сферах. Наразі, основним інструментом для такого спілкування $є$ англійська мова. Отже, людина, що має на меті успішну реалізацію в суспільстві повинна володіти нею на належному рівні.

Освоєння будь-якої іноземної мови залежить перш за все від мотивації до іiі вивчення. Особливо це стосується учнів початкової школи. Так, в 2 класі освітній процес повинен спиратися на практичні дії учнів (адже в другокласників переважає наочно-дієве та наочно-образне мислення), але для тривалої концентрації дитині потрібна зовнішня допомога: цікаві картинки, відео, звукові сигнали, практичність застосування отриманих знань. Все це вимагає пошуку нових технологій, методів та засобів англомовного навчання.

Для дітей цифрового покоління одним 3 найбільш ефективних засобів підтримки інтересу до навчання $є$ використання сучасних цифрових технологій в освітньому процесі. Проте, варто усвідомлювати, що навіть у випадку інтенсивного включення технологій в навчальний процес, урок не буде ефективним, якщо вони використовуватимуться лише в контексті «замінити звичайну дошку на мультимедійну». Мова йде про пошук нових технологій та методик навчання з інтеграцією цифрових технологій в освітній процес. Однією 3 технологій, що дає змогу успішно реалізувати поставлене завдання, а також має величезний потенціал для забезпечення якісної англомовної освіти дітей $\epsilon$ Blended learning.

«Blend» 3 англійської перекладається як «змішувати», «з'єднувати», «комбінувати». Слово «Learning» перекладається як «навчання», «засвоєння». Таким чином, тотожним до словосполучення «Blended Learning» $є$ поняття «змішане навчання».

Виникнення терміну blended learning пов'язане 3 американською педагогікою. А набуло популярності воно завдяки напрацюванням дослідників Бонка і Грехемма [1]. Blended learning - це педагогічна технологія, що поєднує офлайн та онлайн-навчання, забезпечує елементи самостійного контролю учнями шляху, часу, місця і темпу навчання, а також інтеграцію досвіду навчання з вчителем та самостійного навчання.

Змішане навчання має численну кількість варіацій (моделей) ії організації та застосування. Серед численних класифікацій моделей змішаного навчання найбільш широко вживаною $є$ класифікація, розроблена зарубіжними вченими Гейзер Стейкер та Майклом Горном ще в 2012 році [2]. Вони виокремлюють такі 
моделі: ротаційну, гнучку, модель самостійного змішування та поглиблену віртуальну модель. Здійснимо коротку характеристику кожної з них.

Ротаційною називають модель, що побудована згідно принципу чергування навчання в онлайн та офлайн середовищах. Дослідниками було також виділено 4 можливих варіанти організації навчання за такою моделлю. Перший варіант ротація за станціями. Він передбачає, що учні будуть працювати в одному кабінеті й за визначеним графіком проходитимуть різні станції, одна із станцій обов'язково повинна передбачати роботу в онлайн середовищах. Другий варіант - ротація за лабораторіями. Відмінність від першого варіанту в тому, що учні рухаються не в межах кабінету, а в межах навчального закладу. А робота онлайн відбувається не на окремій станції, а в окремому приміщенні - лабораторії. Перевернутий клас - ще один варіант організації ротаційної моделі, в якій учні опрацьовують частину матеріаду вдома та частину в закладі освіти. Здебільшого, вдома засвоюється теоретичний матеріал онлайн, а в аудиторії опрацьовують практичну частину офлайн. І останній варіант - це індивідуальна ротація, за якої учні знаходяться в закладі освіти й проходять окремі станції за індивідуально визначеним графіком.

Наступним видом змішаного навчання є гнучка модель. Подібно до індивідуальної моделі ротації, вона передбачає роботу учнів за індивідуальним розкладом, в якому поєднані різні способи навчання, одним з яких є онлайн навчання. Однак, на відміну від індивідуальної ротації, гнучка модель не $є$ фіксованою, що дозволяє змінювати графіки в режимі реального часу, щоб задовольнити постійно мінливі потреби учнів у навчанні.

Модель самостійного змішування. Організація освітнього процесу за такою моделлю надає можливість опановувати певний курс цілковито онлайн як в закладі освіти, так і поза ним. Щодо компонента роботи в Інтернеті, викладач $\epsilon$ віртуальним, і навчання відбувається або в школі, або поза нею. Цей підхід може застосовуватися, коли в школах немає певних курсів на місці, наприклад, мовних курсів або нових підходів до викладання основних курсів, які відповідають конкретним потребам учнів.

Поглиблена віртуальна модель передбачає, що учні самостійно розподіляють курси на офлайн та онлайн частини. Важливо, що використання такої моделі передбачає охоплення всіх курсів, а не лише якусь певну кількість. Тобто, це комплексний підхід до навчання в школі (на відміну від поодинокого підходу в моделі самостійного змішування).

Гнучка модель, модель самостійного змішування та поглиблена віртуальна модель - складні в організації, хоч і досить ефективні щодо освоєння навчального матеріалу. Окрім цього, їх використання передбачає високий рівень навичок самоорганізації та дисципліни в учнів. Тому, використання таких моделей вважаємо доречним з учнями середніх та старших класів.

Ротаційна модель - найзручніший та найзрозуміліший варіант моделі змішаного навчання англійської мови учнів початкової школи. Беручи до розгляду саме другий клас, вважаємо вважаємо доцільним використання ротації за станціями та моделі перевернутого класу. Адже, ротація за лабораторіями та 
індивідуальна ротація - моделі, які можна впроваджувати з учнями, що мали попередній досвід змішаного навчання.

Окреслимо переваги використання моделі ротації за станціями на уроках англійської мови в 2 класі:

- дозволяє ефективно використовувати робочий час уроку;

- дає можливість опрацьовувати навчальний матеріал всебічно;

- сприяє своєчасному виявленню можливих мовних проблем;

- змінювання видів роботи унеможливлює втому та нудьгування на уроці, підтримуючи мотивацію до здобування знань та їх застосування;

- використання командної роботи сприяє формуванню в учнів навичок співпраці, та вміння прийняття рішень.

Перевернутий клас - ще одна ротаційна модель, яку вважаємо доречною у використанні протягом англомовного навчання другокласників. Це модель, в якій учні чергуються за встановленим графіком між навчанням у класі протягом навчального дня та в режимі онлайн поза робочим часом. Таким чином, вони контролюють, як, коли та де вони опрацьовують матеріал, поданий за допомогою онлайн інструментів, а потім повертаються назад до середовища класу на наступний день, щоб застосувати вивчене в онлайн середовищі [3].

До переваг віднесемо наступні: раціоналізація використання часу уроку; персоніфікований підхід; можливість для кожного учня опрацьовувати теоретичний матеріал у своєму ритмі; психологічний комфорт (оскільки матеріал був попередньо опрацьований, знижується рівень можливої напруги); підвищення інтересу до заняття: завжди цікавіше спілкуватися іноземною мовою, аніж просто вивчати слова на уроці; інтерактивний характер сприяє формуванню іншомовної комунікативної компетенції, бо під час «перевернутих занять» учні вирішують проблемні завдання іноземною мовою.

Таким чином, технологія blended learning $є$ ефективним інструментом для організації результативних уроків англійської мови. Серед численних моделей змішаного навчання в 2 класі доцільно застосовувати ротаційну модель та модель перевернутого класу. Кожна з них реалізує основне завдання початкового іншомовного навчання - сприяє формуванню іншомовної комунікативної компетентності. Обидві мають ряд вагомих переваг. Серед головних інтерактивний характер та психологічний комфорт, що сприяють успішному зануренню в іншомовне освітнє середовище.

\section{Список літератури:}

1. Bonk, C. J., Graham, C. R. Handbook of blended learning: Global Perspectives, local designs. San Francisco, CA: Pfeiffer Publishing, 2006. 624 p.

2. Horn M. B., Staker, H. Classifying K-12 Blended learning. Mountain View, CA Innosight Institute, 2012. $22 \mathrm{p}$.

3. Horn M.B., Staker H. Blended: Using disruptive innovation to improve schools. San Francisco: JosseyBass, 2015. 336 p.

4. Horn M. B., Staker, H. The blended workbook: Learning to design the schools of ourfuture. 2017. 352 p. 
5. Кухаренко В.М,, Березенська С.М., Бугайчук К.Л., Олійник Н.Ю., Олійник T.О., Рибалко О.В., Сиротенко Н.Г., Столяревська А.Л. Теорія та практика змішаного навчання: монографія. Харків: НТУ «ХПІ», 2016. 284 с 


\title{
ПЕРЕВАГИ ЗАСТОСУВАННЯ ПЛАНШЕТУ GEOBOARD НА УРОКАХ МАTЕМАТИКИ У 1 КЛАСІ
}

\author{
Романенко Людмила Віталіївна \\ Київський університет імені Бориса Грінченка, \\ кандидат педагогічних наук, \\ старший викладач
}

\begin{abstract}
Чорнобай Вікторія Петрівна
Київський університет імені Бориса Грінченка, студент другого (магістерського) освітнього рівня
\end{abstract}

Основним завданням Нової української школи є зосередження на гуманізації освітнього процесу, поліпшенні якості освіти та розвитку творчої особистості здобувача освіти. І одним із найважливіших підходів до вирішення цієї проблеми $\epsilon$ застосування освітніх можливостей ігрових технологій у початковій школі. Саме тому, педагогам, котрі працюють у початкових класах на уроці математики доречно застосовувати математичний планшет Geoboard, як ігрову технологію.

Вивчення початкового курсу математики буде ефективним, коли математична інформація для сприйняття на уроці буде візуалізована і зрозуміла дітям першого класу. Ігрова діяльність продовжує залишатися провідною для учнів першого та другого класів, а ігрові технології надають можливість в ігровій формі опановувати математичні уявлення, поняття. Однією із захоплюючих технологій вивчення математики у початковій школі $\epsilon$ ігрові діяльність 3 планшетом Geoboard, i наше дослідження спрямоване на визначення його потенціал та пошуку переваг його застосування на уроках у початковій школі.

Питаннями методики навчання математики у першому класі присвячені роботи багатьох українських науковців, серед яких варто відзначити М. Богдановича, Л. Коваль, О. Комар, Л. Кочину, Г. Лишенка, С. Логачевську, Т. Логачевську, О. Онопрієнко, Н. Руденко, С. Скворцову та інших. Застосування планшету Geoboard в початковій школі досліджували В. Коткова, М. Левшин, Ю. Мельник, Л. Романенко, Л. Петухова, О. Співаковський та ін. Упровадження ігрової діяльності в практику початкової школи було проаналізовано у працях Н. Бібік, Я. Коломінського, Н. Кудикіної, В. Мухіної, О. Проскури, О. Савченко, Н. Скрипченко та ін. Незважаючи на існування досить багатьох досліджень та методичних розробок щодо застосування планшету Geoboard було виявлено, що більшість із них актуальні під час роботи в дошкіллі.

Планшет Geoboard - це проста дитяча іграшка, призначена для дітей віком 38 років. Це дерев'яна або пластикова поверхня, на якому розташовані штирі. Такий доволі простий пристрій останнім часом набуває популярності серед вчителів, котрі працюють у початкових класах на уроках математики, оскільки він має ряд суттєвих переваг над звичними методами вивчення математики [2]. 
Розміри математичного планшету можуть коливатися від 5х5 до 10х10. Обирати розмір потрібно з урахуванням віку дитини. Іграшки з'явилися в середині минулого століття, але математичні планшети набули популярності в Україні лише в 1990-х роках. Geoboard був винайдений Калебом Геттенхо. Він вважав, що ці планшети навчать дітей дедукції через наявність тактильного контакту із планшетом, що стимулює до активної діяльності дітей першого класу під час вивчення математики та активує всі можливі рецептори для сприйняття математичної інформації.

Серед основних переваг планшету Geoboard можна виділити: тренування просторового мислення; розвиток дрібної моторики у дітей 1 класу; сприяє формуванню витримки до дрібної роботи; сприяє розвитку уяви; дає можливість вчителю визначити дітей, які схильні глибоко вивчати математику; сприяє розвитку та використанню художніх навичок [4].

Принцип дії простий: за допомогою штирів, прикріплених до дошки, потрібно розтягнути гумку різного кольору. Сьогодні $\epsilon$ безліч сучасних інтерпретацій даного планшету, а тому його можна купити в магазині іграшок.

Перед застосуванням математичного планшету вчителям варто показати дитині, як потрібно правильно володіти гумкою. Підказати також, як правильно одягати і знімати гумку. Деякі моделі математичних планшетів на задній стороні дошки мають сторону «годинника». Він включає наявність центральних шрифтів, вибитих по колу. Використовуючи іншу сторону планшета, діти можуть розрізняти час і навчитися користуватися годинником.

Остаточний набір математичного планшету містить геометричні фігури (кола, трикутники, квадрати), їх також варто активно демонструвати учням, залучати їх до роботи. Вони дозволять учням першого класу на уроці математики отримати більше варіантів геометричних форм. Першокласники можуть почати малювати $з$ простого контуру, а потім переходити до більш складного контуру. Наприклад, вчитель 3 часом може додати вищезгаданий трикутник до квадрата. Спочатку вчитель, як правило пропонує учню познайомитися з тими чи іншими геометричними фігурами, і лише потім дає завдання знайти ту чи іншу геометричну фігуру. Математичний планшет допомагає дітям на уроці математики розвинути уяву та бути уважними. Слід також доповнювати свій математичний планшет новими способами та методами взаємодії, що дає можливість проводити все новіші розрахунки, пошук геометричних фігур та інше. За допомогою математичного планшету діти можуть відпрацювати свої математичні навички та знати цифри, наприклад: створити форму з чотирма кутами, не обов'язково квадратом або прямокутником; створити схему 35 кутами; створити два різних трикутника; створити форму з чотирма або більше сторонами; створити два квадрати різних розмірів.

Для якісного застосування математичного планшету Geoboard у закладах початкової освіти першого циклу необхідно враховувати й індивідуальні інтереси дітей молодшого шкільного віку до тієї чи іншої теми, котра була запропонована вчителем до опрацювання на уроці математики. При використанні математичного планшету Geoboard прийнято за основу брати інтереси дітей 1 класу, які будуть зацікавлені у створенні продукту та результату 
від вивчення окремих тем з математики, котрі пропонує опрацьовувати вчитель [1].

Регулярне застосування математичного планшету на уроці математики у першому класі сприяє: розвитку пізнавальних здібностей дитини: логічні, просторові, асоціативні, образні, творче мислення, увагу, пам'ять; корисно для вивчення цікавих чисел та геометричних фігур. «Малювання гумкою» - це унікальна можливість «відчути» пальцем форму геометричного візерунка; сприяє розвитку психосенсорної моторики та розвитку дрібної моторики; вирішення різних типів задач на географічній табличці визначає пізнавальні здібності дитини; варіації гри легко моделюються та адаптуються майже до всіх здібностей та віку дитини; Geoboard це хороший спосіб зняти фізичний та психологічний стрес у дітей, а також сприяти розвитку логічних та математичних здібностей; математичні планшети дозволяють дітям вигадувати власні образи, щоб стимулювати їхню уяву та творчі здібності.

Основними видами пізнавальної діяльності учнів першого класу на уроках математики із застосуванням математичного планшету є: дослідницькі, в даному випадку діти 1 класу повинні дотримуватися алгоритму та чіткої структури виконання завдань із математики із активним залученням математичного планшету Geoboard. Наявність актуальності, цілей, об'єкту та предмету дослідження, організація дослідження та підбір методів, які допомогли реалізувати це дослідження, формулювання висновків та захист власно проробленої дітьми роботи. Творчі, де учні можуть опрацювати певну тему 3 математики та на іiі підставі створити чи розробити газету, буклет, листівку та інше із використанням математичного планшету Geoboard. Такі типи роботи на уроці математики із математичними планшетами не мають чіткої структури, як дослідницькі, але спрямовані на розвиток творчого підходу 3 боку дітей початкової школи. Ігрові та пригодницькі, що також не мають чіткої структури створення, але в таких видах роботи із математичним планшетом Geoboard діти можуть розігрувати діалог обираючи героїв та персонажів під час складання алгоритму розв'язання математичних задач та ситуацій. Інформаційний містить чітку структура та спрямований на самостійний збір дітьми 1 класу необхідних матеріалів для його подальшого захисту та загального представлення роботи, котра ними була виконана на уроці математики[2].

За рахунок застосування ігор із математичним планшетом Geoboard діти мають можливість: ознайомитися із системою взаємних відносин між людьми та способами їхньої комунікації, оскільки спочатку це відбувається більше на емоційному рівні, що згодом переростає на інтелектуальний; ефективне залучення емоційної та розумової сфери діяльності, де відбувається ознайомлення дітей із всіма спектрами почуттів, котрі притаманно відчувати людині; діти вчаться розрізняти позитивні та негативні вчинки людей, котрі в соціальному середовищі сприймають по-різному; формування загальноприйнятих моральних та етичних норм поведінки у соціальному середовищі [3].

Математичні планшети Geoboard в сучасному освітньому середовищі мають певні переваги. По-перше це дуже гарний наочний матеріал, який можна подати 
учням не лише у вигляді ілюстрацій, малюнків чи різного роду ілюстрацій, а графічної наочності, яка може бути об'ємно змодельованою і так далі. По-друге, математичні планшети Geoboard не $\epsilon$ іграшкою в освітньому просторі, а виступає ігровою технологією для передачі навчального матеріалу від вчителя до учнів.

Проте, вчителі стикаються 3 проблемою витрати часу для підготовки до уроку з застосуванням математичного планшету Geoboard. Це можна пояснити тим, що для того, щоб активно залучити на занятті необхідно продумати завдання, які пропонуватимуться учням до виконання, розставити посилання на матеріали, які повинні будуть учні опрацювати самостійно для здійснення частково-пошукової діяльності. Крім того варто здійснити підбір необхідних матеріалів, розробити питання для перевірки рівня оволодіння першокласниками навчального матеріалу та інше.

Ігри із математичним планшетом Geoboard мають на меті моделювання певного типу вирішення завдання, котрі розвивають навички самостійності прийняття рішення та пошуку можливостей вирішення того чи іншого завдання. Таким чином діти наче приміряють на себе певні соціальні ролі та вчаться правильно та ефективно взаємодіяти один із одним. Важливо, що головною, в даному випадку, виступає роль, котру діти приміряють на себе 3 метою формування комунікативних та соціальних навичок, які адаптують їх до життя в оточенні інших людей [3].

На якісне опанування початкової математичної освіти впливає здатність вчитися, логічно та критично мислити, застосовувати математичний досвід для вирішення повсякденних задач та завдань, команди, які навчають важливих навичок тощо. Крім того, навчання математики із застосуванням математичного планшету допомагає вчителю сформувати, в учнів першого класу, вміння для самостійного дослідження та аналізу інформації, фінансової грамотності та ділових навичок.

Отже, математичний планшет Geoboard в сучасному освітньому середовищі має певні переваги. По-перше це дуже гарний наочний засіб, який можна подати учням не лише у вигляді ілюстрацій, малюнків чи різного роду ілюстрацій, а графічної наочності, яка може бути об'ємно змодельованою. По-друге, математичні планшети Geoboard не $є$ іграшкою в освітньому просторі, а виступає ігровою технологією для передачі навчального матеріалу від вчителя до учнів та сприяти розвитку логічних та математичних здібностей.

\section{Список літератури}

1. Житєньова Н.В. Сутність візуалізації в навчальному процесі на уроці математики: Збірник наукових праць Кам'янецьПодільського національного університету ім. Івана Огієнка. Серія «Педагогіка». 2013. Вип. 19. С. 18-21. URL: http://nbuv.gov.ua/UJRN/znpkp_ped_2013_19_8 (дата звернення: 16.10.2020).

2. Кудикіна Н.В. Теорія ігрової діяльності дітей : монографія. Київ : НМЦВД КУ імені Бориса Грінченка, 2012. 235 с.

3. Лук'яненко К. Ігри на уроках математики з планшетом Geoboard. Фізикоматематична освіта. Науковий журнал. Суми : СумДПУ ім. А.С. Макаренка, 2014. № 1(2). C. 19-25. 
4. Финкельштейн Б.Б. Математический планшет. Математика, геометрия, развитие речи : Учебно-игровое пособие. Санкт-Петербург : ООО "Корвет", 2006. URL: https://www.stranamam.ru/post/7122154/ (дата звернення: 30.10.2020). 


\section{ПОРІВНЯЛЬНИЙ АНАЛІЗ НАУКОВИХ ДОСЛІДЖЕНЬ У ГАЛУЗІ ПІДГОТОВКИ ФАХІВЦІВ ДЛЯ ЗАБЕЗПЕЧЕННЯ СІМЕЙНОЇ ОСВІТИ В КАНАДІ ТА УКРАÏHI}

Свиридова Тетяна Іванівна

аспірант

Харківський національний педагогічний університет імені Г.С. Сковороди

Постановка та обгрунтування актуальності проблеми. В Україні особливості реалізації сімейної (домашньої) форми здобуття середньої освіти прописано у Положенні про альтернативні форми здобуття освіти, яке було затверджено у вересні 2019 року [2]. Офіційно сімейна освіта в Україні $\epsilon$ відносно новою формою здобуття сімейної освіти, проте наукові дослідження у цьому напрямку було розпочато набагато раніше. Питання «хоумскулінгу» (англ. домашньої освіти) взагалі $\epsilon$ надзвичайно актуальним та поширеним серед вітчизняних науковців, але проблема наукових досліджень у напрямку професійної підготовки фахівців (наприклад, вчителів, гувернерів, т’юторів, консультантів) для забезпечення успішної реалізації сімейної форми здобуття середньої освіти залишається малодослідженою в Україні.

Однією $з$ перших країн світу у вивчені сімейної освіти $є$ Канада. «У сучасному соціумі розвинутих країн світу домашнє навчання набуває все більшого поширення, що потребує удосконалення педагогічної майстерності 3 урахуванням потреб альтернативних форм навчання [5; с. 167]». Враховуючи вищеозначене, метою дослідження $є$ аналіз сучасних наукових тенденцій у галузі підготовки фахівців сімейної освіти в Україні та в Канаді.

Аналіз останніх досліджень і публікацій. Дослідження має у підгрунті результати наукових пошуків провідних українських [2-5] та канадських учених [1, 6-7], таких як А. Б. Ерей, Брайан Рей, Бозетті Лінн, Ван Пелт Д., Огієнко О., Павлюк В., Рубан Л. та інших. Досвід Канади у наукових пошуках в цій сфері заслуговує на увагу, оскільки система підготовки фахівців для забезпечення успішного функціонування домашньої освіти в цій країні налагоджена i перевірена багаторічним досвідом. Звертаємо увагу на необхідність розглянути сучасні наукові тенденції у цій галузі, що проводяться саме в Канаді, де спостерігається активна наукова діяльність.

Виклад основного матеріалу дослідження. У Концепції ООН від 1989 року зазначено, що сімейна освіта є ознакою демократичного суспільства. На цей факт спиралися науковці, які виступали за підтримку сімейної освіти. В своєму дослідженні Огієнко О. зазначає: «функціонування системи педагогічної освіти Канади базується на принципах: демократизму, варіативності, якості, доступності, мобільності, відповідності, а їі сутність розкривається в контексті двох концепцій: початкова підготовка майбутнього вчителя як динамічна система, спрямована на професійний педагогічний розвиток майбутнього 
вчителя: початкова підготовка майбутнього вчителя як методика передачі певного набору теоретичних знань та розвиток практичних навичок і вмінь $[3 ;$ c. 112]».

Наукові дослідження професійної підготовки фахівців для забезпечення сімейної освіти в Канаді направлені на вивчення особливостей підготовки фахівців до специфіки роботи із «домашніми дітьми». У наукових дослідженнях спостерігаються тенденції висвітлення причин переходу на сімейне навчання, історії розвитку, юридичних аспектів, пов'язаних із сімейною формою здобуття середньої освіти, досягнення хоумскулерів, проблеми соціалізації дітей та проблеми безпеки дітей у сім'ї [6].

Результати дослідження свідчать, що «у спектрі світового освітнього простору канадська багаторівнева система вищої педагогічної освіти сформувалася гнучкою та ефективною в економічному та педагогічному аспектах. Вона дозволяє оперативно регулювати підготовку фахівців. Студенти самі відповідно до своїх цілей визначають темп, характер, рівень навчання [4; с. 113]». Результати досліджень методів та форм підготовки фахівців для роботи з дітьми, які перебувають на домашньому навчанні в Канаді грунтовні та заслуговують на більш детальне вивчення. В Національного науководослідницькому інституті домашньої освіти (National Home Education Research Institute) проводяться важливі наукові дослідження в цій сфері, що свідчить про гостру необхідність у фахівцях.

На базі інституту видається рецензований науковий журнал «Дослідник домашньої школи» (Home School Researcher), який існує з 1985 року, та зосереджений на дослідженнях домашної форми здобуття середньої освіти та науковими питаннями, пов'язаними 3 нею. «Дослідження 3 Канади щодо найрізноманітніших аспектів домашньої школи сприяли міжнародним знанням $[7] \gg$.

У порівнянні з Канадою, в Україні не існує окремої науково-дослідницької установи, діяльність якої була б спрямована на вивчення сімейної освіти. Проте окремі дослідження вчених стають дедалі активнішими.

Висновки. За результатами дослідження було зазначено необхідність у подальшому вивченні сучасних наукових ідей Канадський учених у сфері сімейної (домашньої) форми здобуття освіти, оскільки багаторічний Канадський внесок у дослідження домашнього навчання заслуговує на увагу.

\section{Список літератури:}

1. Конвенція про права дитини. 20 листопада 1989 року, (редакція зі змінами, схваленими резолюцією 50/155 Генеральної Асамблеї ООН від 21 грудня 1995 року). Режим доступу: https://zakon.rada.gov.ua/laws/show/995_021\#doc_info https://www.unicef.org/child-rights-convention/convention-text

2. Наказ №955 от 10.07.2019. Про внесення змін до наказу Міністерства освіти і науки України від 12 січня 2016 року № 8. Вилучено з: https://zakon.rada.gov.ua/laws/show/z0852-19

3. Огієнко О. Професійна підготовка вчителів загальноосвітніх шкіл у Великій Британії, Канаді та США: спільне та відмінне / Освіта дорослих: теорія, 
досвід, перспективи. 2011. Вип. 3 (2). С. 105-115. Режим доступу : http://nbuv.gov.ua/UJRN/OD_2011_3(2)_15

4. Павлюк В. Підготовка вчителів англійської мови в системі багаторівневої педагогічної освіти Канади: сучасні тенденції. Порівняльно-педагогічні студії № 4(22), 2014. С. 112 - 1165 .

5. Рубан Л. М. Домашнє навчання як альтернативна форма здобуття початкової освіти (за ідеями американського педагога Джона Холта) / Порівняльно-педагогічні студії № 2 - 3 (20 - 21), 2014. С. 161 - 168

6. Bosetti, Lynn, \& Van Pelt, Deani. (2017). Provisions for Homeschooling in Canada: Parental Rights and the Role of the State. Pro-Posições, 28(2), 39-56. Вилучено 3: https://doi.org/10.1590/1980-6248-2016-0022

7. Ray, Brian. (2017). A Review of research on Homeschooling and what might educators learn. Pro-Posições, 28. Вилучено 3: https://doi.org/10.1590/1980-62482016-0009 


\title{
РОЗВИТОК ОБДАРОВАНОСТІ ВИХОВАНЦІВ ЦЕНТРІВ НАУКОВО-ТЕХНІЧНОЇ ТВОРЧОСТІ
}

\author{
Топузова Алла Василівна, \\ кандидат педагогічних наук, провідний науковий співробітник, \\ Інститут обдарованої дитини НАПН України, \\ м. Київ
}

Дослідженням проблеми технічної творчості займалися ряд авторів: Г. Альтшуллер, А. Антонов, Г. Буш, С. Василейський, М. Давлетшин, П. Енгельмейєр, Е. Мілерян, В. Моляко, Т. Кудрявцев, Ю. Трофімов, П. Якобсон та ін. Не дивлячись на досить велику кількість робіт з питань технічної творчості, проблема технічної обдарованості залишається ще мало вивченою і піднімається у вітчизняній психології, в основному, у роботах $\mathrm{B}$. Моляко та його співробітників.

Провідними компонентами технічної обдарованості за Р. ПономарьовоюСеменовою виступають потребово-мотиваційний і когнітивно-інтелектуальний, оскільки, як вважає автор, їх змістові одиниці здійснюють значний вплив на ефект досягнення результату з погляду новизни, оригінальності й строків реалізації. Критеріями базових проявів технічної обдарованості виступають: інтенсивність пізнавальної потреби в сфері науки і техніки; здатність до проблематизації та науково-технічного аналізу; цінність отриманого результату; “легкість” реалізації (втілення) ідеально-ціннісного способу розв’язання [1].

Поняття індивідуального досвіду (який включає соціальні і біологічні фактори) розглядає М. Холодна. В його структуру М. Холодна включає підструктури когнітивного досвіду, метакогнітивного досвіду (що стосується регуляторної системи психіки), інтенційного досвіду (мотиваційна система) та групу інтелектуальних здібностей [2].

Під здібностями Б. Теплов розумів визначені індивідуально - психологічні відмінності, відрізняючи одну людину від іншої, котрі не зводяться до різного запасу знань і навичок які має людина, а навпаки, обумовлюють швидкість їх надбання [3]. Творчі здібності притаманні будь-якій нормальній людині їх можна розвивати і тренувати. С. Рубінштейн вважав, що здібності людей не тільки проявляються, але і формуються в їх діяльності [4].

Визначено деякі найбільш важливі властивості технічних здібностей учнів. Так, у своїх дослідженнях М. Давлетшин, вивчивши технічні здібності учнів, вважав, що технічними здібностями називаються такі своєрідні сполучення індивідуально-технічних особливостей особистості, які виявляють придатність людини до технічної діяльності. Іншими словами - це здібності до розуміння та виготовлення технічних виробів, здібності до технічного винахідництва [5].

Структуру технічних здібностей досліджував П. Якобсон. Він виділяв основні компоненти, які характеризують технічні здібності: відмінності технічного мислення, цільовий підхід до ділових пропозицій, фактичний розрахунок при їх впровадженні, правильне планування часу, введення нових 
елементів при вирішенні завдань; нео6хідність розвинутої просторової уяви; здібність комбінування; вправність рук. Рівень успіху у технічній діяльності, за даними П. Якобсона, пояснюється наступними обставинами: технічним мисленням, під яким розуміється визначена направленість розуму, та спосіб підходу до речей. При такій направленості технічні завдання вирішуються раціонально, з урахуванням реальних обставин, з використанням в потрібний момент фізико-технічних знань, наявністю розвитку таких якостей особистості як просторова уява, здібність до комбінування, простоти появи асоціацій, пов'язаних 3 темою завдання, яке вирішується; характером інтересів особистості; необхідно щоб школярі проявляли не просто допитливість, інтереси пізнавального характеру, а інтереси специфічні, пов'язані з моментами, які припускають мобілізацію сил особистості, фонди іï знань, умінь, навичок для вирішення завдання [6].

Упродовж останніх років значно зросла увага держави щодо виховання молоді у позашкільних навчальних закладах. Позашкільна освіта посіла вагоме місце у системі безперервної освіти і стала її невід'ємною та унікальною ланкою.

Про державне замовлення на здобуття дітьми позашкільної освіти свідчать законодавчі та нормативні акти, прийняті в нашій країні за останне десятиріччя. У 1991 р. Уряд України підписав Конвенцію ООН про права дитини і Всесвітню декларацію про забезпечення виживання, захисту і розвитку дітей; у вересні цього ж року Верховна Рада України ратифікувала Конвенцію ООН про права дитини. Ратифікація Україною цього документа є незаперечним свідченням відповідальності держави та їі зобов'язань щодо збереження на своїй території проголошених цим міжнародним актом прав дитини. Так, ст. 28,29 Конвенції проголошено, що освіта дитини має бути спрямована на розвиток особи, талантів, розумових і фізичних здібностей дитини в найповнішому обсязі, підготовку дитини до свідомого життя у вільному суспільстві в дусі розуміння, миру, терпимості тощо. У прийнятій 1996 р. Конституції України зазначено, що Основний Закон України відповідає міжнародно-правовим нормам у сфері захисту прав людини, дитини, а зокрема у ст. 53 визначено: „Держава забезпечує розвиток... позашкіль ᄀної освіти”. Ст. 3, 5, 9, 25, 38, 39 Закону України „Про освіту” в редакції від 23 березня 1996 р. розкривають право дитини на освіту, творчий розвиток, станов ᄀлення позашкільної освіти як ланки безперервної освіти.

Сучасне законодавство України визнає необхідність забезпечення умов для розвитку творчих інтересів дітей та молоді. Право на творчий розвиток закріплено у Кодексі про шлюб та сім'ю України, Цивільному процесуальному кодексі України, Кодексі законів про працю України, Основах законодавства про охорону здоров'я, законах України „Про основи соціальної захищеності інвалідів в Україні”, „Про державну допомогу сім'ям із дітьми”, „Про сприяння соціальному становленню та розвитку молоді в Україні”, „Про освіту”. Цей принцип є основним також у Національній програмі „Діти України”. Основним нормативним документом, який визначає державну політику в галузі позашкільної освіти, є Закон України „Про позашкільну освіту”. Прийняття цього Закону суттєво змінило місце і роль позашкільної освіти у структурі 
загальної освіти України, трансформувало їх у нову якість - позашкільну освіту. Постало питання щодо співвідношення між ланками освіти; місця та перспектив позашкільних навчальних закладів на ринку освітніх послуг; ідеологічних засад позашкільного навчального закладу; змісту позашкільної освіти.

Вирішальну роль у подальшому розвитку позашкільної освіти в Україні мало також прийняття низки державних документів та Указів Президента України щодо державної підтримки обдарованої молоді, у яких звертається увага владних структур на проблеми плекання обдарованих і талановитих дітей та молоді в позашкільних навчальних закладах різних типів i, зокрема, у державногромадському об'єднанні учнів - Мала Академія наук України. Це об'єднання стало надбанням вітчизняної освіти і опікується сьогодні Центральними i місцевими органами влади, зокрема, Міністерством освіти і науки України, управліннями та відділами освіти місцевих держадміністрацій, а також Національною Академією наук України, Академією педагогічних наук України, десятками вищих навчальних закладів, академічними установами, громадськими організаціями тощо.

Розвиток педагогічних технологій 3 питань організації науководослідницької роботи учнів в умовах наукових секцій, наукових товариств має під собою глибокі багатовікові корені. Видатні вчені, історики, філософи, мистецтвознавці вісімнадцятого - дев'ятнадцятого століття, такі як Ж. Руссо, А. Гердт, П. Каптєрєв, Дж. Дьюї, Дж. Брунер та відомі педагоги і науковці XX століття Я. Чепіга, А. Музиченко, Т. Кудрявцева, І. Полянський, Б. Всесвятський, К. Ягодовський, П. Блонський, В. Андрєєв розробили методики запровадження дослідницького методу у навчально-виховний процес і довели його пріоритети. Останні десятиріччя вчені України відзначають у своїх працях надзвичайно велику ефективність застосування дослідницьких прийомів i методів у діяльності позашкільних закладів. Особливої уваги заслуговують наукові праці відомих в Україні вчених В. Вербицького, В. Мачуського, В. Обозного, Г. Пустовіта, В. Рибалки, С. Сисоєвої, А. Сиротенка тощо.

Рух щодо залучення учнівської молоді України до дослідницької, пошукової, експериментальної роботи розпочався ще з тридцятих років двадцятого століття, а вже у 1995 році було створено під керівництвом Міністерства освіти України та Національної Академії наук України єдину Малу Академію наук України. Відповідно до Постанови Кабінету Міністрів України № 45 від 26 січня 1994 р. „Про затвердження положення про позашкільний навчально-виховний заклад” в Україні почала розвиватися мережа Малих Академій наук як самостійних позашкільних навчальних закладів.

Проведені дослідження дозволяють зробити висновок, що 1990-1995 роки стали визначальними у створенні системи пошуку талановитої учнівської молоді, яка прагне до наукової творчості. Про це свідчить проведення Всеукраїнських конкурсів-захистів науково-дослідницьких робіт учнів. Головне - було вирішене питання про державну підтримку призерів цих конкурсів, яких почали зараховувати на відповідні факультети на пільгових умовах (за співбесідами). Так, у 1995 році таку можливість отримали 147 призерів 
Всеукраїнського конкурсу - членів МАН. У 1996р.- відповідно 264, у 1997 - 209, у 1998p. - 283, у 2001 - 329, у 2005p.- 412 учнів.

Згідно з державною статистикою, уже за 2000 р. навчанням і вихованням у Малій академії наук України було охоплено 37,6 тис. учнів 8-I I класів, у тому числі у територіальних відділеннях: Кримської АР - 7397, Волинському - 1184, Дніпропетровському -1160, Запорізькому - 2226, Львівському -3534, Одеському - 1472, Тернопільському - 1100, Херсонському -1330, Київському міському - 5317 учнів.

Набула подальшого розвитку мережа таких типів позашкільних навчальних закладів як Малі Академії наук учнівської молоді. Уже мають багатий досвід цієї роботи Львівська, Луганська, Мелітопольська, Тернопільська МАН, а також створена у 2003 році Державна Мала Академія наук учнівської молоді Міністерства освіти і науки України. Вищезазначене свідчить про наявність державного замовлення на цю форму позашкільної освіти.

Нині у нашій державі вже сформовано розуміння важливості проблеми підтримки талановитої та обдарованої молоді як національної, про що свідчить зацікавленість в діяльності МАН органів влади різних рівнів, широких кіл громадськості, вчених, педагогів, батьків, дітей та молоді.

Вирішенню зазначених питань засобами позашкільної освіти особливо сприяло прийняття постанови Кабінету Міністрів України від 27 березня 2002 р. № 378, якою була затверджена Програма розвитку позашкільних навчальних закладів на 2002-2008 рр., що значно посилило увагу органів місцевої влади, а також державних наукових установ, вищих навчальних закладів тощо. Згідно 3 державною статистикою в Україні працює понад 1500 позашкільних навчальних закладів, в яких навчається I млн. 200 тис. учнів віком від 5 до 18 років.

На основі багаторічного наукового аналізу попиту батьків, дітей, зацікавленості представників педагогічної громадськості, працівників науки, освіти та суспільства в цілому, на сучасному етапі відпрацьовані основні засади державної політики щодо підтримки обдарованої молоді. Ця політика здійснюється на принципах: доступності навчання учнів 8-11 класів у наукових гуртках, секціях, наукових товариствах незалежно від місця їх проживання, у обласних, міських, районних центрах, селах, містечках та етнічного і соціального походження, мовних та інших ознак; індивідуалізації навчання та виховання учнів відповідно до їх інтересів; самореалізації та само актуалізації; добровільності вибору учнями типів наукових секцій, гуртків, наукових об'єднань та їх базових навчальних закладів (шкіл, позашкільних закладів, вузів; академічних установ тощо); організаційного, науково-методичного забезпечення навчально-виховного процесу; правового захисту інтересів учнів, їх прагнення опанувати методики наукових досліджень, проведення пошукової, експериментально-дослідницької роботи, а також захист їх особистих наукових досягнень та техніко-технологічних винаходів; стимулювання учнівської молоді до науково-дослідницької роботи; державна підтримка найбільш обдарованих учнів.

Важливим завданням системи позашкільної освіти делегованого їй Міністерством освіти і науки України $є$ саме пошук і підтримка талановитих і 
обдарованих учнів, створення умов для їх розвитку. Аналіз діяльності територіальних відділень МАН України, їх наукових товариств, наукових секцій, гуртків дозволяє зробити висновок, що за кілька десятиріч свого розвитку вона набула авторитету серед педагогічної громадськості, учнівської молоді, батьків як активний засіб формування інтелектуального потенціалу нації.

Проведене нами серед членів Київської МАН «Дослідник» опитування свідчить про їх прагнення до того, щоб: бути освіченою, конкурентноздатною особою у суспільстві з ринковою економікою; планувати власну життєву стратегію, професійно самовизначитись; орієнтуватися у системі найрізноманітніших i неоднозначних цінностей при проведенні науководослідницької роботи; визначити своє життєве кредо, бути соціально активним.

Для забезпечення вищезазначених прагнень дітей та молоді педагогічні колективи позашкільних навчальних закладів України працюють над створенням для обдарованих учнів такого соціокультурного середовища, у якому вони змогли б максимально реалізувати свої задатки і здібності.

Пріоритетом державної політики в галузі позашкільної освіти залишається забезпечення умов для безкоштовного одержання всіма категоріями дітей та молоді, які потребують часткової корекції фізичного та психічного розвитку відповідно до їх можливостей та здібностей. Система державного регулювання позашкільною освітою є відкритою для громадської думки та менш залежною від конкретних посадових осіб. Особливої уваги потребує державна підтримка юних талантів.

Творча технічна діяльність учнів здійснюється у рамках організаційної системи, що склалася, безпосередньо в загальноосвітніх школах, міжшкільних навчально-виробничих комбінатах, позашкільних навчальних закладах, серед яких провідна роль належить центрам науково-технічної творчості i профорієнтації учнівської молоді.

В Україні історично склалася певна організаційна система науково-технічної творчості учнівської молоді. Очолює іiї Державний центр науково-технічної творчості учнівської молоді України, який перебуває у адміністративному підпорядкуванні Міністерства освіти і науки України. Він є організаційнометодичним центром $з$ пошуку технічно обдарованої учнівської молоді, дитячої технічної творчості в Україні. Його головне завдання - залучення учнів до масового руху юних техніків, розширення мережі існуючих і створення нових позашкільних навчальних закладів, які ведуть роботу з техніки з учнівською молоддю, створення технічних гуртків безпосередньо в школах. Він також $є$ основним, організатором проведення усіх масових заходів 3 юними техніками республіки (змагання, зльоти, конкурси тощо). На базі Центру проходять апробацію експериментальні програми науково-технічних гуртків.

Обласні центри науково-технічної творчості і професійної орієнтації учнівської молоді займаються питаннями організації дитячої технічної творчості в областях, проведенням масових заходів з юними техніками, курсів підвищення кваліфікації та семінарів для керівників науково-технічних гуртків. Ці центри знаходяться у підпорядкуванні Обласних управлінь народної освіти і науки. 
Міські та районні центри науково-технічної творчості і профорієнтації учнівської молоді - безпосередні організатори позаурочної роботи з учнями у школах, школах-інтернатах, та за місцем проживання

Центри науково-технічної творчості учнівської молоді, які виникли як тип спеціалізованого позашкільного навчального закладу, існують у переважній більшості міст. Діяльність таких центрів багатогранна. Вони відіграють важливу роль у справі трудового виховання і професійної орієнтації підростаючого покоління. Створюючи на своїй базі розгалужену систему технічних гуртків, центри силами не чисельних співробітників-ентузіастів проводять велику організаційну, пропагандистську, методичну та консультаційну роботу. Вони створюють методичні об'єднання з різних напрямків, через які спрямовують діяльність гуртків, клубів та інших об'єднань учнів у своєму регіоні.

При кожному такому центрі створюється громадський актив, куди входять керівники технічних гуртків позашкільних навчальних закладів і шкіл, працює методична рада 3 педагогів центру та представників установ і організацій, які впливають на розвиток технічної творчості учнів, допомагають у зміцненні матеріальної бази гуртків, у підготовці їх керівників, видавничій та пропагандистській роботі.

Творчою спрямованістю відрізняються клуби юних авіаторів, космонавтів, моряків, які відносяться до системи Міністерства освіти і науки України. В цих дитячих позашкільних навчальних закладах творчий розвиток, трудове виховання i профорієнтація тісно пов'язані 3 військово-патріотичним та фізичним вихованням, з вивченням авіаційної, космічної та морської техніки.

Головною формою організації дитячої технічної творчості у позашкільних навчальних закладах $є$ гурток. За змістом дитячої технічної творчості гуртки поділяються на ряд напрямків, які диференціюються тематикою роботи в них $\mathrm{i}$ віком учнів.

Найбільш масовими $є$ гуртки початкового технічного моделювання i конструювання для молодших школярів. В процесі роботи учні в живій i доступній формі знайомляться 3 елементами техніки i найпростішими технологічними процесами, працюють 3 папером, жерстю, розвивають початкові уміння з обробки деревини, пластмаси, металу та інших матеріалів, отриманих ними на уроках праці. Учні виготовляють технічні іграшки, нескладні моделі машин і механізмів, найпростіші автоматичні пристрої. Суттєве місце тут займають ігри та змагання з виготовленими іграшками та моделями. В останній час молодші школярі все частіше залучаються до роботи в галузі елементарної електротехніки та електроніки.

Гуртки початкового технічного моделювання i конструювання служать доброю пропедевтикою для усіх інших напрямків роботи 3 юними техніками середнього та старшого шкільного віку.

До гуртків спортивно-технічного напрямку відносяться гуртки: авіа-, судно, ракето-, автомоделювання, автоспорту, мотоспорту, радіоспорту, водномоторних та вітрильних видів спорту. В процесі занять учнів займаються конструюванням та виготовленням моделей і діючої техніки з наступною участю у змаганнях з цими моделями і на цій техніці. 
Технічна творчість у виробничо-технічних гуртках відрізняється тим, що в них об'єднуються учні, які проявляють інтерес до промисловості і виробництва, можливостей тієї чи іншої професії, яка розповсюдження на місцевих підприємствах, в аграрних та аграрно-промислових господарствах, до конструювання різноманітних пристроїв, які прагнуть отримати знання та опанувати навичками роботи в тій чи іншій галузі техніки і виробництва. У виробничо-технічних гуртках учні отримують можливість практично працювати і виготовляти не тільки моделі пристроїв, але і діючі зразки електротехнічної, радіотехнічної, сільськогосподарської та іншої техніки, а також технологічних пристосувань для використання в роботі трудових об'єднань школярів. Учні набувають навичок самостійної роботи, вчаться максимально використовувати допомогу спеціалістів i можливості промислового виробництва. Вони накопичують моральний досвід відповідального ставлення до вибраної справи. Одночасно вони вчаться складати, формулювати технічні і виробничі задачі, знаходити оптимальні варіанти їх розв'язання, опановують досвід практичного спілкування в трудовому колективі. Виробничо-технічні гуртки надають широкі можливості для залучення учнів до продуктивної праці, раціоналізаторства i винахідництва.

Предметно-технічні гуртки створюються з метою розширення і поглиблення знань та закріплення практичних умінь учнів з різних навчальних предметів шкільного навчального плану, створення обладнання для поповнення навчальних кабінетів і розвитку на цій основі технічної творчості учнів.

У залежності від віку учнів, їх інтересів і здібностей гуртки розрізняються за змістом та завданнями.

Головне завдання діяльності гуртків початкового моделювання та конструювання формувати в учнів інтерес до науки та техніки, виховувати повагу до корисної пращі, людей праці вчити дітей розуміти красу праці, іiі доцільність та гармонію, формувати у дітей початкові елементи графічної грамотності, конструкторські та технологічні знання і здібності, виховувати уміння працювати у колективі, готовність виконувати завдання, корисні для школи, позашкільного навчального закладу, сім'ї.

Учні підліткового віку займаються переважно у спортивно-технічних гуртках. Головними завданнями роботи технічних гуртків на цьому етапі $\epsilon$ розвиток у дітей творчих і пізнавальних здібностей, поглиблення і розширення ïх інтересів до певних видів технічної праці, знань про світ професій i спеціальностей, сприяння правильній орієнтації на вибір профілю навчання у професійно-технічному училищі, середньому спеціальному або вищому навчальному закладі.

В старших класах учні, як правило, займаються в гуртках виробничотехнічного профілю (технічної кібернетики, мікропроцесорної техніки, інформатики i обчислювальної техніки, радіотехніки, робототехніки, трактористів, ком6айнерів), які мають більш конкретну спрямованість на одну із технічних професій. Змістом роботи таких гуртків передбачається експериментальна та дослідна робота, раціоналізація, винахідництво. 
Головне завдання виробничо-технічних гуртків - формування у старшокласників спеціальних звань, умінь, навичок, сприяння формуванню у них системи знань, які передбачають уміння аналізувати сферу професійної діяльності майбутніх спеціалістів, виділення іiі основних принципів i закономірностей, задоволення і розвиток інтересу до техніки, виробництва, до самоосвіти в тій галузі виробництва і техніки. Опанування сучасними методами конструювання технічних об'єктів, раціоналізаторства та винахідництва.

Вивчення стану роботи у гуртках науково-технічної творчості позашкільних навчальних закладів в Україні показало, що найбільш актуальним в наш час $\epsilon$ залучення до позаурочної роботи учнів старших класів. Так, за статистичними даними Міністерства освіти і науки України кількість старшокласників в гуртках технічної творчості позашкільних навчальних закладів у різні роки не перевищує $10 \%$ від загальної кількості гуртківців, які навчалися у позашкільних навчальних закладах різного профілю.

У рамках констатувального етапу педагогічного експерименту ми вивчали потреби у творчій технічній діяльності вихованців центрів науково-технічної творчості. 3 метою діагностики учням пропонувався ряд тверджень:

- при однаковій оплаті праці я віддав би перевагу більш складній роботі;

- під час роботи в гуртку я отримую нові знання, формую відповідні уміння;

- я переважно берусь за виконання складної роботи, навіть, якщо інші відмовляються від неї;

- часто дбаю про вдосконалення організації і технології праці;

- пізнаю красу творчої технічної праці;

- вибираю і виконую тільки цікаві роботи;

- робота з товаришами дає мені можливість трудитися з бажанням;

- в процесі роботи в гуртку я перевіряю свої знання на практиці;

- від своєї майбутньої роботи я сподіваюсь отримати добрий прибуток;

- моя робота дає мені можливість відчувати відповідальність перед колективом;

- у праці я розвиваю власні творчі здібності.

здійснений аналіз отриманих даних представлено в таблиці 1.

Результати діагностики в учнів 8-11 класів потреби у творчій технічній діяльності (\%).

\begin{tabular}{|c|c|c|c|c|c|c|}
\hline \multirow{2}{*}{ Клас } & \multicolumn{5}{|c|}{ Рівень розвитку } & \multirow{2}{*}{$\begin{array}{c}\text { Середнє } \\
\text { значення }\end{array}$} \\
\cline { 2 - 6 } & & & & & & 0,54 \\
\hline 8 & 12 & 31 & 39 & 10 & 8 & 0,59 \\
\hline 9 & 8 & 29 & 33 & 18 & 12 & 0,56 \\
\hline 10 & 11 & 30 & 35 & 14 & 10 & 0,57 \\
\hline 11 & 10 & 28 & 36 & 17 & 9 & 0,56 \\
\hline $\begin{array}{c}\text { Середнє } \\
\text { арифметичне }\end{array}$ & 10,25 & 29,50 & 35,75 & 14,75 & 9,75 & \\
\hline
\end{tabular}


Аналізуючи дані, наведені в таблиці 1., приходимо до висновку про надзвичайно низький рівень розвитку потреби у науково-технічній діяльності для усіх чотирьох вікових груп. Середні значення для кожної з груп настільки мало відрізняються, що вести мову про динаміку зміни потреби в науковотехнічній діяльності немає сенсу. Зазначимо також, що величина 0,565 складає всього 11,3\% від максимально можливої величини 5 .

Одним із важливих завдань є формуванню в учнів ціннісних орієнтацій, спрямованих на задоволення потреб самовдосконалення, самоствердження, професійного росту, вихованні в учнів любові до праці, позитивного ставлення до всіх видів технічної діяльності, розуміння необхідності творчої технічної праці як для суспільства, так і для життя самої людини. Зміни, що відбувалися в суспільстві за останні роки, суттєво вплинули на всю систему трудових ціннісних орієнтацій, які безпосередньо взаємопов 'язані з інтересами і мотивами творчої технічної діяльності. Мотиваційна сфера особистості формується внаслідок переваги тих чи інших цінностей.

Так, користуючись методикою визначення ціннісного ставлення учнів до науково-технічної діяльності, ми провели таке дослідження на етапі констатувального експерименту. Було встановлено, що більшість учнів на перше місце ставили матеріальний добробут, але мотивом при цьому була допомога своїм батькам, створення сім ї тощо. У структурі потребнісно-мотиваційної сфери учнів даної вікової категорії спостерігається прагнення здобути визнання колективу, задовольнити власні амбіції, а потім вже творче самовдосконалення. Моральні цінності залишаються поза увагою особистості і посідають останні місця у рейтингу (див. табл. 2.).

Дослідження показало, що за рейтинговими показниками учні на перше місце ставили такі цінності, як визнання колективом, забезпечене майбутнє, не тільки своє, а й своєї родини; матеріальні винагороди. Це за нашими спостереженнями підкріплює мотиваційну сферу особистості.

Таблиця 2.

Рейтинг ціннісного ставлення учнів до науково-технічної діяльності

\begin{tabular}{|l|c|c|}
\hline \multicolumn{1}{|c|}{ Поняття цінності } & $\mathbf{1 0}$ кл. & $\mathbf{1 1}$ кл. \\
\hline Користь суспільству & 6 & 7 \\
\hline Творчий характер праці & 7 & 6 \\
\hline Можливість самоствердження & 4 & 4 \\
\hline Можливість творчого самовдосконалення & 5 & 3 \\
\hline Визнання колективом & 3 & 5 \\
\hline Матеріальні винагороди & 2 & 1 \\
\hline Забезпечене майбутнє & 1 & 2 \\
\hline
\end{tabular}

Отже, у позашкільних навчальних закладах, у яких науково-технічна діяльність учнів $є$ провідною (центрах науково-технічної творчості учнівської молоді; клубах юних техніків, авіаторів, моряків, космонавтів і т. д.) бажано проводити цілеспрямовану роботу по розвитку творчої обдарованості учнів. Ці заходи мають розглядатися як складові частини освітнього процесу. 


\section{Список літератури}

1. Матюшкин A.M. Загадки одаренности: проблемы практической диагностики. Москва: Школа-пресс, 2003. 127 с.

2. Холодная М.А. Психологические механизмы интеллектуальной одаренности. Вопросы психологии № 1, 1993. С. 32 -39.

3. Теплов Б.М. Проблемы индивидуальных различий. Москва, 1991. 586 с.

4. Рубинштейн С.Л. Основы общей психологии. СПб: Питер, 2009.712 с.

5. Давлетшин М.Г. Психология технических способностей школьников. Ташкент, 1991. 176c.

6. Якобсон П.М. Технические способности и их изучение у учащихся. Москва: Просвещение, 1994. 175 с. 


\title{
ПОСТУП ЦИФРОВІЗАЦІї ОСВІТИ В УКРАЇНІ: ШЛЯХИ РОЗВИТКУ
}

\author{
Тухтарова Тетяна Карімжанівна, \\ науковий співробітник, \\ Дніпровської академії неперервної освіти, Україна \\ Дуднік Володимир Сергійович, \\ завідувач науково-дослідної лабораторії \\ інформаційних технологій та дистанційного навчання \\ Дніпровської академії неперервної освіти, Україна
}

Світова пандемія COVID-19 для кожної країни стала випробуванням не тільки соціальної, економічної, правової готовності оперативно, але зважено приймати рішучі дії, а й своєрідною перевіркою рівня цифровізації різних сфер діяльності держав. В цих умовах найбільшого збою за останні десятиліття зазнала система освіти. Найактуальнішим в цьому контексті стає оцінювання стану цифровізації освітніх установ, бо саме цифрові технології дозволяють не зупиняти навчальний процес, а безпечно та ефективно продовжувати його в дистанційному або змішаному форматі. Тож сьогодні цифрова спроможність закладів освіти стає пріоритетом номер один.

3 огляду переваг та недоліків дистанційної освіти, про які вже багато написано та проговорено, треба визнати, що альтернативи використанню цифрових технологій у навчанні на сьогодні немає. I не лише через питання безпеки. Цифровізація сприяє спрощенню освітнього процесу, роблячи його більш гнучким, пристосованим до реалій сучасного дня, що у свою чергу забезпечує формування конкурентоспроможних професіоналів. Цифровізація освіти - це не лише інструмент, а й середовище існування, яке відкриває нові можливості: навчання за індивідуальною траєкторією, тобто максимально ефективно і зручно - у будь-який час та в будь-якому місці; безперервна освіта; можливість проектування індивідуальних освітніх маршрутів, тощо [1]. А ще це зменшує навантаження на викладачів: позбавляє непотрібної паперової рутини та автоматизує перевірку робіт здобувачів освіти.

Цифрова грамотність (або компетентність) визнана СС однією з ключових для повноцінного життя та діяльності людини, тому в Законі України «Про освіту» зафіксовано, що формування інформаційно-комунікаційної компетентності є обов'язковим [2].

Цифровізація освіти та формування цифрових компетентностей дають:

- Учителям шкіл та викладачам закладів вищої освіти можливість швидко знаходити нові сучасні матеріали, розвивальні ігри, завдання, кейси для учнів та студентів, спілкуватися з колегами по всьому світу, спільно формувати проєкти, подавати гранти, находити інформацію про професійні заходи, семінари, конференції, міжнародні обміни, а також розповсюджувати власні напрацювання. Цифрові технології спрощують оцінювання та звітність. 
- Для молодих спеціалістів та людей, які прагнуть до навчання впродовж життя, доступ до понад 1500 освітніх онлайн-платформ у всьому світі, де безкоштовно від кращих викладачів всесвітньовідомих навчальних закладів або експертів-практиків можна отримати нові знання та навички.

- Людям з особливими освітніми потребами можливість отримати доступ до освітніх послуг у будь-який час незалежно від місцезнаходження.

- Дорослому населенню (35+) можливість легше адаптуватися до змін сучасного світу.

Безумовно, освітня система вимагає кардинальних змін в організації освітнього середовища, що пов'язано не лише з масштабною діджиталізацією життєдіяльності суспільства, а й з епідеміологічною ситуацією у світі, яка змусила раптово та масово перейти 3 навчальних класів до віртуального простору.

I на сьогодні цифровізація освіти в Україні вже змінює традиційну систему освіти у напрямі формування іï̈ нової якості. Це проявляється в наступному:

- збільшується кількість віртуальних освітніх платформ;

- один електронний ресурс може бути використаний багато разів для надання різних за змістом освітніх послуг;

- впровадження нових технологій в освіті та цифрових освітніх платформ, які надають послуги [3].

Набуває все більшого поширення дистанційна форма навчання, якій сприяє розвиток інформаційних технологій i комунікацій. Цифровізація навчання дозволяє збільшити віртуальну мобільність здобувачів освіти, дає змогу студентам вищих навчальних закладів України навчатись в інших країнах та проходити там стажування. Цифровізація освітніх послуг в Україні дозволяє конкурувати в межах єдиного європейського освітнього простору.

Ключові зміни, які простежуються сьогодні в українські освіті:

- освітні заклади не лише повинні забезпечити навчальний процес, а й стати майданчиком для створення інновацій, що неможливо без злиття 3 наукою $\mathrm{i}$ практикою;

- об‘єднання ресурсів для реалізації спільних проектів, створення освітніх та наукових on-line платформ;

- 3'явилася можливість вибудовування персоніфікованих освітніх траєкторій;

розвиток рівневої системи тематичних модулів;

- на рівні 3 традиційною освітою суспільство почало користуватися нетрадиційною, що можна пояснити зростанням компетенцій до інновацій [4].

Відповідно до «Освіта. Стратегія України 2030» трансформаційні зміни відбуватимуться на всіх рівнях здобуття освіти. Щодо середньої освіти, то цифрові технології дозволяють зробити процес навчання цікавим, мобільним та індивідуальним. При цьому технології не замінюють вчителя, а доповнюють його. Таким урокам властиві адаптивність, керованість, інтерактивність, поєднання індивідуальної та групової роботи, часова необмеженість навчання.

Цифровізація шкіл має реалізовуватися за такими напрямками: 
- доступ до технологій учнів, учителів, адміністраторів шкіл;

- шкільний інтернет;

- цифровий мультимедійний контент;

- цифрові компетентності та грамотність викладачів і учнів;

- кібербезпека та захист даних.

Перші кроки на шляху цифровізації середньої освіти - це:

- створення універсального пакета цифрових послуг для учнів та вчителів (зокрема телеком-послуги);

- цикл тренінгів, курсів підвищення кваліфікації вчителів із цифрової грамотності;

- присвоєння кожному учаснику освітнього процесу унікального цифрового підпису для посвідчення результатів навчання;

- у частині заохочення батьків та громадськості - впровадження моделі BYOD (bring your own device, $з$ англ. «використовуй свій пристрій»). Це істотно підніме рівень забезпечення школярів цифровими засобами у класі, 3G-, 4Gзв'язком. Однак треба передбачити технічну підтримку сімей із незахищених верств населення, а також дітей від небажаного контенту;

- у частині стимулювання виробників шкільних цифрових пристріїв створення привабливих умов для залучення інвестицій;

- створення власного мультимедійного цифрового контенту, трансфер i адаптація міжнародних цифрових продуктів.

Цифрова трансформація в секторі вищої освіти традиційно відбувається у трьох напрямках:

- взаємодія із здобувачами вищої освіти;

- оптимізація процесів;

- зміна бізнес-моделі.

Однак трансформація - це лише інструмент досягнення мети. Та важливо, щоб цілі закладів вищої освіти та цілі здобувачів освіти тут збігалися. Важливим інтегральним показником ефективності закладів вищої освіти в частині навчання повинна стати кількість працевлаштованих за фахом випускників. Університети мають перейти не тільки до цифрових інструментів у традиційному навчальному процесі, а й до повністю нових цифрових моделей навчання; розробити програми цифрової трансформації для забезпечення конкурентоспроможності освітньої, науково-дослідної та господарської діяльності на національному та світовому рівнях [5].

Грамотне використання цифрових ресурсів, можливостей сучасних інноваційних методик і технологій, організація інтерактивної діяльності тощо вимагає розроблення та забезпечення освітніх установ якісним програмним продуктом. Це дозволить отримувати доступ до найрізноманітнішого освітнього контенту, результатів сучасних наукових досліджень, електронних наукових бібліотек на різних мовах світу, створити симулятори, тренажери, віртуальні лабораторії та інтерактивні ігрові ресурси, організувати проєктну діяльність, здійснювати віртуальні екскурсії та подорожі, онлайн-трансляції різних освітніх заходів. 
У цифрову еру перемагатиме той, хто не боїться змінюватися та мислити масштабно. А проведені заходи 3 цифровізації як на державному, так i регіональному рівнях, демонструють, що модернізація освіти України відбувається відповідно до вимог сучасного світу. I це сприяє забезпеченню права кожного на здобуття освіти впродовж усього життя, рівність умов доступу до освіти, незалежно від місця навчання.

\section{Список літератури:}

1. Карплюк С. О. Особливості цифровізації освітнього процесу у вищій школі / С. О. Карплюк // Інформаційно-цифровий освітній простір України: трансформаційні процеси і перспективи розвитку. Матеріали методологічного семінару НАПН України. 4 квітня 2019 р. / За ред. В. Г. Кременя, О. І. Ляшенка; укл. А. В. Яцишин, О. М. Соколюк. К, 2019. 361 с. С. 188-197.

2. Закон України «Про освіту» [Електроний ресурс]. Режим доступу: https://zakon.rada.gov.ua/laws/show/2145-19\#Text

3. Краус К. М. Імперативи формування цифрової освіти в Україні [Електроний ресурс]. Режим доступу: http://dspace.puet.edu.ua/bitstream/123456789/6059/1/\%D0\%9A\%D1\%80\%D0\%B0 $\%$ D1\%83\%D1\%81\%20\%D0\%9A.\%D0\%9C..pdf

4. Криворучко О. С. Імперативи формування та домінанти розвитку цифрової економіки у сучасному парадигмальному контексті / О.С. Криворучко, Н. М. Краус // Парадигмальні зрушення в економічній теорії XIX ст. : зб. наук. пр. за матеріалами III Міжнар. наук.-практ. конф., 2-3 лист. 2017 р. - Київ : КНУ ім. Т. Шевченка, 2017. - С. 681-685.

5. Освіта. Стратегія України 2030 [Електроний ресурс]. Режим доступу: https://www.slideshare.net/UIFuture/2030-148758034 


\title{
ЗАСТОСУВАННЯ АВТЕНТИЧНИХ МАТЕРІАЛІВ ДЛЯ ФОРМУВАННЯ МОВНИХ КОМПЕТЕНЦІЙ НА ЗАНЯТТЯХ 3 ІНОЗЕМНОЇ МОВИ
}

\author{
Юрченко Лариса Василівна \\ Старший викладач кафедри іноземних мов \\ Військова академія (м. Одеса)
}

У двадцять першому столітті, яке характеризується динамічними соціально економічними змінами і необхідністю постійно спілкуватися, англійська мова стала основним засобом міжкультурної комунікації. Формування комунікативної компетенції, яка включає в себе мовну та соціокультурну компетенції, $є$ метою навчального процесу на заняттях з іноземної мови.

Поряд 3 численними методами та принципами ефективного вивчення англійської мови, застосування різних видів автентичних матеріалів формує лінгвокраєзнавчу та міжкультурну компетенції, впливає на особисто-емоційний стан студентів, сприяє підвищенню комунікативно- пізнавальної мотивації.

Слово “автентичний” (в перекладі “справжній, реальний, близький до джерела") використовується в сучасній методиці відносно різноманітних культурних матеріалів, які є справжніми джерелами інформації.

Під час навчального процесу на заняттях 3 іноземної мови доречно застосовувати різні види автентичних матеріалів: автентичні аудіовізуальні матеріали (телевізійна реклама, художні та документальні фільми, кліпи, новини), автентичні аудіоматеріали (пісні, реклама, радіо), автентичні візуальні матеріали (фотографії, картини, слайди, ілюстрації, дорожні знаки, листівки), автентичні друковані матеріали (журнальні та газетні статті, тексти пісень, рахунки, квитки) та реалії (монети, іграшки, предмети побуту). Мова, яка представлена в автентичних матеріалах - це засіб реального спілкування, а інформація, яку одержують за допомогою використання автентичних матеріалів має високий рівень авторитетності та довіри.

Успіх застосування автентичних матеріалів залежить від об'єму та складності завдання. Роль викладача полягає у вмінні диференційовано підходити до потреб та здібностей не тільки всієї групи студентів, але і її окремого представника. Під час підбору автентичного матеріалу слід пам'ятати про важливі критерії, такі, як актуальність та відповідність до теми заняття, інформаційна насиченість та врахування професійних інтересів аудиторії. Велика кількість лексичних, граматичних, фонетичних труднощів обмежує використання автентичних аудіовізуальних матеріалів на початковому етапі вивчення іноземної мови. Різні види комунікативних вправ, які розробляються викладачем, сприяють кращому розумінню, запам'ятовуванню та якісному розвитку комунікативних компетенцій в процесі застосування автентичних матеріалів. Так, перед використанням автентичного аудіовізуального матеріалу (демонстрація відеофільму “Тhe Ceremony of Honor") у групі військових слухачів інтенсивного курсу вивчення англійської мови (Військова академія (м. Одеса) було 
запропоновано прочитати короткий текст “ The Changing of the Guard” та виконати вправи перед переглядом відео, щоб уникнути труднощів під час перегляду автентичного відео. Дана стратегія організації начального процесу сприяла ефективному засвоєнню теми заняття.

Формування мовних компетенцій в процесі застосування автентичних матеріалів не в природньому мовному середовищі має певні обмеження, які пов'язані з рівнем володіння мовою та труднощами соціокультурного аспекту. Для ефективної роботи із автентичним текстом потрібні певні навички та базові вміння, такі, як ігнорування непотрібної інформації, вміння читати по ключовим словам, розуміння коментарів, інтерпретація та подальша трансформація тексту. На думку багатьох науковців, 3 метою уникнути труднощів у розумінні автентичних текстів, допускається методична обробка тексту, не порушуючи його автентичності. Напівавтентичні тексти (semi-authentic texts) були із успіхом застосовані під час проведення заняття із проблемно-вирішальною ситуацією за темою "The Survival in the Desert" у групі військових слухачів із середнім рівнем володіння англійською мовою у Військовій академії (м. Одеса), в той час, як у групі підвищеного рівня володіння англійською мовою тексти використовувались неадаптовані і це не викликало непорозумінь у сприйнятті та обговоренні прочитаного автентичного тексту.

У сучасному суспільстві вивчення іноземної мови актуальне та якісне тільки при умові застосування автентичних матеріалів, які сприяють більш мотивованому та ефективному вивченню іноземної мови, імітують погруження в природне мовне середовище, розвивають здібність до сприйняття національнокультурних особливостей соціальної та мовної поведінки носіїв іноземної мови та якісно формують комунікативні мовні компетенції.

\section{Список літератури:}

1. Peter Hubbard, Hywel Jones, Barbara Thornton, and Rod Wheeler. A Training Course for TEFL. Oxford University Press, 1996. - 89 - 90 p.

2. Локшина С.М. Краткий словарь иностранных слов. Москва: Русский язык, 1979. - c. 41.

3. Jerry G. Gebhard. Teaching English as a Foreign or Second Language: A Teacher Self-Development and Methodology Guide. The University of Michigan Press, 1996. -280 p.

4. Patricia A. Porter and Margaret Grant. Communicating Effectively in English: Oral Communication for Non-native Speakers. Heinle \& Heinle Publishers, A Division of Wadsworth, Inc. Boston, Massachusetts, 1992. - 98 p.

5. Jeremy Harmer. How to Teach English. An Introduction to the Practice of English Language Teaching. Pearson Education Limited, Longman, 2000. - p. 198. 


\title{
LA COMMUNICATION DANS LE ROMAN DE NATHALIE SARRAUTE «LES FRUITS D'OR»
}

\author{
Khabarova Nathaliya \\ Phd, chargée de cours \\ Université national Oles Hontchar de Dnipro
}

Nathalie Sarraute, écrivain francophone, est une des créateurs et des théoriciens du «nouveau Roman». Les Fruits d'Or, publié en 1963 et pour lequel elle a reçu le Prix international de littérature en 1964, occupe une place particulière parmi ses œuvres.

Les Fruits d'Or suscitent tout particulièrement notre intérêt parce que ce roman, interdisciplinaire, abolit toutes les frontières avec les nouvelles formes de communication humaine et s'exprime dans une perspective de mondialisation.

La définition de l'interdisciplinarité du roman provient de la cohabitation entre des concepts littéraires et d'autres issus des sciences naturelles. Selon la biologie, un tropisme est une réaction d'orientation d'un organisme végétal ou de certains animaux, causées par des agents physiques ou chimiques..

Nous pensons que le renoncement à la communication conventionnelle et l'offre de nouvelles voies à grande échelle de communication humaine précèdent la communication plus effective et globale qu'internet nous propose.

Les repères communs des deux communications sont l'annulation de la communication unilatérale et la perturbation de la limite temporelle et spatiale entre le destinateur et le destinataire, entre le texte et le lecteur (l'effet de trois dimensions (3 D)).

Généralement, la littérature est l'un des moyens de la communication humaine. Roman Jakobson, linguiste, littérateur et théoricien de la communication, a conçu un modèle de communication humaine. Selon Jakobson, pour communiquer, il est nécessaire d'avoir le destinateur, le message et le destinataire. Le destinateur est celui qui envoie le message. Le destinataire est celui qui le reçoit. Le contexte est l'ensemble des conditions sociales. Le message c'est le discours, le texte, ce qu'il «faut faire passer», lorsqu'il y a un message. Cela suppose un codage et un décodage, d'où la présence du code. Le contact est la liaison physique et psychologique entre le destinateur et le destinataire. Le code peut être, par exemple, la langue française [1]. 


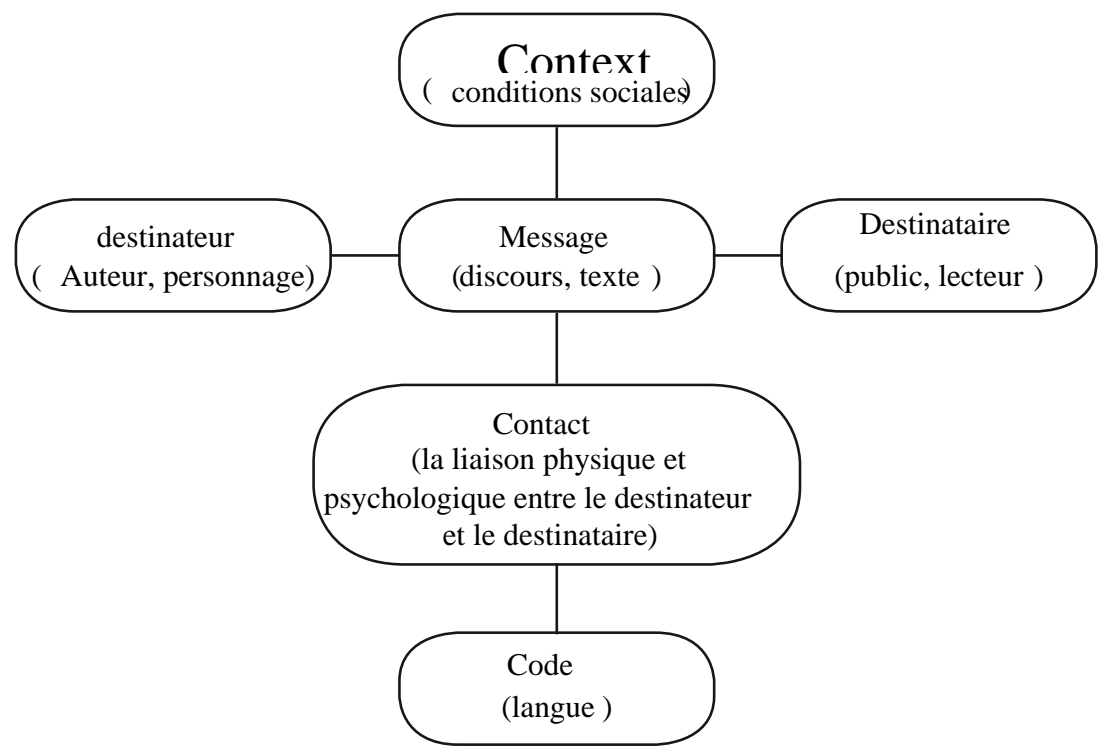

La communication littéraire traditionnelle était unilatérale: l'auteur (le destinateur) créait le texte (le message), qui attendait le lecteur (le destinataire) (le médium de contact) sous la forme d'un livre. Le destinateur et le destinataire étaient éloignés par le temps et l'espace.

Toutefois, dans Les Fruits d'Or, Nathalie Sarraute détruit les frontières temporelles et spatiales en fusionnant l'auteur, le personnage et le lecteur par l'introduction de la technique du tropisme, de la «sous-conversation» et de la conversation ainsi que de la mise en abyme narrative.

Nathalie Sarraute refuse le personnage homogène et introduit au contraire un personnage-voix, doublé et parlant à un autre en soimême. Un personnage-voix avec un tel dédoublement peut dialoguer, polémiquer, se disputer, mais en cas de multidédoublement, il peut parler à toutes les voix, briser l'uniformité du rapport du temps et de l'espace.

Il y a trois niveaux de communication humaine dans Les Fruits d'Or de Nathalie Sarraute:

1. le monde extérieur - le contact - le tropisme ;

2. le tropisme - le message - «la sous-conversation»;

3. «la sous-conversation»-le code conversation.

Au premier niveau de la communication, le destinateur (animé, inanimé, concret, abstrait) provoque une sensation, une réaction instantanée: le tropisme par le mot, par la mimique, par le regard, par le geste et par d'autres facteurs. Dans ce cas, le tropisme est le destinataire.

$\mathrm{Au}$ deuxième niveau, le destinateur du tropisme devient le destinataire, qui enchâsse la réaction et vient à la pensée, à la sousconversation.

$\mathrm{Au}$ troisième niveau, la sous-conversation, en s'entrelaçant, atteint la prononciation / la conversation.

Une telle structure de la communication de Sarraute fait un cercle de chaînes, où, pour que la communication soit perçue globalement, le lecteur doit rejoindre toutes les parties. Une telle universalisation harcèle et chasse la communication de la littérature conventionnelle.

Dans Les Fruits d'Or, Nathalie Sarraute supprime le prénom, le nom et même l'initiale du personnage pour garder seulement le genre, qui est exprimé par les 
pronoms personnels du genre masculin de la troisième personne, par un adjectif et parfois par des noms communs: un homme / une femme (Les Fruits d'Or).

Les catégories grammaticales: les pronoms personnels je, $t u$, $i l$, elle (masculin et féminin), etc., les adjectifs possessifs mon, ton, son, sa (masculin et féminin), etc., font référence non seulement au genre, mais remplacent aussi le personnage traditionnel. Par un tel remplacement, les personnages-types (personnages imaginés), le locuteur, l'audience et l'objet de la conversation, deviennent anonymes.

- Pitié, toi ! Moi, oui, j'avais pitié quand tu as pris cet air... il avait l'air de quelqu'un qui s'est livré. Quelqu'un de faible... il m'a semblé que tu profitais... (Les Fruits d'Or ).

Cet exemple montre clairement que l'utilisation de la technique du tropisme donne une chance à l'écrivain de faire un brusque changement: dans la sous-conversation, c'est le déploiement soudain et inattendu des pronoms comme des personnages qui se remplacent l'un l'autre sans l'identification.

Édouard Morot-Sir, dans son ouvrage, L'art des pronoms et le nommé dans l'œuvre de Nathalie Sarraute, écrit:

Les pronoms ne sont plus soumis à la dictature des noms; ils servent au contraire à briser la gangue substantialiste qui enferme et définit les noms. Loin d'être des substituts, ils animent la trame du discours: ce sont les noms qui vont se situer par rapport aux pronoms [2].

Nous sommes de l'avis du chercheur et nous trouvons que les pronoms libérés de la dictature des noms servent le principe de la généralisation du personnage. Par exemple, le lecteur peut s'identifier aux pronoms personnels $j e, t u, i l$, elle...

Nathalie Sarraute change la réalité romanesque avec l'introduction du personnagevoix et de la «sous-conversation». Sarraute sait bien que la conversation silencieuse du personnage invisible n'était jamais sous surveillance, il est réel et absolument libre. La conversation silencieuse est une sous-conversation, c'est une allusion à la sagesse du silence du roi Salomon qui vivait au dixième siècle avant notre ère. "La parole est d'argent, mais le silence est d'or». L'Homo sapiens parle d'une manière interminable: à haute voix, mais aussi en silence.

Dans la littérature, avec la technique de la «sous-conversation», Nathalie Sarraute fait l'effet de la 3D. C'est une expression qui caractérise l'espace qui nous entoure, tel que perçu par notre vision, en matière de largeur, hauteur et profondeur. Le lecteur participe au processus intérieur psychique de l'Homme. Les personnages de N. Sarraute ne sont plus déterminés par l'auteur. Ils sont des individus indépendants, qui se contrôlent et, de ce fait, de part leurs fonctions et leurs idées, ils égalent l'auteur, qui est leur créateur.

Selon Mikhail Bakhtine, la technique de polyphonie libère la voix du personnage de la dictature de la voix de l'auteur [3]. Sarraute confirme cette thèse et y ajoute les mots de Gustave Flaubert: «La Bovary - c'est moi». N. Sarraute découvre cette formule de la littérature et y ajoute les siennes: «l'auteur, c'est le personnage», «l'auteur et le personnage - tous les deux sont l'auteur», «le lecteur est le personnage et, à la fois, le personnage est le lecteur». Finalement, ces formules répondent à la structure du «stade du miroir» de Lacan. Ici, une telle méthode nous propose des formes universelles de communication. 
Selon Roland Barthes, l'auteur est un personnage moderne, produit par notre société. Donner un auteur à un texte, c'est imposer à ce texte un cran d'arrêt, c'est le pourvoir d'un signifié dernier, c'est fermer l'écriture. R. Barthes tue l'auteur, parce que «la naissance du lecteur doit se payer de la mort de l'auteur» [4]. Barthes donne à un texte la liberté.

Nathalie Sarraute donne au lecteur la possibilité de lire de manières différentes et variées ses œuvres. Cependant, le lecteur est toujours orienté vers le sens primordial du roman.

Nathalie Sarraute donne au lecteur la possibilité de lire de manières différentes et variées ses œuvres. Cependant, le lecteur est toujours orienté vers le sens primordial du roman.

Selon Roland Barthes, l'auteur est un personnage moderne, produit par notre société. Donner un auteur à un texte, c'est imposer à ce texte un cran d'arrêt, c'est le pourvoir d'un signifié dernier, c'est fermer l'écriture. R. Barthes tue l'auteur, parce que «la naissance du lecteur doit se payer de la mort de l'auteur»[4]. R. Barthes donne à un texte la liberté.

Nathalie Sarraute donne au lecteur la possibilité de lire de manières différentes et variées ses œuvres. Cependant, le lecteur est toujours orienté vers le sens primordial du roman.

Nous devons rassembler tous ces aspects, la technique de mise en abyme, la réflexion métaphorique, la polyphonie, les mots et les phrases entrecoupés, etc., pour nous approprier toute l'œuvre de manière complète. Il faudrait également prendre en considération que, dans le roman Les Fruits d'Or, on ne trouve pas d'aspect dogmatique. En lisant ce roman, le lecteur joue avec ses propres imaginations.

\section{Références}

1.Jakobson R. Dialogues The Framework of language / R. Jakobson. - Michigan, 2009 $-132 \mathrm{p}$.

2. MOROT-SIR É. L'art des pronoms et le nommé dans l'œuvre de Nathalie Sarraute / MOROT-SIR É // Romanic Review, LXXII, 2, mars 1981.- p. 204-214.

3. Бахтин М. Автор и герой / М. Бахтин. - Азбука, 2000 -256 с.

4. Barthe R. Le degré zéro de l'écriture / R.Barthe. - Paris , 2014- 192 p. 


\title{
ВИКОРИСТАННЯ ІГОР У ВИВЧЕННІ ГРАМАТИКИ АНГЛІЙСЬКОЇ МОВИ
}

\author{
Васта Валерія, \\ викладач кафедри загальноправових \\ та соціально-гуманітарних дисциплін \\ Херсонського факультету \\ Одеського державного університету \\ внутрішніх справ \\ Пренько Яна, \\ викладач кафедри загальноправових \\ та соціально-гуманітарних дисциплін \\ Херсонського факультету \\ Одеського державного університету \\ внутрішніх справ
}

Освоєння граматики все більше розглядається як вирішальне для засвоєння мови. Проте існує багато розбіжностей щодо ефективності різних підходів до представлення словникових запасів. Більш того, вивчення граматики часто сприймається як виснажливий і трудомісткий процес. У цьому звіті ми вивчаємо деякі традиційні прийоми та порівняємо їх із використанням мовних ігор для презентації та перегляду граматики, щоб визначити, чи успішно вони представляють та переглядають граматику, ніж інші методи.

3 нашого викладацького досвіду помітили, наскільки студенти захоплені практикою мови за допомогою ігор. Вважаємо, що граматичні ігри не тільки веселі, але й допомагають учням вчитися без свідомого аналізу чи розуміння процесу навчання, набуваючи комунікативної компетентності як користувачі другої мови.

Існує безліч методів, пов'язаних з поданням граматики. Однак є кілька речей, які слід пам'ятати незалежно від способу подання нових лексичних одиниць. Якщо викладачі хочуть, щоб учні запам'ятали нову граматику, іiі потрібно вивчити у контексті, відпрацювати, а потім переглянути, щоб учні не забували. Викладачі повинні переконатися, що учні зрозуміли нові слова, які запам'ятаються краще, якщо їх ввести «запам'ятовується». Беручи до уваги все це, викладачі повинні пам'ятати, що вони застосовують різноманітні прийоми для нової граматичної презентації та перегляду[3, с. 200].

Ми пропонуємо такі типи подання граматики:

1. Візуальні прийоми. Це стосується зорової пам'яті, яка вважається особливо корисною при збереженні граматики. Учні краще запам'ятовують матеріал, поданий за допомогою наочних посібників. Візуальні прийоми добре підходять для подання конкретних граматичних предметів. Вони допомагають 
учням змістовно асоціювати представлений матеріал та включити його до своєї системи мовних одиниць.

2. Словесне пояснення. Це стосується використання ілюстративних ситуацій, пов'язаних з вивченим граматичним матеріалом.

Під час обговорення ігор слід враховувати багато факторів, один з яких доцільність. Викладачі повинні бути дуже обережними у виборі ігор, якщо вони хочуть зробити їх прибутковими для навчального процесу. Щоб ігри принесли бажані результати, вони повинні відповідати або рівню учнів, чи їх віку, або матеріалам, які мають бути введені або відпрацьовані. Не всі ігри підходять для всіх учнів незалежно від їх віку. Різні вікові групи вимагають різних тем, матеріалів та режимів гри. Наприклад, діти найбільше отримують користь від ігор, які вимагають пересування, наслідування моделі, змагання між групами тощо. Крім того, структурні ігри, які практикують або посилюють певні граматичні аспекти мови, мають стосуватися здібностей та попередніх знань учнів. Ігри стають складними, якщо завдання або тема не підходять або поза досвідом учнів.

Ще одним чинником, що впливає на вибір гри, є іiі тривалість та час, необхідний для іiі завершення. У багатьох іграх є обмеження за часом, але, за словами SiekPiscozub [4, c.11], вчитель може виділити більше або менше часу залежно від рівня учнів, кількості людей у групі або знання правил гри тощо.

Ігри часто використовуються як короткі розминки або коли залишається трохи часу в кінці уроку. Як зауважує пан Lee, гру не слід розглядати як маргінальну діяльність, що заповнює дивні моменти, коли викладачу та групі немає чим зайнятися [2, с.19]. Ігри повинні лежати в основі навчання іноземних мов. Пан Rixon пропонує використовувати ігри на всіх етапах уроку англійської мови за умови їх відповідності та ретельного відбору. На різних етапах уроку цілі викладачів, пов'язані з грою, можуть відрізнятися:

1. Презентація. Він представляє та забезпечує хорошу модель, роблячи їі зміст ясним.

2. Контрольована практика. Це викликає хорошу імітацію мови та відповідні відповіді.

3. Комунікативна практика. Це дає студентам можливість користуватися іноземною мовою.

Граматичні ігри також добре піддаються ревізійним вправам, які допомагають учням приємно, цікаво згадати граматичний матеріал. Усі автори, згадані у нашому звіті, погоджуються 3 тим, що навіть граматичні ігри спричиняли лише шум та розважали учнів, на них все одно варто звернути увагу та реалізувати їх у групі, оскільки вони мотивують учнів, сприяють комунікативній компетентності та формують плавність. Однак, чи можуть вони 
бути більш успішними для презентації та перегляду, ніж інші методи? Наша педагогічна практика доводить, що відповідь на це питання $є$ абсолютно ствердною.

\section{Список літератури:}

1. D. Bikowski, “Technology for Teaching Grammar," TESOL Encycl. English Lang. Teach, 1st ed. John Wiley \& Sons, Inc., 2018.

2. P. Lee and H. Lin, "The effect of the inductive and deductive data-driven learning (DDL) on vocabulary acquisition and retention," System, vol. 81, pp. 14-25, Apr. 2019.

3. M. Tammenga-Helmantel, E. Arends, and E. T. Canrinus, "The effectiveness of deductive, inductive, implicit and incidental grammatical instruction in second language classrooms," System, vol. 45, no. 1, pp. 198-210, 2014.

4. Teresa Siek-Piskozub, "Gry, zabawy i symulacje w procesie glottodydaktycznym (Seria Językoznawstwo stosowane)", Uniwersytet im. Adama Mickiewicza w Poznaniu; Wyd. 1 edition, P. 159, 1995. 


\title{
ТИПОЛОГІЯ КОМУНІКАТИВНИХ ІНТЕНЦЙ ПОДЯКИ ТА ПРОХАННЯ В ЕПІСТОЛЯРЇ̈ ВАСИЛЯ СТУСА
}

\author{
Загнітко Анатолій Панасович \\ доктор філологічних наук, професор, \\ професор кафедри загального \\ та прикладного мовознавства і слов'янської філології \\ Донецького національного університету імені Василя Стуса \\ м. Вінниця, Україна \\ Овсянніков Владислав Свгенович \\ магістрант \\ Донецький національний університет імені Василя Стуса \\ м. Вінниця, Україна
}

Вступ. Проблеми комунікації в сучасних наукових дослідженнях надзвичайно актуальні. Одне 3 визначальнвих понять комунікативної лінгвістики - комунікативний акт, зміст та спрямованість якого визначувані комунікативною інтенцією. Комунікативна інтенція належить до лінгвістичної прагматики й теорії мовленнєвих актів (Ф. Бацевич (1, с. 28; 2, с. 15)). Особливий статус у лінгвістичній прагматиці належить тексту як комунікативному лінгвосеміотичному висловленню, охоплюючи образ позатекстової дійсності, комунікативну дію, формалізовану структуру та ін. У межах тексту особливий статус належить інтенції, пізнаваність і диференціювання якої вимагає вимагає застосування відповідних методів і методик. Епістолярій становить специфічний різновид тексту з максималізованим виявом авторського Ego.

Термін інтенція запозичений з філософських наук (Дж. Остін (3, с. 22-130)) і послідовно виявлюваний у межах мовленнєвого акту, постаючи виявом його ілокуції (відповідної сили того чи того елементарного висловлення). Типологія ілокутивних функцій (інтенцій) в епістолярному стилі окреслює внутрішні бачення адресантом записів відгуку на внутрішне відчуття та його вербалізованість.

Метою аналізу постає встановлення закономірностей вираження комунікативних інтенцій в епістолярії загалом із визначенням їх реалізації в листах Василя Стуса (1994-1997; 4; 5). Скваліфікована мета актуалізує такі завдання: 1) розгляд сутності комунікативного акту та природу комунікативних інтенцій як елемента стратегії мовленнєвого спілкування; 2) схарактеризувати епістолярний стиль за призначенням, сферою використання, визначальними ознаками; 3) визначити специфіку вираження та реалізації комунікативних інтенцій в епістолярії Василя Стуса.

Матеріали та методи дослідження. Матеріалом постала епістолярна спадщина Василя Стуса, репрезентована у шостому (додатковому) томі «Творів: У 4-х т. шести книгах» (1994-1999). Епістолярій В. Стуса міститься у 2-х книгах. 
У першій наведено листи поета до батьків, дружини й сина, а в другій - до друзів і знайомих. Автографи всіх листів до рідних збережено в архіві родини Василя Стуса, автографи листів до друзів і знайомих - переважно у Відділі рукописних фондів і текстології Інституту літератури ім. Т.Г. Шевченка НАН України, а також в особистих архівах адресатів. Деякі з опублікованих листів було повернуто зі спецфондів КДБ родині митця вже після його смерті. У другій книзі, крім іменного покажчика до обох книг, подано також Словник імен, що трапляються в листах митця.

Методами дослідження $\epsilon$ загальнонаукові (описовий, дистрибутивний, статистичний) i спеціалізовані методи (системний, соціологічний, комунікативний).

Результати та обговорення. Епістолярному стилю властива змістова свобода, політематичність, що зумовлює експлікацію ширшого спектру усталених етикетних одиниць у різноманітних функційних виявах та комунікативних настановах. Епістолярний текст - ідеальне тло для аналізу безперервної динаміки етикетних норм, їхньої синтагматики, а також встановити функційно-парадигмальний спектр етикетних формул у текстовому просторі монолінгвоперсонології.

Сучасне суспільство, розчароване поширенням правдивої та неправдивої інформації про життя видатних особистостей, надає перевагу першоджерелам, де особливий статус займають письменницькі епістолярії, цінні як автентичне джерело відомостей біографічного характеру, а також важливі 3 погляду естетики художнього слова: через необов'язковість оприлюднення письменники відчувають свою розкутість перед законами художньої умовності, тому оповідальна манера їхніх листів, їх наратив на противагу оповіді мистецького твору, стає невимушеним ( 7 , с. $5 ; 8 ; 9$, с. 1). Тому важливим $є$ не лише те, про що говориться в листі, а й те, як саме про це розповідає сам автор, що є підставою для розгляду письменницьких епістоляріїв у їхніх кращих виявах як своєрідну метапрозу з властивим їй відтінком сповідальності.

Особливої уваги вимагає визначення множини комунікативних інтенцій в епістолярії Василя Стуса, який постає безпосереднім і у своїй поезії, і в епістолярії. Відомо, що 1972 р. відзначився першим арештом митця, а в 19721977 роках він відбував покарання у таборах Мордовії, у 1980 році - відбувся другий арешт. Повне ізолювання від рідних мотивували написання значої кількості листів до родини, до друзів та знайомих. Аналіз загального корпусу епістолярію - 383 листів дає змогу окреслити парадигмальний простір комунікативних інтенцій митця. Інтенцію можна розуміти, як: потенційний або віртуальний зміст висловлення; перший етап породження висловлення, за нею йде мотив, внутрішне проказування та реалізація; мета висловлення. В епістолярії Василя Стуса кожен лист пройнятий бажанням «повідомити, довідатися про що-небудь, спонукати до чого-небудь», донести до рідних, знайомих і друзів відповідну інформацію. Як зазначає М. Коцюбинська, «маємо класичний приклад такого епістолярного «автопортрета зі свічкою». Листи Василя Стуса несуть у собі потужний творчий заряд, свідчать про колосальний творчий потенціал. Послання до друзів і знайомих у переважній більшості, а до 
рідних - усі написано в неволі, в умовах «вертикальної труни», «ампутованого існування» (його вислови). Листи були для поета єдиним вікном у світ, єдиним мостом чи каналом, через який можна було подати власне Я. Звідси й повнота самовираження. Це і щоденник, і творча робітня - єдина змога не втратити, зберегти, винести за грати свій оригінальний поетичний вимір, переклади i спогади, власну філософію буття та відданість Долі, нескореність Духу, власний погляд із відстані на «рідну чужину». До цього потрібно додати й спробу «віддаленого» виховання сина, відірваного від нього п'ятирічним малюком (6, с. 172). Заявлений спектр і зумовлює політематичність інтенцій в епістолярії Василя Стуса, які в листах до родини (232) та в листах до друзів (151) реалізовані специфічно.

Листам до рідних властива досить щира, змістовна, емоційно-експресивна наповненість, водночас вони інтелектуально насичені, приваблює їхнє лексичне багатство, прозорість викладу, послідовність висвітлення інформації. Цілком логічно виділити такі різновиди комунікативних інтенцій у таких епістолярних текстах: 1) подяка: Листа одержали. Спасибі Вам (До батьків і сестри, 08.06.1970); Дякую за поздоровлення та листи (До дружини й сина, 11.01.1973); Дуже дякую Шурі за дуже гарне поздоровлення (Там само); Одержав від Василя два листи, дякую за розповідь про Жоржі Амаду та Кендзабуро Ое (До дружини й сина, 15.02.1973); у листах до рідних дуже дякую і/чи дякую дуже з можливим лінеарним дистанціювання на зразок дуже Тобі дякую, дякую Вам дуже використано вісім разів, а дякую - 5, сnасибi -2 . До цього потрібно також додати вживання формул на кшталт дуже вдячний, велика подяка. Подяку Василь Стус висловлює емоційно нейтрально (дякую, вдячний, подякуйте, спасибі) та 3 посиленням експресії (дуже дякую, дуже вдячний), наявна також імплікація подяки (кланяйтеся (ій, йому) од мене).

Інколи адресант варіює дуже дякую й красно дякую або ж використовує контактний (двох- чи трьохкратний) або дистактний повтор формули дякую: $\mathrm{He}$ хотів відсилати Вам листа, бо сподівався одержати Вашого (аби не розминутися!). Дякую. Дочекався. I телеграму і листа Твого, Валю, і відкритку Твою, Дмитрику. Дякую! (До дружини й сина, 03.01.1974); Дякую, дякую Юркові за погромні рецензії на мої переклади. Я до погромів (i куди більших!) уже звик, отже, Юрку, можеш громити й далі, а кулачок Твій-не тяжкий (Там само); Дякую за привітання, хоч, власне, більше святкую свої поразки, ніж перемоги: так гігієнічніше для духа: набувається оптимізм, якого Ти мені зичии. Дякую (До сестри дружини, червень 1974); Одержав Твого листа № 18. Дякую - за фото і Дмитриків лист. Дякую й Риті за «фартового парня». Дякую, дякую, дякую, Вальочку! (До дружини, 15-16.11.1974); Красно дякую Тобі за листа. Красно дякую Тобі за квіти. Красно дякую за віршика, хоч то і не вірш, а баєчка (як хлопчики надибали в лісі ̈̈жачка, а той утік) (До сина, 01.07.1974). Часто повтор спрямований на виокремлення кожного елемента (листа, квітів, віршика), за які митець хоче висловити свою подяку, посилюючи тим самим відповідну комунікативну інтенцію та прагнучи активізувати емоційне насичення віддаленого діалогу; 2) прохання, що постає найчисельнішою групою інтенцій в пістолярії Василя Стуса (92), пор.: Ще раз прошу: перепишіть із 
видавничих планів цікаві новинки і напишіть мені. Бо я не знаю, чи вийшла торік збірка Ліни Костенко, де вийшла Драчева «До джерел». Чи «Київську Старовину» видала «Наукова думка» чи хто інший (До дружини й сина, 15.02.1973); Прошу надсилати листи рекомендовані із повідомленням про вручення (До дружини й сина, лютий 1973). Така комунікативна інтенція виражається використанням дієслів різного способу: а) дійсного (прошу / дуже прошу); б) бажального (просив би / дуже просив би): Дуже просив би, аби Ти в літі поӥхала з Дмитром у Донеиьк - хай там старенькі трохи розвіють свій сум. Крім того, Вони занадто старі, щоб відкладати ие на потім (До дружини й сина, 22.05.1973); в) функційно безособовою конструкцією: Було б не зле, аби Юрко тим часом пробіг ті чернетки чотирьох елегій, які я зробив у Моршині, $i$, може, вислав би мені їх сюди. Я б радо помучився над ними. Це не так спімно, бо поки робота в мене є (До батьків, 22.08.1973); г) наказового: Напиши коли там було одержано мою телеграму «Не едь. Карантин», бо я ї̈ післав термінову - якого саме числа, тоді я напишу куди з проханням так не знущатися - бодай над родичами. Вишліть мені марок (2, 3, 4 коп.) та повідомлень про вручення та поштових відкриток $i$ пишіть рекомендовані листи (До дружини й сина, 15.02.1973); г) поєднання дійсного та наказового: Валю, дуже Тебе прошу - $\underline{\text { ее }}$ смій нічого мені висилати, бо як вишлеш який переказ - поверну назад. Коли ж мені що буде треба, я дам знати (До дружини, 19.11.1973); Дмитрику мій дорогий! Прошу, напиши мені, як Тобі вчиться, як Тобі живеться. Ти вже величкий хлопчик і можеш повідати мені, як чоловік чоловікові (Там само). У таких проханнях відчутний вияв адресанта не як сина, чоловіка, батька, а як митця, якому надзвичайно не вистачає можливості займатися літературою, творчим процесом, перебувати в ньому та відчувати насолоду самореалізації в продукованому: Я хотів би знати про всі літературні новинки України, і тут я попросив би писати_про ие або Олега, або Михасю, які про це знають найкраще. Дуже иікавий новим Тичиною - Сковородою та томом статей, про які згадували в пресі. Інтригує дуже й Рільке Бажанів - щось мені тяжко повірити, що це буде реально, бо синтез це більше оригінальний, аніж природній (крім того, Бажан, здається, перекладав за схожою групою крові, а як він перевтілюється - не знаю) (До батьків, лютий 1973).

В. Стус надзвичайно скучав за сином, що простежувано в почуттєвому наповнені листів до родини, в яких майстерно відтворене поєднання інтенції прохання з інтенцією туги за рідними: Висловлюю обережне прохання - коли мога, коли Ти не маєш якихось заперечень солідних, пов'язаних із тим чи тим, чи не могла б Ти, коли відважсишся на вояж, прихопити всю карточку із собою? Так мені тяжко думати за Дмитра, так мені моторошно думати - побачити його, але не знаючи, коли буде інша нагода побачитися, то й прошу. Із великим трепетом душевним прошу (i вже згадую, як та гнида казала, що йде на побачення з сином, а в мене очі обкипали сльозою і я мусів повертатися до якоїсь карти, аби ввігнати їх назад - сльози - аби гнида не бачила) (До дружини й сина, 08.05.1974).

Пряма адресатність комунікативної інтенції прохання часто передбачає реалізацію піклування про людей зовсім чужих: Будь ласка, передай Марусі, хай 
перешле 5 кг пакунок на ім'я Іллі Івановича Попеляшка. Це старий дідусь, який не має рідні, йому нікому вислати. Можна слати сало, масло, трохи какао. Все - на свій розсуд. Але без меду, бо ие заборонено, як і ковбаса тощо. Бажсано, аби в травні пакунок прийшов сюди (До дружини, 28.05.1975).

Епістолярій Василя Стуса, за словами Михайлини Коцюбинської, «біографія душі» непересічної людської особистості в екстремальних умовах, де інколи сутність людини розмивається і втрачається. Узагальнюючи пережите та усвідомлюючи власне життя як «екзистенційне тривання на своїй межі», Василь Стус у листах до дружини (8.07.76) так визначив свій головний мотив: «...людська душа перед вічністю високого неба, фізичні й духовні борсання в неокрайому морі щоденності, тортури висамітнілого очужілого духу» (6, с. 173). Перечитуючи ці рядки, можна розпізнати глибинний смисл комунікативних інтенцій подяки та прохання, що найпослідовніше реалізовані в листах до дружини та сина, рідних.

\section{Список літератури}

1. Бацевич, Ф.С. Основи комунікативної лінгвістики. Київ: Академія, 2004. $344 \mathrm{c}$.

2. Загнітко А. Лінгвістика тексту: теорія і практикум. Вид. 2, доп. і перероб. Донецьк: ТОВ «Юго-Восток, Лтд», 2007. 313 с.

3. Остин Дж. Слово как действие. Новое в зарубежной лингвистике. Вып. XVII. Москва: Прогресс, 1986. С. 22-130.

4. Стус В. Твори у чотирьох томах шести книгах. Том 6 (додатковий) Книга 1. Львів: Просвіта, 1994. 496 с.

5. Стус В. Твори у чотирьох томах шести книгах. Том 6 (додатковий) Книга 2. Львів: Просвіта, 1997. 262 с.

6. Коцюбинська, М.Х. Епістолярна творчість Василя Стуса. Василь Стус. Твори: В 4-х т. шести книгах. Том 6 (додатковий) Книга 2. Львів: Просвіта, 1997. C. 171-190.

7. Пуніна, О.В. Мовноетикетні одиниці на позначення вибачення в епістолярію письменників XX ст. Донецький вісник Наукового товариства ім. Шевченка. 2007. Т.16. Мовознавство. Донецьк, 2007. С. 5-11.

8. Радевич-Винницький, Я.К. Етикет і культура спілкування. Львів: Сполом, 2001.346c.

9. Морозова Л.І. Письменницький епістолярій у системі літературних жанрів: автореф. ... канд. філол. наук. Київ: Київський національний університет імені Тараса Шевченка, 2007. 24c. 


\title{
КЛАСИФІКАЦІї АНГЛІЙСЬКИХ ЮРИДИЧНИХ TEPMIHIB
}

\author{
Киселевич Ірина Валентинівна \\ старший викладач \\ кафедри загальноправових та соціально-гуманітарних дисциплін \\ Херсонський факультет \\ Одеського державного університету внутрішніх справ \\ Україна
}

Багато вчених дотримуються погляду, відповідно до якого юридичні терміни розподіляються на три категорії за ознакою «зрозумілості» для тієї чи іншої частини населення: 1) загальновживані юридичні терміни; 2) спеціальні юридичні терміни; 3) технічні терміни, запозичені з різних галузей науки й техніки [2, с.70].

Загальновживані юридичні терміни - це звичайні слова, які називають предмети, якості, ознаки, дії, явища й широко використовуються у побутовій мові, художній літературі, ділових документах, законодавстві [2, с.71]. Такі терміни, зазвичай, $є$ прості, доступні й зрозумілі. В юридичній науці вони використовуються у загальноприйнятому значенні й жодного спеціального змісту не мають: document (документ), case (судова справа), law (закон, право), order (порядок), lawyer (адвокат, юрист), safeguard (охорона), testament (заповіт), testifier (свідок), offence (правопорушення), property (власність); їх використання $\epsilon$ доцільним у тих випадках, коли їх значення $є$ зрозумілим для всіх і не породжує жодних сумнівів у певному контексті. Хоч загальновживані юридичні терміни не завжди $є$ функціонально оптимальними через свою багатозначність, однак іноді саме вони можуть найточніше позначити необхідне поняття. Питомість грунту загальнонаціональної англійської мови, на якому виникають терміни, пояснюється, з одного боку, тим, що право регулює різні сфери суспільних відносин, а тому, й не може обійтися без загальнонаукової термінології, а 3 іншого боку, тим, що максимальна точність викладу думки законодавця вимагає термінологічної однозначності, яка може бути досягненою саме завдяки переосмисленню загальновживаних одиниць [2, с.72].

Спеціальні юридичні терміни - це слова або словосполучення, які найточніше визначають потрібне поняття, й дозволяють стисло й чітко передати його зміст: conveyancing (норми права, які регулюють передачу власності на нерухомість), claim (позов), testimony (свідчення), victim (постраждала особа), criminal act (злочинна дія), bribery (хабарництво), racketeering (бандитизм), robbery (пограбування), hooliganism (хуліганство), false pretences (шахрайство), innocent infringer (ненавмисний правопорушник). Такі терміни лежать в основі англійської юридичної термінології, несуть основне змістове навантаження й мають конкретні визначення. Важливо, щоб спеціальне значення загальновживаного слова було очевидним. Якщо цього немає, значення терміна визначається загальним контекстом. Деякі дослідники мови права вважають 
застосування спеціальної юридичної термінології показником високої мовної та юридичної культури [2, с.73].

Технічні терміни - це слова або словосполучення, запозичені з різних галузей науки й техніки. Важливою залишається умова використовувати їх у галузі права в тих самих значеннях, які є за ними закріпленими в тій галузі науки або техніки, з якої вони запозичені [2, с.74]: monopoly power (монопольне право), subject of administration (суб'єкт господарювання), to limit concurrence (обмежувати конкурентність), marketing communications (маркетингові комунікації), leasee (орендар).

Деякі дослідники класифікують юридичні терміни залежно від того, які явища вони виражають [1, с.47]: 1) терміни, які описують моменти або частини судочинства: case assignment (порушення судової справи), interview (дізнання), preliminary investigation (попереднє розслідування), sentence (судовий вирок), line up (упізнання), accusation (звинувачення), commitment to court (передача до суду), trial (судовий процес), criminal prosecution (кримінальне переслідування), arbitral justice (арбітражне судочинство); 2) терміни, які позначають колективні органи або осіб, що працюють у сфері судочинства: court (суд), interview (дізнання), interrogation (допит), accused (звинувачений), prosecutor (обвинувач), defendant (відповідач), investigator (слідчий), witness (свідок), suspect (підозрюваний), offender (правопорушник); 3) терміни, що відображають певні процесуальні дії: perquisition (обшук), crime scene investigation (огляд місця події), seizure (вилучення доказів), detention (тримання), interview (дізнання), interrogation (допит), line up (упізнання), supervision (нагляд), testimony (свідчення); 4) терміни, які вказують на джерело доказів: evidence (речові / знайдені на місці злочину докази), forensic science expertise (криміналістична експертиза), DNA profiling (аналіз ДНК), fingerprinting (дактилоскопічна експертиза), confession (визнання вини), testimony (свідчення).

Отже, ми проаналізували найпоширеніші класифікації англійських юридичних термінів, які влаштовують і правознавців i лінгвістів, проте проблеми пошуку адекватних юридичних термінів, які б правильно й однозначно позначали всі юридичні поняття, й дотепер залишаються невирішеними [3, c.148].

\section{Список літератури}

1. Артикуца Н. В. Мова права і юридична термінологія: Навчальний посібник. -2-ге вид., змін. і доп. - К:. Юрінком Інтер, 2004. - 277 с.

2. Головин Б. Н., Кобрин Р. Ю. Лингвистические основы учения о терминах. М: Высшая школа, 1987. - 103 с.

3.Толста С. А. Основні класифікації правничих термінів // Проблеми культури професійної мови фахівця: теорія та практика. Матеріали VI міжвузівської науково-методичної конференції. - Донецьк: Вид-во Донецьк.юридичного інституту про ДонНУ, 2006. - С.142-149. 


\section{ДИСКУСІЯ ЯК ФОРМА КОЛЕКТИВНОГО ОБГОВОРЕННЯ: ТЕОРЕТИЧНИЙ АСПЕКТ}

Колесникова Лариса Леонідівна, кандидат філологічних наук, доцент кафедри української філології

та загального мовознавства

Д3 «Луганський національний університет

імені Тараса Шевченка»

Досить проблемним і нерозкритим у сучасній науковій думці $є$ вивчення поняття «дискусія» як однієї з форм колективного обговорення. Інтерес до дефініцій цього терміну зумовлений необхідністю вивчення його лінгвістичних особливостей, зокрема в плані опису його жанрової, дискурсивної та мовної специфіки, лінгвістичної інтерпретації актів аргументації, підкреслення ролі логічних і риторичних засобів переконання адресата. Незважаючи на певні досягнення в цій галузі, в україністиці запропонована тема вивчена недостатньо, отже, актуальність нашого дослідження визначена посиленою увагою сучасної лінгвістики до питань забезпечення ефективності мовленнсвої діяльності в умовах глобалізації, а також тим чинником, що лінгвістичні дослідження, присвячені вивченню характеристик дискусійного дискурсу, дотепер не мають комплексного характеру. Мету нашої роботи вбачаємо в аналізі як окремих теоретичних аспектів і параметрів поняття «дискусія», так і в комплексному його вивченні.

У своїй роботі ми послуговуємося поняттям «дискусія» 3 таким його тлумаченням: це універсальна форма комунікативного інтелектуального співробітництва, комунікативною метою якої є взаємоузгодження іiі учасниками відмінних, інколи навіть протилежних позицій 3 дискусійного питання та виявлення істини шляхом когнітивно-аргументативної діяльності. Аналізуючи дискурсивні та прагмариторичні характеристики й особливості дискусії, О. Багрій убачає iї специфіку в органічному науковому поєднанні полемічних та діалогічних відносин, у врівноваженні методів та засобів діалогу та спору, інтенцій згоди та конфронтації, співпраці та критики [1].

Незважаючи на давність поняття „дискусія” (лат. diskussio - дослідження, розгляд, розбір), у вітчизняної лінгвістичній літературі немає однозначності в його визначенні. Словник української мови подає таке тлумачення: «Дискусія. Широке публічне обговорення якого-небудь спірного питання. <..> перен., розм. Спір, суперечка окремих осіб, співбесідників» [2, с. 285].

С. Шевчук потрактовує дискусію (від лат. discussio - дослідження, розгляд) як ,діалогічний метод творчої діяльності групи осіб, побудований на публічному, відкритому, доброзичливому обговоренні актуального, але спірного питання і спрямований на певний позитивний результат. Дискусія - діалог не внутрішній, а зовнішній, відкритий” [3]. Предметом дискусії не може бути другорядне, випадкове для конкретної аудиторії питання, воно має бути проблемним, важливим у цій ситуації й водночас викликати неоднозначні думки 
та пропозиції. Справжня дискусія - не суперечка, не з'ясовування стосунків, вона передбачає об'єктивне й доброзичливе обговорення питання з обов'язковою повагою як до своїх прихильників, так і до опонентів, з опорою на особистіснодіалогічний стиль спілкування. Тому за результатами дискусії не може бути переможців і переможених.

Н. Махновська потрактовує дискусію як усну, інколи письмову, форму організації публічного мовлення, під час якої стикаються різні, зазвичай, протилежні погляди [4, с. 53]. На думку Л. Мацько, „Дискусія - це обговорення певної проблеми або групи питань чи одного дуже важливого питання з метою досягнення істини" [5, с. 187]. Головним для дискусії, вважає дослідниця, $€$ пошук істини шляхом удалої постановки і зіставлення аргументів, а суть iї полягає в публічному викладі своїх думок перед опонентами.

Інші дослідники розуміють дискусію як обговорення проблеми з метою іiі вирішення або встановлення істини. Розглядаючи дискусію з позиції масової комунікації та спілкування, Н. Богомолова потрактовує ііі як вид узаємодії людей у процесі неопосередкованого спілкування з метою критичного засвоєння знань або вирішення проблеми [6]. Ю. Смельянов [7] визначає дискусію як колективне обговорення питання, різного виду проблем (офіційних/неофіційних) або колективне зіставлення інформації.

У сфері комунікакації важливим є відрізняти дискусію від полеміки боротьби двох або більше думок. Досить грунтовним, на наш погляд, $є$ розмежування цих двох понять, подане Л. Мацько. Дослідниця доводить, що дискусія - це не боротьба протилежних думок, а форма співпраці, колективної роботи. Якщо для дискусії головним $є$ пошук істини шляхом вдалої постановки i зіставлення аргументів, то для полеміки головним $\epsilon$ досягнення перемоги шляхом зіткнення різних поглядів, утвердження власного погляду, хоч і на шкоду істині. У дискусії протилежні сторони називаються опонентами, у полеміці - супротивниками, суперниками, конкурентами. У дискусії опоненти шукають істину, компроміс; у полеміці - утвердження власного погляду, перемогу своєї позиції. Дискусія ведеться за певними правилами і за згодою іiі учасників. Тема дискусії формулюється заздалегідь або до початку дискусії. Ïї учасники почергово висловлюють свої положення, думки, у результаті чого дискусія набуває логічного, зв'язного характеру. Мовні засоби дискутування мають бути прийнятними для всіх учасників дискусії, толерантними. Використання непередбачуваних засобів осуджується і може зупинити дискусію без висновків. Натомість полеміка не дотримується таких правил - у ній перемагає ініціатива суперників, ситуативність спілкування, непередбачувані й раптово знайдені „під руку” засоби завжди переконливої, але наполегливої й напористої аргументації [5].

Ми не можемо залишити поза увагою дисертаційну роботу О. Багрій, у якій акцентовано увагу на тому, що «поняття “дискусія”, “спір”, “полеміка”, “діалог”, “диспут” мають спільні сутнісні характеристики, такі, як: інтелектуальна взаємодія суб’єктів пізнання, наявність відмінних позицій з предмету обговорення, розвиток аргументів за допомогою запитань та відповідей, прагнення довести власну правоту та переконати у ній опонента. Однак домінантні ознаки цих понять $є$ відмінними» 
[1, с. 7]. Дискусії властиве дотримання кодексу мовленнєвої ввічливості, що зближує іiї з діалогом; водночас елементи гострої критики, властиві спору та ще більш - полеміці, наявні в дискусії у завуальованому вигляді. Значна кількість спільних характеристик між поняттями “дискусія", “спір”, “полеміка", “діалог” та “диспут” пояснює ту особливість, що в мовознавчій літературі вони часто вживаються як синоніми.

Розгляд дискусії як особливого акту комунікації дозволив Л. Клобуковій створити каталог мовленнєвих дій, що можуть бути покладені в основу комунікативної програми спілкування. У такому разі класифікація мовленнєвих дій будується за типами мовленнєвих намірів ініціатора спілкування:

1) дескриптивні мовленнєві дії - наприклад, уміння навести дефініцію, охарактеризувати що-небудь;

2) директивні мовленнєві дії - наприклад, стимулювання співрозмовника до вираження своєї позиції, обмеження активності опонента в ході обговорення якої-небудь проблеми;

3) когнітивні мовленнєві дії - наведення прикладу, виклад власного погляду, наведення системи аргументів у ході дискусії;

4) кооперативні мовленнєві дії - колективне складання програми дискусії, плану обговорення окремої проблеми в ході підготовки „круглого стола”;

5) експресивні мовленнєві дії - вираження схвалення, заклик учасників дискусії не порушувати регламент, осуд некоректних висловлень;

6) конвенціональні мовленнєві дії - наприклад, формули вибачення тощо [8, c. 12].

У межах нашого дослідження актуальним $є$ тлумачення дискусії з позиції психології. Так, Г. Захарова за ступенем керованості дискусії поділяє на дискусії з лідером; дискусії без явного лідера; дискусії зі змінним лідером. Лідер дискусії, як показує психологиня, «бере на себе функції організатора дискусії, узагальнює висловлювання учасників, групує їх, класифікує. Як наслідок, на всіх етапах дискусії нерідко досягають якісно нового результату, що є малоймовірним в індивідуальній роботі учасників. Залежно від виду досягнутого результату виділяють такі дискусії: дискусії як шлях вирішення проблеми; дискусії як переконання опонента або залучення його на свій бік; дискусії як вплив на пасивну аудиторію» $[9$, с. $19-20]$.

Традиційним для класифікації є критерій ефективності перебігу дискусії. За цим критерієм розглядають такі ії види:

1) неконструктивна - дискусія, у якій має місце безплановий обмін думками, що складається зі спонтанних, стихійних діалогів або суперечок між учасниками;

2) конструктивна дискусія - це засіб досягнення актуальної групової мети; основні ознаки конструктивної дискусії такі: активність кожного учасника; рівноправність учасників під час висловлення своєї думки; задоволеність кожного учасника від спільної дискусії й спілкування;

3) відчуття кожним учасником демократичної атмосфери [Там само].

За досягнутим результатом дискусії можна поділити на результативні, нічийні, невизначені [4, с. 53]. За формою проведення дискусії бувають очні та заочні (шляхом листування або публікації), рівноправні (коли учасники дискусії 
мають рівноправні можливості) і нерівноправні (наприклад, дискусія між учнями й учителем), групові (учасники дискусії чітко поділені на групи) й індивідуальні (кожен учасник захищає власні погляди) [10, с. 163].

Отже, у науковій літературі дискусію трактують і як процес, і як результат, i як мовленнєвий жанр, що передбачає визнання унікальності й рівності партнерів, відмінності й оригінальності їхніх поглядів під час обговорення суперечливого питання, орієнтацію кожного учасника дискусії на розуміння та активну інтерпретацію своєї позиції партнерам.

Список літератури:

1. Багрій О. Наукова дискусія: дискурсивні та прагмариторичні характеристики (на матеріалі англомовних статей середини XX - початку XXI сторіч.): автореф. дис. ... канд. філол. наук: 10.02.04. К., 2010. 20 с.

2. Словник української мови: в 11 т. / редкол. І. К. Білодід та ін. К.: Наук. думка, 1971. Т. II. 550 с.

3. Шевчук С. Українська мова за професійним спрямуванням: підр. для студ. вищ. навч. закл. К.: Алерта, 2012. 696 с.

4. Педагогическое речеведение: словарь-справочник. М.: Флинта, Наука. 1998. $312 \mathrm{c}$.

5. Мацько Л. Риторика: навч. посіб. К.: Вища шк. 2003. 311 с.

6. Богомолова Н. Массовая коммуникации и общение. М.: Знание. 1988. $80 \mathrm{c}$.

7. Емельянов Ю. Обучение паритетному диалогу. Л.: ЛГУ. 1991. 106 с.

8. Клобукова Л. Научная дискуссия как акт коммуникации (лингвометодический аспект). Язык, сознание, коммуникаџия. М.: «Филология». 1998. Вып. 3.120 c. URL: http://www.philol.msu.ru/ slavphil/books/jsk_03_01klobukova.pdf

9. Захарова Г. Теория и методика психологического тренинга. Челябинск, 2008. C. 19 - 20. URL: http://window.edu.ru/resource/019/73019/files/psyrazv19.pdf

10. Казарцева О. Культура речевого общения: теория и практика обучения. М.: Флинта, Наука. 1999. 496 с. 


\title{
НАВЧАННЯ МОРФОЛОГІЇ УКРАЇНСЬКОЇ МОВИ В ГІМНАЗІї: ПРИНЦИПИ ІНДИВІДУАЛІЗАЦІЇ ТА ДИФЕРЕНЦАЦІї
}

\author{
Олійник Алла Михайлівна \\ кандидат педагогічних наук \\ вчитель-методист української мови \\ Київська гімназія східних мов №1 \\ (м.Київ, Україна)
}

Модернізація сучасної освіти сприяє зростанню вимог до рівня готовності нинішніх учнів жити в умовах інформаційного суспільства, мислити й діяти через призму сформованих цінностей та потужних інтеграційних процесів, добре володіти навичками спілкування. 3 огляду на це поділяємо думку учених (3.Бакум, Н. Голуб, О.Горошкіна, Т. Груба, О. Караман, С.Караман та ін.), що добір навчального змісту й організація навчання на уроках вивчення морфології української мови повинні здійснюватися на визначених сучасністю принципах індивідуалізації та диференціації - основних стратегічних напрямах, які охоплюють усі компоненти системи навчання: його цілі, завдання і зміст, шляхи і способи їх досягнення, діяльність учителя й учня, технології навчання, критерії ефективності навчального процесу, систему контролю.

Дидактичні принципи індивідуалізації та диференціації випливають із психології навчання загалом та визначають загальний напрям у розробленні стратегій і тактик навчання української мови та знайшли своє відображення в працях Ю.Бабанського, М.Данилова, А.Дістерверга, Я.Коменського, В.Онищука, Г.Песталоцці, К.Ушинського та ін. Обгрунтування і класифікація принципів навчання висвітлені в працях лінгводидактів (З.Бакум, Н.Голуб, О.Горошкіна, О.Караман, С.Караман, О.Копусь, В.Масальський, В.Мельничайко, Н.Остапенко, М.Пентилюк, К.Плиско, Т.Симоненко, С.Чавдаров та ін.).

Досвід учителів-практиків доводить, що принципи індивідуалізації та диференціації передбачає розроблення індивідуальної освітньої траєкторії навчання учня відповідно до його особливостей, можливостей, потреб, що $\epsilon$ одним з пріоритетних принципів, на які акцентується у Концепції, адже йдеться про учня, як творчу індивідуальність та особистість [1].

Застосування цих принципів на уроках української мови в поєднанні 3 історичною основою сприяють розвитку інтересу старшокласників до спостереження над мовними явищами, пошуковій та навчально-дослідницькій роботі. Зокрема, застосування принципу індивідуалізації на уроках навчання морфології української мови, який базується на дослідницьких засадах, стимулює школярів до пошукової активності, збагачує навчально-пізнавальною інформацією, яка допомагає розкрити нові аспекти у вивченні морфології, виробляє здатність самостійно вирішувати складні завдання та робити узагальнення[7]. Наприклад, пропонуємо учням підтвердити або спростувати 
думку, що прізвища на -ко належать до власне українських. У ході проведених досліджень учні роблять такі висновки: поняття «прізвище» у сучасному розумінні з'явилось історично недавно, ми будемо говорити про зменшенопестливі імена на -ко, що згадуються ще у «Повісті минулих літ» (Синко), у «Лаврентіївському літописі» (Василько), а варіанти імен Петро, Павло, Марко від Павель, Петръ, Маркъ відомі ще з XII століття. Деякі вчені (О.Шахматов, В.Сімович) пов'язують такі зміни з морфологічними чинниками, зауважуючи, що це колишні іменники середнього роду, які набули значення чоловічого [2;c.86].

Реалізація принципів індивідуалізації та диференціації враховує знання i вміння учнів, а також їхню пізнавальну та практичну самостійність, інтереси, вольовий розвиток, працездатність тощо, а також може супроводжуватись проблемними запитаннями, які спонукають учнів до творчого пошуку правильної відповіді, розв'язання складних завдань, спрямовують їх на проведення аналізу, порівняння, що має велике значення для удосконалення знань, умінь та навичок з опрацьованих тем, сприяють активізації мислення, зацікавлюють їх. Наприклад, 1)Згідно з дослідженням Лео Бернетта, одного $з$ найвідоміших менеджерів, які працюють з клієнтами в рекламі, ефективний текст від неефективного відрізняе наявність більшої кількості дієслів. Поміркуйте, чому саме дієслів, а не іменників або прикметників?

2)Як визначити рід іменників кашне, лате, буржуа, бюро, ледi, боа? Чим відрізняються слова аналіз - розбір; орфографія - правопис, дефект вада?[3;с.37]

Як засвідчує досвід учителів-практиків, ефективність означених принципів полягає в розробленні системи диференційованих завдань 3 морфології української мови, розрахованих на різні рівні навчальної підготовленості учнів, адже в результаті їх реалізації ліквідуються прогалини в знаннях, уміннях та навичках учнів, поглиблюється та розширюється діапазон знань окремих учнів 3 морфології, що, згідно із завданнями нової української школи, розвиває індивідуальні здібності кожного учня. Так, опрацювання теми «Розряди прикметників» буде, на наш погляд, більш ефективним, якщо запропонувати учням виконати диференційоване завдання різного рівня складності, а саме: I рівень - утворити всі можливі ступені порівняння прикметників дотепний, щзирий, дорогий, глибокий та дослідити, які морфологічні зміни при цьому виникають? (У прикметнику глибокий - глибший при творенні вищого ступеня суфікс $-\kappa$ - змінюється на $-u$-; спрощенням супроводжується творення вищого ступеня прикметника дорогий - дорожчий; не викликає подібних змін -іш-: дотепний - дотепніший, щиирий - щүиіший); чи можна утворити ступені порівняння від прикметників лисий, босий, дикий, лівий, білий, відповідь обгрунтуйте; II рівень - визначити розряд прикметників легкий ящик та легкий характер, добра слава та добра жінка, молочний туман та молочний коктейль, заяча нора, заяча губа та заяча вдача та з'ясувати, як відбувся перехід прикметників 3 одного розрядув інший; III рівень - підібрати синоніми та антоніми до запропонованих якісних прикметників [4;c.26]. 
Використання завдань на текстовій основі із застосуванням принципів індивідуалізації та диференціації не лише сприяють вдосконаленню вивченого 3 морфології на попередніх уроках, а й сприяють формуванню граматичних та творчих умінь і навичок учнів. Як-от, на уроці узагальнення і систематизації вивченого про іменник учням було запропоновано виконати низку завдань на текстовій основі: у наведених реченнях знайти іменники загальні і власні, назви істот і неістот. Розкрити дужки, пояснити написання великої літери.

Світ знав (М, м)иколу (М,м)иклухо (M,м)аклая як науковця $(\mathrm{P}, \mathrm{p})$ російського,

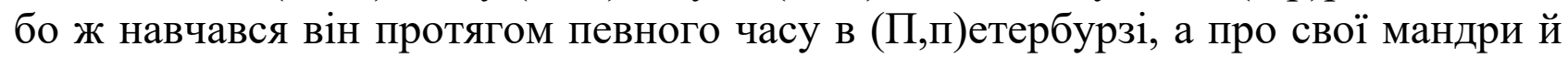
відкриття звітував (Р,p)російському (Г,Г)географічному (Т,т)товариству й $(\mathrm{A}, \mathrm{a})$ кадемії наук. Цей син $(\mathrm{У}, \mathrm{y})$ країнського народу ( $є$ відомості, що народився $(\mathrm{M}, \mathrm{M})$ икола в (М,м)алині на (Ж,ж)итомирщині) належить усьому людству, адже його внесок до світової науки колосальний. Більшу частину свого життя дослідник провів за межами (Р,p)російської імперії, в мандрах по світу. Після закінчення (Г,Г)гейдельберзького й (Л,л)ейпцизського університетів (М,м)икола (М,м)акай працював на островах (I,i)ндонезії, в (П,п)івнічній (А,a)мериці, (А,a)встралії, на островах (Т,т)ихого океану. (За Г.Кропивником)

\section{Лінгвістичне дослідження-обгрунтування:}

- Виписати іменники II відміни, поставити їх у родовому відмінку, пояснити вживання відмінкових закінчень - а(-я) та -у(-ю).

- Чи можливо визначити відміну у слові мандри?

Примітки. 1. Назви істот чоловічого роду мають закінчення -a(-я), іменники, що вказують на збірність, речовину, матеріал, абстрактні явища мають закінчення -у(-ю). 2. Іменники, що мають тільки форму множини на відміни не поділяються.

Творче завдання: використовуючи відомості про родину, мандри та відкриття М.Миклухо-Маклая, написати твір-розповідь, використовуючи невідмінювані іменники іншомовного походження: батько Микола Ілліч Миклуха, мати Катерина Семенівна Беккер, дружина Маргарет-Емма Робертсон; острови Нова Гвінея, Пасхи, Тайті, Сулавесі, Ява; міста Лейпииг, Веймар, Сінгапур, Сідней, Мельбурн; тварини какаду, кенгуру, затока Уотсон-Бей, штат Вікторія.

Завдання для самоконтролю: визначити рід цих іменників. Сформулювати правила визначення роду незмінюваних іменників у написаному творі та доповнити їх додатковими прикладами [3;с.42].

Таким чином, застосування принципів індивідуалізації та диференціації у процесі навчання морфології сприяє формуванню вмінь і навичок учнів, створює на уроці атмосферу співробітництва між усіма учасниками освітнього процесу, розвиває в учнів уміння критично мислити, приймати зважені рішення. Учні мають змогу проаналізувати засвоєні на уроці знання та практичні уміння, застосовуючи їх у творчій навчально-пізнавальній діяльності на уроках морфології. 
Список літератури

1. Концепція вивчення української мови в 5-12-х класах 3Н3 з українською мовою навчання. Книга для вчителя: довідково-метод. видання / упоряд. Н. I. Шинкарук. Харків : Торсінг ПЛЮС, 2005. С. 7-12.

2. Крижанівська О. I. Історія української мови. Історична фонетика. Історична граматика: навчальний посібник. Київ: Академія. 2010.

3. Олійник А. М. Дидактичний матеріал з морфології. Іменник. Профільний рівень. Украӥнська мова й література в школах Украӥни. 2018. №12. С. 36-59.

4. Олійник А.М. Дидактичний матеріал 3 морфології. Прикметник. Профільний рівень. Украӥнська мова й література в школах Украӥни. 2019. №12. С. 23-27.

5. Олійник А. Дидактичний матеріал 3 морфології. Профільний рівень. Українська мова і література в школі: науково-методичний журнал. Київ, 2019. №4. С. 29 - 33 .

6. Олійник А. Перспективи уроку вивчення морфології української мови на профільному рівні в компетентнісній парадигмі. Наукові записки Бердянського державного педагогічного університету. (DOI) Педагогічні науки : зб. наук. пр. Вип. 2. Бердянськ : БДПУ, 2018. 306с.

7. Олійник А. Принципи навчання морфології української мови в профільних класах закладів загальної середньої освіти. Social Educational Project of Improving Knowledge in Economics: Edition 20. Frankfurt, Deutschland; Poitiers, France; Los Angeles, USA. 2018. P. 21-26. URL: http://www.sepikecloud.com 


\title{
РОЛЬ СТРУКТУР, ЩО САМООРГАНІЗУЮТЬСЯ В ПОВЕДІНЦІ НЕРІВНОВАЖНИХ СОЦІО-ГУМАНІТАРНИХ ПРОЦЕСІВ В КОНТЕКСТІ КОНЦЕПТУ «ВRAIN-PSYCHЕ- MIND/CONSCIOUSNESS»
}

\author{
Козобродова Діна Михайлівна, \\ Ph.D., \\ КЦ «Альфалогія»
}

Мета нашого дослідження - розглянути роль структур, що самоорганізуються в поведінці нерівноважних соціо-гуманітарних процесів в контексті концепту/гіпертеорії «brain-psyche-(mind / consciousness...)» (I.B. СршоваБабенко, 2019) з позицій соціально-філософського аналізу.

Даний контекст включає:

- психомірность соціо-гуманітарних процесів (соціальну реальність як психомірне середовище) і методологію дослідження психомірності;

- спільність підходу в дослідженні - синергетичного та психосинергетичного, відповідно, до дослідження складових однойменного концепту і його самого як гіперцілого в статусі «синергетичний об'єкт», або «система / середовище синергетичного порядку»,

- поведінку концепту «brain-psyche-(mind / consciousness...)», або однойменну гіпертеорію, з позицій гіперцілого в значенні того, що стає чи гіперцілісності в значенні того, що стає;

- відносини між складовими концепту як відносини між цілими або цілісностями на підставі філософського принципу/ концептуальної моделі «Тhе Whole - in - The Whole» (I.B. Сршова-Бабенко, 2020; 2021).

Ідеєю нашого дослідження $є$ твердження, що необхідно визначити відповідність уявлень про механізми, характеристики і поведінку явища самоорганізації в умовах діяльності гіперцілого або гіперцілісності, представлених, 3 одного боку, в концепті/гіпертеорії «brain-psyche-(mind / consciousness...)», а 3 іншого, в житті людини, в психомірності соціогуманітарних процесів, пов'язаних з соціальною реальністю.

Особливу увагу приділено нерівноважним соціо-гуманітарним процесам, а саме функціюванню соціальної реальності як психомірного середовища в контексті гіпертеоріi «brain-psyche-mind / consciousness».

У цих тезах робиться перший крок в заявленому дослідженні, яке спирається на уявлення про нерівноважність фізичних процесів, що самоорганізуються (I.P. Пригожин, Г. Ніколіс, 1979), на положення про роботу головного мозку і систему психічної реальності в «точці втрати стійкості» (Г. Хакен, 2001) і на положення психосинергетики про поведінку середовищ / систем різної природи, що самоорганізуються (I. В. Сршова-Бабенко, 2015; 2020). 


\section{Література:}

1. Ершова-Бабенко, И.В. (2015). Психосинергетика. Монография. Херсон, $488 \mathrm{c}$.

2. Ершова-Бабенко, И. В. (2019). Гипертеория «brain-psychemind/consiousness» - постнеклассическое общее решение проблемы и методология исследования психомерности. Ст. 1-я // Norwegian Journal of development of the International Science, Vol.3, No.29, c.45-50

3. Ершова-Бабенко, И. В. (2020). Психосинергетика: методологический статус, теория и практика: юбилейный сборник научных трудов профессора И. В. Ершовой-Бабенко / ред.-сост. В. Б. Ханжи, Н. В. Кривцова. Одесса : Фенікс, $256 \mathrm{c}$.

4. Ершова-Бабенко И.В. (2021). Концепт «brain-psyche(mind/conscousness...)» и гипертеория концепта, Вестник Пермского университета. Философия. Психология. Социология, №3.

5. Пригожин И.Р., Николис Г. (1979). Самоорганизация в неравновесных системах, М.: Мир, 512c.

6. Хакен, Г. (2001). Принципы работы головного мозга: синергетический подход к активности мозга, поведению и когнитивной деятельности. М.: ПЕР СЭ, $351 \mathrm{c}$. 


\title{
МІСЦЕ ХАОСУ В ПОВЕДІНЦІ ЯВИЩА, ВИРАЖЕНОГО КОНЦЕПТОМ «BRAIN-PSYCHE-(MIND/CONSCIOUSNESS...)»
}

\author{
Селіверстова Г.С., \\ Ph.D., \\ Викладач Міжнародний \\ Гуманітарний університет, м. Одесса
}

Мета даного дослідження полягає в тому, щоб в аспекті соціальнофілософського аналізу розглянути питання про місце хаосу в поведінці явища, вираженого концептом «brain-psyche-(mind / consciousness...)», який розробляється в однойменній гіпертеорії (І.В. Єршова-Бабенко, 2019). Тим самим зробити наступний крок у розширенні присутності поняття «хаос» в соціально-гуманітарному знанні кінця XX ст. - на початку XXIст. і зробити перехід на відповідний рівень дослідження хаосу в нових умовах.

Підстави для подібної постановки питання полягають у наступному:

1) Входження поняття «хаос» в соціо-гуманітарну сферу в результаті зміни поглядів на явище хаосу в філософії і науці, що виразилося, зокрема, в переосмисленні значення цього явища. Вперше це було зроблено в роботах бельгійського вченого I. Пригожина (2021), в яких була показана конструктивна роль хаосу в різних природних i, зокрема, в соціальних процесах. Це нове наукове трактування явища хаосу знайшло своє широке застосування в дослідженнях гуманітарної спрямованості в роботах українських філософів, соціологів, психологів і педагогів (Г.С. Селіверстова, 2020).

2) Поведінка кожної зі складових концепту «brain-psyche-mind / consciousness», (його складовими є психіка, мозок, особистість та ін.), яка містить в якості базової характеритики етапи певної хаотизації на різних рівнях i масштабах. Це залежить від того, що кожна 3 цих складових розглядається дослідниками як відкрита нелінійна система або середовище (Г. Хакен, 2001; I.В. Єршова-Бабенко, 1992; 2015). Для такого класу нелінійних динамічних складних систем/середовищ характерна продуктивна функція хаосу, що забезпечує можливість виникнення нового порядку.

3) Присутність в науці початку XXI ст. нового рівня методологї̈ дослідження такого явища, що виражене концептом «brain-psyche-mind / consciousness» 3 позиції гіперцелого, яку воно представляє, і з позиції відносин між цілими, включеними в нього, в рамках концептуальної моделі «The Whole - in - The Whole» (I.В. Сршова-Бабенко, 2020).

Наша ідея полягає в тому, що при переході на методологію нового рівня необхідно розробити уявлення про поведінку хаосу в цих рамках. В такому випадку, необхідно розглянути ситуації та умови, при яких спостерігаються / проявляються хаотичні процеси, а також явище синтезу хаосу, що представлене на рівні кожної складової, включеної в концепт «brain-psyche-mind / consciousness». Нарешті, ситуації та умови, при яких буде спостерігатися явище 
«плато», тобто зависання хаосу, і явище поглинання хаосом різних цілих на рівні його складових і ін.

\section{Література:}

1. Ершова-Бабенко И.В. (1992). Методология исследования психики как синергетического объекта. Одесса: Одеском, 124c.

2. Ершова-Бабенко, И.В. (2015). Психосинергетика. Монография. Херсон, $488 \mathrm{c}$.

3. Ершова-Бабенко, И. В. (2019). Гипертеория «brain-psychemind/consiousness» - постнеклассическое общее решение проблемы и методология исследования психомерности. Ст. 1-я // Norwegian Journal of development of the International Science, Vol.3, No.29, c.45-50

4. Ершова-Бабенко, И. В. (2020). Психосинергетика: методологический статус, теория и практика: юбилейный сборник научных трудов профессора И. В. Ершовой-Бабенко / ред.-сост. В. Б. Ханжи, Н. В. Кривцова. Одесса : Фенікс, $256 \mathrm{c}$.

5. Пригожин, И., Стенгерс, И. (2021). Порядок из хаоса: Новый диалог человека с природой: Пер. с англ./ Общ. ред. В. И. Аршинова, Ю. Л. Климонтовича и Ю. В. Сачкова. М.: URSS, 320с.

6. Селіверстова, Г. (2020). Хаос як предмет соціальної філософії: дис. ... канд. філос. наук : 09.00.03 / Ганна Сергіївна Селіверстова; Одеса: ППНУ ім. К.Д. Ушинського, $185 \mathrm{c}$.

7. Хакен, Г. (2001). Принципы работы головного мозга: синергетический подход к активности мозга, поведению и когнитивной деятельности. М.: ПЕР СЭ, 351 c. 


\title{
ПСИХОЛОГІЧНІ АСПЕКТИ ПРИЙНЯТТЯ РІШЕННЯ ПРО ВСТУП ДО ЗАКЛАДІВ ВИЩОЇ ОСВІТИ ВИПУСКНИКАМИ ШКІЛ (НА ПРИКЛАДІ ЧЕРНІГІВСЬКОГО РЕГІОНУ)
}

\author{
Дроздов Олександр Юрійович, \\ доктор психологічних наук, доцент, \\ завідувач кафедри загальної, вікової \\ та соціальної психології імені М.А.Скока \\ Національний університет «Чернігівський \\ колегіум» імені Т.Г.Шевченка
}

Вивчення прийняття особистістю рішення у проблемних ситуаціях є одним iз класичних напрямків фундаментальних та прикладних досліджень сучасної психологічної науки. В освітній сфері значний практичний інтерес становлять психологічні особливості прийняття рішення про вступ до закладів вищої освіти (3ВО) випускниками загальноосвітніх шкіл. Специфікою цього процесу, на нашу думку, виступає те, що: а) він часто має високий рівень невизначеності (адже сенс рішення стосується зміни звичної життєвої траєкторії, входження у нову реальність); б) серед сучасних абітурієнтів значну частку становлять інфантильні індивіди, які більше керуються логікою «я хочу» або «так хочуть мої батьки / так модно», не прораховуючи реальних власних можливостей чи своєї родини; в) найближче оточення багатьох абітурієнтів часто не має професійних знань і навичок ретельного та зваженого аналізу існуючих освітніх варіантів; результатом стає висока вірогідність використання цими людьми різних стереотипів, помилкових евристик або псевдологічних міркувань типу «щоб дитині було краще»; г) він пов'язаний із прямим і побічним впливом значної кількості різнотипних чинників.

Практично всі викладачі ЗВО України знайомі з ситуацією, коли протягом навчального року адміністрація постійно закликає їх «проводити активну профорієнтаційну роботу», «залучати потенційних абітурієнтів», «потурбуватися про свої майбутні ставки» і т.ін. При цьому за такими закликами іноді втрачається розуміння ефективності (i, відповідно, сенсу) проведення тих чи інших заходів. У той же час кожен психолог знає, що будьякий ефективний психологічний вплив завжди передбачає розуміння його чинників і механізмів, врахування особливостей об'єктів впливу. Метою нашого дослідження стало вивчення чинників, які впливають на прийняття рішення випускниками 11-х класів середніх шкіл Чернігівщини про вступ до 3BO. 
Було використано метод онлайн-анкетування. Посилання на Google-форму надсилалися випускникам через шкільних психологів, адміністрацію шкіл, класних керівників у кінці травня - на початку червня 2021 р. (тобто в період складання зовнішнього незалежного тестування). 3 одного боку, це безумовно ускладнило проведення дослідження, позначившись, зокрема, на відносно невеликій кількості опитаних. Разом із тим, значне інтелектуально-емоційне навантаження у цей період створювало той фон, коли більшість молодих людей більш-менш чітко розуміли, що і навіщо вони роблять. Загальну вибірку утворили 140 випускників 11-х класів (90 дівчат та 50 хлопців). Зазначимо, що така статева диспропорція цілком відповідає даним багатьох інших українських онлайн-опитувань (у яких жінки відповідають частіше від чоловіків). 3 цієї кількості $86 \%$ респондентів презентували м. Чернігів та $14 \%$ - райони Чернігівщини.

Отже, на питання «Чи розглядаєш ти можливість вступу до закладу вищої освіти (університету, інституту, академії тощо)?" переважна більшість (90\%) відповіла «так». Мабуть, це $\epsilon$ артефактом, наслідком того, що в анкетуванні в основному брали участь старшокласники, що були націлені на вступ до ЗВО. Відповідь «ні» дали 7\% опитаних, а «ще не думав(-ла) про це»всього $3 \%$.

На питання «Чи с на даний момент у тебе спеціальність, яку ти обрав(ла) для подальщого навчання?» переважна більшість (84\%) відповіла «так». На цей результат слід звернути увагу, адже він «пролунає» ще в подальших даних.

Наступні два завдання стосувалися суб'єктивної оцінки впливу певних мотиваційних та інформаційних чинників прийняття рішення про вступ до ЗВО. Опитуваним пропонувалося оцінити за допомогою 7-бальної шкали (де 1найменший, а 7 - найбільший бал) важливість кожного 3 запропонованих чинників. Отже, стосовно мотиваційних чинників вступу до 3 ВО було отримано наступну картину (далі подано середньостатистичні значення по загальній вибірці): можливість безкоштовного навчання - 5,49; вартість навчання за контрактом $-5,10$; місце розташування закладу $-4,50$; широке коло спеціальностей, що пропонуються абітуріснтам - 5,10; наявність спеціальності, яка цікавить абітурієнта - 6,36; престижність диплому закладу - 5,32; інформація про якість освіти - 5,81; інформація про викладачів - 5,06; інформація про керівництво закладу - 4,75; інформація про випускників закладу - 4,11; інформація про матеріально-технічне забезпечення закладу - 5,24; легкість вступу до навчального закладу $-5,75$; легкість навчання у навчальному закладі - 5,41.

Отже, найбільш значущими мотиваційними чинниками, на думку опитаних 11-класників, виступають: 1) наявність спеціальності, що цікавить абітурієнта (до речі, за цим чинником мав місце мінімальний показник стандартного відхилення відповідей); 2) інформація про якість освіти; 3) легкість вступу до 3ВО. Можна побачити, що перший чинник $є$ об'єктивним за своїм характером, він майже не залежить від профорієнтаційної роботи працівників ЗВО (хіба що у плані інформування - «у нас це є»); Останні 2 чинники вже передбачають суб'єктивні оцінки (при цьому часто зі слів інших осіб). Але поєднання навіть 
цих суб'єктивних чинників дозволяє побачити відсутність у багатьох випускників навичок критичного мислення та аналізу соціальної інформації (адже мало хто замислюється над тим простим фактом, що «якість освіти» та «легкість вступу» в сучасних українських реаліях - речі майже несумісні). Найменш значущими мотиваційними чинниками для опитаних виявилися: інформація про випускників 3ВО, місце розташування останнього та інформація про керівництво закладу.

За U-критерієм Манна-Уїтні було виявлено ряд статистично вірогідних відмінностей між відповідями дівчат і хлопців. Зокрема, для випускниць-дівчат більш значущими були: місце розташування закладу (при $\mathrm{p}=0,019$ ), престижність диплому закладу (при $\mathrm{p}=0,001$ ), інформація про якість освіти (при $\mathrm{p}=0,001$ ), інформація про викладачів (при $\mathrm{p}=0,016$ ), інформація про керівництво закладу (при $\mathrm{p}=0,048$ ), інформація про матеріально-технічне забезпечення закладу (при $\mathrm{p}=0,008$ ). Можливо, це $\epsilon$ відображенням відомої тенденції серед жінок більше звертати увагу на різні «нюанси».

Стосовно значущості інформаційних чинників вступу до 3 ВО (тобто джерел інформації про нього), ми отримали такі дані: відгуки батьків - 4,36; відгуки вчителів - 4,05; відгуки друзів, однолітків, знайомих студентів - 5,30; відгуки випускників - 5,36; радіо - 2,62; ТБ - 3,14; друковані медіа (газети, журнали) - 2,81; соціальні Інтернет-мережі (студентські чати, Facebook та ін.) 4,48 ; інформація з сайту закладу вищої освіти $-4,89$.

Отже, оцінюючи вплив інформаційних чинників, більш значущими випускники визнають два: відгуки випускників 3ВО (тут мала місце найменша дисперсія; але, що цікаво, у попередньому питанні інформація про випускників закладу була одним із найменш значущих чинників) та відгуки друзів, однолітків, знайомих студентів. Найменш значущими вважалися вплив радіо, друкованих медіа та ТБ. Цікавим $\epsilon$ те, що, за отриманими оцінками, офіційний сайт ЗВО є дещо значущішим, аніж соціальні мережі.

За U-критерієм Манна-Уїтні було виявлено ряд статистично вірогідних відмінностей у відповідях дівчат і хлопців. Зокрема, для випускниць-дівчат більш значущими були: відгуки вчителів (при $\mathrm{p}=0,012)$, радіо (при $\mathrm{p}=0,013$ ), ТБ (при $\mathrm{p}=0,001$ ), друковані медіа (при $\mathrm{p}=0,002$ ), соціальні Інтернет-мережі (при $\mathrm{p}=0,002$ ), інформація $з$ сайту ЗВО (при $\mathrm{p}=0,001$ ). Можливо, це знову ж таки вказує на більш продумані (обережні) шляхи прийняття рішень жінками.

На питання «Яке розташування закладу вищої освіти ти вважасш оптимальним для себе?» (де можна було обирати кілька варіантів відповідей) ми отримали такі відповіді: у Чернігові - 63\%; у Чернігівський або сусідніх областях - 16\%; у Києві - 47\%; у великих містах України (Харків, Одеса, Дніпро, Львів тощо) - 31\%; за кордоном - 20\%; це не має значення - $11 \%$. Така картина, ймовірно, є наслідком впливу ряду ситуативних чинників: 1) COVID-пандемії, яка дещо «відбила» бажання та/можливості багатьом випускникам (a, можливо, й їхнім батькам) навчатися за кордоном; 2) невтішної соціально-економічної ситуації, погіршення фінансових спроможностей значної частини населення (Чернігівщина багато років $є$ одним із найбільш «депресивних» регіонів України за соціально-економічними показниками); напевно, саме цим пояснюється 
бажання багатьох опитаних навчатися «ближче до дому» або у Києві, адже відомо, що саме столичні ЗВО мають більше місць державного замовлення (до того ж вони часто стереотипно сприймаються як осередки «престижної / якісної» освіти). Мабуть, цим самим пояснюється й високий показник ЗВО інших мегаполісів України.

Отримані дані дозволяють зробити наступні висновки. Традиційні форми рекламно-агітаційної діяльності (в т.ч. із залученням викладачів, традиційних медіа) $\epsilon$ малоефективними в сучасних умовах. Інформаційний вплив на потенційних абітурієнтів бажано організовувати за принципом «рівний рівному» (але поза контекстом формального офіціозу) та через Інтернет-простір. Прийняття рішення випускниками про вступ до ЗВО - складний динамічний процес, у якому прямо чи побічно задіяна велика кількість різнотипних (когнітивних, мотиваційних, соціально-демографічних тощо) змінних. В умовах COVID-пандемії, постійних змін правил вступу з боку Міністерства освіти і науки України, підвищення вартості навчання, «вступна поведінка» абітурієнтів стає малопрогнозованим явищем, залежним у т.ч. й від ряду ситуативних чинників. Враховуючи методологію нашого дослідження (суб'єктивний характер методу опитування, стихійний характер вибірки тощо), вищевказані результати надалі бажано порівнювати 3 даними аналогічних досліджень серед першокурсників, які вже вступили до ЗВО (це дасть можливість реальніше оцінити значущість тих чи інших чинників). 


\section{ПИТАННЯ ОПТИМІЗАЦЇ̈ ФУНКЦІОНАЛЬНИХ СТАНІВ МУЗИКАНТІВ-ВИКОНАВЦІВ (СОЦІАЛЬНО- ПСИХОЛОГІЧНИЙ АСПЕКТ)}

Зелінська Вікторія Олександрівна, Викладач з дисципліни “Фортепіано", Дніпропетровської академії музики ім. М. Глінки коледж

Должикова Валентина Василівна, Викладач з дисципліни “Фортепіано” Дніпропетровської академії музики ім. М. Глінки коледж

Хотімська Анастасія Борисівна, психолог, ФОП «Приватна психологічна практика»

\section{Зелінська Дар'я Андріївна} психолог, ФОП «Приватна психологічна практика», м. Дніпро, Україна

Введення./Introductions. Професія музиканта вимагає від людини значної фізичної та моральної витривалості, доброго здоров'я і працездатності. Працюючи в класі за фахом зі студентами-піаністами, ми неодноразово переконувалися в тому, що повільне формування технічних навичок, фізична $\mathrm{i}$ емоційна скутість при виконанні твори, сценічні «втрати» далеко не завжди пов'язані з методичними прорахунками педагога або зі слабкими здібностями і лінню учня.

Причиною невдач нерідко виявляються проблеми психологічні, які часто потребують спеціального соціально-психологічного «опрацювання». Необхідність мати гарний вигляд, впевнено почувати себе на публіці, справлятися 3 конфліктними або іншими стресовими ситуаціями актуалізує потребу в спеціальних методах, спрямованих на формування у музиканта навичок саморегуляції, внутрішніх засобів підтримки оптимального самопочуття і стресостійкості.

Ключові слова./ Keywords: музиканти-виконавці, функціональні стани, оптимізація, психологія.

Aim. Дослідити різновиди засобів психологічного коригування по оптимізації функціональних станів музикантів-виконавців 3 метою створення особливої програми особистісно-орієнтованої корекції професійного розвитку музикантів.

Результати та їх обговорення./ Results and discussion. Найбільш доступною i поширеною формою надання психологічної допомоги професіоналам, яка реалізується безпосередньо в виробничих умовах, $\epsilon$ використання комплексу засобів, що сприяють поліпшенню загального самопочуття, підвищення працездатності і корекції негативних функціональних станів, що виникають в 
процесі виконання різних видів праці. У спеціальній літературі цей напрям позначається як робота по оптимізації функціональних станів людини і має тривалу історію освоєння.

Великий матеріал по даному напрямку досліджень узагальнено в цілому ряді публікацій. Серед них можна виділити цикл досліджень А.Б. Леонової (1984, $1987,1989,1993)$ і А.С. Кузнєцової $(1987,1993)$, в яких розглянуті основні засоби та принципи проведення оптимизационной роботи 3 різними групами професіоналів, а також наведені дані по оцінці ефективності впровадження такого роду заходів в практику. В основі цього напрямку психокорекційної та профілактичної роботи лежить використання методів саморегуляції станів, до числа яких відносяться такі класичні техніки як нервово-м'язова релаксація, ідеомоторне тренування, сенсорна репродукція образів і аутогенне тренування. Крім того, в якості ефективних додаткових способів психологічної корекції і профілактики поточного функціонального стану використовуються спеціалізовані види гімнастики (перш за все - дихальної), прийоми самомасажу, елементи сугестії і самогіпнозу. Самостійне значення має застосування світло-і цветомузикальний впливів, застосуванню яких приділяється значна увага. Вони використовуються і як самостійний засіб впливу на стан людини, і як об'єднуючий компонент, що зв'язує воєдино різні техніки і процедури в рамках єдиного сеансу психологічної саморегуляції.

Привабливою особливістю даних методів є їх відносна простота і доступність застосування. Базовими техніками саморегуляції станів може опанувати кожна людина - як в ході самостійної роботи (що менш ефективно), так і під керівництвом фахівця. При цьому по відношенню до практично здорових людей не існує жорстких обмежень і протипоказань в їх використанні. Тому дану групу цілеспрямованих впливів можна віднести до категорії методів «соціальної психогігієни», спрямованої на загальне оздоровлення різних контингентів працездатного населення.

Різні форми медитації також успішно можуть бути застосовані з метою психокорекції. Медитація - поняття багатогранне. У практиці під словом «медитація» мається на увазі досить широке коло явищ - від звичайної аутогенного тренування до релігійно-містичного дійства або молитви. Крім того, існує певне коло «динамічних медитацій», що є синтезом танці-рухових технік і дихальних прийомів. Однак часто причина несприятливих функціональних станів людини корениться набагато глибше і має соціально-психологічні передумови.

Відчуття «неуспішності» і «незадоволеності працею», невпевненість в собі, труднощі в спілкуванні, страх невдачі, замкнутість або переважна агресивність, зайва залежність або відчуття ізольованості, а також багато інших проблем людського самоусвідомлення та самовираження, в кінцевому рахунку, також впливають на самопочуття і діяльність професіонала. Тому рішення даних проблем вимагає проведення спеціальної соціально-психологічної роботи, спрямованої на подолання особистісних труднощів у людини, пов'язаних 3 труднощами її соціальної адаптації.

Питання оптимізації функціональних станів музикантів-виконавців, проте, 
нерідко висвітлювалися в науково-методичній літературі, присвяченій формуванню і розвитку музикантів. В даному контексті слід згадати тілесно орієнтований метод, розроблений педагогом-піаністкою А.А.ШмідтШкловський i спрямований, в основному, на лікування професійних захворювань рук піаністів (тендовагінітів, миозитов, контрактур м'язів, різних форм нервово-м'язових захворювань). Особливий інтерес представляють два розділи ії роботи - «Про профзахворювання рук піаністів» і «Приклади лікування профзахворювань піаністів».

Метод заснований на тонко диференційованій гімнастиці для рук в поєднанні 3 психогимнастикою i психорегулюючим тренуванням, a також 3 «перевихованням» повсякденних рухів (дихання, ходьба, постава і т.д.). Метод в чомусь аналогічний методу Ф.М.Александера або М.Фельденкрайз. ШмідтШкловський вдалося відновити працездатність багатьом піаністам, які були визнані профнепридатними. «Після іiі виступу на Всесоюзних педагогічних читаннях в Москві в 1958 році до неї приїжджали педагоги і піаністи з Москви, Риги, Вільнюса, Магадана, Києва, Архангельська та інших міст країни. Багато музикантів завдяки А.А.Шмідт-Шкловський змогли повернутися до професії, яка, здавалося, була втрачена назавжди. Зверталися до неї не тільки 3 приводу захворювань рук. Найчастіше вона допомагала піаністам позбутися незручності і скутості під час гри, подолати технічне відставання і знайти необхідні кошти для прояву своєї індивідуальності. Це виявилося можливим, перш за все тому, що А.А.Шмідт-Шкловська впливала на всі сторони особистості учня ».

Серйозним науковим дослідженням, яке також виходить за рамки вузько професійних виконавських завдань, $є$ робота Савшінского C.I. «Режим і гігієна праці піаніста» (1963). Вона 3 успіхом може зайняти гідне місце в ряду досліджень в руслі психології праці. Розглядаючи проблеми стомлення, організацію режиму праці та відпочинку, норми роботи піаніста, автор пропонує комплекс психологічних і психофізичних засобів, що сприяють плідності роботи і перешкоджають зниження працездатності. Савшінского рекомендує комплекс методів, що включають гімнастику, самонастройку i психологічну саморегуляцію. Життєздатність методів психологічної саморегуляції в процесі професійної адаптації музикантів-виконавців, зокрема, для подолання естрадного хвилювання загальновідома. Аналізуючи методи психологічної допомоги та підтримки музикантів-виконавців, можна виділити групу методів, що включають аутогенне тренування ( «активне самонавіювання», «суггестивную релаксацію»).

Методика «суггестивной релаксації» активно використовується в практиці музичної освіти багатьох країн світу: «метод активного самонавіювання (в різних модифікаціях) використовували і використовують у своїй практиці багато відомих виконавців і музиканти-педагоги», психорегулюючі тренування здатні також попередити «наступ втоми в процесі занять в репетиторіях, особливо в передконцертний період», відновити загальну працездатність виконавця, а також відрегулювати «професійно значущі психофізіологічні функції ».

Центральною ланкою методу психорегулюючого тренування для музикантів стають спеціальні групи словесних формул, пов'язані з особливостями діяльності 
музиканта-виконавця і з його конкретними професійними завданнями. У процесі підготовки до концертного виступу також допустимі (в деяких випадках) сеанси гіпнозу. «Під час експериментальних сеансів гіпнозу ми моделювали діяльність в умовах публічного виступу, викликаючи позитивні «творчі» емоції, імітуючи успішні виступи в відповідальних концертах, іноді, навпаки, естрадне хвилювання, домагаючись оптимізації психічного стану за допомогою прямого навіювання або пропонуючи випробуваному використовувати прийоми психорегулюючого тренування в гіпнотичному стані. Гіпнотичні сеанси ми успішно використовували також і для «виправлення» негативною мотивації і в цілях формування адекватної самооцінки».

Висновки./Conclusions. Критично осмисливши і узагальнивши результати психологічної допомоги музикантам-професіоналам, ми прийшли до висновку про необхідність створення особливої програми, спрямованої на вирішення всього комплексу специфічних проблем, присутніх у даної групи фахівців Програми особистісно-орієнтованої корекції професійного розвитку музикантів. Істотну роль в утриманні програми грають спеціально підготовлені методи індивідуального та групового консультування. 


\title{
ПСИХОЛОГО-ПЕДАГОГІЧНІ АСПЕКТИ МОТИВАЦЇ̈ МАЙБУТНІХ ФАХІВЦІВ ЦИВІЛЬНОГО ЗАХИСТУ ДО НАВЧАННЯ ЯК ВИЗНАЧАЛЬНА УМОВА АКАДЕМІЧНОЇ ДОБРОЧЕСНОСТІ
}

\author{
Кришталь Аліна Олександрівна \\ кандидат педагогічних наук, \\ доцент кафедри суспільних наук, \\ Черкаський інститут пожежної безпеки \\ імені Героїв Чорнобиля НУЦЗУ
}

Здобувачі освіти, зокрема і майбутні фахівці цивільного захисту, мають нині значні можливості та повноваження щодо регулювання освітніх питань i формування актуального освітнього компоненту. Однак, не зважаючи на вищезгадане, такі проблеми як низький рівень мотивації та порушення академічної доброчесності досі мають місце. Проблема мотивації діяльності, зокрема - навчальної, $є$ однією $з$ ключових у психології та педагогіці. Актуальність цієї проблеми зумовлена значним впливом мотивації на успішність у майбутній професійній діяльності, на здатність проявити свої можливості та здібності, підтримувати процес особистісного зростання, на самореалізацію та задоволеність життям тощо.

Різноманітні аспекти мотивації висвітлені у працях К. Бік, О. Вдовиченко, Г. Грибенюка, С. Занюка, О. Ковальчука, О. Леонтьєва, О. Мамічевої, В. Осьодло та ін.). Виокремлюють внутрішню i зовнішню мотивації, найефективнішою з яких ввжається внутрішня («інтринсивна» за Г. Гекгаузеном або «процесуальна» за С. Занюком). Навчально-професійна мотивація $\epsilon$ внутрішньою рушійною силою, що сприяє розвитку професіоналізму майбутнього фахівця цивільного захисту, забезпечує формування потреби у цілеспрямованому самовихованні та самопідготовці до майбутньої професійної діяльності.

На думку науковців (Л. Беш, Б. Дмитришин, С. Занюк， Б. Коломієць, А. Крилов, О. Мацюра, В. Полянська, О. Яскевич та ін.), розвиток навчальнопрофесійної мотивації відбувається безпосередньо у процесі навчальнопрофесійної діяльності та спілкування, а також особистісного і професійного становлення за умови системного переходу на відповідний рівень розвитку самосвідомості людини.

У дослідженнях, що стосуються дотримання принципів академічної доброчесності у закладах вищої освіти, виокремлюють такі чинники, що найчастіше провокують академічні порушення:

- умови та форма навчання;

- недостатньо чітко окреслені мета і результат навчання;

- не розуміння сутності критеріїв оцінювання знань, умінь та навичок 3 окремих навчальних дисциплін; 
- мінімальні прояви рефлексії;

- низький рівень внутрішньої мотивації здобувачів вищої освіти;

- викривлене уявлення щодо взаємозв'язку отриманих оцінок і якості набутих знань, умінь та навичок;

- страх зазнати осуду з боку батьків або друзів;

- переосмислення власних уподобань щодо майбутньої професійної діяльності тощо.

Належний рівень розвивального освітнього середовища апріорі позитивно позначається на навчально-професійної мотивації майбутніх фахівців цивільного захисту. Застосування сучасних технологій інтерактивного навчання сприяє залученню кожного здобувача освіти до активної участі у процесі підготовки, особливо це актуально нині, зважаючи на пандемію, в умовах змішаної та дистанційної форм навчання (передбачено наявність технічних засобів навчання і доступ до швидкісного інтернету).

Чітке формулювання мети навчання, акцентування на майбутньому результаті та рефлексія є невід'ємними компонентами будь-якої технології навчання, відповідно, і процесу професійної підготовки в цілому. Моделювання дисциплінарного і соціального змісту професійної діяльності майбутнього фахівця цивільного захисту передбачає засвоєння ним теоретичних знань, що корелюють 3 предметними результатами. Як наслідок встановлених зв'язків зростає і рівень академічної доброчесності.

3 психологічної точки зору, рефлексія якнайкраще активує механізми самоідентифікації та особистісного становлення майбутніх фахівців цивільного захисту у контексті майбутньої професійної діяльності.

Якісна зміна вектору мотивації можлива за рахунок переосмислення значущості процесу підготовки та зростання рівня соціальної мотивації. Таким чином, відбувається переорієнтація з «цінність для когось» на «цінність для мене». Активна соціалізація, що передбачає участь у підготовці до виступів на науково-практичних конференція, семінарах, круглих столах, участь у практичних навчаннях служби цивільного захисту, стажуванні, а також будь-які зміни, що наближують умови навчального середовища до професійного, здатні підвищити внутрішню мотивацію майбутніх фахівців цивільного захисту.

Отже, дотримання академічної доброчесності майбутніми фахівцями цивільного захисту напряму залежить від їхньої навчально-професійної мотивації. Підвищити рівень мотивації можливо за рахунок забезпечення оптимальних умов навчання, розвивального освітнього середовища, моделювання змісту та результату професійної підготовки, активної соціалізації тощо. Перспективною для подальшого дослідження вважаємо проблему соціальної мотивації майбутніх фахівців цивільного захисту.

\section{Список літератури}

1. Європейський простір вищої освіти та Болонський процес : Навчальнометодичний посібник / Т.М. Димань, О.А. Боньковський, А.Г. Вовкогон. БНАУ, 2017. - Одеса. : НУ «ОМА», 2017. - 106 с. 


\section{ПСИХОЛОГІЧНІ ОСОБЛИВОСТІ СІМЕЙ, ЯКІ ВИХОВУЮТЬ ДИТИНУ 3 ОСОБЛИВИМИ ОСВІТНІМИ ПОТРЕБАМИ}

Пономарьова Валентина Леонідівна

викладач

Ізмаїльський державний гуманітарний університет

Захарченко Вікторія В'ячеславівна

студентка

Ізмаїльський державний гуманітарний університет

Сім'ї, які мають дітей $з$ особливими освітніми потребами, потребують особливої соціально-психологічної підтримки. Процес адаптації дитини 3 особливими освітніми потребами до соціального середовища займає тривалий період життя і часто змушує батьків жити, задовольняючи потреби дитини, залишаючись не в змозі приділяти увагу своїм власним інтересам, потребам, можливостям реалізації, що не може не позначатися на процесі виховання.

У даній статті розкриваються теоретичні аспекти вивчення психологічних особливостей сімей, які виховують дитину з особливими освітніми потребами.

Дослідженням психологічних особливостей сімей, які виховують дітей 3 особливими освітніми потребами, займалися багато авторів, які в своїх роботах наголошували на вплив, який чиниться соціальним середовищем на розвиток дитини, і загальний психологічний клімат в родині. Дана характеристика різних психологічних особливостей сім'ї: внутрісімейний психологічний клімат, задоволеність подружжя шлюбом, стиль сімейного виховання, ідентичність $і$ стабільність сім'ї, згуртованість і гнучкість сімейної системи, індивідуальні психологічні особливості сімейних партнерів. Наведені приклади, яким чином кожна представлена психологічна особливість може впливати на виховання, розвиток і становлення особистості дитини з особливими освітніми потребами.

До умовах існуючої кризи проблеми виживання слабо-захищених категорій населення, серед яких значяться діти 3 особливими освітніми потребами та їх родини, стоять найгостріше. Україні, як і в усьому світі, спостерігається тенденція зростання дітей з особливими освітніми потребами. У Міжнародній стандартній класифікації освіти діти 3 особливими освітніми потребами визначаються як діти, які, маючи придбані або вроджені розлади психічного або фізичного розвитку, ряд соціальних проблем, відхиляються від умовної норми [2,c.138].

Термін «діти з особливими освітніми потребами» в цілому описує всіх дітей з розвитком, що відрізняється від умовної норми, і чиї освітні потреби ширше загальноприйнятого зразка. Таким чином, ми говоримо про дітей педагогічно запущених, з особливостями психічного або фізичного розвитку, з інвалідністю 
або без неї, крім того, про дітей з соціально вразливих груп (з неблагополучних сімей, сиріт і т.д.).

Практика показує, що допомога дітям з особливими освітніми потребами більш ефективна, якщо грунтується на особистих, людських взаєминах, що можна здійснити в повній мірі тільки в родині. Надаючи соціальнопсихологічний вплив на батьків, ми можемо впливати і на дитину [1,c.120].

Таким чином, в даній статті зроблена спроба узагальнити дані по психологічним особливостям сімей, які виховують дитину 3 особливими освітніми потребами, і змістити акцент уваги з реабілітації та корекції дітей 3 особливими освітніми потребами на психологічну допомогу і супровід їх батьків.

В якості основної теоретичної бази дослідження було розглянуто системний підхід до вивчення сім'ї різних авторів:

Ткачова.В.В зазначає, що сім'я $є$ первинним соціальним оточенням для дитини i прийняття сім'єю $€$ найважливішою умовою прийняття його суспільством [9,с.15].

У роботах Добринін.О.А під соціально-психологічним кліматом сім'ї розуміється інтегративну властивість сім'ї, яке показує ступінь задоволеності шлюбних партнерів основними показниками життєвого процесу сім'ї, загальним стилем і настроєм відносин [3,c.12].

Нікольська.І.М зазначає, що психологічний клімат у сім'ї 3 дитиною 3 особливими освітніми потребами, з одного боку, відображає те, як сім'я змогла адаптуватися до особливостей дитини, прийняти їх i, з іншого боку - як сім'я вибудовує свої відносини з навколишнім «здоровим »світом в залежності від сприйняття особливостей своєї дитини і обмеження його можливостей [8,c.68].

Практика показує, що часто в сім'ях, які виховують дитину з особливими освітніми потребами, виникає неблагополучний внутрісімейний психологічний клімат, відбувається соціальна ізоляція, пов'язана 3 нестачею емоційної підтримки, позитивних контактів, велика ймовірність відходу з родини емоційно віддалилася батька. Це є значним стресовим чинником для всіх членів сім'ї дитини і перешкоджає його оптимальному розвитку.

Калугіна. Е.Л виявила, що серед сімей 3 дітьми 3 особливими освітніми потребами незадоволеність шлюбом виникає як наслідок значного невідповідності між очікуваннями від появи дитини і реальною ситуацією після його народження. У сім'ї може бути відсутнім чітка життєва перспектива i переважати тривожність, пов'язана 3 цим. Члени сім'ї не бачать можливостей полегшення проблем в майбутньому [5,с.230].

Наступною психологічною особливістю сімей, які виховують дитину 3 особливими освітніми потребами, є стиль сімейного виховання. Стилі сімейного виховання складаються під впливом суб'єктивних і об'єктивних причин, на стиль сімейного виховання впливає соціально-психологічний клімат у сім'ї, а також національні звичаї, в яких виховувалися батьки. Складнощі контакту з дитиною 3 особливими освітніми потребами, проблеми догляду та виховання можуть ускладнювати виховну функцію сім'ї. 
Добряков. І.В і Церетелі.С.В відзначають, що найбільш часто зустрічається стилем виховання в сім'ях, які виховують дитину з особливими освітніми потребами, є гіперопіка. Батьки намагаються зняти 3 дитини будь-яку відповідальність і зробити за нього все, навіть те, що він може зробити сам. Дитину поміщають в «тепличні умови». Шкодуючи дитини і допомагаючи йому, батьки самі обмежують можливості його прояви і розвитку. Досить часто вони мають високий рівень виховної невпевненості і схильні проектувати на дитину власні негативні якості. У багатьох дітей з особливими освітніми потребами відзначаються порушення в особистісному розвитку через те, що батьки використовують неправильні стилі виховання [4,с.179].

Психологічними особливостями сім'ї також називають згуртованість i гнучкість сімейної системи.

Лидерс. А. Г дає наступне визначення згуртованості - це структура сім'ї 3 точки зору здатності реагувати на внутрішні і зовнішні впливи, здатність чинити опір природним стресо-генним факторам при проходженні етапів життєвого циклу і адекватність реакцій сім'ї на вертикальні стресори [7,с.432].

Красильникова. Е.Д зазначає, що в сім'ях, які виховують дитину 3 особливими освітніми потребами, переважає роз'єднаний рівень сімейної згуртованості і хаотичний рівень сімейної адаптації. Тільки $20 \%$ сімей за цими показниками є збалансованими. У сім'ях з хаотичним рівнем сімейної адаптації напруженість від особливостей дитини вище. У міру дорослішання дитини адаптація сім'ї підвищується, набуваючи більш нормативний рівень [6,с.115].

Таким чином, грунтуючись на системному підході, був узагальнений комплекс основних психологічних особливостей сімей, які виховують дітей 3 особливими освітніми потребами, що впливають на успішне виховання, розвиток і становлення особистості дитини, до яких відносяться:

1) неблагополучний внутрісімейний психологічний клімат;

2) незадоволеність шлюбом;

3) стиль сімейного виховання - гіперопіка;

4) порушення сімейної ідентичності;

5) роз'єднаний рівень сімейної згуртованості і хаотичний рівень сімейної адаптації;

Систематизація соціально-психологічних теорій і концепцій вітчизняних і зарубіжних авторів, які зачіпають проблему психологічних особливостей сімей, які виховують дітей з особливими освітніми потребами, у сучасному суспільстві виявляють необхідність включити в фокус уваги, крім реабілітації дітей 3 особливими освітніми потребами, психологічний супровід i корекцію психоемоційного стану батьків , підвищення соціальної адаптації сім'ї.

\section{Список літератури}

1. Аккерман Н. Кризи виживання слабо-захищений категорій населення.-М. 2004. $-138 \mathrm{c}$.

2. Альошина Ю. Є., Гозман Л. Я., Дубровська Є. М. Соціально-психологічні методи дослідження подружніх відносин: спецпрактикум із соціальної психології. - М. 1987. - 120 с. 
3. Добриніна О. А. Проблема формування сприятливого соціальнопсихологічного клімату сім'ї: ... канд. психол. наук. - М., 1993.-С.12.

4. Добряков I. В., Церетелі С. В. Значення пренатальних факторів у формуванні типу сімейного виховання здорової дитини та дитини 3 дитячим церебральним паралічем - М., 2003. - С. 178-180.

5. Калугіна Е. Л. Задоволеність шлюбом і подружні цінності в родині після народження другої дитини -2011. - Т. 17. - № 4. - С. 230-234.

6. Красильникова Е. Д. Психологічні особливості сімей, які виховують дітей 3 різними варіантами порушення психічного здоров'я // Питання психічного здоров'я дітей та підлітків (Науково-практичний журнал психіатрії, психології, психотерапії та суміжних дисциплін). -2012 (12). - № 2. - С. 114-123.

7. Лидерс А. Г. Психологічний обстеження сім'ї: навч. посібник-практикум для студ. фак. психології вищ. навч. закладів. - 2-е изд., Стер. - М.: Академія, 2007. - 432 с.

8. Микільська I. М. Клінічна психологія і психотерапія родини і дитинства в парадигмі биопсихосоциальной моделі хвороби і здоров'я -М., 2011. - С. 68-74.

9. Ткачова В. В. Історичний екскурс в проблему сім'ї, яка виховує дитину 3 відхиленнями у розвитку // Психологія сім'ї і хвора дитина: навч. посібник: хрестоматія. Мова, 2007. - С. 15-18. 


\title{
ПОДОЛАННЯ ОСОБИСТІСНИХ ДЕЗАДАПТАЦІЙНИХ ПОРУШЕНЬ ВІЙСЬКОВОСЛУЖБОВЦІВ ТА ВОЇНІВ АТО/ООС ЧЕРЕЗ РЕАЛІЗАЦЮЮ «Я-КОНЦЕПЦЇ̈»
}

\author{
Сальнікова Тетяна Вікторівна, \\ аспірант кафедри психології діяльності в особливих умовах \\ Національний університет цивільного захисту України, \\ Харків, Україна
}

В українському суспільстві останніми роками склалася нова досить специфічна когорта населення - ветерани активних бойових дій (ATO/OOC) [14]. Дані військовослужбовці та воїни АТО/ООС мають досить значний травматичний психофізичний «досвід», який вони набули під час перебування в зоні активного бойового конфлікту на сході України, який надає вкрай негативного впливу на стан їх психофізіологічного здоров'я. Даний «досвід» провокує нові досить відчутні психофізіологічні стреси через необхідність соціальної адаптації та ресоціалізації в «мирному» середовищі, нерозуміння близьких та оточуючих, труднощі та перепони звичайного спілкування, професійного профорієнтування та самовизначення й самореалізації таких осіб після їх повернення з зони проведення АТО/ООС $[5,6]$. Через вплив даних психофізіологічних чинників отриманий при перебування в зоні ведення активних бойових дій стрес значно посилюється й потенціюється, що викликає значну психосоціальну дезадаптацію комбатантів у соціумі.

Дані тенденції викликають так званий «синдром АТО», через який за визначеннями спеціалістів у 20,0\% учасників активних бойових дій в нашій державі в наступні роки буде спровоковано хронічний посттравматичний стресовий розлад. Враховуючи дані тенденції на сьогодні існує проблема напрацювання реабілітаційцних механізмів подолання особистісних дезадаптаційних порушень військовослужбовців та воїнів АТО/ООС, що досить вдало регулюється реалізацією «Я-концепції» у таких пацієнтів. Дана концепція цілковито підпорядковується й відповідає умовам індивідуальної реабілітаційної програми адаптації та соціалізації комбатантів, яка в умовах ведення гібридної війни вимагає від відповідних фахівців швидкого реагування на запити військовослужбовців та воїнів АТО/ООС - учасників активних бойових дій в напрямку організації та проведення їх ефективної індивідуальної комплексної реабілітації. Першочергово комбатанти потребують своєчасної адекватної індивідуальної професійної соціо-психологічної соціалізації та адаптації до умов «мирного» соціуму, запорукою успішності реалізації якої $є$ впровадження певного комплексу індивідуальних психокорекційних та соціоадаптаційних реабілітаційних механізмів [7, 8]. Реалізація цих механізмів подолання певних (отриманих в умовах ведення активних бойових дій) особистісних дезадаптаційних «настанов» цілковито вирішується впровадженням певних засобів та прийомів особистісної «Я-концепції», яка спроможна враховувати усі індивідуальні та середовищні чинники та «внутрішні переживання» комбатанта 
і сприяє формуванню врівноваженої та стійкої до впливу зовнішніх та внутрішніх психочинників особистості. Реалізація «Я-концепція» задля подолання особистісних дезадаптаційних порушень ветеранів АТО/ООС дозволяє активно формувати у комбатанта певні поведінкові «шаблони» соціально активного життя, що в повній мірі відповідає його індивідуальним та особистісним потребам і дає змогу активно розв'язати його існуючі особистісні суперечності 3 урахуванням наявних ціннісно-орієнтаційних потреб та потенціалів.

Залучення «Я-концепції» для подолання особистісних дезадаптаційних проявів комбатантів дозволяє впливати на їх особистість на всіх рівнях соціально-психологічної дезадаптованості особистості:

-ситуативної дезаптованості (вплив можливий із залученням засобів психологічного захисту);

-стійкої ситуативної дезадаптивності (вплив через особистісні «уникнення» певних психотравмуючих ситуацій або через кардинальне «руйнування» психотравмуючих чинників;

-загальної соціально-психологічної дезадаптованості (вплив через особистісні «напрацювання» подолання патологічних комплексів, переродження особистості і перманентної фрустрації 3 виробленням певних захисних механізмів).

\section{Список літератури}

1. Ануфрієва Н. М., Зелінська Т. Н., Туриніна О. Л. Соціальна психологія: навч.-метод. комплекс. К.: МАУП, 2006. 200 с.

2. Комар 3. Психологічна стійкість воїна: підручник для військових психологів. К.: Stabilization Support Services, 2017. 184 с.

3. Соціально-психологічні технології управління військовими колективами: навч.-метод. посіб. / Т. Л. Грицевич, О. С. Капінус, Т. М. Мацевко, П. П. Ткачук. Львів: НАСВ, 2018. 256 с.

4. Лесков В. О. Соціально-психологічна реабілітація військовослужбовців із районів військових конфліктів: автореф. дис. ... канд. псих. наук. Хмельницький: Національна академія Державної прикордонної служби України імені Богдана Хмельницького, 2008. 22 с.

5. Іващенко С. Н., Шахліна Л. Я., Лазарєва О. Б. Особливості побудови фазової моделі фізичної реабілітації військовослужбовців, що постраждали внаслідок бойових дій // Науковий часопис НПУ імені М. П. Драгоманова. 2016. Вип. 3 (72). С. 63-67.

6. Якубова Л. Структурно-функціональна модель соціальної реабілітації осіб, що повернулись із зони АТО // Молодь і ринок. 2017. № 5 (148). С. 50-54

7. Військова психологія і педагогіка: підручник; за заг. ред. Л. А. Снігур. Луцьк: ПВД «Твердиня», 2010. 576 с.

8. Балашова С. П., Васильєв С. П., Дубровинський Г. Р. Практичний курс військової психології: навч. посіб. Ч. 2. К.: Київський національний університет імені Тараса Шевченка, 2013. 172 с.

9. Алгоритм роботи військового психолога щодо психологічного 
забезпечення професійної діяльності особового складу Збройних Сил України (методичні рекомендації). К.: НДЦ ГП ЗСУ, 2016. 147 с.

10. Алалыкина Н. Н. Эффективность психолого-акмеологической реабилитации военнослужащих: дис. ... канд. психол. наук. М.: РГБ, 2003. 200 с.

11. Жаданюк А. С. Психологические особенности динамики формирования личностных качеств в условиях профессионального стресса (на материале деятельности работников спецподразделений на Северном Кавказе): дисс... канд. псих. наук. Ярославль, 2005. 198 с. 


\title{
ВРАХУВАННЯ ПОТРЕБ ОСОБИСТОСТІ У МОЛОДШОМУ ШКІЛЬНОМУ ВІЦІ ЯК ОСНОВА СОЦІАЛЬНОЇ УСПІШНОСТІ
}

\author{
Стрижак Алла Євгеніївна, \\ здобувачка $\mathrm{PhD}$, спеціальності «Психологія» \\ Національний педагогічний університет імені М. П. Драгоманова
}

Теоретик українського державності В'ячеслав Липинський у своїй концепції щодо національного розвитку, висловив тезу яка визначає взаємозв'язність між сталим формуванням нації та розвитком її еліти [1].

Проінтерпретуємо вказану тезу В'ячеслава Липинського для сучасності. В сучасній українській школі, починаючи вже 3 початкової школи, важливо організовувати психолого-педагогічний процес формування справжньої еліти майбутнього. Основу такої стійкої спільноти, яка набуває національну ідентифікацію можуть складати учні, які досягають певний рівень соціальної успішності. Своєю чергою, вже від рівня сформованості у них соціальної успішності залежить їх власне благополуччя та ступінь можливої участі у створенні необхідних для українського суспільства матеріальних і духовних цінностей.

Аналіз філософської, соціальної, психолого-педагогічної літератури дає підстави розуміти під соціальною успішністю такі особливості особистості, які дозволяють повноцінно включатися в систему «ми» соціальних конструктивних відносин, усвідомлюючи цінності-потреби, розвивати свої здібності, досягаючи успіх у різних діяльностях, усвідомлюючи себе суб'єктом діяльності.

Дійсно, стан досягнення успішності у соціумі сприяє формуванню важливих для дитини якостей та потреб. У психолого-педагогічному аспекті саме освітній заклад має допомогти учню/учениці в вирішенні цієї важливої проблеми шляхом забезпечення сприятливих психолого-педагогічних умов для задоволення даної життєвої потреби. На практиці, здебільшого у закордонних дослідженнях $є$ педагогічні форми і методи, з акцентом педагогічні, її вирішення у відношенні старшокласників, підлітків, по-одинокі молодших школярів, але бракує психолого-педагогічних досліджень щодо формування соціальної успішності у молодших школярів в Україні.

Ми визначаємо соціальну успішність молодших школярів як інтегративне утворення особистості, яке характеризується: ціннісним ставленням до себе як до діяча; володінням гнучкими програмними знаннями та уміннями; емоційновольовими і комунікаційними якостями активної особистості.

Стан соціальної успішності особистості важливий на всіх етапах життя людини, але починати формувати цей феномен доцільно вже у молодшому шкільному віці. Для молодшого шкільного віку властиві свої цінності-потреби, без задоволення яких процес формування соціальної успішності не може бути забезпеченним. Звертаючись до розгляду потреб дітей молодшого шкільного 
віку, доцільним $€$ надання характеристики даному віковому періоду крізь призму потреб.

Соціальна ситуація розвитку молодших школярів/-ок у віковий період (від 67 до 10-11 років) веде до зміни провідної діяльності з ігрової до навчальної. Це потребує від дитини нових знань та навичок, що грунтуються на новоутвореннях цього вікового періоду. У цей період у молодших школярів/-ок відбувається розвиток таких важливих для подальшого життя психічних процесів як саморегуляція поведінки, довільність дій, внутрішній план дій - виробляється вміння організовувати навчальну діяльність, рефлексія, вміння свідомо ставити власні цілі дій і знаходити засоби для їх досягнення.

Важливим аспектом Концепції Нової української школи $є$ дитиноцентризм, який виражається в орієнтації на особистісні потреби школярів/школярок у процесі навчання [2]. Потреби є одним із внутрішніх регуляторів поведінки, джерелом активності, за умови можливостей їх задоволення. Провідні характеристики людських потреб - це сила, періодичність виникнення й спосіб задоволення. Потреба завжди має прояви антиципування щодо предмета іiі задоволення.

Розглядаючи потреби зробимо наголос на вікових особливостях їх розвитку з огляду на ієрархічність потребової системи. Ієрархія потреб для кожної людини різна, і може перебудовуватися протягом життя, в залежності від віку, нового життєвого досвіду, що змінює систему цінностей людини. Залежно від того, наскільки розвинений сам організм, «...від рівня психологічного, особистісного розвитку людини і від ряду інших причин, потреби можуть бути різними» $[3$, c.303]. На початку навчання потреби у дітей мають слабкий контроль.

А. Маслоу визначає сім рівнів базових потреб зростання людини: фізіологічні; у безпеці; у приналежності і любові, спілкуванні; у визнанні; пізнавальні потреби; самоактуалізації.

Метою Національної стратегії розбудови безпечного і здорового процесу навчання у новій українській школі $є$ формування безпечних умов навчання в закладах освіти [4]. До потреб у безпеці відносяться: санітарні та інші норми; кібербезпека; захист від дискримінації, поширення неправдивої інформації, булінгу тощо. Втім, психологічна небезпека в процесі навчання в дітей молодшого шкільного віку виражається в остраху: покарання за погані оцінки (34 клас), припуститися помилки, критики, провальної поведінки, пред'явлення високих вимог дорослими. Через це у дітей виникає тривожність, невротизація, байдужість, відстороненість, шкільна фобія, що призводить до шкільної дезадаптації і як наслідок до соціальної неуспішності.

Запобіжником шкільної дезадаптації $є$ врахування: особливостей особистісної, вольової, інтелектуальної готовності дітей молодшого шкільного віку до систематичного навчання і засвоєння знань; пристосування до нової соціальної ситуації розвитку (початок шкільного навчання). Уточнимо, що шкільна адаптація - це шлях до адаптованості, успішної інтеграції молодших школярів/-ок у процес навчання, шлях до узгодженості із самим собою.

Сформованість у дітей молодшого шкільного віку потреб здорового харчування, рухливого способу життя, відповідального використання Інтернету, 
безконфліктної комунікації, ненасильницької взаємодії $\epsilon$ передумовою їх соціальної успішності.

Взаємозв'язок потреби у безпеці з особливостями молодшого шкільного віку, полягає у підтримці, розумінні дитини референтами успішної адаптації до процесу навчання. Відчуття дитиною безпеки, захищеності з боку дорослих впливає на розвиток оптимістичного світосприйняття, ініціативності, самостійності, впевненості у своїх силах, сприяє досягненню успіхів у провідній діяльності, комунікації з іншими. Соціальна успішність взаємопов'язана 3 задоволенням потреби у психологічній безпеці суб'єктивним відчуттям благополуччя власного життя.

Формування соціальних потреб розпочинається ще у дошкільному віці дитини як процес готовності дитини до школи і характеризується тривалістю, нерівномірністю, динамічністю. Заклад дошкільної освіти забезпечує базисне формування соціальних потреб дитини, а початкова школа сприяє подальшому їх формуванню. До потреб у приналежності і любові належать потреби: в увазі, схваленні, отриманні підтримки, заохоченні, встановленні добрих стосунків із однокласниками, спілкуванні, співпраці, взаєморозумінні, співпереживанні, отриманні допомоги з боку референтних осіб. Ці потреби у наслідку ініціюють особистісні мотиви молодших школярів/-ок. Ефективність забезпечення формування потреб афіліації у молодших школярів/-ок залежить від рівня успішності проходження процесу наступності між засвоєнням нових навичек взаємодії і спілкування та актуалізацію наявного досвіду спілкування, адаптації до шкільної взаємодії, крізь призму розвитку рефлексії. Задоволення потреби у приналежності і любові в молодших школярів/-ок $є$ передумовою безпечного дитинства і як наслідок щасливого дитинства.

Становище молодших школярів/-ок серед однокласників та одноліток визначається статусом у групі. Молодші школярі/-ки, які успішно проходять процес наступності між дошкільною і початковою освітою, беручи участь у спільних видах діяльності разом із однокласниками, вже розуміють своє становище, яке вони займають у системі цих взаємин. Місце першокласника в групі головним чином залежить від його успіхів у придбанні знань та моральних якостей. Соціальний статус молодших школярів/-ок корелює із соціальною успішністю у відображенні рівня відповідності якостей, ціннісним орієнтаціям групи. Потреба у визнанні співвідноситься із соціальною успішністю молодших школярів/-ок - гідною оцінкою вчителем позитивних результатів у різних видах діяльності в процесі навчання, яка приносить задоволення та почуття поваги до себе. Депривація потреби у визнанні викликає у молодших школярів/-ок негативну «Я-концепцію», занижену самооцінку, захисні реакції (агресию, лінощі, апатію, невпевненість, психосоматичні стани).

Допитливість молодших школярів/-ок відрізняється від допитливості дошкільників/-иць певною внутрішньою зацікавленістю в отриманні інформації 3 метою задоволення пізнавальної потреби і характеризується прагненням проникнути за межі відомого. У цьому віці дітей цікавлять різноманітні речі, їм подобається інтелектуальне напруження, розмірковування, дослідження, тобто їм цікаво пізнавати. Проявом потреби у пізнанні $\epsilon$ отримання позитивного 
емоційного задоволення від пізнання, особливо коли вдається дослідити нове знання, відчути радість від вирішення задачі. Недостатнє задоволення потреби у пізнанні призводить дитину до шкільної дезадаптації і як факт до соціальної неуспішності.

Успішне виконання дитиною різних видів діяльності зокрема, провідної навчальної, забезпечується розвитком здібностей за допомогою організованої діяльності вчителем/-ькою. При цьому діяльність повинна відповідати основним умовам розвитку здібностей, до яких відносять позитивні емоції, інтерес, протиріччя між актуальним рівнем розвитку здібностей і вимогами діяльності. Розвиток здібностей $\epsilon$ процесом: розвитку функціональної системи, що реалізовує конкретну психологічну функцію, в сукупності їі компонентів і зв'язків; розвитку операційних механізмів; розвитку оперативності в системі функціональних і операційних механізмів; оволодіння суб'єктом своїми пізнавальними здібностями, через рефлексію і оволодіння операційними механізмами відносно конкретних функцій [5]. Важливими умовами розвитку здібностей виступають інтенсивна мотивація суб'єкта діяльності, наявність у нього пізнавальних інтересів, інформаційна насиченість змісту діяльності, наполегливість у доланні труднощів у процесі досягнення мети, інструментальна операційно-результативна характеристика праці, емоційно-вольові властивості, зокрема любов до самої справи тощо [6].

У молодшому шкільному віці, ще не можна говорити про сформовану ієрархію потреб і пов'язану 3 нею усталеність способів поведінки, про сформованість новоутворень віку. Основною функцією особистісних i соціальних потреб у молодшому шкільному віці є встановлення балансу між суб'єктом (дитина молодшого шкільного віку) і соціальною ситуацією розвитку суб'єкта (вимоги процесу навчання до дитини), який $є$ передумовою соціальної успішності дитини.

Список використаної літератури:

1. Липинський В.К. Національна аристократія // Консерватизм: Антологія / Упоряд. О. Проценко, В. Лісовий. - К.: Смолоскип, 1998. - 598с.

2. МOH України Концепція Нової української школи https://mon.gov.ua/storage/app/media/zagalna\%20serednya/nova-ukrainska-shkolacompressed.pdf (дата звернення 23.09.2021p.).

3. Немов Р.С. Психологический словарь / Р.С. Немов. - М. : Гуманитар. изд. центр ВЛАДОС, 2007. — 560 с. : ил.

4. Про Національну стратегію розбудови безпечного і здорового освітнього середовища у новій українській школі Указ Президента України; Стратегія від 25.05.2020 № 195/2020 https://zakon.rada.gov.ua/laws/show/195/2020\#Техt (дата звернення 17.01.2021p. )

5. Ошанин Д,А, Концепция оперативности в инженерной и общей психологии. М.: Наука, 1977. С 131-146.

6. Рибалка В.В. Словник із психології та педагогіки обдарованості і таланту особистості: термінологічний словник / Рибалка В.В. - Київ, Житомир : Вид-во ЖДУ ім. І. Франка, 2016. - 424 с. 


\title{
ПРОБЛЕМИ СУЇЦИДАЛЬНОЇ АКТИВНОСТІ СЕРЕД ЗАСУДЖЕНИХ В УСТАНОВАХ ВИКОНАННЯ ПОКАРАНЬ
}

\author{
Суліцький Вадим Володимирович \\ кандидат психологічних наук, доцент \\ Інститут людини Київського університету імені Бориса Грінченка
}

В останній час проблема самогубств серед різних верств населення в Україні набуває катастрофічних показників. Щодня у засобах масової інформації 3'являються повідомлення про суїцидальні випадки серед підлітків, осіб похилого віку, військових, засуджених. За даними Всесвітньої Організації Охорони Здоров'я, щороку близько 800 тисяч людей позбавляють життя самогубством, а кожні 40 секунд на планеті вчиняється один випадок суїциду. В Україні середній рівень самогубств серед населення складає 18,5 випадків на 100000 населення. У той же час, цей показник серед чоловіків дорівнюється 34,5, а серед жінок $-4,7$. Таким чином за рівнем суїцидальної активності Україна посідає дев'яте місце серед країн світу [1].

Для нашої держави проблеми профілактики та попередження самогубств $\epsilon$ актуальними у зв'язку з загостренням вирішення питання щодо створення умов для психологічної безпеки громадян. Дана проблема висвітлюється і в «Концепції розвитку охорони психічного здоров'я в Україні на період до 2030 року», де одним із основних завдань щодо розв'язання проблем у сфері охорони психічного здоров'я, заплановано впровадження заходів профілактики самогубств серед осіб, які відбувають покарання у місцях позбавлення волі [2].

В останні роки Міністерством Юстиції України були підписані два основних документи, що регламентують діяльність персоналу Державної кримінальновиконавчої служби України у питаннях запобігання суїцидальної активності серед засуджених. Це: «Політика щодо боротьби 3 самогубствами та самоушкодженнями» та «Інструкції щодо реалізації політики щодо боротьби 3 самогубствами та самоушкодженнями». У документах зазначено, що «засуджені та/або особи, узяті під варту як специфічна група населення, відрізняються підвищеним рівнем самогубств порівняно зі схожими 3 іншими характеристиками контингенту в загальній популяції. Шляхом впровадження в практику Інструкцій щодо реалізації Політики щодо боротьби з самогубствами та самоушкодженнями можна добитися значного зниження рівня самогубств $\mathrm{i}$ суїцидальних спроб» [3; 4].

Але, останнім часом ми спостерігаємо, що рівень суїцидальної активності серед засуджених не зменшується та залишається високим у порівнянні $з$ цими показниками серед інших вразливих категорій населення України. Так у 2019 та 2020 роках особами, які перебувають в місцях позбавлення волі, вчинено 100 самогубств (50 випадків у кожному році). 3 них у 2019 році: у виправних колоніях допущено 34 самогубства, у слідчих ізоляторах та УВП - 16; у 2020 році - у виправних колоніях допущено 37 самогубства, у слідчих ізоляторах та УВП - 
12, у виховній установі - один випадок.

Більше 50\% вчинених самогубств припадає на засуджених, які відбувають покарання за вбивство (29 - 2019 рік; 28 - 2020 рік); за крадіжку (25 - 2019 рік; $32-2020$ рік).

Найбільш суїцидонебезпечним часом є світла пора доби (період з 08.00 до 16.00 години). У цей час в 2019 році було допущено $59 \%$ самогубств (порівняно з 2018 - 37\% самогубств; 32020 роком - 45\% самогубств). Також, можна вважати суїцидонебезпечним більш ранній час, з 06.00 до 08.00, коли було вчинено $15 \%$ самогубств (порівняно з 2018 році - 19\% самогубств). Але, в 2020 році $17 \%$ випадків самогубств було вчинено в період часу з 22.00 до 03.00 . Окрім того, з 20.00 до 22.00 допущено 12\% випадків самогубств. Цей факт дає підставу стверджувати, що закономірність вчинення самогубств засудженими в залежності від часу доби є умовною та протирічить твердженням авторів, які визначають суїцидонебезпечним часом доби з 03.00 до 06.00 .

Вікові особливості засуджених-суїцидентів також мають низку особливостей. Так, у 2019 році найчастіше самогубства вчиняли особи у віці від 25 до 35 років (48\%) (порівняно з 2018 - 42\%), також від 41 до 49 років (16\%) (порівняно з 2018 - 26\%). У 2020 році найчастіше самогубства вчиняли особи у віці від 30 до 35 років (33\%) та у віці від 25 до 29 років (23\%). Випадки самогубств серед осіб, старше 41 року та понад 60 років становлять $20 \%$.

Найважчим днем для потенційних самогубств, вчинених протягом 2019 року, виявився вівторок - на нього приходиться 20,4\% всіх самогубств. Наступними по важкості днями були вихідні - субота та неділя, на які приходиться по 16\% самогубств. У 2020 році $25 \%$ самогубств припадало на понеділок, $21 \%$ - на четвер, $15 \%$ суїцидальних випадків було зафіксовано у середу та п'ятницю. Це спростовує встановлену закономірність про те, що найбільш суїцидонебезпечними днями тижня є вихідні дні.

Найбільш складними періодами відбування покарання, 3 точку зору виникнення ризику суїциду, $є$ перший рік в установі (2018 році - 39\% суїцидів; 2019 році - 43\%; 2020 році - 37,5\%), що свідчить про складність протікання процесів адаптації засуджених до умов позбавлення волі. Інший такий період від 2 до 5 років. На нього припадало у 2018 році - 26\% суїцидів; у 2019 році $22,4 \%$, у 2020 році $-27 \%$.

У той же час, треба зазначити, що більшість засуджених, які вчинили самогубства, не мали психологічних і поведінкових ознак схильності до суїцидальних вчинків. Так у 2018 році цей показник складав $76 \%$ від загальної кількості засуджених-суїцидентів, у 2019 році - 84\%, у 2020 році - 64\%. Але, майже половина 3 них до засудження мали проблеми із вживанням алкоголю та психоактивних речовин.

Аналіз соціальних зв'язків засуджених-суїцидентів у 2019 році надає такі результати:

28,6\% (2020 рік - 12,5\%) - підтримували їх з дружиною (співмешканкою);

$16,3 \%$ (2020 рік - 19\%) - з батьками;

$16,3 \%$ (2020 рік - 8\%) - рідними, близькими та знайомими;

24,5\% (2020 рік - 27\%) - не підтримували соціальні зв'язки. 
Засуджені-суїциденти (2018 рік - 87\%; 2019 рік - 93,9\%; 2020 рік - 94\%), до перебування в установах покарань не працювали або не були офіційно працевлаштовані. І лише $11 \%$ мали робітничі спеціальності.

Найбільш поширеними причинами, які впливають на прийняття особою рішення про самогубство, у 2020 році були:

- погіршення відносин з близькими людьми - 21\% (у 2019 році - 28,6\%);

- втрата соціально-важливих орієнтирів - 9\% (у 2019 році - 18\%);

- недоліки в роботі з профілактики та попередження самогубств серед засуджених - 54\% (у 2019 році - 38,8\%) [5].

Серед чинників, що впливають на суїцидальну активність засудженихсуїцидентів, $\epsilon$ ix індивідуально-психологічні особливості. Ми провели дослідження в Микитинській установі виконання покарань (87) м. Горлівки Донецької області. Його результати раніше не друкувалися в наукових виданнях. В обстеженні взяли участь 74 засуджених, які були схильні до самогубства та перебували на профілактичному обліку.

Дослідження проводилося за психодіагностичними методиками: $16 \mathrm{PF}$ (Р. Кеттелла); Ситуативна й особистісна тривожність (Ч. Спілбергера); СЖО (Д. Леонтьєва).

Отримані результати дозволили нам визначити такі психологічні особливості засуджених-суїцидентів:

16 PF (Р. Кеттелла): низькі показники за шкалами В - інтелект, I - емоційна сенситивність, Н - соціальна сміливість, С - сила Я мають кореляцію з високими показниками за шкалами $\mathrm{L}$ - підозрілість та $\mathrm{F}_{2}$ - тривожність $(\mathrm{r}=0,86 ; \mathrm{P}<0,01)$. Великі результати (стени) за фактором L вказують, що засуджені-суїциденти ставляться до інших людей, у тому числі і працівників установ виконання покарань, з недовірою; підозрюють, що їм заважають; часто ображаються та мають прояви ворожнечі під час спілкування. Вони пам'ятають помилки та критичні випади з боку інших засуджених і працівників; хвилюються, що кажуть про них інші; довго залишаються під впливом психотравмуючої ситуації.

Якщо засуджений-суїцидент має сильну тенденцію до підозрілості разом 3 низькими показниками за факторами А і Н, ми спостерігаємо відхилення у його поведінці за параноїдальним типом.

Данні, які ми отримали за фактором В, не є надійними. Р. Кеттелл вказував на цей факт через низьку надійність і обмеженість цієї шкали для визначення інтелекту.

Загалом, середньостатистичний портрет засудженого-суїцидента за психодіагностичною методикою 16 PF Р. Кеттелла такий: «Схильні та надають перевагу залишатися на самоті, важко встановлюють соціальні контакти, із підозрою ставляться до інших людей. Уперті. Завжди приймають самостійні рішення. Вони важко пристосовуються до життя, мають внутрішні страхі. Під впливом ситуації фрустрації сильно хвилюються та впадають у розпач (відчай). Чутливі до загрози».

Ситуативна й особистісна тривожність (Ч. Спілбергера): дану групу засуджених можна віднести до категорії високо тривожних людей, які схильні сприймати загрозу власній самооцінці та життєдіяльності у великому діапазоні 
ситуацій і реагувати станом особистісної тривожності $(\mathrm{r}=0,94 ; \mathrm{P}<0,01)$. Вони нерішучі, невпевнені у собі. Висока ситуативна тривожність $(\mathrm{r}=0,91 ; \mathrm{P}<0,01)$ вказує на наявність напруги, хвилювання, нервозності у поведінці. Вони чуттєві до критики, не мають планів на майбутнє.

СЖО (Д. Леонтьєва): засуджені-суїциденти не мають цілей на майбутнє, життя позбавлене сенсу, спрямованості та перспектив у часі. Їх можна охарактеризувати як людей, які живуть минулим, днем вчорашнім $(\mathrm{r}=0,78$; $\mathrm{P}<0,01)$. Це підтверджує висновки дослідження К. Маздібаєва, що люди, які орієнтовані на минуле часто не задоволені власним соціальним становищем, розглядають процес свого життя порожнім, не цікавим [6]. Окрім цього, засудженим-суїцидентам притаманні втомленість, незадоволеність життям. Вони відчувають, що навколишнє оточенні не проявляють до них інтерес ( $\mathrm{r}=$ $0,83 ; \mathrm{P}<0,01)$.

Цікавим є той факт, що засуджені-суїциденти знають, що людині дано контролювати власне життя, але вони не вірять у власні сили контролювати події свого життя ( $\mathrm{r}=0,87 ; \mathrm{P}<0,01)$.

Таким чином, за результатами дослідження можна вважати, що засудженісуїциденти мають такий середньостатистичний психологічний портрет: «Це людина віком від 20 до 35 років, яка підозріло, з недовірою ставиться до оточення, схильна звинувачувати інших у своїх негараздах. Вони не забувають помилок або критики у свій адрес з боку інших людей. Їх тривожить, що про них кажуть інші «за їх спинами». Довго залишаються під впливом подій, що відбулися у минулому. Під впливом ситуацій вони стають емоційними, але швидко втомлюються і втрачають впевненість у власних силах. Засудженісуїциденти схильні до впертості, мають власну точку зору й байдуже ставляться до соціального оточення. Через велику ситуаційну та особистісну тривожність, вони стають нерішучими та невпевненими. Вони живуть минулим і не мають планів на майбутнє».

\section{Список літератури:}

1. Електронний pecypc. Самогубство. Вікіпедія. URL: https://uk.wikipedia.org/wiki/\%D0\%A1\%D0\%B0\%D0\%BC\%D0\%BE\%D0\%B3\%D $1 \% 83 \% \mathrm{D} 0 \% \mathrm{~B} 1 \% \mathrm{D} 1 \% 81 \% \mathrm{D} 1 \% 82 \% \mathrm{D} 0 \% \mathrm{~B} 2 \% \mathrm{D} 0 \% \mathrm{BE} \quad$ (дата звернення 18.09.2021 року).

2. Концепції розвитку охорони психічного здоров'я в Україні на період до 2030 року : Розпорядження Кабінети Міністрів України від 27.12.2017 року № 1018-p. URL : https://zakon.rada.gov.ua/laws/show/1018-2017-\%D1\%80\#Text (дата звернення 18.09.2021 року)

3. Політика щодо боротьби з самогубствами та самоушкодженнями. Київ, 2017. $11 \mathrm{c}$.

4. Інструкції щодо реалізації політики щодо боротьби з самогубствами та самоушкодженнями. Київ, 2017. 9 с. 
5. Матеріали засідання Робочої групи Департаменту з питань виконання кримінальних покарань 3 профілактики та попередження самогубств серед ув'язаних і засуджених від 31.07.2021 року.

6. Маздибаев К. Стратегии совладания с жизненными трудностями. Журнал социологии и сочиильной антропологии, 1998. № 2. Т 1. С. 100-111. 


\title{
ГЕНДЕРНИЙ АСПЕКТ У ВИЩІЙ МЕДИЧНІЙ ОСВІТІ
}

\author{
Фоміна Людмила Василівна,
} доктор медичних наук, професор, кафедра анатомії людини, начальник навчального відділу

Марчук Іванна Анатоліївна, кандидат педагогічних наук, доцент, кафедра філософії та суспільних наук

Ревіна Тетяна Григорівна, ст. викладач, кафедра біологічної фізики, медичної апаратури та інформатики

\section{Паюк Інна Миколаївна,} методист, навчальний відділ Вінницький національний медичний університет ім. М.І.Пирогова

Історія розвитку людства тісно пов'язана із глобальними перетвореннями, а останні десятиліття характеризуються всеосяжним інформаційним впливом на всі сфери життя людини, у тому числі на економічну (структурні зміни на ринку праці, боротьба за сфери впливу, створення нових бізнес-моделей та стартапів); соиіальну (збільшується тривалість життя, посилюється урбанізація, шириться міжнародна міграція); культурно-цивілізаційну (складні перформанси в сучасному мистецтві, антиглобалістичні ідеї, освітні інновації, інклюзія).

Найближчими роками сучасні тенденції до глобального розвитку цифрових технологій змінять коло найбільш потрібних професій. За оцінками світових експертів, оприлюднених BBC, Forbes, Trade Schools Colleges та інших, найбільш необхідними будуть фахівці, які зможуть проєктувати, впроваджувати нову техніку і технології, а також професії, пов'язані із забезпеченням життя та здоров'я людини: біогенетик; біоінженер; біоінформатик; біофармаколог; телехірург, IT-лікар; медична сестра; фізіотерапевт; нейропсихолог [1]. Отже професії, пов'язані зі збереженням здоров'я, освітою, наданням послуг, творчістю, залишаться актуальними і в цифровому світі, оскільки їх ніяк не замінити автоматизованими системами навіть із використанням штучного інтелекту. I важливим, на нашу думку, має бути гендерний аспект у підготовці таких фахівців.

3 огляду на сказане, розглянемо основні тенденції у вступних кампаніях 3 урахуванням гендерного аспекту у національний вищій медичній освіті та у Вінницькому національному медичному університеті ім. М.І.Пирогова зокрема. В основі нашого дослідження лежить статистичний аналіз, чинне законодавство України та світовий досвід реалізації паритетного права кожного у сучасному 
цифровому світі, адже рівноправна участь жінок і чоловіків у всіх сферах життєдіяльності суспільства і держави $є$ важливою умовою й гарантією забезпечення прав і свобод людини та запорукою демократичної інтеграції нашої країни.

Сьогодні серед зайнятого населення України гендерної нерівності не виявляємо, але по окремих сферах діяльності спостерігаємо певні статистичні відхилення. Відзначимо гендерний дисбаланс саме у галузі вищої медичної освіти: якщо років 10 тому ми могли спостерігати гендерний паритет, то сьогодні уже на $70 \%$ - це фемінізована сфера, тобто у вищій медичній освіті України на дві третини сьогодні переважають жінки (табл. 1).

Таблиця 1.

Чисельність здобувачів вищої освіти у закладах України станом на початок 2020-2021 навчального року

\begin{tabular}{|l|c|c|}
\hline \multicolumn{1}{|c|}{ Показники } & жін., \% & чол., \% \\
\hline \multicolumn{1}{|c|}{1} & 2 & 3 \\
\hline Україна, всього здобувачів вищої освіти & 53,0 & 47,0 \\
\hline $\begin{array}{l}\text { Україна, зараховано магістрів на І курс галузі знань } \\
\text { 22 «Охорона здоров'я» }\end{array}$ & 70,7 & 29,3 \\
\hline ВНМУ ім. М.І.Пирогова, подано заяв на всі спеціальності & 70,7 & 29,3 \\
\hline $\begin{array}{l}\text { ВНМУ ім. М.І.Пирогова, зараховано магістрів на І курс } \\
\text { галузі знань «Охорона здоров’я» }\end{array}$ & 68,0 & 32,0 \\
\hline $\begin{array}{l}\text { ВНМУ ім. М.І.Пирогова, подано заяв на спеціальність } \\
\text { 222 «Медицина» }\end{array}$ & 69,7 & 30,3 \\
\hline $\begin{array}{l}\text { ВНМУ ім. М.І.Пирогова, зараховано магістрів на І курс } \\
\text { спеціальність 222 «Медицина» }\end{array}$ & 70,2 & 29,8 \\
\hline
\end{tabular}

Медична галузь роками вважалася статусною i, як правило, ми спостерігали гендерний паритет при вступі, однак останніми роками галузь переходить у розряд «суто жіночої» поруч з педагогічною освітою $(88,7 \%)$, гуманітарними науками $(79,8 \%)$, сферою обслуговування $(68,2 \%)$ [2]. Може тому ми спостерігаємо таку тенденцію, що галузь стрімко стає низькооплачуваною та непрестижною? Як спростувати гендерний стереотип в Україні, що у виборі професійної діяльності не повинно бути поділу на ринку праці, через який жінки концентруються у найменш престижних та низькооплачуваних сферах діяльності, а всі мають рівні можливості і права? Згідно зі звітом Світового банку «Women, business and the law 2019: a decade of reform» в Україні досі не досягнуто у цьому питанні рівності між чоловіками та жінками. Серед лідерів - Бельгія, Данія та Латвія. Україна ж опинилась на одному рівні із Білоруссю, Азербайджаном та Замбією, набравши трохи більше 78 балів зі ста. В Україні й досі існує дисбаланс в оплаті праці на користь чоловіків [3]. За даними Державної служби статистики України, у III кварталі 2020 року середньомісячна заробітна плата жінок складала 91,1\% від заробітної плати чоловіків [2].

Зміни, які відбуваються у сучасному суспільстві, технологіях, знаннях, вимагають від випускників вміння пристосовуватися, опановувати нові 
професійні навички, критично мислити та бути креативними. I як зазначено у Стратегії розвитку вищої освіти до 2030 року, актуальності набувають також навички системного мислення, програмування, міжгалузевої комунікації, вміння працювати в умовах невизначеності, мультикультурність і володіння декількома мовами, екологічність мислення, мультифункціональність. Отже, перед випускниками сьогодення постають складні завдання: вміти поєднати спеціалізовані і необхідні знання у рамках обраної професії, що сприятиме безперервному професійному розвитку особистості, відповідальності за формування індивідуальної освітньої траєкторії. То може сьогодні саме тому кількісно переважають здобувачі-жінки у сфері охорони здоров'я, що готові швидко реагувати і призвичаюватися до умов стрімкого розвитку інноваційних технологій та доказової медицини, впроваджувати нові методи лікування i діагностики захворювань, переймати новітні інформаційні та сучасні телемедичні технології? (табл. 2).

Таблиця 2.

Здобувачі вищої освіти - випускники, 2020 рік

\begin{tabular}{|l|c|c|}
\hline \multicolumn{1}{|c|}{ Показники } & жін., \% & чол., \% \\
\hline \multicolumn{1}{|c|}{1} & 2 & 3 \\
\hline Випускники, Україна & 52,8 & 47,2 \\
\hline Випускники галузі знань 22 «Охорона здоров’я», Україна & 71,7 & 28,3 \\
\hline Випускники спеціальності «Лікувальна справа», Україна & 67,2 & 32,8 \\
\hline $\begin{array}{l}\text { Випускники спеціальності «Лікувальна справа», ВНМУ } \\
\text { ім. М.І.Пирогова }\end{array}$ & 67,7 & 32,3 \\
\hline
\end{tabular}

Отже, випуск фахівців галузі знань 22 «Охорона здоров'я» 2020 року підтверджує, що професія медичного працівника схоже перетворюється на типово «жіночу». Ця тенденція зберігається і зараз: на всіх факультетах, окрім стоматологічного, перевага серед здобувачів вищої освіти - магістрів - за жінками (табл. 3).

«Чому жінка не може бути більш затребуваною, ніж чоловік?» - запитує Henry Higgins y «My Fair Lady». Можливо, у майбутньому запитуватимуть, чому чоловік не може бути настільки ж затребуваним, як жінка. У багатих країнах дівчата вчаться набагато краще, ніж хлопці, більше дівчат отримують вищу освіту, і саме жінки здебільшого обіймають найбільшу кількість посад. Очевидно, що саме жінки зараз $є$ найпотужнішим двигуном глобального зростання. У 1950-му лише одна третина американських жінок робочого віку мали оплачувану роботу. Сьогодні дві третини жінок мають роботу і складають майже половину робочої сили США. Хоча в деяких країнах з розвинутою економікою (наприклад Італії, Німеччині, Японії) все ж частка зайнятих жінок складає лише $40 \%$ або й менше [4]. 
Таблиця 3.

Загальна кількість здобувачів вищої освіти у ВНМУ ім. М.І.Пирогова, 2020 р.

\begin{tabular}{|l|c|c|}
\hline \multicolumn{1}{|c|}{ Спеціальності } & жін., \% & чол., $\%$ \\
\hline \multicolumn{1}{|c|}{1} & 2 & 3 \\
\hline 221 Стоматологія & 49,6 & 50,4 \\
\hline 222 Медицина & 66,5 & 33,5 \\
\hline 225 Медична психологія & 73,8 & 26,2 \\
\hline 228 Педіатрія & 79,0 & 20,1 \\
\hline 226 Фармація & 82,7 & 17,3 \\
\hline
\end{tabular}

За спеціальностями Національне агентство із забезпечення якості вищої освіти констатує колосальну кількісну перевагу студентів соціальноекономічного і гуманітарного напряму - 75 тис. осіб. Далі у порядку спадання 28 тис. майбутніх інженерів, 14 тис. медиків, 12 тис. педагогів [5]. Щодо гендерного розподілу $\boldsymbol{y c i x}$ здобувачів вищої освіти, то тут майже досягнуто гендерного паритету (53\% жінок до 47\% чоловіків) (рис. 1). Це підтверджують дані Державної служби статистики України, до того ж вони демонструють відносну стабільність цього індексу впродовж останніх 10 років на рівні бакалаврату та магістратури.

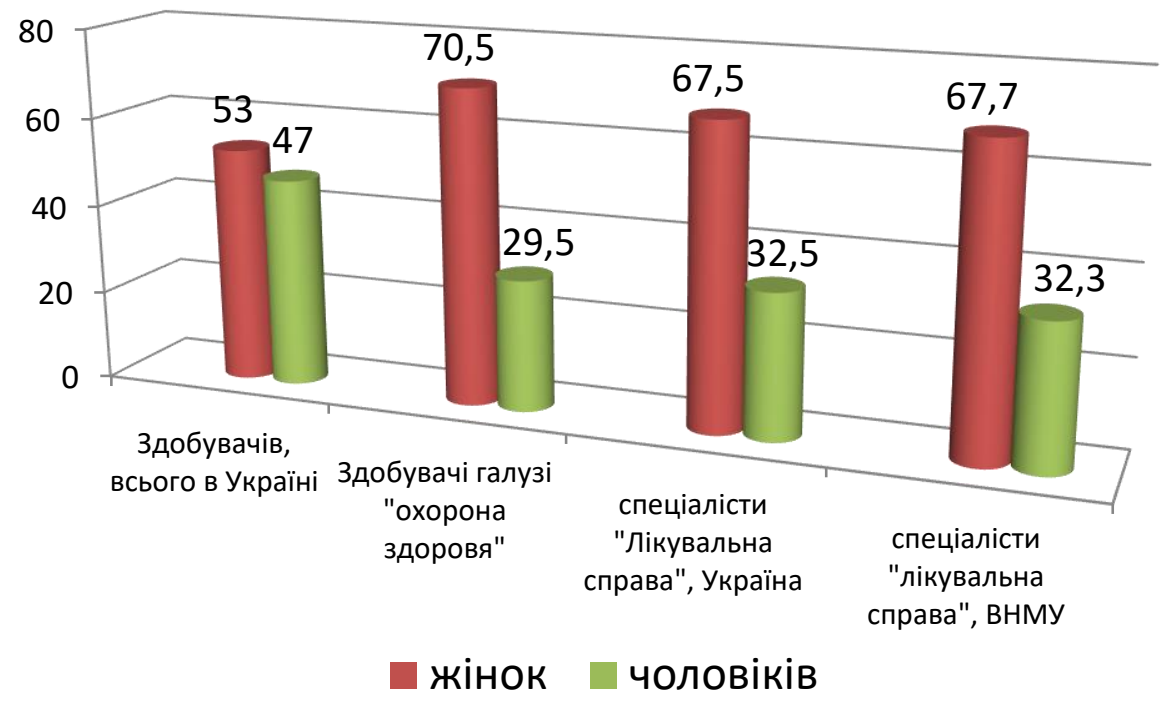

Рис. 1. Розподіл здобувачів вищої освіти - спеціалістів - у ЗВО на початок 2020-2021 навчального року

Також перевагою України є наближення до гендерного паритету серед працюючих із вищою освітою та науковими ступенями: серед загальної чисельності осіб з вищою освітою та науковими ступенями в Україні жінок 30,4\% - 3-тє місце у світі. Ця висока цифра все ж не настільки оптимістична, адже тільки 20\% жінок входять до керівного складу закладів вищої освіти, а науковий ступінь доктора наук та вчене звання професора, що $є$ основним в академічній кар'єрі, - теж характерне зменшення частки жінок - всього $12 \%$. Хоча й варто зауважити, що фемінізація кваліфікованих наукових кадрів в Україні почалася з середини 1990-х: у 1995-2012 роках загальна кількість 
докторів наук в Україні зросла на 60\%, а жінок серед них - на 190\%. Для кандидатів наук ці цифри становлять 53\% і 137\% відповідно [6]. Для порівняння показник працюючих жінок із вищою освітою та науковими ступенями в інших країнах набагато менший: у Великій Британії - 23,4\% (16-те), Польщі - 21,1\% (25-те), Німеччині - 13,5\% (51-ше у світі).

У найбільш розвинутих країнах дипломи отримує більша кількість жінок, ніж чоловіків: у США на 100 випускників-хлопців припадає 140 дівчат, у Швеції - 150, а, наприклад, у Японії - лише 90 студенток на 100 хлопців.

2013 року у Японії тодішнім прем'єром Сіндзо Абе було введене поняття жінкономіка (Womenomics). У цій країні протягом десятиліть близько 60\% жінок кидали оплачувану роботу після народження першої дитини: жінки доглядали за дитиною, а чоловіки утримували фінансово сім'ю, - пише ВBC, - бо традиційно чоловіки отримують вищу заробітну плату. За даними Всесвітнього економічного форуму (World Economic Forum, 2020), дохід японських жінок у середньому на понад 40\% нижчий, ніж у чоловіків. Дані японського уряду свідчать про те, що 2019 року звільнилися лише 42,1\% матерів, а кількість жінок на ринку праці збільшилася: до 70,9\% віком 15-64 років, і до 77,7\% віком 25-44 років [7].

Проте й в Україні результати опитування, проведеного Соціологічною групою «Рейтинг» протягом 21-25 лютого 2020 року, підтверджують, що в сім'ї (парі) більше заробляє саме чоловік (60\%), тільки $23 \%$ - такої думки про жінок, $17 \%$ вважають, що обидва заробляють приблизно однаково [8].

Отже, задля досягнення паритету у сфері вищої медичної освіти необхідно вживати заходів щодо повернення популярності медичної професії та подолання гендерних стереотипів. 11 вересня 2020 року Україна приєдналась до Партнерства Біарріц і взяла на себе зобов'язання серед іншого навчання дітей принципів рівності жінок і чоловіків; зменшення розриву в оплаті праці жінок i чоловіків. Сподіваємось, що це поверне престижність праці медичного працівника та збільшить кількість чоловіків, які прагнутимуть здобути вищу медичну освіту. Гендерна складова, яка безпосередньо пов'язана 3 людським потенціалом, $є$ однією з найважливіших у Європейському Союзі, і такою має стати в Україні у різних сферах, зокрема й вищій медичній освіті. Оприлюднення «Стратегії упровадження гендерної рівності та недискримінації у сфері освіти «Освіта: гендерний вимір - 2020» $\epsilon$ світоглядним орієнтиром для рівних прав i можливостей кожного [1]. Цим документом, зокрема, передбачено інститут радництва з гендерних питань та моніторинг паритетності представлення жінок і чоловіків у керівництві закладами вищої освіти.

Отже, стабільний розвиток сучасного суспільства залежить, у тому числі, й від реалізації принципу гендерної рівності, як індикатора сталого розвитку країни, а статистичні дані все ж підтверджують фемінізацію української вищої медичної освіти протягом останніх років, окрім стоматологічного напряму, де зберігається гендерний паритет.

\section{Список літератури:}

1. Міністерство освіти і науки України // https://mon.gov.ua/ua 
2. Державна служба статистики України // http://www.ukrstat.gov.ua/

3. Звіт Світового банку «Women, business and the law 2019: a decade of reform» // https://openknowledge.worldbank.org/bitstream/handle/10986/31327/WBL2019 .pdf

4. Майбутнє всесвітньої економіки знаходиться у жіночих руках // http://www.management.com.ua/tend/tend058.html

5. Національне агентство із забезпечення якості вищої освіти // https://naqa.gov.ua/

6. Стрельник Олена. Освіта як фабрика смислів: від статево-рольоваго підходу до гендерно-чутливих змін // https://genderindetail.org.ua/season-topic/genderafter-euromaidan/osvita-yak-fabrika-smisliv-vid-statevo-rolovogo-pidhodu-dogenderno-chutlivih-zmin-1341286.html

7. Компанія «Повага». «Жінкономіка» зазнала невдачі: що не так із системою працевлаштування в Японії?// https://povaha.org.ua/zhinkonomika-zaznalanevdachi-shho-ne-tak-iz-systemoyu-pratsevlashtuvannya-v-yaponiyi/

8. Соціологічна група «Рейтинг». Роль жінок у сучасному суспільстві // http://ratinggroup.ua/research/ukraine/rol_zhenschin_v_ukrainskom_obschestve. html 


\section{ИССЛЕДОВАНИЕ ВЛИЯНИЯ ТЕРМОХИМИЧЕСКОЙ ОБРАБОТКИ НА ВЫХОД ПЕКТИНА}

Бобылькова О.М.

магистр,

Егорова О.A.

аспирант,

Алексеев Г.В.

профессор

Национальный исследовательский университет ИТМО, г. Санкт-Петербург

Пектиновые вещества содержатся во всех высших растениях, особенно во фруктах, и в некоторых водорослях. Пектиновые вещества в растительном сырье могут быть в двух формах - водорастворимой (пектин) и водонерастворимой (протопектин).

Таблица1 - Структурный состав некоторых пектинов в зависимости от вида сырья

\begin{tabular}{|l|c|c|c|}
\hline \multicolumn{1}{|c|}{ Источник сырья } & $\begin{array}{l}\text { Содержание } \\
\text { пектина,\% к массе } \\
\text { сухих веществ }\end{array}$ & $\begin{array}{l}\text { Содержание } \\
\text { галактуронов } \\
\text { ой кислоты, \% }\end{array}$ & $\begin{array}{l}\text { Степень } \\
\text { метоксилирования } \\
\text { пектина }\end{array}$ \\
\hline $\begin{array}{l}\text { Корзинки } \\
\text { подсолнечника }\end{array}$ & $11-26$ & 93 & $35-40$ \\
\hline Картофельные волокна & 13 & 55 & 34 \\
\hline Выжимки яблочные & $14-26$ & 70 & $70-80$ \\
\hline Выжимки цитрусовые & $20-30$ & 80 & $73-80$ \\
\hline Свекольный жом & $15-25$ & 55 & 65 \\
\hline
\end{tabular}

Наиболее богатые по содержание пектиновых веществ являются фрукты: яблоки, айва, вишня, слива и многие цитрусовые плоды.

Эта группа включает плоды с содержанием сухих веществ 3,3-19,9\% (яблоки, айва, вишня, виноград, смородина, клубника), а так же субтропические и тропические плоды, в которых содержание пектиновых веществ 5,5-15,8\% (лимоны, апельсины, мандарины, инжир, гранаты).

Значимым для сырья пектинового производства является содержание галактуроновой кислоты в пектине, наибольшее содержание наблюдается у 
корзинок подсолнечника (85-90\%) цитрусовых плодов $(80,4-85,4 \%)$ меньше - у вишни(44,0-48,2\%).

Пектин - хорошо растворимое в воде вещество, состоящие из остатков полигалактуроновой кислоты. Делится на высокоэтерифицированный (содержание карбоксильных групп в котором более 50\%) и низкоэтерифицированный пектин (менее 50\%).

Таблица 2 - Молекулярная масса пектина полученного из различного сырья.

\begin{tabular}{|c|c|}
\hline Пектин & Молекулярная масса, кДа \\
\hline Яблочный & $23,8-33,7$ \\
\hline Цитрусовый & $39,2-48,7$ \\
\hline Свекловичный & $23,6-26,8$ \\
\hline Корзинок подсолнечника & $25,1-30,8$ \\
\hline Кормового арбуза & 27,6 \\
\hline
\end{tabular}

Производство пектина - один из развивающихся бизнесов с ежегодным увеличением производства на 3-4\%, мировой объем которого составляет приблизительно 25-35 тыс. т в год. Пектины применяются в различных областях производства.

Пектиновые вещества имеют богатый комплекс свойств, поэтому они является очень востребованным в пищевой промышленности для производства продуктов леченого и профилактического действия.

В нашей стране производство пектина отсутствует, поэтому спрос на пектин обеспечивается импортными производителями.

Самыми крупными поставщиками пектина является Китай, США, Германия, Польша, Дания. В нашу страну пектин импортирует такие компании как Cargill (Франция), CP Kelc о (Дания,Германия) и Herbstreith\&Fox (Германия).

Нами исследовано изменение свойств пектина в процессе его производства из цитрусовых при предварительной заморозке сырья.

Молекулярная масса пектина после заморозки апельсинов при $-32{ }^{\circ} \mathrm{C}$ равна 26302.

Цитрусовый пектин имеет молекулярную массу от 23000 до 360000, из таблицы 3 видно, что молекулярная масса пектина, полученного из замороженных апельсинов, имеет тенденцию к небольшому снижению с понижением температуры замораживания, но, тем не менее, все значения соответствуют молекулярным массам пектина с высокой желирующей способностью. Это уменьшение можно отнести к деструкции молекул под действием низкой температуры. Полученные данные позволяют рекомендовать предварительное замораживание сырья при производстве пектина высокого качества.

Полученные данные объединяли в таблицу 3. 
Таблица 3 - Молекулярная масса растворов пектина

\begin{tabular}{|l|l|}
\hline Сырье & М.м. \\
\hline Свежие апельсины & 37153 \\
\hline Замороженные апельсины при $-3{ }^{\circ} \mathrm{C}$ & 32359 \\
\hline Замороженные апельсины при $-22^{\circ} \mathrm{C}$ & 28840 \\
\hline Замороженные апельсины $-32{ }^{\circ} \mathrm{C}$ & 26302 \\
\hline
\end{tabular}

Проведенные исследования физико-химических свойств пектинов позволяют определить возможность их наиболее эффективной переработки. Величины важнейших свойств могут зависеть от способа выделения пектина и способа обработки сырья.

В частности для измельчения предварительно замороженного сырья может быть использовано следующее устройство.

Необходимый результат достигается тем, что предложенное устройство для тонкого измельчения замороженного сырья, состоит из цилиндрического корпуса с загруженным бункером, в котором установлен внутри него горизонтально на валу барабан. На наружной поверхности барабана укреплено терочное средство в виде гибкой стальной ленты, размещенной на наружной поверхности барабана и снабженной расположенными по всему периметру вдоль барабана полосами из абразивных частичек. В нижней части корпуса расположена решетка для измельченного продукта и прижима для регулирования степени измельчения. Прижим выполнен полым и перфорированным со стороны дугообразной оболочки, обращенной в сторону терочного средства, а со стороны стенки с прижимающим винтом снабжен каналом, обеспечивающим возможность сообщения с источником химического реагента.

Сущность устройства поясняется схемами, где на рис.1 изображен фронтальный разрез устройства, а на рис.2 его разрез в профильной плоскости.

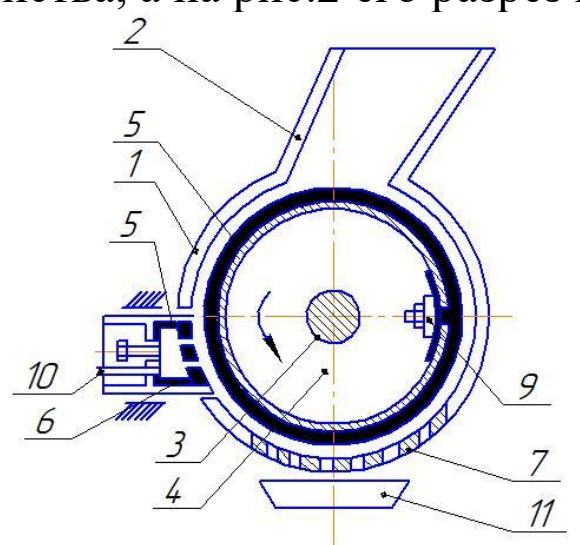

Рисунок 1 - Фронтальный разрез устройства

Устройство состоит из цилиндрического корпуса 1 с загрузочным бункером 2 , установленного внутри него горизонтально на валу 3 барабана 4, на наружной поверхности которого укреплено перфорированное терочное средство 5. 


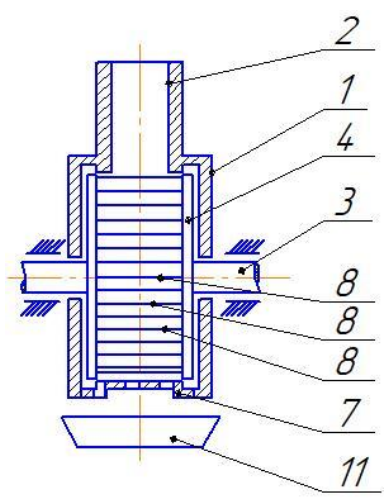

Рисунок 2 - Профильный разрез устройства

Полый прижим 6, в который через питающий шланг подается необходимый химический реагент и осуществляется регулирование степени измельчения, а также расположенная в нижней части корпуса 1 решетка 7 для измельченного продукта. Терочное средство 5 выполнено в виде гибкой стальной ленты, размещенной на наружной поверхности барабана 4 и снабженной расположенными по всему периметру вдоль барабана полосами 8 из абразивных частичек, гальванически прикрепленных к ленте. Терочное средство 5 укреплено на барабане 4 с помощью зажима 9. Для регулирования степени измельчения продукта прижим 6 снабжен регулировочным винтом 10 .

Работает измельчитель следующим образом.

Через загрузочный бункер 2 в зону измельчения поступает исходное сырье. Под действием полос 8, отдельные кусочки сырья поступают в промежуток между барабаном 4 и прижимом 6, где тонко измельчаются, одновременно обрабатываясь, поступающим через перфорацию терочного средства 5, химическим реагентом, при этом абразивные частички полос 8 разрушают практически все клетки, в которых содержатся волокна пектина. Степень измельчения или перетир обеспечивается регулированием расстояния между прижимом 6 и полосами 8, а также использованием абразивных частичек более мелкой фракции. Измельченное сырье проходит через решетку 7 и собирается в поддоне 11, расположенном под устройством. Терочное средство 5 в предлагаемом устройстве выполнено из перфорированной стальной ленты.

Результаты, полученные в ходе данного исследования, позволяют рекомендовать использование низкотемпературной схемы обработки пектиносодержащего сырья для увеличения выхода конечного продукта с сохранением его качества в производстве пектина с использованием лимонной кислоты.

\section{Список литературы}

1. Handbook of hydrocolloids /Edited by G.Phillips, P.A. Williams. -Cambridge: Woodhead Publishing limited , 2000. - 490 p.

2. Донченко Л.В., Фирсов Г.Г. Пектин: основные свойства, производство и применение Москва: ДеЛи принт, 2007. - 276 с.

3. Устройство для тонкого измельчения сырья. Патент РФ №204881 от 16.06.2021, Бобылькова О.М., Алексеев Г.В. и др. 


\title{
FEATURES OF DISTANCE EDUCATION IN THE FIELD OF COMPUTER SCIENCE IN UKRAINE
}

\author{
Gorokhovatskyi Volodymyr, \\ Doctor of Technical Sciences, professor \\ Kharkiv National University of Radio Electronics \\ Baryshnikova Polina, \\ Master in informatics \\ Kharkiv National University of Radio Electronics
}

Forced distance learning has become a challenge for all participants in the educational process: students, teachers, pupils, and parents. It turned out to be not easy to organize high-quality training with the use of digital technologies, to inspire and motivate students, to give advice on technical problems. But Ukraine is no exception - no state, no educational system in the world was ready for this [1].

Currently, in Ukraine, distance learning is carried out in accordance with the Regulation on distance learning with changes approved by Order № 1115 of 08.09.2020. According to this Regulation, modern information and communication technologies are the basis for distance education control measures.

Nowadays, the amount of information that should be used, transmitted, assimilated during training is constantly increasing.

It is the growth of information that has led to the emergence of virtual universities and e-learning, because e-resources are the only form that can keep up with the increase in intellectual content. The so-called e-learning acts as a new technological environment for knowledge transfer.

Training of specialists in computer specialties has its own peculiarities, including the remote form of its implementation. The specifics of training specialists in the field of information technology are that they must constantly adapt to changes in the external environment, which is changing rapidly under the influence of the rapid development of computer technology. This especially affects the technology of studying modern computer disciplines related to the areas of artificial intelligence and computer vision systems [2-7].

The teacher of modern computer, technical, mathematical disciplines has a task not only to prepare students in accordance with educational standards but also to promote the formation of professionally important competencies, skills of finding, collecting, and processing necessary information, effective teamwork, project implementation, responsibility not only for themselves but also for the results of teamwork, the desire to independently master new information technologies, specific tools and specialized software.

Such activities require the use of modern e-learning technologies, the development of an open educational environment, and raising the digital competencies of higher education teachers to the appropriate level. 
Leading IT companies have an interest in educational institutions due to the need for skilled workers $[1,8]$. NIX Solutions has been cooperating with Kharkiv Universities for many years, the company has been successfully creating software products for foreign clients and training IT specialists in its own training center for about 25 years. In addition, the companies involved in the educational process in the Kharkiv region include Soft Serve, Global Logic, Ciklum, Data Art, Sigma Software, Plarium, and many others. At present, most leading educational institutions have laboratories and classrooms equipped with the participation of IT companies, invite company specialists to give guest lectures, hold master classes, etc.

It can be argued that innovative means of information and communication technologies and their competent combination can significantly improve learning outcomes in the field of computer science; they contribute to the comprehensive development of personality, the formation of professional competencies and professional skills, remove territorial boundaries for education and expand limits of professional development of the applicant.

\section{References:}

1. EPAM University Program. Available: https://www.training.epam.ua.

2. Gorokhovatskyi O., Gorokhovatskyi V., and Peredrii O. (2018) Analysis of Application of Cluster Descriptions in Space of Characteristic Image Features, Data, 3(4), p. 52.

3. Gorokhovatsky V. (2014) Structural analysis and intellectual data processing in computer vision. SMIT: Kharkiv, 316 p.

4. Гороховатский В.А., Передрий Е.О. (2009) Корреляционные методы распознавания изображений путем голосования систем фрагментов, Радіоелектроніка. Інформатика. Управління, 1(20), С. 74-81.

5. Gadetska S.V., and Gorokhovatsky V.A. (2018) Statistical Measures for Computation of the Image Relevance of Visual Objects in the Structural Image Classification Methods, Telecommunications and Radio Engineering, 77(12), pp. 1041-1053.

6. Gorokhovatskiy V.A. (2011) Compression of Descriptions in the Structural Image Recognition, Telecommunications and Radio Engineering, 70(15), pp. 13631371.

7. Гороховатський В.О., Творошенко І.С. (2021) Методи інтелектуального аналізу та оброблення даних: навч. посібник. Харків: ХНУРЕ, 92 с.

8. Стрюк А.М., Рассовицька М.В. (2014) Система хмаро орієнтованих засобів навчання як елемент інформаційного освітньо-наукового середовища ВНЗ, Інформаційні технології і засоби навчання, 4(42), С. 150-158. 


\section{THE HISTORY OF THE EMERGENCE AND DEVELOPMENT OF THE SYSTEM AMVER AND ITS ROLE IN SEARCH AND RESCUE AT SEA}

Kalinichenko Yevgeniy Head of NCS Department ONMU, Ph.D., Docent, Master Mariner, AFNI

Kalinichenko Grygorii, Ph.D., Senior Lecturer Odessa Maritime institute

Aloshyn Oleksii, Student of Odessa National Maritime University

Mutychko Olexandr, Student of Odessa National Maritime University

Mankevych Mykola Master Mariner, Senior Lecturer Odessa National Maritime University

The genesis of the Amver system ultimately finds its roots in the RMS TITANIC disaster in 1912. Ships passing within sight of the ill-fated passenger liner were unaware that it had hit an iceberg and was sinking. Upon later investigation, those who had seen the distress flares from the stricken ship admitted they thought they were merely part of the maiden voyage celebrations!

However, the resultant idea of a ship reporting system that could identify other ships in the area of a ship in distress, which could then be sent to its assistance, would not become a reality until the advent of computer technology. As late as the midtwentieth century the world's commercial shipping fleet and burgeoning air transport system lacked an available full-time, global emergency reporting system. On April 15, 1958 the United States Coast Guard and commercial shipping representatives began discussions which led to the creation of Amver.

Originally known as the Atlantic Merchant Vessel Emergency Reporting (AMVER) System, it became operational on July 18, 1958. Amver began as an experiment, confined to waters of the North Atlantic Ocean, notorious for icebergs, fog and winter storms. Vice Admiral Alfred C. Richmond, Coast Guard Commandant at the time, called on all commercial vessels of U.S. and foreign registry, over 1,000 gross tons and making a voyage of more than 24 hours, to voluntarily become Amver 
participants. The basic premise of Amver, as a vehicle for mariner to help mariner without regard to nationality, continues to this day.

The first home of the Amver Center was at the Customs House in downtown New York City, due to the fact that many commercial cargo and passenger lines operating in the Atlantic maintained offices nearby, and Amver's success would depend on close ties to the merchant fleet. Subsequent homes for the Amver computer would include Washington, D.C; Governors Island, New York; and now at Martinsburg, West Virginia. A Visitors Center has continuously resided in New York, currently at the Coast Guard's Battery Park Building, just a few blocks from the old Customs House.

The system's first computer was an IBM RAMAC (Random Access Method Accounting Control), characterized as being able to "evaluate information and determine the position of vessels through dead reckoning." The product of the computer was a "Surface Picture" or "SURPIC" of an area of the ocean, indicating the Amver-participating ships in the vicinity. The world's oldest maritime radio station, Sweden's Gothenburg Radio (SAG) which began operating in 1905, was the charter network participant in 1958.

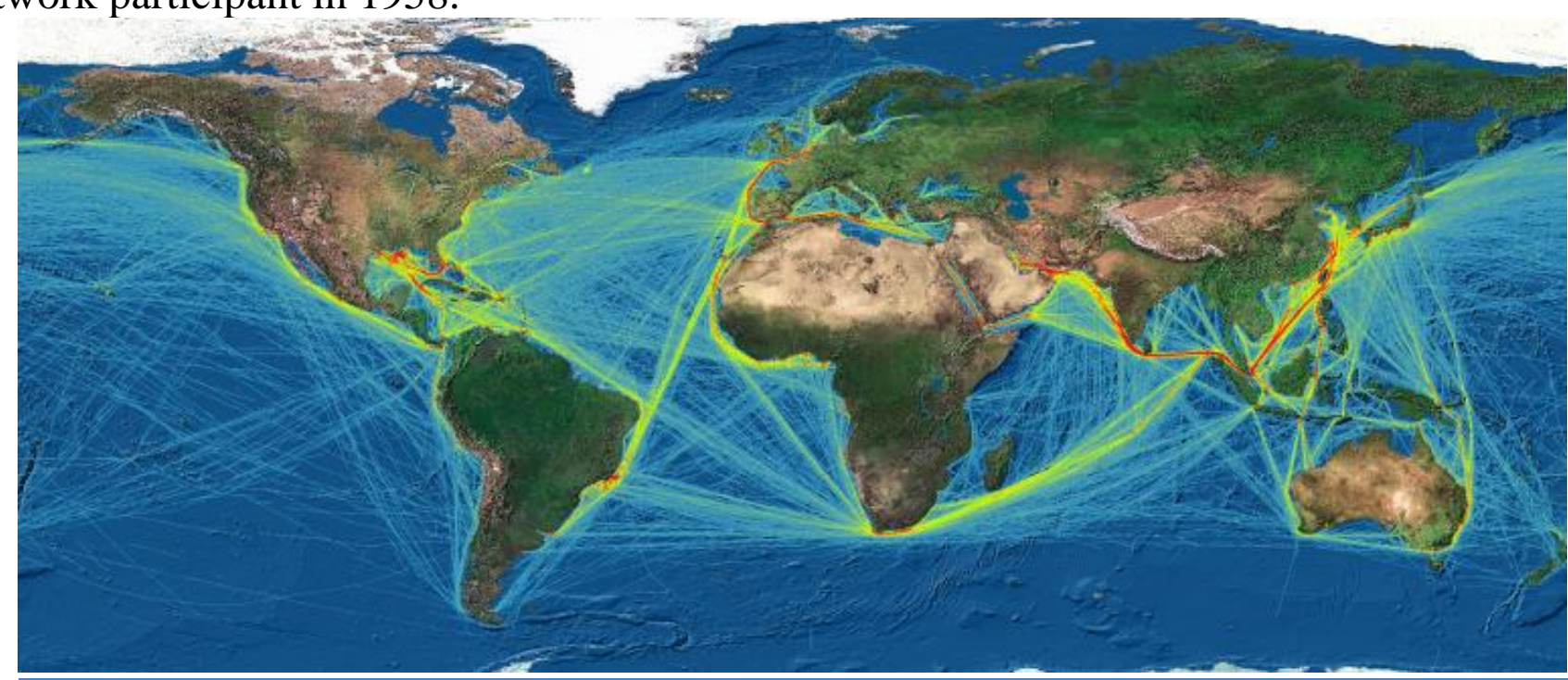

Only two years after Amver began, its database had grown to 5,000 vessels for an average of 770 ships "on plot" during a 24-hour period. The system began receiving sail plans, position, diversion and final (arrival) reports from all around the world. Even today, Amver remains the only worldwide ship reporting system, though several similar "regional" systems have been created.

By 1962, Rescue Coordination Centers (RCCs) in England and Ireland were offered and began using, search and rescue (SAR) information from Amver. By 1963, Amver was plotting vessels on voyages worldwide. It soon became evident the more ships that participated in the system, the more effective it became. The system's technology allowed international SAR agencies to locate a ship in distress, and determine how many, and what type, vessels were in the vicinity. In its first decade of service, Amver information proved its worth in a variety of rescue and disaster scenarios.

In the early years, Amver-participating ships responded to situations as varied as an engine room explosion which seriously injured two crewmen aboard the M/V CHRYISSI; a 17-year old Norwegian seaman injured in a fall aboard the M/V GYLFE; 
a 10-year old boy experiencing sharp abdominal pains aboard the M/V WOLVERINE STATE; an SOS reporting a fire aboard the Japanese M/V SUWAHARU MARU; and, an expectant mother needing medical aid aboard the SS DORIC.

In 1966, the Coast Guard moved its regional headquarters from the Customs House to Governors Island, in upper New York Bay. The move included the Amver Center and consolidated all New York area Coast Guard activities, including a Rescue Coordination Center, at one site. One year after the move, AMVER's title was revised to read Automated Merchant Vessel Reporting program.

Amver's second decade was marked by rapid technological progress. It took Amver only a short time, in the view of its operators and customers, to prove its cost effectiveness as a SAR tool. After all, participation was free of any costs! In critical situations of a fire, flooding or medical emergency, SAR mission coordinators found Amver invaluable in saving precious response time. In 1967, Spanish radio stations Cadiz Radio (EAC), Vigo Radio (EAF), and Santa Cruz de Tenerife Radio (EAT) joined the Amver network of coast radio stations. This increased the system's coverage in the eastern Atlantic and Mediterranean regions.

By 1968, an additional 37 coast radio stations in the Pacific and 28 in the Atlantic were cooperating partners in Amver and the international effort to pursue and promote the safety of life at sea. As a service to the maritime community, frequencies of participating radio stations were published in the quarterly AMVER BULLETIN Magazine.

In 1971, the system was formally expanded worldwide as operations were shifted to Washington hosted on a Control Data Corporation mainframe computer at the Department of Transportation Systems Center. Amver's name required revision once again to reflect its global reach. But at this point, the AMVER acronym was so well known in the industry that the Coast Guard was reluctant to change it. Instead, the title was changed to the "Automated (computerized) Mutual-assistance (its basic premise) Vessel Rescue (its stated purpose) System. Today, due to its global acceptance and familiarity, it is simply called Amver.

Amver took its place in the history of the 1960s and 1970s by playing an important role in the U.S. space program. Amver was a part of the Mercury, Gemini, Apollo and Skylab Programs, providing the National Aeronautics and Space Administration (NASA) with a prospective maritime support plan in the event of a space flight emergency. At the same time, Amver continued its job of protecting mariners at sea, as in the case of a Scottish seaman aboard the M/V TYNE BRIDGE whose life was saved when an Amver SURPIC produced a nearby passenger liner with a doctor on board.

Amver's growing reputation pulled in new cooperating radio systems to the network. Twelve stations in the United Kingdom joined in 1978 and were directly responsible for a dramatic increase in the number of participating vessels. By 1980, Amver Centre specialists were processing 2,000 reports every 24 hours.

On October 4th, 1980, Amver made its mark in the world news media by orchestrating the response to an engine room fire and flooding aboard the Dutch liner PRINSENDAM, carrying 519 passengers and crew. The tanker WILLIAMSBURGH, the M/V GREATLAND, the S/S SOHIO INTREPID and the S/S PORTLAND 
diverted. The 1,095-foot tanker arrived on scene in less than 7 hours, and ultimately took 175 survivors aboard from lifeboats, motor launches and life rafts. In recognition of Amver's role in the safe evacuation of everyone on board, the Government of Norway mandated that all its merchant ships participate in the Amver system.

Amver development has followed the state-of-the-art from punch cards and vacuum tubes, through the printed circuit board, to the microchip. In 1982, database maintenance operations were shifted to two Prime 750 mini-computers installed at the Operations Computer Center on Governors Island.

In October of 1982, the first joint Amver/satellite-alerting rescue occurred, using the experimental Argos and Cospas-Sarsat system. December of that year saw the U.S. Maritime Administration and the Coast Guard sign an agreement making Amver participation mandatory for U.S.-flag shipping, and suspending the requirement for the filing of reports to the overlapping USMER reporting system. This benefited many U.S. masters, already Amver participants, who were juggling reports to two parallel systems, and allowed for a consolidated plot of all U.S. shipping worldwide.

On the occasion of the concurrent 25th Anniversaries of Amver and the International Maritime Organization in 1983, IMO published an open letter to all mariners, endorsing the value of the Amver system. That year, Amver participation grew by 16 percent. In 1985, a snapshot of Amver's last three years had the system tracking 87,543 voyages.

The decision was made in the late 1980s to become even more proactive in Amver recruitment by exhibiting at, or attending, industry exhibitions and trade shows, such as Posidonia (Greece); the Seatrade Tanker Show (UK); SMM (Germany); Cruise Shipping (USA); SASMEX (UK); NEVA (Russia); Maritime Cyprus, and Super Yacht (France).

The U.S. Coast Guard also created an annual Amver Awards Program as a way of rewarding those ships which remain "on plot" for at least 128 days in a calendar year. These awards have become instrumental in Amver recruitment and retention. Amver awards are a tribute to the support of a ship's crew, management, and ownership, which is so integral to the program's success.

Amver award ceremonies have been hosted by U.S. Embassies and Consulates abroad; and maritime industry organizations, such as the Norwegian Shipowners Association; the German Shipowners Association; and the Propeller Club of the United States (Ports of Piraeus, London and Limassol), among others.

The awards consist of a Letter of Appreciation to the company, a Certificate of Merit to each ship, and a colored Amver pennant, representing a ship's continuous participation in the program: blue for (1) year; gold (5) years; purple (10) years. A distinctive plaque is presented for (15) years, an engraved pewter plate for (20) years, and an acrylic globe for (25) years.

In addition, several special annual awards have been subsequently created by maritime organizations such as LLP, Ltd. (Publishing) (UK); PTT Telecom Netherlands (U.S.) (Satellite Communications) Inc.; Argus Business Media (SAFETY AT SEA Magazine) (UK); the Association For Rescue At Sea (AFRAS); and the New York Council of the Navy League, honoring ships involved in rescues requiring extraordinary ship handling, heroism or danger. 
With the advent of the Global Maritime Distress and Safety System (GMDSS), the role of Amver was redefined to complement the emerging technology. Rescue coordination centers around the world seized on the value of Electronic Position Indicating Radio Beacons (EPIRBS), Inmarsat-C and Digital Select Calling terminal auto-alarms to "take the search out of search and rescue." Then, attention could be turned to Amver as a tool for the rescue phase of the operation. As the industry became familiar with this technology, Amver-participating ships have been instrumental in investigating potentially accidental alerts, thus saving limited SAR resources for actual emergencies, and saving money and lives.

The beginning of the 1990s saw the need for the entire software package of Amver to be rewritten in UNIX/Windows technology to keep pace with the evolution of data processing. This new version would provide more capacity; mechanisms for recurrent routings and maintaining ships on station (e.g., research ships or fishing factory ships); graphic plot depiction; and parser capability, once again bringing Amver current with the state-of-the-art. Home for the Amver Center was moved to the Operations Systems Center, a new facility designed and built to consolidate many Coast Guard computer systems at Martinsburg, West Virginia. Contracted out to civilian operation, this facility released many staff members for reassignment throughout the Coast Guard.

In 1992, an Amver-participating ship recovered famed French yachtswoman Florence Arthaud after her trim ran capsized during a solo race. This resulted in Amver's first exposure on national network television on the NBC "Today" Show. Host Joe Garagiola conducted a live interview with Ms. Arthaud while a filmed segment, shot in the Rescue Coordination Center on Governors Island, explained Amver. During the Columbus Quincentennial celebrations in New York, Amver hosted the arrival of the 35 Tall Ship masters of OPSAIL 1992 to a receiving line of dignitaries including Secretary of Transportation Andrew Card, Senator Frank Lautenberg (D-NJ), and Coast Guard Commandant, Admiral John Kim.

The Amver rescue of explorer Tim Severin from the 60-foot bamboo sailing junk HSU FU, while reenacting the voyage of its Chinese namesake in the year $218 \mathrm{BC}$, received mention in the pages of National Geographic magazine. In 1994, a television crew from "60 Minutes New Zealand," aboard a vintage PBY plane, filmed the actual ditching of the aircraft at sea and their rescue by a Norwegian Amver-participating ship. Later that year, six Amver-participating ships converged on the burning Italian cruise ship ACHILLE LAURO to recover 504 of the 976 survivors. And, in the largest single Amver operation in its history, a flotilla of 41 ships from 18 nations searched over a six-day period to recover the only two survivors of the 31 crewmembers from the sunken bulk carrier SALVADOR ALLENDE.

As Amver sought to enhance its stature in the international arena, award ceremonies featured the first participation by a sitting Head of State, President Glafkos Clerides of Cyprus. Other presentation officials included Prince Albert of Monaco and Secretary General William O'Neil of the International Maritime Organization. In 1995, the Amver Visitors Center in New York City hosted a visit by King Harald and Queen Sonja of Norway, following in the footsteps of his father, King Olav V, who also visited the Amver Center in 1968. 
Other distinguished guests at the Amver Visitors Center have included former National Security Advisor VADM John Poindexter; Mr. Vasily Kuprianovsky, Personal Advisor to Russian President Yeltsin; Greek Coast Guard RADM Nicholas Kalyvas; cruise ship OCEANOS SAR mission coordinator, South African Air Force Colonel George Hallowes; Turkish Coast Guard Commandant RADM Ekmel Totrakan; Mr. Christoph Hinz, Director General, German Ministry of Transport; classes of the World Maritime University and industry, media, military and diplomatic officials from many nations.

Following a visit and presentation to Chinese government officials at the Shanghai Maritime Academy, the People's Republic of China announced its intention to allow vessels of its COSCO national fleet to participate in Amver. Just several months later, in April of 1996, the Chinese container ship GAO HE rescued a retired U.S. Navy captain from his stricken sailing vessel in the Pacific.

Taking advantage of the media-conscious era of the 1990s, Amver's visibility has been heightened by its feature in several episodes of the syndicated weekly television series "Coast Guard,"; the Public Broadcasting System/Cable program "World Business Review," hosted by former U.S. Secretary of Defense Caspar Weinberger; and a radio talk show on WPWA in Philadelphia.

Development of the "information highway" led to an analysis and evaluation of the potential benefits to Amver of economies and efficiencies presented by global e-mail, the Internet, and customized communications/ship-management software packages. In conjunction with the National Oceanic and Atmospheric Administration (NOAA) and COMSAT (the U.S. signatory to Inmarsat) Amver has assisted in the development of "compressed message" software to move report data at high speed and low cost to encourage more frequent, user-friendly reporting and thus increase plot accuracy at a time when many shipping companies are removing full-time radio officers from GMDSS-compliant ships.

Today, over 22,000 ships from hundreds of nations participate in Amver. An average of 4,000 ships are on the Amver plot each day and those numbers continue to increase The Amver Center computer receives over 14,000 Amver messages a day.. Over 2,800 lives have been saved by Amver-participating ships since 2000. The success of Amver is directly related to the extraordinary cooperation of ships, companies, SAR authorities, communication service providers and governments in supporting this international humanitarian program to protect life and property at sea.

In the coming years, Amver officials will turn their attention to negotiating with other nations and major national ship registries to solicit their endorsement and active encouragement of ships under their purview to enroll in the Amver system, thus keeping it vibrant, vital and successful. Amver will continue to work with commercial ship tracking companies to find new ways to integrate their clients vessel positions into the Amver system. Amver will also act as a resource for SAR authorities managing maritime incidents in the newly navigable waters of the Arctic.

\section{A SURface PICture (SURPIC) of an Area of the Ocean}

Sail plan, position and/or diversion data reported to the Amver Center computer is used to produce a Surface Picture (referred to as a SURPIC) of an area of the ocean, 
which indicates the relative position of all Amver-participating ships around a specific geographic point (the location of the ship in distress.)

It resembles an air traffic controller's screen. The ship in distress is at the center position of intersecting crosshairs and a series of concentric circles indicating mileage increments from the position of the distress. The SURPIC can show the position of ships from a radius of as little as 50 miles around, out to 500 miles around. Obviously, the larger and further the radius, the more steaming time would be required for one ship to come to the aid of another.

The Search and Rescue (SAR) mission coordinator, typically in a rescue coordination center, calls up a SURPIC by inputting the latitude and longitude of a ship in distress; the desired radius of the SURPIC, usually 250 miles around; and the date and time of the information desired, which can be either real-time or projected several hours ahead in the event of a vessel dead in the water, which winds and currents will cause to drift significantly over a period of time.

The SURPIC can be in a radius (or circular) format, or in a rectangular format (which makes it easier for the SAR mission coordinator to overlay aircraft search patterns.) Once the parameters have been input, the Amver Center computer will provide a listing in text format of the Amver-participating ships in the area.

The SURPIC will list each ship's name, radio call sign and predicted latitude and longitude (based on each ship's reported course and speed, calculated by a system of dead reckoning.) The computer will also indicate (based on its calculations from the position of each ship to the ship in distress), the hours to intercept; the distance in nautical miles; and it will have already calculated the new course each ship must come to in order to make the intercept.

For the information of the SAR mission coordinator, the computer will indicate the national flag of each ship, whether it is carrying a doctor, nurse or paramedic (as reported in the sail plan), and the Inmarsat telephone number of the ship, if it is carrying such equipment.

However, as the saying goes, one picture is worth a thousand words, so the SAR mission coordinator can also "plot" this data in graphical format (similar to the air traffic controller's screen.) The SURPIC now indicates the ship in distress at the center of the crosshairs, and an icon indicating the relative position of each Amverparticipating ship to it. By "clicking" on the icon with a computer mouse, two databases of information about that ship can be opened in a "windows" format.

The first "window" is downloaded from the Lloyds Register Fairplay database, to which the U.S. Coast Guard subscribes, and which is updated twice a month to reflect changes. This database indicates the type and size of the ship, its physical characteristics, and the speed it is capable of making. The second "window" is information reported specifically to Amver by way of the sail plan and position reports. This data indicates such items as whether the ship is carrying a radio officer, the normal watch and which radio station the ship is in contact with, and/or whether there are trained medical personnel on board.

After quickly reviewing and evaluating the information presented, the SAR mission coordinator can select the best one or several ships to respond to the emergency. A number of considerations and variables go into this selection. The closest ship might 
obviously be asked to divert, or perhaps one further away that can make better speed. In a medical emergency, the ship with the doctor or nurse may be asked to respond.

Weather and sea state conditions might mitigate against diverting a relatively smaller ship to respond. Conversely, a ship with a smaller freeboard (height above water) might be better suited to recover survivors from a raft in heavy seas than a huge supertanker or containership. And, of course, considering the commercial nature of the ships involved, a SAR mission coordinator would prefer to divert a ship heading toward the distress, rather than turn one around, all other things being equal. Amver provides all this invaluable information in seconds, at the touch of a button.

Another type of SURPIC (called a "Track line" or "Snapshot" SURPIC) is used in aviation emergencies to look "downrange" of an aircraft in distress and determine an area where there is a cluster of ships that could conduct an immediate recovery effort for passengers/survivors. This benefit could enable the SAR mission coordinator to arrange with the aircraft for a controlled ditching into a specific area of the ocean, favorable to a successful rescue operation.

Requests for SURPICs from rescue coordination centers (RCCs) outside the United States are processed by the nearest U.S. Coast Guard RCC, and forwarded by the most expeditious means (telephone, fax, telex) to assist in that nation's response to an emergency within its area of responsibility under international agreements. Amver computer terminals reside only in U.S. Coast Guard RCCs to ensure Amver data is used only for SAR purposes.

\section{References:}

1. https://www.imo.org/en/OurWork/Safety/Pages/IAMSARManual.aspx

2. https://www.aoml.noaa.gov/phod/goos/seas/amverseas_software.php 


\title{
METHOD FOR REDUCING WEIGHT DESIGN OF THE STATICALLY DETERMINATE TRUSSES OF AEROSPACE STRUCTURES
}

\author{
Miroshnikov Vitaly \\ D.Sc., Professor \\ National Aerospace University named after N. Ye. Zhukovskiy \\ "Kharkov Aviation Institute" \\ Savin Oleksandr \\ Ph.D., Associate Professor \\ National Aerospace University named after N. Ye. Zhukovskiy \\ "Kharkov Aviation Institute" \\ Sobol Volodymyr \\ Ph.D., Associate Professor \\ National Aerospace University named after N. Ye. Zhukovskiy \\ "Kharkov Aviation Institute" \\ Younis Basheer \\ Ph.D., Associate Professor \\ National Aerospace University named after N. Ye. Zhukovskiy \\ "Kharkov Aviation Institute"
}

\begin{abstract}
This article discusses how to decrease the weight of structure by optimization of member sizing and structural configuration of truss structures and material of truss aerospace.

The multitude of considerations affecting structural design of aerospace structures, the complexity of the load distribution through a redundant structure, and the large number of intricate systems required in an airplane, make weight estimation a difficult and precarious career [2]. When the detail design drawings are complete, the weight engineer can calculate the weight of each and every part thousands of them-and add them all up ... and indeed this is eventually done. But in the advanced design phase, this cannot be done because there are no drawings of details. One may start the design process with only very simple estimates of the overall empty weight of the aircraft based purely on statistical results. Some of these correlations are not bad, such as the observation that the ratio of empty weight to gross weight of most airplanes is about $50 \%$.

Stress Analysis of Statically Determinate Trusses of aerospace structures. A lot of aerospace structures can be idealized as truss structures. This is clearly illustrated in Fig. 1, where it can be seen that the ribs in the wing are built up as a truss structure [5]. Also in space applications, trusses are widely used because of their simplicity and light-weightiness [1].
\end{abstract}




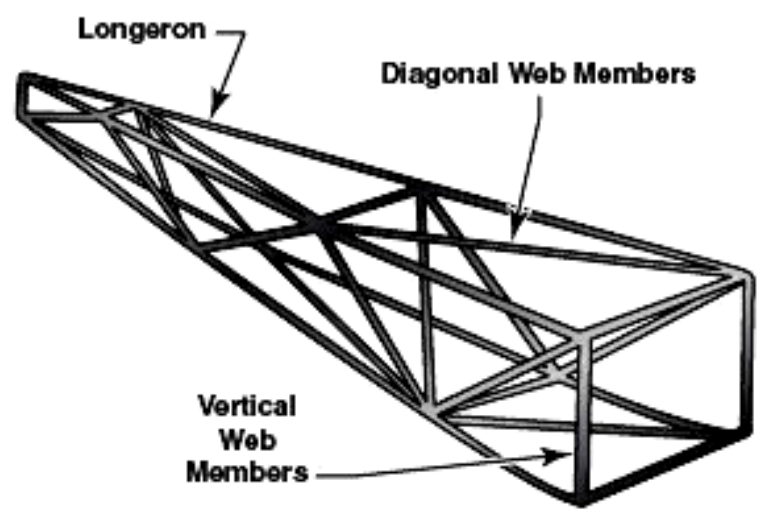

Figure 1. Rib truss structure example

Truss Properties. A truss is a structure built up from truss members, which are slender bars with a cross-section- al area A and having a Young's modulus $E$.
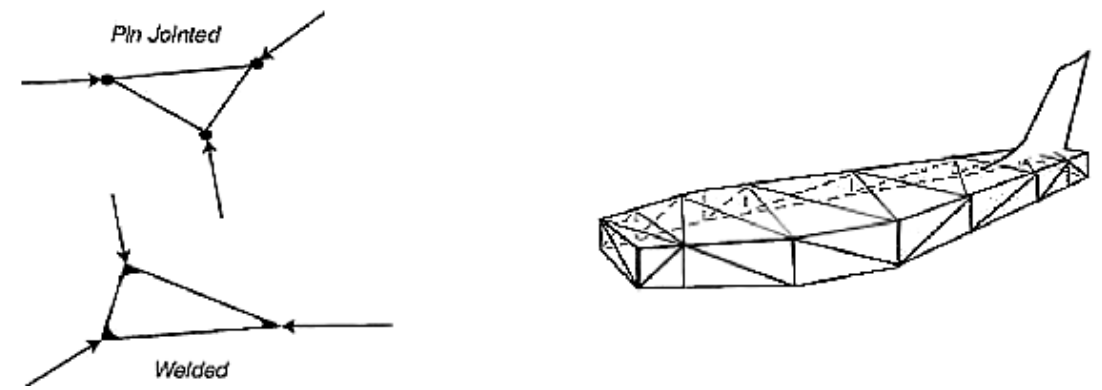

Figure 2. Typical simple truss structure

The following assumptions apply when analyzing a truss structure (Fig. 2). Bar elements can only transfer loads axially. These forces can be either tensile, tending to elongate the bar, or compressive, tending to shorten the bar. The bar elements are pinjoined together. This has as a consequence that the joints only transfer forces from one bar element to the other, and no moments [4]. If the bar elements were welded together, or attached with a plate, also moments would have been transferred, which is in contradiction with the earlier mentioning that bar elements are only suited to take axial loads, and no moments [3]. Loadings can only be applied at the joints of the truss. This inherently means that the weight of the bar, which would act at the midpoint of a uniform bar, is neglected.

Stress Analysis and Design of Statically Determinate Trusses. A truss is statically determinate if the numbers of unknowns is equal to the numbers of equations. Stress Analysis and Design of Statically Determinate Trusses [1] node, two forces in $\mathrm{x}$ and y direction act, that can be constructed for the problem. The unknowns are the truss member forces and the reaction forces at the truss supports. There are $\mathrm{m}$ truss member forces and $\mathrm{r}$ reaction forces.

So a necessary condition for static determinacy of a truss structure is

$$
m+r=2 n
$$

If $m+r>2 n$, the truss structure is indeterminate.

The reaction forces are due to the supports of the truss structure. The two support types that we use for truss structures are the pinned joint and the roller support. Both supports can be inspected in Fig. 3. 
Support Type

Pinned node

Roller support
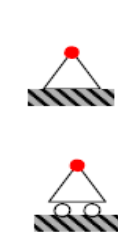

Reactions

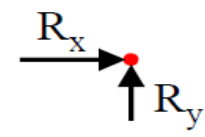

个 $\mathrm{R}_{\mathrm{y}}$

Figure 3. Truss support types

Two trusses are given in Fig. 4. One of them is statically determinate and one is indeterminate.

Figure out why they are determinate or indeterminate.
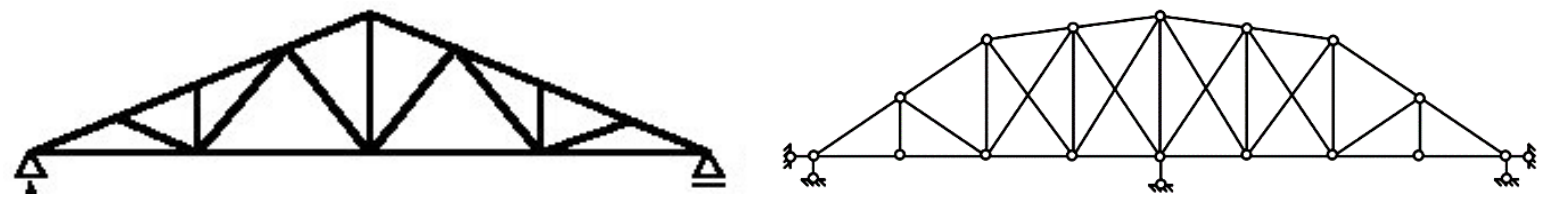

Figure 4. Statically determinate and indeterminate trusses

Truss Analysis. Forces in either of the two directions at each node is equal to zero $\left(\sum \mathrm{Fx}=0\right.$ and $\left.\sum \mathrm{Fy}=0\right)$. The method of joints is highlighted in Fig.5.
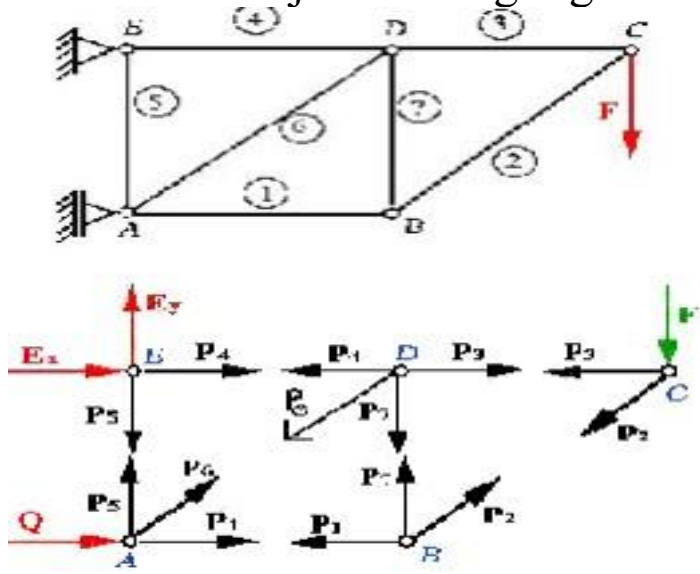

Figure 5. Internal force distribution inside a truss

Finally each node has its own applied force $P_{j}$, which can be zero in case of the absence of the force.

The procedure for analyzing a truss is as follows. Define the truss as described in the previous section. Draw each node separately including the member forces and if relevant, the applied forces and reaction forces on the node. By convention, we draw the direction of the member forces away from the node (see also Fig. 5). This does not mean that all forces are tensile. Compressive forces will come out negative. The reaction forces should be drawn in the positive axis directions and applied forces should remain in their original direction! Sum all the forces per node and per direction and equate them to zero for equilibrium. Solve the obtained equations from the previous item to get the unknown forces (notice that in case of a statically indeterminate truss, you would have too few equations!), both member and reaction forces. Check global equilibrium to see whether the reaction forces come out right. This gives additional confidence in the solution. 
Notice that if the convention of drawing the unknown member forces away from the node is used, the compressive member forces come out negative automatically. Now that the member forces are known, the member stresses $\frac{3}{4} j$ can be retrieved using

$$
\sigma_{j}=\frac{P_{j}}{A_{j}} .
$$

Notice that only the cross-sectional area itself is needed for the calculation of the member stress, so the shape of the cross section, albeit a square or a circle, is irrelevant. Also notice that since a truss member can only take normal forces, only normal stress is calculated, so no shear stress is present in a truss member.

Summary. As the price of crude oil continues to soar, airlines are under increasing pressure to find innovative ways to minimize fuel costs, with the adoption of light weight aerospace structures interior materials a key focus for many operators [2].

Developers and manufacturers for the airplane interiors segment, said that nearly all carriers - even low-cost airlines - are looking for ways to run their operations more efficiently with - out compromising their services in the ultra-competitive industry. "Fuel costs are spiraling for the entire industry, which is having a significant impact on many operators' bottom lines. These rising operating costs are forcing airlines to get creative in their thinking and to examine new ways of reducing their fuel consumption or face extinction."

Cabin weight reduction is one of the solutions, and something that is already being implemented. Airlines are pulling out all the stops to reduce their loads.

References:

1. Aircraft Stress Analysis and Structural Design byMostafa Abdalla, Roeland De Breuker, Zafer GÄurdal and Jan Hol. 2007.

2. Article Light weight interiors crucial to reduce spiralling airline fuel costsUnited Arab Emirates: Saturday, May 24 - 2008.

3. Nicolai, L.M., Fundamentals of Aircraft Design, METS, Inc., 6520 Kingsland Court, San Jose, CA, 95120, 1975. Stinton D., The Design

4. Shevell, R.S., Fundamentals of Flight, Prentice Hall, 1983.

5. Roskam, J., Aircraft Design, Published by the author as an 8 volume set, 1985 1990 


\section{ANALYSIS OF CLUSTERING METHODS IN THE PROBLEMS OF CONSTRUCTING SOCIAL GRAPH MODELS}

\section{Syrotenko Olena,}

Student,

Kharkiv National University of Radioelectronics, Kharkiv, Ukraine

Annotation. This report talks about using of cluster analysis in the problems of detecting community structures for the construction of social graph models. Cluster analysis in sociology is implemented by three main groups of algorithms: hierarchical clustering, probabilistic clustering, and graph-theoretic clustering. The report reviewed and analyzed the advantages and disadvantages of each group.

Keywords: cluster analysis, hierarchical clustering, probabilistic clustering, graphtheoretic clustering, social graph, community structures.

Social graph models are undirected graphs in which vertices are social objects and edges are social connections between objects. They are widely used in social media analysis, predicting social behavior and generating user content.

The use of cluster analysis methods allows data to be grouped by highlighting common points and dividing populations into separate subsets. In general, there are three main groups of cluster algorithms that are most appropriate to use in the social network analysis:

- hierarchical clustering;

- probabilistic clustering;

- graph-theoretic clustering.

The hierarchical clustering methods are based on working with the distances between groups. Depending on it, the following algorithms are distinguished: betweengroups linkage, within-groups linkage, single linkage, complete linkage, centroid clustering, median clustering, Ward's method.[1] The result of the work of the hierarchical clustering algorithms is a dendrogram. It is a diagram representing a tree that is built considering the metrics of distances between clusters.

The most efficient algorithm is the one that leads to natural clustering. Single linkage clustering calculates the distance between clusters as the minimum distance between their objects. Complete linkage clustering calculates distance as the maximum distance between objects.[2] The most accurate algorithms in the social network analysis are Centroid clustering and Ward's method. However, Centroid clustering does not take into account the size of the merged clusters when calculating the average center.

Ward's minimum variance method is based on using an objective function to select and combine pairs of clusters. This objective function can be any function that reflects the investigator's purpose. Clusters with the minimum distance are combined at each 
step.[3] Ward's method is used for small amounts of data and is implemented by the following mathematical formula:

$$
R_{\text {ward }}(U, V)=\frac{|U| \cdot|V|}{|U|+|V|} \rho^{2}\left(\sum_{u \in U} \frac{u}{|U|} \sum_{v \in V} \frac{v}{|V|}\right),
$$

$\mathrm{R}(\mathrm{U}, \mathrm{V})$ - distance between clusters,

$\mathrm{U}, \mathrm{V}$ - clusters,

$\rho(\mathrm{u}, \mathrm{v})$ - distance between objects of single-element clusters

The probabilistic clustering method, k-means method, is used to analyze huge sociological data. The aim of the method is to build a given number of clusters at a maximum distance from each other. [4] The algorithm consists of two main stages. The first one is a random selection of k-points as the initial geometric center. The second one is recalculation of the centroid for each cluster using mathematical formulas:

$$
\begin{gathered}
S_{i}^{(t)}=\left\{x_{p}:|| x_{p}-m_{i}^{(t)}\left\|^{2} \leq\right\| x_{p}-m_{j}^{(t)} \|^{2} \forall j, 1 \leq j \leq k\right\}, \\
m_{i}^{(t+1)}=\frac{1}{\left|S_{i}^{(t)}\right|} \sum_{x_{j} \in S_{i}^{(t)}} x_{j}
\end{gathered}
$$

The result of the k-means algorithm is a group of the Voronoi cells of the cluster means.

The key advantages of the k-means method are the high speed and efficiency of the algorithm and the possibility of using it for preliminary partitioning.

The disadvantages of the method include the impossibility of working with discrete data and the dependence of the work result on a random choice of the geometric center.

The k-means method is very similar to the expectation-maximization algorithm. However, the result of the expectation-maximization algorithm is Gaussian models. They allow clusters to have different shape and are more flexible than the Voronoi cells. The idea of the expectation-maximization algorithm is to build models using a linear combination of multivariate normal distributions. The algorithm consists of two main stages: expectation and maximization.

The expectation stage is characterized by the calculation of values of the expected parameters using statistical methods. The maximization stage consists in maximizing the likelihood function by increasing the value of its mathematical expectation.[5] The expectation-maximization algorithm works with hidden variables and posterior probabilities and is described by the formula:

$$
Q(\Theta)=E_{T}\left[\log _{p}(X, T \mid \Theta) \mid X\right]=\int_{-\infty}^{\infty} p\left(T \mid X, \Theta_{n}\right) \log _{p}(X, T \mid \Theta) d T,
$$

$\mathrm{Q}(\Theta)$ - mathematical expectation of log likelihood,

$\log _{p}(X, T \mid \Theta)$ - expectation under condition $\mathrm{X}$,

$p\left(T \mid X, \Theta_{n}\right)$ - conditional latent component distribution

$p(T \mid \Theta)$ - probability of hidden data

The graph-theoretic clustering methods simplify working with data by visualizing selected groups. The methods are based on direct work with components of graph theory such as edges and vertices. They include: Girvan-Newman algorithm, minimum 
spanning tree, layer-by-layer clustering. They require a higher qualification of the analyst because specific packages are used in the algorithms.

The Girvan-Newman algorithm is used to detect community structures in complex systems. Its point is to transform the network by gradually removing edges. It works with intermediate edges, while other similar algorithms focus on center edges. [6] The result is a set of clusters whose objects are related within groups but have no characteristics in common with external groups.

The minimum spanning tree algorithm consists in combining all data into one cluster and then dividing the cluster by removing the edges of the maximum length.[7] The MST algorithm has better performance than the k-means algorithm. However, it requires an initial determination of the step size and threshold value.

The layer-by-layer clustering algorithm works with a value, called a distance threshold. It determines the level of the distance between the vertices in the graph for sequential dividing it into subgraphs. The distance threshold value controls the depth of the cluster hierarchy which makes it possible to create both hierarchical and flat structures.

In summary, three main approaches to working with social network data in the form of graph models have been analyzed. The probabilistic algorithms are most effective in the primary analysis of large amounts of data that are heterogeneous. The results of the graph-theoretic algorithms are distinguished by their high accuracy and speed. Such algorithms make it possible to take into consideration not only the characteristics of objects but also the connections between them. The hierarchical approach provides the greatest variability of possible algorithms that have the highest data processing optimization. However, the speed and visual aspect of the result directly depends on the input data.

\section{References:}

1. Добрина О. А. Анализ данных в социологии: учеб. пособие. Новосибирск: НГАСУ (Сибстрин), 2013. 100 с.

2. Шитиков В. К. Классификация, регрессия, алгоритмы Data Mining с использованием R. 2017. URL: https://github.com/ranalytics/data-mining.

3. Szekely G. Hierarchical Clustering via Joint Between-Within Distances: Extending Ward's Minimum Variance Method. 2005. URL: https://home.ipipan.waw.pl/j.mielniczuk/Szekely-Rizzo_2005.pdf.

4. Часовских А. Обзор алгоритмов кластеризации данных. 2010. URL: https://habr.com/ru/post/101338/.

5. Орешков В. ЕM - масштабируемый алгоритм кластеризации. 2021 URL: https://loginom.ru/blog/em

6. Newman M. Modularity and community structure in networks. 2006. URL: https://www.pnas.org/content/pnas/103/23/8577.full.pdf.

7. Jain A. Data Clustering: A Review. 1999. URL: https://www.ee.columbia.edu/ sfchang/course/svia/papers/jain99data-clusteringreview.pdf 


\title{
SOME ASPECTS OF MODERN DEVELOPMENT FOR SIGN LANGUAGE RECOGNITION SYSTEMS
}

\author{
Tvoroshenko Iryna, \\ Ph.D., Associate Professor \\ Kharkiv National University of Radio Electronics \\ Kharchenko Anastasiia, \\ Master in informatics \\ Kharkiv National University of Radio Electronics
}

Today, video communication is gaining momentum, it is becoming available in different countries around the world, allowing you to talk and see employees. However, this technology is not available to a large percentage of people with hearing and speech impairments. Gesture recognition and sign language features in video communication systems can overcome this barrier and view video communication at a new modern level.

There is a lot of research on image recognition techniques [1-5], some of them allow you to interact with a computer using hand gestures, including sign language recognition.

Recognition and classification of images [6-10], in particular gestures, is not a new task, but active research in this area has been carried out in the last decade, which is associated with the rapid development of artificial intelligence methods [9-14]. Gesture recognition from video sequences requires the separation of both spatial and temporal features, which, in turn, requires the development of new or improvement of existing recognition methods [15].

The main task of sign language recognition is to obtain the translation of gestures in the form of text for communication between ordinary people and people with hearing impairments. Areas of application of this direction - systems of contactless humanmachine interaction $[9,10]$.

A sign language recognition video communication system can become really important in the lives of people with hearing impairments and in the lives of those around them. Thus, it is possible not only to give the opportunity to communicate with people with hearing impairments at a distance in cases where text messages are not enough, but to communicate with people who speak and do not speak sign language. Video communication is a sign language to text or voice translator.

Gestures - are various body movements that are a non-verbal way of conveying information.

Movement of fingers, hands, head, shoulders, facial expressions: all of the above are gestures. With the help of gestures you can convey an independent information unit, supplement the verbal series, convey feelings, etc. Movements are divided into static (perceived simultaneously) and dynamic (perceived in a certain period of time), 
they have a certain interpretation in manual alphabets and contactless human-machine interfaces.

A hand gesture recognition system - is a set of computer technologies and mathematical algorithms that allows you to solve the problem of recognizing a certain group of hand gestures.

Gesture recognition can be used, for example, in the following areas of human activity:

- Control of computer and household devices:

1) In a computer application, each hand configuration is mapped to a specific command. The person shows a gesture, the system recognizes the configuration of the hand and sends the necessary command to the computer;

2) The position of the palm is compared with the position of the mouse cursor on the screen. Hand movements lead to cursor movements. Commands to click the mouse buttons are compared with different hand configurations;

3) Recognized fingertip positions can be used to control a computer or home devices with a few fingers at the same time;

- Creation of natural human-machine interfaces for the deafblind people:

1) Gesture recognition can be used to enter text into a computer using hand gestures, which is easier and more natural for deafblind people than entering text using a computer keyboard;

2) Gesture recognition can be used to create online communication applications when network bandwidth is low and video communication is not possible. Having recognized hand gestures at one end of the network, you can show the animation of the same gestures at the other end, transmitting over the network only the characteristics of the displayed gestures;

- Manipulation of three-dimensional models of objects. To work with threedimensional models [16], usually use a computer mouse, which is not very convenient for this task. Having three-dimensional coordinates of a hand and fingertips, it is possible to create the Human-Computer Interaction system which will allow to operate models in all directions of three-dimensional space;

- Virtual reality applications. By supplementing the gesture recognition system with devices such as stereoscopic glasses, you can create virtual reality software applications where the user can "touch" imaginary objects.

Nowadays, in order to learn a language, it is enough to have access to the network from any device. Every day, a large number of sites appear on the Internet, through which you can find many methods and lessons of learning foreign languages, including video lessons.

The created mobile applications are aimed at learning in an exciting way any language, but sign language is a unique language that differs from others by a nonverbal way of transmitting information. Words and sentences in sign language are shown through hand gestures, fingers and facial expressions. One gesture of sign language can mean a letter, a word and even express feelings.

The handwritten alphabet or the dactyl alphabet - is an alphabet used in dactylology that reproduces the spelling of a word with the help of the fingers. Communication with a dactyl is considered verbal. To indicate a letter, change the position of the fingers. 
Most letters of the dactyl alphabet are similar to the printed ones, which makes it easier to learn. Possessing a manual alphabet, there is communication between a deaf person and a hearing person. However, difficulties may arise during such communication when the person does not speak sign language. To solve these problems, research is being conducted to create automatic sign language translation systems and systems equipped with a more natural human-machine interface for deaf people.

Given that the handwriting alphabet has only a fraction of the gestures used in deafmute language, automatic handwriting recognition opens the way for more natural human-machine interfaces, removes the communication limitations faced by deaf people in everyday life.

Unlike people who become deaf as a result of an accident or illness, people who are deaf from birth prefer sign language instead of plain text. They find it easier to accept and display gestures than to read or type on a computer or phone keyboard.

There are various sign languages in the world, American deaf culture is one of the most developed, American Sign Language (ASL) is the basis for the development of recognition systems for other sign languages.

According to the World Health Organization, there are 360 million people with hearing impairments and deaf people in the world. Given the rapid development of communication technologies, the problem of communication of people with hearing impairments continues to be relevant. There are more and more studies to solve this problem every day. Consider the current developments in the field of simultaneous translation from sign language.

One of the areas of sign language translation is related to the development of robotics. Machine translation from sign language has been possible since 1977, when a robotic arm was created. Later, the use of cyber-gloves with motion sensors became the main one, such projects as CyberGlove and VPL Data Glove appeared. Using cyber gloves is one way that allows a computer to track a person's movements and translate them into spoken or written language.

In 2002, Ryan Patterson, in the United States, developed a simplified glove. The device allows you to track the gestures of the deaf alphabet, and then wirelessly transfer data to a portable device that displays text on the screen. The glove had to be taught to feel the hand of a particular person. More useful are gloves that can capture entire characters. For example, CyberGlove has 18-22 sensors and connects to a host computer via a serial cable (CyberGlove, n.d.); while VPL Data Glove has sensors that are fiber-optic transducers that measure finger bending angles.

A practical example of the use of these technologies is the SignAloud project implemented by a group of students from the University of Washington. With the help of two gloves equipped with sensors that monitor movement and transmit data to a computer system via Bluetooth, the developers were able to translate into English American Sign Language (ASL).

Despite the high accuracy, these technologies impose certain restrictions on users: the need to use special technical devices, the inability to take into account the articulation. 
Kinect Sign Language Translator - is a translator developed in 2012 by a Chinese team in collaboration with the Microsoft Research Asian team. The translator consists of two modes: translation mode and communication mode. Translation mode is able to translate individual gestures into written text (words) and vice versa. Translator mode can also determine hand postures and shapes, as well as trajectory, using machine learning, pattern recognition, and computer vision technologies. Communication mode can translate complete sentences, and the conversation can be automatically translated using a 3D avatar. The Kinect peripheral to the Microsoft Xbox360 gaming console is used to read gestures.

SignAll - is an automatic system of the Hungarian company Dolphio Technologies for the translation of American Sign Language (ASL). The works have been underway since 2015. This study is based on computer vision and natural language processing (NLP), uses Microsoft's Kinect and webcams with depth sensors (depth sensor and 3 webcams) connected to a computer. Computer vision technology reads the gestures and facial expressions of a deaf person, and the natural language processing system converts the collected data into a simple English phrase. The disadvantage is that a complex structure of three cameras, a sensor and a computer must be installed to read the sign language.

MotionSavvy - is a device for sounding American Sign Language and vice versa. Developed in 2012 by a team from the Rochester Institute of Technology (National Technical Institute for the Deaf). The team used a tablet with a Leap Motion sensor. The Leap Motion 3D controller recognizes hand movements performed by the user over the surface of the tablet. As a result, the image of the gesture is displayed on the screen and it is translated into text or voiced.

The Sign2 Conversion System was designed to convert American Sign Language (ASL) to English (written and spoken). The current system only includes finger gestures in a controlled environment using computer vision, but the long-term goal is to translate complete offerings in natural environments, including integration with personal digital assistants (PDAs) and smartphones.

Not only large companies make efforts to make better and more comfortable communication of people with hearing impairments with the external environment. Deaf programmer Oleksiy Prykhodko presented a prototype of a system that is able to translate sign language into the text of his native language.

Oleksiy Prykhodko is the only deaf programmer in the world who is working on creating an automatic gesture translator into audio language. According to him, today there are many companies that claim to have been able to create a ready-made translator for the deaf, but there is no "perfect" among them.

The program that Prykhodko is working on works by analogy with the human brain. With the help of the camera, it recognizes the picture and captures the gestures, which it then converts into images. Then they are translated into a model and processed by a system that compares them with the data in the neural network. After the complete processing process, the computer displays a text translation that already corresponds to the gestures.

The method of randomized decision forests is a machine learning algorithm used in classification, regression and clustering problems. In gesture recognition problems, 
this method is used to recognize the positions of key characteristics of the human body and to classify the configuration of the hand. It is on this technology that the human gesture recognition system released by Microsoft in 2010 is based. This method allows you to recognize the positions of 20 parts of the body, including the positions of the palms of both hands, receiving at the entrance one far-sighted image of a person. Positioning of the desired points of the body is carried out with the help of random forests of solutions, which are learned by sampling images from 100,000 different poses of the human body.

So, it is established that the practical significance of gesture recognition on video is not limited to sign language translation; gesture recognizer can be integrated into other systems, such as virtual or augmented reality technology, interfaces for entering information using gestures, game development.

Because of this, research, development and implementation of gesture recognition tools on video sequences using artificial intelligence apparatus [17-19] are important and urgent tasks not only for the development of information technology, but also for the development of society as a whole.

\section{References:}

1. Kobylin O., Gorokhovatskyi V., Tvoroshenko I., and Peredrii O. (2020) The application of non-parametric statistics methods in image classifiers based on structural description components, Telecommunications and Radio Engineering, 79(10), pp. 855863.

2. Gorokhovatskyi V.O., Tvoroshenko I.S., and Vlasenko N.V. (2020) Using fuzzy clustering in structural methods of image classification, Telecommunications and Radio Engineering, 79(9), pp. 781-791.

3. Tvoroshenko I.S., and Gorokhovatsky V.O. (2020) Effective tuning of membership function parameters in fuzzy systems based on multi-valued interval logic, Telecommunications and Radio Engineering, 79(2), pp. 149-163.

4. Tvoroshenko I.S., and Gorokhovatsky V.O. (2019) Modification of the branch and bound method to determine the extremes of membership functions in fuzzy intelligent systems, Telecommunications and Radio Engineering, 78(20), pp. 18571868.

5. Gorokhovatskyi V., Rusakova N., and Tvoroshenko I. (2020) The application of image analysis methods and predicate logic in applied problems of magnetic monitoring, Telecommunications and Radio Engineering, 79(20), pp. 1801-1811.

6. Гороховатський В.О., Творошенко І.С. (2021) Методи інтелектуального аналізу та оброблення даних: навч. посібник. Харків: ХНУРЕ, 92 с.

7. Творошенко І.С. (2021) Технології прийняття рішень в інформаційних системах: навч. посібник. Харків: ХНУРЕ, 120 с.

8. Кобилін О.А., Творошенко І.С. (2021) Методи цифрової обробки зображень: навч. посібник. Харків: ХНУРЕ, 124 с.

9. Flah P. (2015) Machine learning. The science and art of building algorithms that extract knowledge from data, Moscow, Russia: DMK Press, 400 p., (in Russian).

10. Nong Ye. (2013) Data Mining: Theories, Algorithms, and Examples, Florida, USA: CRC Press, 349 p. 
11. Asaad Ma. Babker, Abd Elgadir A. Altoum, Irina Tvoroshenko, and Vyacheslav Lyashenko (2019) Information Technologies of the Processing of the Spaces of the States of a Complex Biophysical Object in the Intellectual Medical System HEALTH, International Journal of Advanced Trends in Computer Science and Engineering, 8(6), pp. 3221-3227.

12. Yousef Ibrahim Daradkeh, and Iryna Tvoroshenko (2020) Application of an Improved Formal Model of the Hybrid Development of Ontologies in Complex Information Systems, Applied Sciences, 10(19), p. 6777.

13. Kucherenko Ye.I., Filatov V.A., Tvoroshenko I.S., and Baidan R.N. (2005) Intellectual Technologies in Decision-Making Technological Complexes Based on Fuzzy Interval Logic, East European Journal of Advanced Technologies, 2, pp. 92-96.

14. Matarneh Rami, Tvoroshenko Irina, and Lyashenko Vyacheslav (2019) Improving Fuzzy Network Models For the Analysis of Dynamic Interacting Processes in the State Space, International Journal of Recent Technology and Engineering, 8(4), pp. 1687-1693.

15. Daradkeh Y.I., Gorokhovatskyi V., Tvoroshenko I., Gadetska S., and AlDhaifallah M. (2021) Methods of Classification of Images on the Basis of the Values of Statistical Distributions for the Composition of Structural Description Components, IEEE Access, 9, pp. 92964-92973.

16. Tvoroshenko I.S., and Kramarenko O.O. (2019) Software determination of the optimal route by geoinformation technologies, Radio Electronics Computer Science Control, 3, pp. 131-142.

17. Кучеренко С.I., Творошенко I.C. (2011) Оперативне оцінювання простору станів складних розподілених об’єктів з використанням нечіткої інтервальної логіки. Штучний інтелект, 3, С. 382-387.

18. Кучеренко Е.И., Корниловский А.В., Творошенко И.С. (2010) О методах настройки функций принадлежности в нечетких системах. Системы управления, навигащии и связи, 1(13), С. 94-98.

19. Кучеренко Е.И., Творошенко И.С. (2003). Процессы принятия решений в сложных системах на основе нечетких интервальных представлений. Вісник Національного технічного університету «ХПI». Тематичний випуск: Системний аналіз, управління та інформаційні технології. Х.: НТУ «ХПІ», 1(7), С. 79-86. 


\title{
ABOUT CLASSIFICATION OF THE METHODS IN DESIGN OF MEDICAL INFORMATION SYSTEMS
}

\author{
Tvoroshenko Iryna, \\ Ph.D., Associate Professor \\ Kharkiv National University of Radio Electronics \\ Mahomet Anna, \\ Master in informatics \\ Kharkiv National University of Radio Electronics
}

Today, medical information systems (MIS) - are a necessary guide for establishing interaction between different institutions and appeals [1-13]. During the pandemic, the demand for information systems in the hospital was increased as never before, so competition among medical information system developers increased too. Therefore, to compete with other MIS, developers need to improve systems or immediately create a level of functionality that will allow the facility to provide a better level of service for its patients.

Developing and then putting into operation the MIS, require a lot of human and material resources [11-13]. The MIS, which has either better functionality or a lower price, will also be in demand in the marketplace. For this purpose at the beginning of designing of system it is necessary to define a technique which will allow to reduce cost and to increase efficiency of MIS.

The project - is a documentation that describes the design decisions for the creation and use of MIS, they define [1]:

- System architecture;

- Structure;

- Information storage conditions;

- Characteristics of technical means;

- Composition and functional characteristics of software components.

MIS design is the process of converting input data into an MIS project, namely the transformation of information about the object of automation and system requirements [14].

It will also be useful to study design methods in analog systems.

The objects of design can be both individual elements of the system and sets of elements that belong to the functional subsystems or subsystems of support [15].

Functional subsystems implement the main functions of the system - business functions.

Support subsystems support service functions - authorization in the system, data archiving, etc.

The algorithm is the basis of any design method. It determines the project actions, their sequence, resources, composition of performers, the funds needed to perform 
these actions. The MIS design process is divided into a set of interrelated actions, each of which can have its own object [16].

Actions are divided into:

- Design (to form or change the current project);

- Evaluation (to produce evaluation of design results according to the established criteria).

We will assume that the total number of states that MIS undergoes during its development, from the moment of the decision to create systems to the moment of its full implementation - is the life cycle of the medical information system.

Basic requirements for technological design:

- The chosen technology should maximally reflect all stages of the project life cycle and serve as a basis for the connection between the design and maintenance of the system during its operation;

- The project created with the help of this technology must meet the requirements of the customer as much as possible; these requirements can be replaced, edited during the creation of MIS;

- The chosen technology should ensure the efficiency and economic profitability of the system, namely the minimum cost of resources for the design and subsequent maintenance of the information system.

Consider the classification of MIS design methods.

Classification according to the degree of use of standard design solutions and the level of automation [17].

According to the degree of use of standard design solutions, the following methods of MIS design can be distinguished:

- Standard design methods that involve the assembly or configuration of MIS from ready-made standard components of the system;

- Methods of individual design, in which design solutions are developed from the beginning independently, in accordance with the requirements of information systems and without relying on ready-made standard components for assemblies.

According to the degree of automation, design methods can be divided into two categories:

- Automated design methods, design solutions are generated or configured using special tools;

- Methods of manual design, MIS design is carried out manually, without the use of special tools.

The combination of different features of the classification of design methods determines the nature of the design method. There are two main classes of methods: canonical and industrial methods.

Canonical methods are based on the technology of manual individual design. Industrial methods are based on computer-aided design technology.

The design technologies currently in use involve the development of the system in several stages [18-21].

The typical content of the life cycle of the information system is reduced to the implementation of the following stages: 
1. Planning stage and analysis of MIS requirements (pre-design stage). Includes research and analysis of the facility and the existing medical information system, determination of requirements for MIS, preparation of feasibility study and terms of reference for system development. In the feasibility study should be presented economic calculations that confirm the feasibility of developing MIS. The terms of reference reflect the purpose of the MIS, the requirements for the MIS, its subsystems and types of support, as well as restrictions on design resources.

2. MIS design (technical design, logical design). Development of the composition of automated functions and the composition of support subsystems, information storage structure, design of the technical project of the information system in accordance with the formulated requirements.

3. Implementation (working design, physical design). Includes program development, information filling of databases, creation of work instructions for the personnel, registration of the working project. Implementation is based on the MIS technical project.

4. Implementation (testing, proven operation). Complex adjustment of subsystems of information system, training of the personnel, step-by-step introduction of information system on divisions of the enterprise, carrying out acceptance tests, transfer of information system in operation.

5. Operation (maintenance, modernization). Collection of statistics on the functioning of the information system, correction of errors and shortcomings, adaptation of the system to the changed conditions of functioning, formulation of requirements for the next version of the information system.

Thus, a well-chosen method of designing a medical information system will provide a comprehensive software product, the main purpose of which is to automate all the main processes associated with the work of medical institutions of general and narrow specialization.

The developed automated medical information system will quickly and efficiently establish electronic document management, work with patients, carry out operational accounting of administrative staff, control all organizational and financial issues.

\section{References:}

1. Творошенко И.С. (2010) Анализ процессов принятия решений в интеллектуальных системах, Системи обробки інформації, 2, С. 248-253.

2 Tvoroshenko Irina, Ahmad M. Ayaz, Mustafa Syed Khalid, Lyashenko Vyacheslav, and Alharbi Adel R. (2020) Modification of Models Intensive Development Ontologies by Fuzzy Logic, International Journal of Emerging Trends in Engineering Research, 8(3), pp. 939-944.

3. Lyashenko V., Mustafa S.K., Tvoroshenko I., and Ahmad M.A. (2020) Methods of Using Fuzzy Interval Logic During Processing of Space States of Complex Biophysical Objects, International Journal of Emerging Trends in Engineering Research, 8(2), pp. 372-377.

4. Asaad Ma. Babker, Abd Elgadir A. Altoum, Irina Tvoroshenko, and Vyacheslav Lyashenko (2019) Information Technologies of the Processing of the Spaces of the States of a Complex Biophysical Object in the Intellectual Medical System HEALTH, 
International Journal of Advanced Trends in Computer Science and Engineering, 8(6), pp. 3221-3227.

5. Tvoroshenko I.S., and Gorokhovatsky V.O. (2020) Effective tuning of membership function parameters in fuzzy systems based on multi-valued interval logic, Telecommunications and Radio Engineering, 79(2), pp. 149-163.

6. Kucherenko Ye.I., Filatov V.A., Tvoroshenko I.S., and Baidan R.N. (2005) Intellectual Technologies in Decision-Making Technological Complexes Based on Fuzzy Interval Logic, East European Journal of Advanced Technologies, 2, pp. 92-96.

7. Tvoroshenko I.S., and Gorokhovatsky V.O. (2019) Modification of the branch and bound method to determine the extremes of membership functions in fuzzy intelligent systems, Telecommunications and Radio Engineering, 78(20), pp. 18571868.

8. Matarneh Rami, Tvoroshenko Irina, and Lyashenko Vyacheslav (2019) Improving Fuzzy Network Models For the Analysis of Dynamic Interacting Processes in the State Space, International Journal of Recent Technology and Engineering, 8(4), pp. 1687-1693.

9. Кучеренко С.I., Творошенко I.C. (2011) Оперативне оцінювання простору станів складних розподілених об'єктів з використанням нечіткої інтервальної логіки. Штучний інтелект, 3, С. 382-387.

10. Кучеренко Е.И., Корниловский А.В., Творошенко И.С. (2010) О методах настройки функций принадлежности в нечетких системах. Системы управления, навигаџии и связи, 1(13), С. 94-98.

11. Кучеренко Е.И., Творошенко И.С. (2003). Процессы принятия решений в сложных системах на основе нечетких интервальных представлений. Вісник Національного технічного університету «ХПI». Тематичний випуск: Системний аналіз, управління та інформаційні технологіï. Х.: НТУ «ХПІ», 1(7), С. 79-86.

12. Кучеренко Е.И., Творошенко И.С. (2010) Прикладные аспекты моделирования нечетких процессов в сложных системах, Збірник наукових пращь Харківського університету Повітряних сил, 1, С. 127-131.

13. Творошенко И.С., Дехтярь А.П. (2005) Информационные технологии в задачах компьютерной диагностики с использованием интеллектуальных систем, Клиническая информатика и Телемедицина. Компьютерная Медицина2005, C. 138.

14. Yousef Ibrahim Daradkeh, and Iryna Tvoroshenko (2020) Application of an Improved Formal Model of the Hybrid Development of Ontologies in Complex Information Systems, Applied Sciences, 10(19), p. 6777.

15. Tvoroshenko I.S., and Kramarenko O.O. (2019) Software determination of the optimal route by geoinformation technologies, Radio Electronics Computer Science Control, 3, pp. 131-142.

16. Гороховатський В.О., Творошенко І.С. (2021) Методи інтелектуального аналізу та оброблення даних: навч. посібник. Харків: ХНУРЕ, 92 с.

17. Творошенко I.C. (2021) Технології прийняття рішень в інформаційних системах: навч. посібник. Харків: ХНУРЕ, 120 с.

18. Кобилін О.А., Творошенко I.C. (2021) Методи цифрової обробки зображень: навч. посібник. Харків: ХНУРЕ, 124 с. 
19. Daradkeh Y.I., Gorokhovatskyi V., Tvoroshenko I., Gadetska S., and AlDhaifallah M. (2021) Methods of Classification of Images on the Basis of the Values of Statistical Distributions for the Composition of Structural Description Components, IEEE Access, 9, pp. 92964-92973.

20. Кучеренко С.І., Творошенко І.С., Анопрієнко Т.В. (2016) Моделювання та оцінювання станів складних об'єктів із застосуванням формальної логіки, Системи обробки інформації, 2, С. 76-82.

21. M. Ayaz Ahmad, Irina Tvoroshenko, Jalal Hasan Baker, Liubov Kochura, Vyacheslav Lyashenko (2020) Interactive Geoinformation Three-Dimensional Model of a Landscape Park Using Geoinformatics Tools, International Journal on Advanced Science, Engineering and Information Technology, 10(5), pp. 2005-2013. 


\title{
PROTECTION OF ELECTRONIC DOCUMENTS BY MEANS OF AN ELECTRONIC DIGITAL SIGNATURE
}

\author{
Zatula Anastasiia \\ student \\ National Aviation University \\ Gulak Natalia \\ Candidate of Technical Sciences, Docent \\ National Aviation University
}

The use of electronic digital signatures greatly simplifies the work process for individual entrepreneurs, individuals and companies. It allows you to quickly sign a document, while maintaining its integrity, and provides a guarantee that it will not be changed by other users after signing.

Electronic digital signature (EDS), in essence, the props of an electronic document, which is a software cryptographic (encrypted in the appropriate way) way to represent the number obtained by changing the electronic document as a digital sequence using the author's private key.

The EDS system is useful and convenient, as it requires high reliability to prevent errors and confirmation of legal force in the transmission of electronic documents. The reliability of the system depends on many factors, but can be reduced to two main ones.

The first factor to avoid cases of forgery of documents: this factor is special because it is difficult for the user to take responsibility for the security and reliability of software that provides a digital signature. Therefore, it is necessary to ensure the protection of the software environment by organizational restrictions, rules and the use of software protection and security administrator.

The second factor includes the reliability of the public key encryption algorithm, the security of the private key provided by the security and reliability of the key generator and its features.

This digital information processing allows:

- Integrity check: in case of any accidental or intentional change of the document, the signature will be invalid, as the signature is placed on the basis of the original document and corresponds only to it;

- Control of the validity of the signature of an owner who has a signature key certificate;

- The impossibility of renouncing authorship: that is, in order to create a signature, you need to know the private key, and it must be known only to the owner, so he can't renounce his signature;

- Confirmation of signing the electronic document, if it has passed the successful verification. 
An electronic signature is appended for the same purposes as a normal signature under paper documents to confirm the identity of the signatory, in cases provided by law intended to confirm the identity of the signatory of the electronic document, and serves as an analogue of a personal signature.

If accidental or intentional changes are made to the electronic document, the EDS will automatically become invalid, because it is calculated by a special algorithm that is tied to the original state of the document and is valid only for him. The electronic signature provides a guarantee that the integrity check will detect various forgeries, respectively, forgery of documents in most cases in practice becomes impractical in advance.

The general scheme of digital signature creation is three interconnected processes:

1) Key pair generation. Using the key generation algorithm from the set of possible private keys, the private key is selected and the corresponding public key is calculated.

2) Signature formation. For a given electronic document, the signature is calculated using a private key.

3) Verification of the signature. For document and signature data, it is possible to determine the validity of the signature using a public key.

It is important that this process requires two requirements: verification of the signature with a public key that corresponds to the private key used in signing; without a private key it should be difficult to create a legitimate digital signature.

By law, information about the ownership of a public key to a particular user must be documented by the relevant responsible authority. Such a document is called an EDS public key certificate.

The problem of protection of keys from substitution is solved by means of certificates. The certificate allows you to certify the details of the owner, which are in the document, and his public key signed by a proxy.

The key certification center is designed to service users' public key certificates, provide services, record time, as well as, if necessary, the means to generate private and public keys. Change the status of certificates, namely, block, renew or revoke, and destroy user private keys in accordance with the procedure specified in the certification center.

The certification authority generates a private key and its own certificate, generates end-user certificates and certifies their authenticity with its digital signature. The center also reviews compromising certificates and expired certificates, maintains databases of issued and revoked certificates. If you contact a certification authority, you can obtain your own public key certificate, another user's certificate, and find out which keys have been revoked.

The private key is the most vulnerable component of the entire digital signature cryptosystem. An attacker who snatched a user's private key can create a valid digital signature of any electronic document on behalf of the user. Therefore, special attention should be paid to the method of storing the private key.

There are many ways and devices to store a private key. The most secure way to save it is to save it on a smart-card. In order to use a smart card, the user not only needs 
to have it on hand, but also enter the PIN code, as a result, we will receive two-factor authentication. After that, the signed document or its hash is transferred to the card, its processor signs the hash and sends the signature back. In the process of forming a signature in this way there is no copying of the private key, so all the time there is only a single copy of the key. In addition, copying information from a smart-card is more difficult than from any other storage device.

In accordance with the law "On electronic digital signature", the owner is responsible for the protection of the private key.

From all the above, it is possible to conclude that the electronic digital signature is an effective solution for all who have switched to electronic document management. Documents can be digitally signed and delivered to the destination in minutes. All participants in electronic document management receive the same opportunities regardless of their distance from each other.

It is almost impossible to forge an electronic digital signature - it requires a large number of calculations that can't be implemented at the current level of mathematics and computer technology for a specific time as long as the information contained in the signed document remains relevant.

Additional protection against forgery is provided by the certification of the public key of the signature.

\section{References:}

1) Babilova MP Effective document management: from traditional to electronic. M .: Type. MEV, 2004

2) Semilitov SI Electronic document as a product of technological progress in documenting information and the object of legal regulation // State and Law, 2003. №1

3) Panasenko SP Encryption algorithms. Special guide. - СПб $\quad \therefore$ БХВПетербург, 2009

4) Dance DV Reliability of information protection of electronic digital signature system, Bulletin of the National Technical University of Ukraine KPI, series - Radio Engineering - 2007, №34 


\title{
ПРЕПОДАВАНИЕ ДИСЦИПЛИНЫ «ПРИКЛАДНАЯ МЕХАНИКА» В СОВРЕМЕННЫХ УСЛОВИЯХ ВЫСШЕГО ОБРАЗОВАНИЯ
}

\author{
Баева Татьяна Юрьевна, \\ старший преподаватель
}

Тирасполь,Приднестровский государственный унверситет им.Т.Г.Шевченко

\section{Гречушкина Валентина Петровна,}

старший преподаватель

Тирасполь,Приднестровский государственный унверситет им.Т.Г.Шевченко

Аннотация: В работе рассмотрены некоторые аспекты преподавания технической дисциплины «Прикладная механика» в условиях дистанционного обучения на основе использования в учебном процессе современных информационных технологий. На примере решения конкретной задачи из курса «Сопротивление материалов» указано поэтапное формирование информационной компетенции.

Ключевые слова: Прикладная программа, междисциплинарная связь, сопротивление материалов, информационная компетентность, инженерные расчеты, практические занятия.

Курс « Прикладная механика» состоит из трех разделов - Сопротивление материалов, теория механизмов и машин, детали машин. Данная дисциплина является общетехнической и предназначена для расширения знаний по инженерной подготовке. Курс включает все виды учебной нагрузки - лекции, практические занятия и лабораторные работы. Материал излагается в кратком объеме, соответствующем учебной программе, в порядке, прослеживающим взаимосвязь от теоретических положений статики до практического применения формул «Сопротивления материалов» при расчете элементов конструкций и деталей машин. Практические занятия посвящены решению расчетнографических задач. Порядок выполнения практических занятий регламентируется последовательностью изучения лекционного материала. Решение задач позволяет овладеть основными навыками проектировочно проверочных работ. Лабораторные работы дают представления о механических испытаниях материалов, позволяют ознакомиться с устройством механических передач и редукторов, а также проводить доказательство и проверку законов «Сопротивления материалов»путем сравнения теоретических данных с результатами, полученными при испытаниях.

Инновационным подходом является преподавание дисциплины дистанционно, используя информационные технологии и Интернет. Дистанционное преподавание дисциплины имеет ряд приемуществ, но создает и дополнительные задачи в работе преподавателя. Конспектирование основных моментов лекционных занятий для студентов является обязательным. Важно, чтобы каждая лекция исчерпывающее охватывала определенную тему курса и 
представляла собой логически законченную тему. Необходимо уделить внимание студентов на межпредметную связь данной дисциплины ( Физикой, Математикой Теоретической механикой, Строительной механикой, Теорией упругости, Статикой сооружений). Хорошие результаты дает проведение лекции в диалоговом формате, т.к. появляется возможность установить уровень остаточных знаний. Учитывая, что время, отведенное на аудиторные занятия минимально, проблема интенсификации процесса обучения без потери качества знаний становится актуальной.

Для устранения пробелов в знаниях и формировании устойчивых практических умений при изучении технических дисциплин, возможна замена значительных объемов текстовой информации графической. Большинство студентов технических специальностей, склонны к более эффективному усвоению учебного материала представленного именно в таком - графическом виде. Процесс усвоения информации в этом случае становится более продуктивным.

Осуществляя переход к высоким технологиям обучения, к формированию новой учебной среды, интенсифицируя процесс обучения, весьма эффективно было бы совместное использование в учебном процессе по техническим дисциплинам как контрольно-обучающих тестов, так и мультимедийных и интерактивных учебных пособий для всех видов учебных занятий. Особенностью тестов по техническим дисциплинам - является профессиональный язык, на котором мыслят специалисты - язык техники Предлагаемые задачи должны иметь проблемный характер, требовать для решения привлечения широкого спектра знаний, свойственного разным учебным дисциплинам, способствовать развитию профессионального мышления.

Существует ещё на одна особенность изучения технических дисциплин в вузах - необходимость проведения лабораторных работ.Дпя проведения занятий по классической методике обучения необходимо использование реального лабораторного оборудования высокой стоимости и требующее высококвалифицированное обслуживание. В настоящее время программные средства и возможности вычислительных систем позволяют выполнить высококачественную имитацию любого технологического оборудования с максимально приближенными к реальности параметрами (виртуальные лабораторные работы). Таким образом, выход в такой ситуации возможен, опять же, за счет использования современных информационных технологий интерактивных учебных пособий, позволяющих снизить потребность в реальном оборудовании и одновременно повысить эффективность обучения. Взаимосвязь и преемственность общетехнических дисциплин позволяет поэтапно построить методику формирования информационной компетентности. Это помогает будущему специалисту осуществлять профессиональную информационную деятельность, осуществляя процесс постоянного накопления качественного опыта.

В процессе изучения дисциплины «Прикладная механика» студенты выполняют расчетно - графические задачи по каждому разделу курса. Студенты 
решают задачу двумя способами- вначале аналитически, потом с применением различных прикладных программ. Представим формирование информационной компетентности на примере решения стандартной задачи «Сопротивления материалов» с применением прикладных программ.

Для балки, опирающейся на шарниры, определяются реакции опор, поперечные силы и строятся эпюры поперечных сил и изгибающих моментов. Для аналитического решения данной задачи, студент использует знания, полученные при изучении теоретической механики, для определения реакции опор, составляя уравнения равновесия системы, В качестве проверочного способа, студенту предлагается воспользоваться онлайн - программой «Расчет рамы, фермы, балки онлайн» Применение этой программы способствует формированию ряда компетенций. При моделировании данной расчетной схемы , студент должен представлять какие данные он должен ввести (как балка закреплена, направление внешних сил и их вид, количество участков балки), а также должен учитывать отсутствие привязанности к конкретным единицам измерения. В данном случае, при расчете загруженной балки закрепляются навыки по сбору и анализу исходных данных и полученного результата. В работе использовали «Обучающий программный комплекс на CD - ROM» O.B. Мкртычева. Комплекс эффективно используется в дистанционной форме обучения . Интерфейс программ комплекса не требует специального обучения. При решении задачи контролируется каждый шаг решения, сопровождается соответствующими построениями на экране, в случае ошибки выдает подсказку. Результат сохраняется и можно его распечатать. В комплексе представлены задачи по всем разделам курса «Сопротивление материалов» и сопровождаются учебным пособием. Используемый комплекс повышает качество обучения и уменьшает время для усвоения материала. При всех оптимистических перспективах, открываемых новыми информационным технологиями, место компьютеру найти не просто в учебном процессе . Только правильное его применение позволяет получить ожидаемый уровень профессиональной компетентности, [1 - 4]

\section{Список литературы}

1.О.В. Мкртычев Сопротивление материалов обобщающий программный комплекс CD-ROM, -2005, Изд. ACB

2. Steif P.S.,Naples L.M. Desing and Evaluation of Problem Solving Courseware Modules For Mechanics of Materials //Journal of Engineering Education. 2003. Vol.92. P.239 - 247

3. Потемкин А.Н., Викулов А.С., Романовский Б.В. Использование интерактивных учебных пособий в условиях непрерывного профессионального образования. Современные научные исследования. Выпуск 1. - Концепт. - 2013. - ART 5 4.Калашников, Г. О. Методика преподавания дисциплины «Прикладная механика» в рамках формирующейся формы тотального дистанционного образования // Молодой учёный. 2014. - № 1. - C. 532-533. 


\title{
АНАЛІЗ ТЕХНОЛОГІЙ ФУНКЦІОНАЛЬНИХ ЖИРОВМІСНИХ ПРОДУКТІВ
}

\author{
Бандура Валентина, \\ Доктор технічних наук, професор, \\ Національний університет біоресурсів \\ і природокористування України
}

Актуальною тенденцією зараз у світі є споживання функціональних харчових продуктів, які мають позитивний вплив майже на всі процеси в організмі.Функціональний харчовий продукт має містити у своєму складі лікарські засоби або може споживатися для профілактики або пом'якшення хвороби людини. Це стосується і жировмісних продуктів.

Особливе місце в наукових дослідженнях займають трансізомерні жирні кислоти. 3 метою зниження рівня трансізомерів у маргариновій продукції i кулінарних жирах використовують глибоку гідрогенізацію рослинних олій (соняшникової, соєвої, ріпакової, пальмової) до саломасу з низьким вмістом транс-ізомерів. Потім переетерифікують суміш саломасу з рідкою соняшникою олією або сумішшю соняшникової з пальмовою олією чи пальмовим стеарином [1].

Перспективним вважають додавання до олій екстрактів різноманітних рослин (моркви, петрушки, кропу, часнику, обліпихи, шипшини та ін.), що не лише збагачують їх біологічними речовинами, але й надають специфічний, пікантний аромат та смак. Створено технологію і рецептуру дієтичної олії, збагаченої фосфоліпідами, $\beta$-каротином і екстрактом шипшини. Така олія має високу біологічну активність, сприяє виведенню 3 організму холестерину, нейтральних ліпідів, нормалізує обмінні процеси, рекомендована для вживання онкологічним хворим [1].

Запропоновано технологію низькокалорійних олій, які отримують 3 композиційної суміші вершків (масова частка жиру 50-55 \%) і рослинної олії. Емульгатором служить фосфатидний концентрат. Харчові рослинні фосфатиди мають високу біологічну активність, яка проявляється у нормалізації ліпідного обміну, функціонального стану печінки, підвищенні антиоксидантних функцій організму [1].

У виробництві олієжирових продуктів функціонального призначення доцільніше використовувати не індивідуальні антиоксиданти, а їх суміші. Завдяки прояву синергізму ефективність подібних сумішей набагато вища, ніж застосування індивідуальних антиоксидантів. Для жирів i олій широко розповсюджені комплексні антиокислювачі, до складу яких входять бутилгідроксианізол і бутилгідрокситолуол. [1].

Розробка нових видів функціональних емульсійних продуктів базується на включенні в рецептуру речовин 3 науково доказаним лікувальнопрофілактичним ефектом. У деяких видів майонезу яєчний порошок повністю замінений знежиреним соєвим борошном. Завдяки особливим технологічним 
прийомам розроблені нові види майонезів з біологічно активною добавкою на основі морської капусти, збагаченої селеном. Вибір добавки обумовлений тим, що морська капуста є природним джерелом макро- і мікроелементів, причому ряд мікроелементів, у тому числі рідкоземельні метали, можуть накопичуватися водоростями в кількостях, що в багато разів перевищують концентрацію цих елементів у морській воді. Морська капуста містить калій, магній, марганець, залізо, цинк, фосфор, селен, йод, фтор та інші, більшість з яких входять до складу ферментів. Із біогенних мікроелементів найбільш вагомими є селен і йод [2].

Запропонована методологія створення функціональних жироводневих емульсійних продуктів з введенням подрібненої рослинної сировини (плодів і квітів глоду, квітів бузини, кореневища валеріани, трави материнки, звіробою, квітів календули, листя кропиви, ламінарії, коріння лопуха, насіння льону, насіння і листя подорожника, плодів шипшини та ін.) [2].

Можна виділити деякі аспекти формування функціональних жирових продуктів - зниження загальної жирності продукту; зниження ТЖК (трансізомери жирних кислот), НЖК (натуральні жирні кислоти), холестерину, продуктів окислення ліпідів; підвищувати ПНЖК (поліненасичені жирні кислоти), в першу чергу - омега-3 жирні кислоти; баланс жирокислотного складу; збагачення продуктів жиророзчинними функціональними інгредієнтами; використання високоочищених рослинних олій; зниження використання тваринних жирів, що містять холестерин; використання рафінованих олій, багатих омега-3 жирними кислотами: соєвого, ріпакової, лляної, конопляної, гірчичної.

Розроблення продуктів функціонального призначення, засноване на науково обгрунтованих методиках і повинне сприяти усуненню виникаючих протиріч між нутриціологією і харчовою промисловістю. Правилом повинні стати технології, що виключають і заміщають традиційні компоненти їжі ціннішими 3 фізіологічної точки зору аналогами, без порушення традиційних споживчих характеристик продуктів. У зв'язку з цим створення комбінованих продуктів, що містять жири, і благотворно впливають на здоров'я $\epsilon$ актуальним завданням харчової промисловості.

\section{Список літератури:}

1. Сирохман I. В. Товарознавство харчових продуктів функціонального призначення: навч. пос. [для студ. вищ. навч. закл.] / I. В. Сирохман, В. М. Завгородня. Київ, Центр учбової літератури, 2009. 544 с. ISBN 978-966-364-8033. С. $440-448$

2. Характеристика емульсійних жирових продуктів функціонального призначення [Електронний ресурc]: https://infopedia.su/9x43d4.html. 


\section{БЛОК ЖИВЛЕННЯ СИСТЕМ АВТОМАТИКИ}

Білюк Іван Сергійович

кандидат технічних наук, доцент, Національний університет кораблебудування ім. адм. Макарова, Україна

\section{Савченко Олег Валерійович} завідувач лабораторіями кафедри автоматики Національний університет кораблебудування ім. адм. Макарова, Україна

\section{Шарейко Дмитро Юрійович} кандидат технічних наук, доцент, Національний університет кораблебудування ім. адм. Макарова, Україна

\section{Гаврилов Сергій Олексійович} кандидат технічних наук, доцент, Національний університет кораблебудування ім. адм. Макарова, Україна

\section{Фоменко Андрій Миколайович}

викладач

Національний університет кораблебудування ім. адм. Макарова, Україна

У більшості сучасних системах автоматики практично не використовуються аналогові блоки живлення. Їм на зміну прийшли імпульсні претворювачі напруги, які мають менші масогабаритні показники та доволі високий ККД.

Принцип роботи імпульсного блоку живлення показано на спрощеній структурній схемі, яка показана на рисунку 1. Живлення через мережевий фільтр та випрямляч проходить до згладжувального фільтру. Далі блок керування формує прямокутні імпульси та подає їх через інвертор на силовий трансформатор, який служить для зниження напруги та гальванічної розв'язки високовольтної та низковольтної частини блоку живлення. Після трансформатору живлення проходить через вихідний випрямляч та фільтр до споживача.

Запропонований імпульсний блок живлення відноситься до стендів 3 дослідження систем автоматики [1], промислових роботів і може бути використаний в інших технічних пристроях електромеханічних систем керування. 


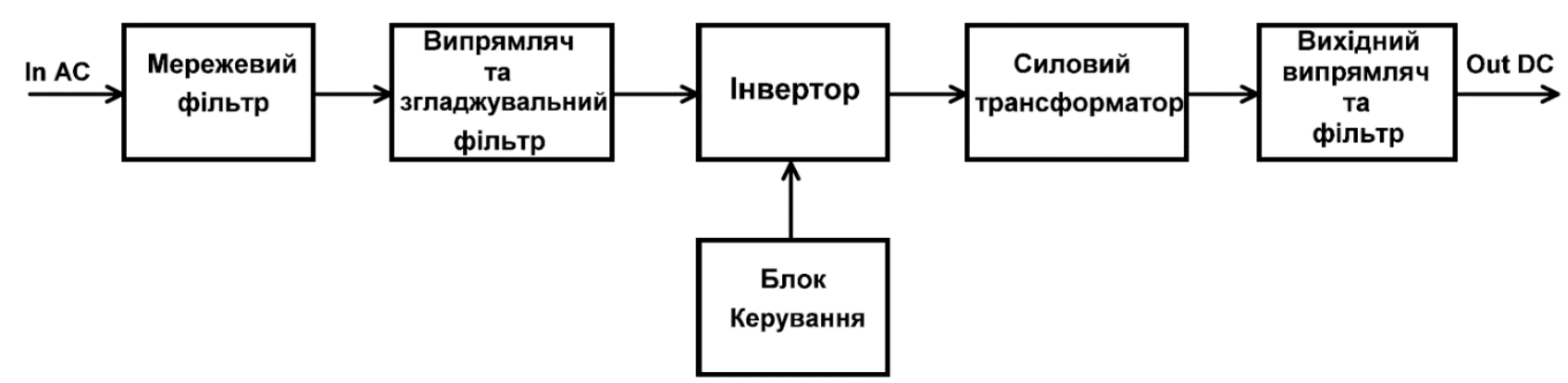

Рисунок 1 - Спрощена структурна схема блоку живлення

Задачею роботи є створення простого імпульсного блоку живлення, в якому $\epsilon$ можливість корегування частоти роботи мікросхеми та зменшення паразитних коливань у ланцюзі силового трансформатора.

Для вирішення цієї задачі було додано змінний резистор R4, за допомогою якого можна корегувати частоту роботи мікросхеми, рисунок 2. Також у блоці живлення було використано додатковий фільтр від високочастотних паразитних коливань, комутаційних перешкод, що виникають у трансформаторі внаслідок ключового режиму роботи транзисторів VT1 та VT2, який складається з котушки індуктивності L2, конденсатора C11 та резистора R7. Система стала більш стабільною за рахунок виключення можливості насичення магнітопроводу і зниження втрат в ньому. Також було додано сигнальний світлодіод HL1 для відображення наявності живлення мікросхеми.

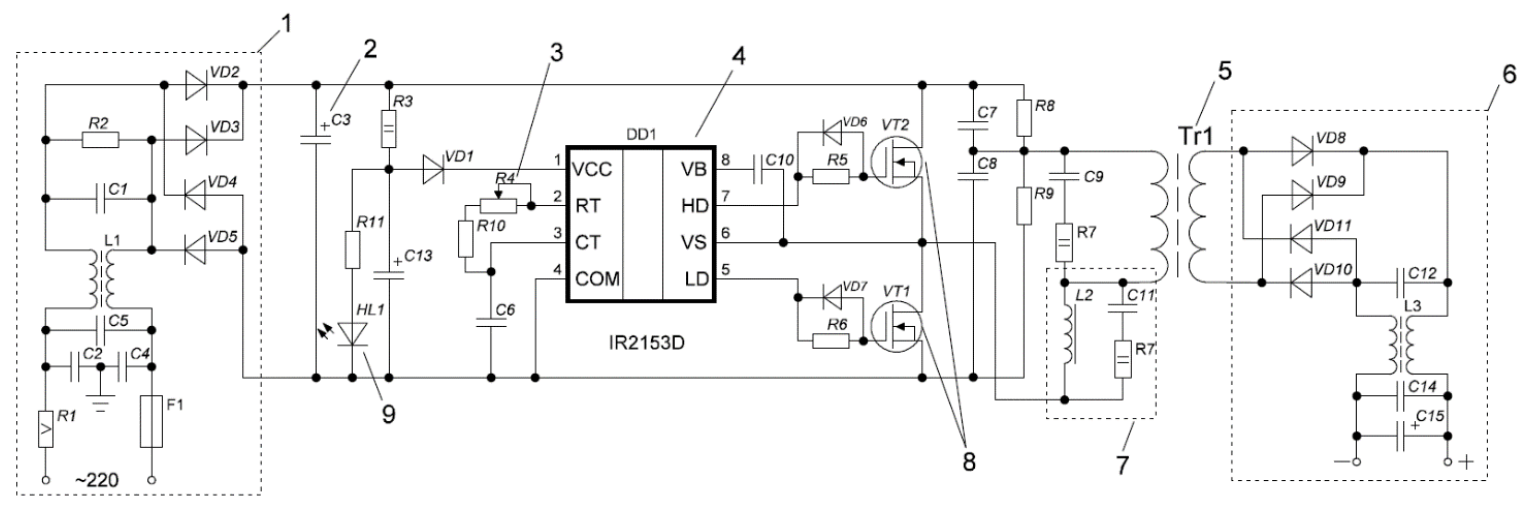

Рисунок 2 - Принципова схема блоку живлення

Покращення компактності, надійності та довговічності системи досягається за рахунок використання плівкових ємностей, додаткового фільтру пригнічення високочастотних паразитних коливань та використання трансформатора на феритовому тороїдальному магнітопроводі.

Блок живлення систем автоматики складається 3 принципової схеми на рисунку 2, на якій розташовані: вхідний діодний міст 3 фільтром - 1 , накопичуючи ємність - 2, змінний резистор - 3, мікросхема IR2153D [2] - 4, тороїдальний трансформатор - 5, вихідний діодний міст 3 фільтром - 6, додатковий фільтр - 7, транзисторні ключі - 8, сигнальний світлодіод - 9 . 
Блок живлення систем автоматики відповідає поставленій задачі та може бути використаний в системах автоматики.

Література:

1. Пат. 142438. Україна. Блок живлення систем автоматики / О. В. Савченко, І. С. Білюк, Д. Ю. Шарейко, А. М. Фоменко, С. І. Ольшевський, С. О. Гаврилов, А.М Мозговий, М.Г. Мозговий, Л.А. Фоменко, О. В. Майборода, А.В. Надточій (Україна). - Заявл. 30.10.2019; опубл. 10.06.2020, Бюл. № 11.

2. SELF-OSCILLATING HALF-BRIDGE DRIVER IR2153(D)(S) \&(PbF) // https://www.infineon.com/. Режим доступу: https://www.infineon.com/dgdl/Infine on-IR2153-DataSheet-v01_00-N.pdf?fileId=5546d462533600a4015355c8c5fc16af. 


\title{
УДОСКОНАЛЕННЯ МЕТОДУ ВИЗНАЧЕННЯ АДГЕЗЇ̈ БІТУМНОГО В'ЯЖУЧОГО ДО ПОВЕРХНІ СКЛА
}

\author{
Галкін Андрій, \\ кандидат технічних наук, \\ старший науковий співробітник кафедри \\ технології дорожньо-будівельних матеріалів, \\ Харківський національний автомобільно-дорожній університет,
}

Пиріг Ян кандидат технічних наук, старший науковий співробітник, старший науковий співробітник кафедри технології дорожньо-будівельних матеріалів, Харківський національний автомобільно-дорожній університет

Роман Павло завідувач сектору органічних в'яжучих ДП "Дорцентр"

Вступ. Довгострокове прогнозування властивостей асфальтобетону $\epsilon$ складним комплексним завданням, оскільки на асфальтобетон в процесі експлуатації впливає безліч факторів навколишнього середовища, таких як коливання температур, присутність хімічних речовин та води, навантаження від транспортних засобів. Більш того, якість самого матеріалу залежить як від якості складових компонентів, так i від дотримання технологічних параметрів виготовлення та ущільнення суміші.

Найбільш вразливим компонентом асфальтобетону можна вважати бітум, оскільки саме його параметри більшою мірою визначають властивості асфальтобетону. В загальному наближенні поведінка бітуму в асфальтобетоні обумовлена двома типами взаємодій та їх посиленням або послабленням із зміною умов - когезією та адгезією. Когезія обумовлює опір зсуву в шарах бітуму, в той час як адгезія визначає опір відриванню бітумної плівки від твердої поверхні. За цим міцність асфальтобетону обумовлюється найменшою 3 цих взаємодій.

Майже всі показники бітуму (крім технологічних) базуються на його когезійних властивостях за різних температур. Це справедливо відносно пенетрації, власне, когезії, температури розм'якшеності, температури крихкості, певною мірою й розтяжності. Тільки один показник, що нормується ДСТУ 4044 [1], відноситься до адгезії бітуму із мінеральним матеріалом - зчеплюваність із поверхнею скла за ДСТУ Б В.2.7-81 [2].

Аналіз публікацій. Пошуки оптимального методу визначення адгезійних властивостей бітуму були розпочаті ще в 20 -х 30 -х роках минулого сторіччя $\mathrm{i}$ призвели до створення значної кількості методик в наш час. Умовно ці методи можна поділити на три групи. 
До першої групи слід віднести методи, які вимірюють міцність зчеплення бітуму з поверхнею, вираженою в одиницях міцності (Па, кг $\left./ \mathrm{Mм}^{2}\right)$, або роботи (Дж/м $\mathbf{M}^{2}$ ерг $\left./ \mathrm{cm}^{2}\right)$ або енергії (Дж, ерг).

Розробки перших методів визначення адгезійної міцності бітумів - метод Аріано (метод Міланського дорожнього університету) [3], та метод Калужської лабораторії СРСР [4], були розпочаті наприкінці 30 -х років минулого сторіччя. За обома методами визначають зусилля розриву кам'яних зразків, з'єднаних шаром в'яжучого. У методі Міланського університету шліфують поверхні, які поєднуються бітумом, в той час як за методом Калужської лабораторії мова йде про свіжий злам суцільного зразка (за перерізом), який по-новій склеюється бітумом під постійним тиском в гарячому стані.

В наш час розвитком цих методів можна вважати Direct Tensile Bond Test [5], та удосконалений варіант - Bitumen Bond Strength (BBS) Test [6]. В першому методі за допомогою ручного механізму від кам'яної пластини відривається приклеєний наважкою бітуму металевий диск. Максимальне зусилля фіксується для розрахунку адгезії за умов адгезійного відриву. Необхідність контролювати швидкість прикладення навантаження призвела до створення методу BBS, за яким диск відривається за допомогою пневматичної системи, в якій поступово зростає тиск. Змінюючи стан поверхні до якої приклеюється бітум (суха чи волога) оцінюється вплив вологості на зчеплення в'яжучого з поверхнею.

За використанням однакового принципу - вимірювання сили відривання шару бітуму від поверхні зразка кам'яного матеріалу чи сталевого елементу у випробуванні на прямий розтяг, низка методів відрізняється типом випробувального обладнання, умовами випробування та методами підготовки зразків. Проте, іншу схема випробування реалізовано для оцінки адгезійної міцності бітумів у методах відшарування «peel test» [7]. В цих випробуваннях шар бітуму на гнучкій стрічці відривається за схемами, наведеними на рис 1.
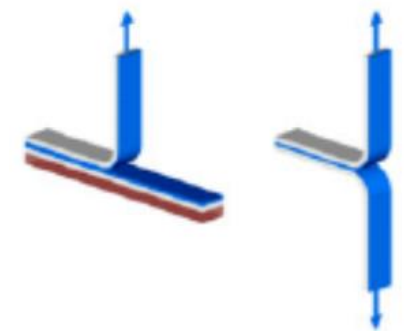
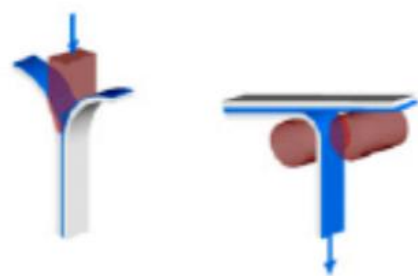
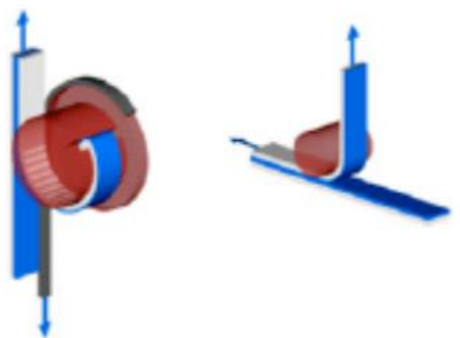

Рисунок 1. Схеми випробування адгезії бітуму за «peel test»

Перевагами цих методів $є$ точність контролювання швидкості відривання шару бітуму (відшарування) та товщини самого шару в'яжучого.

Окремо можна виділити випробування за умовами яких окремі щебінки, втоплені в шар бітуму відриваються або за рахунок удару від металевої кулі 3 іншого боку пластини (Vialit Plate Test) [8], або за рахунок центробіжної сили за обертання диску у Nynas Spin Tester [9] (аналог - пристрій «ЦП-НТУ» [10]).

Всім вказаним методам першої групи є притаманним суттєвий недолік. В багатьох випадках спостерігається змішаний тип розриву - адгезійно-когезійний, коли на мінеральній поверхні залишаються області, вкриті бітумом. Тобто 
когезія дорівнювала або була нижчою за адгезію, і отримане значення не $є$ дійсним. Це суттєво обмежує умови проведення випробування, оскільки за малих швидкостях та високих температурах (за відсутності вологи) адгезійна взаємодія перевищує когезійну, через що вимірювання адгезії стає неможливим.

До другої групи методів можна віднести методи, які оцінюють змочування поверхні мінерального матеріалу бітумом. Енергія адгезійної взаємодії прямим чином впливає на крайовий кут змочування. Чим більше адгезія, тим краще розтікається бітум по поверхні і менше кут краю краплі в'яжучого. Пряме спостереження та вимірювання такого кута за отриманим зображенням, наведеним на рис 2. а, призвело до створення методу сидячої краплі (Sessile Drop Method [11]).

Інший метод дозволяє оцінити силу, з якою рідина розтікається по поверхні. При зануренні пластини в рідину, вона буде втягуватись або виштовхуватись в залежності від крайового кута змочування. Вимірювання цієї сили (рис 2. б) також дає чисельну характеристику адгезійної взаємодії рідини (бітуму) 3 матеріалом пластини. Створений на основі цього явища метод статичного кута контакту отримав назву Wilhelmy Plate Method (метод пластини Вільгельму) [12].
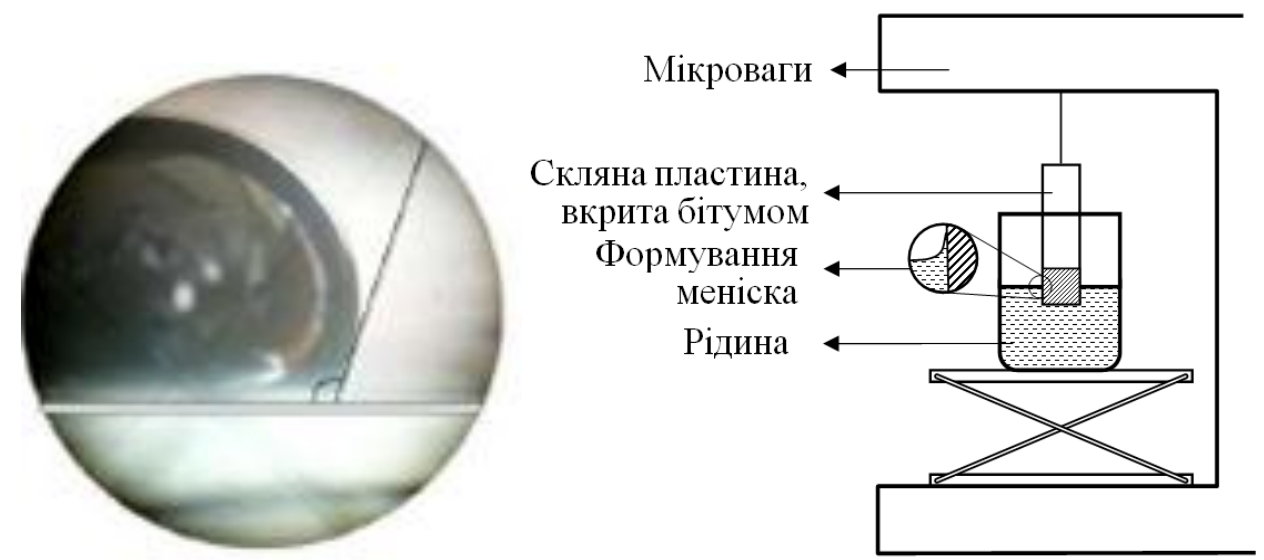

Рисунок 2. Крайовий кут змочування (а) та метод пластини Вільгельму (б)

Ще одним випробуванням, спрямованим на оцінювання модулю пружності плівки в'яжучого та енергії міжфазного руйнування, яка відповідає адгезійній міцності є нещодавно вдосконалений Blister Test [13]. На пластину мінерального матеріалу наноситься «диск» в'яжучого. Через отвір в пластині (під центром диску) подається рідина, яка починає відокремлювати бітум від мінеральної поверхні. Вимірювання висоти диску, яка збільшується за рахунок води, та тиску всередині дозволяють отримувати потрібні результати.

Методи другої групи теоретично обгрунтовані, і дають уявлення про процеси що протікають на межі бітум-кам'яний матеріал, але їх недоліком $\epsilon$ «аналітичність», а саме невідповідності умов випробування реальним умовам експлуатації покриття.

До третьої групи методів слід віднести методи, в яких аналізується бітумомінеральна суміш. Ці методи найбільш чисельні через принципову простоту випробувань. Сутність методів цієї групи полягає у випробуванні 
певної фракції мінерального матеріалу, обробленої бітумом на ступінь відшарування бітумної плівки від поверхні зерен кам'яного матеріалу за певних умов. Витримування бітумомінеральних сумішей у воді призводить до оголення мінеральних поверхонь, i цей процес протікає інтенсивніше із зростанням температури, або за прикладення сторонньої механічної дії (струшування, циклічного навантаження, тощо), або за присутності агресивних речовин чи розчинів.

Одним 3 перших подібних методів, що був розроблений ще в 30-40-х минулого століття та знайшов широке розповсюдження, $€$ метод Ріделя та Вебера [14]. За цим методом бітумомінеральну суміш кип'ятіли впродовж 1 хв у воді. В подальшому автори модифікували метод замінивши воду на розчини вуглекислого натрію різної концентрації. За міцність прилипання бітуму приймали концентрацію вуглекислого натрію у воді, за якої від поверхні мінеральних часток повністю відшаровується бітум.

В СРСР в середині минулого століття було розроблено декілька варіантів методу визначення зчеплюваності, за якими оцінювали зменшення площі поверхні кам'яних матеріалів, оброблених бітумом, після витримування в киплячій воді [15].

В системі ASTM також стандартизовано метод випробування в киплячій воді (Boiling Water Test - ASTM D 3625 [16]). Для випробування асфальтобетонну суміш поміщають в скляну ємність 3 дистильованою водою, що має температуру вище $85{ }^{\circ} \mathrm{C}$ але не кипить, та витримують в ній впродовж 10 хв. Візуально оцінюється площа поверхні, яка залишилась вкритою бітумом.

Разом із значною кількістю методів статичного випробування бітумомінеральних сумішей розроблювались методи в яких суміш, занурена у воду або агресивне середовище, піддавалася механічної дії - вібрації як у методі Нікольсона [17] та «Wash Test», розробниками якого були A.V. Dow та O.R. Tyler [18], або обертанню в пляшках, як у поширеному в Европі та стандартизованому на території України Rolling Bottle Test [19].

Попре велику кількість експериментальних даних, та простоту виконання випробування за цими методами, вразливою ланкою залишається оцінювання відсотка площі поверхні матеріалу, що залишилась вкритою бітумом. Через наявність мінералів різного забарвлення в більшості методів оцінювання виконується візуально, що, навіть за умови використання експертної групи що проводить оцінювання, залишається відносно суб'єктивним. Використання комп'ютерних програм, за допомогою яких, за спеціальних умов освітлення, можливо виконати відповідну оцінку $\epsilon$ перспективним напрямком, як i використання барвника, що сорбується оголеною мінеральною поверхнею. В останньому випадку відсоток оголеної поверхні визначається через інтенсивність падіння забарвлення розчину в якому витримується (або який пропускається) через суміш. Проте, зазначені розробки поки що не можуть забезпечити високу точність результату в умовах використання в виробничій лабораторії.

Метод визначення показника зчеплення, розроблений в ХНАДУ. В 90-х роках минулого століття в лабораторії ХНАДУ було розроблено метод адгезії, 
який в подальшому було стандартизовано як ДСТУ Б В.2.7-81-98 [2]. Розробники методу виходили 3 положення що при порівнянні якості в'яжучих бітум необхідно перевіряти на адгезію до найбільш несприятливої поверхні, (для визначення адгезіі бітуму до конкретного кам'яного матеріалу використовувались шліфовані пластини з цього матеріалу).

Із збільшенням вмісту в гірській породі силікатів (окислу кремнію - $\mathrm{SiO}_{2}$ ) адгезія бітумів до поверхні погіршується. Більш того, чим менше шорсткість поверхні, тим легше відділюється плівка бітуму водою в випробуванні. Необхідно було знайти еталонний матеріал, 3 постійним хімічним складом, гладкою поверхнею, розповсюджений та простий в експлуатації, i, в першу чергу, із якомога високою концентрацією $\mathrm{SiO}_{2} .3$ цих умов було обрано скло.

Попередньо підготовані (обезжирені) скляні пластини вкривались плівкою досліджуваного бітуму, завтовшки 200 мкм, витримувались певний час за високої температури у строго горизонтальному положенні, щоб вирівняти поверхню, та, після остигання, розміщувались у водяній бані на 25 хвилин за температури $75{ }^{\circ} \mathrm{C}$ (для бітумів з поверхнево-активних речовин $85^{\circ} \mathrm{C}$ ). Відсоток площі поверхні, який залишався вкритим бітумом, приймався як значення адгезії. Прозорість скла дозволяла зробити одну важливу річ - обчислювати значення адгезії із підвищеною точністю. Під склом розміщувалась палетка i рахувались вічки, «заповнені» бітумом повністю або на половину. Це переводило візуальну оцінку у кількісну, менш залежну від оператора. Через певний час було розроблено комп’ютерну програму, яка визначала різницю між двома зображеннями - скла повністю вкритого бітумом до випробування, та того ж скла після випробування. Через такий метод точність визначення переставала залежати від оператора, i обмежувалась лише технічними параметрами обладнання.

Вдосконалення методу, розпочате в 2019 році, мало на меті: заміну листового скла, яке приймалось як еталонне; розширення методу для випробування модифікованих полімерами та енергозберігаючими домішками в'яжучих; включення у стандарт можливості використання комп'ютерного обладнання для оцінювання площі зразка, вкритої бітумом. У виконаній за два роки роботі були перевірені всі параметри випробування, і відповідні оптимальні режими та операції, необхідні для визначення адгезії, винесені у проект нового ДСТУ «Бітум та бітумні в'яжучі. Метод визначення показника зчеплюваності 3 поверхнею скла і кам'яних матеріалів».

За новим ДСТУ використовується скло предметне для мікроскопічних досліджень, для якого спрощено процедуру підготовки - поверхню пластин миють господарським милом та ретельно промивають водопровідною водою, кип'ятять у вертикальному положенні у дистильованій воді протягом 30 хв та висушують у вертикальному положенні у сушильній шафі за температури (105 \pm 5) ${ }^{\circ} \mathrm{C}$ протягом $(30 \pm 5) \mathrm{xв.}$

Через фіксовану площу таких пластин, наважка бітуму у 0,35 г. дозволяє отримати шар в'яжучого, товщиною 200 мкм (для розподілення в'яжучого за площею скла зручно використовувати розподілюючий столик, подібний до того що входить в комплект АТХ-20). Температура розподілення на $(85 \pm 2){ }^{\circ} \mathrm{C}$ вище 
температури розм'якшеності в'яжучого. При цій же температурі пластини витримують 5 хвилин у сушильній шафі у строго горизонтальному положенні, після чого охолоджують протягом 30 хвилин на повітрі.

Для охолоджених пластин визначають площу, вкриту бітумом, і пластини розміщують у водяній бані з дистильованою водою за температури $85{ }^{\circ} \mathrm{C}$. Зміну площі визначають через 25 хвилин (або 50 хвилин). Загальний вигляд комплекту випробувального обладнання і пластин до та після випробування наведено на рис 3.
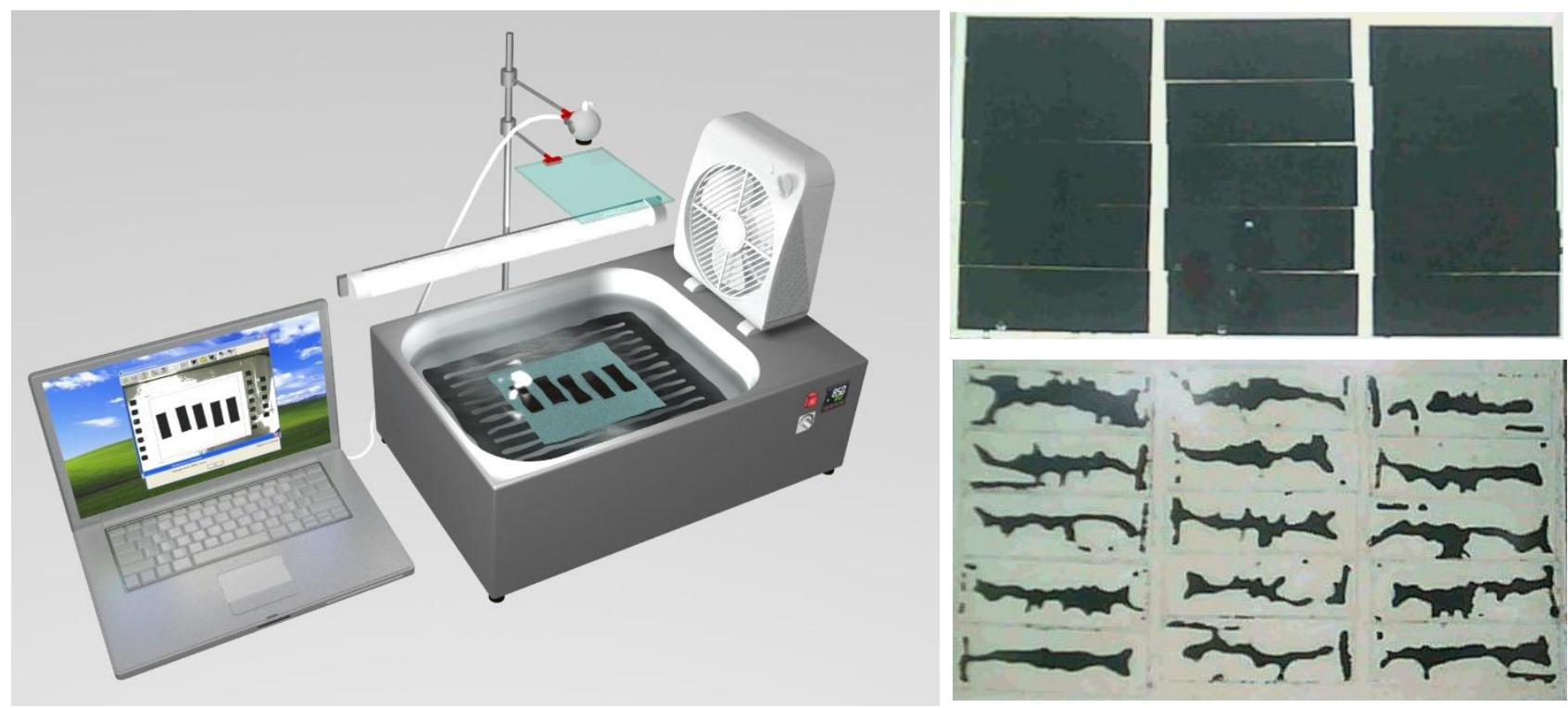

Рисунок 3. Зовнішній вигляд комплекту обладнання та серія зразків до та після випробування адгезії

Аналогічним чином, у разі необхідності, випробування проводиться на попередньо відшліфованих пластинах кам'яного матеріалу.

Зараз лабораторією ХНАДУ закінчено підготовку програмного комплексу, який дозволяє в процесі випробування оцінювати зміну площі безперервно у часі за потоковим аналізом даних, що надходять в вебкамери, розташованої над водяною банею із зразками. Заплановано розроблення комплексу устаткування для визначення адгезії бітуму за цим методом.

Висновки. Серед чисельної кількості методів визначення адгезії на даний час не існує методу, який був би вільним від недоліків. Більша частина ускладнень пов'язана 3 тим що поверхня кам'яного матеріалу, до якого визначається адгезія бітуму, має складний полімінеральний склад і вимагає трудомістких процедур 3 підготовки, або відрізняється малою точністю отриманого результату. В проекті ДСТУ $\epsilon$ можливим встановлення адгезійних властивостей різноманітних бітумних в'яжучих з високою точністю та оперативністю отримання результату. Загальна тривалість випробування за цим методом не перевищує $2-3$ годин. За необхідності визначення адгезії бітуму до конкретного матеріалу можливе використання пластин 3 цього матеріалу. За цим, через наявність темних мінералів на досліджуваній поверхні, точність методу може знижуватись. 


\section{References:}

1. ДСТУ 4044:2019. Бітуми нафтові дорожні в'язкі. Технічні умови. [Чинний від 2020-05-01]. Вид. офіц. Київ: Держстандарт України, 2019. 15 с.

2. ДСТУ Б.В.2.7-81-98. Будівельні матеріали. Бітуми нафтові дорожні в'язкі. Метод визначення показника зчеплення з поверхнею скла та кам'яних матеріалів [Чинний з 1999-03-01]. Вид. офіц. Київ: Державний комітет будівництва, архітектури та житлової політики України, 1999. 5 с.

3. Х Международный дорожный конгресс. Москва: Автотрансиздат. 1957. $364 \mathrm{c}$.

4. Поляков М.П., Кострико М.Т. Определение удельного сцепления вяжущих с каменными материалами. Строительство дорог. 1940. № 12. С. 33 36.

5. Zhou F., Li H., Chen P., Scullion T. Laboratory evaluation of asphalt binder rutting, fracture, and adhesion tests. Texas A\&M Transportation Institute. 2014. 75 p.

6. AASHTO TP 91:2015. Standard Method of Test for Determining Asphalt Binder Bond Strength by Means of the Asphalt Bond Strength (ABS). Test standard by American Association of State and Highway Transportation Officials, 2015. 14 p.

7. Horgnies M., Toubeau P., Fezai H., Darque-Ceretti E.Adhesion between aggregates and bitumen characterized by peel tests and surface analyses. $4^{\text {th }}$ World Congress on Adhesion and Related Phenomena, At Arcachon, France. 2010. 2 p.

8. Analysis of available data for validation of bitumen tests. Report on phase 1 of the BiTVal project / editor C. Nicholls. 2006. 213 p.

9. Авербах Э.И., Давидова А.Р. , Яхнин Е.Д. Адгезия частиц наполнителей к битумам. Исследование свойств битумов, применяемых вдорожном строительстве. Труды Союздорнии. Вып. 46. 1970, С. 115-123.

10. Центрифуга $з$ подвійним тілом обертання для визначення міцності адгезії: пат. 91954 Україна, МПКВ04B 3/00, G01N 19/00. № а 2010 00242; заявл. 13.01.2010 ; опубл. 10.09.2010, Бюл. № 17. 4 c.

11. Naveed A. Asphalt mixture moisture sensitivity evaluation using surface energy parameters: PhD thesis / University of Nottingham. 2001. 306 p.

12. Bhasin A. Development of methods to quantify bitumen-aggregate adhesion and loss of adhesion due to water: doctoral dissertation / Texas A\&M University. 2003. $158 \mathrm{p}$.

13. Fini E., Al-Qadi I., Masson J.F. A new blister test to measure bond strength of asphaltic materials. Asphalt Paving Technology-Proceedings. 2007. № 76. P. 275-302.

14. Herbert Abraham Asphalt and allied substances. New York: D.Van Norstrand Company, $1929.650 \mathrm{p}$.

15. Лысихина А.И., Ханина Ц.Г. Об определении сцепления органических вяжущих с поверхностью щенбя. Дориздат. 1951. 14 с.

16. ASTM D 3625-2012. Standard Practice for Effect of Water on BituminousCoated Aggregate Using Boiling Water. ASTM International. 2012. 2 p.

17. Лысихина А.И. Поверхностно-активные добавки для повышения водоустойчивости дорожных покрытий с применением битумов и дегтей. Москва: Автотрансиздат. 1959. 232 с. 
18. Melson L.B. The adhesion of bituminous materials to mineral aggregate. Oregon state college. $1941.74 \mathrm{p}$.

19. ДСТУ EN 12697-11:2018 (EN 12697-11:2012, IDT). Бітумомінеральні суміші. Методи випробування гарячих асфальтобетонних сумішей. Частина 11. Визначення зчеплюваності між заповнювачем і бітумом. [Чинний від 2019-0101]. Вид. офіц. Київ: УкрНДНЦ. 2018. 41 с. 


\title{
ТЕХНОЛОГІЯ ХЛІБА ІЗ ПРОРОСЛОГО ЗЕРНА ПШЕНИЦ
}

\author{
Герасимчук Олена Петрівна, \\ кандидат с.-г. наук, доцентка \\ кафедри технології зберігання і переробки зерна \\ Уманський національний університет садівництва
}

Харчова цінність хліба, як і будь-якого харчового продукту, визначається в першу чергу його калорійністю, засвоюваністю, вмістом у ньому додаткових факторів харчування: вітамінів, мінеральних речовин і незамінних амінокислот. Смак і аромат хлібобулочних виробів залежить від складу i властивостей використовуваної сировини і від процесів, що відбуваються в тісті при випічці, умов зберігання сировини та готових виробів [1].

Найбільшу цінність представляє хліб з пророслого зерна пшениці, так як при проростанні зерна важко засвоювані з'єднання переходять в більш прості, утворюється додаткова кількість вітамінів, амінокислот, мінеральних речовин, легкозасвоюваних вуглеводів. Недоліком хліба на основі цільного зерна $є$ специфічні органолептичні властивості, щільність текстури, низькі смакові якості, що відрізняють його від традиційних сортів хліба, що є чинником, що знижує обсяг масового споживання. Незважаючи на це, цільнозерновий хліб викликає все більший інтерес у пекарів, i у покупців, оскільки ринок ще недостатньо насичений цим продуктом, населення в міру зростання освіченості i рівня життя стало уважніше ставитися до свого здоров `я, і цей продукт вже не потребує потужної рекламної підтримки $[1,2]$.

Головна особливість технології хліба з пророслого зерна пшениці, на відміну від традиційних способів приготування, полягає в підготовці зерна, який являється найбільш тривалим етапом. Тому велике значення має скорочення попередньої підготовки і підвищення безпеки зерна, поліпшення якості хліба.

Дослідження по розробленню технології виробництва хліба 3 пророслого зерна пшениці проводили в умовах науково-дослідної лабораторії кафедри технології зберігання і переробки зерна Уманського національного університету садівництва.

Тривалість проростання зерна пшениці залежно від гідромодуля i температури води при замочуванні проводили в два етапи: на першому етапі експерименту зерно замочували у воді в умовах кімнатної температури $\left(20{ }^{\circ} \mathrm{C}\right)$, iз співвідношенням зерна і води: $1: 0,6 ; 1: 0,8 ; 1: 1 ; 1: 1,2 ; 1: 1,4 ;$ на другому етапі експерименту зерно замочували у воді температурою 15, 20, 30 i $40{ }^{\circ} \mathrm{C}$, при гідромодулі 1:1. Зерно пророщували до отримання проростків довжиною 1 мм.

Оптимальну дозу густої зернової закваски визначали за допомогою лабораторних випічок хліба з використанням 20 \%, 30 \%, 40 \% і 50 \% густої зернової закваски. Закваску готували з активованого лактобактерина для густих хлібних заквасок на борошні 3 цільнозмеленого пророслого зерна пшениці, шляхом внесення борошна 3 поживною сумішшю. 
Нами була досліджена залежність часу проростання зерна пшениці від гідромодуля і температури води при замочуванні. На першій стадії експерименту зерно замочували у воді при кімнатній температурі $\left(20^{\circ} \mathrm{C}\right)$, із співвідношенням зерна і води від 1:0,6 до 1:1,4. Оптимальним співвідношенням зерна і води при мінімальній тривалості пророщування до досягнення довжини проростків 1,0 мм (24 год) є 1:1.

Далі зерно замочували у воді з температурою від $15{ }^{\circ} \mathrm{C}$ до $40{ }^{\circ} \mathrm{C}$, при гідромодулі 1:1. Підвищення температури води до $40{ }^{\circ} \mathrm{C}$ прискорювало процес пророщування зерна на 2 години, так як температура $40-55{ }^{\circ} \mathrm{C} \epsilon$ оптимальною для дії багатьох ферментних систем зерна і активність ферментів в цих умовах зростає. Однак для замочування зерна в умовах $40{ }^{\circ} \mathrm{C}$ потрібне спеціальне обладнання, що з економічної точки зору не вигідно для виробництва.

Отже, тривалість пророщування зерна пшениці в воді до отримання проростків довжиною 1,0 мм досягається за 24 години при кімнатній температурі води $\left(20^{\circ} \mathrm{C}\right)$.

Наступним етапом було дослідження впливу розробленої технології, що включає стадію замочування зерна пшениці в водному розчині, а також використання різних дозувань густої зернової закваски при приготуванні тіста, на зміну вологості і кислотності тіста в процесі приготування тіста. Вологість і кислотність тіста визначали відразу після його замісу, і після бродіння. збільшення дозування густої зернової закваски з $20 \%$ до $50 \%$ привело до підвищення кислотності. Максимальною кислотністю характеризується зразок 3 дозуванням закваски $50 \%$, кислотність якого становила $8,7 \pm 0,3^{\circ}$. Досягнення такої кислотності необхідне для інактивації $\alpha$-амілази, яка проявляє свою активність при проростанні зерна.

Встановлено, що приготування тіста за розробленою технологією при приготуванні тіста на густій зерновій заквасці сприяе інтенсифікації газоутворення, незначного зниження структурно механічних і поліпшенню фізико-хімічних властивостей тіста.

Органолептичні показники якості цільнозернового хліба оцінювали за 5-ти бальною системою 3 урахуванням коефіцієнта вагомості у відповідності 3 загальноприйнятою шкалою бальної оцінки хлібобулочних виробів. Аналіз результатів бальної оцінки показав, що хліб, отриманий з використанням розробленої технології, має поліпшені органолептичні властивості.

Встановлено, що застосування розробленої технології хліба з пророслого зерна пшениці з використанням густої зернової закваски в дозуванні 40 \% на стадії приготування тіста, покращує показники тіста: поліпшуються фізикохімічні показники, практично не змінюються структурно-механічні показники тіста; поліпшуються фізико-хімічні показники хліба: пористість підвищується на $15 \%$, питомий об`єм на $11 \%$, в порівнянні з контролем.

\section{Література:}

1. Кравченко М. Ф., Криворучко М. Ю., Антоненко А. В. Структурномеханічні властивості прісного тіста 3 борошна пророщеного зерна пшениці. Міжнар. наук.-практ. журн. «Товари і ринки». 2012. № 1. С. 82-88. 
2. Бастриков Д., Панкратов Г. Новий продукт з цільного зерна пшениці. Хлібопродукти. 2006. №4. С. 36-37. 


\section{ОБГРУНТУВАННЯ ПРОЦЕСУ УЩІЛЬНЕННЯ СТЕБЛОВИХ ЗАЛИШКІВ КУКУРУДЗИ}

\section{Корчак Микола Миколайович}

к.т.н., доцент

Подільський державний аграрно-технічний університет

Процес ущільнення при запропонованій технології обробітку грунту виконує ущільнення згорнених стеблових залишків кукурудзи. Для забезпечення процесу ущільнення використовується робочий орган - коток, який має циліндричну поверхню та основні технологічні параметрами - діаметр і ширину. Коток ущільнює згорнену стеблову масу по рядках посіву грубостеблових культур. Щоб дослідити дію котка на стеблові залишки, розглянемо його взаємодію із сформованим стебловим валком (рис. 1).

Від дії сили $N$ на стебла виникають сили тертя $F_{2}$ (рис. 1) між ободом котка і стеблами, які направлені в сторону, зворотню напрямку руху котка. Защемлення стебел між котком і поверхнею поля проходить у тому випадку, коли [1]:

$$
F_{1}+F_{2} \cdot \cos \alpha>N^{\prime},
$$

але

$$
\begin{gathered}
N^{\prime}=N \cdot \sin \alpha . \\
F_{2}=N \cdot \operatorname{tg} \varphi_{2}, F_{1}=Q \cdot \operatorname{tg} \varphi_{1} . \\
Q=N^{\prime \prime}+F_{2} \sin \alpha=N \cdot \cos \alpha+N \cdot \operatorname{tg} \varphi_{2} \cdot \sin \alpha .
\end{gathered}
$$

Провівши скорочення на $N$, і розділивши на $\cos \alpha$, одержимо:

$$
\alpha \leq \frac{\operatorname{tg} \varphi_{1}+\operatorname{tg} \varphi_{2}}{1-\operatorname{tg} \varphi_{1} \cdot \operatorname{tg} \varphi_{2}}, \text { або } \operatorname{tg} \alpha \leq \operatorname{tg}\left(\varphi_{1}+\varphi_{2}\right) .
$$

Стебла не будуть переміщуватись перед котком при умові [1]:

$$
\alpha \leq \varphi_{1}+\varphi_{2} .
$$

Кут $\alpha$ залежить від висоти стебел $h_{\text {зас.ст }}$ і діаметра котка $D_{\kappa}$.

$$
\operatorname{tg} \alpha=\frac{\sqrt{1-\cos ^{2} \alpha}}{\cos \alpha}=\frac{2 \sqrt{h D_{\kappa}-h^{2}}}{D_{\kappa}-2 h} .
$$

Відповідно

$$
\operatorname{tg}\left(\varphi_{1}+\varphi_{2}\right) \geq \frac{2 \sqrt{h D_{\kappa}-h^{2}}}{D_{\kappa}-2 h} .
$$

Знаючи кути тертя $\varphi_{1}$ і $\varphi_{2}$ та діаметр котка $D$, можна визначити висоту стебел, які ущільнює коток, не переміщуючи їх вперед.

Кут обхвату обода котка:

$$
\cos \alpha=\frac{(r-h)}{r}=\frac{\left(D_{\kappa}-2 h\right)}{D_{\kappa}}=1-\frac{2 h}{D_{\kappa}},
$$

де $D_{\kappa}-$ діаметр котка;

$h$ - глибина колії котка.

Задавши глибину колії котка і кут обхвату, можна визначити допустимий мінімальний діаметр котка. 


$$
D_{\kappa} \geq \frac{2 h_{\text {заг.cm }}}{(1-\cos \alpha)} .
$$

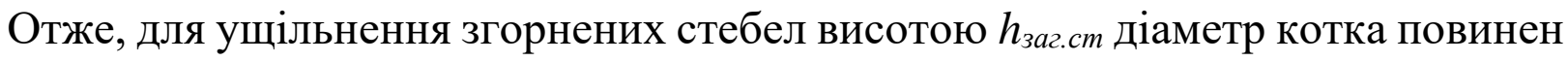
задовольняти наступній умові:

$$
D_{\kappa} \geq h_{\text {заг.cm }} \cdot \operatorname{ctg} \frac{\varphi_{1}+\varphi_{2}}{2},
$$

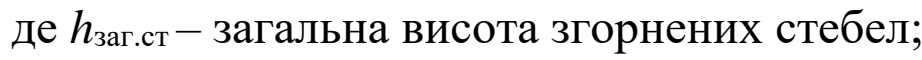

$\varphi_{1}, \varphi_{2}-$ відповідно кути тертя стебел до котка та грунту;

Ущільнюючу дію котка визначаємо за формулою [2]:

$$
P=9,8 \cdot \frac{m}{b},
$$

де $m$ - маса котка, кг;

$b$ - ширина котка, см;

$P$ - питомий тиск, що припадає на 1см ширини котка, Н/см.

Мінімальне значення діаметра котка може бути визначене по умові недопущення намотування стебел на коток із співвідношення [3]:

$$
D_{\kappa} \geq \frac{l_{c \max }}{\pi},
$$

де $D_{\kappa}$ - діаметр барабана котка, см;

$l_{c \max }$ - максимальна довжина стебел, см.

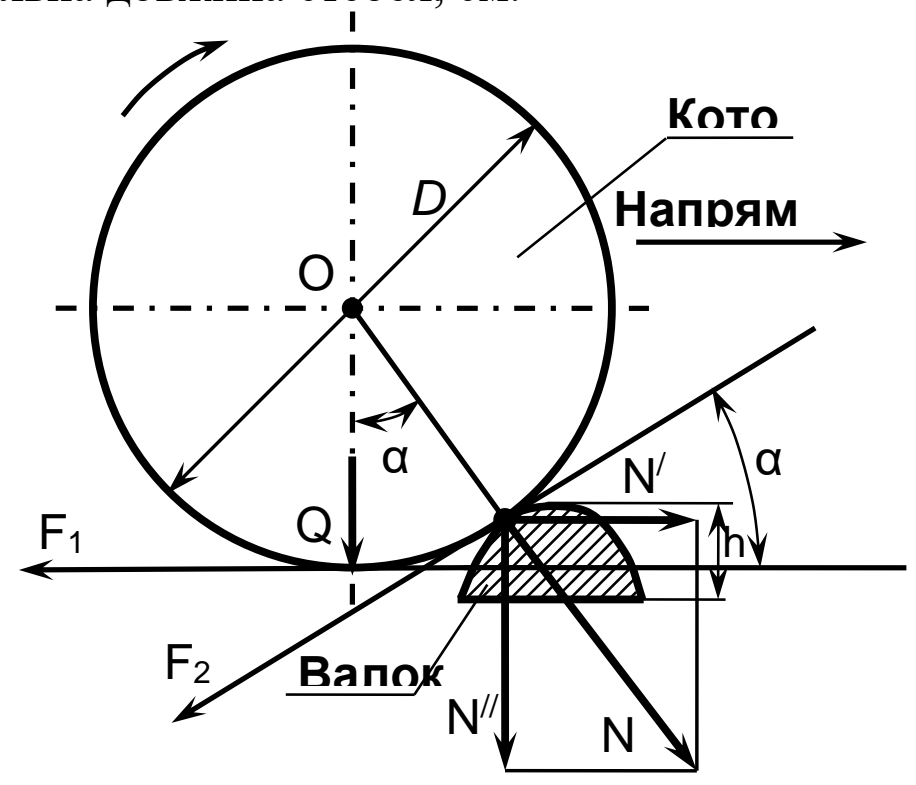

Рис. 1. Схема дії котка на стебла: $h$ - висота валка; $D$ - діаметр котка; $\alpha$ - кут між горизонталлю і дотичною до кола котка, проведений в точці дотику його із стеблами; $N$ - сила, нормальна до поверхні котка в точці дотику із стеблами

Ширина котка рівна:

$$
B_{\kappa}=B_{\phi p}=d_{\kappa},
$$

де $d_{\kappa}$ - діаметр кореневища, см.

Тяговий опір котка:

$$
P_{\kappa}=0,86 \cdot k \cdot \sqrt[3]{\frac{G^{4}}{g_{0} \cdot B_{\kappa} \cdot D_{\kappa}}},
$$

де $G$ - сила тиску котка на рослинні залишки та грунт; 
$g_{o}$ - коефіцієнт об’ємної деформації грунту.

Затрати потужності:

де $P_{\kappa}$ - тяговий опір котка;

$$
N_{\kappa}=P_{\kappa} \cdot V_{n},
$$

$V_{n}$ - поступальна швидкість.

Висновки. 1. Дослідження прикочувального котка дали змогу обгрунтувати основні його параметри: діаметр $D_{\kappa}=0,20 \ldots 0,24 \mathrm{м}$, ширина $b_{\kappa}=0,20 \ldots 0,25$ м.

2. Обгрунтований процес ущільнення та робочий орган, що його виконує реалізований у розробці подрібнювача рослинних залишків грубостеблових культур. Основні результати досліджень опубліковані в матеріалах конференцій та наукових фахових виданнях [4-26].

\section{Список літератури}

1. Войтюк Д.Г. Сільськогосподарські машини. Основи теорії та розрахунку / Войтюк Д.Г., Барановський В.М., Булгаков В.М. - К. : Вища освіта, 2005. - 464 c.

2. Синеоков Г.Н. Теория и расчёт почвообрабатывающих машин / Г.Н. Синеоков, И.М. Панов. - М. : Машиностроение, 1977. - 327 с.

3. Корчак М.М. Дослідження характеру засміченості поля листостебельними та кореневими залишками після збирання кукурудзи / М.М. Корчак, С.В. Єрмаков // Збірник наукових праць Подільського державного аграрнотехнічного університету. - Кам'янець-Подільський, 2007. - Вип. 15. - С. 498-504.

4. Корчак М.М. Розробка комбінованого способу та подрібнювача для грунту, засміченого рослинними залишками / М.М. Корчак // Вісник Львівського національного аграрного університету: Агроінженерні дослідження. Львівський національний агроуніверситет, 2009. - №13, т. 1. - С. 155-163.

5. Корчак М.М. Теоретичні дослідження впливу дискового ножа на процес розрізання рослинних залишків грубостеблових культур в міжряддях / М.М. Корчак // Збірник наукових праць Подільського державного аграрно-технічного університету. - Кам'янець-Подільський, 2009. - Вип. 17. - С. 450-458.

6. Корчак М.М. Теоретичні дослідження впливу розподільника на процес розподілу розрізаних рослинних залишків грубостеблових культур з міжрядь на рядки посіву / М.M. Корчак // Збірник наукових праць Подільського державного аграрно-технічного університету. - Кам'янець-Подільський, 2010 - Вип. 18. - С. 517-524.

7. Корчак М.М. Аналіз технологій і конструкцій машин для обробітку грунту, засміченого рослинними залишками грубостеблових культур 3 розробкою комбінованого способу та подрібнювача для його реалізації / М.М. Корчак // Праці ТДАТУ, 2010 - Вип. 10, Т.7-С. 299-312.

8. Корчак М.М. Результати відсіюючого та пошукових експериментальних досліджень подрібнювача рослинних залишків грубостеблових культур / М.М. Корчак // Збірник наукових праць Вінницького національного аграрного університету. Серія: Технічні науки. - Вінниця, 2011. - Вип. 9. - С. 76-94.

9. Корчак М.М. Дослідження вібраційного вирівнювального грунтообробного пристрою / М.М. Корчак // Вісник аграрної науки, № 4. - К., 2011. - С. 72-74. 
10. Корчак М.M. Результати основних польових експериментальних досліджень подрібнювача рослинних залишків грубостеблових культур / М.М. Корчак // Збірник наукових праць Подільського державного аграрно-технічного університету. - Кам'янець-Подільський, 2011. - Вип. 19. - С. 531-542.

11. Корчак М.М. Теоретичні дослідження впливу котка на процесс ущільнення розрізаних та згорнених рослинних залишків грубостеблових культур по смугах обробітку / М.М. Корчак // Збірник наукових праць Подільського державного аграрно-технічного університету. - Кам'янецьПодільський, 2013. - Вип. 21. - С. 407-410.

12. Корчак М.М. Обгрунтування технологічної функціональної моделі способу обробітку грунту після збирання грубостеблових культур / М.М. Корчак // Збірник наукових праць Подільського державного аграрно-технічного університету. - Кам’янець-Подільський, 2016. - Вип. 24, ч.2. - С. 165-174.

13. Корчак М.М. Аналіз результатів пошукових експериментальних досліджень подрібнювача рослинних залишків грубостеблових культур / М.М. Корчак // Подільський вісник: сільське господарство, техніка, економіка. Кам'янець-Подільський, 2017. - Вип. 25. - С. 99-114.

14. M. Korchak, S. Yermakov, V. Maisus, S. Oleksiyko, V. Pukas, I. Zavadskaya. Problems of field contamination when growing energy corn as monoculture. E3S Web of Conferences. Krynica, Poland. 6th International Conference - Renewable Energy Sources. Volume 154 (2020). (ISSN: 2267-1242).

15. V. Sheichenko, I. Marynchenko, I. Dudnikov, M. Korchak. Development of technology for the hemp stalks preparation. Independent Journal of Management and Production.State agrarian and engineering university in Podilia. V. 10, № 7. p. 687 701 (2019). (ISSN: 2236-269X).

16. Корчак М.M. Теоретичне обгрунтування робочого органу для вирівнювання грунту / М.М. Корчак, Т.В. Дудчак, Д.В. Вільчинська // Вісник Житомирського державного технологічного університету, Вип. 1, 2019 - С. 6976. (ISSN 1728-4260).

17. N. Korchak. Дослідження комбінованого подрібнювача рослинних залишків. - LAP LAMBERT Academic Publishing, 2019. - 73 c. (ISBN: 978-6200-27842-5).

18. Корчак М.М. Теоретичні дослідження впливу фрези на процес подрібнення рослинних залишків грубостеблових культур по смугах обробітку / М.М. Корчак, Т.В. Дудчак, Д.В. Вільчинська // Подільський вісник: сільське господарство, техніка, економіка. - Кам'янець-Подільський, 2020. - Вип. 32. C. 113-123. (pISSN 2706-9052, eISSN 2706-851X).

19. Корчак М.М. Обгрунтування технологічних параметрів фрезерного робочого органу для смугового обробітку грунту / M.M. Корчак // Abstracts of I International Scientific and Practical Conference «Topical aspects of modern science and practice» (21-24 September, 2020), Frankfurt am Main, Germany 2020. - P. 378384. (ISBN - 978-1-64945-866-7).

20. Корчак М.М. Обгрунтування технологічних параметрів дискового робочого органу для розрізання стеблових залишків кукурудзи / М.М. Корчак // Abstracts of II International Scientific and Practical Conference «Development of 
scientific and practical approaches in the era of globalization» (28-30 September, 2020), Boston, USA 2020. - P. 234-239. (ISBN - 978-1-64945-867-4).

21. Корчак М.М. Обгрунтування динамічних властивостей дискового робочого органу для розрізання грубостеблових залишків в міжряддях / М.М. Корчак // Abstracts of III International Scientific and Practical Conference «Theory, science and practice» (05-08 October, 2020), Tokyo, Japan 2020. - P. 414-422. (ISBN - 978-1-64945-868-1).

22. Корчак М.M. Обгрунтування технологічних параметрів котка для ущільнення рослинних залишків кукурудзи / M.M. Корчак // Abstracts of IV International Scientific and Practical Conference «Integration of scientific bases into practice» (12-16 October), Stockholm, Sweden 2020. - P. 492-496. (ISBN - 978-164945-864-3).

23. Корчак М.М. Удосконалення механізації обробітку грунту після збирання кукурудзи з розробкою комбінованого способу обробітку поля / М.М. Корчак // Матеріали I Міжнародної наукової конференції з міждисциплінарних досліджень (19-21 січня 2021 року), Берлін, Німеччина 2021. - C. 1023-1029. (ISBN - 978-163684-352-0).

24. Корчак М.М. Подрібнювач рослинних залишків 3 напрямними орієнтирами / M.M. Корчак // Abstracts of XIV International Scientific and Practical Conference «Actual problems of science and practice» (27-28 April 2020), Stockholm, Sweden 2020. - C. 408-414. (ISBN - 978-1-64871-632-4).

25. Корчак М.М. Технологія обробітку грунту, засміченого рослинними залишками з орієнтуванням згорнених стебел / М.М. Корчак // Abstracts of XII International Scientific and Practical Conference «Impact of modernity on science and practice» (13-14 April 2020), Edmonton, Canada 2020. - C. 404-409.

26. Mykola Korchak, Serhii Yermakov, Taras Hutsol, Lesya Burko, Weronika Tulej. Features of weediness of the field by root residues of corn // Environment. Technology. Resources. Proceedings of the 13th International Scientific and Practical Conference. Rezekne, Latvia, Volume 1, P. 122 - 126 (2021).

DOI: 10.17770/etr2021vol1.6541 


\title{
ВПЛИВ НЕСИНУСОЇДАЛЬНОСТІ НАПРУГИ НА РОБОТУ ВУЗЛА НАВАНТАЖЕННЯ 3 КОНДЕНСАТОРНИМИ УСТАНОВКИМИ
}

\begin{abstract}
Лисяк Владислав Георгійович канд. техн. наук, доцент кафедри електроенергетики та систем управління Національний університет «Львівська політехніка»
\end{abstract}

Сабат Мирослав Богданович канд. техн. наук, доцент кафедри електроенергетики та систем управління Національний університет «Львівська політехніка»

Шелех Юрій Леонідович канд. техн. наук, доцент кафедри електроенергетики та систем управління Національний університет «Львівська політехніка»

\section{Чечель Вадим Олександрович} здобувач вищої освіти інституту енергетики та систем керування Національний університет «Львівська політехніка»

\section{Вступ}

На роботу компенсувальних установок впливають умови експлуатації та електроприймачі мережі в якій працює КУ. Зокрема, значний вплив на роботу КУ має несинусоїдність напруги мережі. Збільшення кількості споживачів електричної енергії в системах електропостачання, до складу яких входять напівпровідникові перетворювачі (НП), зумовлює наявність вищих гармонік напруги (струму) та призводить до збільшення коефіцієнта несинусоїдності, як одного з визначальних показників якості електричної енергії.

Основним методом покращення синусоїдності напруги в мережах $\epsilon$ використання фільтрокомпенсувальних пристроїв $[1,2,3]$, застосування яких вимагає детального вивчення характеристик мережі, визначення складу наявних гамонік та аналізу можливості виникнення нових.

Дослідження впливу несинусоїдальності в електричних мережах на КУ є актуальною темою та дозволить оцінити умови роботи КУ 3 метою їх покращення.

\section{Основна частина}

Вищі гармоніки значною мірою впливають на роботу конденсаторних установок. Викривлення форми кривої напруги помітно позначається на виникненні й протіканні іонізаційних процесів у діелектриках. За наявності газових включень в ізоляції виникає іонізація, явище якої полягає в утворенні об'ємних зарядів і наступної їх нейтралізації. Нейтралізація зарядів пов'язана 3 розсіюванням енергії, наслідком якої є електричний, механічний і хімічний вплив на навколишній діелектрик. У результаті розвиваються місцеві дефекти в 
ізоляції, що призводить до зниження іiі електричної міцності, зростанню діелектричних втрат i, в остаточному підсумку, до скорочення терміну служби. Також за несинусоїдальної напруги на затискачах батареї конденсаторів у діелектрику з'являються активні втрати, обумовлені струмами вищих гармонік.

В умовах промислових підприємств, як правило, конденсатори, періодично працюють в режимі, близькому до резонансу струмів на частоті якої-небудь із гармонік; внаслідок систематичних перевантажень вони швидко виходять із ладу. Порівняємо деякі режими роботи досліджуваного вузла навантаження 3 конденсаторною батареєю та без конденсаторної батареї (рис. 1 - рис. 2).

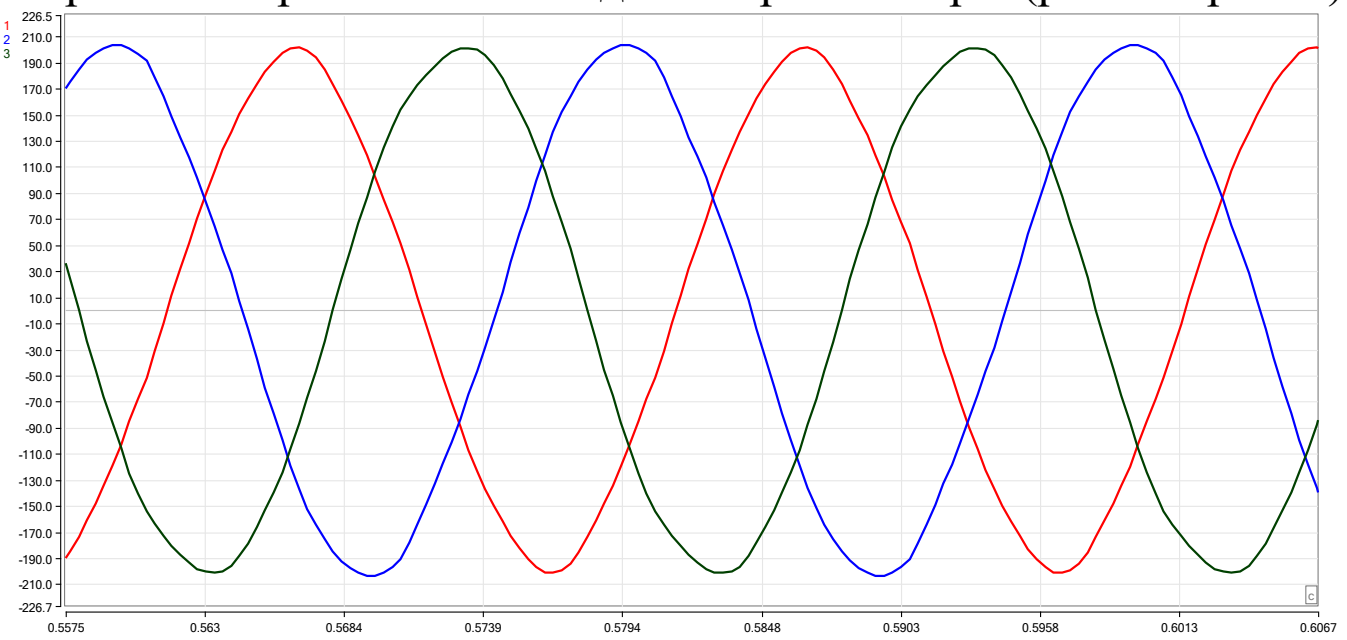

Рисунок 1. Осцилограми напруги при ввімкненому активно-індуктивному навантаженні.

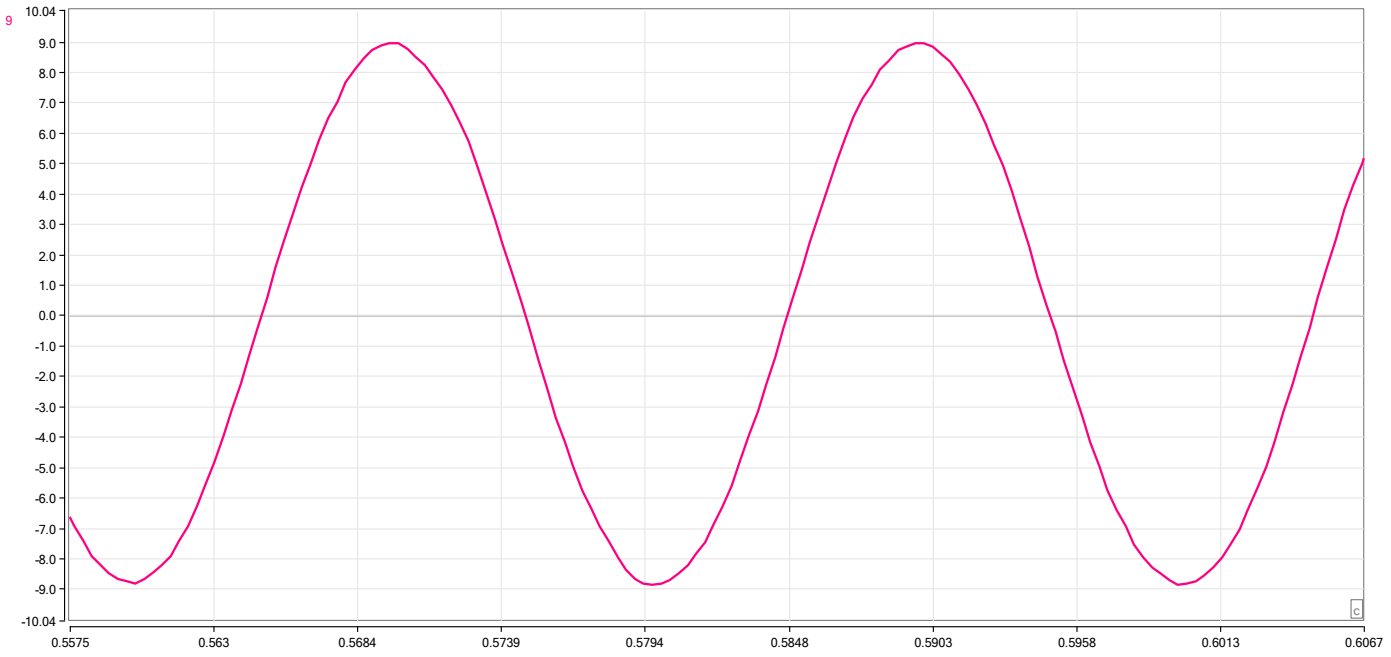

Рисунок 2. Осцилограма струму активно-індуктивного навантаження.

Як видно із поданих вище осцилограм (рис 1-2), це нормальний режим роботи мережі без конденсаторної батареї та джерела вищих гармонік.

Існують такі апарати в яких неможливо зменшити гармоніки конструктивними засобами. В цьому випадку між апаратом і системою необхідно розташувати пристрій, здатний запобігати розповсюдження гармонік в системі. Цей пристрій є фільтром, який іноді складається з конденсаторів, іноді утвореною комбінацією ємнісних та індуктивних опорів, включених послідовно та паралельно таким чином, щоб отримати пропускну ділянку необхідної ширини. Фільтри, підключені паралельно, представляють собою елемент мережі 3 великою повною провідністю, що поглинають гармоніки. Вони можуть бути 
доповнені іншими фільтрами, включеними послідовно в систему і створюють фільтр-пробки. Для дослідження роботи фільтра вищих гармонік були зібрані схеми, що зображенні на (рис. 3).

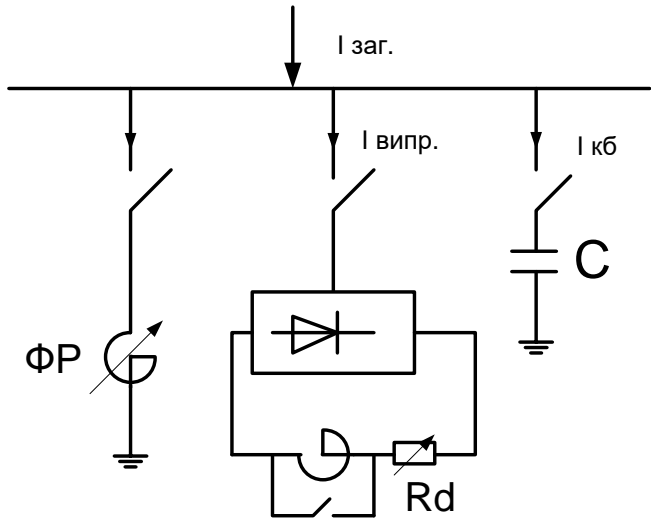

A)

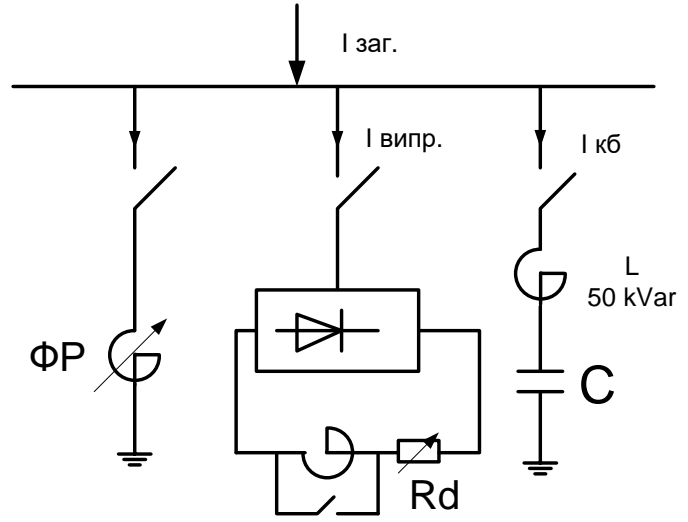

Б)

Рисунок 3. Схеми для зняття дослідних характеристик впливу вищих гармонік на конденсаторну установку: а) не захищена фільтрами; б) захищена фільтрами.

Розраховуємо частоту яку фільтруватиме дросель у схемі Б:

Конденсаторна батарея з'єднана у трикутник, ємність конденсаторів у фазі рівна 48 мікрофарад. Отже:

$$
X_{c}=\frac{1}{2 \pi f C}=\frac{1}{2 * 3.14 * 50 * 48 * 10^{-6}}=22,1 \text { Ом. }
$$

Індуктивність трифазного дроселя згідно його паспорту складає $0,76 \mathrm{мГн.}$

Індуктивний опір становить:

$$
X_{L}=2 \pi f L=2 * 3,14 * 50 * 0,76=0,23 \text { Ом. }
$$

Знайдемо частоту на яку буде налаштований фільтр:

$$
f=\sqrt{\frac{f_{\text {мережі }}^{2}}{X_{l} / X_{c}}}=\sqrt{\frac{50^{2}}{\frac{22,1}{0,23}}}=490,3 \text { Гц. }
$$

Отже, фільтр налаштований на фільтрацію 10 гармоніки і вище.

Знімаємо характеристики установки без фільтруючого дроселя, зображуємо їх на (рис.4, рис.5):

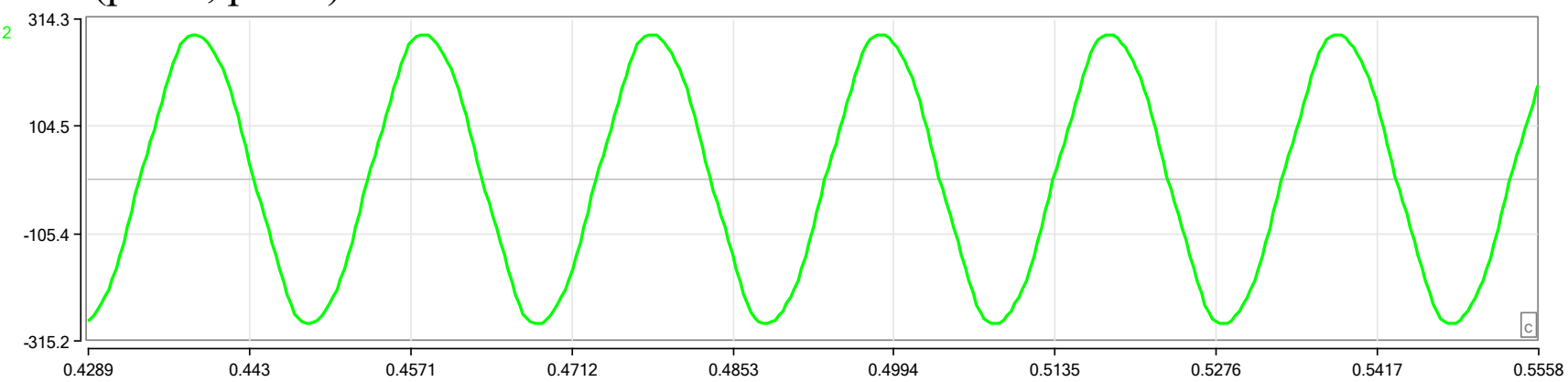

Рисунок 4. Графік синусоїди у вузлі навантаження (конденсаторна батарея без фільтра). 


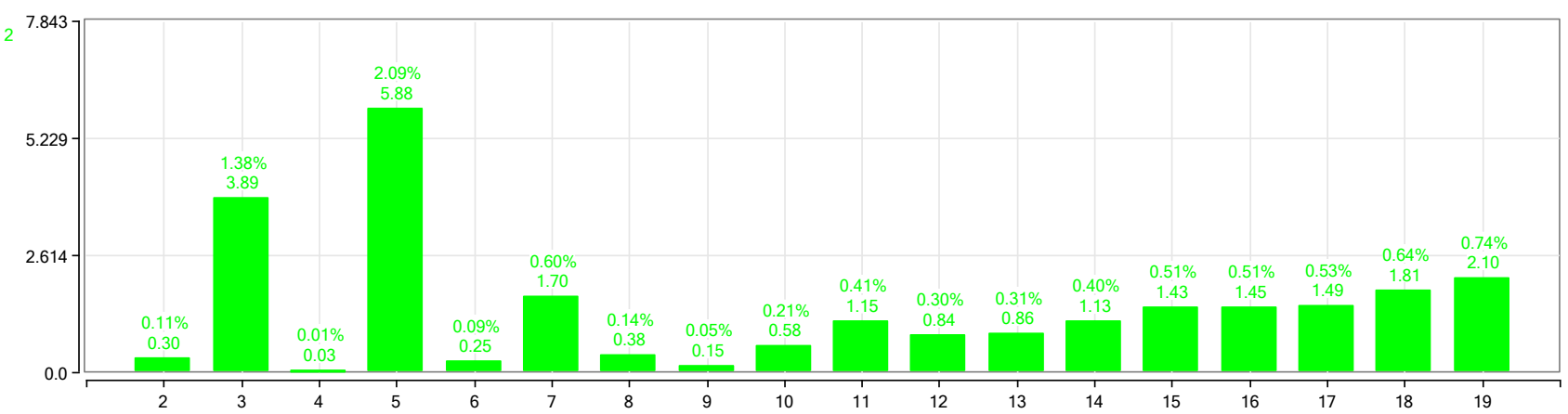

Рисунок 5. Гістограма гармонік напруги (конденсаторна батарея без фільтра).

Тепер знімаємо характеристики установки 3 фільтруючим дроселем, зображуємо їх на (рис.6, рис.7):

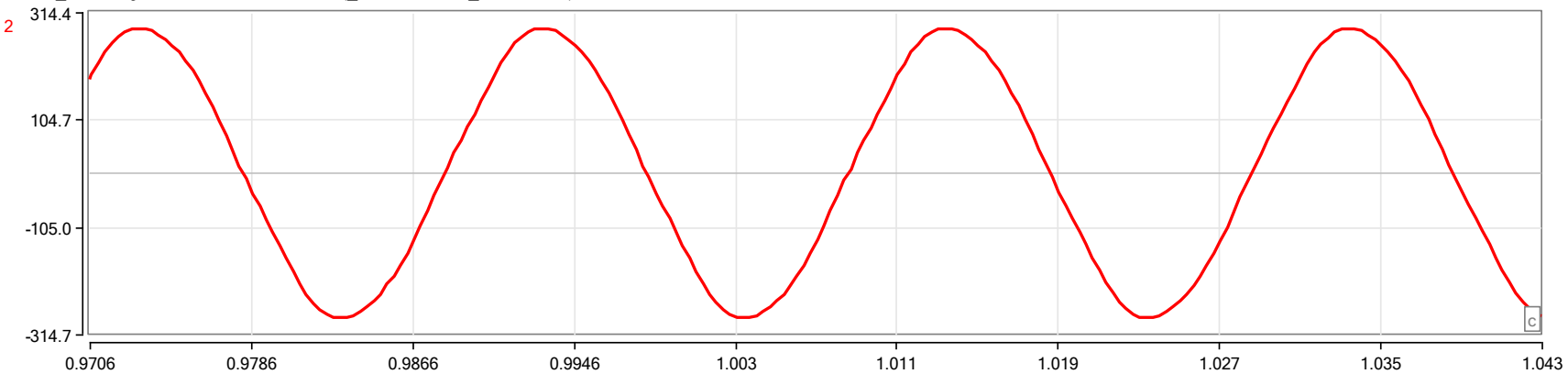

Рисунок 6. Графік синусоїди у вузлі навантаження (конденсаторна батарея 3 фільтром).

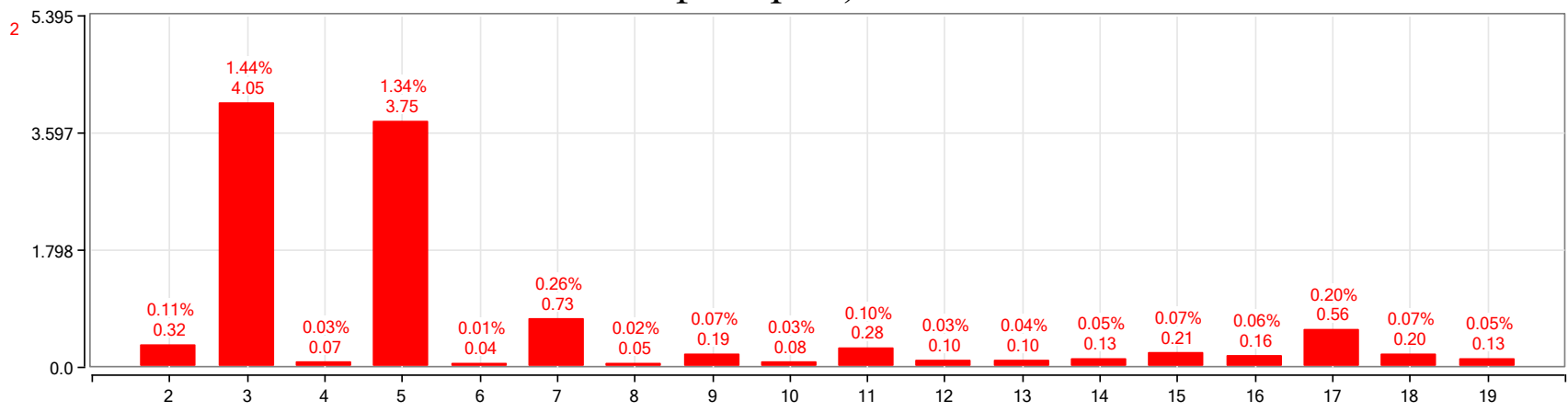

Рисунок 7. Гістограма гармонік напруги (конденсаторна батарея з фільтром).

\section{Висновок}

Як видно з гістограм гармонік напруги, фільтр виконує свої функції - (10) гармоніка зменшилась у сім разів, (11) та у чотири рази, (13) майже у дев'ять разів. Також 3 графіків роботи при ввімкненому активно-індуктивному навантаженні(тобто 3 увімкненою конденсаторною батареєю), можемо дійти висновку, що це $\epsilon$ найбільш правильний та збалансований режим роботи вузла навантаження.

\section{Список літератури}

1. Стогній Б.С., Кириленко О.В., Денисюк С.П. (2010) Інтелектуальні електричні мережі електроенергетичних систем та їхнє технологічне забезпечення. Технічна електродинаміка, (6), 44-50.

2. Жаркін А.Ф., Новський В.О., Малахатка Д.О. (2015) Гібридні фільтрокомпенсуючі перетворювачі для трифазних систем 3 нелінійними та змінними навантаженнями. Технічна електродинаміка, (4) , 48-52. 
3. Михальський В.М., Соболєв В.М., Чопик В.В., Шаповал I.А. Стратегія мінімізації небажаних складових миттєвої потужності із застосуванням різних топологій паралельних активних фільтрів. Технічна електродинаміка. 


\section{ИНФОРМАЦИОННАЯ БЕЗОПАСНОСТЬ В СИСТЕМАХ НЕПРЕРЫВНОЙ ИНТЕГРАЦИИ И ПОСТАВКИ}

Майстренко Андрей Андреевич,

студент

Национальный Авиационный Университет

Гулак Наталия Константиновна

К.т.н., доцент

Национальный Авиационный Университет

\section{Определение CI/CD}

Непрерывная интеграция - это методология разработки и набор практик, при которых в код вносятся небольшие изменения с частыми коммитами. И поскольку большинство современных приложений разрабатываются с использованием различных платформ и инструментов, то появляется необходимость в механизме интеграции и тестировании вносимых изменений.

C технической точки зрения, цель СI - обеспечить последовательный и автоматизированный способ сборки, упаковки и тестирования приложений. При налаженном процессе непрерывной интеграции разработчики с большей вероятностью будут делать частые коммиты, что, в свою очередь, будет способствовать улучшению коммуникации и повышению качества программного обеспечения.

Непрерывная поставка начинается там, где заканчивается непрерывная интеграция. Она автоматизирует развертывание приложений в различные окружения: большинство разработчиков работают как с продакшн-окружением, так и со средами разработки и тестирования.

Инструменты CI/CD помогают настраивать специфические параметры окружения, которые конфигурируются при развертывании. А также CI/CDавтоматизация выполняет необходимые запросы к веб-серверам, базам данных и другим сервисам, которые могут нуждаться в перезапуске или выполнении каких-то дополнительных действий при развертывании приложения.

Зрелая практика CI/CD позволяет реализовать непрерывное развертывание: при успешном прохождении кода через $\mathrm{CI} / \mathrm{CD}$-конвейер, сборки автоматически развертываются в продакшн-окружении. Команды, практикующие непрерывную поставку, могут позволить себе ежедневное или даже ежечасное развертывание. Хотя здесь стоит отметить, что непрерывная поставка подходит не для всех бизнес-приложений.

Непрерывная интеграция улучшает коммуникации и качество и при этом разработчики часто коммитят свой код в репозиторий исходного кода. При небольших изменениях проще выявлять дефекты и различные проблемы, чем при больших изменениях, над которыми работали в течение длительного периода времени. Кроме того, работа с короткими циклами коммитов уменьшает 
вероятность изменения одной и той же части кода несколькими разработчиками, что может привести к конфликтам при слиянии.

Команды, внедряющие непрерывную интеграцию, часто начинают с настройки системы контроля версий и определения порядка работы. В целях безопасности исходного кода и защиты его от утечек нормальной практикой является контроль доступа к репозиторию с предоставлением доступа через ssh.

Этап сборки заключается в автоматизации упаковки необходимого программного обеспечения, базы данных и других компонент. Например, если вы разрабатываете Јava-приложение, то СI упакует все статические файлы, такие как HTML, CSS и JavaScript, вместе с Java-приложением и скриптами базы данных.

CI не только упакует все компоненты программного обеспечения и базы данных, но также автоматически выполнит модульные тесты и другие виды тестирования.

Большинство CI/CD-инструментов позволяет запускать сборку вручную, по коммиту или по расписанию. Командам необходимо обсудить расписание сборки, которое подходит для них в зависимости от численности команды, ожидаемого количества ежедневных коммитов и других критериев. Важно, чтобы коммиты и сборка были быстрыми, иначе долгая сборка может стать препятствием для разработчиков, пытающихся быстро и часто коммитить.

Непрерывная поставка - это автоматическое развертывание приложения в целевое окружение. Обычно разработчики работают с одним или несколькими окружениями разработки и тестирования, в которых приложение развертывается для тестирования. Для этого используются такие CI/CD-инструменты как Jenkins, CircleCI, AWS CodeBuild, Azure DevOps, Atlassian Bamboo, Travis CI.

Типичный CD-конвейер состоит из этапов сборки, тестирования и развертывания. Более сложные конвейеры включают в себя следующие этапы:

- Получение кода из системы контроля версий и выполнение сборки.

- Настройка инфраструктуры, автоматизированной через подход “инфраструктура как код”.

- Копирование кода в целевую среду.

- Настройка переменных окружения для целевой среды.

- Развертывание компонентов приложения (веб-серверы, АРІ-сервисы, базы данных).

- Выполнение дополнительных действий, таких как перезапуск сервисов или вызов сервисов, необходимых для работоспособности новых изменений.

- Выполнение тестов и откат изменений окружения в случае провала тестов.

- Логирование и отправка оповещений о состоянии поставки.

Например, в Jenkins конвейер определяется в файле Jenkinsfile, в котором описываются различные этапы, такие как сборка (build), тестирование (test) и развертывание (deploy). Там же описываются переменные окружения, секретные 
ключи, сертификаты и другие параметры, которые можно использовать в этапах конвейера. В разделе post настраивается обработка ошибок и уведомления.

B более сложном CD-конвейере могут быть дополнительные этапы, такие как синхронизация данных, архивирование информационных ресурсов, установка обновлений и патчей. CI/CD-инструменты обычно поддерживают плагины. Например, у Jenkins есть более 1500 плагинов для интеграции со сторонними платформами, для расширения пользовательского интерфейса.

При использовании CI/CD-инструмента разработчики должны убедиться, что все параметры сконфигурированы вне приложения через переменные окружения, как минимум, это повысит уровень безопасности данной системы. $\mathrm{CI} / \mathrm{CD}$-инструменты позволяют устанавливать значения этих переменных, маскировать пароли и ключи учетных записей, а также настраивать их во время развертывания для конкретного окружения.

Также в CD-инструментах присутствуют дашборды и отчетность. В случае сбоя сборки или поставки они оповещают об этом. При интеграции CD c системой контроля версий и agile-инструментами облегчается поиск изменений кода и пользовательских историй, вошедших в сборку.

Многие команды, использующие CI/CD-конвейеры в облаках используют контейнеры, такие как Docker, и системы оркестрации, такие как Kubernetes. Контейнеры позволяют стандартизировать упаковку, поставку и упростить масштабирование и уничтожение окружений с непостоянной нагрузкой.

Есть множество вариантов совместного использования контейнеров, инфраструктуры как код и $\mathrm{CI} / \mathrm{CD}$-конвейеров.

При стандартизации сборки образов контейнеров Docker есть множество хороших практик, которых рекомендуют придерживаться в целях безопасности.

Основными из них являются:

- Использование стандартизированного интерфейса для ввода секретов

- Создание политики RBAC для непрерывного управления секретами

- Аутентифицирование доступа с помощью идентификационных данных компьютера

- Использование передовых методов безопасности для уменьшения вероятности взломов

- Организация аудита доступа к секретам

- Использование многоэтапных сборок Docker-контейнеров

Рассмотрим немного детальнее каждых из пунктов:

1) Как правило, для секретов используют специальные хранилища секретов(по типу Azure Key Vault). Интерфейс в этом хранилище является стандартизированным, сами секреты хранятся там в закрытом виде, а получение доступа к ним осуществляется по названию ключа(заголовок или тег). 
2) В такого рода хранилищах есть возможность настройки ролевого доступа(RBAC), что уменьшает вероятность утечки секретов и учётных данных.

3) Рекомендуется использовать доменные учётные записи с жёстко прописанными правами доступа, при чём сам процесс осуществления доступа рекомендуется привязывать к конкретной стандартизированной для этого машине.

4)Сама инфраструктура должна соответствовать последним трендам безопасности, как минимум в рамках бюджета и здравого смысла. Рекомендуется иметь последние стабильные версии операционных систем, ПО и установленные важные патчи базопасности, грамотно сконфигурированные фаерволы, IPS/IDS и, возможно, SIEM-систему. Разумеется, для каждой инфраструктуры рекомендации могут отличаться, но направление понятно.

5) Включено логирование в режиме аудита для доступов к секретам. Хранилища секретов такой функционал предоставляют.

О многоэтапной сборке Docker-контейнеров поговорим немного подробнее.

Docker-контейнер - это минималистичный образ операционной системы, только с необходимыми утилитами для выполнения нужных функций. Одними из основных свойств такого образа являются стандартизированность и компактность.

Приведём пример: нужен образ системы с предустановленным Python, модулями к нему, веб-сервер Арасһе и само веб-приложение. В таком случае пишут Dockerfile, в котором шаг за шагом описывается процесс сборки контейнера на основе, например Ubuntu или любой другой подходящей системы, и конвейером описывается предустановка нужного ПО и утилит, необходимых для работы. Наиболее распространенная практика - просто последовательно установить ПО и утилиты, веб-сервер, скопировать исходники приложения, собрать его в нужный вид и установить на веб-сервер. После этого контейнер запускают и пользуются веб-приложением.

К такому подходу есть ряд вопросов в плане безопасности.

Первый из них - копирование исходников из репозитория прямо в контейнер и дальнейшая сборка приложения. В таком случае исходники или их следы могут остаться в самом контейнере, что является недопустимым. В данном случае рекомендуется использовать многоэтапную сборку. Что это значит?

При многоэтапной сборке сначала собирается образ системы как отдельный этап сборки(stage, стейдж), в котором устанавливаются нужные для сборки приложения инструменты, скачиваются исходники, происходит сборка и упаковка готового приложения как артефакт. На следующем этапе устанавливаются нужное ПО для функционирования веб-сервера и самого приложения, загружается артефакт с готовым приложением с предыдущего этапа и разворачивается для дальнейшего использования.

В таком случае в конечном образе-контейнере не останется следов исходного кода, что сильно повысит кредит безопасности системы. 


\section{Список литературы}

1. What is a $\mathrm{CI} / \mathrm{CD}$ pipeline? [Електронний pecypc] - Режим доступу до pecypcy: https://www.redhat.com/en/topics/devops/what-cicd-pipeline.

2. CI/CD concepts [Електронний pecypc] - Режим доступу до ресурсу: https://docs.gitlab.com/ee/ci/introduction/.

3. What is $\mathrm{CI} / \mathrm{CD}$ ? Continuous integration and continuous delivery explained [Електронний ресурс] - Режим доступу до ресурсу: https://www.infoworld.com/article/3271126/what-is-cicd-continuous-integration-andcontinuous-delivery-explained.html.

4. Use multi-stage builds [Електронний ресурс] - Режим доступу до ресурсу: https://docs.docker.com/develop/develop-images/multistage-build/. 


\title{
ПРОГНОЗУВАННЯ ТЕХНІЧНОГО СТАНУ ЕЛЕКТРОДВИГУНІВ В УМОВАХ ЕКСПЛУАТАЦЇ
}

\author{
Потапенко Микола Валентинович \\ к.т.н., старший викладач кафедри енергетики і автоматики \\ ВП НУБіП України «Бережанський агротехнічний інститут» \\ м.Бережани, Україна
}

\section{Шаршонь Віталій Любомирович \\ асистент кафедри енергетики і автоматики ВП НУБіП України «Бережанський агротехнічний інститут» м.Бережани, Україна}

Прогнозування технічного стану електродвигунів полягає у визначенні їх майбутнього стану на підставі вивчення тих чинників, від яких цей стан залежить. Прогнозування може здійснюватися як в процесі розробки, так і в період експлуатації електродвигунів. В останньому випадку метою прогнозування $\epsilon$ своєчасне виявлення несприятливого стану електродвигуна i розробка рекомендацій щодо підвищення рівня його надійності.

Експлуатація електродвигунів, які знаходяться в незадовільному технічному стані призводить:

- до прямих фінансових втрат, пов'язаних 3 непрогнозованим виходом їх 3 ладу та викликаним цим порушенням технологічного процесу;

- до значних (близько 5\%) непрямих непродуктивних витрат електроенергії, які зумовлені підвищеним електроспоживанням.

У практиці експлуатації термін служби електродвигунів, що застосовуються в сільськогосподарському виробництві та їх вузлів $\epsilon$ значно менший ніж в електродвигунів, що застосовуються в інших галузях промисловості. Основною причиною виходу з ладу є низький рівень технічного обслуговування і поточного ремонту, низької ефективності існуючих способів i засобів діагностичного контролю, а також складні умови експлуатації в сільському господарстві.

Прогнозування технічного стану електродвигунів в умовах експлуатації $\epsilon$ досить складним завданням. Це пов'язано з тим, що на їх стан впливає поєднання великого числа факторів. Деякі з них є детермінованими, а деякі з них мають випадкову складову. Вплив будь-який з цих складових в кожному конкретному випадку може бути переважаючим, що створює певні труднощі в прогнозуванні технічного стану.

Основним завданням прогнозування $є$ визначення залишкового ресурсу електродвигунів. Своєчасне прогнозування їх залишкового ресурсу в умовах експлуатації дозволяє скоротити трудомісткість ремонтних робіт, визначити терміни поточних ремонтів або терміни заміни, а також встановити строки періодичності проведення технічного обслуговування і ремонту [1].

Прогнозування залишкового ресурсу дає можливість певною мірою передбачити можливі пошкодження i відмови електродвигунів. За даними 
прогнозу експлуатаційна служба сільськогосподарського підприємства може прийняти організаційно-технічні заходи, що виключають простої технологічного обладнання або визначити терміни проведення капітального ремонту.

Існує декілька методів прогнозування: метод лінійного прогнозування, екстраполяційний, інтерполяційний та ін. [2]. Кожен з цих способів має свої переваги і недоліки. Одним 3 основних недоліків цих методів $є$ складність практичної реалізації прогнозу про стан електрообладнання на конкретних сільськогосподарських об'єктах, які характеризуються різноманітними умовами експлуатації. Для електротехнічної служби сільськогосподарських підприємств необхідний досить простий метод, що дозволяє без складних математичних розрахунків отримати прийнятні результати для практичної реалізації.

Достатньо зручним методом прогнозування $€$ розрахунок ймовірнісних характеристик надійності, які можуть бути отримані за статистичними даними [3]. Для цього збираються дані про кількість відмов електрообладнання, яке знаходиться на об'єктах сільськогосподарського виробництва за певний календарний проміжок часу (квартал, рік і т.д.). Далі за статистичними даними визначаються ймовірнісні характеристики надійності: ймовірність безвідмовної роботи $P(t)$, інтенсивність відмов $\lambda(t)$ для вибраного інтервалу часу.

Результат прогнозування отримують у вигляді ймовірності того, що зазначені характеристики надійності будуть знаходиться в заданому діапазоні, тобто у вигляді ймовірності:

$$
P\left(y_{\text {nоч }} \leq y \leq y_{\text {zp }}\right),
$$

де $y$ - вибраний параметр надійності; $y_{\text {поч }}, y_{z p}$ - межі зміни параметра надійності за нормативними даними.

Ймовірнісні характеристики надійності електродвигунів, які підлягають ремонту визначаються за виразами:

$$
\begin{gathered}
P(t)=e^{-\lambda t}, \\
\lambda(t)=\frac{\sum_{i=1}^{n} n(t)}{N_{0} \cdot \Delta t},
\end{gathered}
$$

де $n(t)$ - число відмов за проміжок часу $\Delta t$, що отримано за статистичними даними; $N_{0}$-загальна кількість встановлених електродвигунів на об'єкті.

Таким чином, завдання експлуатаційної служби сільськогосподарського підприємства полягає в тому, що на основі обробки експлуатаційної інформації щодо інтенсивності відмов, отриманої за статистичними даними, прогнозувати настання моменту граничного стану електродвигунів та вжити заходів для виключення можливості появи несправностей і 3 подальшим зняттям його 3 експлуатації для проведення ремонту.

\section{Список літератури:}

1. Губаревич О. В., Невзлін Б.І. Надійність і діагностика електрообладнання: Навчальний посібник. Луганськ: Вид-во СНУ ім. В. Даля, 2004. 156 с. 


\section{TRENDS IN THE SCIENTIFIC DEVELOPMENT}

2. Кирса В.И. Прогнозирование технического состояния машин. К.: Урожай, 1978. $72 \mathrm{c}$.

3. Коваленко И.Н. Расчет вероятностных характеристик систем. К.: Техніка, $1982.95 \mathrm{c}$. 


\section{ЗАГАЛЬНА ОРГАНІЗАЦІЙНА НАУКА О.О. БОГДАНОВА - ТЕКТОЛОГІЯ-ОСНОВА ТЕОРІЇ СИСТЕМ ТА МЕТОДОЛОГЇ̈}

Савенко Володимир Іванович канд. техн. наук, д.т.н.. доктор будівництва. професор Київський національний університет будівництва і архітектури (КНУБА)

Гончаренко Тетяна Андріївна канд..техн.наук, доцент КНУБА

Клюсва Вікторія Василівна асистент КНУБА

\section{Полосенко Олександр Васильович аспірант КНУБА}

\section{Победа Сергій Сергійович}

аспірант

О.О. Богданов значно випередив час у своїх творчих пошуках та здобутках. На жаль, сьогодні у підручниках вищої школи з організації та управління важко знайти згадку чи посилання на праці О.О.Богданова, який по праву $\epsilon$ засновником цього напрямку в науці. Настав час віддавати борги.

Тектологія О.О. Богданова $є$ прототипом сучасної методології та кібернетики і була опублікована ще у 1912 році.[1,4]

Творчість О.О.Богданова, задачі, предмет досліджень та методи тектології - це, перш за все, організаційна діяльність. Доцільна організація діяльності (взаємодії) певної сукупності елементів та умови синергічної взаємодії елементів системи з позицій загальної організаційної науки як ніколи актуальна сьогодні. Загальні властивості об'єктів динамічного (мінливого) світу, закономірності, виявлені О.О. Богдановим, дали людству потужний інструмент пізнання природи та суспільства і зокрема організаційного процесу як явища. Розв'язання будь-якої задачі - організаційний акт.[2,3]

Концепція системного підходу до аналізу явищ природи і соціуму, об'єднання спеціалізованих наукових методів (теорія графів, теорія систем, теорія фірми та ін.), інформаційні технології - ефективні засоби для вирішення завдань загальної організаційної науки.

Олександр Олександрович Богданов (Малиновський) 1873-1928, випускник Харківського університету вніс неоціненний доробок у вітчизняну і світову науку, проте широкому загалу вчених його ідеї залишилися невідомі. Основні ідеї "Тектології", загальної організаційної науки, отримали подальший розвиток в сучасній методології і загальній теорії систем. Більш глибоке сучасне 
розуміння і оцінка спадщини Олександра Олександровича викладено в методологічній реконструкції Тектології проведеній О.С. Анісімовим в його книзі «Організаційні онтології і аналіз систем діяльності, О.О. Богданов і сучасна методологія ".[1]

Олександр Олександрович Богданов народився 10 (22) серпня 1873 p. Він був економістом, біологом, математиком, лікарем, філософом і революціонером. Життя О.О. Богданова (справжнє прізвище Малиновський) цікаве, повчальне, мінливе і глибоко суперечливе. Студентом, почавши займатися революційною діяльністю, він від прихильності до ідей народовольчества пройшов шлях до члена ЦК РСДРП від більшовиків (1905-1910рр.). Був соратником Леніна і брав активну участь у становленні більшовицької партії, а в 1911 р розчарувавшись, взагалі відійшов від політичної роботи.

Наукова творчість Богданова відрізняється динамікою і широтою інтересів. Маючи медичну освіту, він активно займався громадськими науками. Переробляючи і пропагуючи "Капітал" Маркса, Богданов створив "Короткий курс економічної науки" [4], а потім в співавторстві "Курс політичної економії" [4]. До філософських праць відноситься його книга "Основні елементи історичного погляду на природу" [2], де він намагався з'єднати марксизм з ідеями Е. Маха. Широко відома критика цієї спроби Леніним в роботі "Матеріалізм і емпіріокритицизм". Однак різка і безкомпромісна відповідь Богданова на цю критику замовчувалася і не обговорювалася. О.О. Богданов створив також кілька художніх творів. Після Жовтневої революції Богданов брав активну участь в науковому та громадському житті, будучи членом ЦК Пролеткульту і членом Президії Комуністичної академії, в створенні якої він брав активну участь. У 1926 р Богданов очолив створений ним перший в світі Інститут переливання крові.Вважаючи переливання крові "могутнім" засобом медицини, Богданов ставив перед собою не тільки науково-дослідні, але і практичні завдання. Однак найбільш ризиковані досліди він вважав за краще проводити на собі. Це саме по собі, свідчить про неабиякі особисті якості, про принциповість і кришталеву чесність. Дванадцятий експеримент закінчився трагедією, О.О. Богданов важко захворів і 7 квітня 1928p. помер. Широкий світогляд і спектр інтересів, енциклопедична освіченість, винятковий життєвий досвід і невичерпна особиста енергія дозволили йому сформулювати основні ідеї системного підходу, які до сьогоднішнього дня мають фундаментальне наукове значення .[2,3] Книга "Тектологія. Загальна організаційна наука "[2] - головна теоретична робота Богданова, яка за змістом набагато випередила свій час, але була незрозуміла i не прийнята сучасниками. Розвиток наукового знання показав, що Богданов передбачив багато положень кібернетики, загальної теорії систем і сучасної методологіi.[3] Він випередив роботи Н. Вінера і Л. фон Берталанфі більш ніж на 30 років і по праву вважається автором першого варіанту загальної теорії систем і провісником кібернетики [ 2 ]/.

Безумовно, системні уявлення не $є$ його відкриттям. Слово "система" з'явилося в Стародавній Греції і спочатку означало поєднання, пристрій, організація, устрій, союз. Спочатку воно було пов'язане з формами соціальноісторичного буття, пізніше поняття порядку було перенесено на Всесвіт.[4] В 
античній філософії термін "система" характеризував упорядкованість і цілісність природних об'єктів, а термін "синтагма" - впорядкованість і цілісність штучних об'єктів. Тектологія в буквальному перекладі з грецької означає "вчення про будівництво". Сам Богданов розумів тектологію як розвинену і узагальнену методологію науки. Він ставив завдання "вироблення універсально-загальних організаційних методів, які поклала б кінець анархії і дробленню організаційного досвіду" [2 ]

Тектологію Богданов розглядає, як науку що знаходиться в тісному зв'язку з трьома основними циклами наукового знання: 3 науками математичними, природними (фізико-біологічними) і суспільними.[3,5] "Вона (тектологія ) є по суті, їх розвинена узагальнена методологія" [ 3 ] /. Методологічну спрямованість Богданова продовжили сучасні методології. Найбільш яскравим і послідовним представником методології був ідеолог і лідер Московського методологічного гуртка Г.П.Щедровицький (1929-1994рр.), Під його керівництвом разом 3 роботами Маркса, Фіхте, Канта, Гегеля піддавався аналізу комплекс ідей і система поглядів О.О . Богданова. Організаційна позиція, введена Богдановим, виявлення, вивчення, конструювання організованостей, допомогла аналізу організаційної діяльності, створенню необхідних у цій діяльності методів, знань. У своєму розвитку ця ідея привела до необхідності вивчення в методології теорії діяльності та розумової складової організаційної діяльності -

Сучасна методологія вирішила проблему, поставлену Богдановим по розробці символічних, абстрактних схем, які виражають узагальнені структурні відносини 3 такою ж формальною чистотою, як в математиці відношення величин.[1,5] У методологічній практиці використовуються схематичні зображення, які виражають діяльні, просторово-діяльні і системо-діяльні організованості. У цій лінії розробок виняткове місце займає розроблена Анісімовим О.С. абетка теорії діяльності - містить парадигму теоретикодіяльнісної мови.[1,6] Використання абетки дозволяє конструювати схеми як формули в математиці під будь-яку організаційну задачу.

Анісімов О.С. називає Богданова "першим методологом" [ 1], який сформулював проблему, вихідну для методологічного простору. Об'єднуючи спеціалізовані наукові методи, вирішуючи питання універсумально-практичного характеру організованості форм, О.О. Богданов створив унікальну концепцію системного підходу до аналізу явищ в природі і соціумі.[2,3] "Тектологія" по поставленим завданням, за своїм підходом, по використовуваних методів розв'язання задач і проблем $є$ прототипом сучасної методології. Не

випадковим $є$ також посилання на те, що людина повинна вчитись

у Природи та Вищого Розуму, бо системи створені Природою (нап-

риклад сім*ї організованих тварин) значно перевершують своєю

досконалістю створені людиною системи. Геном досконалості природне творіння і людині ще треба багато над собою працювати, щоб досягти навіть відомих, створених Природою систем, не говорячи про надконцептуальне управління і діяльність на рівнях більш високих, ніж людський рівень розуму на даному етапі розвитку людства.[5,6] 


\section{Література}

1. Анісімов О.С. Організаційні онтології і аналіз систем діяльності (О.О. Богданов і сучасна методологія) .- М .: ФГТУ Росак АПК, 2002.

2. Богданов О.О. Тектологія. Загальна організаційна наука. Кн. 1 - $M$.: Економіка, 1989.

3. Богданов О.О. Тектологія. Загальна організаційна наука. Кн. 2 -.: $M$ Економіка, 1989.

4.Савченко О.В. Тектологія О.О. Богданова як прототип сучасної методології // Матеріали міжвузівської науково-практічної конференції молодих вчених "Ідеї Богданова А.А. і сучасність". - М., РАГС, 2003

5. Савенко В.І. Клюєва В.В. ma ін.. Ділова досконалість, якість, енергозберігаючі технології - ефективні засоби розвитку підприємства / // Управління розвитком складних систем. - 2016. - No26. - С. 187 - 193.

6. Калита П.Я. Грани качества УАЯ-К. 2014 -с 366 


\title{
“ЕКСПЕРИМЕНТАЛЬНІ ДОСЛІДЖЕННЯ ГІДРОДИНАМІЧНИХ, ЕНЕРГЕТИЧНИХ І МАСООБМІННИХ ХАРАКТЕРИСТИК ЕЖЕКТОРІВ ДЛЯ ОЧИЩЕННЯ ПРИРОДНИХ І СТІЧНИХ ВОД"
}

\author{
Філіпович Юрій Юрійович \\ Доцент кафедри Гідроенергетики, \\ теплоенергетики та гідравлічних машин, \\ кандитат технічних наук, Навчально-наукового \\ Інституту водного господарства та \\ природооблаштування \\ Національного університету водного \\ господарства та природокористування \\ Мишкало Тетяна Іванівна \\ студентка 5-го курсу гідроенергетики \\ Навчально-наукового \\ Інституту водного господарства та \\ природооблаштування \\ Національного університету водного \\ господарства та природокористування
}

\section{1. Теоретичні основи гідродинаміки ежекторних пристроїв.}

Принцип дії струменевих насосів заключається в безпосередній передачі енергії від робочої рідини , яка володіє великим запасом енергії ,до іншої яка водолідіє меншим запасом енергії. Цей принцип, здійснюється шляхом безпосереднього втягнення в рух частинок транспортуємої рідини частинками робочої рідини, яка рухається з великою швидкістю, виключає необхідність проміжних механізмів, які використовуються, наприклад, в поршневих і центробіжних насосах.

Принцип дії водоструменевого насоса заключається в наступному (рис.1). по напірній трубі 1 робоча вода підводиться до сопла 2, через яке протікає в змішувальну камеру 3 , а потім через дифузор 4 подається в робочий трубопровід 5. Надходячи в звужений переріз дифузора 4, струмінь води із напірної труби 1 набуває великої швидкості, в результаті чого тиск в даній області падає нижче атмосферного (енергія тиску переходить в кінетичну енергію). Завдяки вакууму вода 3 нижнього резервуара піднімається по всмоктувальній трубі 6 в змішувальну камеру, де змішується з робочою водою і разом з нею подається в робочий трубопровід 5.

Для встановлення гідравлічених залежностей між між різними параметрами струмини в водоструменевому насосі напишемо рівняння Бернуллі для перерізів 1-1 і 0-0, вказаних на схемі цього насоса (див. Рис.1), позначив $v_{1}, \rho_{1}$ i $\omega_{1}$ 
відповідно швидкість, тиск і площа живого перерізу в перерізі 1-1, а через позначив $v_{0}, \rho_{0}$ i $\omega_{0}$ - аналогічні параметри струмини в перерізі 0-0 на виході 3 сопла :

$$
\begin{aligned}
& \frac{\rho_{1}}{\gamma}+\frac{v_{1}^{2}}{2 \cdot g}+h=\frac{\rho_{0}}{\gamma}+\frac{v_{0}^{2}}{2 \cdot g}+\varsigma \frac{v_{0}^{2}}{2 \cdot g}, \quad \text { Згідно умови нерозривності струмини } \\
& v_{0}=v_{1} \frac{\omega_{1}}{\omega_{0}} .
\end{aligned}
$$

де $\mathrm{h}$ - вертикальна відстань між перерізами 1-1 і 0-0.

Тоді рівняння Бернуллі запишеться так :

$$
\frac{\rho_{1}}{\gamma}+\frac{v_{1}^{2}}{2 \cdot g}+h=\frac{\rho_{0}}{\gamma}+\frac{v_{1}^{2}}{2 \cdot g}(1+\varsigma) \frac{\omega_{1}^{2}}{\omega_{0}^{2}},
$$

Звідки

$$
\frac{\rho_{0}}{\gamma}=\frac{\rho_{1}}{\gamma}+h+\frac{v_{1}^{2}}{2 \cdot g}\left[1-(1+\varsigma) \frac{\omega_{1}^{2}}{\omega_{0}^{2}}\right],
$$

Для створення вакууму в змішувальній камері необхідно, $\rho_{0} / \gamma$ було менше нуля. При йьому з однієї сторони, повинна виконуватись нерівність

$(1+\varsigma) \frac{\omega_{1}^{2}}{\omega_{0}^{2}}>1, \quad$ звідки $(1+\varsigma) \omega_{1}^{2}>\omega_{0}^{2}$,

а $з$ іншої сторони, повинна виконуватись наступна умова :

$$
\begin{array}{r}
\frac{\rho_{0}}{\gamma}+h<\frac{v_{1}^{2}}{2 \cdot g}\left[1-(1+\varsigma) \frac{\omega_{1}^{2}}{\omega_{0}^{2}}\right], \\
\text { звідси } \frac{v_{1}^{2}}{2 \cdot g}>\frac{\frac{\rho_{1}}{\gamma}+h}{1-(1+\varsigma) \frac{\omega_{1}^{2}}{\omega_{0}^{2}}} .
\end{array}
$$

Залежності (1.1) і (1.2) встановлюють зв'язок між основними гідравлічними елементами струмини і визначають умови роботи водоструменевого насоса.

\section{2. Використання ежекторів в системах водопостачання і водовідведення} та в будівництві.

Ежектори, або струменеві апарати знайшли широке застосування у народному господарстві. Їх використовують при очищенні берегових колодязів у системі водопостачання, при розробці грунту методом гідромеханізації, застосовуються вони в установці вакуумного зниження грунтових вод, на насосних станціях - для заливу основних насосів, на ГЕС в системі технічного водопостачання.

\section{Також ежектори знайшли свос застосування при штучній ежекційній} аерації природних і стічних вод.

Кисневий режим водойм відноситься до числа важливих факторів, які визначають інтенсивність процесів самоочищення, він характеризується концентрацією розчиненого у воді кисню. 
Нерідко в результаті потраплення в водойму органічних речовин, які знаходяться в стічних водоах, вміст розчиненого в воді кисню падає нижче норми, встановленої для даної категорії користувачів. Крім цього, концентрація розчиненого кисню може знижуватися в період кригостою, коли реаерація відсутня. Це призводить до замору риби і інших водних організмів.

Промисловість і сільське господарство пов'язане з використанням великої кількості води із водойм і, відповідно, утворення стічних вод, які скидуються в них. В зв'язку з цим важливою $є$ проблема скиду в водний об'єкт стічних вод, наперед насичених киснем (наприклад, до концентрації 4-6г/ $\mathrm{M}^{3}$ ).

В зв'язку з насиченням води водойм і скидуємих в них стічних вод киснем використовують штучну аерацію, на яку витрачається значна кількість електроенергії. В теперішній час існує багато систем і типів штучної аерації, найбільш розпоширеними 3 яких для аерації природних і стічних вод $\epsilon$ механічна, пневматична i ежекційна. В вітчизняній і закордонній практиці накопичений значний досвід по створенню нових і вдосконаленню існуюючих систем аерації.

До недоліків пневматичної аерації слід віднести маожливість засмічення повітрепропусних приладів (наприклад, перфорованих трубопроводів або фільтрососів різних типів) i, як наслідок, необхідність їх видалення для профілактичного ремонту. Крім цього, монтаж повітрепропускного приладу необхідно здійснювати строго горизонтально 3 ціллю рівномірного виходу стиснутого повітря. Накінець, для пневматичної аерації необхідні прилади компресорної станції і прокладання повітряної магістралі, що веде за собою значні затрати .

До основних недоліків механічних аераторів відносяться складність їх конструкції і експлуатації, необхідність влаштування опорної або надійної якірної (для плавучих аераторів) систем, а також можливість травмування риби (особливо мальків) ротором і мішалкою, які обертаються безпосередньо в воді водойми, і низька надійність їх роботи.

Найбільш ефективним, простим і надійним по конструкції $є$ ежекційні аератори. Можемо відмітити, що до переваг ежекційних аераторів відносяться висока окислювальна здатність, яка досягає 5 кг $\mathrm{O}_{2} / \mathrm{M}^{3}$ води в час при

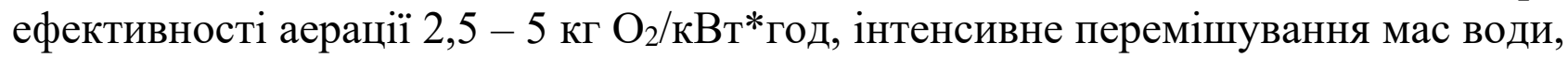
простота конструкції аераторів, можливвість використання в експлуатації серійно виговлених низьконапірних насосів, висока надійність системи аерації і простота ii обслуговування. Ежекційні аератори підсмоктують повітря 3 атмосфери, утворюють направлену вниз водоповітряну струмину, яка проникаючи в воду, захоплює додаткову кількість атмосферного повітря i забезпечує інтенсивне перемішування мас води, за рахунок чого досягається висока ефективність аерації, яка перевищує пневматичну аерацію в 4-5 раз і механічну - в 2-3 рази.

\section{3 Експериментальні дослідження ежекторів}

3.1Принципова схема установки для досліджень 
До складу дослідної вакуумної установки входить вакуумний котел, вакуум у якому може створюватися вакуум-насосом типу РМК (робоча характеристика останнього після багаторічної експлуатації відрізняється від заводської, і тому він умовно названий нами вакуумним насосом РМК-2*), або ежектором, який в свою чергу був оснащений трьома змінними соплами. Об'єм вакуумного котла становить 900 літрів. До вакуум-котла було під'єднано дві живильні труби 3 діаметрами 50 і 81,5 мм. Для дослідження робочого циклу вакуум-системи, вакуумний котел був оснащений вакуумметром та водомірним склом. До складу установки увійшли також відцентровий насос марки Д 320-50 (6 НДв-60), відцентровий насос марки КМ 90 / 35 та водомірний лотік.

Вакуумна установка оснащена двома вакуум-насосами (на рисунку показано лише один) 1 , а також ежектором із трьома змінними соплами. Для порівняння варіантів обладнання установки вона була оснащена двома живильними трубами 23 і 24, а в подальшому iii було дооснащено третьою живильною трубою діаметром 200 мм , тоді як звичайно живильна труба буває лише одна.

Об'єм вакуумного котла 16 становить 900 літрів (діаметр $\mathrm{D}_{K}=800$ мм, висота $\left.\mathrm{h}_{\mathrm{K}}=1800 \mathrm{мm}\right)$. Котел оснащено водомірним склом 13 та вакуумметром 15. До складу установки входят також відцентровий насос 7 марки Д 320-50 (6 НДв-60), відцентровий насос 17 марки КМ 90 / 35 з електродвигунами 12 та 18 та водомірний лотік.

Стенд, який знаходиться у насосній лабораторії є науково-дослідним. На ньому можна вирішувати різноманітні задачі: досліджувати робочий цикл вакуумної системи на насосних станціях, знімати характеристики вакуумних насосів, а також характеристики ежектора 3 трьома змінними соплами діаметрами $\mathrm{d}_{\mathrm{c}}=25,30$ і $35 \mathrm{mм}$.

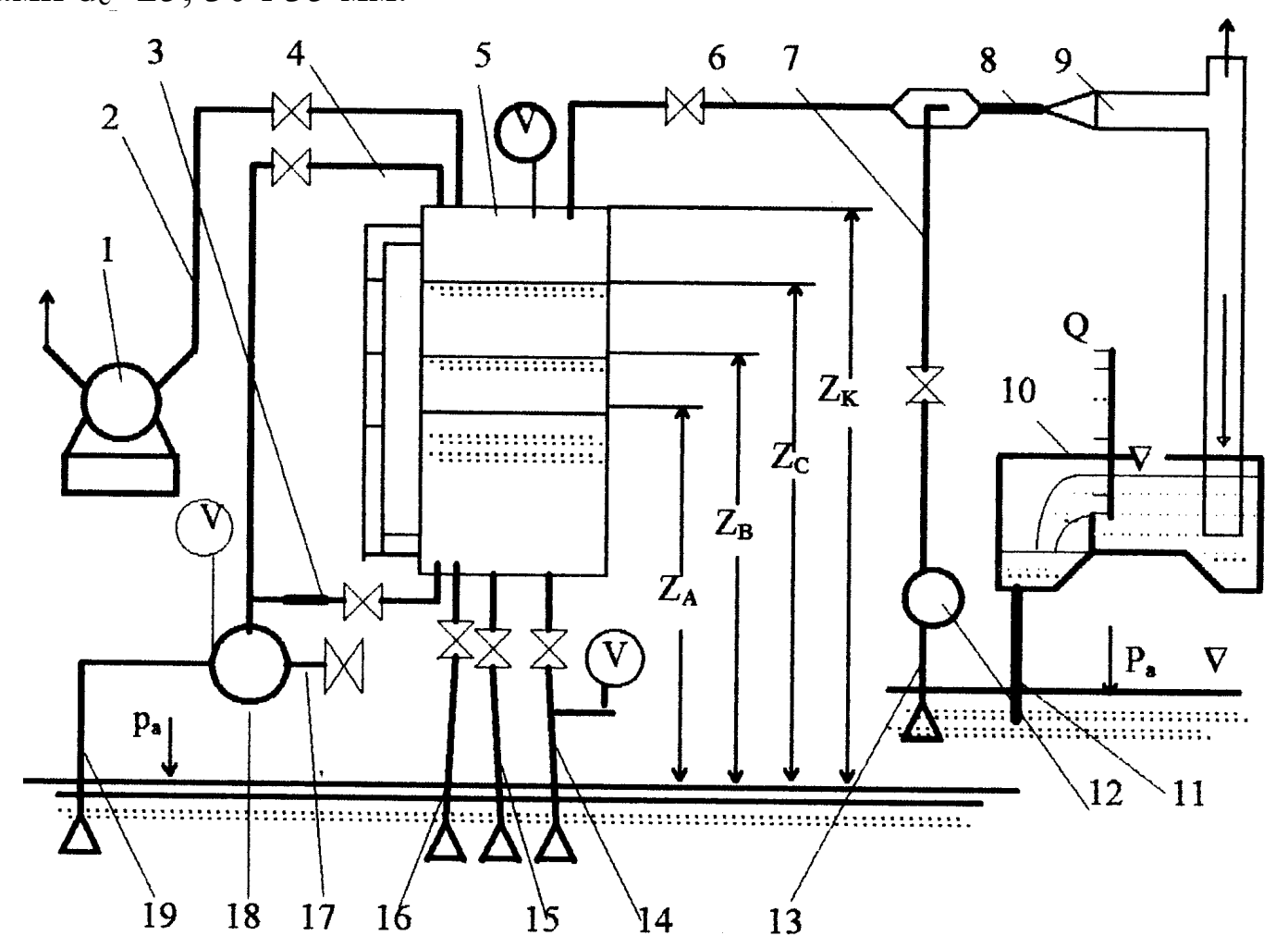

Рис. 1. Схема експериментальної вакуумної установки РДТУ: 
1 - вакуумний насос і його всмоктувальна комунікація 2;

3 і 4 - вакуумні комунікації відцентрового насоса;

5 - вакуумний котел;

6 - всмоктувальна комунікація ежектора;

7 - напірна труба відцентрового насоса, який живить водою ежектор;

8 - ежектор;

9 - труба, яка відводить гідроповітряну суміш від ежектора;

10 - витратомірний лотік ежектора;

11 - водоскидна труба витратомірного лотока;

12 і 13 - відцентровий насос, який живить ежектор і його всмоктувальна труба;

14, 15 і 16 - живильні труби вакуумного котла;

17 - напірна труба відцентрового насоса 18;

18 і 19 - відцентровий насос і його всмоктувальна труба.

Крім цього до складу експериментального стенду входять всмоктувальний 3 та напірний 4 трубопроводи вакуум-насоса, циркуляційний бачок 6 , вакуумні комунікації, оснащені пробковими кранами та манометр.

3 метою спостереження за заливом відцентрового насоса 7 на трубі для заливу насоса 8 влаштована прозора вставка 11. Труба для заливу 7 вмонтована у днище вакуумного бака 16.

Для подальших досліджень існуюча вакуумна установка у 1998 році була дооснащена вакуумним насосом марки RV 550-01-EЕ чеського виробництва та живильною трубою діаметром 200 мм довжиною 19,4 м.

Вакуумні комунікації ежектора та вакуумного насоса оснащені пробковими кранами миттєвої дії. Залив вакуум-насосів відбувається із напірних трубопроводів. Відліки часу ведуться з допомогою секундоміра 3 ціною поділки $0,2 \mathrm{c}$.

В процесі виконання досліджень застосовувалася наступна контрольновимірювальна апаратура:

- вакуум у вакуумному котлі вимірювався зразковими механічними вакуумметрами 3 ціною поділки 0,1 м;

- рівень води у котлі визначався за шкалою водомірного скла, яка має ціну поділки 1 мм;

- потужність електродвигунів відцентрових насосів вимірювалася ватметром;

- розміри вакуумного котла, вакуумних комунікацій та живильних труб вимірювалися металевою лінійкою з ціною поділки 1 мм.

Поряд із застосуванням вакуумного насоса використовується також і спосіб відсмоктування повітря із корпусу відцентрового насоса і його всмоктувального водоводу ежектором. Водоструменеві ежектори застосовуються тоді, коли на насосних станціях $є$ напірна система, яка не залежить від роботи самої станції.

\section{2 Методика досліджень}


Відбираємо в колбу з резервуару воду до проведення досліду. Записуємо номер колби в журнал досліджень. Заливаємо водою і вмикаємо у роботу відцентровий насос 12 при перекритому крані і закритій засувці . Потім поступово відкривають засувку до повного її відкривання. Коли режим роботи насоса установлюється і рівень води у лотку стає постійним у часі, знімаюють покази вакуумметра, миттєво відкривають кран i одночасно включають секундомір. Заміряні параметри $\mathrm{Q}_{\mathrm{p}} \mathrm{i} \mathrm{V}_{0}$ записується у журнал досліджень.

Через 10 секунд знімаюють нові покази вакууметра i роблять нове вимірювання витрати. Такі виміри 3 дотриманням прийнятого інтервалу часу тривають до тих пір, поки значення вакууму в котлі не досягне свого максимуму, про що буде свідчити припинення його подальшого зростання у часі. Паралельно до вимірювання вакууму робимо відбір води в колби при різних значеннях рівнів заповнення вакуумного котла 5 при цьому записуюючи номери колб і значення рівня води в журнал досліджень. В заповнених водою колбах визначають кількість розчиненого у воді кисню.

Досліди можна проводити при різних діаметрах сопл робочої струмини $\mathrm{dc}=25,30$

\section{3 Результати експериментальних досліджень}

Виконано по три серії дослідів (із зміною витрати води в ежекторі) при трьох різних значеннях діаметра сопла ежектора.

Отримані залежності витрати повітря від діаметра сопла ежектора свідчать, що із збільшенням діаметра сопла витрата повітря збільшується, але при зміні діаметра сопла із 30 на 35 мм характер кривої стає більш пологим. Проведені техніко-економічні розрахунки свідчать, що найбільш ефективним при даних розмірах вакуумної установки є діаметр сопла 30 мм. Залежність між витратою води і витратою води у ежекторі при різних значеннях діаметра сопла ежектора також підтверджує вищенаведене.

Коефіцієнт ежекції $\mathrm{K}$ - це співвідношення витрати повітря до витрати води в ежекторі. Досліди свідчать, що із збільшенням діаметра сопла ежектора коефіцієнт ежекції зменшується. Зменшення витрати повітря пояснюється зменшенням зазору між зовнішніми стінками сопла та внутрішніми стінками камери змішування.

Дата проведення $\quad 15.03 .02$

\begin{tabular}{|c|c|c|l|c|c|}
\hline & Кількість кисню & д досліду & & Витрата води,л/с & Рівень води,см \\
\hline 1$)$ & 10,248 & $\begin{array}{c}\text { до } \\
\text { досліду }\end{array}$ & & & \\
\hline 2$)$ & 8,968 & 1 дослід & D=35Mм & 13 & 8 \\
\hline 3$)$ & 10,297 & 2 дослід & & 13 & 12 \\
\hline 4$)$ & 10,297 & 2 дослід & & 13 & 60 \\
\hline 5$)$ & 10,717 & 2 дослід & 13 & 130 \\
\hline
\end{tabular}


Дата проведення 18.03 .02

\begin{tabular}{|c|c|c|l|c|c|}
\hline & Кількість кисню & N досліду & & Витрата води,л/с & рівень води,см \\
\hline 1$)$ & 9,58 & $\begin{array}{c}\text { до } \\
\text { досліду }\end{array}$ & & & \\
\hline 2$)$ & 9,42 & 1 дослід & $\mathbf{D = 3 5} \mathbf{M M}$ & 14 & 120 \\
\hline 3$)$ & 9,63 & 2 дослід & & 10 & 75 \\
\hline 4$)$ & 9,62 & 3 дослід & & 12 & 120 \\
\hline
\end{tabular}

Дата проведення 18.03 .02

\begin{tabular}{|c|c|c|l|c|c|}
\hline & Кількість кисню & N досліду & & Витрата води,л/с & рівень води,см \\
\hline 1$)$ & 9,62 & 1 дослід & & 14 & 70 \\
\hline 2$)$ & 9,87 & 1 дослід & $\mathbf{d = 3 0} \mathbf{M m}$ & 14 & 110 \\
\hline 3$)$ & 9,9 & 2 дослід & & 10 & 70 \\
\hline 4$)$ & 9,68 & 2 дослід & & 10 & 110 \\
\hline 5$)$ & 9,76 & 3 дослід & & 12 & 70 \\
\hline 6$)$ & 9,49 & 3 дослід & 12 & 110 \\
\hline
\end{tabular}

Дата проведення $\quad 19.03 .02$

\begin{tabular}{|c|c|c|l|c|c|}
\hline & Кількість кисню & $\begin{array}{c}\mathrm{N} \\
\text { досліду }\end{array}$ & & Витрата води,л/с & рівень води,см \\
\hline 1$)$ & 9,618 & $\begin{array}{c}\text { до } \\
\text { досліду }\end{array}$ & & & \\
\hline 2$)$ & 9,396 & 1 дослід & $\mathbf{d = 2 5} \mathbf{M m}$ & 10 & 70 \\
\hline 3$)$ & 9,526 & 2 дослід & & 8 & 70 \\
\hline 4$)$ & 9,774 & 3 дослід & & 6 & 70 \\
\hline & & & & & \\
\hline
\end{tabular}

15.03.03 При $\mathrm{d}=35 \mathrm{Mm}$

\begin{tabular}{|c|c|c|c|c|c|}
\hline \multirow{2}{*}{\begin{tabular}{|l} 
Час, \\
Сек \\
\end{tabular}} & \multicolumn{2}{|c|}{$\begin{array}{l}\text { Значення } \\
\text { вакуума }\end{array}$} & \multicolumn{2}{|c|}{ Рівень води } & \multirow{14}{*}{$\begin{array}{l}\text { Qпов }=0,0064 \\
\text { Qвод }=0,013\end{array}$} \\
\hline & 1 & 2 & 1 & 2 & \\
\hline & & $\mathrm{q}=13 \pi /$ & & & \\
\hline 0 & 3,2 & 3,2 & 3 & 2 & \\
\hline 10 & 3,25 & 3,35 & 10 & 6 & \\
\hline 20 & 3,4 & 3,5 & 19 & 18 & \\
\hline 30 & 3,48 & 3,6 & 30 & 28 & \\
\hline 40 & 3,58 & 3,7 & 40,5 & 39 & \\
\hline 50 & 3,8 & 3,82 & 50,5 & 49 & \\
\hline 60 & 3,9 & 3,9 & 60,5 & 59 & \\
\hline 70 & 4 & 4 & 70 & 69 & \\
\hline 80 & 4,06 & 4,1 & 80 & 79 & \\
\hline 90 & 4,15 & 4,2 & 90 & 89 & \\
\hline 100 & 4,28 & 4,27 & 100 & 99 & \\
\hline
\end{tabular}




\begin{tabular}{|l|l|l|l|l|}
\hline 110 & 4,36 & 4,35 & 110 & 109 \\
\hline 120 & 4,45 & 4,45 & 119 & 119 \\
\hline 130 & 4,55 & 4,58 & 129 & 129 \\
\hline 140 & 4,66 & 4,68 & 138 & 138 \\
\hline
\end{tabular}

18.03.0 при $\mathrm{d}=35 \mathrm{~mm}$

\begin{tabular}{|c|c|c|c|c|c|c|c|}
\hline Чac, & $\begin{array}{l}\text { Значенн } \\
\text { я }\end{array}$ & Рівень & \begin{tabular}{|l|} 
Значен \\
ня
\end{tabular} & $\begin{array}{c}\text { Рiвен } \\
\text { ь }\end{array}$ & \begin{tabular}{|l} 
Значен \\
ня
\end{tabular} & Рівень & \multirow{27}{*}{$\begin{array}{l}\text { При q=14л/с } \\
\text { Qпов }=0,0075 \\
\text { Qвод }=0,0140\end{array}$} \\
\hline Сек & $\begin{array}{l}\text { Вакуум } \\
\text { у }\end{array}$ & води & $\begin{array}{l}\text { вакуум } \\
\text { у }\end{array}$ & води & $\begin{array}{l}\text { Вакуум } \\
\text { y }\end{array}$ & води & \\
\hline & $\mathrm{q}=14 \pi / \mathrm{c}$ & & $\mathrm{q}=10 \pi / \mathrm{c}$ & & $\begin{array}{l}\mathrm{Q}=12 \pi / \\
\mathrm{c}\end{array}$ & & \\
\hline & 1 & 1 & 2 & 2 & 3 & 3 & \\
\hline 0 & 3,3 & 22 & 3,42 & 22 & 3,8 & 62 & \\
\hline 10 & 3,5 & 32 & 3,48 & 25 & 3,85 & 66 & \\
\hline 20 & 3,65 & 46 & 3,5 & 27 & 3,9 & 70 & \\
\hline 30 & 3,8 & 57 & 3,52 & 31 & 3,95 & 72 & \\
\hline 40 & 3,9 & 66 & 3,55 & 33 & 3,97 & 75 & \\
\hline 50 & 4 & 78 & 3,58 & 35 & 4 & 78 & \\
\hline 60 & 4,1 & 89 & 3,6 & 37 & 4,02 & 81 & \\
\hline 70 & 4,2 & 94 & 3,62 & 40 & 4,04 & 83 & \\
\hline 80 & 4,3 & 108 & 3,68 & 43 & 4,08 & 86 & \\
\hline 90 & 4,4 & 119 & 3,7 & 45 & 4,1 & 89 & \\
\hline 100 & 4,5 & 129 & 3,72 & 47 & 4,12 & 92 & \\
\hline 110 & 4,6 & 140 & 3,75 & 50 & 4,15 & 94 & \\
\hline 120 & 4,7 & 149 & 3,78 & 52 & 4,18 & 97 & \\
\hline 130 & & & 3,8 & 55 & 4,2 & 100 & \\
\hline 140 & & & 3,82 & 58 & 4,22 & 102 & \\
\hline 150 & & & 3,85 & 61 & 4,26 & 105 & \\
\hline 160 & & & 3,88 & 63 & 4,28 & 108 & \\
\hline 170 & & & 3,9 & 66 & 4,3 & 110 & \\
\hline 180 & & & 3,92 & 68 & 4,32 & 112 & \\
\hline 190 & & & 3,95 & 71 & 4,35 & 115 & \\
\hline 200 & & & 3,98 & 73 & 4,4 & 118 & \\
\hline 210 & & & 4 & 74 & 4,42 & 121 & \\
\hline 220 & & & 4,02 & 77 & & & \\
\hline
\end{tabular}


18.03.0 при $\mathrm{d}=30 \mathrm{~mm}$

2

\begin{tabular}{|c|l|c|c|c|l|c|}
\hline Час, & $\begin{array}{l}\text { Значенн } \\
\text { я }\end{array}$ & Рівень & $\begin{array}{l}\text { Значен } \\
\text { ня }\end{array}$ & $\begin{array}{l}\text { Рівен } \\
\text { ь }\end{array}$ & $\begin{array}{l}\text { Значен } \\
\text { ня }\end{array}$ & Рівень \\
\hline Сек & вакууму & води & $\begin{array}{l}\text { вакуум } \\
\text { у }\end{array}$ & води & $\begin{array}{l}\text { Вакуум } \\
\text { у }\end{array}$ & води \\
\hline & q=14л/с & & q=10л/с & & $\begin{array}{l}\text { Q=12л/ } \\
\text { с }\end{array}$ & \\
\hline & 1 & 1 & 2 & 2 & 3 & 3 \\
\hline 0 & 3,4 & 20 & 3,45 & 25 & 3,45 & 20 \\
\hline 10 & 3,55 & 25 & 3,5 & 30 & 3,6 & 34 \\
\hline 20 & 3,7 & 50 & 3,55 & 37 & 3,7 & 46 \\
\hline 30 & 3,85 & 64 & 3,6 & 45 & 3,8 & 60 \\
\hline 40 & 4 & 79 & 3,7 & 50 & 3,9 & 68 \\
\hline 50 & 4,12 & 92 & 3,78 & 56 & 4 & 82 \\
\hline 60 & 4,25 & 104 & 3,85 & 62 & 4,1 & 93 \\
\hline 70 & 4,35 & 114 & 3,9 & 68 & 4,2 & 103 \\
\hline 80 & 4,5 & 129 & 3,95 & 74 & 4,32 & 115 \\
\hline 90 & & & 4 & 80 & 4,4 & 124 \\
\hline 100 & & & 4,05 & 85 & & \\
\hline 110 & & & 4,12 & 93 & & \\
\hline 120 & & & 4,16 & 98 & & \\
\hline 130 & & & 4,22 & 104 & & \\
\hline 140 & & & 4,3 & 111 & & \\
\hline 150 & & & 4,35 & 116 & & \\
\hline
\end{tabular}

При q=14л/с

Qпов $=0,0113 \mathrm{~m}^{3} / \mathrm{c}$ Qвод $=0,0140 \mathrm{~m}^{3} / \mathrm{c}$

$$
\mathrm{K}=0,8036
$$

При q=10л/с

Qпов $=0,0060 \mathrm{~m}^{3} / \mathrm{c}$ Qвод $=0,0100 \mathrm{~m}^{3} / \mathrm{c}$

$$
\mathrm{K}=0,6000
$$

При q=12л/с

Qпов $=0,0100 \mathrm{~m}^{3} / \mathrm{c}$ Qвод $=0,0120 \mathrm{~m}^{3} / \mathrm{c}$

$$
\mathrm{K}=0,8333
$$

19.03.0 при $\mathrm{d}=25 \mathrm{~mm}$

\begin{tabular}{|c|c|c|c|c|c|c|}
\hline Час, & $\begin{array}{l}\text { Значенн } \\
\text { я }\end{array}$ & Рівень & $\begin{array}{l}\text { Значен } \\
\text { ня }\end{array}$ & $\begin{array}{l}\text { Рівен } \\
\text { ь }\end{array}$ & $\begin{array}{l}\text { Значен } \\
\text { ня }\end{array}$ & Рівень \\
\hline Сек & вакууму & води & $\begin{array}{l}\text { вакуум } \\
\text { у }\end{array}$ & води & $\begin{array}{l}\text { Вакуум } \\
\text { у }\end{array}$ & води \\
\hline & q=10л/с & & q=8л/с & & Q=6л/с & \\
\hline & 1 & 1 & 2 & 2 & 3 & 3 \\
\hline 0 & 3,4 & 20 & 3,45 & 20 & 3,45 & 20 \\
\hline 10 & 3,55 & 29 & 3,55 & 29 & 3,5 & 26 \\
\hline 20 & 3,65 & 39 & 3,62 & 38 & 3,52 & 29 \\
\hline 30 & 3,75 & 49 & 3,68 & 45 & 3,6 & 32 \\
\hline 40 & 3,82 & 58 & 3,78 & 50 & 3,65 & 37 \\
\hline 50 & 3,92 & 69 & 3,84 & 52 & 3,68 & 42 \\
\hline 60 & 4,02 & 77 & 3,88 & 63 & 3,7 & 46 \\
\hline 70 & 4,12 & 87 & 3,95 & 70 & 3,75 & 50 \\
\hline 80 & & & 4 & 76 & 3,8 & 54 \\
\hline 90 & & & & & 3,85 & 58 \\
\hline
\end{tabular}

При q=10л/с

Qпов $=0,0129 \mathrm{~m}^{3} / \mathrm{c}$ Qвод $=0,0100 \mathrm{~m}^{3} / \mathrm{c}$

$$
\mathrm{K}=1,2857
$$

При $\mathrm{q}=8$ л/с

Qпов $=0,0113 \mathrm{~m}^{3} / \mathrm{c}$ Qвод $=0,0080 \mathrm{M}^{3} / \mathrm{c}$

$$
\mathrm{K}=1,4063
$$




\begin{tabular}{|c|l|l|l|l|c|c|}
\hline 100 & & & & & 3,88 & 62 \\
\hline 110 & & & & & 3,92 & 67 \\
\hline 120 & & & & & 3,95 & 71 \\
\hline 130 & & & & & 4 & 75 \\
\hline
\end{tabular}

При q=6л/с
Qпов=0,0069
Qвод $=0,0060 \mathrm{~m}^{3} / \mathrm{c}$

$$
\mathrm{K}=1,1538
$$

Список Літератури

1. Рекомендации по проектированию систем заливки центробежных насосов / Под ред. Палишкина Н.А., Подласова А.В., Строчак В.А.- К.- УкрНИИГиМ, 1981.- 42c.

2. Назаров Н.Т. Расчет рабочего цикла вакуум-системы на автоматизированной насосной станции // Гидравлика и гидротехника.- 1992.- Вып.55.- С.3-8.

3. Назаров Н.Т. Вакуумные установки автоматизированных насосных станций настоящего и будущего. Лабораторные исследования, теоретические изыскания, гидравлические расчеты.- Ровно: изд-во РГТУ.-1999.-112 с.

4. Назаров М.Т., Філіпович Ю.Ю. Робочий процес вакуумної установки автоматизованої насосної станції і зв'язок його з параметрами живильної труби // Вісник РДТУ. Гідромеліорація та гідротехнічне будівництво.- Зб.наук.праць. Спецвипуск.- Рівне, 1999.- № .- С. .

5. Філіпович Ю.Ю. Вплив розмірів елементів вакуумної системи автоматизованої насосної станції на тривалість іï робочого циклу // Водне господарство України.- 1999.- № 5-6.- С. 39-41. 


\section{АНАЛІЗ РИНКУ ТА ПОПИТУ ШОКОЛАДУ В УКРАЇНІ}

\section{Шубіна Лідія Юріївна,}

к. т. н., доцент

Харків, Харківський торговельно-економічний інститут Української інженерно-педагогічної академії

\section{Чорна Тетяна Олександрівна,}

к. х. н., доцент

Харків, Харківський торговельно-економічний інститут Української інженерно-педагогічної академії

\section{Куранда Анастасія Олексіївна,}

магістрант

Харків, Харківський торговельно-економічний інститут Української інженерно-педагогічної академії

Кондитерський ринок - один 3 найбільш розвинених в харчовій промисловості України. Одним із складових секторів цукристих кондитерських виробів є шоколад.

Шоколад, найбільш яскравий представник номенклатури кондитерських виробів, давно вважається продуктом повсякденного споживання. У споживачів збереглося ставлення до шоколаду, як до насолоди, споживчі переваги шоколаду оцінюються блискучою поверхнею, сильним і тонким «шоколадним» ароматом $\mathrm{i}$ пікантною гіркотою в смаку.

Шоколад постійно користується популярністю серед населення України, він посідає друге місце, поступаючись тільки борошняним виробам.

Однак український шоколадний ринок залишається нестабільним та постійно змінюється. За останні три роки ємність шоколадного сегменту виросла майже на $25 \%$ [1]. Причиною такого насичення ринку $є$ нарощування імпорту. Закордонні компанії вважають Україну хорошим ринком збуту, навіть за умов пандеміï Covid-19. Найбільшими постачальниками шоколаду стали Польща (на суму близько 20 млн. дол.), Німеччина (9,4 млн. дол.), Нідерланди (9,3 млн. дол.).

Важливе місце в дослідженні шоколадного ринку відіграє експорт продукції. Згідно 3 даними Державної служби статистики Україна за останні роки спостерігалося зниження об'ємів експорту українських солодощів понад $30 \%$.

Динаміка експорту шоколаду та шоколадних виробів показує значний спад на ринку. Це пов'язано зі спадом економіки та пандемічною кризою. Найбільший експорт шоколадної продукції відбувся в Казахстан (на суму близько 20 млн. дол.).

Друге місце у списку найбільших країн-імпортерів українського шоколаду посідають США. Минулого року США імпортували українського шоколаду на 17,1 млн дол. 
Білорусь посідає третє місце у списку найбільших країн-імпортерів українського шоколаду із річним показником у 16,7 млн дол.

На вітчизняному ринку виробників шоколаду та шоколадних виробів в лідери входять - корпорація ROSHEN (29\%), «АВК» $(18 \%)$, «МИЛЛЕНИУМ» $(16 \%)$ i «KONTI GROUP» $(16 \%)$ :

- «ROSHEN»: кондитерська корпорація, одна 3 найбільших виробників кондитерських виробів в Україні та Східній Європі. У рейтингу «Global Top 100 Candy Companies - 2020» вона увійшла до ТОП-30 кращих виробників кондитерської продукції, посівши 27 місце. Фабрики компанії розташовані в Україні (Київська, Кременчуцька, Вінницькі фабрики), Литві (Клайпедська фабрика), Угорщині (Bonbonetti Choco Kft) [2];

- «АВК»: сьогодні компанія входить до складу найбільших компаній світу. У рейтингу «Global Top 100 Candy Companies - 2020» посідає 65 місце. До складу корпорації «АВК» входять Дніпровська кондитерська фабрика, ТОВ «Бджола: виробництво глазурі» [2];

- «МИЛЛЕНИУМ»: сьогодні компанія входить до складу найбільших компаній світу. У рейтингу «Global Top 100 Candy Companies - 2020» посідає 74 місце [2];

- «KONTI GROUP»: компанія входить до лідерів галузі. До складу компанії входить сучасна Костянтинівська кондитерська фабрика та логістичний центр класу «А» в місті Дніпрі. У рейтингу «Global Top 100 Candy Companies» «KONTI GROUP» посідає 80 місце [2].

Інші виробники - «Монделіс Україна» (представлена в Україні торговими марками: «КОРОНА», MILKA, «ЛЮКС», JACOBS, CARTE NOIRE, «ВЕДМЕДИК» «БАРНІ», РІCNIC); «Бісквіт-шоколад», «Світоч» (господарі швейцарська Nestle), «Полтавакондитер» (американська Sigma) утримують по 5$6 \%$ ринку.

На даний момент шоколад залишається одним з найпопулярніших харчових продуктів не тільки серед дітей, але і серед дорослих [3].

Найбільш популярним на сьогоднішній день в Україні $є$ шоколад з добавками (горіхи, родзинки), який споживають 44,1 \% споживачів шоколадної плитки. Наступне місце у рейтингу популярності займає пористий шоколад $-14,8 \%$ споживачів. Потім - чистий шоколад без добавок (11,8 \%).

Найменшим попитом користуються шоколад 3 наповнювачами (4 \%), зменшується попит на традиційний молочний шоколад, що миттєво відобразилося на пропозиції кондитерів, які замінюють молочну продукцію новинками - з різноманітними видами горіхів та хрусткими наповнювачами.

Аналізуючи переваги споживачів щодо вибору типу шоколаду можна простежити певні тенденції: 44,5 \% споживачів віддають перевагу молочному шоколаду; 33,3 \% - чорному і 5,7 \% - білому.

На даний час у світі все більш посилюється поширення цукрового діабету, який характеризується численними побічними явищами, такими як судинні захворювання, отримання інвалідності, приводячи в результаті до летальних наслідків. 
3 огляду на це, багато дієтологів радять людям з підвищеним цукром або для попередження цукрового діабету виключити зі свого раціону шоколад.

Але низка сучасних дослідницьких робіт доводять позитивні властивості шоколаду. Саме флавоноли шоколаду сприяють профілактиці захворювань нервової системи, а флавоноїди мають протизапальну, нейропротекторну, антіканцерогенну дію [4].

В даний час активно збільшується число найменувань шоколаду. Крім традиційного чорного, молочного, класичного з'явився шоколад 3 різними добавками спецій, ароматичної сировини тощо.

Порівняльні дослідження класичного шоколаду, а також шоколаду 3 добавками червоного перцю і розмарину за змістом загальних фенолів, здатності вловлювати вільні радикали показали збільшення загального вмісту фенолів в зразках шоколаду з добавками червоного перцю і розмарину. Антирадикальна активність цих видів шоколаду також вище, ніж у класичного.

Таким чином слід зазначити, що існує значний інтерес до питань про корисні властивості шоколаду як фахівців $з$ дієтології, фізіології харчування, харчової хімії, так і простих споживачів.

\section{Список літератури}

1. Загричанська А. В. Аналіз сучасного кондитерського ринку України / А. В. Загричанська, В. Я. Голюк // Актуальні проблеми економіки і управління: Зб. наук. праць. - К.: КПІ ім. Ігоря Сікорського - Вип. 15. - 2021. - С. 21-26. 2. Лобачева I. Ф. Аналіз ринку шоколадних виробів в Україні / І. Ф. Лобачева, Ю. С Беженар // Актуальні проблеми економіки: Зб. наук. праць. - Вінниця : ВТЕІ КНТЕУ - ВИп. 25. - 2018. - С. 847-852.

3. Быков Д. Е. Шоколад как продукт для функционального питания / Д. Е. Быков, Н. В. Макарова, Д. Ф. Валиулина // Вестник МГТУ. - 2018. - Т. 21, - № 3. - С. 447-459.

4. Тутельян В. А. Биологически активные вещества растительного происхождения. Флавонолы и флавоны: распространенность, пищевые источники, потребление / В. А. Тутельян, Н. В. Лашнева // Вопросы питания. 2013. - T. 82, - № 1. - C. 4-22. 
The authors of the II International Scientific and Practical Conference «Trends in the scientific development» were representatives of the following educational institutions:

V.N. Karazin Kharkiv National University; Institute of Water Problems and Land Reclamation; National Research Center «Institute of Soil Science and agrochemistry named after O.N. Sokolovsky»; A.N. Beketov Kharkov National University of Urban Economy; Separate structural subdivision "Rivne Vocational College of the National University of Life and Environmental Sciences of Ukraine"; Kharkiv National Medical University; Institute of General and Emergency Surgery named after V.T. Zaitsev National Academy of Medical Sciences of Ukraine; Chortkiv Educational and Scientific Institute of Entrepreneurship and Business; West Ukrainian National University; University of Banking; Dnipro State Agricultural and Ecocnomic University; Odesa Mechnikov National University; Poltava State Agrarian Academy; Ivan Franko National University of Lviv; National University Civil Defense of Ukraine; Kuban State University; Poltava Institute of Business; Odesa State University of Internal Affairs; Yaroslav Mudryi National Law University; Pavlodar government teachers' training institute; Georgian Technical University; Academy of Management and Performance; Lviv Polytechnic National University; Dniprovsk State Technical University; Al-Farabi Kazakh National University; Kyiv National Economic University named after Vadym Hetman; Ukrainian military medical academy; Dnipro State Medical University; Bukovinian State Medical University; Astana Medical University; Scientific Center for Preventive Toxicology, Food and Chemical Safety named after Academician L.I. Medvedya; Bogomolets National Medical University; Odesa National Medical University; Kharkiv Humanitarian-Pedagogical Academy; Georgian Technical University; Central Ukrainian State Pedagogical University; Donetsk National Medical University; Lesya Ukrainka Eastern European National University; Kharkiv National Pedagogical University named after G.S. Skovoroda; Peoples' Friendship University of Russia; Russian University of Economics G.V. Plekhanov; Borys Hrinchenko Kyiv University Institute of Gifted Children; Dnieper Academy of Continuing Education; Odessa Military Academy; Donetsk National University; Luhansk National University named after Taras Shevchenko; Kyiv Gymnasium of Oriental Languages №1; International Humanitarian University; National University "Chernihiv Collegium "named after Taras Shevchenko; College of Dnepropetrovsk Academy of Music M. Glinka; Heroes of Chernobyl Cherkasy Fire Safety Institute; Izmail State Humanitarian University; National University of Civil Defense of Ukraine; Drahomanov National Pedagogical University; Vinnytsia National Pirogov Medical University; ITMO University; Kharkiv National University of Radio Electronics; Odessa Maritime institute; National Aerospace University named after N. Ye. Zhukovskiy "Kharkov Aviation Institute"; Transdniestrian State University; Admiral Makarov National University of Shipbuilding; Kharkiv National Automobile and Highway University; Uman National University of Horticulture; Podolsk State Agrarian Technical University; National Aviation University; Berezany Agrotechnical Institute; Kyiv National University of Building and Architecture; Kharkiv Trade and Economic Institute of the Ukrainian Engineering and Pedagogical Academy. 


\title{
TRENDS IN THE SCIENTIFIC DEVELOPMENT
}

\author{
Scientific publications
}

Materials of the II - International Science Conference «Trends in the scientific development», Vancouver, Canada. 417 p.

(September 28 - October 01, 2021)

UDC 01.1

ISBN - 978-1-63972-062-0

DOI - 10.46299/ISG.2021.II.II

Text Copyright (C 2021 by the International Science Group (isg-konf.com).

Illustrations (C) 2021 by the International Science Group.

Cover design: International Science Group (isg-konf.com) ${ }^{\circledR}$

Cover art: International Science Group (isg-konf.com) ${ }^{\odot}$

All rights reserved. Printed in the United States of America.

No part of this publication may be reproduced, distributed, or transmitted, in any form or by any means, or stored in a data base or retrieval system, without the prior written permission of the publisher.

The content and reliability of the articles are the responsibility of the authors. When using and borrowing materials reference to the publication is required. Collection of scientific articles published is the scientific and practical publication, which contains scientific articles of students, graduate students, Candidates and Doctors of Sciences, research workers and practitioners from Europe, Ukraine, Russia and from neighboring countries and beyond. The articles contain the study, reflecting the processes and changes in the structure of modern science. The collection of scientific articles is for students, postgraduate students, doctoral candidates, teachers, researchers, practitioners and people interested in the trends of modern science development.

The recommended citation for this publication is: Makieieva N., Odinets Y., Poddubnaya I., Kulikova D. Pain syndrome in art // Trends in the scientific development. Abstracts of II International Scientific and Practical Conference. Vancouver, Canada. 2021. Pp. 35-43.

URL: https://isg-konf.com. 